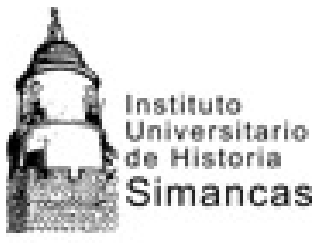

Instituto Universitario de Historia Simancas

Universidad de Valladolid

Doctorado europeo "Europa y el mundo atlántico: poder, cultura y sociedad" Tesis Doctoral con Mención Internacional en el título de Doctor

Autor: Benito Peix Geldart

Directores: Dr. José-Vidal Pelaz López y Dr. Lars Berggren

\title{
RELACIONES POLÍTICAS Y DIPLOMÁTICAS ENTRE ESPAÑA Y SUECIA DE 1931 A 1939
}
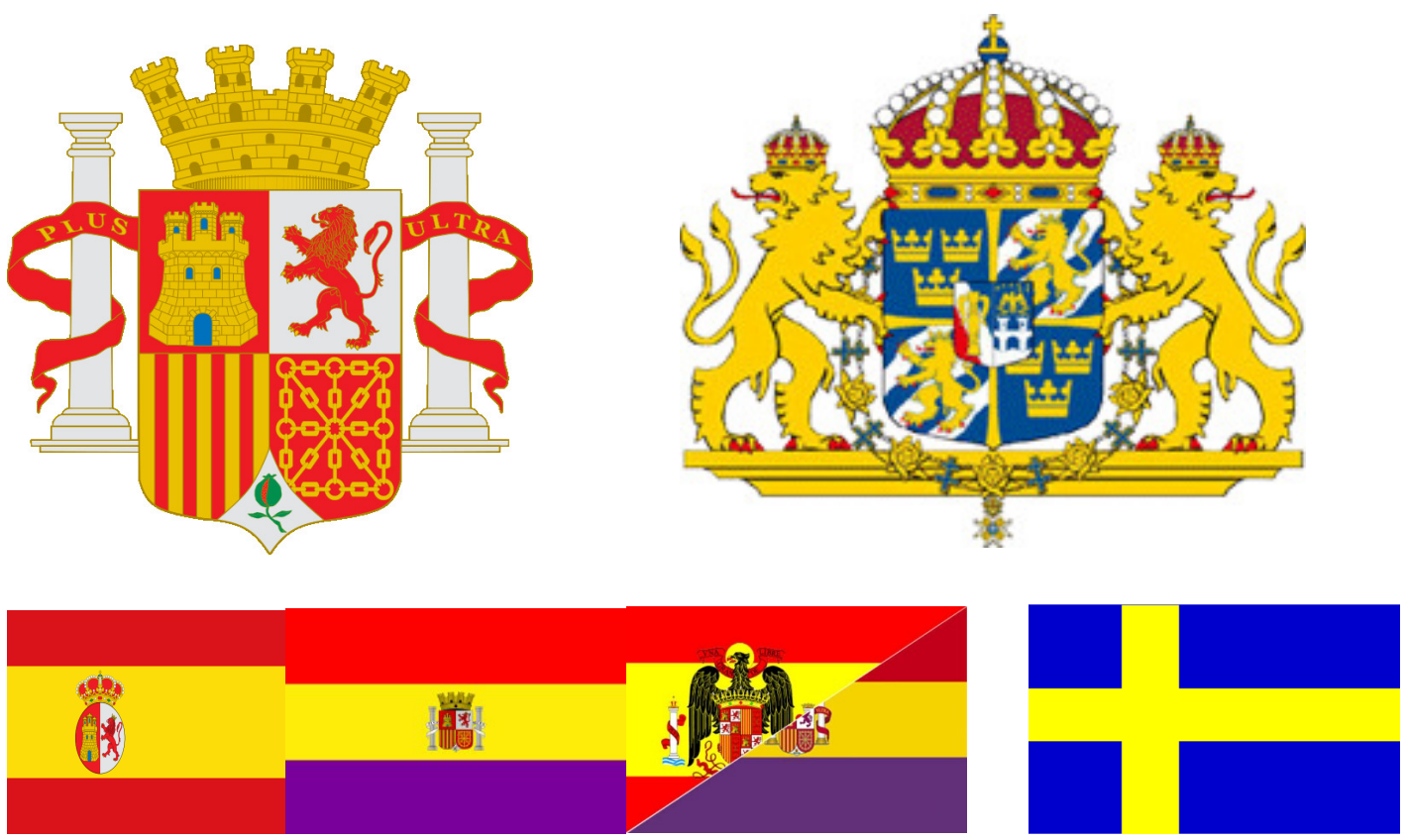

A mis padres, mis hermanos y sus cónyuges, mi sobrino, y a los demás miembros de mi familia 



\section{INDICE}

INDICE

Capítulo 1

1.1. Planteamiento general y objeto del presente estudio

1.2. Presupuestos teórico-metodológicos-

1.2.1. Posibilidades y problemas de la historia comparada y de la historia de las relaciones internacionales $-20$

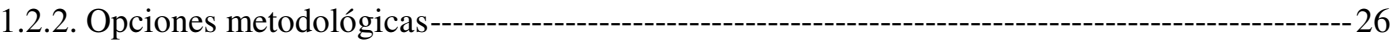

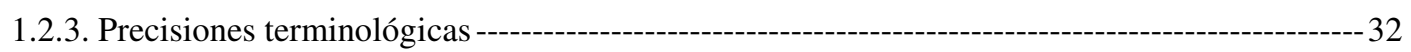

1.3. Fuentes para el estudio de las relaciones hispano-suecas de 1931 a 1939 ----------------------------34

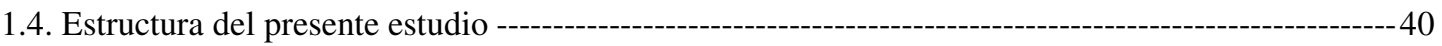

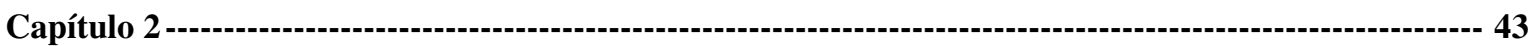

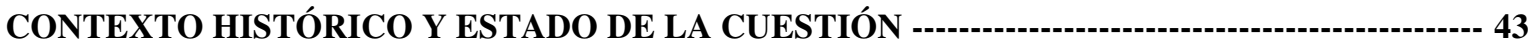

2.1. Las relaciones históricas entre España y Suecia -------------------------------------------------------------43

2.1.1 Suecia y España hasta 1900-------------------------------------------------------------------------------43

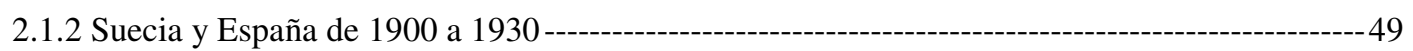

2.2. Las relaciones entre Suecia y España de 1931 a 1939 en la historiografía sueca ---------------------58

2.3. Las relaciones entre Suecia y España de 1931 a 1939 en la historiografía española -----------------63

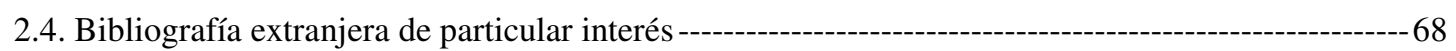

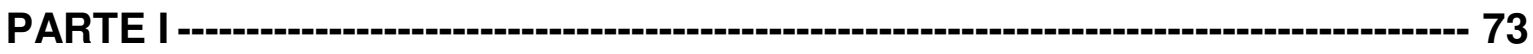

REPÚBLICA EN ESPAÑA, SOCIALDEMOCRACIA EN SUECIA --------------- 73

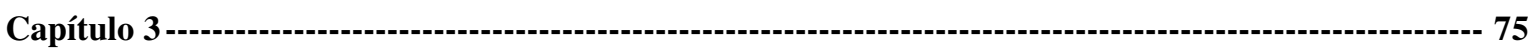

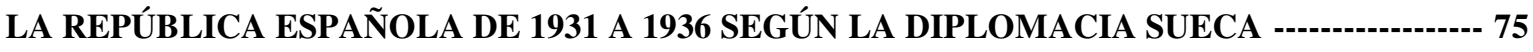

3.1. La Legación de Suecia en Madrid. Los ministros plenipotenciarios de Suecia en España ----------75 
3.2. La política interior española de 1931 a 1936 según la diplomacia sueca------------------------------- 80

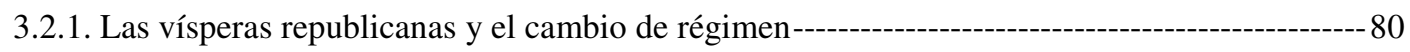

3.2.2. La situación política española en el primer bienio republicano-------------------------------- 89

3.2.3. La situación política española en el segundo bienio republicano----------------------------- 106

3.3. Preocupaciones específicas de la diplomacia sueca respecto a España (1931-1936)--------------- 116

3.3.1. Los avances del comunismo y las relaciones con la URSS-------------------------------- 116

3.3.2. La España del Frente Popular y la amenaza de guerra civil -------------------------------------- 124

3.4. La política exterior de la República según la diplomacia sueca ------------------------------------ 131

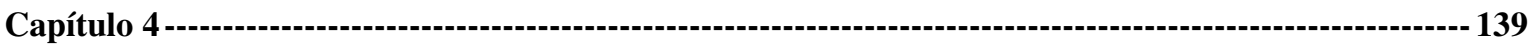

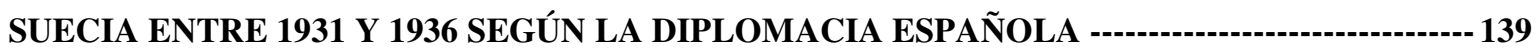

4.1. La Legación de España en Estocolmo. Los ministros de España en Suecia ------------------------- 139

4.2. La política interior sueca de 1931 a 1936 según la diplomacia española---------------------------- 144

4.2.1 La política interior sueca hasta la llegada al poder de la socialdemocracia--------------------- 144

4.2.2. La política interior sueca durante el gobierno de Per Albin Hansson (1932- 1936)--------- 151

4.3. Preocupaciones específicas de la diplomacia española respecto a Suecia (1931-1936) ----------- 163

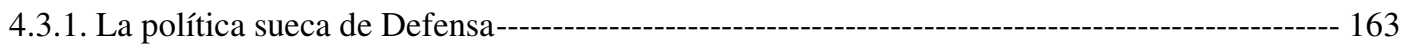

4.3.2. La actitud de Suecia ante el nazismo y la Alemania de Hitler ---------------------------------- 169

4.4. La política exterior sueca de 1931 a 1936 según la diplomacia española --------------------------- 180

4.4.1. Aspectos generales de la política exterior sueca 1931-1936 ---------------------------------- 180

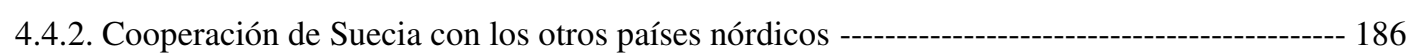

4.4.3. Relaciones bilaterales de Suecia con algunos países entre 1931 y 1936 ---------------------- 190

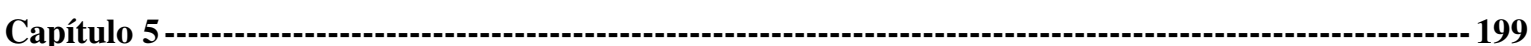

LAS RELACIONES BILATERALES ENTRE ESPAÑA Y SUECIA DE 1931 A 1936 ---------- 199

5.1. Suecia ante el cambio de régimen político en España ------------------------------------------------ 199

5.1.1 El reconocimiento de Suecia al gobierno de la República Española----------------------------- 199

5.1.2. Alfonso XIII y Suecia tras la instauración de la República Española--------------------------- 205

5.2. La colaboración entre España y Suecia en la Sociedad de Naciones---------------------------------- 211

5.2.1. Neutralidad y pacifismo como claves comunes de la política exterior de España y de Suecia211

5.2.2. Iniciativas comunes hispano-suecas a favor de la paz: El "grupo de los neutrales"---------- 214

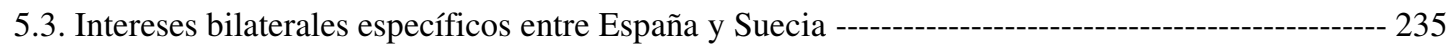

5.3.1. La imagen del propio país en el país de destino --------------------------------------------- 235

5.3.2. La gestión diplomática de los asuntos bilaterales sueco-españoles ---------------------------- 242

5.4. Contactos entre líderes políticos y sindicales españoles y suecos ----------------------------------- 250 
6.1. La guerra civil española según la diplomacia sueca

6.2. Suecia y la política de no intervención 275

6.3. Las relaciones diplomáticas de Suecia con la República Española de 1936 a 1939 ---------------- 282

6.3.1. La actividad diplomática de la Legación de Suecia en Madrid --------------------------------- 283

6.3.2. La actividad diplomática de la Legación de España en Estocolmo ----------------------------- 289

6.4. La actualidad política sueca según la diplomacia española------------------------------------------- 301

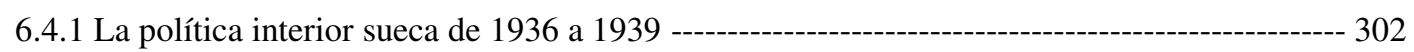

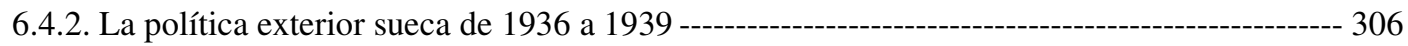

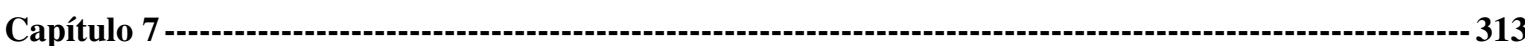

SUECIA Y LA ESPAÑA DE FRANCO DE 1936 A 1939 -

7.1. La diplomacia sueca respecto a la España de Franco hasta el intercambio de agentes------------- 313

7.1.1 La labor de información de la diplomacia sueca acerca de la España de Franco -------------- 314

7.1.2 Cuestiones bilaterales y conflictos diplomáticos suecos con la España de Franco ------------ 319

7.2 El intercambio de agentes entre Suecia y la España de Franco --------------------------------------- 326

7.2.1 Las presiones del mundo empresarial sueco a favor de la España de Franco ------------------ 327

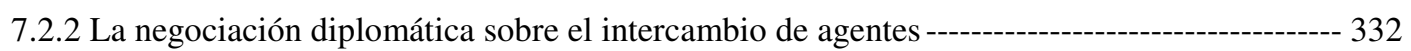

7.2.3 El agente sueco en Burgos y el reconocimiento oficial del gobierno franquista por Suecia - 340

7.3. La actividad de la representación de la España franquista en Suecia --------------------------- 346

7.4. Las relaciones diplomáticas entre Suecia y España de abril a diciembre de 1939 ------------------ 357

Capítulo 8

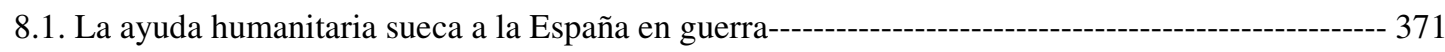

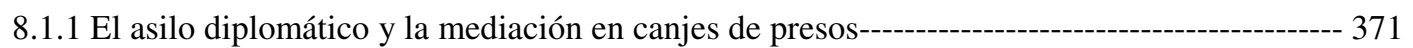

8.1.2 La ayuda material sueca a la España en guerra-------------------------------------------------- 379

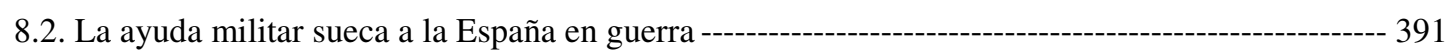

8.2.1. Los voluntarios suecos al servicio de la República Española -------------------------------- 391

8.2.2. Los voluntarios suecos al servicio de la España de Franco--------------------------------------- 405

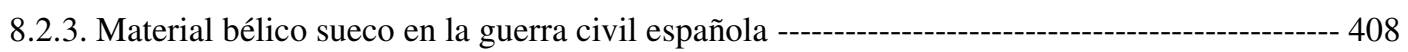


APÉNDICES

FUENTES

FUENTES NO IMPRESAS

1. Archivos Españoles

2. Archivos suecos

FUENTES IMPRESAS, DIARIOS Y MEMORIAS - 481

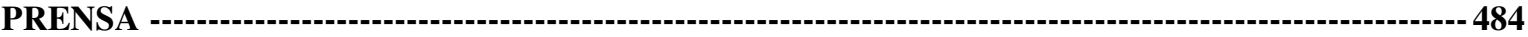

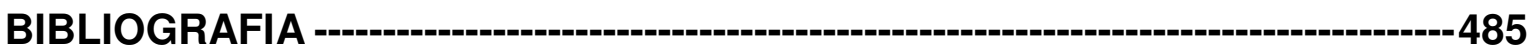

1. Aspectos generales, teoría y método histórico. - 487

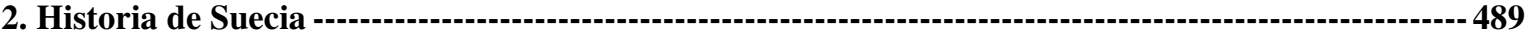

3. Relaciones Suecia- España --o---o 494

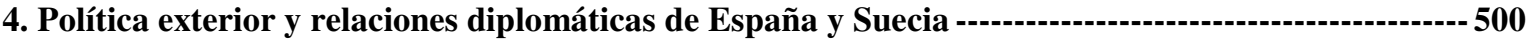

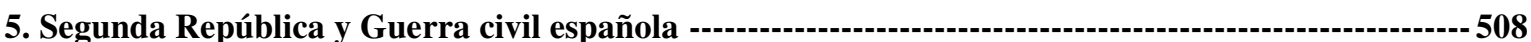

ENGLISH SUMMARY ---

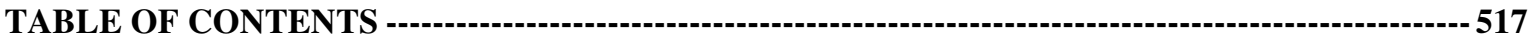

NOTE TO THE ENGLISH SUMMARY -

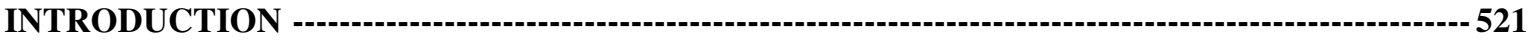

SUMMARY OF PART I AND PART II (CHAPTERS 3 - 8) -

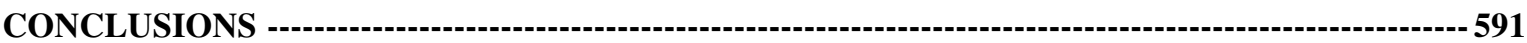




\section{$\underline{\text { ABSTRACT }}$}

This comparative history study aims to fill a gap in the historiography of international relations of the interwar period by analyzing the political and diplomatic relations between Sweden and Spain during the 1930s, a crucial period in the history of both countries. It is based on a large number of primary sources in Swedish and Spanish archives, mainly diplomatic dispatches. A qualitative method that is commonly used in historical research has been adopted. The study shows the highly positive image of Sweden conveyed by Spanish diplomats in the 1930s as well as the more negative vision Swedish diplomats had of the Spanish Republic. It also points out the existence of a range of political and diplomatic contacts that were more intense than expected, basically framed within the field of co-operation between the so-called neutral countries in the League of Nations, which led to the joint declarations of 1934 and 1936.

In its second part, the study addresses the relations of Sweden with each of the two areas in which Spain was divided during the Civil War, and also Swedish intervention in the war itself, in both its humanitarian and military aspects. The study confirms that Sweden showed an unprecedented solidarity with the Spanish Republic at grassroots level, but officially maintained a scrupulous attitude of neutrality in "the Spanish question". This ambiguity was also reflected in the informal but real ties Swedish governments had with Franco's Spain during the war years, which seem to have been closer and friendlier than what might have been expected.

KEY WORDS: Spanish-Swedish Relations, Diplomacy, League of Nations, 1930s, Spanish Civil War

El presente estudio de historia comparada pretende cubrir una laguna en la historiografía de las relaciones internacionales del período de entreguerras, analizando las relaciones políticas y diplomáticas entre Suecia y España durante la década de los años treinta del siglo XX, crucial en la historia de ambos países. Está basado en una abundante documentación consistente en fuentes primarias suecas y españolas, especialmente despachos diplomáticos, estudiados a través de métodos cualitativos habituales en la investigación histórica. El estudio muestra la imagen eminentemente positiva transmitida 
por los diplomáticos españoles de la Suecia de los años treinta y la más negativa de los diplomáticos suecos acerca de la República Española. Asimismo, saca a la luz la existencia de una serie de contactos políticos y diplomáticos más intensa de lo que a primera vista cabía esperar, en el marco de la cooperación de los llamados países neutrales en la Sociedad de Naciones, que condujo a las declaraciones comunes de 1934 y de 1936.

En su segunda parte, el estudio afronta las relaciones de Suecia con cada una de las dos zonas en que quedó dividida España durante la guerra civil, y la intervención sueca en la misma en el aspecto humanitario y en el de ayuda militar. El estudio confirma que Suecia mostró una solidaridad sin precedentes con la República Española a nivel popular y humanitario, pero mantuvo una actitud de escrupulosa neutralidad oficial en la llamada "cuestión española". Esa ambigüedad quedó también reflejada en las relaciones oficiosas que los gobiernos de Suecia mantuvieron con la España de Franco, más estrechas y cordiales de lo conocido hasta ahora en la historiografía.

PALABRAS CLAVE: Relaciones España-Suecia, Diplomacia, Sociedad de Naciones, Años treinta, Guerra civil española 


\section{ABREVIATURAS}

AFLC Archivo de Francisco Largo Caballero

AGA Archivo General de la Administración

AGMAV Archivo General Militar de Ávila

AHN Archivo Histórico Nacional (Madrid)

AHPCE Archivo histórico del Partido Comunista de España

ALA Archivo de Luis Araquistáin

ALJA Archivo de Luis Jiménez de Asúa

AMAEC Archivo del Ministerio de Asuntos Exteriores y Cooperación, Madrid $(\mathrm{R}=$ Archivo Renovado; $\mathrm{PG}=$ Personal $)$

ARAB Archivo y Biblioteca del Movimiento Obrero sueco, Estocolmo (Arbetarrörelsens arkiv och bibliotek)

$\mathrm{CDMH}$ Centro Documental de la Memoria Histórica (PS=Sección Político-Social)

FPI Archivo de la Fundación Pablo Iglesias

KA Archivo de la Guerra (Krigsarkivet)

KB Biblioteca Nacional, Estocolmo (Kungliga Biblioteket)

LO Unión de Sindicatos suecos (Landsorganisationen i Sverige)

PSOE Partido Socialista Obrero Español

RA Archivo Nacional de Suecia, Estocolmo (Riksarkivet)

SAC Organización Central de Trabajadores de Suecia (Sveriges arbetares centralorganisation)

SAE Asociación Sueca General de Exportadores (Svenska Allmänna Exportföreningen)

SAP Partido Obrero Socialdemócrata (Socialdemokratiska Arbetarepartiet)

SÄPO Policía de Seguridad sueca (Säkerhetspolisen)

SHfS Comité Sueco de Ayuda a España (Svenska hjälpkommittén för Spanien)

SKfSB Comité sueco de mujeres a favor de los niños de España (Svenska kvinnokommittén för Spaniens barn)

SKP Partido Comunista de Suecia (Sveriges Kommunistiska partiet)

SP Partido Socialista (Socialistiska partiet)

SSA Archivo municipal de Estocolmo (Stockholms Stadsarkivet) 
SSK Asociación de Voluntarios Suecos en España (Svenska Spanienfrivilligas kamratförening)

UD Ministerio de Negocios Extranjeros (Riksarkivet, Utrikesdepartementet) 
INTRODUCCIÓN 



\section{Capítulo 1}

\section{PLANTEAMIENTO Y PRESUPUESTOS}

Un problema fundamental en las relaciones políticas sueco-españolas del siglo XX ha sido la falta de conocimiento y entendimiento de la situación en el país contrario (...). Desde esta perspectiva, la investigación y un mayor conocimiento de la historia de nuestros dos países es vital para profundizar y desarrollar nuestras buenas relaciones ${ }^{1}$

\subsection{Planteamiento general y objeto del presente estudio}

Las palabras del diplomático sueco Berndt Fredriksson, que encabezan estas líneas, constituyen el marco fundamental de inspiración del presente trabajo. España y Suecia son, efectivamente, dos países europeos con muchas cosas en común y, al mismo tiempo, lejanos uno del otro por mentalidad, forma de ser, conocimiento y comprensión mutua.

La constatación de las diferencias - la lejanía más mental que física - entre ambos países ha sido resaltada por la gran mayoría de los contados estudios históricos que hasta la fecha se han ocupado de las relaciones entre España y Suecia. A pesar de ello, se ha insistido también en lo que constituye, en un contexto europeo, el punto más significativo que acaso tengan en común. Nos referimos al encuadramiento de los dos países en lo que se ha dado en llamar la "periferia de Europa".

Ese encuadramiento es perfectamente aceptado por la generalidad de los suecos, forma parte de su conciencia histórica y conceptual del hecho europeo. Aún hoy, casi veinte años después de la entrada de Suecia en la Unión Europea, es frecuente en Suecia la expresión "Europa" o, en su caso, "el continente" para referirse al conjunto de países situados entre el sur de la península escandinava y de las Islas Británicas por un lado y el Mar Mediterráneo por otro.

En España, por el contrario - y por razones históricas evidentes - ha prevalecido una cierta actitud de rechazo a ser considerada "periferia" de Europa, visible incluso a un nivel académico. Ha habido, y sigue habiéndola, una tendencia a resaltar el carácter plenamente

\footnotetext{
${ }^{1}$ FREDRIKSSON, Berndt., "La historia de las relaciones bilaterales entre Suecia y España. Embajadores suecos en España”, en MAQUEDA ABREU, Consuelo, (coord.), Poder, derecho y legislación, Madrid: UNED, Marcial Pons y Fundación Berndt Wistedt, 2001, pp. 45-77, p. 75.
} 
europeo-continental de España. La historiografía española, por eso, ha preferido utilizar el término "semiperiférico" - propuesto por Immanuel Wallerstein ${ }^{2}$ - para referirse a España en un contexto europeo.

Independientemente de la visión subjetiva que al respecto se tenga, no cabe duda de que desde el punto de vista geográfico y también desde un punto de vista histórico pensamos que es perfectamente válido utilizar el término de "países de la periferia europea" para referirse a Suecia y a España durante los dos últimos siglos, la llamada Edad Contemporánea. Utilizamos aquí ese término - "periférico" - en el sentido indicado por Roberto Russell y Juan Gabriel Tokatlian:

La condición periférica corresponde a una situación geográfica - distante del centro gravitante del sistema internacional con mayor poder - a una situación política - carente de una amplia capacidad de autonomía en el plano externo - y a un estatus militar - irrelevante desde la perspectiva estratégica de los actores más preponderantes y recursivos ${ }^{3}$.

A pesar de la distancia geográfica y cultural entre ambos países, en la segunda década del siglo XX compartieron una realidad común: su carácter neutral en la Gran Guerra. Ello acercaría entre sí a ambos países, situados en una posición similar en la escena internacional, que conllevaba un incremento de sus intereses comunes: en concreto, en la actitud a adoptar ante las grandes potencias europeas, tanto en el plano político como en el económico.

Por eso, es bastante sorprendente el hecho de que no abunden los estudios comparativos relativos a ese período y a los años que siguieron - el período de entreguerras, de 1918 a 1939 - entre ambos países ${ }^{4}$.

Tortella analizó desde un punto de vista comparativo los procesos de modernización, en sus diferentes aspectos, en ambas zonas geográficas, resaltando los puntos comunes entre Suecia y España: en ambos casos, se trataba del país más grande (exceptuando a Rusia) en sus entornos respectivos, el mundo báltico y el mediterráneo, respectivamente.

\footnotetext{
${ }^{2}$ WALLERSTEIN, Immanuel, World-systems analysis: an introduction, Duke University Press, 2004.

${ }^{3}$ RUSSELL, Roberto \& TOKATLIAN, Juan Gabriel, "Relaciones internacionales y política interna: los neutrales en la segunda guerra mundial, un estudio de caso”, en Foro internacional, núm. 163, 2001, pp. 63103.

${ }^{4}$ Contamos, no obstante, con algunas notables excepciones, principalmente SCHMITT, Hans A. (coord.), Neutral Europe between war and revolution, Charlottesville: University of Virginia Press, $1988 \mathrm{y}$ JERNECK, Magnus; MÖRNER, Magnus; TORTELLA, Gabriel \& ÅKERMAN, Sune (coord.), Different paths to Modernity: A Nordic and Spanish perspective, Lund: Nordic Academic Press, 2005. Es éste el más detallado estudio de historia comparada sobre Suecia y España en la edad contemporánea.
} 
Ambos son países con un subsuelo rico en minerales, especialmente hierro, siendo los principales exportadores de este metal en el siglo XIX. Ambos entraron en el siglo XIX como ex-imperios venidos a menos desde el punto de vista económico, siendo bien patente la desproporción entre sus recursos naturales y su poder político y militar en el contexto europeo $^{5}$.

Además de esas similitudes, también es digna de mención la aparición simultánea de acontecimientos de corte revolucionario en ambos países en 1917, en gran parte motivados por el impacto de la guerra en los países neutrales ${ }^{6}$.

Por otra parte, no parece necesario insistir en los contrastes y las diferencias entre ellos hasta las décadas finales del siglo XX, por ser evidentes. Entre otros, destaca la homogeneidad de Suecia frente a la diversidad regional española, así como la mayor tradición democrática del país escandinavo y la primacía en él del ideal del consenso, en contraste con España.

Gracias al discreto auge de los estudios de historia comparada - método a nuestro parecer utilísimo, a pesar de sus evidentes dificultades, en cuanto aporta a menudo perspectivas nuevas y válidas no accesibles a los estudios puramente temáticos dentro de una historiografía basada únicamente en fuentes locales - que se ha podido apreciar en los últimos tiempos, han aparecido algunos estudios sobre las relaciones hispano-suecas. El detonante fue el proyecto conjunto propuesto por el gobierno sueco a través de su entonces Embajador en España, Tomas Bertelman, que resultó en la organización de los llamados "Encuentros históricos Suecia-España",

\footnotetext{
${ }^{5}$ TORTELLA, Gabriel, "Sweden and Spain - Different Paths towards Modernity?" en JERNECK, Magnus; MÖRNER, Magnus; TORTELLA, Gabriel \& ÅKERMAN, Sune (coord.), Different paths to Modernity: A Nordic and Spanish perspective, Lund: Nordic Academic Press, 2005, pp. 18-30;

${ }^{6}$ KOBLIK, Steven, "Sweden, 1917: Between reform and Revolution", en SCHMITT, op.cit., pp. 111-132; MEAKER, Gerald H., "A civil war of words: The ideological impact of the First World War on Spain, 19141918”, en SCHMITT, Hans A. (coord.), op. cit., pp.1-65. Con todo, resulta un tanto exagerado poner en un nivel de paridad la revolución rusa y los sucesos de ese año en Suecia (escisión en dos del partido socialdemócrata en febrero, creación del primer gobierno con participación socialdemócrata, limitación del poder regio, etc.) o incluso, aunque el malestar social fuera más evidente que en el país escandinavo, con los sucesos de España (desórdenes sociales, motines de la oficialidad del Ejército, huelga general, crisis del gobierno Dato, etc.).

${ }^{7}$ Los Encuentros fueron organizados por la Fundación Berndt Wistedt, y contaron con la participación de varias universidades y un gran número de organizaciones públicas y privadas de ambos países, incluidos los respectivos gobiernos y, por parte española, también algunas Comunidades Autónomas. En Suecia, el coordinador fue el catedrático emérito de la Universidad de Gotemburgo, Magnus Mörner, y en España, los profesores Enrique Martínez Ruiz y Magdalena de Pazzis Pi Corrales, de la Universidad Complutense de Madrid. Estos encuentros han sido enormemente útiles y, tomados en su conjunto, suponen un aporte inestimable a la historia comparada de los dos países. Más adelante tendremos ocasión de volver más en concreto sobre ellos, en particular a las aportaciones y artículos que hacen directa referencia al tema de este trabajo, ya que constituyen el grueso de las aportaciones de la investigación histórica actual al respecto.
} 
Con todo, el acento fundamental en el proyecto mencionado se puso en la Edad Moderna, no en la Contemporánea. De hecho, apenas hay estudios sobre las relaciones entre Suecia y España durante el siglo XX, y los pocos que tocan esta temática, tanto en España como en Suecia, lo hacen en el marco de la guerra civil española. Los años de la Dictadura de Primo de Rivera y los de la Segunda República hasta el comienzo de la guerra en julio de 1936 son, para la historiografía de ambos países, poco menos que terreno virgen. Respecto a la época de Franco, el material existente en los archivos suecos es tan abundante como escasos son los estudios históricos suecos, de cierta profundidad, sobre la misma. Cualquier proyecto de investigación sobre el tema no contará apenas con bibliografía en la que apoyarse.

Respecto a las relaciones diplomáticas, además, llama la atención el hecho de que, aunque no hayan sido históricamente especialmente prolijas ni especialmente significativas, la información oficial sobre Suecia contenida en la página web del Ministerio de Asuntos Exteriores español y la referente a España en su homónimo sueco, ni siquiera se refiera a las relaciones entre ambos países anteriores a 1979.

Nos encontramos, por tanto, en un terreno prácticamente inexplorado por la historiografía. Este dato constituye el aspecto fundamental que avala la conveniencia del estudio que nos proponemos abordar aquí.

El objeto del mismo es analizar en profundidad las relaciones diplomáticas entre Suecia y España durante la década de los años treinta del siglo XX, que coinciden con los de la Segunda República y la guerra civil española.

Confiamos en que el estudio de la documentación diplomática sueca y española de la época, pueda ofrecer valiosas aportaciones para una mejor comprensión del desarrollo histórico, en su doble vertiente de política interna y de política exterior, de ambos países. Esperamos poder cubrir así una laguna historiográfica importante, pues el escaso interés historiográfico por la cuestión hasta la fecha resulta, cuanto menos, llamativo, máxime teniendo en cuenta que fue Suecia el país del mundo que, proporcionalmente al tamaño de su población, más ayuda material y personal dio a la República Española en sus años de mayor prueba.

El análisis de las relaciones diplomáticas sueco-españolas en estos años cruciales en la historia contemporánea presenta, indudablemente, una interesante serie de cuestiones, tanto respecto a España como respecto a Suecia. 
Respecto a España: ¿Qué visión dio la diplomacia sueca del desarrollo político de la España republicana durante el período 1931-1936, y de los avatares de los tres años de guerra civil que fueron su triste colofón? ¿Qué aspectos de la vida política española interesaron especialmente a los diplomáticos suecos en España, y por qué? ¿Qué valoración mereció la política exterior de la República a los observadores suecos? ¿Cómo se compagina la visión sueca de la España de la época con lo establecido por la historiografía existente? Un aspecto a tener en cuenta, en cada una de esas preguntas, es el de la concordancia o no de la imagen sueca de la España de la época con los datos aportados por la historiografía española.

Respecto a Suecia: ¿cómo vieron los diplomáticos españoles en Suecia la transformación del país escandinavo, durante el período que nos ocupa, en uno de los primeros Estados de bienestar del planeta? ¿Cuáles fueron las cuestiones relacionadas con Suecia que más preocuparon a la diplomacia española, y cuál fue la causa de ese interés? ¿Cómo valoró la diplomacia española la política exterior de Suecia, especialmente en el marco de la Sociedad de Naciones? Análogamente a lo expuesto para España, cabe preguntarse si la imagen que dieron los diplomáticos españoles sobre Suecia corrobora o desmiente la visión del período en la historiografía sueca.

El tercer grupo de cuestiones concretas planteadas por esta investigación son las relacionadas con las relaciones bilaterales propiamente dichas entre Suecia y la República Española: ¿Cómo fueron esas relaciones bilaterales? ¿Qué tipo de cooperación tuvieron Suecia y España en el marco de la Sociedad de Naciones, y en qué campos colaboraron de manera primordial? ¿Cómo se configuraron las relaciones de Suecia con la República Española durante los años de la guerra civil? ¿De qué manera apoyó Suecia a la República en guerra? ¿Qué conflictos se produjeron entre Suecia y la República Española?

Y finalmente, un cuarto grupo se centraría en las relaciones de Suecia con la España de Franco: ¿Qué relaciones tuvo Suecia con la España franquista entre el 18 de julio de 1936 y el final de la década? ¿Qué ayuda recibió la España de Franco de Suecia durante la guerra civil? ¿Hubo conflictos entre Suecia y la España franquista?

Nos centraremos aquí, principalmente, en el análisis concreto de la actividad y actuación de las Legaciones y los agentes diplomáticos españoles en Suecia y de sus homónimos suecos en España durante los años treinta del siglo XX, aunque también haremos referencia a algunos contactos a nivel no institucional entre representantes 
políticos y sindicales de los dos países con sus homónimos en la medida que hayan quedado reflejados en la documentación diplomática sueca y española.

Para ello, analizaremos las fuentes disponibles en los archivos de los respectivos Ministerios de Asuntos Exteriores de ambos países, el Utrikesdepartementet sueco, y el Ministerio de Asuntos Exteriores y Cooperación español.

Además, para el estudio de la intervención de Suecia en la guerra civil española, haremos uso de un gran número de fuentes primarias contenidas en otros archivos, civiles y militares, suecos y españoles. Enseguida comentaremos esto con más detalle en un apartado propio, al igual que haremos con la exposición del estado de la cuestión en la historiografía sueca y española.

\subsection{Presupuestos teórico-metodológicos}

Antes de proceder al análisis y comentario de las fuentes disponibles sobre las relaciones entre España y Suecia en la década de los treinta del pasado siglo y de exponer el estado de la cuestión en la historiografía sueca y española, es necesario hacer algunas precisiones en torno a los presupuestos teórico-metodológicos del presente estudio.

\subsubsection{Posibilidades y problemas de la historia comparada y de la historia de las relaciones internacionales}

El presente estudio presenta un cierto carácter interdisciplinar. No puede ser de otra manera tratándose de la historia de las relaciones internacionales entre dos países europeos en el siglo XX, tema a caballo entre la historia contemporánea, el derecho internacional público o derecho de gentes, y las relaciones internacionales.

Este tipo de estudios perdió actualidad a lo largo de la segunda mitad del siglo XX. No faltan las corrientes que consideraron el estudio de la historia de las relaciones políticas y diplomáticas como un tema superado en el debate moderno sobre el objeto y método de la Historia. En efecto, no pocas veces, nuestro objeto de estudio es considerado, aún hoy, un tema obsoleto, propio de una historiografía de siglos anteriores, en los que el auge de la historia política de la propia nación parecía reclamar para sí el monopolio de atención por parte de los historiadores.

Es cierto que tradicionalmente se ha puesto el énfasis en las relaciones de poder entre Estados, relaciones en las que la diplomacia sería el instrumento adecuado, en manos de las autoridades respectivas, para hacer prevalecer su punto de vista y sus intereses nacionales 
en el contexto internacional. También lo es que, desde el punto de vista metodológico, las investigaciones sobre este aspecto han seguido generalmente métodos convencionales, a menudo de carácter más cuantitativo que cualitativo, en el estudio de la documentación generada por las Embajadas y Cancillerías.

Con frecuencia, se ha dejado de lado todo lo que no fuera el análisis de las intenciones y el grado de cumplimiento de los objetivos de política exterior de cada país. Esto ha llevado necesariamente a que la Historia de las Relaciones Internacionales se haya encontrado a caballo entre las Ciencias Sociales (Ciencias Políticas, Sociología, Derecho Internacional Público) y la Historia, con un cierto predominio de aquéllas y de sus métodos propios sobre la segunda. Esto se ve, por ejemplo, en el primado de la perspectiva de poder o en la aplicación del método del actor racional como único adecuado. Esto es aplicable al estado de estas cuestiones tanto en Suecia como, quizá aún en mayor medida, en España.

El auge de la historia económica y social, así como de las nuevas perspectivas metodológicas en términos de estudios de clase, género, generación, etnia o microhistoria, junto a enfoques teórico-metodológicos basados en las teorías del discurso - siguiendo a autores clave de lo que ha dado en llamarse postmodernismo, como Foucault o Ricoeur ha motivado un claro descenso, en las últimas décadas, de los estudios sobre historia de las relaciones internacionales, tanto en Suecia como en España.

En Suecia, concretamente, las investigaciones sobre temas de historia política en general brillan actualmente por su ausencia prácticamente total en los proyectos de investigación de los departamentos universitarios de Historia. Hay excepciones que confirman la regla, pero la investigación histórica está centrada en su mayoría en la historia posterior a la primera Guerra Mundial, con preponderancia de los estudios de historia social y conceptual, en detrimento de la historia política.

Esto se refleja también en la organización de los propios departamentos de Historia en las Universidades del país: No existen, salvo excepciones, cátedras especializadas en Historia Antigua, Medieval, Moderna o Contemporánea. Los titulares de las Cátedras llevan en su mayoría el título general de Catedrático de Historia, con el añadido, en algunos casos, de "en especial historia de...", siendo especialidades comunes la historia de género, la historia del deporte, la historia de las relaciones laborales, la historia medioambiental, la historia social, la historia local y, últimamente, la Didáctica de la Historia o incluso, en algún caso, lo que se ha denominado "historia temprana" (äldre historia), considerando como tal toda la historia anterior a 1750. 
En general, podría decirse que, mientras en España siguen primando los aspectos sustantivos de la historia, con la consecuencia ineludible de la exigencia de la especialización en el ámbito de conocimiento propio (Edad Media, Edad Moderna, etc.), en Suecia han prevalecido los aspectos adjetivos, la concentración en cuestiones de teoría y método históricos como la característica principal que define al historiador, con la consecuencia de una diversificación en su labor investigadora. Así, mientras el historiador español es especialista en una época concreta, el sueco es más bien un generalista experto en la aplicación de teorías y métodos históricos independientemente del período al que se refieran.

Lo antedicho ha llevado a que, en la práctica, los cursos de Teoría y Metodología de la Historia ocupen el lugar central en los planes de estudios de Historia de las Universidades suecas desde hace décadas. Sólo muy recientemente se han empezado a ver tendencias de un cambio de sensibilidad a este respecto, volviéndose a recuperar ámbitos bastante olvidados, como la historia medieval.

Tampoco en España - como ya comentamos - ha estado precisamente en auge la historia de las relaciones internacionales. Si exceptuamos la Revista de Estudios Internacionales (Centro de Estudios Constitucionales), los Cuadernos de Historia Moderna y Contemporánea (Facultad de Geografía e Historia de la Universidad Complutense) y Espacio, Tiempo y Forma, es rara la aparición de artículos sobre el tema hasta los años noventa. Es llamativo, además, que un país como España no posea una colección de Documentos Diplomáticos como hay en la mayor parte de los países del mundo occidental ${ }^{8}$.

Tras la creación de la Comisión Española de la Historia de las Relaciones Internacionales en 1992, el panorama empieza a cambiar y hay un interés creciente por la Historia de las relaciones internacionales. En las "Primeras Jornadas sobre Historia de las Relaciones Internacionales" en 1994, Pereira Castañares expuso con claridad una serie de aspectos fundamentales: el objeto de estudio de la Historia de las Relaciones Internacionales, la concreción de campos temáticos para su desarrollo, el aspecto internacional y la metodología propia de las mismas ${ }^{9}$.

\footnotetext{
${ }^{8}$ MORALES LEZCANO, Víctor, "Historia de las relaciones internacionales: España contemporánea" en Revista de Estudios Internacionales Vol. 7. Núm. 2. Abril-junio 1986, pp. 575-582;

${ }^{9}$ PEREIRA CASTAÑARES, Juan Carlos, "La historia de las relaciones internacionales en España. Respuestas, propuestas y conclusiones", en Cuadernos de Historia Contemporánea. $n$. 18, Madrid: Servicio de Publicaciones de la Universidad Complutense, 1996.
} 
A comienzos del presente siglo, Neila Hernández hizo una buena síntesis del desarrollo de la historia de las relaciones internacionales en distintos países (España, Francia, Reino Unido, Alemania, Italia, etc), donde, tras algunas aproximaciones teóricas acerca del lugar de la historia en la "ciencia de la sociedad internacional", recorría las principales aportaciones teóricas en este campo, ilustrando bien el paso de la historia diplomática tradicional, de fuerte cariz historicista, a la historia de las relaciones internacionales así como los intentos de superación del paradigma estatalista que, a pesar de todo, ha seguido siendo dominante ${ }^{10}$.

Existen, evidentemente, diversas aproximaciones a nuestro campo de estudio, como puso de manifiesto la participación de varios especialistas no españoles en las Jornadas de 1994. Al respecto, decía Moreno Juste:

La estrecha colaboración entre investigadores de nacionalidad, formación e ideologías diferentes aparece como especialmente apta para el estudio de la historia de las Relaciones Internacionales, donde necesariamente intervienen distintas sensibilidades personales e ideológicas, coexisten diferentes aproximaciones metodológicas, cohabitan opuestas interpretaciones sobre hechos recientes y, suelen diferir, incluso, las concepciones sobre la historia en general (...)

El debate sobre la situación de la historia de las relaciones internacionales en cada país, parece mantener un común denominador, homogeneizador en muchas ocasiones de la polémica: relacionar problemas de método con carencias epistemológicas ${ }^{11}$.

Desde entonces, los estudios de las relaciones bilaterales entre Estados han seguido teniendo preferencia sobre las cuestiones generales de política exterior. En este marco se encuadran estudios como los de Marina Casanova ${ }^{12}$, Mercedes Montero ${ }^{13}$ o Ascensión

10 NEILA HERNÁNDEZ, José Luis, "La historia de las relaciones internacionales: Notas para una aproximación historiográfica", en La historia de las relaciones internacionales, Ayer n. 42, Madrid: Marcial Pons, 2001.

${ }^{11}$ MORENO JUSTE, Antonio, "La historia de las relaciones internacionales en España", en Cuadernos de Historia Contemporánea. N. 18, Servicio de Publicaciones de la Universidad Complutense, Madrid, 1996, p. 217. Remitimos a las ponencias y comunicaciones de esa publicación para un estudio detallado del estado de la cuestión a mediados de los años noventa del siglo XX.

12 CASANOVA, Marina "Las relaciones diplomáticas hispano-belgas durante la guerra civil española: el caso del barón de Borchgrave", Espacio, Tiempo y Forma, Serie V, Historia Contemporánea, tomo V, 1992, pp. 293-302.

${ }^{13}$ MONTERO CALDERA, Mercedes, "La acción diplomática de la Segunda República Española en México (1931-1939)", en Espacio, Tiempo y Forma, Serie V, Historia Contemporánea. 14, 2001, pp. 251-286. 
Martínez y Alfredo Moreno ${ }^{14}$, que son precisamente los más próximos temáticamente al presente estudio.

Con todo, es evidente que, a partir del año 2000, los estudios de historia de relaciones internacionales han entrado en una etapa de gran esplendor y de mucha mayor diversificación. Buena prueba de ello es la reciente segunda edición de la obra coordinada por Pereira Castañares titulada "La política exterior de España: de 1800 hasta hoy", tanto por la amplitud y diversidad de temas y enfoques que contiene, como por el rigor científico de las aportaciones de un gran número de expertos y colaboradores, como Calduch Cervera, Cordero Olivero, García Pérez, Huguet Santos, Lemús, Neila Hernández, Montero Juste o Torre del Río, entre otros.

En esta obra se presenta, además del detallado estado de la cuestión en la historiografía (en el capítulo 2, del propio Pereira Castañares), una visión de conjunto del desarrollo de la política exterior de España, centrado especialmente en los últimos años: la posición geoestratégica de España, la importancia del sector exterior para la economía española, la organización de la administración exterior y la actividad de las Comunidades Autónomas, el papel de la diplomacia, las Fuerzas Armadas y los medios de comunicación, la incidencia de las migraciones, el factor cultural y la cooperación al desarrollo. Además, se presentan con gran claridad las coordenadas básicas de la política exterior de España en sus distintas vertientes: Europa, Latinamérica, el mundo Mediterráneo, Asia y África. Al final, en varios capítulos se aborda una panorámica general de las relaciones exteriores de España en su recorrido histórico ${ }^{15}$.

También en Suecia hay bastantes trabajos dedicados al estudio de las relaciones bilaterales del país con otros países, destacando aquellos con los que por una u otra razón ha habido más relaciones por parte sueca: Inglaterra, Rusia, Turquía, etc.

Al respecto, no deja de llamar la atención el distinto enfoque teórico y metodológico del tema en ambos países: mientras que en los españoles se observa una primacía, a nuestro modo de ver, de la perspectiva de los actores frente a la centrada en las cuestiones estructurales, en Suecia es precisamente a la inversa; mientras en España, como se ha dicho, se tiende a estudiar las relaciones desde una perspectiva que podríamos llamar "vertical descendente" - analizando el papel y la acción de los representantes diplomáticos

\footnotetext{
${ }^{14}$ MARTÍNEZ RIAZA, Ascensión \& MORENO CEBRIÁN, Alfredo, "Al servicio de la República. La acción exterior de España en el Perú, 1936 - 1939” en CSIC Revista de Indias, vol. LXVII, núm. 241, 2007.

${ }_{15}^{15}$ PEREIRA CASTAÑARES, Juan Carlos (coord.), La politica exterior de España: de 1800 hasta hoy, Madrid: Ariel, 2010.
} 
en cumplimiento de las instrucciones recibidas por su gobierno, y también desde una perspectiva de defensa de la propia esfera nacional de poder en el marco internacional - en Suecia predomina la perspectiva "horizontal" - del estudio de los diversos grupos sociales que influyen en la política internacional - e incluso la de la llamada historia desde abajo (historia underifrån).

Buen ejemplo de esto son los abundantes ensayos surgidos a partir de los años cincuenta, basados en las memorias de los voluntarios suecos de las Brigadas Internacionales o de periodistas $\mathrm{u}$ hombres de negocios suecos que vivieron la guerra española de cerca. Se trata de una perspectiva que también ha tomado auge en España en los últimos tiempos. No faltan tampoco, en Suecia, enfoques desde el punto de vista teórico-metodológico de la historia de las mentalidades, mientras que en España este tipo de trabajos son más minoritarios. Una excepción a este respecto es el estudio de María de los Ángeles Egido León ${ }^{16}$, y que precisamente por eso constituye un punto de referencia obligado para estudios del tipo que nos ocupa.

En definitiva, los estudios suecos ${ }^{17}$ sobre historia de las relaciones internacionales siguen las notas distintivas propias del conjunto de la investigación histórica sueca de las últimas décadas, muy influida por las teorías epistemológicas postkuhnianas: en el fondo hay un concepto relativista de la realidad, plasmado en lo que Alvesson y Sköldberg llaman el trilateralismo de la verdad, (det trilaterala sanningsbegreppet), distinguiendo entre la verdad representativa, la verdad aplicativa y la verdad significativa. En la hermenéutica predominante en Suecia se opta claramente por este tercer concepto de verdad, que, siguiendo a Heidegger y Ricoeur, no presupone ni correspondencia ni utilización, sino que es significado, descubrimiento de un sentido más profundo a nivel subjetivo $^{18}$.

Esto se traduce, en la práctica, en el predominio casi absoluto de trabajos de investigación histórica con fuerte carga teórica, cuyo objeto es llegar a una mejor comprensión de las estructuras subyacentes al devenir histórico de un período concreto. El énfasis está más bien en las discusiones teóricas y conceptuales con la bibliografía

\footnotetext{
${ }^{16}$ EGIDO LEÓN, María de los Ángeles, La concepción de la política exterior española durante la II República. Madrid: UNED, 1987.

${ }^{17}$ Toda la bibliografía sueca utilizada en este trabajo aparecerá en las notas a pie de página según su título sueco, y solamente el nombre de la ciudad de edición y la abreviatura "pp", en su caso, aparecen en castellano. En la lista de bibliografía al final del estudio se incluye entre paréntesis la traducción al castellano de los títulos correspondientes.

${ }_{18}$ ALVESSON, Mats, \& SKÖLDBERG, Kaj, Tolkning och reflektion: vetenskapsfilosofi och kvalitativ metod, 2 ed., Lund: Studentlitteratur, 2008, p. 47 s.
} 
existente en la materia, que en el análisis empírico de las fuentes disponibles. Las implicaciones metodológicas de la llamada teoría crítica del conocimiento, de la escuela de Frankfurt, se dejan sentir.

Es fundamental, en todo trabajo de historia comparada, tener conciencia de las diferencias de enfoque propias de la tradición historiográfica en cada país, para una mejor comprensión e interpretación de la bibliografía disponible, y también a la hora de presentar aportaciones válidas para la historia de cada uno de los países.

\subsubsection{Opciones metodológicas}

En el presente estudio, por tratarse de una tesis doctoral en una Universidad española - aunque con la colaboración de la Universidad sueca de Lund, donde hemos realizado una larga estancia - hemos optado por dar prioridad al enfoque, más propio de la historiografía española, del riguroso análisis empírico de la "evidencia primaria de época", es decir, de las abundantes fuentes primarias disponibles y su interpretación a la luz de los avances de la historiografía existente. No obstante, por haber recibido nuestra formación histórica en ambas tradiciones, la sueca y la española, es probable que aparezcan en nuestro análisis, de forma más o menos consciente, formas o categorías más habituales en el país escandinavo que en España.

Somos conscientes de que los enfoques metodológicos para un estudio de las relaciones diplomáticas entre Suecia y España pueden ser diversos, pero nos inclinamos por seguir un método cualitativo según las prácticas de la hermenéutica histórica moderna, si bien basado preferentemente en la abducción como aspecto integrador y superador de los métodos tradicionales: tanto de los exclusivamente inductivos propios de la llamada teoría fundamentada (grounded theory) propuesta por Glaser y Strauss ${ }^{19}$ - que son probablemente los más utilizados internacionalmente - como de los puramente deductivos, ya sean éstos de corte popperiano, marxista o postmodernista. La abducción va del dato empírico a la teoría interpretativa, y de ésta a la búsqueda de nuevos datos empíricos, que a su vez conllevarán ajustes en el modelo interpretativo. Nos parece un instrumento adecuado para estudios de relaciones políticas y diplomáticas bilaterales entre países.

Por otra parte, la naturaleza de las principales fuentes históricas que constituyen la base empírica de este estudio - los despachos diplomáticos de los Ministros

\footnotetext{
${ }^{19}$ GLASER, Barney G. \& STRAUSS, Anselm L., The discovery of grounded theory, Chicago: Aldine, 1967.
} 
Plenipotenciarios de Suecia y España acreditados ante los gobiernos de Madrid y de Estocolmo durante el período 1931-1939 - aconseja tener en cuenta, a la hora del análisis interpretativo, algunos aspectos propios de la analítica discursiva tan propia de los planteamientos postmodernistas y post-estructuralistas actualmente en boga. Nos referimos, en concreto, a todo lo relacionado con la narración histórica desde el punto de vista conceptual, la teoría narrativa.

Sin pretender entrar aquí en profundidades epistemológicas, vale la pena detenerse brevemente en este punto. Según Carlshamre, el concepto de narración o narrativa puede definirse de manera heurística como distinto de la crónica, la descripción y los anales. La característica esencial de la narración como concepto es su temporalidad, al referir sucesos acontecidos en un orden determinado y durante un cierto espacio de tiempo, frente al carácter atemporal de la descripción, en la que no se hace referencia a cambios, repeticiones, duración, etc. Se distingue de los anales en que éstos narran sucesos sin interrelacionarlos entre sí, aspecto que es propio de la narración histórica, donde se tiene en cuenta la causalidad y el aspecto teleológico, es decir, las intenciones que mueven a los distintos actores y el fin perseguido ${ }^{20}$.

Gran parte de los despachos diplomáticos sobre la realidad política, económica y social de un país, producidos y enviados durante un determinado lapso de tiempo, constituyen una narrativa histórica específica según la definición de Carlshamre. Tomando como base la actualidad político-social presente, vista a través del filtro de las fuentes de información disponibles para el diplomático en cuestión, e interpretada según las categorías subjetivas del informante, los despachos dan lugar a una narración escrita de los acontecimientos de un país, narración que está dotada de una fuerte carga teleológica. Su objetivo específico es, en efecto, facilitar al gobierno respectivo los datos necesarios para que éste pueda tomar decisiones informadas en su política exterior.

En este sentido, la narración/narrativa diplomática, independientemente de su contenido específico, es fuente importante de decisiones. Incide, por así decir, directamente en el desarrollo histórico subsiguiente, en cuanto es tomada como elemento básico para la actuación de otros actores en un proceso histórico. Por ello, consideramos tan importante el estudio de los despachos diplomáticos para la mejor comprensión de un período histórico.

\footnotetext{
${ }^{20}$ CARLSHAMRE, Staffan, Förklara och berätta vad som hänt. Fyra uppsatser om historiens filosofi, Gotemburgo: Universidad de Gotemburgo, 1995, pp. 71-84.
} 
Cuestión clave, a la hora de proceder al análisis de los mismos, es la comprensión del contexto histórico en que surgieron, y esto nos lleva inevitablemente a la persona de sus autores, los funcionarios diplomáticos singulares que los produjeron. Ellos están, como cualquier otra persona, influidos por los acontecimientos históricos que han vivido, por sus condicionamientos genéticos y sus tradiciones histórico-culturales, así como su entorno social. En el momento de plasmar sobre el papel su interpretación de la vida política del país de destino se encuentran realidad histórica y autor del despacho, su horizonte de experiencias y sus esperanzas de futuro ${ }^{21}$.

La historiografía tradicional sobre relaciones diplomáticas insistía mucho en la personalidad y el carácter de legados y embajadores como aspecto decisivo en las relaciones internacionales bilaterales.

Esta visión, propia de una historiografía en la que los aspectos personalistas priman sobre los estructurales, debe, sin duda, matizarse. Obviamente, las características personales del Ministro o Cónsul, su formación y contactos, su visión de la realidad política internacional vigente en un determinado momento y su conocimiento del país ante el que están acreditados, tienen su influencia, y mucha, en la relación establecida, y más aún en el tipo de información que envían a sus superiores sobre el país de destino.

Concedido lo anterior, hay que resaltar también los aspectos estructurales de toda relación internacional bilateral: "ningún hombre es una isla", valga la conocida expresión, y menos aún un diplomático de carrera, imbuido por formación, por profesión y por tradición de unos modos de hacer y de un espíritu de cuerpo con una solera de siglos.

Además, por lo que se refiere al mundo diplomático en particular, este aspecto estructural no queda limitado al propio Ministerio y escalafón, sino de manera muy singular al conjunto del Cuerpo Diplomático acreditado en cualquier capital. No en vano goza esta institución de posición propia, como conjunto de los diplomáticos extranjeros en un país determinado, con un Decano al que el Derecho y los usos internacionales dotan de determinadas funciones de coordinación de la labor diplomática. Esto tiene como consecuencia que la influencia de unos diplomáticos en otros es directa y muy concreta, siendo práctica habitual el recurso a fuentes comunes de información en el país receptor, e incluso la cooperación a la hora de informar a los gobiernos respectivos en un sentido afín.

\footnotetext{
${ }^{21}$ Cfr. WIKLUND, Martin, "Meaning in History beyond instrumental Rationality. The concepts of meaning and rationality of meaning in Jörn Rüsens's theory of history", en Ideas in History, no. 2, 2008, pp.74-77; KOSELLECK, Reinhart, Erfarenhet, tid och historia. Om historiska tiders semantik, Gotemburgo: Daidalos, 2004, passim; RÜSEN, Jörn, "Historical Narration: Foundation, Types, Reason”, History \& Theory, no.4, 1987.
} 
Este aspecto, insoslayable en cualquier caso, tuvo particular relevancia en el caso de la guerra civil española, como más adelante veremos.

Según el conocido filósofo de la historia alemán Jörn Rüsen, los acontecimientos históricos tienen un carácter prenarrativo, y se convierten en narraciones al preguntarse por ellos el sujeto (el historiador o, en nuestro caso, el diplomático que escribe). Según Rüsen, las grandes narrativas históricas cumplen una función orientadora y legitimadora de la identidad histórica de los pueblos. La narración histórica es verdadera si es respetuosa con los acontecimientos que narra y con las normas interpretativas establecidas por el consenso de los historiadores. La narración debe tener credibilidad empírica y normativa, a la vez que coherencia narrativa ${ }^{22}$.

Asimismo, en relación con la política exterior, cobran especial importancia los aspectos retóricos. Per Jansson, en un estudio sobre el discurso político sueco en materia de seguridad en la Europa de entreguerras, sostiene que el lenguaje no sólo es transmisor de significado, sino también medio de creación del mismo. Así, desde una postura constructivista, la función de las metáforas va más allá del mero adorno retórico. Al analizar el lenguaje utilizado por los políticos suecos en la Sociedad de Naciones, concluye que abunda lo que llama el uso de "narrativas míticas": el recurso a palabras y expresiones que apelen a las creencias y sentimientos más profundos del público al que van dirigidos. Es decir, el discurso político se basa a menudo en un esquema explicatorio muy simple, basado en las creencias de una sociedad ${ }^{23}$.

En esto sigue Jansson a Geis ${ }^{24}$, que a su vez es deudor de Potter y Wetherell ${ }^{25}$, quienes afirman que los textos sociales no solamente describen realidades, sino que hacen realidades, y tienen por tanto implicaciones políticas. Aunque no compartimos del todo la tesis extrema de Geis - que defiende el constructivismo a ultranza, es decir, el lenguaje como realidad incluso más objetiva que la realidad misma - pensamos que el papel del lenguaje político como medio de creación de nuevas realidades sociales es un factor importante para explicar el devenir histórico, algo que no siempre ha sido bien comprendido. Para ilustrarlo, sin necesidad de acudir a ejemplos muy manidos como el de la retórica de Hitler o de Goering, baste citar, por lo que se refiere a España, los discursos de Azaña y de Prieto en la campaña electoral de 1936, o, por parte sueca, los discursos de

\footnotetext{
${ }^{22}$ RÜSEN, Jörn, Berättande och förnuft. Historieteoretiska texter, Gotemburgo: Daidalos, 2004, pp. 55-73.

${ }^{23}$ JANSSON, Per, Säkerhetspolitikens språk - Myt och metafor i svensk säkerhetspolitisk diskurs 19191939), Lund: Studentlitteratur 1991.

${ }^{24}$ GEIS, Michael, The language of Politics, Nueva York: Springer, 1987.

${ }^{25}$ POTTER, Jonathan \& WETHERELL, Margaret, Discourse and Social Psychology, Londres: Sage 1987.
} 
Per Albin Hansson sobre el "hogar popular" y los del ministro sueco de Negocios Extranjeros, Rikard Sandler, en $1936^{26}$.

Otro factor interesante que presentan los despachos diplomáticos en cuanto fuente histórica es la combinación que ofrecen - siempre que no sean estudiados individualmente, sino en relación con otros anteriores y posteriores, a lo largo de un lapso de tiempo determinado - del aspecto sincrónico con el diacrónico. A veces, esto es posible incluso en relación con un único suceso, y lapsos de tiempo muy breves. Con frecuencia, unos mismos acontecimientos aparecen doblemente narrados, en un despacho singular al momento de producirse, y en la memoria trimestral o semestral subsiguiente.

La combinación de lo sincrónico con lo diacrónico permite apreciar no sólo cambios de valoración, sino incluso variaciones en el contenido de los conceptos utilizados. La importancia del aspecto diacrónico - que con frecuencia muestra una tensión entre los cambios de significación de los conceptos y las alteraciones del momento histórico, que no siempre van parejos - es uno de los temas fundamentales en las teorías del historiador alemán Reinhart Koselleck, para quien el factor "tiempo" adquiere casi la categoría de personaje histórico. En contraste, el británico Quentin Skinner destaca como central el aspecto sincrónico, insistiendo en que los conceptos utilizados por un autor han de entenderse según su contexto retórico, es decir, su contenido específico depende del momento concreto en que ha sido utilizado, y de la intención del autor al utilizarlo ${ }^{27}$.

A la hora de proceder al análisis de las fuentes empíricas sobre las que se basa este estudio nos proponemos tener en cuenta los distintos parámetros teóricos que acabamos de comentar. No obstante, en consonancia con la opción teórica-metodológica que hemos adoptado - método cualitativo "abductivo", basado en la "teoría fundamentada" de Glaser y Strauss -, seguiremos especialmente a Skinner en la cuestión de interpretación conceptual, por considerarlo más afín con el método elegido. Este autor, en efecto, rechaza el método analítico-discursivo al afirmar que no es posible hacer historia de los conceptos en sí mismos, sino sólo la de la utilización retórica de los mismos en diversas situaciones. Lo decisivo son las intenciones del autor, lo que quiso decir ${ }^{28}$.

\footnotetext{
${ }^{26}$ SANDLER, Rickard, Utrikespolitiska kringblick: anföranden 1936, Estocolmo, 1937.

27 KOSELLECK, Reinhart, The Practice of Conceptual History. Timing History, Spacing Concepts, Stanford: Stanford University Press, 2002, p. 36 y s.; SKINNER, Quentin, "Rhetoric and Conceptual Change", Finnish Yearbook of Political Thought, no. 3, 1999, pp. 73 y ss.

${ }_{28}$ TULLY, James (coord.), Meaning \& Context: Quentin Skinner and his Critics, Cambridge: Cambridge University Press, 1988, p. 283.
} 
Finalmente, interesa destacar el valor de los despachos diplomáticos como fuente histórica, pero sin olvidar sus limitaciones. Son fuentes de sumo interés, ya que, aparte de lo ya señalado, no sólo constituyen una fuente narrativa de primer orden sino que, además, dejan constancia "en presente" de las expectativas, rumores, planes y pensamientos, de las circunstancias políticas y del día al día del devenir histórico. En ellos se puede apreciar claramente cómo valoraban los hechos - a medida que se iban produciendo - los representantes diplomáticos, la opinión pública, y sobre todo las personas de cuyo juicio se fiaban los informadores. En este sentido, los informes diplomáticos son como las páginas de un periódico cualificado, de un diario cuyas fuentes de información son privilegiadas pues van desde políticos del más alto nivel en el país receptor hasta informes de los servicios secretos propios y de los países amigos.

Y en ese mismo sentido, lo que constituye su fuerza, es también su limitación como fuente: vemos la realidad a través de los ojos de una sola persona - o a lo sumo dos informadores, en los casos en que diplomáticos subalternos, por ausencia del jefe de misión, hicieron sus veces como redactores de despachos - con todas las limitaciones e implicaciones que ello conlleva. Se trata de informadores situados en inmejorable posición desde el punto de vista de su cercanía temporal y espacial a los acontecimientos y a los centros del poder político, pero también susceptibles de presentación tendenciosa de los mismos, por formación personal y cultural o por interés político propio o de las fuentes a su disposición. Este último aspecto, el de la subjetividad o tendencia, queda sin embargo mitigado por el hecho de su distanciamiento respecto al país sobre el que informan.

Es evidente, sin embargo, que todo despacho diplomático, sobre todo si se refiere a la apreciación de la realidad política, depende de la información recabada, por el Embajador o el Cónsul, de personas muy concretas de su entorno, nacionales del país de residencia. Y es indudable que esas personas, y su visión de la situación política y económica de su patria, ejercerán una gran influencia en el resultado final de los despachos. A la hora de valorar el contenido de las informaciones que contienen es importante tener esto en cuenta.

Al mismo tiempo, es importante no perder de vista el contexto histórico en el que fueron formulados los despachos y lo que el historiador americano Hexter llamó la macroretórica imperante en una sociedad, es decir, el tipo de argumentos y de recursos 
retóricos aceptados en un contexto social determinado, en este caso los círculos diplomáticos españoles y suecos de la época ${ }^{29}$.

En el presente estudio, optamos por presentar de forma sistemática las fuentes diplomáticas disponibles, recurriendo profusamente al empleo de citas directas. Las de mayor extensión se presentarán en párrafos separados, mientras que las más cortas quedarán incluidas en el texto principal, debidamente entrecomilladas. La versión española de los documentos suecos citados es traducción propia nuestra, y en algunos casos donde la expresión empleada tiene especial relevancia hemos incluimos entre paréntesis el término sueco correspondiente.

Esta opción metodológica viene motivada por el deseo de dar mayor transparencia y credibilidad al análisis. Se trata de una estrategia consciente, en línea con las aportaciones teóricas de Quentin Skinner anteriormente expuestas, ya que las expresiones y las formas de decir utilizadas por los autores (en nuestro caso, los diplomáticos) son fundamentales para una mejor comprensión del mensaje que quisieron transmitir.

\subsubsection{Precisiones terminológicas}

Conviene, antes de cerrar este apartado, hacer algunas precisiones terminológicas. Se trata de explicar el uso que hacemos en estas páginas de algunos términos que podrían dar lugar a discusión.

En primer lugar, hemos preferido evitar el uso de la palabra "Embajador" para designar a los jefes de las representaciones diplomáticas de Suecia en Madrid y de España en Estocolmo, a pesar de que ése es el término habitual hoy en día. En su lugar, hemos optado por utilizar el término técnico con el que eran designados en la época: el de Ministros Plenipotenciarios, o - de manera resumida - Ministros de Suecia (o de España) en Madrid (o en Estocolmo).

Hasta la década de los años cincuenta del siglo XX, se distinguía, en el mundo diplomático, entre dos tipos de representación, las Embajadas (a cuyo frente estaba un Embajador) y las Legaciones (dirigidas por un Ministro). Sin entrar en especificaciones detalladas de tipo técnico, la diferencia entre una Embajada y una Legación era de rango. El número de Embajadas era mucho más reducido que el de Legaciones. Cada país mantenía una Embajada solamente en aquellos países que eran especialmente importantes para su política exterior, manteniendo relaciones a nivel de Legación con el resto. Así, en

\footnotetext{
${ }^{29}$ HEXTER, Jack H., The History Primer, New York: Allen Lane, 1972, p. 299 y ss.
} 
Estocolmo no había, en los años treinta del siglo XX, ninguna Embajada, teniendo todas las representaciones diplomáticas allí la categoría de Legaciones. En Madrid había algunas Embajadas - Reino Unido, Francia, Estados Unidos, Alemania, Argentina, Méjico, etc. - y bastantes Legaciones.

Somos conscientes de que el uso del término "Ministro" en este contexto puede inducir a confusión - y de hecho algunos historiadores actuales utilizan sin más el término "embajador" para designarles - pero nos parece preferible mantener el término histórico correcto, para evitar anacronismos.

De forma habitual, hemos optado por utilizar los términos en uso en la época para designar las distintas realidades objeto de nuestro estudio. Por ejemplo, designamos a los Ministerios de Asuntos Exteriores de cada país y a sus titulares con el nombre utilizado entonces: Ministerio de Estado, en la España republicana, y Ministerio de Negocios Extranjeros, en Suecia (así llamaron los diplomáticos españoles al Utrikesdepartementet sueco).

Hemos hecho alguna excepción puntual, utilizando el término "Ministerio de Asuntos Exteriores" para designar al organismo franquista encargado de esos menesteres, a pesar de que durante la guerra tuvo diversos nombres y la categoría de Secretaría.

Asimismo, utilizamos el término "presidente del gobierno" para designar al jefe del ejecutivo sueco, en vez de utilizar la traducción literal del título sueco, "Ministro de Estado" (Statsminister). La razón es obvia: evitar confusiones, al tratarse del término utilizado para designar al Ministerio español encargado de las relaciones exteriores. Los diplomáticos españoles utilizaron en la época diversas expresiones para referirse al Statsminister sueco ("Presidente del Consejo de ministros, jefe del gobierno, presidente del gobierno" o sencillamente el nombre del susodicho).

Utilizamos también, de manera preferente, la expresión "España de Franco" o "España franquista" para referirnos a la llamada "España Nacional" o Estado Español, aunque técnicamente este término no sea del todo correcto. El motivo de esta opción terminológica es que ése fue el nombre más comúnmente usado por la diplomacia sueca para referirse a la misma, aunque en ocasiones aparezcan también en los informes suecos expresiones como "España nacionalista", "el gobierno de Salamanca" o "el gobierno de Burgos". Esta última fue la más habitual en los dos primeros meses de la contienda. A partir de entonces, la denominación "España de Franco" (Francospanien) es la predominante en Suecia. 


\subsection{Fuentes para el estudio de las relaciones hispano-suecas de 1931 a 1939}

Exponemos a continuación una panorámica de los fondos documentales disponibles en los archivos suecos y españoles para nuestro estudio de las relaciones políticas y diplomáticas entre España y Suecia de 1931 a $1939^{30}$. Dada la abundancia de fuentes documentales primarias, no hay necesidad de acudir a otro tipo de material.

Los principales Archivos donde se encuentran fondos documentales de mayor relevancia para la temática objeto de nuestro estudio son, sin duda, los de los respectivos Ministerios de Asuntos Exteriores: el Archivo de Ministerio de Asuntos Exteriores y Cooperación, en Madrid (AMAEC) y el Archivo del Ministerio de Negocios Extranjeros incluido en el Archivo Nacional de Suecia (Riksarkivet, UD-arkiv, RA, UD) en Estocolmo.

Además, por lo que se refiere a España, analizaremos fondos del Centro Documental de la Memoria Histórica de Salamanca (CDMH), del Archivo General de la Administración (AGA) y del Archivo de la Fundación Pablo Iglesias (FPI) en Alcalá de Henares, del Archivo Histórico Nacional en Madrid (AHN), y del Archivo Histórico Militar, Sección Guerra Civil, Ávila (AGMAV).

En Suecia hay documentación relevante también en el Archivo y biblioteca del movimiento obrero sueco (Arbetarrörelsens arkiv och bibliotek, ARAB) en Estocolmo, en el Archivo sueco de medios audiovisuales y digitales en la Biblioteca Real de Estocolmo (Kungliga Biblioteket, Sveriges Media och Databas arkiv, KB, SMDA), en el Archivo de la Polícía de Seguridad (Riksarkivet, Säkerhetspolisens arkiv, RA-SÄPO), en el Archivo de la Guerra (Riksarkivet, Krigsarkivet, RA, KA) y en algunos archivos locales.

Llama la atención que la guía de Martínez Ruiz y Pi Corrales no mencione ningún fondo documental referido a Suecia durante los años treinta del siglo XX en el Archivo Histórico Nacional. Quizá sea esto debido a que la guía no desciende a cuestiones de

\footnotetext{
${ }^{30}$ En una investigación preliminar no publicada, nuestro Trabajo fin de Master titulado Relaciones políticas y diplomáticas entre España y Suecia de 1929 a 1939. Estado de la cuestión, introducción y fuentes para su estudio, Valladolid, 2010, comentamos in extenso los diversos fondos disponibles en España que hacen referencia a Suecia. Aquí sólo mencionaremos los más relevantes.
} 
detalle y se refiere fundamentalmente a conjuntos de fondos documentales más o menos específicos, completos y clasificados ${ }^{31}$.

En el Archivo Histórico Nacional hay algunos fondos relativos a políticos republicanos que tuvieron relación con Suecia, y algunas cuestiones más, pero en general de escaso interés ${ }^{32}$.

El Archivo general de la Administración contiene más documentación de relevancia para nuestro tema, aunque los principales fondos relativos a Suecia son de épocas anteriores. Por desgracia, la correspondencia de la Embajada de España con el Ministerio sueco de Asuntos Exteriores relativa a los primeros años del siglo XX, es la que contiene mayores lagunas ${ }^{33}$.

La documentación del AGA más interesante a efectos de este estudio es, sin duda, la contenida en los libros de entradas y salidas de escritos entre el Ministerio de Estado y las Embajadas y Legaciones. Contienen el registro completo de la correspondencia de entradas y salidas del Ministerio con las representaciones diplomáticas de España, numerados correlativamente, y gracias a ellos podemos conocer los temas sobre los que ha habido correspondencia. Esto es importante para cubrir las lagunas en los fondos del Archivo del Ministerio de Asuntos Exteriores que, por desgracia, existen en demasía: por ejemplo, los despachos de la Legación de España en Estocolmo correspondientes al año 1931, que no hemos conseguido localizar ${ }^{34}$.

Por fortuna, disponemos de posibilidades de contrastar la información con los fondos del Archivo Nacional de Suecia (Riksarkivet). Esta última documentación es muy abundante $\mathrm{y}$, en general, óptima en cuanto a orden y contenido, sin apenas lagunas documentales: también por esto, la documentación sueca puede ayudar a completar lagunas en los archivos españoles. También ayuda a cubrir lagunas la documentación de los años

\footnotetext{
${ }^{31}$ MARTÍNEZ RUIZ, Eduardo \& PI CORRALES, Magdalena de Pazzis, Sweden in Spain's general archives. Sources for hispano-swedish history. Suecia en los Archivos generales españolas. Fuentes para la historia hispano-sueca, Madrid: Fundación Berndt Wistedt, 2001.

${ }^{32}$ AHN, Diversos Títulos Familias, 3251, N. 229; 3254, N. 7 y Causa General de Madrid, Embajadas y Legaciones, L. 1563, paquete 10, doc. 4; también hay documentos en otras partes de la Causa General, recientemente trasladada al CDMH de Salamanca.

${ }_{33}$ AGA, Asuntos Exteriores, Caja 14068, carpeta 25; Cajas 14076 al 14078.

${ }^{34}$ AGA, Asuntos Exteriores, L. AE 6402, pp. 178-183 y AE 6403, pp. 126-128(año 1931); L. AE 6422, pp. 168-176 (año 1932); L. AE 6443 pp. sueltas, pp. 29-30 y pp. 118-125 (año 1933). L. AE 6464, pp. 143-152 (año 1934); L AE 6489, PP. 169-182 (AÑO 1935); L AE 6533 pp.189-199 (año 1936-37); L. AE 6544 (año 1937); L AE 3194 (año 1938); L AE 5991 pp. 160-240 (año 1939); AGA, Secretaría General del Movimiento, caja 27.
} 
1937 y 1938 de las Embajadas de España en Londres, París, Oslo y, especialmente, Helsinki (ya que allí era Ministra Isabel de Palencia, que lo era también en Estocolmo) ${ }^{35}$.

Por su parte, el Archivo del Ministerio de Asuntos Exteriores y Cooperación contiene en su "archivo renovado" (AMAEC, R) abundante información respecto a nuestro tema, por desgracia distribuida en muchos legajos diferentes, lo que la hace a veces difícilmente abarcable. Son relativamente pocos los legajos que contienen documentación completa, desde el punto de vista cronológico, de los despachos diplomáticos españoles, como por ejemplo el legajo AMAEC R 341, que recoge la mayor parte de los despachos de la Legación española en Estocolmo al Ministerio de Estado durante los años 1932 a 1934. Los temas son variadísimos, pero la mayor parte se refieren a asuntos de carácter político: desde información sobre los resultados de elecciones municipales y generales, cambios de gobierno, el estado de la opinión pública, envío de copias de los diarios de sesiones del Parlamento sueco, información sobre los sucesos más significativos de la vida nacional, como por ejemplo el suicidio de Ivar Kreuger y sus implicaciones políticas, y de modo especial todo lo relativo a política laboral y a política de control y defensa frente al fascismo y al nazismo. Un plato fuerte son los informes semestrales enviados por los Ministros de España, dando cuenta, de modo resumido de lo más notable de cada semestre concluido.

Al mismo tiempo, hay que decir, desde el punto de vista de la crítica de fuentes, que no es infrecuente encontrarse documentos que se han hecho desaparecer o incluso algunos que de antemano no se registraron ${ }^{36}$.

La documentación relativa a 1934 está más diseminada, y la de 1931 no hemos podido localizarla. La de los años de guerra, con las lagunas lógicas, está también en varios legajos Hay también información enviada a las autoridades de la otra zona de España por sus representantes, primero oficiosos y luego oficiales, en Estocolmo ${ }^{37}$.

\footnotetext{
${ }^{35}$ Cfr. AGA, Asuntos Exteriores, cajas nn. 5297, 5289, 5302, 5310 y 12093.

${ }^{36} \mathrm{Cfr}$. AMAEC R 341, donde quedan los márgenes de un documento rasgado de forma tal que no cabe duda de que ha sido eliminado conscientemente del archivo; AMAEC R 850, 18, despacho de 29 de enero de 1935: es la contestación a la Orden del Ministerio de Estado número 129/1934, y en el documento aparecen a lápiz unas palabras: "Orden verbal de archivarlo sin registrarlo". El despacho trata sobre la probable actitud de Suecia ante un conflicto bélico internacional.

${ }^{37}$ Cfr. AMAEC R 860, 74, AMAEC R 698, 10; AMAEC R 1785, AMAEC R 642, AMAEC R 1058, AMAEC R 4016, AMAEC R 1069, AMAEC R 1051, AMAEC R 1048 y AMAEC R 4002. La lista de legajos utilizables de este archivo es muy amplia.
} 
En el Archivo de la Fundación Pablo Iglesias en Alcalá de Henares se recogen los fondos de políticos y líderes sindicales socialistas, algunos de los cuáles tuvieron relación con Suecia. Este es el caso de Margarita Nelken, por ejemplo, que visitó el país en 1935 y tuvo una serie de actos políticos. Hay también cierta documentación referida a Isabel Oyarzábal de Palencia ${ }^{38}$.

El Centro Documental de la Memoria Histórica (CDMH) de Salamanca, a pesar de su ingente cantidad de fondos documentales, apenas contiene material clasificado relativo a Suecia. Se conservan algunas cartas de miembros de la SAC, organización sueca afín a la CNT-FAI española, enviando listas de suscriptores a revistas como por ejemplo Frente Libertario o circulares reservadas del comité nacional de la CNT que tocan temas de la política exterior de la República durante la guerra. También hay un informe del delegado de la CNT que asistió al Congreso de la SAC celebrado en Estocolmo el día 11 de septiembre de 1938, por citar algunos ejemplos ${ }^{39}$.

El problema básico de este archivo, desde el punto de vista de la investigación, es la cantidad de fondos aún no catalogados convenientemente y la dispersión de la documentación. No existe, por ejemplo, un registro por nacionalidades de los Brigadistas Internacionales de quienes se cuenta con documentación en el archivo. Sin embargo, queremos realizar una búsqueda más a fondo a partir del material general sobre los miembros de las Brigadas Internacionales que permita localizar nombres de brigadistas suecos que, por una u otra razón, hayan dejado rastro documental en este Archivo, para después contrastar los datos obtenidos con los existentes en Suecia, y completar, si es el caso, los hallazgos de la historiografía sueca al respecto.

Algo similar ocurre con los archivos militares españoles, como el de Ávila: los datos relativos a Suecia están dispersos, y supone mucho esfuerzo localizarnos. Sin embargo, hay referencias y expedientes relativos a algunos suecos, información de los suecos que lucharon en las Banderas de la Legión, información del número de prisioneros extranjeros en los campos de concentración, documentación de los servicios de inteligencia de la Legión Condor y del SIFNE sobre contrabando de armas, etc. Es especialmente este

\footnotetext{
${ }^{38}$ FPI-AH-73-38; FPI-ALA-98-27 y 28; FPI-AFLC-195-17; FPI-ALJA-450-1. El Archivo histórico del Partido Comunista de España, por su parte, no contiene nada de interés relativo a Suecia.

${ }^{39}$ CDMH, PS-Madrid, 1008/18; PS-Madrid 468/2; CDMH, PS-Barcelona, 523/10-17; CDMH, PS-Madrid, $663 / 44$
} 
material relativo al espionaje y de contrabando de armas el que puede resultar de más interés de cara a la aportación de datos hasta ahora desconocidos en Suecia ${ }^{40}$.

Respecto a los archivos suecos, es fundamental el Archivo Nacional (Riksarkivet), con sede en Estocolmo, en cuyo seno se engloban actualmente todos los Archivos generales estatales suecos. Los fondos documentales referidos a España durante los años 1920-1945 se encuentran en el archivo del Ministerio de Asuntos Exteriores (Utrikesdepartementet, UD), en la sección denominada "sistema de archivo de 1920" (1920-års dossierssystem). Hay cuatro legajos que contienen los despachos de los representantes diplomáticos suecos en España durante el período comprendido entre noviembre de 1929 y julio de 1936. Se trata de una documentación de primer orden, por lo completa y lo detallada que es. Además, por el principio de publicidad que imponen las leyes suecas a la Administración del Estado, que reduce a un mínimo las cuestiones reservadas, el material está, por lo que hemos podido colegir, completo y sin lagunas de ningún tipo ${ }^{41}$.

Los documentos relativos a los tres años de la Guerra civil están archivados en un archivo especial denominado "Guerra civil española", en 23 legajos. Aparte de los informes diplomáticos sobre la marcha de la guerra, el resto está ordenado según un criterio temático y no cronológico: "ayuda humanitaria sueca a España", "conflicto del Lola" o "establecimiento de relaciones con el gobierno de Franco"42.

Otros legajos contienen los fondos relativos a la actividad diplomática sueca en el seno del Comité de No Intervención de Londres, las entrevistas del Ministro sueco de Negocios Extranjeros con Embajadores y ministros extranjeros, lo tratado en el Comité parlamentario de Asuntos Exteriores o los fondos relacionados con el comercio exterior sueco en relación a España. Además, son también importantes los expedientes personales de los diplomáticos suecos destinados a España, en especial el de Ivan Danielsson ${ }^{43}$.

Asimismo, está conservado el archivo completo de la Legación de Suecia en Madrid, desde 1880 hasta 1995. Se trata de un total de 460 legajos que ocupan 35 metros de estantería, relativos en su mayoría al período 1920-1995. La mayoría se refiere a cuestiones de trámite, principalmente en cuestiones comerciales y consulares. No todos los

\footnotetext{
${ }^{40}$ AGMAV, Cajas 2472, 2481, 1092.

${ }^{41}$ RA, UD, 1920-års dossierssystem, H. Vol. 420-423.

${ }^{42}$ RA, UD, 1920-års dossierssystem, Vol. 1504-1528.

${ }^{43}$ RA, UD, HP 430:B; RA, Utrikesnämnden, Vol. 3, 4 y 5; RA, UD: P1: 167.
} 
documentos están disponibles a los investigadores, hay partes reservadas en conformidad con la ley de secretos oficiales. De estos fondos, los más relevantes para nuestra investigación son los diarios del Agregado militar de Suecia del período 1936-1942, los libros de registro de entradas y salidas (diarios), y la correspondencia entre los diplomáticos suecos acreditados en Madrid y algunos funcionarios del Ministerio de Negocios Extranjeros relativa a gestiones concretas ${ }^{44}$.

El Archivo y Biblioteca del Movimiento Obrero sueco (ARAB), en Estocolmo, contiene los fondos documentales de los partidos y sindicatos suecos de corte "noburgués", por usar terminología común en Suecia. El material que hay en él sobre la guerra civil española es abundantísimo. Aparte de los archivos institucionales, aquí están recogidos los archivos privados de muchos voluntarios suecos de las Brigadas Internacionales. Se trata de material con un notable interés en cuanto son testimonios de primera mano, pero lógicamente también con evidentes dificultades por tener una acusada tendencia, usado el término desde el punto de vista de las teorías de crítica de fuentes.

Se trata de una documentación inabarcable en un solo estudio y que supera los límites del ámbito específico de nuestra investigación. No obstante, haremos referencia a algunos fondos de este archivo en cuestiones relevantes a nuestro ámbito. ${ }^{45}$.

También el Archivo sueco de Medios Audiovisuales de la Biblioteca Nacional, en Estocolmo, contiene algunos fondos de interés: una entrevista radiofónica de 1937 a dos corresponsales suecos en España; varios documentales sobre la guerra civil y sobre las

\footnotetext{
${ }^{44}$ RA, UD, Beskickningsarkivet: Madrid, Vol. C3 (1929 - 1933) C4 (1934 - 1939), C5 (enero - abril 1939), C6 (mayo - diciembre 1939); C2 (1934 - 1939), C3 1939 (hasta abril 1939) y C4 1939 (desde mayo 1939); Vol. E1 31 (1925-1937), E1 32 (1937-38) y E1 33(1938-39); F 1 C Vol. 44-49.

${ }^{45}$ El listado de archivos privados dentro del ARAB que contienen material de interés es impresionante: Gösta Andersson, Stig Berggren, Gustav Blomberg, Georg Branting, Per Eriksson, Gösta Hjärpe, Max Hodann, Ernst Ingvar Karlsson, Carl Mattson, Sixten Olsson Rogeby, Knut Olsson, Kajsa Rothman y Helmut Rüdiger. Además, hay decenas de legajos con fondos sobre la guerra civil española de diversas organizaciones: International Rescue Committee, Svenska frontkämparnas stödfond (Fondo de ayuda a los combatientes suecos), Svenska hjälpkommittén för Spanien (Comité Sueco de Ayuda a España), Spanienkommittén för Stockholm (Comité de Ayuda a España de Estocolmo), Nyköpings lokala Spanienkommitté (Comité de Ayuda a España de Nyköping), Sveriges arbetares centralorganisation (SAC) (Central Sindical de Trabajadores de Suecia), Södra förstädernas Spanienkommitté (Comité de Ayuda a España de los barrios del sur de Estocolmo), y especialmente de la Svenska Spanienfrivilligas kamratförening (Asociación de Camaradas Voluntarios suecos en España). A ellos, hay que añadir los archivos de los partidos políticos y de las organizaciones sindicales: Partido Comunista sueco (SKP, 4 legajos), el Partido Socialista (SP, 6 legajos), la Unión de Sindicatos (LO, 8 legajos), el Partido Socialdemócrata (SAP, 13 legajos específicos): cfr. ARAB. VP Kommunistiska partiet, Serie ÖS, vol. 4-7; ARAB, Socialistiska partiet, Serie E1, vol. 3, 7, 10, 14, 18 y 23; ARAB, LO, arkiv nr. 2964, E09A, vol. 016 a 022; F08E, vol. 09; ARAB, SAP, Serie F02,D y serie E5.
} 
iniciativas suecas en la misma (Hogares de huérfanos y Hospital sueco-noruego de Alcoy), y un documental de la visita de Alfonso XIII a Suecia el 14 de agosto de $1931^{46}$.

\subsection{Estructura del presente estudio}

Una vez expuestos el planteamiento general, los presupuestos teóricos y metodológicos y las fuentes documentales que sirven de base al presente estudio, presentamos a continuación la estructura que nos proponemos seguir en el mismo.

El ámbito temporal de nuestra investigación son los años 1931 a 1939, período crucial en la historia de los dos países que aquí consideramos, Suecia y España. En España, esos años corresponden a los del nacimiento, desarrollo, y final de la Segunda República y tienen una clara línea divisoria con el comienzo de la guerra en julio de 1936. En Suecia, la división tradicional es entre el "período de las minorías parlamentarias" hasta las elecciones de septiembre de 1932, y la llamada "época de Per Albin Hansson", el presidente del gobierno socialdemócrata-agrario que - con la excepción transitoria del verano de 1936 - dirigiría los destinos de Suecia en el resto de la década.

Hemos optado por estructurar este trabajo siguiendo la línea divisoria tradicional en la historiografía española, dividiendo nuestra exposición en dos períodos: el período de paz (1931-1936) y el de guerra (1936-1939). Nuestro estudio se estructura, por lo tanto, en dos partes expositivas principales, flanqueadas por una parte introductoria inicial y una parte conclusiva final.

A la parte introductoria corresponden dos capítulos de menor extensión que los de las partes expositivas. El capítulo primero expone el planteamiento general y los presupuestos de la investigación y consta de cuatro apartados. El primero plantea los objetivos y cuestiones fundamentales del mismo. El segundo expone los presupuestos teóricometodológicos en una triple vertiente: a) las posibilidades y problemas de la historia comparada y de la historia de las relaciones internacionales; b) las opciones teóricometodológicas del presente estudio; y c) algunas precisiones terminológicas. El tercer apartado hace una presentación general del material a utilizar, las fuentes archivísticas suecas y españolas. El cuarto, dedicado a la estructura, es el que ahora nos ocupa.

\footnotetext{
${ }^{46}$ KB, SMDB, SR-Minnen 2009-09-25; Skånefilmer, n. 55-94/2000-94 rollo 03.
} 
El capítulo segundo se centra en el encuadre histórico de las relaciones políticas y diplomáticas entre Suecia y España y en el estado actual de la cuestión concreta - las relaciones en la década de los treinta del siglo XX - en la historiografía española y sueca.

Seguirá a continuación la parte expositiva, estructurada en las dos partes a que hemos hecho referencia:

a) Parte primera: Las relaciones entre Suecia y España de 1931 a 1936

b) Parte segunda: Las relaciones entre Suecia y España de 1936 a 1939

Cada una de esas partes estará, a su vez dividida en tres capítulos.

A la primera parte, dedicada a las relaciones en los años de la Segunda República anteriores a la guerra civil, corresponden los capítulos tercero, cuarto y quinto. El primero de ellos expone la visión de la República Española de 1931 a 1936 que transmitió la diplomacia sueca a su gobierno (capítulo 3); el segundo, la visión de la Suecia del mismo período que dieron los diplomáticos españoles en Estocolmo (capítulo 4); y finalmente, las relaciones diplomáticas bilaterales entre España y Suecia en el período (capítulo 5).

La segunda parte, a la que corresponden los capítulos sexto, séptimo y octavo, presenta las relaciones de Suecia con cada una de las dos zonas de España. En primer lugar, se exponen las relaciones con la República (capítulo 6) y después las relaciones con la España de Franco (capítulo 7). El último capítulo está centrado en la intervención de Suecia en la guerra civil española (capítulo 8).

Finalmente, sigue el capítulo final, dedicado a las conclusiones.

No quiero acabar estas líneas introductorias sin manifestar mi profundo agradecimiento a cuantos han hecho posible este trabajo. Toda tesis doctoral supone un proceso enriquecedor y apasionante, y en su realización colaboran muchas personas, de manera más o menos activa, pero siempre importante. Especial mención merece la dirección y el personal del Instituto de Historia Simancas de la Universidad de Valladolid, que aceptó mi proyecto de investigación en el marco de su prestigioso programa de Doctorado "Europa y el atlántico: poder, cultura y sociedad". Mi agradecimiento se dirige igualmente a mis directores de tesis, los Dr. José-Vidal Pélaz López y Lars Berggren y al Departamento de Historia de la Universidad sueca de Lund, donde pude realizar una estancia de un año entero de duración en el marco de este trabajo. Mi recuerdo se dirige también al personal - atento, servicial y de gran profesionalidad - de los diversos Archivos españoles y suecos donde he llevado a cabo mis investigaciones, en particular, entre los 
primeros, los del Ministerio de Asuntos Exteriores de Madrid, el Archivo General de la Administración de Alcalá de Henares, el Centro Documental de la Memoria Histórica y el Archivo General Militar de Ávila; y, entre los suecos, el Riksarkivet, el Arbetarrörelsens arkiv y la Kungliga Biblioteket.

Y finalmente, agradezco a todos mis colegas doctorandos, y a todos mis amigos, por su paciencia y apoyo en el camino emprendido. 


\title{
Capítulo 2
}

\section{CONTEXTO HISTÓRICO Y ESTADO DE LA CUESTIÓN}

\begin{abstract}
España, al elegir durante el siglo XX el aislamiento y la neutralidad, antes de caer víctima de la no intervención de las democracias occidentales, se separó del ritmo europeo ${ }^{l}$
\end{abstract}

\subsection{Las relaciones históricas entre España y Suecia}

\subsubsection{Suecia y España hasta 1900}

Las relaciones históricas entre España y Suecia apenas habían captado la atención de la historiografía hasta muy recientemente. En Suecia, Magnus Mörner ${ }^{2}$ y el Instituto Iberoamericano de la Universidad de Gotemburgo fueron pioneros en el despertar del interés académico por las relaciones entre Suecia y España. Después, los "Encuentros históricos España-Suecia”, iniciados al final de los años noventa del pasado siglo, han hecho las aportaciones principales sobre la cuestión. En España, salvo algún trabajo esporádico ${ }^{3}$, hasta hace muy poco tampoco ha habido trabajos monográficos sobre relaciones históricas con Suecia.

Basándonos principalmente en los trabajos de Mörner y otros investigadores suecos, presentamos a continuación un somero encuadre general de las relaciones hispano-suecas a través de la historia.

Desde hace cinco siglos, con los primeros reyes de la dinastía Vasa, se puede hablar de goticismo. Con ese nombre se designó al principio las corrientes de pensamiento que pretendían situar en Suecia la patria de los godos, en concreto en la región de Götaland. La parte occidental de la misma (Västergötland) sería el feudo de los visigodos, si bien este

\footnotetext{
1 AUBERT, Paul, "avant-propos", en "España, Europa y el Mediterráneo", Bulletin d'Histoire Contemporaine de l'Espagne, n. 27, junio 1998, p. 15: “L'Espagne, en choisissant, au cours du XXe siècle, l'isolement et la neutralité, avant d'être victime de la non-intervention des démocratiesoccidentales, s'est détachée du rythme européen"

${ }^{2}$ MÖRNER, Magnus, España y Suecia en el siglo XVII: problemas y alcandes de los enfoques comparativos. Gotemburgo: Instituto Ibero-americano, 1998; BENSON, Ken, MÖRNER, Magnus \& SÖHRMAN, Ingmar, Relaciones entre España y Suecia desde mediados del siglo XVII hasta comienzos del XIX, Gotemburgo: Sección de español, Universidad de Gotemburgo, 2002; GYBERG, Erik, Spanien i svensk litteratur: en bibliogralfi = España en la bibliografía sueca: una bibliografía . Gotemburgo: Biblioteca universitaria de Gotemburgo, 1973.

${ }^{3}$ HILLMAN, Adolfo, “Ojeada a las relaciones históricas entre España y Suecia”, Revista crítica de historia y literatura, 1894.
} 
extremo no es un hecho históricamente comprobado. Posteriormente, el término goticismo pasó a designar el movimiento cultural de carácter nacionalista pan-escandinavo, que surgió a mediados del siglo XIX. En ese contexto se inscriben algunas obras del primer literato de Suecia, August Strindberg, sobre las relaciones del país escandinavo con España y Portugal y algunas huellas de los países ibéricos en la historia sueca 4 .

Históricamente, son conocidas las incursiones de los vikingos en la península Ibérica durante los siglos IX, X y $\mathrm{XI}^{5}$. Los vikingos suecos tenían sus rutas de comercio y navegación hacia el este, mientras que los vikingos que tuvieron contacto con España fueron de la zona suroeste de la península escandinava, es decir, de Dinamarca, Escania, Hallandia y Noruega.

En la Edad Media los principales contactos fueron a través de las peregrinaciones a Santiago de Compostela, especialmente la de Santa Brígida de Suecia y su séquito. Santa Brígida se rodeó pronto de colaboradores españoles, entre ellos el que fuera Obispo de Jaén Alonso de Pecha, que como confesor suyo en los últimos años de su vida fue el depositario y editor de las Revelaciones de la Santa ${ }^{6}$.

A comienzos de la Edad Moderna, los contactos entre Suecia y España son esporádicos, como en relación con el acceso al trono sueco en 1520 de Isabel, la hermana del Emperador Carlos V y consorte del rey de la Unión de Kalmar Cristián II ${ }^{7}$, o la embajada de Francisco de Eraso en Suecia en 1579, consecuencia de los primeros contactos diplomáticos entre España y Suecia que habían tenido lugar en la época de Felipe II, en Roma, entre el embajador español Juan de Zúñiga y el embajador sueco Pontus de la Gardie. El embajador sueco había ofrecido a Felipe II la ayuda de la flota sueca y de una fuerza militar terrestre para resolver los problemas de Flandes, pidiendo a cambio una base comercial (puerto o tierra) en la Frisia occidental. El Rey de España

\footnotetext{
${ }^{4}$ STRINDBERG, August, "Relations de la Suède avec l'Espagne et le Portugal jusqu'à la fin du dix-septième siècle", Boletín de la Real Academia de la Historia, T.16, Madrid, 1890, pp. 321-342; "Spanska och portugisiska minnen ur svenska historien", Samlade skriften 27, Estocolmo, 1917, pp. 67-90.

${ }^{5}$ Una obra de referencia en castellano se encuentra en MORALES ROMERO, Eduardo, Historia de los Vikingos en España, Madrid :Colección Malos Tiempos, 2006.

${ }^{6}$ Sobre Santa Brígida y España cfr. ALMAZÁN, Vicente, Santa Brígida de Suecia - peregrina, política, mística, escritora, Santiago de Compostela: Xunta de Galicia, 2000; MARTÍNEZ RUIZ, Enrique y PI CORRALES, Magdalena de Pazzis (coord.), El mundo escandinavo, Santa Brígida y el Camino de Santiago. (Encuentros Históricos Suecia-España VIII), Santiago de Compostela: Fundación Berndt Wistedt, 2002; BORGENSTIERNA, Anne Christine (coord.), Santa Brígida, patrona de Europa, Fundación Berndt Wistedt, Valladolid, 2005.

${ }^{7}$ Sobre Isabel de Suecia cfr. PEIX GELDART, Benito, "Isabel la luterana", en ZALAMA, Miguel Ángel (dir.) et al., Juana I en Tordesillas: su mundo, su entorno, Valladolid, 2010, pp. 333-346.
} 
envió al capitán Francisco de Eraso pero al final, a pesar de llegar un acuerdo preliminar sobre la propuesta de liga o alianza, todo quedó en agua de borrajas ${ }^{8}$.

Durante la primera mitad del siglo XVII, las relaciones entre ambos países no pudieron ser más tirantes. La entrada de Suecia en la guerra de los Treinta Años colocó al país en hostilidad directa con la Monarquía de los Habsburgo. Los ejércitos de Gustavo II Adolfo - conocido en España como "el monstruo de Stockholmia" - y los Tercios españoles se enfrentaron en el campo de batalla. Suecia y España se encontraron, como ha dicho Mörner, en polos opuestos. Solamente con la firma del Tratado de Westfalia, que puso fin a la Guerra de los Treinta Años, se hicieron amigos los grandes diplomáticos de ambos países, Saavedra Fajardo y Schering Rosenhane. La actividad diplomática entre España-Suecia durante la década 1640-1650, en torno a la paz de Westfalia, fue intensa y dio lugar a numerosos encuentros ${ }^{9}$.

Tras el acceso al trono de la Reina Cristina, España tuvo embajadores en Estocolmo, Bernardino de Rebolledo y Antonio Pimentel de Prado. Los despachos de Pimentel son una fuente básica para el conocimiento de la época. Tuvo éste gran influencia en la Corte de Estocolmo y fue confidente de la Reina Cristina incluso después de su abdicación ${ }^{10}$.

Por otra parte, Matthias Palbitzki, el primer Embajador sueco en Madrid, consiguió ventajas comerciales a través de un acuerdo de libre comercio con España sobre algunos

\footnotetext{
${ }^{8}$ QUATREFAGES, René, "Las relaciones diplomáticas hispano-suecas (s. XVI-XVII)", en MARTÍNEZ RUIZ, Eduardo y PI CORRALES, Magdalena de Pazzis (coord.), España y Suecia en la Época del Barroco (1600-1660), Fundación Berndt Wistedt, Madrid, 1998, p. 995.

${ }^{9}$ MÖRNER, Magnus, Episodios de la historia de las relaciones hispano-suecas: España y Suecia a través de los tiempos, imágenes y realidades, Madrid: Fundación Berndt Wistedt, 1996, pp. 8 y ss; CORREDERA NILSSON, Enrique, Todos somos godos. Las relaciones hispano-suecas desde la década de 1640 hasta la Paz de Oliva, Madrid: Editorial complutense, 2009, especialmente pp. 109-130

${ }^{10}$ Sobre la Reina Cristina hay más bibliografía con alguna referencia a España: RODÉN, Marie Louise, "La reina Cristina de Suecia, España y la política de la corte papal en el siglo XVII", en MARTÍNEZ RUIZ, Eduardo \& PI CORRALES, Magdalena de Pazzis (coord.), España y Suecia en la Época del Barroco (16001660), Madrid: Fundación Berndt Wistedt, 1998; OCHOA BRUN, Miguel Ángel, Embajadas y embajadores en la Historia de España, Madrid: Aguilar, 2002, pp. 305-309; GONZÁLEZ CAÑAL, Rafael, "El Conde de Rebolledo y la Reina Cristina de Suecia: una amistad olvidada", en Tierras de León, núm. 26, 1986, pp. 93108; ALLENDESALAZAR, Ursula, La Reina Cristina de Suecia, Madrid: Marcial Pons Historia, 2009; VÁSQUEZ LOPESA, Julián, Bajo el signo de la diplomacia: la reina Cristina en la literatura del Siglo de Oro: del Conde Bernardino Rebolledo a Calderón y Bancer Candamo, Gotemburgo: Instituto iberoamericano, 1998; En sueco, están publicados los despachos del Embajador de España Pimentel de Prado, en BERENCREUTZ, Nils (ed.), Don Antonio Pimentels depescher från drottning Christinas hov 1652-1656 jämte svarsskrivelser och spanska statsrådsprotokoll, Estocolmo, 1961. Cfr. también nuestro trabajo sobre la reacción en Suecia a la conversión de la reina: PEIX GELDART, Benito "Drottning Kristinas trosförändring: den svenska reaktionen 1655-1660", trabajo inédito fin de máster en la Universidad de Estocolmo, 1998.
} 
productos, especialmente la sal y el cobre, y consiguió también la liberación de los presos de la batalla de Nordlingen ${ }^{11}$.

Sobre las relaciones entre ambos países en el siglo del Barroco existe un estudio monográfico comparado de ambos países, dividido por áreas: las políticas nacionales; España y Suecia en una Europa en Guerra: recursos, medios y ejércitos; las monarquías y sus estructuras; la cultura barroca en Suecia y en España; los testimonios artísticos de la relación hispano-sueca; y el análisis comparativo final, de Magnus Mörner ${ }^{12}$.

En 1667 Suecia envió un embajador a Madrid, Carl Tungel. Al año siguiente, tras la Paz de Aquisgrán en la que España se comprometió a pagar subsidios a las naciones garantes del mismo - entre las que estaba Suecia - el Conde de Fernán Núñez llegó como embajador a Suecia, para concretar las cuestiones del subsidio y para favorecer el comercio. No resultó fácil. Los suecos, según el embajador de España, "en medio término no admiten ni excluyen". Suecia se encontraba en una posición ambigua: por un lado, era firmante de la Triple Alianza de 1668 con Inglaterra y los Estados Generales, pero por otra le unían estrechos vínculos con Francia, a la que terminaría dando su apoyo ${ }^{13}$.

El siglo XVIII supuso cambios radicales para ambos países: en España, la época borbónica con su centralización del Estado; en Suecia, la llamada "época de la libertad", en el que el Parlamento tomó de hecho las riendas del Estado. Ambos países, a consecuencia de las guerras del siglo XVII y los veinte primeros años del XVIII, habían perdido protagonismo en la escena internacional, pasando a ser potencias de segundo rango. Eso tuvo su reflejo en el rango de los representantes diplomáticos que se intercambiaron, que manifiestan claramente la poca importancia que ambos países concedían entonces a las relaciones mutuas.

La cooperación entre los dos países mejoró a partir de mediados de siglo como consecuencia del problema de los piratas berberiscos en el Mediterráneo, que llevarían a Suecia a enviar navíos de su Marina de guerra para combatirlos. En general, las relaciones fueron buenas, pues por parte española el interés diplomático era que Suecia se mantuviera del lado francés en los conflictos internacionales, cosa que también era la opinión mayoritaria en el país nórdico. En 1749 llegó a Suecia el marqués de Grimaldi, el que sería secretario de Estado con Carlos III, que desaconsejó la firma del tratado comercial y

\footnotetext{
${ }^{11}$ MÖRNER, Magnus, Episodios de la historia de las relaciones hispano-suecas..., p. 10; FREDRIKSSON., op. cit., pp. 47.

${ }^{12}$ MARTÍNEZ RUIZ, E. y DE PAZZIS PI CORRALES, M. (coord.), España y Suecia en la Época del Barroco..., índice, pp. 5-9.

${ }^{13}$ RA, sección Hispanica, Vol. 2, despachos de Tungel; QUATREFAGES, op. cit., p. 1001-1005.
} 
militar con Suecia que se llevaba negociando desde los tiempos del marqués del Puerto por no parecerle beneficioso para España. También fue embajador español en Suecia el marqués de Puentefuerte, enviado para tratar de evitar un acercamiento de Suecia a Maria Teresa de Austria, candidata al trono imperial ${ }^{14}$.

Al mismo tiempo, en Cádiz se habían instalado un cierto número de comerciantes suecos, motivando la necesidad de la presencia en Madrid de embajadores suecos que velaran por sus intereses. El primer embajador permanente en la capital de España fue Peter Axel Fleming, nombrado en 1741. De los informes que envió a Suecia se desprende el carácter preeminentemente comercial de los intereses suecos en España en esta época. No en vano, la famosa Compañía de las Indias orientales sueca utilizaba el puerto de Cádiz como base de todas sus operaciones con China, especialmente en el período $1732-1806^{15}$.

A partir de 1761, los Embajadores de España tendrán como principal función "recordar la existencia de España" y recabar información sobre la organización política, económica y comercial. Lo mismo se puede afirmar de los embajadores suecos en Madrid. También aumentaron las relaciones culturales y comerciales entre los dos países, normalizándose las relaciones ${ }^{16}$.

Sorprende un tanto que sobre las relaciones políticas y diplomáticas entre España y Suecia durante el siglo XIX apenas haya trabajos monográficos ${ }^{17}$. Respecto a ellas escribió Facundo Goñi:

\footnotetext{
${ }^{14}$ SÁNCHEZ DIANA, José María., "Relaciones de España con Suecia en el siglo XVIII", Revista Hispania LXXXVIII, 1962, pp. 590-627; LAVANDEIRA HERMOSO, Juan Carlos, "Las relaciones diplomáticas hispano-suecas: Una visión de conjunto a mediados del siglo XVIII" en BENSON, MÖRNER \& SÖHRMAN, op. cit.; Cfr. FREDRIKSSON, op.cit., p. 51, sobre los intentos del embajador sueco Ernst August Vellingk de conseguir un préstamo español para la guerras de Carlos XII de Suecia. Sobre la labor del primer Embajador borbónico en Suecia, el marqués del Puerto, cfr. MARTÍNEZ RUIZ, Enrique y PI CORRALES, Magdalena de Pazzis, "Guerra y comercio. La propuesta de un tratado comercial hispano-sueco a mediados del siglo XVIII" y LAVANDEIRA HERMOSO, Juan Carlos, "Política y comercio de mediados del siglo XVIII: Algunos informes del marqués del Puerto desde la Embajada española en Suecia", ambos en RAMOS SANTANA, Alberto, (coord.) Comercio y navegación entre España y Suecia (siglos $X$-XX), Cádiz: Fundación Berndt Wistedt, 2000.

${ }^{15}$ FREDRIKSSON, op. cit., p. 53.

${ }^{16}$ SILVÁN, Leandro, "Relaciones científicas hispano-suecas en el siglo XVIII", Boletín de la Real sociedad bascongada de amigos del país, San Sebastián, 1981; LÖFLING, Petri, Petri Loefling Iter Hispanicum eller Resa til spanska länderna uti Europa och America, förrättad ifrån år 1751 til år 1756, med beskrifningar och rön öfver de märkvärdigaste växter publicado tras su muerte por Carl Linnaeus, Estocolmo, 1758; NILZÉN, Göran, “Anders Nordencrantz som konsul i Portugal", en Personhistorisk tidskrift 1986, pp. 42-56; LAVANDEIRA HERMOSO, Juan Carlos, op. cit., 2002, p. 54-61; MÖRNER. Magnus, "España y Suecia desde finales del siglo XVII hasta comienzos del XIX: algunas notas introductorias", en BENSON, MÖRNER \& SÖHRMAN, op. cit., p. 15-26.

${ }^{17}$ La principal excepción es BÉCKER, Jerónimo, Historia de las relaciones exteriores de España durante el siglo XIX. Apuntes para una historia diplomática (Volumen 3 de Historia de las Relaciones Exteriores de España durante el siglo XIX), Madrid: Estab. tip. de J. Ratés, 1924.
} 
En cuanto a la Suecia, también se halla con la España en comunicación amistosa que no ha sufrido interrupción desde el tratado de paz concluido en Stockolmo en 19 de marzo de 1813. Dio ocasión a este tratado la guerra europea contra Napoleón, en la cual es sabido que la Suecia, separándose del partido del conquistador, se unió á la Rusia para hostilizarle. La Suecia por el tratado referido reconoció explícitamente las cortes de Cádiz y la constitución que estas decretaron, siguiendo el ejemplo de las demás potencias en aquel peligroso conflicto. Posteriormente, en 26 de abril de 1841 se ajustó un convenio por el cual quedaron facultados los súbditos de Suecia y España para adquirir recíprocamente bienes en ambos países, sin satisfacer el derecho denominado jus detractas ni otro alguno, en la misma forma que lo había estipulado España con otras naciones, según indicamos poco antes. Actualmente reside en Stockolmo un encargado de negocios de España, y á su vez la corte sueca tiene en Madrid un agente diplomático con igual carácter ${ }^{18}$.

Entre 1813 y 1815 ocupó el cargo de Embajador en Madrid una figura de la alta nobleza sueca, Jacob Gustaf De la Gardie. Los años 1812-1813 fueron importantes desde el punto de vista de las relaciones con España, enfrentadas por un conflicto durante las guerras napoleónicas que había llegado a provocar la retirada del enviado sueco en Madrid, Adlerberg, en 1806. En 1810, Suecia nombró heredero al trono a Jean-Baptiste Bernadotte, antiguo mariscal de Napoleón que luego se convirtió en su enemigo. Suecia entró en la liga antinapoleónica y como tal pasó a ser aliada de España. El resultado fue el Tratado de Paz y Amistad entre Suecia y España de 1813. Al poco tiempo, en 1815 fue nombrado encargado de negocios sueco en Madrid Gustaf Daniel Lorich, cargo que ocupó durante nada menos que 37 años. Lorich se decantó claramente por el partido isabelino ${ }^{19}$.

Posteriormente, entre los embajadores de Suecia en Madrid durante el siglo XIX, hubo bastantes noruegos. De hecho, durante esa época - Noruega estaba entonces, entre 1815 y 1905, en unión personal con Suecia - la preponderancia de diplomáticos noruegos en el servicio exterior fue notable. Las memorias de uno de ellos, Wedel Jarlsberg describen muy bien la vida de los diplomáticos de la época ${ }^{20}$.

\footnotetext{
${ }^{18}$ GOÑI, Facundo, Tratado de las relaciones internacionales de España: Lecciones pronunciadas en el Ateneo de Madrid, Madrid: R. Rodríguez de Rivera, 1848, p. 194.

19 FREDRIKSSON, op. cit., p. 63; cfr. también RA, Hispanica, Gustaf Daniel Lorichs depescher. Los despachos de Lorichs analizan detalladamente toda la realidad política española del turbulento período en el que le tocó vivir. Que sepamos, no han sido aún objeto de estudio pormenorizado.

${ }^{20}$ WEDEL JARLSBERG, Fredrik, Reisen giennem livet, Oslo 1932.
} 


\subsubsection{Suecia y España de 1900 a 1930}

Hasta aquí hemos seguido básicamente a Berndt Fredriksson en su trabajo sobre los Embajadores de Suecia. Sorprende, sin embargo, que su estudio pase directamente de hablar de los Embajadores anteriores a 1914 a los de la década de 1940. Silencio incomprensible a primera vista, y que es un motivo más a favor de la importancia y necesidad de un estudio pormenorizado de las relaciones hispano-suecas en el período de entreguerras. Sencillamente, no parece existir ninguno. Hay una importante laguna historiográfica.

Se ha dicho que España se replegó en sí misma a partir del primer tercio del siglo XIX inhibiéndose de la política exterior, a consecuencia de factores como la crisis bélica, la inestabilidad política, la crítica situación económica y la pérdida de las colonias americanas. A partir de 1833 irían entrando en España las ideas de europeismo, de equilibrio de poder, de necesidad de un orden internacional, y la neutralidad se convirtió en el ideal de política exterior, para garantizar la paz y salvar las colonias.

La historiografía española moderna sobre relaciones internacionales - de la mano de autores como Jover Zamora, Martínez Carreras, Pereira Castañares, Seco Serrano, Tusell Gómez, Neila Hernández, etc. - ha ido poniendo en discusión esos tópicos vigentes sobre una pretendida tibetatización de España y su aislamiento de la esfera internacional en el siglo XIX y primer tercio del XX. Algunos autores, como Sebastian Balfour y Paul Preston, señalan que las crisis y guerras civiles de España son formas específicas de crisis más globales a nivel europeo ${ }^{21}$. Efectivamente, como dice Torre del Río:

Entre 1875 y 1914, la política exterior española se desarrolló en el marco de los tres grandes procesos que, en esos años, fueron transformando el sistema internacional europeo: el sistema bismarckiano, la redistribución colonial de los años noventa y la formación de la entente franco-británica y del sistema bipolar que precede a la Primera Guerra Mundial ${ }^{22}$.

Por otra parte, la bipolaridad del sistema internacional y el despegue del capitalismo en España en el período de entreguerras, llevaron al país a acortar distancias con la Europa avanzada, contribuyendo a dar cierta "autonomización" a la política exterior española. El

\footnotetext{
${ }^{21}$ BALFOUR, Sebastian \& PRESTON, Paul, (coord.), España y las grandes potencias en el siglo XX. Barcelona: Crítica, 2002.

${ }^{22}$ TORRE DEL RÍO, Rosario de la, "Recogimiento, crisis del 98 y nueva orientación internacional", en PEREIRA CASTAÑARES, Juan Carlos, La política exterior de España (1800-2003): historia, condicionantes y escenarios, Madrid: Ariel, 2003.
} 
monarca, Alfonso XIII, adoptaría gran protagonismo en la dirección de la política exterior $^{23}$. El Rey postulaba un neutralismo, siempre que no se pusiera en entredicho la integridad territorial de España o de sus últimos reductos coloniales. Sin embargo, a juicio de muchos, faltaba una visión clara de política exterior, siendo supeditada ésta a los problemas de orden interno ${ }^{24}$.

Moreno Juste destacó el concepto y el afán de "europeización” como una coordenada básica de la política exterior española a lo largo de los siglos XIX y $\mathrm{XX}^{25}$. En este sentido cabría esperar un mayor protagonismo de las relaciones entre Suecia y España, los "grandes periféricos", dos de los más importantes países neutrales en las dos guerras mundiales. A primera vista parece, sin embargo, que no fue así, si consideramos la escasez de referencias a Suecia en la historiografía española de relaciones internacionales del período $^{26}$.

La dictadura del General Primo de Rivera trajo consigo grandes cambios, con un intento de potenciación y regeneración de toda la administración española, aunque se hizo con ciertas contradicciones. Se potenció la diplomacia cultural y el Ministerio de Estado fue sustituido por el directorio militar. Al instaurarse el directorio civil en 1925 fue restablecido, estando a su frente como Ministro de Estado José Yanguas Messía. Tras su dimisión, asumió Primo de Rivera personalmente la cartera, hasta la supresión de la misma a fines de 1928. No se restablecería hasta el 21 de febrero de $1930^{27}$.

En este período tiene lugar el enfrentamiento con Suecia en el seno de la Sociedad de Naciones, que acaba con el veto del país nórdico a la adjudicación a España de un puesto en el Consejo Permanente de la organización internacional y el consiguiente abandono temporal de la misma por parte de España. Fue la gran "ofensiva diplomática de España"

\footnotetext{
${ }^{23}$ NIÑO RODRÍGUEZ, Antonio, "Política de alianzas y compromisos coloniales para la Regeneración internacional de España, 1898-1914”, en TUSELL, Javier, AVILÉS, Juan \& PARDO, Rosa (coord.), La política exterior de España en el siglo XX, Madrid: Biblioteca Nueva, 1997, pp. 31-94.

${ }^{24}$ Así lo afirman JOVER ZAMORA, José María, GÓMEZ-FERRER, Guadalupe y FUSI, Juan Pablo, España: sociedad, política y civilización (siglos XIX y XX), Madrid: Areté, 2001.

${ }^{25}$ MORENO JUSTE, Antonio, "Del problema de España a la España europeizada: excepcionalidad y normalización en la posición de España en Europa”, en PEREIRA CASTAÑARES, Juan Carlos (coord.), La política exterior de España...., pp. 295-317.

${ }^{26}$ Suecia no aparece mencionada en la obra de SECO SERRANO, Carlos, "Alfonso XIII y la diplomacia española de su tiempo", en Corona y diplomacia: La monarquía española en la historia de las relaciones internacionales, Madrid: Biblioteca Diplomática Española, 1988, pp. 185-211. Por su parte, la única referencia a Suecia en la lista bibliográfica de PEREIRA CASTAÑARES, Juan Carlos (coord.), La política exterior de España...., pp. 575-607, es un opúsculo de MÖRNER, Magnus, Episodios de la historia de las relaciones hispano-suecas: España y Suecia a través de los tiempos, imágenes y realidades $=$ Episoder ur de svensk-spanska förbindelsernas historia: Spanien och Sverige genom tiderna, bilder och verklighet, Madrid: Fundación Berndt Wistedt, 1996.

${ }^{27}$ NEILA HERNÁNDEZ, José Luis, "Regeneracionismo y política exterior en el reinado de Alfonso XIII (1902-1931)", en Cuadernos de Historia de las Relaciones Internacionales, n. 3, Madrid, 2002, pp. 50-52.
} 
en la Sociedad de Naciones, que debe enmarcarse, a nuestro parecer, en el contexto de la política de acercamiento a Italia del dictador español, en un momento en que el control del Mediterráneo occidental adquiere dimensiones internacionales, con la agresiva actividad de Abd-el-Krim en Marruecos. Sorprendente, no son muchos los estudios sobre este asunto en la historiografía española ni en la sueca ${ }^{28}$.

Tampoco abundan las referencias bibliográficas sobre los acuerdos comerciales entre Suecia y España en 1928, ni sobre las visitas oficiales que por esos años hicieron el Rey de España a Suecia y el de Suecia a España ${ }^{29}$. Igualmente, es prácticamente desconocida la estancia de Alfonso XIII en Suecia, como huésped de Gustavo V, en el verano de 1931, recién instaurada la República ${ }^{30}$.

La carrera diplomática, reorganizada en España en 1928, iba pronto a verse sometida a duras pruebas, con el advenimiento de la República en 1931 pero, sobre todo, con la rebelión militar de julio de 1936, que dividiría en dos la diplomacia española ${ }^{31}$.

La llegada de la República supuso una evidente ruptura del sistema tradicional español, pero en el ámbito de las relaciones políticas y diplomáticas, sus efectos, por lo general, tardaron en hacerse sentir en la práctica. Sin embargo, la idea de una diplomacia "discreta" y no "secreta", de un cambio basado en una "psicología del diálogo", fue ya preconizada por Luis de Zulueta, Ministro de Estado de la República desde diciembre de 1931 hasta junio de $1933^{32}$.

No cabe duda de que la Segunda República asumió el reto de dar protagonismo a España en el exterior desde una perspectiva reformista. Sus principios básicos, tal como los expone el profesor Neila Hernández ${ }^{33}$, fueron el ideal de paz y la reformulación de la neutralidad como eje de la política exterior. Hay consenso entre los investigadores en que

\footnotetext{
${ }^{28}$ Existe un estudio monográfico (tesis doctoral) sobre este particular: CASTIELLA, Fernando María, Una batalla diplomática, Barcelona: Planeta, 1976; cfr. también BLEDSOE, Gerie Brown, "The Quest for Permanencia: Spain's Role in the League Crisis of 1926”, Iberian Studies, 4/1975, pp. 14-21; BLEDSOE, Gerie Brown, La oficina española de la Sociedad de Naciones, Revista de Política Internacional 127/1973; ANDERSSON, Ingvar, Sveriges historia. Estocolmo: Natur och Kultur, 5 ed., 1962, p. 442.

${ }^{29}$ Cfr. AMAEC, R, 1164, 2 sobre el tratado de comercio hispano-sueco de 1928; AMAEC, R, 4017, 19 sobre la conciliación España-Suecia del 26 de abril de 1928; AMAEC, R 1075, 22 sobre la comisión de arbitraje con Suecia.

${ }^{30}$ Cfr. libro de registro de entradas de Embajadas y Legaciones correspondiente a 1931, en AGA, L. AE 6402, pp. 178-183, entrada del 19 de agosto.

${ }^{31}$ CASANOVA, Marina, La diplomacia española durante la guerra civil, Biblioteca Diplomática Española, Sección Estudios 13, MAE, Madrid 1996.

${ }^{32}$ ZULUETA, Luis de, "La política exterior de la República", Tierra firme, 3, 1935, p. 14.

${ }^{33}$ NEILA HERNÁNDEZ, José Luis, "El proyecto internacional de la Segunda República: Democracia, paz y neutralidad" en PEREIRA CASTAÑARES, Juan Carlos (coord.), La política exterior de España..., pp.453$474 ;$ p. 458
} 
no se trataba de un planteamiento original y ni siquiera muy concreto, faltando una doctrina oficial de la neutralidad de la República ${ }^{34}$.

Egido León calificó esa política exterior como política de "neutralidad positiva" Esta expresión es, a nuestro modo de ver, perfectamente aplicable, tanto a la política exterior de España como a la de Suecia en este período ${ }^{35}$.

El desarrollo histórico y el papel de España en el período de entreguerras son bien conocidos del lector español, en sus tres períodos fundamentales, Dictadura, República y Guerra civil, y sería prolijo e innecesario proceder aquí a un resumen, aunque fuera muy somero, de los mismos. Sí resulta necesario - aún sin pretensión de exhaustividad - dar una visión general de la historia de Suecia y de su papel específico en la escena internacional, particularmente europea, de 1900 a 1930.

El período 1905-1920 supuso el asentamiento definitivo de la democracia y el parlamentarismo en el país. Tras la separación de Noruega en 1905, la atención del gobierno liberal sueco pudo centrarse en las cuestiones interiores, en especial la cuestión de la organización y los gastos de defensa, y la cuestión de la representación política, que llevaría en 1909 al sufragio universal masculino. El femenino no llegaría hasta 1921.

El comienzo del siglo fue también un período de importantes reformas: la creación del Tribunal Supremo Administrativo, la modernización del sistema fiscal y de la legislación mercantil, y la extensión del matrimonio civil. La conflictividad social se dejó sentir especialmente en la huelga general de 1909. En las elecciones de 1911 quedó clara la evolución que estaba experimentando Suecia, de paso de un sistema liberal a un sistema democrático, con la pérdida del poder por parte de los conservadores, la victoria de los liberales y el gran avance del partido socialdemócrata.

Uno de los puntos más significativos en esa evolución fue la cuestión de la Defensa. El Parlamento se encontraba dividido y el descontento de amplios sectores de la sociedad sueca con la política de retrasos en el rearme del Ejército culminó con la masiva manifestación que reunió, el 6 de febrero de 1914, a 30.000 campesinos de Suecia en Estocolmo, en apoyo de una política de incremento inmediato del presupuesto de defensa militar. La manifestación provocó una aguda crisis política y supuso el canto del cisne del sistema liberal y de la posición del monarca como árbitro de la política. Abrió las puertas a la instauración definitiva del sistema democrático.

\footnotetext{
${ }^{34}$ QUINTANA NAVARRO, Francisco, España en Europa, 1931-1936. Del compromiso de paz a la huida de la guerra, Madrid: Nerea, 1993.

${ }^{35}$ EGIDO LEÓN, op.cit., pp. 82-90 y pp. 254-256
} 
Con la guerra mundial, ante la que Suecia se mantuvo neutral, la tradicional vinculación del país con Alemania se vio sometida a fuerte prueba. Condujo inmediatamente a una crisis de gobierno y a la formación de un Gabinete estrictamente técnico, bajo la dirección de Hjalmar Hammarsköljd como primer Ministro. A consecuencia de la guerra, este gobierno en funciones siguió ejerciéndolas durante la mayor parte del conflicto. No faltaban problemas, en primer lugar la falta de alimentos, lo cual produjo fuertes tensiones sociales, con manifestaciones en protesta por el racionamiento, expropiaciones de tierras de campesinos y enfrentamientos entre manifestantes y fuerzas del orden público.

Las elecciones parlamentarias de 1917 dieron la victoria a los socialdemócratas y a los liberales, que formaron gobierno en coalición. Unía a ambos el objetivo común de democratizar completamente el sistema electoral, hasta entonces sometido a profundas restricciones sobre todo en el ámbito de las elecciones municipales. La toma de posesión del nuevo gobierno, con Edén como primer Ministro y Hjalmar Branting como ministro de Finanzas, el 19 de octubre de 1917, se considera tradicionalmente en la historiografía sueca como el momento de asentamiento definitivo de la democracia parlamentaria. La labor legislativa del nuevo gobierno culminó en la aprobación, en mayo de 1919, de la nueva normativa constitucional (sufragio universal) y laboral (introducción de la jornada de 8 horas).

En 1920 ingresó Suecia en la Sociedad de Naciones, y por primera vez presidía el gobierno un socialdemócrata, Hjalmar Branting. El período de 1920 a 1932 es conocido con el nombre de "época de las minorías parlamentarias" (minoritetsparlamentarismens tid), caracterizado por una sucesión de nueve gobiernos débiles, sin mayoría parlamentaria, con frecuentes crisis de gobierno: en doce años hubo once presidentes del gobierno. A mediados de década, el clima cultural del país era de intenso pacifismo, y la cuestión de la organización de la defensa pasó a un primer plano. También cobraron especial protagonismo la legislación relativa a la educación y a la organización de las relaciones laborales.

La crisis diplomática con España en la Sociedad de Naciones tuvo lugar durante el gobierno liberal de Carl Gustaf Ekman (1926-1928): Suecia se opuso a que España tuviera puesto en el Consejo de la Sociedad de Naciones, apoyó el ingreso de Alemania y cedió su 
propio puesto en el Consejo a Polonia para posibilitar un compromiso en línea con el espíritu de Locarno ${ }^{36}$.

Un conocido estudio sueco sobre la política exterior de Suecia sostiene que en ella ha habido cuatro cambios de paradigma: en 1434, 1630, 1812 y 1991 . Desde 1812 - última vez que el país se vio directamente afectado por el flagelo de la guerra - hasta 1991, la política exterior sueca estaba centrada en dos coordenadas básicas: la neutralidad y la mediación en los conflictos internacionales ${ }^{37}$.

Cabe preguntarse si el veto sueco de 1926 a las aspiraciones de España de obtener un asiento permanente en el Consejo de la Sociedad de Naciones está en consonancia con esta política. Por parte sueca la respuesta es afirmativa: se trataba en ese caso de mediar a favor de la Alemania injustamente tratada por el Tratado de Versailles.

En las últimas décadas se ha reabierto con fuerza en Suecia el debate sobre la política de neutralidad, a veces con carácter reivindicativo: un libro de una periodista sueca de principios de los años noventa rompió varios lustros de silencio respecto a una política que, a juicio de muchos, fue en realidad colaboracionismo encubierto con el régimen nazi ${ }^{38}$. La imagen de que Suecia actuó siempre de manera forzada, como consecuencia de la existencia permanente de una amenaza de invasión por parte del Tercer Reich ha sido también cuestionada por la historiografía alemana reciente ${ }^{39}$.

Desde entonces, los estudios han sido abundantes, y los títulos de los mismos son significativos: "El equilibrio de poder y la permanencia al margen de alianzas: la política exterior sueca en el siglo XX”, de Nils Andrén"4; “¿A favor de la clase obrera sueca o política soviética?: el movimiento comunista en Suecia y sus relaciones con Moscú 1920-

\footnotetext{
${ }^{36}$ NORBORG, Lars-Arne, Sveriges historia under 1800- och 1900-talen. Svensk samhällsutveckling 18091992, Estocolmo: Almqvist \& Wiksell, 1993, pp. 183-187; MELIN, Jan, JOHANSSON, Alf W.\& HEDENBORG, Susanna, Sveriges historia: koncentrerad uppslagsbok - fakta, årtal, tabeller, kartor, Estocolmo: Rubén Prisma, 1997, pp. 210-214; ANDERSSON, Ingvar, op. cit., p. 442.

${ }^{37}$ BERGQUIST, Mats, "Fyra paradigmskiften i svensk utrikespolitik", Nordisk tidskrift för vetenskap, konst och industri 2009(85):1, pp. 47-58; Sobre estos aspectos, cfr. también TINGSTEN, Herbert, Svensk utrikesdebatt mellan världskrigen, Estocolmo: Aldus/Bonnier, 1944/1964; HIRSCHFELDT, Lennart (coord.), Svensk utrikespolitik under 1900-talet, Estocolmo, 1958; o también ÅMARK, Klas, Makt eller moral: svensk offentlig debatt om internationell politik och svensk utrikes- och försvarspolitik 1938-1939. Estocolmo, 1973; STEENE, Mikael, "Role model or power pawn?: the changing image of Swedish foreign policy, 1929-1987”, en SUNDELIUS, Bengt (coord.), The committed neutral: Sweden's foreign policy, Boulder: Westview Press, 1989

${ }^{38}$ BOËTHIUS, María-Pía, Heder och samvete, Sverige under andra världskriget, Estocolmo: Ordfront, 1999.

${ }^{39}$ RADOWITZ, Sven, Schweden und das Dritte Reich 1939-1945: die deutsch-schwedischen Beziehungen im Schatten des Zweiten Weltkrieges, Hamburgo: Krämer, 2005.

40 ANDRÉN, Nils, Maktbalans och alliansfrihet: svensk utrikespolitik under 1900-talet, Estocolmo: Nordstedt, 1996.
} 
1970”, de Lars Björlin"; "La alternativa británica: la cuestión del camino a seguir en la política exterior sueca después de la Primera Guerra Mundial”, de Torbjörn Norman ${ }^{42}$; la dura crítica al socialismo sueco "El mito de la neutralidad: análisis crítico de la política exterior sueca", de Tommy Hansson ${ }^{43}$; el trabajo de Leif Dahlberg "Por encima de la voluntad del pueblo: sobre la política exterior sueca"44; el de Ingemar Ottosson "¿Guerra en nombre de la paz o neutralidad a cualquier precio? - Suecia, la Sociedad de Naciones y la cuestión de la seguridad colectiva en 1935-36" 45 . La lista no es exhaustiva.

La neutralidad sueca en la Primera Guerra Mundial también fue discutida en su momento, pese a que Hammarskjöld se propuso desde el primer momento que fuera una neutralidad estricta en consonancia con todas las normas del derecho internacional. Así lo haría también España. Sin embargo, la neutralidad, en la práctica, favoreció a Alemania: por ejemplo, Suecia intercedió ante los gobiernos británico, italiano y rumano pidiéndoles que no entrasen en guerra con Alemania. Asimismo, se negó a participar en el bloqueo comercial a Alemania, aunque eso llevó a recortes en la importación sueca de países aliados, con las consiguientes consecuencias de falta de alimentos, etc. Al caer el gobierno Hammarskjöld en 1917, los aliados favorecieron la victoria de liberales y socialdemócratas al sacar a la luz, en la recta final de la campaña electoral, un dato conocido desde antes, el “asunto Luxburg”. Ese era el nombre del representante diplomático alemán (Ministro) en Buenos Aires, que se había servido del Ministerio de Negocios Extranjeros sueco para hacer llegar a Berlín información sobre movimiento de buques aliados. El nuevo gobierno Edén-Branting entró inmediatamente en negociaciones con los aliados y consiguió un acuerdo comercial que puso fin a la carencia de artículos de primera necesidad en Suecia ${ }^{46}$.

En 1918, la política exterior sueca de neutralidad volvió a ponerse a prueba con la guerra civil finlandesa. Con una opinión pública dividida entre la derecha que favorecía al ejército "blanco" del mariscal Mannerheim y la izquierda que se inclinaba por el ejército

\footnotetext{
${ }^{41}$ BJÖRLIN Lars, "För svensk arbetarklass eller sovjetisk utrikespolitik?: den kommunistiska rörelsen i Sverige och förbindelserna med Moskva 1920-1970", en JUNGAR, Sune \& JENSEN, Bent (red.) Sovjetunionen och Norden, Helsinki : FHS, 1997.

${ }_{42}$ NORMAN, Torbjörn, "Det brittiska alternativet: vägvalsfrågor i svensk utrikespolitik efter första världskriget”, en ASKLÖF, Louise \& CARLQUIST, Erik, Humanismen som salt och styrka (Acta Bibliothecae regiae Stockholmiensis), Estocolmo: Atlantis, 1987, pp. 432-449

${ }^{43}$ HANSSON, Tommy, Neutralitetsmyten : en granskning av svensk utrikespolitik, Estocolmo: Contra, 1991

${ }^{44}$ DAHLBERG, Leif, Över folkets huvud : om svensk utrikespolitik, Estocolmo: Bonnier, 1967

${ }^{45}$ OTTOSSON, Ingemar, Krig i fredens intresse eller neutralitet till varje pris? Sverige, NF och frågan om kollektiv säkerhet 1935-36, Malmö: Liber/Gleerup, 1986.

${ }^{46}$ NORBORG, Lars-Arne, op. cit., 1993, p. 259.
} 
"rojo"47, el gobierno se mantuvo neutral. Esto no gustó a los vencedores finlandeses, y la relación con Suecia se enfrió aún más cuando algunos barcos de guerra suecos fueron enviados al archipiélago de Åland, de soberanía finlandesa pero de mayoría suecoparlante (en Finlandia, aún hoy, hay 300.000 personas cuya lengua materna es el sueco, que también es idioma oficial en el país. En el archipiélago de Åland es el único oficial). Un referéndum celebrado en 1919 dio el resultado de que el 96\% de los habitantes de las islas querían volver a pertenecer a Suecia. A pesar de ello, la Sociedad de Naciones decidió que siguiera perteneciendo a Finlandia, aunque con un régimen especial.

El final de la guerra mundial supuso un cambio grande de escenario internacional para Suecia: sus dos poderosos vecinos, Alemania y Rusia, habían salido de la misma muy debilitados. La Sociedad de Naciones recién fundada daba alas a un optimismo pacifista que fue particularmente fuerte en los liberales y socialdemócratas.

La primera cuestión que se le planteó a Suecia fue la entrada o no en la Sociedad de Naciones. Desde el punto de vista sueco, la organización tenía claros defectos: los países neutrales no habían tenido nada que decir en su fundación, los vencidos aún menos, y la URSS y los Estados Unidos se mantenían al margen. En Suecia se cuestionó, por tanto, si la entrada en la Sociedad de Naciones era o no era un apartarse de la política de neutralidad $^{48}$. Al final se decidió el gobierno por la entrada, para dar un voto de confianza a ese intento de velar por la paz mundial, con el sólo voto en contra del partido conservador, que protestaba por el trato de que había sido objeto Alemania. Existe un trabajo monográfico sobre Suecia y el sistema de sanciones de la Sociedad de Naciones, donde se puede encontrar también amplia bibliografía ${ }^{49}$.

La política sueca en la Sociedad de Naciones siguió la línea de defender los intereses de los países pequeños frente a las grandes potencias, de intentar hacer la Sociedad más universal abriéndola a los países perdedores en la Gran Guerra, y de promover los acuerdos

\footnotetext{
${ }^{47}$ En Suecia son habituales la expresiones, en política, de "bloque burgués" y "bloque rojo", sin que ello suponga un juicio de valor ni tenga matices peyorativos. Usamos aquí los términos "blanco" y "rojo" en el sentido habitual en Suecia.

${ }_{48}$ Así lo afirma claramente, entre otros, ANDERSSON, op. cit., p. 449. Cfr. también AF MALMBORG, Niklas, Neutrality and State-Building in Sweden, Nueva York: Palgrave, 2001, p. 178: "The clearly hostile attitude of the victorious powers towards neutrality, as a general principle and due to its pro-German effects during the war in particular, placed the small states under pressure to reconsider their policies. Neutrality was in principle incompatible with collective security".

${ }^{49}$ SILANDER, Martin, Debatten om NF och dess sanktionssystem: Vilhelm Lundstedt och hans antagonister. Trabajo fin de máster inédito. Halmstad: Högskolan i Halmstad, 2006.
} 
internacionales de desarme ${ }^{50}$. Esta línea no sólo iba en consonancia con los ideales humanitarios e internacionalistas de la época, sino que era probablemente la que mejor promovía los intereses nacionales de Suecia: la seguridad y la paz en su entorno, posibilitando una reducción de los gastos en Defensa y la realización de más reformas sociales ${ }^{51}$.

Además, es sintomático del modo de ser y de actuar del país el hecho de que esa actuación en el seno de la Sociedad de Naciones no se limitara tan sólo a una postura oficial, política, gubernamental. El apoyo a la gran potencia con la que desde hacía más siglos la unían estrechos lazos culturales, Alemania, fue bien explícito también a otros niveles, por ejemplo, el académico y estudiantil ${ }^{52}$.

España no es mencionada en la bibliografía sueca de carácter general sobre la política exterior del país. Es un dato sintomático del papel secundario de España dentro de la política exterior sueca, aunque, por otra parte, no podemos olvidar que existe mucha bibliografía específica sobre el papel de Suecia en la guerra civil española, como más adelante veremos.

Capítulo aparte, pero indudablemente importante para entender la actitud política sueca entre las dos guerras mundiales, es la política financiera, y la cuestión de los acuerdos sobre créditos, aspecto que será un punto frecuente en las relaciones con España $^{53}$.

El mantenimiento de la política de neutralidad sueca durante la segunda guerra mundial y la guerra fría, y el papel preponderante tomado por el país en el marco de las Naciones Unidas desde 1950 - hasta el punto de considerarse a sí mismo como una potencia diplomática de primer orden ${ }^{54}$ - tuvo su base en la política llevada a cabo de manera consecuente a partir de 1812, y especialmente en el período 1919-1939.

\footnotetext{
${ }^{50}$ Un estudio monográfico sobre el papel de Suecia en la conferencia de desarme de 1932 en TRÖNNBERG, Stefan, Nedrustning under mellankrigstiden: Sverige och nedrustningskonferensen $i$ Geneve 1932, Solna: Seelig, 1985.

${ }^{51}$ NORBORG, Lars-Arne, op. cit., p. 263.

52 ÅHLSBERG, Bengt, Studenter och storpolitik - Sverige och det internationella samarbetet 1919-1931. Lund: Lunds University Press, 1995; cfr. también JANSSON, op. cit., 1991 y LINDER, Jan, Mellankrigstiden: Sverige och Europa, Estocolmo: Infomanager, 1993.

${ }^{53}$ Sobre los acuerdos de crédito suecos en el período que nos ocupa cfr. SJÖGREN, Hans, Kreditförbindelser under mellankrigstiden: krediter i svenska affärsbanker fördelade på ekonomiska sektorer och regioner, Uppsala: Uppsala Economic Papers, 1989.

${ }^{54}$ NOORD, Fredrik, Den diplomatiska stormakten, Karlstad: Karlstads Universitet, 2001.
} 


\subsection{Las relaciones entre Suecia y España de 1931 a 1939 en la historiografía sueca}

En las páginas anteriores hemos tenido ya ocasión de referirnos a aportaciones historiográficas que directa o indirectamente se refieren al tema que es objeto de nuestro estudio. Pasamos a continuación a exponer y a comentar, de una manera más estructurada, la historiografía que consideramos más representativa, tanto en Suecia como en España, para el estudio de las relaciones entre Suecia y España en los años treinta del siglo XX, así como algunos trabajos de investigadores de terceros países al respecto.

No comentaremos la bibliografía disponible a nivel general para el estudio de la política interna de cada país, de la República o la guerra civil española en general, y también la existente sobre las relaciones entre Suecia y España en épocas anteriores.

Los trabajos de investigación suecos sobre las relaciones Suecia-España en los años treinta no son muchos, y los que hay, con alguna notoria excepción ${ }^{55}$, se centran en algún aspecto concreto de las relaciones (bien sean las comerciales, las culturales o las humanitarias) durante la guerra civil.

Ante todo, debemos destacar que no existe ningún estudio monográfico sueco sobre las relaciones políticas y diplomáticas entre Suecia y España en el período 1931-1939. En cambio, la bibliografía sobre Suecia y la guerra civil española, especialmente sobre los voluntarios suecos que lucharon en las Brigadas Internacionales y sobre la labor humanitaria del Comité sueco de Ayuda a España, es abundante.

El autor sueco que más ha estudiado la cuestión es, sin duda, Marcos Cantera Carlomagno $^{56}$. Entre sus aportaciones, la principal a efectos del presente estudio es el segundo de los tres trabajos citados en nota, "Suecia y la guerra civil española". En él analiza el papel de Suecia desde diversos puntos de vista, aunque el tema de las relaciones comerciales - con las consiguientes relaciones entre los empresarios y organizaciones empresariales de uno y otro país - ocupe en él el puesto preponderante.

Cantera Carlomagno ha llevado llevar a cabo un análisis contrastado y comparado de las fuentes disponibles en ambos idiomas y países. Su enfoque teórico y metodológico es

\footnotetext{
55 JERNECK, Magnus, MÖRNER, Magnus, TORTELLA, Gabriel \& ÅKERMAN, Sune (coord.), op. cit., 2005.

56 Sus aportaciones principales a nuestro tema son: CANTERA CARLOMAGNO, Marcos, "El reconocimiento del gobierno nacionalista por parte de Suecia: una primera prueba de fuerza”, en TUSELL, Javier, AVILÉS, Juan y PARDO, Rosa (coord,), op. cit., Madrid 1997; Sverige och spanska inbördeskriget, Lund: Historiska media, 1999; "Bang, Dagens Nyheter och Utrikesdepartementet”, en När Alving blev Bang, Lund: Historiska Media, 2001, pp. 69-85
} 
más afín con el predominante en España, de mayor cercanía al material empírico. Presenta al lector sueco un cuadro muy expresivo de la relación con la España de la guerra civil, desde diversos aspectos: el de la solidaridad, el del dilema político, el del problema comercial, el diplomático - también entre bastidores - ocasionado por la partición de España en dos zonas soberanas en la práctica, y los avatares de las decisiones tomadas por el gobierno sueco en la cuestión española. Utiliza fuentes del archivo del Ministerio de Negocios Extranjeros sueco (Utrikesdepartementet), del comité parlamentario de asuntos exteriores (utrikesnämnden), del archivo de la Asociación general de Exportadores suecos (SAE) y de algunos importantes medios de comunicación suecos, así como las memorias de dos figuras preeminentes de la Suecia de la época, Tage Erlander y Herbert Tingsten.

Las fuentes españolas son utilizadas en mucha menor medida, tan sólo siete legajos del Archivo del Ministerio de Asuntos Exteriores español. Esta parquedad de fuentes es quizá la mayor deficiencia del estudio.

Además, la tesis doctoral de Cantera Carlomagno sobre Suecia en los informes diplomáticos italianos en los años treinta del siglo XX, similar en estructura y contenido a nuestra investigación, que sacó a la luz datos hasta entonces desconocidos, y dejó abierta la puerta para investigaciones futuras, contiene obviamente elementos de interés ${ }^{57}$.

Sin embargo, esta tesis fue objeto de críticas en el mundo académico de Suecia, especialmente en lo referente al uso de las fuentes diplomáticas italianas - que algunos consideraron unilateral y acrítico, sin contrastarlas con otras fuentes suecas - y la extrapolación de conclusiones, a veces con insuficiente base empírica ${ }^{58}$.

Un trabajo de importancia fundamental para nuestro estudio es la tesis doctoral de Bertil Lundvik ${ }^{59}$. Se trata de un análisis de la actuación del movimiento obrero sueco, en sus cinco actores principales (los tres partidos: socialdemócrata, socialista y comunista; y los dos sindicatos predominantes: LO y SAC), en relación con la guerra española.

Sus conclusiones básicas son:

57 CANTERA CARLOMAGNO, Marcos, Ett folk av mänsklig granit: Sverige i den italienska utrikespolitiken 1932-1936, Lund: Historiska Media, 1995.

${ }^{58}$ Existe una recensión muy crítica de la tesis de Cantera por AF MALMBORG, Niklas, "Sverige i det fascistiska Italiens utrikespolitik" en Historisk Tidskrift, 1997, pp. 158-167. Af Malmborg sostiene que Cantera acepta sin más la opinión expresada por los diplomáticos italianos acerca de la existencia de rasgos comunes entre el fascismo y la socialdemocracia sueca.

${ }^{59}$ LUNDVIK, Bertil, Solidaritet och partitaktik: den svenska arbetarrörelsen och spanska inbördeskriget 1936-1939, Uppsala/Estocolmo: Almqvist \& Wiksell international (distr.), 1980. Otras aportación de este autor es: "De svenska handelsintressena och utrikespolitiken under spanska inbördeskriget", en ERIKSSON, Maj-Lis (coord.), Med eller mot strömmen? en antologi om svenska folkrörelser, Estocolmo: Sober, 1980, pp. 61-79; 
a) la socialdemocracia y su sindicato LO optaron por la política de neutralidad completa, aunque sus simpatías estuvieran del lado de la República;

b) los socialistas y la central sindicalista se esforzaron por crear opinión para que el gobierno cambiara de actitud, al tiempo que apoyaban todo lo que podían a la República; y el partido comunista se encargó de organizar el envío de más de 500 voluntarios a luchar en las Brigadas Internacionales.

Sobre el papel del movimiento obrero sueco en la guerra civil, la historiografía sueca es muy abundante. Los aspectos políticos destacan principalmente en las aportaciones de Jändel sobre la solidaridad en lucha y de Jönsson \& Kennerström sobre el radicalismo obrero sueco y la guerra civil española. Este último es especialmente interesante por el profundo análisis que realiza de las diversas posturas y enfrentamientos motivados por la guerra de España dentro del movimiento obrero sueco en general, y de los sindicalistas en $\operatorname{particular}^{60}$.

Una obra reciente de gran interés al respecto es la titulada “¡No pasarán! La guerra civil española y el ajuste de cuentas con el fascismo", que resume adecuadamente los diversos aspectos de la intervención de Suecia en la guerra civil ${ }^{61}$.

Merecen especial mención también los trabajos de Kennerström, Gustavsson, \& Karlsson, Dalin, Henrikson, Mattson y Gröndahl, junto con los documentos de época del anarquista Berner y el socialdemócrata G. Branting. Estos autores parten, en general, de unas posiciones ideológicas afines a uno u otro de los sectores del movimiento obrero sueco, lo que evidentemente se manifiesta en sus trabajos. Teniendo esto en cuenta a la hora de valorar sus aportaciones, no cabe duda de que constituyen interesantes contribuciones a nuestro tema de estudio ${ }^{62}$.

${ }^{60}$ JÄNDEL, Richard, Kämpande solidaritet, Estocolmo: AKS/ARAB, 1996; JÖNSSON, Claes-Göran \& KENNERSTRÖM, Bendt, Den svenska arbetarradikalismen och spanska inbördeskriget, Estocolmo: Arkiv 1977.

${ }^{61}$ HELGESSON, Patrik, JÄNDEL, Richard, \& WEIJDEGÅRD, Nils (coord.), No pasaran!: Spanska inbördeskriget och uppgörelsen med fascismen, Svenska Spanienfrivilligas vänner, 2008.

${ }^{62}$ KENNERSTRÖM, Berndt, "Socialistiska partiet och spanska inbördeskriget: den problematiska principfastheten”, en Arkiv 6, 1974; GUSTAFSSON, Kerstin \& KARLSSON, Mekki, Spaniens sak var vår, Estocolmo: Svenska fredskommittén \& Svenska Spanienfrivilligas vänner, 1992; DALIN, Stefan, "En bortglömd solidaritetsrörelse: det svenska Spanien-engagemanget 1936-1939”, en ALÉX, Peder, \& HJELM, Johnny (coord.), Efter arbetet, Lund: Studentlitteratur, 2001; HENRIKSON, Göran, "Spaniens sak är vår: Spanienrörelsen i Örebro län 1936-1939”, en Från bergslag och bondebygd, Örebro: Örebro läns museum; 1979 (33), pp. 61-85; MATTSON, Carl, Spaniens sak var vår: solidaritetsrörelsen $i$ Värmland 1936-1939: kampen mot krig och fascismen, Karlstad: ABF Värmland, 1982; GRÖNDAHL, Birgitta, De ideologiska motsättningarna i den spanska syndikalismen 1910-1936, Estocolmo: Federativs förlag, 1981, y de la misma autora Frihetlig kommunism i praktiken: experiment i självförvaltning i Spanien 1936-1939, Estocolmo: Federativs förlag, 1986; BERNER, Rudolf, S. A. C.: el movimiento anarcosindicalista en Suecia: su obra en favor de la España antifascista, Barcelona: Tierra y Libertad, 1938; BRANTING, Georg, Kamp och 
Otro tipo de estudios suecos analizan la guerra de España a partir del material de prensa disponible. Los más significativos son los de Berglund, Nilsson y Dalin ${ }^{63}$. Con carácter monográfico, existen también algunos trabajos de interés sobre el hospital sueconoruego establecido en Alcoy ${ }^{64}$.

Otro gran campo, el más extenso, es el de estudios relativos a los participantes en las Brigadas Internacionales. Los más completos, hasta la fecha, son la ya citada tesis doctoral de Lundvik, y las recientes aportaciones de Lundberg y de Gyllenhaal \& Westberg. El de Lennart Lundberg reviste un interés especial para nuestro trabajo debido al marco contextual que utiliza, analizando - si bien muy resumidamente - el papel de la Legación de Suecia en Madrid y los oficiales suecos encargados del control de las fronteras por el Comité de No-intervención de Londres. El de Gyllenhaal y Westberg es el más completo y detallado sobre la actividad de los voluntarios suecos en la guerra española. Contiene fotografías y está bien documentado en el material archivístico y bibliográfico disponible, si bien se centra demasiado en los aspectos militares ${ }^{65}$.

También aportan datos de interés los trabajos de G. Nilsson y de Ericson Wolke. Una de las fuentes básicas utilizadas por estos autores es el análisis sobre la guerra civil española elaborado en dos volúmenes en 1938 y 1942 por el Estado Mayor del Ejército Sueco, que la Ministra de la República Española en Estocolmo calificaría como "superficial”, opinión que no compartimos ${ }^{66}$.

Un subgrupo dentro de este tipo de trabajos lo constituyen las memorias de antiguos combatientes de las Brigadas Internacionales y los estudios basados en ellas, así como en cartas escritas por ellos en su momento. Son muy abundantes. De entre ellos, merecen

\footnotetext{
humanitet: En rapport avgiven vid möte i Auditorium den 13 febr. 1939 av Georg Branting; Estocolmo: Svenska hjälpkommittén för Spanien, 1939.

${ }^{63}$ BERGLUND, Åsa, Spanska inbördeskriget $i$ svensk arbetarpress, Uppsala: Uppsala Universitet, 1974; NILSSON, Per, Spanska inbördeskriget och Sverige: stockholmspressen och krigsslutet, Estocolmo: Historiska Institutionen, 1976; DALIN, Stefan, "Den svenska lokalpressen och spanska inbördeskriget", en Presshistorisk årsbok, 22, 2005, y del mismo autor "Värmlandspressen och Spanienfrågan" en GUSTAFSSON, Karl Erik \& RYDÉN, Per (coord.), Folk och press i rörelse, Gotemburgo: NordicomSverige, 1999, pp. 151-170.

${ }^{64}$ RABO, Erik, "Spanienhjälpens fältsjukhus under spanska inbördeskriget: svensk-norsk insats för demokratin" en Läkartidningen 2003(100):44, pp. 3522-3525; MYKLEBUST, Jon Olav \& Beneito Lloris, Ángel, "A hospital for Spain!: Scandinavian solidarity in a time of civil war, Alcoy: ZOE Imatge-Arts, 2009.

${ }^{65}$ LUNDBERG, Lennart, Svenskarna i spanska inbördeskriget 1936-1939, Gotemburgo: Tre böcker, 2001; GYLLENHAAL, Lars \& WESTBERG, Lennart, "I spansk tjänst 1936-1939: På titanernas första slagsfält", en Svenskar i krig 1914-1945, Lund: Historiska media, 2006, pp. 111-164.

${ }^{66}$ NILSSON, Göte, Svenskar i spanska inbördeskriget, Estocolmo: Norstedt, 1972; ERICSON WOLKE, Lars, "Frivilliga i strid", Populär historia 2006:7/8, pp. 32-36; FÖRSVARSSTABEN, Det spanska inbördeskriget I (1938) y Det spanska inbördeskriget II (1942), Estocolmo: Militärlitteraturföreningens förlag, 1938 y 1942; La opinión de la diplomática española en AMAEC, R 642, 3.
} 
destacarse las aportaciones de Brännström, Olsson Rogeby, Meurling, Risberg, Yrlid, Sjöstedt y Björk, además del libro propagandístico publicado en la época por la noruega Lindbaeck $^{67}$. La lista podría hacerse más larga.

Como se puede observar, hay estudios que tocan aspectos de las relaciones políticas entre España y Suecia, pero no hay nada sobre las relaciones diplomáticas.

Por otra parte, la historiografía sueca sobre la guerra civil española en cuanto tal (no en cuanto a su relación con Suecia) es casi inexistente. Aparte del libro ya citado del Estado Mayor, cabe nombrar la publicación en 1937 de una colección de dibujos sobre la guerra de niños españoles por Kajsa Rothman ${ }^{68}$ y la colección de discursos y declaraciones sobre la misma de destacados activistas suecos bajo el título "España, la clase obrera y el militarismo" ${ }^{, 69}$.

El resto de textos escritos en sueco sobre la guerra en general, son traducciones o resúmenes de obras extranjeras, o capítulos sobre el particular en libros de texto para las escuelas. En este contexto, por tanto, es notable que acabe de publicarse un libro de Kerstin Ekström titulado: "Los supervivientes de la guerra civil española y de la dictadura franquista",70.

Si esto es así por lo que se refiere a la guerra civil española, la situación es aún más extrema sobre la II República entre 1931 y 1936. No hemos encontrado ni un solo libro o artículo sueco sobre el tema. También son pocos los trabajos relativos a las relaciones diplomáticas de Suecia con otros países, aunque existen algunos respecto a Inglaterra,

\footnotetext{
${ }^{67}$ BRÄNNSTRÖM, Sven, "En spanienfrivillig från Västerbotten berättar”, en Oknytt 1998 (19:1/2)., Holmsund: Oknytt, p. 44.; RISBERG, Åsa, Att försöka påverka världen med ord: Eyvind Johnson och spanska inbördeskriget, Estocolmo: Natur och kultur, 1975, pp. 76-83; OLSSON (ROGEBY), Sixten, Spanska frontminnen, Estocolmo: Arbetarkultur, 1938 y De stupade för Spaniens demokrati, Estocolmo: Arbetarkultur, 1977); YRLID, Rolf Till Madrid: tre svenskars närvaro under det spanska inbördeskriget, Lund: Atlantis, 2006; SJÖSTEDT, Jonas, Brev till en broder. Spanienkämpen Bengt Segersons personliga skildring från det spanska inbördeskriget, Simrimshamn: Svenska Frivilligas vänner, 2009 y del mismo autor, "Från Västerbotten till Spanien". Västerbotten 2008:3, pp. 32-51, y Masthugget, Moskva, Madrid: berättelsen om Bengt och Greta, Estocolmo: Carlsson, 2009; MEURLING, Per, Den blodiga arenan: en bok om det spanska kriget, Estocolmo: Universal Press 1937; LINDBAECK, Lise, Bataljon Thäelmann, 1938 y De internationella brigaden, Estocolmo: Solidaritetens förlag, 1939; BJÖRK, Kaj, Spanien i svenska hjärtan, Estocolmo: Arbetarrörelsens arkiv och bibliotek, 2001.

${ }^{68}$ ROTHMAN, Kajsa, Spanska barn ritar om kriget, med inledning av Kajsa Rothman, 1937.

${ }^{69}$ ADAMSSON, Einar; FALUDI, Ivan; FLYG, Nils; HOLMSTRÖM, Axel; LINDE, Ebbe; NERMAN, Ture \& ÖSTERBERG, Axel, Spanien, arbetarklassen, militarismen, 1938.

${ }^{70}$ EKSTRÖM, Kerstin, Överlevarna: Från spanska inbördeskriget och Francodiktaturen, Estocolmo: Carlsson, 2010.
} 
Francia, Prusia, Rusia, Estados Unidos, Turquía, Grecia, Letonia, Estonia, Polonia, Corea y Japón $^{71}$.

La relativa ausencia de trabajos específicos modernos sobre las relaciones de Suecia con otras potencias, puede sorprender. La explicación debe buscarse, por un lado, en la centralidad que para Suecia han tenido, y tienen, las relaciones multilaterales, especialmente en el marco de la Sociedad de Naciones y, posteriormente, de las Naciones Unidas; y por otro, en la falta de interés de la historiografía de la segunda mitad del siglo XX por la historia política.

\subsection{Las relaciones entre Suecia y España de 1931 a 1939 en la historiografía española}

La bibliografía española respecto al período en cuestión como tal es demasiado extensa y suficientemente conocida para intentar siquiera resumirla aquí. Nos centraremos, por eso, en nombrar aquí algunas aportaciones de especial interés para nuestro tema.

Entre las publicaciones españolas de especial interés contextual para nuestro estudio merecen especial mención las aportaciones - citadas en el capítulo anterior - de Egido León sobre la política exterior de la Segunda República y los trabajos de los Pereira Castañares, que constituyen un punto de referencia sine qua non para todo historiador que pretenda profundizar en las relaciones internacionales de la España del siglo XX, junto con los de Neila Hernández ${ }^{72}$.

Pereira Castañares, en el capítulo dos de su conocida obra sobre las relaciones internacionales, titulado "Los estudios Internacionales en España: la política exterior. Un estado de la cuestión", da una visión sintética y acertada sobre las coordenadas básicas de

\footnotetext{
${ }^{71}$ Son clásicas las tesis doctorales de GRIMBERG, Carl, De diplomatiska förbindelserna mellan Sverige och Preussen 1804 - 1808, Gotemburgo: Universidad, 1903 y de BEHRE, Göran, Underrättelseväsen och diplomati: de diplomatiska förbindelserna mellan Sverige och Storbritannien 1743-1745 = El Servicio de Inteligencia y la diplomacia: relaciones diplomáticas entre Suecia y Gran Bretaña entre 1743 y 1745, Gotemburgo: Universidad de Gotemburgo, 1965; LEJIN̦Š, Atis, "Sveriges och Lettlands relationer 19871991: ockupationsfrågan", en Kungl. Krigsvetenskapsakademiens handlingar och tidskrift (209):4; 2005, pp. 97-107; SYDOW, Erik von, "Diplomatiska relationer mellan Estland och Sverige under mellankrigstiden", en Estländare i Sverige: historia, språk, kultur, Uppsala: Uppsala multiethnic papers, 1988, pp. 49-53.

${ }^{72}$ De este último autor, cfr. NEILA HERNÁNDEZ, José Luis, "El proyecto internacional de la República. Democracia, paz y neutralidad (1931-1936)", en PEREIRA CASTAÑARES, Juan Carlos (coord.), La política exterior de España...; y también "La política exterior de la España Republicana (1931-1936): excepcionalismo y normalidad historiográfica", Studia Historica, Historia Contemporánea, 22, Salamanca, 2004.
} 
la acción exterior española. El título del subcapítulo relativo a la década que nos ocupa, es muy sugerente: "República y guerra: del debate intelectual a la ideologización del análisis" ${ }^{73}$.

En general, toda la historiografía básica sobre relaciones internacionales es importante para el encuadramiento contextual de las relaciones diplomáticas entre Suecia y $\operatorname{España~}^{74}$.

Asimismo, dentro de este marco general, las obras recientes de Ángel Viñas son punto de referencia obligado. Viñas es buen conocedor del tema, muy riguroso en su labor de documentación y análisis de fuentes, y hombre de gran experiencia internacional, lo que le hace especialmente apto para este tipo de estudios.

En "La soledad de la República..." es relevante para nosotros lo relativo al cambio de rumbo y a la estrategia republicana de nombramientos de diplomáticos para ganarse a las democracias occidentales ${ }^{75}$.

La obra "El escudo de la República..." tiene también interés por todo lo que refiere sobre la financiación del esfuerzo de guerra republicano, en el cual no faltaron las ramificaciones nórdicas y bálticas ${ }^{76}$.

Finalmente, "El honor de la República...", obra principal por la abundancia de datos que aporta, las interesantes discusiones con las aportaciones de otros historiadores, así como por su un apéndice documental, no contiene referencias a Suecia. Es interesante ver si la interpretación de Viñas sobre el papel desempeñado por Negrín, y sobre la actitud británica en relación con España, encuentra eco en la documentación diplomática sueca ${ }^{77}$.

Sin embargo, es probablemente la obra coordinada por este autor sobre los diplomáticos republicanos la que más directamente se relaciona con nuestro estudio ${ }^{78}$. En ella se analiza detalladamente la labor llevada a cabo por las Embajadas de la República

\footnotetext{
${ }^{73}$ PEREIRA CASTAÑARES, Juan Carlos, La política exterior de España...; Cfr. también, del mismo autor, Introducción al estudio de la política exterior de España (siglos XIX y XX), Akal, Madrid, 1983.

${ }^{74}$ Algunas aportaciones interesantes son: MORALES LEZCANO, op.cit., pp. 575-582; y MORENO JUSTE, "La historia de las relaciones internacionales..."; BALLESTEROS, Ángel, Diplomacia y relaciones internacionales, $4^{\mathrm{a}}$ edición, Madrid, 2009.

${ }^{75}$ VIÑAS, Ángel, La soledad de la República. El abandono de las democracias y el viraje hacia la Unión Soviética, Barcelona: Crítica 2006, pp. 256-265.

${ }^{76}$ VIÑAS, Ángel, El escudo de la República. El oro de España, la apuesta soviética y los hechos de mayo de 1937, Barcelona: Crítica, 2007.

${ }^{77}$ VIÑ̃AS, Ángel, El honor de la República. Entre el acoso fascista, la hostilidad británica, y la política de Stalin. Barcelona: Crítica 2009.

${ }_{78}$ VIÑNAS, Ángel, (coord.), Al servicio de la República: Diplomáticos y guerra civil, Madrid: Marcial Pons Historia, 2010.
} 
española en Londres, París, Washington, Berna, Praga y Méjico, además de consideraciones de carácter común a todas ellas. En un capítulo introductorio a cargo de Julio Aróstegui se estudia la cuestión.

También son de interés las obras de Elorza y Bizcarrondo sobre la internacional comunista, Quintana Navarro sobre España en Europa 1931-1936 y Cervera sobre el Madrid en guerra. Esta última contiene referencias a Suecia ${ }^{79}$.

Otros dos autores de relevancia para nuestra investigación, por haberse ocupado en varios trabajos de aspectos de política exterior y diplomacia en la España de los años treinta, son Enrique Moradiellos y Antonio Manuel Moral Roncal. El primero describe bien la situación internacional con respecto a España en los años treinta, la nueva estrategia del Komintern, la hostilidad reinante, etc. Tiene particular interés todo lo referente a la actitud de Inglaterra, tema en el que Moradiellos es especialista, y que es fundamental para nuestro estudio, debido a las estrechas relaciones que Suecia desarrolló con Inglaterra precisamente durante todo el período de la política de apaciguamiento. Las obras de Moradiellos contiene numerosas referencias a material archivístico, tanto español como británico, y son por tanto muy útiles ${ }^{80}$.

Antonio María Moral Roncal es el único autor español, hasta ahora, en analizar cuestiones relativas al papel jugado por la Legación de Suecia en la capital de España durante los años de guerra civil. Se trata de un estudio serio y profundo, basado en una gran riqueza de fuentes documentales, que resulta imprescindible para cualquier estudio ulterior sobre la cuestión. Lamentablemente, dedica muy poco espacio a Suecia, sin percatarse bien del papel que jugó el país escandinavo para la España en guerra, desde el punto de vista de su contribución a la República en ayuda humanitaria e, incluso, en número proporcional de voluntarios que vinieron a luchar. Esto resulta extraño para los historiadores suecos, aunque se entiende que, fuera de las fronteras del país escandinavo, no se conozca tanto su contribución a la guerra española ${ }^{81}$.

\footnotetext{
79 ELORZA, Antonio \& BIZACARRONDO, Marta, Queridos camaradas: La internacional comunista y España, Barcelona: Planeta, 1999; QUINTANA NAVARRO, España y Europa...; CERVERA, Javier, Madrid en guerra: La ciudad clandestina, Madrid: Alianza Editorial, 2006, p. 379.

${ }^{80}$ MORADIELLOS, Enrique, El reñidero de Europa: las dimensiones internacionales de la Guerra Civil española, Barcelona: Península, 2001; y del mismo autor, "El mundo ante el avispero español: intervención y no-intervención extranjera en la Guerra Civil”, en JULIÁ, Santos (coord.), República y Guerra en España (1931-1939), Madrid: Espasa, 2006, pp. 287-362.

81 MORAL RONCAL, Antonio Manuel, Diplomacia humanitarismo y espionaje en la Guerra Civil española, Madrid: Biblioteca Nueva, 2008, pp. 494-496.
} 
Gran parte de la obra de Moral Roncal está centrada en temas relacionados con el asilo diplomático durante la guerra civil, y por tanto relevantes para nuestro estudio ${ }^{82}$.

También se ha ocupado de las relaciones diplomáticas de España durante la Segunda República y la guerra civil Marina Casanova. Y Pérez Ruiz tiene un trabajo interesante al respecto $^{83}$.

En el campo de las relaciones diplomáticas bilaterales, predominan en la historiografía espanola los trabajos referentes a países de Hispanoamérica. Sin embargo, las conexiones con Suecia son, en estos trabajos, prácticamente inexistentes ${ }^{84}$. Últimamente, ha aumentado también los estudios sobre el este de Europa en la historiografía española de relaciones internacionales ${ }^{85}$.

El clásico libro de Azcárate sobre su embajada en Londres roza cuestiones relacionadas con Suecia, por la relación que la política exterior británica tenía con la sueca en este período. Algo similar ocurre respecto a las labores de espionaje en Francia y a los planes de mediación, objeto de las aportaciones de Luengo Teixidor, y Marquina Barrio ${ }^{86}$.

Finalmente, hay un trabajo centrado en Islandia sobre las repercusiones de la guerra civil española en los países nórdicos que refleja bien la idea popular en Escandinavia sobre

\footnotetext{
${ }^{82}$ MORAL RONCAL, Antonio Manuel, El asilo diplomático en la Guerra Civil Española, Madrid, 2001; "Asaltos y cierres de legaciones extranjeras: un grave asunto diplomático en el Madrid de la Guerra Civil (1936-1939)", Revista de Arte, Geografia e Historia, 4, (2001), Madrid, pp. 221-247; "The Allies and the Spanish Civil War", en BALFOUR, Sebastian \& PRESTON, Paul, (coord.), Spain and the Great Powers in the Twentieth Century, Londres: Routledge, 1999, pp. 96-126; "El auxilio diplomático suizo (1936-1939): Humanitarismo y neutralidad benevolente en la Guerra Civil Española", en Cuadernos de Investigación Histórica, 22, (2005), pp. 349-372; "El Madrid de 1936 a través de las memorias inéditas del marqués de Alquibla", Revista de Arte, Geografía e Historia, 5, Madrid, 2002, pp. 293-313.

${ }^{83}$ CASANOVA, Marina, La diplomacia española..., "Las relaciones diplomáticas hispano-belgas..." y "Depuración de funcionarios diplomáticos durante la Guerra Civil", Espacio, Tiempo y Forma. Revista de la Facultad de Geografía e Historia, 1, UNED, 1987; PÉREZ RUIZ, José Luis, La depuración de la carrera diplomática española (1931-1980), Burgos: Dossoles, 2006.

${ }^{84}$ Citaremos algunos: TABANERA, Nuria, Ilusiones y desencuentros. Acción de la diplomacia Republicana en Hispanoamérica (1931-1939), Madrid: Cedeal, 1996; MARTÍNEZ RIAZA \& MORENO CEBRIÁN, "Al servicio de la República...; MARTÍNEZ RIAZA, Ascensión, "La lealtad cuestionada. Adscripción política y conflicto de autoridad en la representación española en el Perú, 1933-1939”, Hispania. Revista Española de Historia, LXVI/ 223, Madrid, 2006, pp. 671-694; VARGAS CARIOLA, Juan Eduardo, COUYOUMDJIAN, Juan Ricardo \& DUHART, Carmen Gloria, España a través de los informes diplomáticos chilenos, 19291939, Santiago de Chile: Ministerio de Relaciones Exteriores de Chile, 1994.

${ }^{85}$ Cfr. MARTÍN DE LA GUARDIA, Ricardo \& PÉREZ SÁNCHEZ, Guillermo A., "La Europa del Este en la historiografia española de las relaciones internacionales", en La historia de las relaciones internacionales, Ayer n. 42, Madrid: Marcial Pons, 2001, pp. 125-148.

${ }^{86}$ AZCÁRATE, Pablo de, Mi embajada en Londres durante la Guerra civil española, Barcelona: Ariel, 1976; LUENGO TEIXIDOR, Félix, Espías en la Embajada. Los servicios de información secreta Republicanos en Francia durante la guerra civil, Bilbao: Universidad del Pais Vasco, 1999; MARQUINA BARRIO, Antonio, "Planes internacionales de mediación durante la Guerra Civil", en Revista de Estudios Internacionales, tomo 5, núm. 3, 1984.
} 
la guerra española. Sin embargo, apenas cita fuentes documentales de los otros países, y da una visión demasiado ingenua y simplificada del tema ${ }^{87}$.

Podrá acaso sorprender la ausencia en esta relación de trabajos sobre la política exterior del franquismo. La historiografía se ha centrado habitualmente, al referirse al tema, en períodos posteriores. Del período de la guerra civil, cuando se ha hecho referencia al mismo, se ha tratado habitualmente de sus relaciones con cuatro países: Alemania, Italia, Inglaterra y Francia. En algún caso se habla de la diplomacia "durante el primer franquismo" pero generalmente se entiende por tal los años inmediatamente posteriores a la victoria franquista.

Aunque recientemente ha habido un gran aumento de estudios sobre el franquismo, a todos los niveles - quizá con un cierto predominio de nuevas perspectivas, por ejemplo, desde el punto de vista de "historia cultural" 88 - son aún escasos los que hacen referencia a la labor diplomática de la España de Franco durante los años de la guerra. Se trata de una razón más que avala la importancia del estudio de los despachos de los representantes del gobierno de Burgos en el extranjero ${ }^{89}$.

Existe abundante bibliografía sobre las cuestiones relacionadas con las Brigadas Internacionales, si bien de muy variado rigor histórico-científico. No falta algún estudio sobre los brigadistas escandinavos que aporta cifras y datos que no son confirmados en absoluto por las fuentes documentales nórdicas ${ }^{90}$.

La primera aproximación sistemática, por parte española, a los voluntarios suecos de las Brigadas fue dada por Borrás en 1977. Sin embargo, y a pesar de su brevedad, el trabajo más informativo en castellano sobre la participación sueca en las Brigadas Internacionales es el de Norling - abogado sueco residente en España - del año 2005, que recoge correctamente las aportaciones de la historiografía sueca existente hasta entonces ${ }^{91}$.

\footnotetext{
${ }^{87}$ YRAOLA, Aitor, "La repercusión de la Guerra Civil Española en los Países Nórdicos", Cuadernos de Historia Contemporánea, 16, 1994.

${ }^{88}$ Cfr. por ejemplo MAZA ZORRILLA, Elena, La España de Franco: (1939-1975), San Sebastián de los Reyes (Madrid): Actas, 2002.

${ }^{89}$ Los despachos del Conde de Torata desde Estocolmo son muy informativos al respecto. Cfr. AGA, AE 6544, libro de Entradas de Embajadas/Legaciones, 1937; AE 5991 Libro de Entradas de Embajadas y Legaciones de 1939 (pp. 160-240);

${ }^{90}$ Un caso paradigmático es VIDAL, César, Las Brigadas Internacionales, Madrid: Espasa, 1998.

${ }^{91}$ BORRÁS, Isabel, Svenskarna och det spanska inbördeskriget: en bibliografi = Los suecos y la guerra civil española: una bibliografia, 1977; NORLING, Erik, "¡Viva la República! Voluntarios suecos en la Guerra Civil española”, Historia Militar, octubre 2005, pp. 127-133.
} 
Existen también trabajos sobre aspectos concretos de la ayuda humanitaria sueca durante la guerra civil. Entre ellos merecen destacarse los de Beneito y Duroux ${ }^{92}$.

Finalmente, en la abundante bibliografía de carácter general sobre las Brigadas Internacionales pueden encontrarse algunos aspectos de interés ${ }^{93}$.

Al ser tan amplia la bibliografía existente sobre la guerra civil española, hemos procurado en esta exposición ceñirnos mucho al tema específico que nos ocupa, pero es evidente que para un estudio serio de la cuestión deben conocerse todas las aportaciones fundamentales más recientes de la historiografía española y extranjera sobre la España de la guerra civil.

\subsection{Bibliografía extranjera de particular interés}

Cerramos este capítulo con una presentación de algunos trabajos de la historiografía extranjera de interés para el estudio de las relaciones entre España y Suecia en la década 1931-1939, entendiendo por tal la que no es ni sueca ni española.

En primer lugar, nos parecen muy importantes las obras generales de autores extranjeros sobre este período de la historia sueca y española, porque suponen un acercamiento a la realidad histórica desde una postura inicial de mayor desconocimiento del medio concreto en que se desarrollaron los acontecimientos, para bien y para mal. Para mal, en cuanto la posibilidad de interpretaciones no válidas, por falta de comprensión de las circunstancias locales, es mayor; para bien, en cuanto que aportan una perspectiva externa, y por tanto en principio menos partidista, a la cuestión debatida. Externa no quiere decir necesariamente más objetiva, porque el historiador está siempre imbuido de su propia subjetividad, de su propio "ser-en-la-historia". Pero sí es cierto que es una subjetividad diferente de la del historiador local, y por ello este tipo de aportaciones resultan, de ordinario, enriquecedoras.

\footnotetext{
${ }^{92}$ BALLESTER, Gemma \& BENEITO, Ángel, L'Hospital "Sueco-Noruego" d'Alcoi durant la guerra civil espanyola: un exemple de solidaritat, Barcelona: L'Ullal Ediciones, 2010; DUROUX, Rose, "La ayuda de Noruega y Suecia”, en ALTED VIGIL, Alicia, GONZÁLEZ MARTELL, Roger \& MILLÁN, María José, El exilio de los niños, 2003, Madrid: FPI, pp. 126-143.

${ }^{93}$ RODRÍGUEZ DE LA TORRE, Fernando, Bibliografía de las Brigadas Internacionales y de la participación de extranjeros a favor de la República, (1936-1939), Albacete: Instituto Estudios Albaceteños, 2006; ÁLVAREZ, Santiago, Historia política y militar de las Brigadas Internacionales, Madrid: Compañía literaria, 1996; CIERVA, Ricardo de la, Brigadas Internacionales 1936-1939, Madridejos, Toledo, 1997; OLAYA MORALES, Francisco, La intervención extranjera en la guerra civil. Móstoles: Ediciones Madre Tierra, 1990;
} 
Entre estos estudios, destacaremos en primer lugar el de Radosh, Habeck y Sevostianov, fundamental en cuanto recoge fondos documentales de capital importancia. Sus interpretaciones han sido objeto de debate en la historiografía, entre otros por parte de Ángel Viñas, en su reciente trilogía sobre la República ${ }^{94}$.

En segundo lugar, destacaremos una aportación que recoge con cierto detalle un tema fundamental de nuestro estudio, las negociaciones diplomáticas entre España y Suecia en el seno de la Sociedad de Naciones durante los años de la Segunda República anteriores a la guerra. Se trata de la obra de Berdah sobre la relación de la República con las grandes potencias, que completa la conocida de Balfour y Preston sobre el mismo tema ${ }^{95}$.

En el capítulo correspondiente, analizaremos en detalle las aportaciones de Berdah y las contrastaremos con los resultados empíricos de nuestra investigación en los fondos archivísticos españoles y suecos.

En general, todas las grandes aportaciones de autores extranjeros sobre la guerra civil española - Thomas, Payne, Preston, Bolloten, Beevor, por citar las más conocidas - son obras de consulta obligada a los efectos del presente trabajo ${ }^{96}$.

Sobre el papel del comunismo y otras ideologías en relación con la guerra civil, aparte de la clásica y discutida obra de Catell, destacamos las aportaciones de Rees y Thorpe, la de Roberts y la de Schieder y Dipper ${ }^{97}$.

Dentro de los estudios específicos sobre las Brigadas Internacionales, es fundamental el de Skoutelsky, probablemente la obra reciente más completa y mejor documentada sobre el tema. Entre otras aportaciones de gran interés, aclara muchos temas

\footnotetext{
${ }^{94}$ RADOSH, Ronald, HABECK, Mary \& SEVOSTIANOV, Grigory (Eds.), España traicionada, Barcelona: Planeta, 2002.

${ }^{95}$ BERDAH, Jean-François, La democracia asesinada: la República española y las grandes potencias, 1931 1939, Barcelona: Crítica, 2002; BALFOUR \& PRESTON, op. cit.

${ }^{96}$ THOMAS, Hugh, La guerra civil española, Barcelona: De Bolsillo, 2003; PRESTON, Paul, Revolución y guerra en España, 1931-1939, Madrid: Alianza, 1986; La guerra civil española: reacción, revolución y venganza, Barcelona: De Bolsillo, 2011; PAYNE, Stanley, La primera democracia española: la Segunda República, 1931-1936. Barcelona: Paidos Ibérica, 1995; PAYNE, Stanley \& TUSELL, Javier, La guerra civil: una nueva visión del conflicto que dividió España, Madrid: Temas de Hoy, 1996; BOLLOTEN, Burnett, La Guerra Civil española: Revolución y Contrarrevolución, Madrid: Alianza Editorial, 1997; BEEVOR, Antony, La guerra civil española, Barcelona: Crítica, 2005.

${ }^{97}$ CATELL, David Tredwell, Communism \& the Spanish Civil War, New York, 1965; REES, Tim \& THORPE, Andrew (coord.), International Communism and the Communist International, 1919-1943, Manchester: Manchester University Press, 1998; ROBERTS, Geoffrey, "Soviet Foreign Policy and the Spanish Civil War, 1936-1939", en LEITZ, Christian. \& DUNTHORN, David J., Spain in an International Context, 1936-1959, Nueva York: Berghan Books, 1999, pp. 81-103; SCHIEDER, Wolfgang \& DIPPER, Christoff, Der Spanische Bürgerkrieg in der internationalen Politik (1936-1939). Munich: Nymphenburger Verlagshandlung, 1976.
} 
relativos a la intervención del Komintern en la organización de las Brigadas. Deja claro que más del $80 \%$ de los brigadistas provenían de las clases obreras. También otras obras generales pueden ser de interés ${ }^{98}$.

Respecto a los voluntarios internacionales a favor de la España franquista y las cuestiones relacionadas con la ayuda internacional en forma de material bélico, hay tres trabajos relevantes, de Keene, Othen y Howson, respectivamente ${ }^{99}$.

La obra de Howson está muy documentada sobre el esfuerzo y logros de los contendientes en la compra y adquisición de armas en el extranjero. Aparecen en ella referencias a la presencia, aunque fuera marginal, de armamento de fabricación sueca en el Ejército Popular de la República.

En línea con las opciones metodológicas que presiden nuestra investigación, que ya presentamos anteriormente, es probable que los datos empíricos que nos encontremos en nuestro estudio de los despachos diplomáticos exijan un replanteamiento del marco historiográfico de la misma. En concreto, la incidencia que en ellos se aprecie del interés particular de los diplomáticos por aspectos concretos de la vida política española o sueca, nos habrán de llevar necesariamente a ampliar el marco historiográfico aquí presentado con otras historiografía que tenga relevancia a los temas de que se trate. Haremos referencia a la misma dentro del apartado que corresponda, en cada capítulo.

En su conjunto, la historiografía española y extranjera disponible parece dar la siguiente visión de las cuestiones que nos ocupan:

1. Apenas consta que haya habido relaciones políticas y diplomáticas entre España y Suecia dignas de mención, en los años treinta del siglo XX.

2. Durante la guerra civil española, Suecia no ocultó sus simpatías por la causa de la República, aunque oficialmente fue neutral.

\footnotetext{
${ }^{98}$ SKOUTELSKY, Rémi, Novedad en el frente: las brigadas internacionales en la guerra civil española, Madrid, 2006; BERG, Angela, Die Internationalen Brigaden im Spanischen Bürgerkrieg 1936 - 1939 , Essen: Klartext, 2005; JACKSON, Michael, Fallen sparrows: the international brigades in the Spanish civil war, Philadelphia: American Philosophical Society, 1994; RICHARDSON, Dan, Comintern Army: The International Brigades and the Spanish civil war, Lexington: University Press of Kentucky, 1982.

${ }^{99}$ KEENE, Judith, Fighting for Franco: International volunteers in Nationalist Spain during the Spanish civil war 1936-1939, Londres/Nueva York: Leicester University Press, 2001; OTHEN, Christopher, Las brigadas internacionales de Franco, Barcelona: Destino, 2007. Este estudio apareció posteriormente en inglés (Franco's International Brigades:Foreign Volunteers and Fascist Dictators in the Spanish Civil War, Londres: Reportage Press, 2008), y en octubre de 2012 en versión revisada bajo el título Franco's International Brigades: Adventurers, Fascists, and Christian Crusaders in the Spanish Civil War, Londres: C Hurst \& Co Publishers Ltd, 2012.
} 
3. Aunque Suecia acogió a algunos refugiados en el edificio de su Legación en Madrid, prestó una ayuda considerable a la República en guerra, concretada en ayuda médica (Hospital sueco-noruego de Alcoy), ayuda a la infancia (orfelinatos), ayuda económica (víveres y dinero enviados por el Comité sueco de Ayuda a España) y ayuda militar en forma de voluntarios de las Brigadas Internacionales.

4. Suecia, como país democrático, no mantuvo relaciones con el régimen de Franco durante la guerra civil. De hecho, fue uno de los últimos países en reconocerlo de iure.

Por su parte, la historiografía sueca disponible, coincide en general con la española y extranjera, pero con una peculiaridad notable: los estudios más específicos sobre la cuestión, llevados a cabo por Lundvik y por Cantera Carlomagno, matizan mucho la cuestión de las buenas relaciones con la República. Muestran una visión bastante más crítica, con la adopción de una política deliberadamente ambigua por parte del gobierno socialdemócrata-agrario de Suecia desde el comienzo de la guerra, que contaba con el apoyo tácito de la opinión pública general, aunque no de las bases de los partidos de izquierda. Según el análisis de estos autores, las relaciones entre Suecia y España fueron más estrechas e intensas de lo que se piensa habitualmente, y esto es válido también por lo que se refiere a las relaciones con la España de Franco, especialmente promovidas por círculos empresariales suecos.

Confiamos en que el presente estudio, que utiliza de forma exhaustiva la documentación primaria disponible tanto en Suecia como en España, pueda aportar una contribución válida al estudio de las relaciones internacionales entre ambos países, contradiciendo, ratificando o matizando el estado actual de la cuestión.

Terminamos aquí la exposición de la bibliografía básica para el tema que nos ocupa. La selección es nuestra, y puede evidentemente ser discutida y ampliada. Como se ha podido constatar, sin embargo, es notable la escasez de ensayos, monografías y obras de consulta sobre el tema concreto de nuestro estudio, lo cual constituye una laguna que merece la pena llenar por medio de un estudio detallado. 



\title{
REPÚBLICA EN ESPAÑA, SOCIALDEMOCRACIA EN SUECIA
}

\author{
La expresión "sentarse a la mesa del poder" \\ es en sumo grado aplicable a los actores de \\ la vida política española ${ }^{1}$ \\ Las relaciones entre ambos países, si han \\ sido consideradas como excelentes, se debe \\ tal vez al hecho de que no existían 2 .
}

\footnotetext{
${ }^{1}$ Palabras del Secretario de la Legación de Suecia en Madrid, Einar Ytterberg, en diciembre de 1933: RA, UD, 1920-års dossierssystem, vol. 421, despacho n. 536 de 22.XII.1933.

${ }_{2}^{2}$ Palabras de Julio Sánchez Oliván, Ministro de España en Estocolmo, despacho n. 46 de 15 de febrero de 1934, AMAEC R, 860, 74. El texto completo del despacho, en apéndice n. 1.
} 



\title{
Capítulo 3
}

\section{LA REPÚBLICA ESPAÑOLA DE 1931 A 1936 SEGÚN LA DIPLOMACIA SUECA}

\author{
España es el país de las sorpresas ${ }^{1}$
}

\subsection{La Legación de Suecia en Madrid. Los ministros plenipotenciarios de Suecia en España}

Aunque las relaciones diplomáticas entre España y Suecia se remontan al siglo XVI, solo desde mediados del siglo siguiente se pudo contar con la presencia de representantes diplomáticos permanentes. A partir de entonces, la gran mayoría de los diplomáticos suecos en Madrid fueron diplomáticos de carrera. Durante el siglo XX, Suecia destinó a Madrid un total de veinticuatro jefes de Misión, de los cuales solamente dos lo fueron ante la República Española: Carl Ivan Danielsson, hasta el verano de 1936, y Erik Johan Sixten Wisén durante los años de la guerra civil (1936-1939). Ante el gobierno del General Franco fue Agente de Suecia, desde finales de 1938 hasta el fin de la guerra, el diplomático Nils Fredrik Hampus Berencreutz - que había sido Secretario de la Legación en Madrid bajo Ivan Danielsson en los años veinte y luego sería Embajador sueco en España entre 1948 y 1951 - y, a partir de abril de 1939, Karl Ivan Westman, hermano de un conocido Ministro del gobierno de Suecia. Lennart Petri, que más tarde sería el primer Embajador sueco en Madrid tras la muerte de Franco, recogió sus experiencias sobre estos períodos en sus memorias, a las que tendremos ocasión de referirnos ${ }^{2}$.

En el período que nos ocupa sobresale la figura de Carl Ivan Danielsson, por su largo tiempo en el cargo y su especial conocimiento de España. Danielsson fue Ministro Plenipotenciario de Suecia en España en 1921-1922 y en 1925-1937³.

\footnotetext{
${ }^{1}$ Palabras del Ministro Plenipotenciario de Suecia en Madrid, Carl Ivan Danielsson, en noviembre de 1931: RA, UD, 1920-års dossierssystem, vol. 420, despacho n. 504 de 5.XI.1931.

${ }^{2}$ FREDRIKSSON, op. cit., pp. 45-77; en particular pp. 74-77; PETRI, Lennart, Sverige i stora världen. Minnen och reflexioner från 40 års diplomattjänst, Estocolmo: Atlantis, 1996.

${ }^{3}$ Diplomático de carrera, Danielsson pertenecía a una familia de la alta burguesía. Había nacido en El Havre (Francia) el 13 de agosto de 1880 y falleció el 21 de julio de 1963 en Nogaredo (Trentino, Italia). Estuvo casado dos veces. Su primera esposa fue Ella Langard, con quien residió en España y que le dio dos hijas. Su segunda, ya jubilado, fue María Lodron Laterano, a la que conoció posiblemente en Austria. Le correspondió representar a Suecia ante la España de Alfonso XIII y Primo de Rivera y, más tarde, ante la España
} 
La figura y carrera diplomática de Carl Ivan Danielsson es un tanto singular, por no decir enigmática. El estudio de su expediente personal en el Ministerio sueco de Negocios Extranjeros así lo da a entender, ya que hay aspectos importantes de su gestión diplomática que no están suficientemente detallados, en concreto los relativos a sus cambios de destino. Parece haber dejado algunos cargos en condiciones irregulares: dejó Austria a principios de los años veinte por "circunstancias especiales"; fue objeto de una discreta "expulsión" de España por voluntad de Azaña en 1936, truncada por el estallido de la guerra; y fue declarado "persona non grata" en Egipto durante la Segunda Guerra Mundial. También hay referencias a sus pases a situación de "disponible para la realización de ciertos trabajos especiales", como aparece en una nota manuscrita sin firmar del 24 de septiembre de 1924; y, finalmente, está el asunto de su salida del cargo de Ministro plenipotenciario sueco en Budapest a principios de 1945, tras haber caído en manos del Ejército soviético y conseguir, con apoyo vaticano, refugiarse en Rumania, hasta que pudo volver a Suecia en abril de ese año como correo diplomático desde Moscú ${ }^{4}$.

¿Cómo explicar este curriculum irregular? A falta de una mayor información al respecto, pensamos que caben dos líneas de explicación posibles: la primera es que Danielsson fuera una persona que, por convicción política o por otros motivos, entraba fácilmente en conflicto con las autoridades de los países donde estuvo destinado, dando lugar a frecuentes tensiones de tipo diplomático, como ha quedado patente.

Si así fuera, sería un diplomático mediocre que carecería de aptitudes básicas para ejercer la más alta representación de Suecia en los países de destino, lo que en buena lógica hubiera debido llevarle a su apartamiento del Cuerpo Diplomático o, al menos, a su nombramiento para tareas de menor responsabilidad, en países africanos o asiáticos con los que Suecia tuviera menos relaciones.

Por otra parte, y a favor de esta explicación, está el hecho cierto de que los problemas diplomáticos de Danielsson en España y Egipto sucedieron ya al final de su carrera, cercana ya la edad de jubilación, cuando pertenecía, por tanto, al grupo de diplomáticos de carrera de la época anterior a la subida al poder de la socialdemocracia, que no siempre fueron vistos con buenos ojos por ésta ${ }^{5}$.

republicana. De sus muchos y prolijos despachos se deducen claramente sus simpatías por el régimen monárquico de gobierno.

${ }^{4}$ RA, UD: P1: 167, expediente personal de Carl Ivan Danielsson.

${ }^{5}$ A favor de esta tesis habla también el hecho de que, como señala Levine, Wallenberg consiguió del jefe del gobierno sueco, Per Albin Hansson, ser eximido de la obligación de consultar todos sus pasos con Danielsson, así como las escasísimas menciones a Ivan Danielsson en la opinión pública y la historiografía 
La segunda explicación, que, a la luz de las fuentes de que disponemos, consideramos también plausible, es que Danielsson fuera un hombre de confianza de las autoridades suecas para llevar a cabo misiones delicadas. Da la impresión, por la documentación contenida en su expediente personal, que altos funcionarios del Ministerio sueco de Negocios Extranjeros, como el Barón Beck-Friis, jefe de la sección política del mismo, confiaban en él. Y, considerando los eufemismos y silencios del expediente, además de su ayuda a los refugiados políticos en la guerra española y en la mundial, no cabe descartar que fuera así.

Corrobora de algún modo esta segunda explicación el expediente de servicios de Danielsson. Consta, por su expediente personal, que gozaba de prestigio: entre 1917 y 1921 fue Primer Secretario de la Embajada sueca en Berlín. Luego fue nombrado Encargado de Negocios en Varsovia, y Ministro Plenipotenciario en España durante los años 1921-1923; y más tarde fue jefe del Departamento de Personal del Ministerio de Negocios Extranjeros de Estocolmo. A principios de los años veinte, la prensa se hizo eco de algunos rumores sobre su posible nombramiento como Embajador en Washington; y en los años treinta, y hasta su jubilación en 1945, fue Ministro Plenipotenciario en lugares de cierta importancia desde el punto de vista del equilibrio político-militar, como España (ya que, tras su salida en 1936, se ocupó del seguimiento de la guerra civil, desde el Ministerio de Negocios Extranjeros en Estocolmo), Egipto y Budapest.

En esta última capital, Danielsson fue jefe de misión del mítico Raoul Wallenberg. Ya desde antes de la llegada de éste a la capital húngara habían comenzado el Ministro Danielsson y el attaché Per Anger a proteger a los judíos de la capital, expidiendo pasaportes, al igual que el vicecónsul suizo Karl Lutz, el Embajador español Ángel Sanz Briz y el Nuncio papal Angelo Rotta ${ }^{6}$. En esto Danielsson seguía fiel a su comportamiento durante la guerra civil española, en la que no dudó en utilizar su ascendiente diplomático para facilitar la evacuación de los refugiados políticos en las Legaciones escandinavas en Madrid.

Nosotros pensamos que ambas hipótesis - la de Danielsson como diplomático del antiguo régimen, creador de conflictos e incómodo para el gobierno sueco; y la de

suecas, mientras que sus dos subordinados, Per Adner y Raoul Wallenberg, gozaron del prestigio público inherente a su labor humanitaria a favor de los judíos húngaros. En todo caso, no cabe duda que sus simpatías políticas eran claramente de derechas, no afines a la socialdemocracia, cfr. LEVINE, Paul A., LEVINE, Paul A., Raoul Wallenberg i Budapest. Människan, myten och förintelsen, Lund: Historiska Media, 2011, passim. ${ }^{6}$ LEVINE, op. cit.; VV. AA., Ángel Sanz Briz: Homenaje a la memoria del Excmo. Sr. Embajador de España, Valladolid: Instituto de Estudios Europeos (Univ. de Valladolid), 2009. 
Danielsson como hombre de confianza de sus superiores, encargado de cuestiones delicadas - se pueden conjuntar, pues no son necesariamente excluyentes: nos hallamos ante un diplomático de prestigio que cuenta con la confianza con sus superiores administrativos, y con un hombre de ideas conservadoras y por tanto no especialmente afín a los políticos socialdemócratas que tomaron las riendas del poder en Suecia a partir de 1932.

Su sucesor en el cargo, Erik Wisén, al que le correspondería dirigir la Legación de Suecia durante la guerra civil española, tenía una personalidad algo distinta. Fue agregado comercial de la Legación en Madrid, bajo Danielsson, durante el segundo bienio de la República, y por lo tanto conocía bien la realidad española. Mantuvo una cierta amistad con Georg Branting ${ }^{7}$, el político del ala izquierda de la socialdemocracia sueca que fue presidente del Comité de Ayuda a España durante la guerra y abogado de la Legación de España en Estocolmo, entre otros cargos. Las autoridades franquistas, tanto durante la guerra como al final de la misma, no dejaron de resaltar las simpatías del matrimonio Wisén por la España republicana y las de Danielsson por la suya propia ${ }^{8}$.

Esta apreciación de la postura política de los diplomáticos suecos, sin embargo, no deja de ser un tanto simplista: Como veremos más tarde, ambos diplomáticos se muestran críticos, en sus despachos acerca de la situación política española, y censuran todo lo que consideran extremista, sea cual sea su signo político. Danielsson no dudará en llamar "fanáticos" a los grupos extremistas de la derecha española de corte fascista o de corte clerical, como también lo hará con los grupos de izquierdas que procedían a la quema de iglesias y conventos o incitaban a la lucha contra el orden establecido por cauces no democráticos. Tampoco Wisén tendrá reparos en exponer claramente al gobierno sueco todo aquello que no consideraba propio de un Estado democrático y en algunos casos hará constar su protesta ante el gobierno de la República.

\footnotetext{
${ }^{7}$ Consta el trato a nivel personal de Erik Wisén y su esposa Alexandra con Georg Branting: cfr. RA: Beskickningsarkivet, F1 C, vol. 49. Esto no significa, sin embargo, que compartiera sus mismas ideas políticas.

${ }^{8}$ Cfr. AMAEC, R 832, 1: "Elemento indeseable entre el personal [de la Legación de Suecia en España] es la esposa del encargado de Negocios extranjeros (sic) Sra Wisén, amiga íntima de algunos cabecillas rojos y denigradora de los españoles nacionalistas". Alejandra Wisén, (de soltera Loviaguine), era rusa. Respecto a Danielsson, cfr. AGA, Asuntos Exteriores, Caja n. 5290, despacho n. 90 de la representación en Oslo, de 29.I.1937; cfr. también AMAEC R 602, 5, despacho de 1.IX.1937 de Gabriel Dafonte, representante oficioso en Suecia del gobierno de Burgos: habla de "las extraordinarias simpatías que siente el Sr. Danielsson por la causa nacional". También dice que Danielsson es "persona no excesivamente grata a este gobierno, tipo frente-popular, [lo cual le] obliga a aceptar resignadamente ciertas misiones..." Esta última afirmación parece confirmar la primera explicación que apuntábamos como una de las dos posibles sobre la actuación profesional del diplomático.
} 
Además de la Legación - situada en un palacete de la calle Zurbano de Madrid, donde se encuentra aún hoy -, Suecia contaba en España con una gran red de cónsules y vicecónsules, la mayoría de carácter honorario, que eran ciudadanos españoles o de terceros países: un Cónsul General en Madrid, cónsules en Barcelona, Cádiz, Alicante, Bilbao, Canarias y Mallorca y vicecónsules en Sevilla, Vigo, Madrid, Alicante, Santander, San Sebastián, Sanlúcar de Barrameda, Las Palmas de Gran Canaria, la Coruña, Jerez de la Frontera, Almería, Málaga, Santa Cruz de Tenerife y Gijón, además de Valencia y Tarragona ${ }^{9}$.

En la Legación de Suecia en Madrid, por tanto, durante la mayor parte de la década de los treinta del siglo XX - hasta el nombramiento de Westman como Ministro Plenipotenciario ante Franco - hubo tan sólo dos jefes de misión, dato que, en sí mismo, y más aún comparado con la situación de la Legación de España en Estocolmo, es manifestación clara de la estabilidad política del país escandinavo.

Carl Ivan Danielsson fue, como quedó dicho, el Ministro plenipotenciario de Suecia en España durante la mayor parte de la década de los veinte y los seis primeros años de la década de los treinta. Fue extremadamente prolijo en sus informaciones a su gobierno acerca de la realidad política española, que a menudo se concretan en uno o incluso varios despachos semanales. Es fácil, a tenor de los mismos, seguir la política española prácticamente semana a semana. Lo que no es tan sencillo es conocer cuáles eran sus fuentes pues, como es habitual en el mundo diplomático, suele ocultarlas, limitándose a expresiones como "según mi informador", o "según fuente fidedigna". En ocasiones, sin embargo, deja entrever algún nombre, como el del Nuncio Apostólico u otros colegas del Cuerpo Diplomático acreditado en Madrid, el del Cónsul General de Suecia Luis de la Peña, o algunos cargos de la aristocracia cercanos a la Casa Real: el edecán de S.M., el marqués de Valdeiglesias, etc. En esto sigue la práctica habitual de los diplomáticos de todo tiempo: apoyarse en sus contactos con la clase política y empresarial del país donde residen, y de sus colegas de otros países, a la hora de formar su juicio sobre la realidad del país.

Los informes de Danielsson y, posteriormente, de Wisén, son la fuente fundamental para conocer la visión que recibió el gobierno sueco de la realidad política de la República Española.

\footnotetext{
${ }^{9}$ RA, Beskickningsarkivet, C 3 B: 272; AMAEC, R 790, 3.
} 


\subsection{La política interior española de 1931 a 1936 según la diplomacia sueca}

\subsubsection{Las vísperas republicanas y el cambio de régimen}

Comenzamos nuestra exposición mostrando la visión que transmitió la Legación de Suecia en Madrid sobre la política interior española ya desde la época final de la Dictadura, es decir, en las vísperas republicanas.

Los primeros informes confidenciales de Danielsson al Ministerio sueco de Negocios Extranjeros sobre la delicada situación política española y los planes para "volver a la normalidad, es decir, para la puesta en vigor de una nueva constitución" son de noviembre de 1929. Danielsson se hace eco de los rumores que circulaban sobre un endurecimiento de la dictadura "en dirección fascista", y hace notar el descontento de los oficiales de Artillería y de la Armada y de los estudiantes de Madrid, además de las protestas por el dirigismo paternalista de la economía. Aunque la situación de la peseta, con grandes oscilaciones en su cotización, era un factor de riesgo, la situación financiera parecía estable. Algunos creían que el fin del gobierno de Primo de Rivera estaba próximo, pero el Cuerpo Diplomático en Madrid no creía en un cambio inmediato de régimen ${ }^{10}$.

Sin embargo, a los pocos días Danielsson se vio obligado a rectificar esa información: una semana más tarde titulaba uno de sus despachos “iHa llegado a su fin la Dictadura española?", y comentaba el levantamiento de la censura de los comunicados de prensa con el extranjero y los rumores de nuevas elecciones a Cortes.

En los despachos de los meses sucesivos fue informando sobre los planes de desmantelamiento progresivo de la Dictadura y de retorno a la normalidad constitucional según la Constitución de 1876. Opinaba que la Nación española estaba harta de dictadura y había mostrado su descontento mediante campañas denigratorias. Al descontento con la dictadura achacaba la situación de la peseta, sujeta a vaivenes a causa de especulación internacional contra la misma; y se mostraba crítico con Primo de Rivera por involucrar al Rey en su política. Era evidente que Primo de Rivera tenía en aquel momento a todo el mundo en su contra, incluso al Ejército. La caída del dictador y la subida al poder de Berenguer - sobre el cual escribió Danielsson que era conocido en Suecia por la visita de

\footnotetext{
${ }^{10}$ RA, UD, 1920-års dossierssystem, vol. 420, despachos de 7.IX. y 5.XII.1929.
} 
Alfonso XIII de 1928 - fue contestada desde el principio, y algunos grupos estudiantiles se enfrentaron a la policía al grito de “¡Abajo Berenguer, viva la República!" .

No obstante, pocos días después Danielsson comenzó a dar otra visión del nuevo gobierno de Berenguer. En febrero de 1930 escribió que había sido "muy bien recibido", y que los rumores internacionales sobre la posibilidad de la instauración de una República en España no tenían base alguna. Citaba lo que consideraba logros del nuevo gobierno: la amnistía de delitos políticos, la sustitución de políticos "primorriveristas", la libertad de prensa, la anulación de actos ilegales de la dictadura, la revisión de los presupuestos de los Ministerios para reducir el gasto público y la intención de convocar las Cortes. A pesar de todo, hacía notar que no había todavía libertad de reunión política y que seguía existiendo una cierta censura, por lo que la opinión republicana iba ganando fuerza, apoyada por los socialistas, los partidos republicanos, los intelectuales de izquierda, parte del Ejército e incluso algunos políticos conservadores.

En general, Danielsson pensaba que Berenguer tenía "la intención honrada" de hacer que España volviera a la normalidad constitucional, y opinaba que para ganar su objetivo debía proceder "despacio y sistemáticamente", ya que el gran problema para la convocatoria de elecciones a Cortes era la ausencia de unas listas electorales fiables, puesto que las anteriores a 1923 estaban obsoletas y las elaboradas en la Dictadura habían sido manipuladas.

Según Danielsson, las informaciones de la prensa extranjera sobre la convulsa situación política española, dominada por huelgas y manifestaciones revolucionarias, eran "muy exageradas y tendenciosas", aunque la gran incógnita era el futuro del Republicanismo, ya que hasta el Conde de Romanones empezaba a considerar la posibilidad de la instauración de una República con el Rey Alfonso como Presidente. Otros políticos, como Sánchez Guerra en su famoso discurso del 27 de febrero de 1930, se habían pronunciado por la sustitución de Alfonso XIII - que se habría hecho indeseable por su apoyo a la dictadura - por su hijo don Juan o por una República ${ }^{12}$.

La situación política había obligado al gobierno a hacer un alto en el camino de normalización. Las manifestaciones, tras las declaraciones de Sánchez Guerra, habían sido más serias de lo que parecía a primera vista, y los estudiantes habían "cubierto de golpes a

\footnotetext{
${ }^{11}$ RA, UD, 1920-års dossierssystem, vol. 420, despachos de 5, 8, 21, 22, 26,28 y 29.I.1930; telegramas de 22 y 31.I. 1930.

${ }^{12}$ RA, UD, 1920-års dossierssystem, vol. 420, despachos de 4, 8, 11, 17, 21, 22, 25 y 28.II.1930. El enfrentamiento de los dos hijos mayores de Primo de Rivera con un militar quedó también recogido en los despachos.
} 
grupos de gente que se negaba a dar vivas a la República”. Se gritaba “¡Muera el Rey!”, y había otros signos preocupantes. En un despacho confidencial, con copia directa al Rey Gustavo V, escribía Danielsson que las ideas republicanas habían cobrado mucha fuerza tras los ataques de Sánchez Guerra y que miles de personas de todas las clases sociales habían estampado sus firmas en el Palacio Real en apoyo del Rey. La situación era poco clara, pero Danielsson desmentía los rumores de la prensa extranjera acerca de una posible abdicación de Alfonso XIII, de la convocatoria de una huelga general, etc. Comentaba también que "algunos colegas hablan de una conspiración militar de los generales Saro y Cavalcanti para reinstaurar la Dictadura”, pero el Rey no lo había aceptado. Concluía diciendo que Berenguer tenía buenas intenciones, pero evidentemente no estaba a la altura de las circunstancias que su misión requería; y que se discutía públicamente la posibilidad de que las nuevas Cortes tuvieran carácter constituyente ${ }^{13}$.

A mediados de marzo, el diplomático informaba de la muerte y entierro de Primo de Rivera, señalando que su "fuerte patriotismo e indudable honor" estaban fuera de toda duda y que la prensa señalaba sus dos aciertos, la guerra de Marruecos y la paz social, y su gran fallo, el no haberse retirado a tiempo. Primo de Rivera, en opinión de Danielsson, era popular entre la gente sencilla, pero no entre los intelectuales ${ }^{14}$.

Los monárquicos se iban reorganizando poco a poco, y también los socialistas. La manifestación-homenaje a Pablo Iglesias con gran participación de la clase trabajadora se había desarrollado con un "orden modélico". Mientras tanto, seguía la propaganda republicana y en Cataluña, cuya independencia cultural e idiomática había reprimido la Dictadura, se abogaba por la creación de una República Federal Ibérica. En Portugal - país en el que Danielsson era también Ministro Plenipotenciario - no se veía esto con buenos ojos y se hablaba del "peligro español". Las elecciones se retrasaban porque el gobierno quería disponer de unas listas electorales fiables. Un acto monárquico en la nueva plaza de toros de Madrid no había tenido éxito "a pesar de la propaganda realizada". Parecía también que las mujeres no podrían votar en las elecciones, a pesar de que ya tenían voto en las elecciones locales y Primo de Rivera les había prometido el sufragio también en las Generales ${ }^{15}$.

Daba cuenta también Ivan Danielsson de la actividad política de Indalecio Prieto y Melquíades Álvarez, mencionando las acusaciones de Prieto a Alfonso XIII y a su

\footnotetext{
${ }^{13}$ RA, UD, 1920-års dossierssystem, vol. 420, despachos de 1 y 6.III.1930.

${ }^{14}$ RA, UD, 1920-års dossierssystem, vol. 420, despachos de 17 y 20. III.1930

${ }^{15}$ RA, UD, 1920-års dossierssystem, vol. 420, despachos de 8 y 23.IV.1930
} 
camarilla de haber ganado mucho dinero con las concesiones públicas. De todas formas, el problema del republicanismo español era su desunión, puesto que no se decidían a unirse en un solo partido.

A Danielsson le sorprendía la "imparcialidad" del gobierno, al tiempo que se sucedían los mítines y protestas estudiantiles, incitados por personalidades como Miguel de Unamuno. En mayo escribió que "pocos españoles con los que he hablado han dejado de expresarme su preocupación por la situación política". Los viejos partidos estaban desorganizados; la izquierda deseaba aprovechar la ocasión para traer la República, y las elecciones obligaron a los partidos a decantarse por una postura clara al respecto. En opinión del viejo Conde Gimeno, del Partido de Romanones, con quien Danielsson se había entrevistado, no se saldría de esta crisis si el Ejército no se decidía a intervenir, pero todos los generales estaban a favor de la Monarquía. Gimeno opinaba que Berenguer debía dejar el paso a un gobierno fuerte, pero no había nadie en España con carisma suficiente para dirigirlo. De todas formas, los republicanos no podían aspirar más que a unos 70 escaños, del total de $420^{16}$.

A partir de junio de 1930, se puede observar un ligero cambio cualitativo en los informes de Ivan Danielsson al gobierno sueco. El tono más bien positivo con que había presentado al gobierno Berenguer, resaltando su "buena voluntad" o sus esfuerzos por reconducir a España a un sistema de normalidad constitucional, se volvió algo más crítico. El detonante, a nuestro entender, fue la vuelta a la censura, con la prohibición de discusiones políticas, algo inadmisible desde la perspectiva democrática sueca. Danielsson no dudará ahora en calificar al gobierno de "dictatorial" argumentando que eso era la causa de la inseguridad política, de la oposición contra Berenguer, de la caída de la peseta, etc. Como aspecto positivo, dentro de todo esto, señalaba la suavización de la política gubernamental respecto a Cataluña, al mencionar el viaje del Rey a Barcelona, y su entrevista con Santiago Alba, que le sugirió que encargara a las nuevas Cortes una revisión profunda de la Constitución, para convertir a la Monarquía en constitucional y democrática, siguiendo el modelo británico.

De los incidentes de Sevilla, la huelga general y los tres días de "sangrientos combates entre la policía y los manifestantes" acusaba Danielsson a los comunistas y otros grupos de izquierda de Barcelona, citando como fuente al propio Berenguer, en una reunión con un grupo de diplomáticos. Quizá proceda de la misma fuente la información

\footnotetext{
${ }^{16}$ RA, UD, 1920-års dossierssystem, vol. 420, despachos de 2, 7 y 11.V.1930
} 
que enviaría más tarde: “es conocido - escribía - que los sindicatos españoles apenas tienen dinero, por lo que el gobierno ha podido mostrar que el oro ruso se ha introducido en el país para repartirlo a los huelguistas"17.

A pesar de todo, concluía Danielsson, el que existiera en España una dictadura de hecho podía tener consecuencias más graves que dar rienda suelta al libre juego político ${ }^{18}$. Llamaba la atención "la gran pluralidad de opiniones políticas existentes y la desunión política que se deja sentir incluso en el seno de cada uno de los partidos políticos respecto a cual sea la forma de gobierno preferible".

Había un tema al que el diplomático sueco se refería con frecuencia: las vicisitudes de la censura. El 15 de septiembre parecía cantar victoria: "por fin se acaba la censura en España". Pero dos semanas después hubo de informar que se había implantado de nuevo. A finales de septiembre informó de los rumores acerca de la posible dimisión del Duque de Alba, atacado por "el órgano clerical El Debate por sus viajes al extranjero".

En el otoño de 1930, tras la dimisión de Argüelles, tuvo que reconocer que la situación había empeorado mucho, con "huelgas continuas de carácter revolucionario, con sangrientos encontronazos entre manifestantes y policía”. Aludía al arresto de los líderes republicanos y sindicalistas por incitar a la huelga general. La situación era, según Danielsson, de mucho nerviosismo y algunos - sin duda de los círculos en los que se movía el diplomático - veían como única solución una nueva Dictadura.

En su análisis sobre las huelgas, Danielsson mezclaba los motivos políticos y los económicos. Comentaba que, a pesar de que las condiciones laborales habían mejorado en cierta medida durante la Dictadura, muchos españoles seguían viviendo "bajo el mínimo existencial" y se hacía sentir la subida de precios motivada por la caída de la peseta. En relación con los disturbios del 12 de noviembre escribió que las huelgas no eran planeadas sino que estaban motivadas por accidentes y reacciones populares, aunque los comunistas, e incluso los monárquicos liberales, intentaban aprovecharse de ellas para hacer caer al gobierno. Sin embargo, consideraba que la prensa extranjera exageraba la magnitud de los desórdenes, que "para los españoles son sólo de relativa importancia, y casi se pueden calificar de diversión popular"19.

\footnotetext{
${ }^{17}$ RA, UD, 1920-års dossierssystem, vol. 420, despacho de 22.XII.1930.

${ }^{18}$ RA, UD, 1920-års dossierssystem, vol. 420, despachos de 18 y 26.VI. y de 3.VII.1930.

${ }^{19}$ RA, UD, 1920-års dossierssystem, vol. 420, despachos de 9.VII.1930; 20.VIII.1930; 8, 15 y 30.IX.1930; 16.X.1930; 22.XI.1930; 21.XI.1930. La última frase está tomada del despacho n. 513 de 19.XI.1930: [oroligheterna] som ur spansk synpunkt äro av relativt obetydlig natur och mera kunna rubriceras som folknöjen, i den utländska pressen förstoras.
} 
El levantamiento de Jaca y el motín de Cuatro Vientos merecieron, como es lógico, dos telegramas cifrados específicos al Ministerio sueco de Negocios Extranjeros seguidos de detallados despachos, en los que, tras dar cuenta de los hechos, opinaba (basado en rumores y comentarios, pues había otra vez censura de prensa) que Jaca era parte de un complot militar a favor de la República planeado en bastantes otros lugares, sobre todo del norte de España, y que "por la intervención del Ejército en la actual lucha política española entre el gobierno y la oposición a la actual forma de gobierno, la situación política se había hecho aún más grave". Añadía que los republicanos, seguros de que en las elecciones habría una mayoría monárquica, hacían lo posible por desestabilizar el régimen ${ }^{20}$.

Aún así, Danielsson seguía claramente influido por las informaciones que recibía de círculos progubernamentales, y en sus informes intentaba quitar importancia a lo que entendía que eran rumores exagerados por parte de la prensa. Buena muestra es la memoria-resumen de fin de año, a la que pertenece este párrafo:

Si se juzga por la prensa extranjera, la situación de España es caótica y a Alfonso XIII no le queda otra solución que exiliarse cuanto antes. Pero en honor a la verdad hay que decir que la mayor parte de las informaciones de la prensa internacional han sido no solo exageradas y tendenciosas, sino a menudo también falsas. Es cierto que por la censura no se sabe todo, pero parece que el gobierno no ha querido ocultar los hechos más significativos. Hoy hay calma completa en el país. Parece actualmente demostrado que Jaca y Cuatro Vientos han sido episodios de un intento general de derrocar el régimen político. Su fracaso se debió al hecho de que los de Jaca se rebelaron antes de lo previsto, y sobre todo porque la mayoría del Ejército se mantuvo fiel al Rey y al gobierno. También el pueblo, en su mayor parte, se ha mantenido pasivo, y en los casos en que ha habido violencia, se ha podido siempre comprobar la implicación de elementos comunistas

La intención del gobierno, "sin duda alguna sincera", de volver a aplicar la Constitución de 1876, se había encontrado con la oposición de elementos contrarios al régimen, que procuraban crear desorden para favorecer el cambio del mismo. Las ideas republicanas habían crecido en número de adeptos durante los últimos años, especialmente tras la caída del general Primo de Rivera y muchos consideraban que Alfonso XIII era el responsable de aquella larga dictadura. Sin embargo, "no hay duda de que la monarquía es claramente la forma de gobierno preferida por las clases populares para las que la política

\footnotetext{
${ }^{20}$ RA, UD, 1920-års dossierssystem, vol. 420, telegramas n. 7 y 8 de 15 y 16.XII.1930; despacho n. 553 de 18.XII.1930; despacho n. 561 de 16.XII.1930
} 
no es una mera palabra hueca"; aunque añadía que los republicanos se habían podido beneficiar de la "epidemia de huelgas" que había tenido lugar en el país, a menudo con carácter de pura anarquía, desórdenes callejeros y pillajes, Danielsson advertía entre los republicanos un cierto temor por la influencia negativa que el recurso a métodos de lucha puramente comunistas pudieran tener sobre la causa republicana. La intervención militar en Jaca y Cuatro Vientos había sido un golpe duro para el gobierno, pero estaba claro que éste y el Rey contaban con el apoyo mayoritario del ejército. Las nuevas Cortes serían ordinarias, no constituyentes, aunque la izquierda lo hubiera pedido así, e incluso entre grupos de la derecha había quien decía que esta sería la mejor solución ${ }^{21}$.

En enero de 1931, un detallado informe de Danielsson titulado "el movimiento republicano español", volvía a referirse a Jaca y a Cuatro Vientos - "episodios de un complot organizado para introducir la República en España” - y a los avances del republicanismo, dirigido por Alcalá Zamora, "del que se dice que ofreció toda su gran fortuna para ganar adeptos al republicanismo". Los republicanos llevaban a cabo un trabajo intenso de agitación, mediante panfletos que atacaban violentamente al Rey. Por esa razón, al diplomático le sorprendía el optimismo del régimen monárquico: "A uno de mis colegas le dijo el Rey Alfonso en la comida de Año nuevo en Palacio, que la Monarquía podía confiar en el Ejercito y que no había motivo alguno de preocupación".

Quizá lo más llamativo de su análisis sea el párrafo siguiente:

Un aspecto de la lucha política actual digno de consideración es la tendencia de carácter puramente revolucionario que se ha dejado sentir en varias ocasiones, según se dice, por influencia directa de la Unión Soviética. Para un observador neutral es llamativa la forma en que se extiende en la opinión pública, e incluso entre las clases sociales que en modo alguno deberían ser contrarias a la Monarquía, una animosidad creciente contra el monarca, al que se le hace responsable de este estado de caos político insoportable a largo plazo $^{22}$.

Haciéndose eco de los rumores sobre un posible cambio de gobierno, informaba Danielsson que Berenguer deseaba dimitir, pero Alfonso XIII se oponía decididamente. Según las informaciones que había recibido "de una persona bien informada", había dos tendencias entre los monárquicos: un grupo, formado por La Cierva, Maura, el Conde Bugallal, Romanones y Alhucemas, junto con el almirante Magaz, que deseaban seguir la

\footnotetext{
${ }^{21}$ RA, UD, 1920-års dossierssystem, vol. 420, despacho n. 573 de 22.XII.1930.

${ }^{22}$ RA, UD, 1920-års dossierssystem, vol. 420, despacho n. 6 de 7.I.1931.
} 
línea actual, y otro, de orientación izquierdista, bajo Santiago Alba y Melquíades Álvarez, junto con Sánchez Guerra y Cambó, que abogaba por la convocación de Cortes Constituyentes. Sin embargo, no parecía que fueran a conseguirlas. Los socialdemócratas y republicanos, según Danielsson, preferían no participar en la campaña electoral y promovían la abstención. Danielsson y varios Embajadores con los que había hablado opinaban que el Rey cometía un gran error al no distanciarse del gobierno actual y convocar unas Cortes Constituyentes. La situación estaba tranquila pero era "la calma que precede a la tempestad" 23 .

En febrero comunicó Danielsson a Suecia la convocatoria a Cortes con carácter extraordinario, la dimisión de Berenguer, y la formación del gobierno Aznar. Mencionaba que "una persona que está especialmente cercana a los actores principales" no ocultaba su preocupación por la situación actual, porque temía que los grupos de izquierdas se hicieran con el triunfo y llevaran a cabo sus radicales programas de reformas. La posición del Ejército era un interrogante amenazador: “¿Se mantendrá pasivo o considerarán algunos generales, siguiendo ejemplos conocidos anteriormente, llegado el momento de intervenir para salvar al país de una situación de completo caos político y social, en cuyo caso caería España de nuevo en una dictadura militar?". Mencionaba el rumor no confirmado de que algunos generales (Martínez Anido, Barrera y Cavalcanti) habían ofrecido al Rey sus servicios para reinstaurar una dictadura militar en el país. Por otra parte, se decía que los coroneles y los jefes de los regimientos de Madrid habían acordado no permitir que las tropas se involucraran en los acontecimientos políticos.

A pesar de la "incierta y amenazadora" situación política, Danielsson opinaba que el gobierno Aznar aún podía controlar la situación. Romanones le había dicho a Danielsson que no se dejara influir por la prensa internacional sobre lo que pasaba en España ${ }^{24}$. La situación era difícil, ciertamente, pero el país era claramente monárquico. Entre los socialistas, informaba Danielsson, había dos tendencias respecto a la instauración de la República: una, partidaria de usar todos los medios, incluso los revolucionarios. Otra tendencia se oponía a utilizar medios ilegales. Julian Besteiro y Andres Saborit, que representaban "el elemento sensato del partido", tuvieron que dejar sus puestos en la Junta central y los socialistas decidieron participar en las elecciones municipales y provinciales,

\footnotetext{
${ }^{23}$ RA, UD, 1920-års dossierssystem, vol. 420, despacho n. 46 de 30.I.1931; n. 69 de 7.II.1931.

${ }^{24}$ RA, UD, 1920-års dossierssystem, vol. 420, despacho 109 de 26.II.1931.
} 
aunque la mayoría se opuso a participar en las elecciones generales y decidió "seguir su actividad revolucionaria para conseguir un cambio de régimen" ${ }^{25}$

Los sucesos de los días 12 al 14 de abril de 1931 fueron seguidos al detalle por la Legación de Suecia ${ }^{26}$. El día 13 informaba Danielsson que "en el conflicto en curso entre republicanos y monárquicos, la parte del pueblo español que piensa y actúa políticamente ha dado a conocer sus preferencias libremente y sin dejar lugar a dudas". El 15, en el primer despacho desde la proclamación de la República, junto con la información detallada del cambio de régimen, resumía el diplomático sueco sus impresiones de la forma siguiente:

Con una velocidad inusitada se han sucedido los acontecimientos. El cambio de régimen se ha llevado a cabo de forma pacífica y sin derramamiento de sangre. La abrumadora victoria de los partidos antidinásticos en las elecciones municipales, que ha debido resultar una sorpresa hasta para los propios vencedores, parece haber paralizado totalmente a los partidarios de la monarquía. La segura mayoría monárquica en la mayor parte del país significó poco, pues la vida política se concentra en las ciudades y estas dieron por abrumadora mayoría su sentencia de muerte al régimen monárquico (...

El entusiasmo en la ciudad tras la proclamación de la República era indescriptible y durante todo el día, declarado festivo, ha estado la gente por la calle dando vivas a la República. A pesar de la ausencia de policías en las calles no ha habido excesos dignos de mención $(\ldots)$

Es demasiado pronto para predecir las consecuencias de este cambio de régimen para el país. A favor de la efectividad del nuevo régimen habla el hecho de que la Republica haya podido establecerse sin derramamiento de sangre, al igual que el hecho de la neutralidad del Ejército. Es, sin embargo, poco creíble que los republicanos puros sean más que una pequeña parte de los que han echado abajo a la monarquía. La mayoría parece consistir en socialistas, cuya colaboración a largo plazo con un jefe de gobierno republicano parece problemática, y en un gran número de personas que querían vengarse en la persona del Rey Alfonso de las injusticias sufridas durante la dictadura de Primo de Rivera y que solo por ello votaron a la coalición republicano-socialista.

\footnotetext{
${ }^{25}$ RA, UD, 1920-års dossierssystem, vol. 420, telegramas n. 2, 3, 4 y 5 de 14, 16, 17 y 18.III.1930; despachos n. 73 de 10.II.1931; n. 79 y 80 de 14.II.1930; despacho confidencial n. 84 de 16.II.1931; n. 88 de 18.II.1931; n. 96 de 20.II.1931; n. 107 de 26.II.1931; cfr. también Ibidem, Nota de la Legación de España en Estocolmo al Gobierno sueco de 21.II.1931.

${ }^{26}$ RA, UD, 1920-års dossierssystem, vol. 420, telegramas n. 7 de 13.IV.1931; n. 13, 14 y 15 de 14.IV.1931: Despacho n. 183 de 13.IV.1931 y despacho n. 186 de 15.IV.1931. Como se ve, sólo en la tarde del 14 de abril se enviaron a Estocolmo tres telegramas.
} 


\subsubsection{La situación política española en el primer bienio republicano}

El 17 de abril de 1931 informaba Danielsson que la autoridad del nuevo gobierno republicano parecía ser acatada en todo el país y que los posibles peligros para el nuevo Régimen vendrían de parte de los comunistas, y no de los monárquicos. Alcalá-Zamora apenas había abandonado su despacho y ya se habían gestado un respetable numero de decretos sobre asuntos políticos y se habían anunciado profundas reformas sociales y administrativas, siendo "el punto más negro, por el momento, la cuestión catalana"27.

Con la llegada de la República, entraban en la escena política española nuevos nombres. Alcalá-Zamora recibió al Ministro plenipotenciario sueco a finales de abril y éste envió a su gobierno una breve semblanza sobre los nuevos dirigentes de España. En ella aparecen Fernando de los Ríos, al que consideraba el líder de los republicanos intelectuales, del que comentó su prestigio en los círculos universitarios y obreros, y su decidido apoyo del levantamiento de diciembre de 1930; Manuel Azaña, el más joven de todos, pero hombre a tener en cuenta; Indalecio Prieto, líder de las huelgas revolucionarias de 1917, gran orador parlamentario y "declarado enemigo del comunismo y del anarcosindicalismo"; Albornoz y Domingo, presentados como organizadores del partido radical-socialista, y Diego Martínez Barrio como ejemplo de político "moderado". Describía a Largo Caballero, al que llamaba co-fundador del partido socialista y hombre fuerte de la UGT y del movimiento obrero español (a excepción de los comunistas y los anarcosindicalistas), nombrado por Primo de Rivera miembro del Consejo de Estado por razones de táctica política, y definía como "un gran táctico, en nada doctrinario" 28.

Dentro de las preocupaciones específicas de Suecia respecto a la Segunda República Española ocupa un lugar principal la influencia en la misma, presentida o real, de las ideas comunistas y anarcosindicalistas, y en particular de la Unión Soviética. Analizamos este aspecto en un apartado propio, centrándonos aquí en el resto del análisis sueco que realiza Danielsson de la política interior española.

Estos fueron los temas principales de la evolución política española durante el primer bienio republicano tratados por la Legación de Suecia en Madrid:

1. El depuesto Rey Alfonso XIII y la causa monárquica ${ }^{29}$.

2. La legislación en materia religiosa y las difíciles relaciones Iglesia-Estado.

\footnotetext{
${ }^{27}$ RA, UD, 1920-års dossierssystem, vol. 420, despacho n. 189 de 17.IV.1931

${ }^{28}$ RA, UD, 1920-års dossierssystem Vol. 420, despacho n. 211 de 27.II.1931.

${ }^{29}$ Abordaremos este aspecto en el capítulo 5, al que remitimos.
} 
3. Las Cortes Constituyentes y el asentamiento del régimen republicano en España.

4. El intento de golpe de Estado militar y las huelgas revolucionarias.

5. Las grandes reformas: la cuestión catalana y la reforma agraria.

6. La situación financiera y la evolución política española en 1933.

Habitualmente estos temas se entremezclaban entre sí en los despachos que enviaban a Estocolmo, lo cual no es de extrañar ya que se solapaban cronológicamente, y en cierta medida lo harán también en esta exposición, aunque seguiremos un esquema más temático que cronológico. De hecho, ya a primeros de mayo de 1931 salen a relucir todos estos aspectos: Danielsson escribía que el gobierno de la joven República estaba muy activo, resaltando que el conflicto latente con la Generalitat se había calmado un tanto y que estaban en curso las reformas de la ley electoral y del Ejército - reforma que "parece bien pensada, pues España tiene 300 generales y 22.000 oficiales para un ejercito de 150.000 hombres" - pero que la relación con la Iglesia Católica estaba tensa a causa de las declaraciones del Cardenal Primado Segura favorables a Alfonso XIII, quien, por su parte, había dicho a los monárquicos españoles que prescindieran de su persona a la hora de cumplir sus deberes ciudadanos ${ }^{30}$.

\subsubsection{La legislación en materia religiosa y las difíciles relaciones Iglesia- Estado.}

Los sucesos de mediados de mayo de 1931, con la quema de iglesias y la declaración del estado de sitio fueron cubiertos al detalle por la Legación ${ }^{31}$. En su análisis de la situación da la impresión de que Danielsson se dejó llevar por el impacto que le produjeron estos hechos: llama la atención el fuerte tono de algunas de sus expresiones, algo que contrasta con la habitual cautela diplomática y con su carácter sueco. Dice Danielsson que los disturbios de Madrid, motivados por "la provocación de jóvenes monárquicos", manifestaban el "triunfo de las tendencias radicales sobre las más sensatas". Las masas obreras urbanas, en respuesta, se habían dejado llevar por "su innata malquerencia contra los jesuitas a causa de la política clasista de éstos, malquerencia que había cobrado fuerza por el conflicto entre el Primado de España y el Gobierno de la República” y por la lentitud y blandura del gobierno en exigir responsabilidades a los políticos de la dictadura. Ese ambiente, decía Danielsson, había sido aprovechado por los comunistas, tras lo cual se

\footnotetext{
${ }^{30}$ RA, UD, 1920-års dossierssystem Vol. 420, despacho n. 237 de 10.V.1931

${ }^{31}$ RA, UD, 1920-års dossierssystem Vol. 420, telegrama cifrado n. 22 de 11.V.1931, telegramas 23 y 24 de 13.V.1931; despachos n. 240 de 12.V.1931 y 245 de 17.V.1931.
} 
produjo el ataque a iglesias y monasterios, ataque que había presenciado personalmente, pudiendo constatar la pasividad del público y de las autoridades. El gobierno, sorprendido por los acontecimientos, echaba la culpa a un complot de los monárquicos, contra los que decidió proceder con dureza, al igual que, tras la pasividad inicial, contra los comunistas.

El diplomático sueco se mostraba extremadamente crítico ante la pasividad del gobierno, que no dudó en achacar los sucesos a unos motivos políticos premeditados. Consideraba que la hipótesis del complot monárquico era "poco creíble” y que

La pasividad, al menos inicial, que caracterizó la postura del gobierno ante los fanáticos ataques de las masas a las iglesias acaso sea una estrategia gubernamental para no perder el contacto con las masas (...)

La expresión puesta en boca de uno de mis colegas el día de la proclamación de la República, "Ahora se ha implantado en España la República, después se encargarán los españoles de llevar a cabo la revolución”, amenaza con hacerse realidad.

No bastó la fuerte reacción posterior del gobierno y de la población para hacer cambiar de opinión al Ministro plenipotenciario sueco en Madrid. El 17 de mayo escribía a su gobierno que era "muy difícil prescindir de la sospecha de que el ataque de las masas populares a los edificios eclesiásticos se llevó a cabo con la aprobación, al menos parcial, del gobierno", que así habría básicamente solucionado dos de los puntos principales del nuevo programa republicano, a saber: por una parte, la amenaza de una reacción monárquica, y por otra, la cuestión de la separación Iglesia-Estado. Aducía Danielsson, para fundamentar su opinión, lo que el Nuncio le había contado sobre el abandono de sus puestos por parte de frailes y monjas - que habían salido de España o se habían refugiado con familias amigas - y los informes que le había dado el cónsul sueco en Cádiz sobre los ataques a monasterios e iglesias en aquella ciudad. Según esos informes, el Ejército había querido intervenir, ante la pasividad de la Policía y la Guardia Civil, sin que el Gobernador civil lo permitiera. Sólo cedió su poder al gobernador militar cuando los monasterios habían sido saqueados e incendiados ${ }^{32}$.

La cuestión religiosa fue seguida con sumo interés por la Legación de Suecia en Madrid: la quema de conventos, las medidas de separación entre la Iglesia y el Estado, la denegación del placet vaticano a Zulueta, y especialmente, la confrontación del Cardenal

\footnotetext{
${ }^{32}$ RA, UD, 1920-års dossierssystem Vol. 420, despachos n. 240 de 12.V.1931 y 245 de 17.V.1931; cfr. también despacho n. 257 de 23.V.1931 sobre la denegación del "placet" a Zulueta por parte del Vaticano.
} 
Primado Segura con la República y sus consecuencias, con diversas manifestaciones a nivel popular, etc. En este contexto, expresaba Danielsson sus dudas de que los problemas se pudieran resolver sin una ruptura completa con el Vaticano y manifestaba el temor de que la cuestión religiosa se convirtiera en causa de graves males para España, teniendo en cuenta "por una parte, el fanatismo religioso que caracteriza a gran parte de la población española y por otra la excitación de los ánimos provocada en gran parte por las tácticas de la prensa de izquierdas de atacar a todas las instituciones del antiguo régimen".

Poco después, informaba Danielsson de la crisis del gobierno y la dimisión de Alcalá-Zamora al no poder aceptar éste las medidas adoptadas por las Cortes, en virtud de los artículos 3 y 24 de la nueva Constitución, sobre la separación de la Iglesia y el Estado, la prohibición a los religiosos de ejercer la enseñanza, la supresión de los jesuitas y nacionalización de sus propiedades, que supondría una transformación radical de la economía española, dadas "las grandes inversiones de capital eclesiástico en ferrocarriles, bancos y centrales eléctricas". Se estaba empezando a formar un movimiento clerical y los obispos habían dejado entrever que podrían llamar a los católicos a la desobediencia civil. Todas estas medidas habían favorecido al protestantismo en España ${ }^{33}$.

Por otra parte, no dejó de llamar la atención al diplomático sueco que el Nuncio presumiera de la labor de la Iglesia cuando felicitó a Alcalá-Zamora por su nombramiento como Presidente de la República. También le sorprendió la argumentación de los círculos clericales para intentar evitar su disolución, que consideró "típicamente jesuítica", por lo que no era extraño que los jesuitas hubieran perdido apoyo incluso entre los católicos practicantes $^{34}$.

Temía Danielsson, no obstante, que la cuestión religiosa tuviera consecuencias graves, pues “Azaña no tiene razón al decir durante el debate parlamentario que España había dejado de ser católica. La inmensa mayoría del pueblo español mantiene su profunda fe religiosa y está dispuesta a cualquier sacrificio para defender la causa de la Iglesia Católica". Confiaba, sin embargo, en que triunfara la cordura y el asunto se solucionara sin llevar las cosas al extremo ${ }^{35}$.

Cuando, por fin, entró en vigor la nueva Ley de Congregaciones religiosas, la Legación envió a Estocolmo traducción de la misma al francés, con su correspondiente

\footnotetext{
33 RA, UD, 1920-års dossierssystem Vol. 420, despacho n. 257 de 23.V.1931; despacho n. 299 de 19.VI.1931; telegrama 24 de 15.X.1931; despacho n. 465 de 15.X.1931; despacho n. 505 de 6.XI.1931; despacho n. 69 de 11.II.1932.

${ }^{34}$ RA, UD, 1920-års dossierssystem Vol. 420, despacho n. 567 de 14.XII.1931; despacho n. 49 de 26.I.1932.

${ }^{35}$ RA, UD, 1920-års dossierssystem Vol. 420, despacho n. 590 de 29.XII.1931
} 
comentario. Danielsson afirmaba que en ninguna cuestión había dejado el nuevo régimen español su sello revolucionario de forma tan clara como en el tratamiento de la cuestión religiosa. Le sorprendía el corto plazo acordado para la transferencia de la educación al poder civil, algo que podía causar graves problemas, pues 700.000 niños se podían quedar sin escuela, mientras no hubiera quien sustituyera a los religiosos. En los ambientes católicos, seguía diciendo el informe, la irritación era grande, los Obispos habían hablado de excomunión e incluso el Papa había criticado la ley. También informaba la Legación de las manifestaciones religiosas en las calles españolas, con "socialistas y republicanos gritando ‘AAbajo Cristo!', y el gobierno “tomando partido contra los católicos”, lo cual a los diplomáticos suecos les parecía sumamente peligroso, "sobre todo teniendo en cuenta el fanatismo religioso de gran parte del pueblo español" ${ }^{36}$.

La Legación de Suecia se refirió de nuevo a esta cuestión al informar de la caída del gabinete de Azaña en 1933. Danielsson no creía la versión oficial (de desavenencias en la remodelación del gobierno como base de la crisis); y pensaba - "por lo que de fuente fiable he podido colegir" - que la causa era la tensa relación entre Azaña y Alcalá-Zamora acerca de la Ley de Congregaciones religiosas ${ }^{37}$.

Es significativo constatar la aprensión y sorpresa con que los diplomáticos de un país tradicionalmente protestante, cuya imagen de la Iglesia Católica no era precisamente positiva, vieron la política radical de laicización que llevó a cabo la Segunda República Española desde el primer momento.

\subsubsection{Las Cortes Constituyentes y el asentamiento del régimen republicano en España.}

A las elecciones a las Cortes Constituyentes se refirió Danielsson en bastantes ocasiones. En un importante despacho confidencial de finales de junio ${ }^{38}$ decía que la “agitación electoral” proseguía en todo el país, especialmente por parte de la izquierda, con una "agresividad creciente de los grupos extremistas" que en ciertos lugares, sobre todo en Andalucía, llevaban a cabo una "política de terror". Todo parecía indicar que la coalición republicana-socialista seguiría gobernando. Danielsson había oído comentar que si las elecciones no daban el resultado esperado, "el gobierno actual sería sustituido por una dictadura republicana con Lerroux como dictador". Sin embargo, a pesar de que las

\footnotetext{
${ }^{36}$ RA,UD, 1920-års dossierssystem HP, Vol. 421, despacho n. 287 de 14.VI.1933.

${ }^{37}$ RA, UD, 1920-års dossierssystem HP Vol. 421, despacho n. 273 de 9.VI.1933.

${ }^{38}$ RA, UD, 1920-års dossierssystem Vol. 420, despacho n. 309 de 25.VI.1931.
} 
discusiones políticas eran exaltadas, pensaba Danielsson que las elecciones podrían celebrarse con relativa calma, como de hecho sucedió, aunque estaba claro el fuerte viraje a la izquierda que había dado gran parte de la clase política y ocasionado una "política persecutoria contra los partidarios del antiguo régimen".

Las elecciones se celebraron en "circunstancias relativamente pacíficas" y se decía que el proyecto de Constitución se inspiraría en la Constitución francesa, alemana y americana. También el acto de apertura de las Cortes tuvo lugar "de forma tranquila y digna". Las elecciones habían sido, escribía Danielsson, "una derrota completa de los extremistas, tanto de derecha como de izquierda", aunque los "elementos extremistas de la clase obrera española" estaban "en pugna abierta contra la República"39.

Asimismo, llamó mucho la atención a los diplomáticos suecos la falta de claridad sobre la distribución de fuerzas políticas en las Cortes Constituyentes ${ }^{40}$.

Danielsson se mostró crítico en bastantes ocasiones con lo que consideraba faltas de espíritu democrático del nuevo régimen republicano. En octubre de 1931 informaba a su gobierno diciéndole que el gabinete de Azaña, a través de una ley de defensa de la República inspirada en una ley similar alemana, había recibido unas "facultades dictatoriales", y presentaba al presidente del Consejo de Ministros como "hombre muy enérgico y de autoridad indiscutible, como lo prueba su reforma del Ejército. La evolución de los sucesos en el país exigen, sin duda, que al frente del gobierno haya un líder decidido y eficaz". ${ }^{41}$ En abril de 1932 volvería a insistir en el asunto, al decir que Azaña recibía "la absolución de la mayoría de la Cámara por las decisiones, a menudo arbitrarias, que toma contra los adversarios del régimen en virtud de la Ley de defensa de la República", insistiendo en que el gobierno tenía "poderes dictatoriales"

Ya antes se había expresado Danielsson de forma similar al comentar, con un desagrado y una sorpresa apenas disimulados, que el gobierno provisional de la República

39 RA, UD, 1920-års dossierssystem Vol. 420, despacho n. 305 de 23.VI.1931; despacho n. 295 de 16.VI.1931; despacho n. 321 de 30.VI.1931; despacho n. 327 de 5.VII.1931; telegrama 13 de 16.VII.1931; despacho n. 369 de 23,VII.1931; despacho n. 370 de 25.VII.1931; despacho n. 386 de 31.VII.1931.

${ }^{40}$ RA, UD, 1920-års dossierssystem Vol. 420, despacho n. 357 de 15.VII.1931. En este despacho hay una anotación marginal a lápiz, probablemente del jefe de la Sección política del Ministerio sueco de Negocios Extranjeros, que dice literalmente: "Muy extraño que se tenga el acto de apertura de un Parlamento cuando aún no se conoce su composición definitiva”. En un despacho posterior, n. 534 de 23.IX.1931, Danielsson explicará que por fin estaba clara la distribución de fuerzas políticas en el Parlamento ya que hasta entonces, en las listas sobre miembros de cada partido, aparecían 510 nombres, es decir, más del número total de diputados: "El motivo de esta divergencia, por increíble que parezca, es que en varios casos la misma persona (diputado) aparece como miembro de más de un partido".

${ }^{41}$ RA, UD, 1920-års dossierssystem. HP 36, Vol. 420, despacho n. 480 de 22.X.1931.

${ }^{42}$ RA, UD, 1920-års dossierssystem, HP 36, Vol. 421, despacho n. 150 de 6.IV.1932. 
intentaba "resolver las cuestiones mas vitales del país de forma completamente dictatorial (på rent diktatoriskt vis) antes de la convocatoria de elecciones a Cortes" ${ }^{\text {"43 }}$, lamentando que "exigencias que guardan gran semejanza con el programa de los Jacobinos durante la Revolución francesa" hubieran contado con el voto a favor de 116 de los 342 miembros presentes en el Ateneo de Madrid - cuyo director era Manuel Azaña - al discutir este organismo las reformas políticas a proponer al gobierno ${ }^{44}$.

Criticaba Danielsson también la actitud de quienes, como Largo Caballero, amenazaban con el recurso a medidas violentas - y por tanto antidemocráticas - en el caso de que se quisiera parar la labor reformadora de las Cortes ${ }^{45}$. Sólo tras el nombramiento de Alcalá-Zamora como presidente de la República alabó el Ministro sueco la "menos intransigente" actitud del partido socialista español ${ }^{46}$.

Sobre la Constitución, de cuyos trabajos de redacción informó puntualmente la Legación, dijo Danielsson, usando palabras fuertes, que tenía un carácter "extremadamente radical, casi sectario", y que era expresión de la voluntad de los socialistas y los socialistas radicales, sin contar en modo alguno con el resto de la población, por lo que muchos pensaban que había "nacido muerta". En otras ocasiones, los diplomáticos suecos la llamaron "obra claramente radical" o "Constitución democrática, basada en la alemana, con marcado color de izquierdas, que contiene aspectos muy radicales, a menudo en forma de principios”. Estaba claro que a Danielsson no le gustó el texto constitucional ${ }^{47}$.

Acerca del nuevo gobierno de Azaña pensaba que aunque oficialmente no se dijera así, suponía en la práctica el cese del acuerdo entre socialistas y republicanos al dejar las principales carteras en manos de los socialistas, señalando las prioridades del mismo: presupuesto, reforma agraria, el estatuto catalán y la ley electoral, seguidas de la legislación sobre divorcio, la secularización de los cementerios y la reforma de las administraciones locales ${ }^{48}$.

\footnotetext{
${ }^{43}$ RA, UD, 1920-års dossierssystem, HP 36, Vol. 420, despacho n. 268 de 31.V.1931.

${ }^{44}$ RA, UD, 1920-års dossierssystem Vol. 420, despacho n. 249 de 18.V.1931.

${ }^{45}$ RA, UD, 1920-års dossierssystem Vol. 420, despacho n. 538 de 27.XI.1931

${ }^{46}$ RA, UD, 1920-års dossierssystem Vol. 420, despacho n. 548 de 3.XII.1931. Sobre el ceremonial de la instalación de Alcalá-Zamora como presidente comentó Danielsson que "a los ojos de todo demócrata auténtico recuerda demasiado a los tiempos de la extinta Monarquía”, RA, UD, 1920-års dossierssystem Vol. 420, despacho n. 567 de 14.XII.1931. Cfr. también despacho n. 12 de 9.I.1932.

${ }^{47}$ RA, UD, 1920-års dossierssystem Vol. 420, despachos n. 467 de 31.X.1931, n. 482 de 15.X.1931, n. 561 de 11.XII.1931 y n. 590 de 29.XII.1931,

${ }^{48}$ RA, UD, 1920-års dossierssystem Vol. 420, despachos n. 568 de 15.XII.1931 y n. 578 de 18.XII.1931.
} 
No ocultaba Danielsson su preocupación por lo que consideraba un peligro para el carácter democrático de la República, que veía amenazado por el viraje a la izquierda del gobierno:

\begin{abstract}
Hay rumores intensos de que se avecinan graves sucesos: habría un plan coordinado de los elementos moderados para intentar romper el poder político de la izquierda, que actualmente se ejerce de forma completamente dictatorial (på fullt diktatoriskt vis). El movimiento no pretendería una restauración monárquica sino devolver a la República su carácter propio, de respeto a las distintas opiniones políticas. Se espera que la acción de la derecha se lleve a cabo en la elección presidencial, que se espera para poco antes de la Navidad. No hay duda de que está comenzando una fuerte reacción en todo el país contra el curso político y social que las autoridades están imponiendo ${ }^{49}$.
\end{abstract}

A partir de enero de 1932, en marcha ya la nueva República, el carácter alarmista de los meses anteriores se modera un poco en los informes de la Legación sobre la política española. En el aniversario de la República, en abril, consideraba Danielsson que había pasado el peligro de una restauración de la Monarquía, viendo más riesgo para la República por parte de la izquierda ${ }^{50}$.

Aparece a partir de entonces con más frecuencia en sus informes la figura de Lerroux, al que presentaba como un político centrista, "revolucionario a ojos de la reacción conservadora y conservador a ojos de la anarquía izquierdista", pero de quien decía citando como fuente a "una persona cercana al líder del partido radical" - que, si hiciera falta, estaría dispuesto a usar métodos revolucionarios directos para llegar al poder y que estaba en connivencia con los oficiales que no eran extraños a la posibilidad de un golpe de Estado $^{51}$.

\title{
3.2.2.3. El intento de golpe de Estado militar y las huelgas revolucionarias
}

A pesar de ese cauto optimismo, la posibilidad de un golpe de Estado militar sigue estando presente en los informes diplomáticos que se reciben en Estocolmo antes del verano de 1931. Ese temor se agudiza tras los desórdenes sociales de enero de 1932.

\footnotetext{
${ }^{49}$ RA, UD, 1920-års dossierssystem Vol. 420, despacho n. 516 de 13.XI.1931.

${ }^{50}$ RA, UD, 1920-års dossierssystem Vol. 420, despacho n. 181 de 16.IV.1932.

${ }^{51}$ RA, UD, 1920-års dossierssystem Vol. 420, despacho n. 91 de 24.II.1932 y despacho confidencial n. 114 de 11.II.1932.
} 
Danielsson cita expresamente al general Sanjurjo, cuya fidelidad a las ideas republicanas pone en duda, como probable líder de un levantamiento ${ }^{52}$.

Efectivamente, ya en 1931 había enviado Danielsson un despacho confidencial acerca de los rumores que había oído sobre un posible golpe de Estado militar para reimplantar la Dictadura. Según esos rumores, los generales Sanjurjo, Queipo de Llano, Burguete y Cavalcanti habrían amenazado con ponerse al frente de una nueva dictadura militar si el gobierno no conseguía garantizar el orden. Al respecto, dice el diplomático sueco que "a pesar de lo increíble de esta información, considerando ejemplos anteriores de la historia política de España, hay que estar preparado ante cualquier sorpresa"53. Volvería al tema meses después, diciendo que había "ruido de sables", habladurías acerca de un golpe de Estado con ayuda militar en cuanto se aprobara la Constitución, a la par que rumores sobre una posible restauración monárquica en la persona del infante don Juan - "En enero, Juan el Tercero, se oye por las calles de Madrid" - para concluir que España era "el país de las sorpresas, pero tal como están las cosas es más probable que un posible golpe de Estado llevara al país más a la izquierda todavía" ${ }^{54}$.

A finales de año, el tono del diplomático sueco se volvió aún más alarmista:

En una tertulia en la que participé, un alto oficial del Ejército dijo que en círculos militares se contaba con que el enfrentamiento político tuviera sangrientas consecuencias. También en círculos oficiales hay un cierto nerviosismo. Hace unos días fueron apresadas algunas personas, entre ellas el hijo mayor del difunto dictador Primo de Rivera, que parece involucrado en un complot monárquico ${ }^{55}$.

Como es sabido, el asunto cobró la máxima actualidad con el intento de golpe de Estado del general Sanjurjo en agosto de 1932. Einar Ytterberg - en ausencia por vacaciones de Danielsson - informaba en agosto al gobierno sueco de la llamada "Sanjurjada", diciendo que los golpistas no contaban con apoyo fuera del Ejército, sino que, movidos por los acontecimientos de Alemania, se habrían dejado llevar de sus sentimientos contra la República y de su malestar por la reforma del Ejército. El golpe, mal preparado, no podía sino fracasar.

\footnotetext{
${ }^{52}$ RA, UD, 1920-års dossierssystem Vol. 420, despacho n. 73 de 16.II.1932; despacho n. 83 de 21.II.1932;

${ }^{53}$ RA, UD, 1920-års dossierssystem Vol. 420, despacho n. 250, de 19.V.1931.

${ }^{54}$ RA, UD, 1920-års dossierssystem Vol. 420, despacho n. 482 de 15.X.1931.

${ }^{55}$ RA, UD, 1920-års dossierssystem, Vol. 420, despacho n. 516 de 13.XI.1931.
} 
Se extendía Ytterberg sobre el papel de los militares en la política española. La diferencia de perspectiva respecto a su jefe Ivan Danielsson queda muy clara: para este diplomático sueco, el intento de golpe de Estado mostraba que la República corría más peligro de caer a consecuencia de un pronunciamiento militar que de una acción de las izquierdas sindicalistas y comunistas, pues el ambiente en los círculos militares era claramente antirrepublicano. Al mismo tiempo, el fracaso del mismo era prueba de que la República se iba asentando frente a los extremismos de derecha y de izquierda. Alababa Ytterberg a Azaña, llamándole "un gran hombre de Estado". El problema era, según Ytterberg, que la República no había conseguido de momento el apoyo del mundo empresarial español, y no era fácil cambiar esto en un país donde la oposición apenas tenía posibilidades de hacerse oír por vías legales, pues "unas elecciones parlamentarias no manipuladas por las autoridades son cosa rara en España"56.

A su vuelta, Danielsson informó de la condena e indulto de Sanjurjo, alabando la actitud del gobierno que marcaba así las diferencias entre la República y la Dictadura anterior. En su análisis, se detenía en las consecuencias políticas del intento de golpe de Estado, que no habrían sido otras sino la de consolidar la República y fortalecer sobremanera la posición de Manuel Azaña, debilitada por los debates sobre el estatuto catalán y la reforma agraria. Ello se debía al "incondicional apoyo popular” al gobierno de la República en relación con la Sanjurjada. En informes posteriores, al tratar de la cuestión catalana y la reforma agraria, no dejaría de insistir en ello. En opinión de la diplomacia sueca, con la sentencia condenatoria a Primo de Rivera en diciembre de 1932 quedaron definitivamente saldadas las cuentas de España con la dictadura ${ }^{57}$.

En 1933, tras la subida al poder de Hitler en Alemania y los graves sucesos en relación con los desórdenes anarcosindicalistas en Barcelona y Casas Viejas, la Legación profundiza en sus informaciones sobre el alcance del peligro nazi y fascista en España. En marzo, alertaba sobre el inicio de un movimiento fascista español, "a imagen extranjera". Gobierno y población habían reaccionado bien, impidiendo la distribución de la publicación "El Fascio". El movimiento fascista español era, según Danielsson, heredero de la Dictadura de Primo de Rivera y de la Unión Patriótica, pero apenas había terreno propicio en España para que el movimiento se hiciera fuerte, especialmente teniendo en

\footnotetext{
${ }^{56}$ RA, UD, 1920-års dossierssystem HP, Vol. 421, Telegrama n. 3 de 11.VIII.1932; Despacho n. 319 de 11.VIII.1932; despacho n. 321 de 14.VIII.1932. La palabra pronunciamiento está en español, en el despacho diplomático sueco.

${ }^{57}$ RA, UD, 1920-års dossierssystem HP, Vol. 421, despacho n. 398 de 14.X.1931. Cfr. también despacho n. 335 de 28.VIII.1932 y despacho n. 529 de 28.XII.1932.
} 
cuenta que sus bases eran exclusivamente las juventudes de extrema derecha. Respecto al nazismo, señalaba Danielsson el rechazo generalizado por parte de la prensa y de la opinión pública española, hasta el punto de que el Gobierno había tenido que intervenir para contener las manifestaciones frente a la Embajada alemana y las de otros países dictatoriales - Italia, Portugal, etc. - dentro de los límites exigidos por las convenciones diplomáticas internacionales ${ }^{58}$.

Si el peligro para la República por parte de los extremistas de derecha disminuía drásticamente a consecuencia del fracaso del golpe de Estado del general Sanjurjo, no era así por lo que respecta a la amenaza por parte de la extrema izquierda.

El problema de las huelgas revolucionarias y los desórdenes de inspiración comunista y anarcosindicalista es un tema muy presente en los informes de la Legación de Suecia desde antes de la implantación de la República, como ya hemos visto. De hecho, es raro el despacho diplomático sueco del período que nos ocupa en el que, de una u otra forma, no se haga referencia a las numerosas huelgas y desórdenes que sacuden al país y a la difícil situación social que atraviesa España. Ya hemos visto cómo el Ministro plenipotenciario de Suecia en Madrid criticó lo que consideraba connivencia del gobierno al no contener los desórdenes callejeros ni la quema de conventos de mayo de $1931^{59}$.

El tono alarmista siguió estando presente durante el resto de ese año y a comienzos de 1932. Según el diplomático sueco, tanto entre los socialistas como entre los republicanos españoles había dos tendencias, una moderada y otra radical. Al ver la actitud de las masas populares, las clases conservadores burguesas vivían en un ambiente de pánico y muchas familias se habían ido de España, llevándose cantidades apreciables de dinero. Los grupos extremistas habían tratado de impedir por medios violentos el normal desarrollo de la campaña electoral y tras las elecciones habían declarado la guerra abierta a la República, que se había visto forzada, para defenderse, a adoptar medidas represivas propias de los tiempos de la Dictadura ${ }^{60}$.

En un despacho confidencial de la primavera de 1932 decía Danielsson que

la voluntad del gobierno de Azaña de rechazar las violaciones del orden público ha sido ratificada en los últimos tiempos. Las huelgas de sindicalistas y comunistas han sido

\footnotetext{
${ }^{58}$ RA, UD, 1920-års dossierssystem HP, Vol. 421, despachos n. 120 de 20.III.1933 y n. 139 de 30.III.1933.

59 Sería prolijo recoger aquí de forma exhaustiva los despachos referidos a la cuestión social. Citamos algunos de ellos en un apartado posterior, al tratar la cuestión de la influencia de la URSS y del comunismo en España.

${ }^{60}$ RA, UD, 1920-års dossierssystem Vol. 420, despachos n. 268 de 31.V.1931; n. 309 de 25.VI.1931; n. 370 de 25.VII.1931;
} 
rechazadas por el gobierno con fortaleza, con el apoyo de la opinión pública, que ve a la guardia civil usar sus armas casi a diario con total indiferencia. Por ello, parece que la Republica, por el momento, y por mucho tiempo, está segura de los intentos de derrocamiento, aunque siempre hay que contar con que los extremistas sigan creando problemas y destrozando la economía nacional ${ }^{61}$.

Sin embargo, según la Legación de Suecia, la acción del gobierno para paliar los desórdenes ocasionados por las movilizaciones obreras no fue bien vista por algunos socialistas. Al mismo tiempo, no dudaban los diplomáticos suecos en señalar que el aumento de la tensión social se debía, además de a una mejor organización de los grupos extremistas, fundamentalmente a la situación de la industria española, cuya crisis llevaba a las empresas a despedir trabajadores, con la consiguiente ola de huelgas de solidaridad. El ejemplo de las huelgas de Ferrol fue referido en detalle por la Legación al Ministerio de Negocios Extranjeros sueco ${ }^{62}$.

Los graves sucesos de enero de 1933 son calificados por la Legación sueca de "complot terrorista", "movimiento terrorista", y "movimiento de huelgas revolucionarias". Al analizar la situación, Danielsson opina que en su origen se encuentra la protesta del anarco-sindicalismo español por la presencia de tres ministros socialistas en el gobierno de la República, aunque no deja de señalar que no descarta que la Unión Soviética haya tenido algo que ver en el asunto. Tendremos ocasión de volver sobre ello ${ }^{63}$.

Los sucesos de Casas Viejas, "donde una veintena de rebeldes armados fueron sumariamente ejecutados por las fuerzas policiales enviadas desde Madrid", fueron también referidos con todo detalle al Ministerio sueco de Negocios Extranjeros, señalando que

este triste episodio que al principio, a sabiendas o no, fue ocultado por el gobierno, ha dado lugar a tormentosos debates parlamentarios donde la oposición, especulando quizá con la conocida aversión de los socialistas por los habitualmente violentos métodos que utiliza la

\footnotetext{
${ }^{61}$ RA, UD, 1920-års dossierssystem Vol. 421, despacho confidencial n. 198 de 29.IV.1932.

${ }^{62}$ RA, UD, 1920-års dossierssystem Vol. 421, despacho n. 150, de 6.IV.1932; cfr. también despacho n. 307 de 3.VII.1933, donde dice que los comunistas y sindicalistas "continuaron sus esfuerzos por preparar el terreno para una revolución social no sin el apoyo de algunos sectores del socialismo, que en varias ocasiones se mostraron críticos de la escasez de resultados del cambio político de hace un año". Respecto a la situación de la industria y al desempleo, cfr. RA, UD, 1920-års dossierssystem Vol. 421, despacho n. 259 de 3.VI.1932.

${ }^{63}$ RA, UD, 1920-års dossierssystem Vol. 421, despacho n. 1 de 3.I.1933; despacho n. 18 de 11.I.1933; n. 28 de 13.I.1933;
} 
fuerza pública española, trataron de desacreditar a Azaña a los ojos del partido socialdemócrata haciéndole responsable de los excesos cometidos por la policía en Casas Viejas ${ }^{64}$.

En mayo, el, intento fallido de huelga general fue descrito por la Legación como un nuevo intento de los sindicalistas de provocar la caída del Gobierno, para llevar a cabo su política revolucionaria. Su fracaso se debió, según los diplomáticos suecos, a los esfuerzos del gobierno y a la decisión de la parte más moderada del movimiento obrero, la UGT, de no secundar la huelga. Mencionaron también el arresto de Goded, presuntamente implicado en un nuevo complot militar, aspecto éste último que fue negado por Azaña ${ }^{65}$.

Finalmente, a finales de 1933, el Secretario de la Legación, Einar Ytterberg, se refirió a nuevos desórdenes sociales de sesgo anarcosindicalista, comentando que a pesar de que el partido socialista se había mantenido al margen de los mismos, hubieran podido tener consecuencias graves porque no se podía contar con la lealtad del Ejército. Decía que "de buena fuente" había podido saber la Legación que la "propaganda comunista, o mejor dicho, extremista" tenía éxito entre los suboficiales. Al final la situación en el Ejército se había calmado y la huelga revolucionaria se pudo controlar, pero era patente que la mayoría de la población española estaba "en contra de estos extremistas". Añadía que este tipo de desórdenes podrían tener consecuencias políticas, "por ejemplo en el movimiento fascista, que parece tiene muchos adeptos entre los jefes y oficiales del ejercito, especialmente los pasados a la reserva por las reformas de Azaña",66.

\subsubsection{Las grandes reformas: la cuestión catalana y la reforma agraria}

La diplomacia sueca en Madrid informó profusamente acerca de la llamada "cuestión catalana" desde los días del efímero gobierno Aznar, y la consideraba una de las prioridades del gobierno. A finales de abril de 1931, los diplomáticos informaron del acuerdo con los catalanes de regular la cuestión en la Constitución, y el cónsul honorario sueco en Barcelona - el barón Esponella, miembro del ala moderada del partido regionalista catalán - consideraba que la relación con Madrid era tensa, pero que el gobierno provisional de la República había sido aceptado de buena fe y casi por unanimidad; y todo dependía de que los actuales dirigentes no hiriesen los sentimientos de nadie, en materia de religión, autonomía regional y respeto a la propiedad privada. Para el

\footnotetext{
${ }^{64}$ RA, UD, 1920-års dossierssystem Vol. 421, despacho n. 154 de 7.IV.1933.

${ }^{65}$ RA, UD, 1920-års dossierssystem Vol. 421, despacho n. 219 de 10.V.1933.

${ }^{66}$ RA, UD, 1920-års dossierssystem Vol. 421, despacho n. 536 de 22.XII.1933.
} 
barón, los dos grandes problemas eran el separatismo y el comunismo, y esperaba que la derecha española apostara por la República, pues si lo hacía por la vuelta a la Monarquía habría guerra civil.

En un informe confidencial de mayo de 1931 comentaba el Ministro plenipotenciario sueco en Madrid del dilema con el que se enfrentaba la joven República española: necesitaba a toda costa asentarse como régimen político, y para eso debía fortalecer la unidad del país; y por otra parte, debía atender las reivindicaciones del pueblo catalán, que demandaba autonomía. Si le concedía esa autonomía, establecería un precedente que abriría la puerta a reivindicaciones similares por parte de los nacionalistas vascos y de otras zonas del pais. Además, las consecuencias económicas para el gobierno central serían graves, y podrían llegar incluso a los 160 millones de pesetas.

Ivan Danielsson estimaba que la solución de la cuestión catalana, al igual que la reforma agraria, dependía en buena medida de quién predominara en la lucha de poder entre Manuel Azaña y el líder de la oposición Alejandro Lerroux, por las diferencias de opinión dentro del gobierno al respecto. Como ejemplo cita la postura de Indalecio Prieto sobre Cataluña. En agosto pudo informar de una "victoria completa de los partidarios de la autonomía" catalana, pese a que la prensa de Madrid intentara minimizar el asunto y hubiera una cierta animosidad contra los catalanes en el resto de España. El Estatuto catalán era por ello, opinaba Danielsson, una fuerte arma propagandística para la derecha española, y este punto manifestaba claramente la "clara distancia entre la clase política gobernante y una gran parte de la opinión pública", lo cual podría ser peligroso para el régimen republicano.

El acuerdo parlamentario de junio sobre la autonomía catalana, alcanzado tras “interminables debates", no dejó de ser en cierto sentido una victoria pírrica. Danielsson se mostró sorprendido - y por el tono de sus palabras, crítico - por el hecho de que en "en la decisión sólo participaran 184 de los 470 diputados. En esta cuestión vital, por lo tanto, la mayoría de los parlamentarios no ha sentido la necesidad de pronunciarse".

Fue el intento de golpe de Estado del General Sanjurjo el que unió a los políticos republicanos de tal forma que el Estatuto pudo aprobarse con el apoyo incluso del Partido Radical. Al final, explicaba Danielsson, se prestó más atención a los deseos independentistas catalanes que a la opinión pública española, que prefería mantener la unidad administrativa y nacional de la República. Finalmente, tras describir los actos solemnes de proclamación del Estatuto en San Sebastián, se preguntaba Danielsson sobre 
el futuro funcionamiento práctico del mismo, considerando que las demás regiones de España no dejarían de exigir una autonomía similar. Por lo demás, la Legación sueca expuso de forma concisa y clara, sin glosas especiales, las disposiciones de aplicación del Estatuto, la convocatoria a Cortes catalanas, etc. ${ }^{67}$

El otro gran tema de 1932 fue la reforma agraria. El contenido de esta reforma y muchos de sus pormenores fueron objeto de un despacho específico de la Legación de Suecia. En el informe trimestral siguiente, comentó Danielsson que la reforma había sido objeto de largos debates parlamentarios en los que la oposición había aducido que el beneficio práctico para los campesinos era pequeño comparado con la enorme transformación social que se produciría con ella. En un análisis posterior, informaba que la reforma agraria se benefició también del intento de golpe de Estado, porque gracias a él se pudieron incluir en la misma ciertas disposiciones confiscatorias de las tierras de los involucrados y de otros Grandes de España. Por otra parte, los costos de la reforma tuvieron consecuencias importantes en la economía española ${ }^{68}$.

\subsubsection{La situación financiera y la evolución política española en 1933.}

El desarrollo de la vida política española en 1933, que culminaría con las elecciones generales del 19 de noviembre de 1933, las primeras con sufragio universal en España, fue seguido con bastante detalle por la Legación de Suecia. Los despachos diplomáticos suecos ponen el acento en el deterioro de la situación económica - motivado por los costes de las grandes reformas del primer bienio republicano - más que en los desórdenes sociales - que por tenerlos bajo control no suponían una amenaza para el gobierno - como aspecto determinante del viraje a la derecha de la opinión pública española.

Ya en las vísperas republicanas se refirió Danielsson a la situación de la economía española en el contexto del desastre de Wall Street de 1929. Comentaba que la recesión producida por ese hecho se había visto agudizada por las medidas restrictivas de EE.UU. y de Francia contra los productos españoles. A pesar de todo, la economía española escribía - había estado equilibrada durante la Dictadura, debiéndose la caída de la peseta a la especulación internacional. Las consecuencias para la moneda española de la

\footnotetext{
${ }^{67}$ RA, UD, 1920-års dossierssystem HP, Vol. 421, despachos n. 85 de 17.II.1931; n. 210 de 26.IV.1931; n. 220 de 30.IV.1931; n. 223 de 11.V.1932; n. 237 de 10.V.1931; n. 268 de 18.VI.1932; n. 361 de 30.VI.1932; n. 396 de 7.VIII.1931; n. 398 de 14.X.1932; n. 482 de 15.X.1931; n. 518 de 18.XII.1931; n. 529 de 28.XII.1932.

${ }^{68}$ RA, UD, 1920-års dossierssystem HP, Vol. 421, despachos n. 130 de 23.III.1932; n. 130 de 3.VII.1932; n. 398 de 14.X.1932 y n. 425 de 23.IX.1933
} 
inestabilidad política interna se habían manifestado en grandes fluctuaciones, aunque la política gubernamental había hecho que la peseta se volviera a revalorizar y el jefe del Banco Internacional Quesnay había manifestado su confianza en la política económica del gobierno. La baja cotización de la peseta había ayudado a la exportación española, que había subido mucho en los últimos meses ${ }^{69}$.

Un año después, comentaba Danielsson que la economía había acusado la crisis de confianza inherente al cambio de régimen, pero que la crisis mundial había afectado poco a España por la poca dependencia del país respecto al extranjero. De hecho, la moneda había permanecido bastante estable respecto a las monedas basadas en el patrón oro. En diciembre, la ley de relaciones entre el Estado y el Banco Central suponía, en opinión del diplomático sueco, un paso en el camino de nacionalización del Banco. También estaba sobre el tapete la cuestión de la nacionalización de la red telefónica. El gobierno de la República se proponía revisar además los tratados comerciales con otros países, y deseaba suprimir la cláusula de nación más privilegiada. Esto, como veremos, tuvo consecuencias para Suecia ${ }^{70}$.

La relación mutua entre economía y política quedó de manifiesto en los cambios de gobierno de 1933, que fueron explicados por los diplomáticos suecos, en parte, en clave económica, aunque no exclusivamente, porque hacían hincapié en el gran descontento de la opinión pública conservadora hacia las medidas del gobierno, especialmente en materia religiosa y social. Las elecciones municipales del 23 de abril de 1933 mostraron la fuerza que estaba adquiriendo la derecha española. Ya mencionamos cómo Danielsson achacaba la caída del gabinete Azaña a la creciente tensión entre el jefe del gobierno y el Presidente de la República a causa de la Ley de Congregaciones. Según el diplomático sueco, AlcaláZamora no quiso firmar las nuevas disposiciones del tribunal de Garantías constitucionales sin consultar a otros líderes políticos:

\footnotetext{
No es ningún secreto que Alcalá-Zamora en su interior está bastante descontento con la radicalidad política y social del gobierno Azaña y que en las circunstancias actuales preferiría un gobierno mas moderado, de corte burgués, cosa no posible mientras los socialistas compartan el poder. Ya hay negociaciones para un nuevo gobierno republicano-socialista bajo el socialdemócrata Besteiro con tres ministros del partido radical $^{71}$
}

\footnotetext{
${ }^{69}$ RA, UD, 1920-års dossierssystem, vol. 420, despacho n. 582 de 29.XII.1930.

${ }^{70}$ RA, UD, 1920-års dossierssystem, vol. 420, despacho n. 590 de 29.XII.1931.

${ }^{71}$ RA, UD, 1920-års dossierssystem, HP, vol. 421, despacho n. 273 de 9.VI.1933; Respecto a las elecciones municipales cfr. RA, UD, 1920-års dossierssystem, HP, vol. 421, despacho n. 187 de 25.IV.1933.
} 
El 30 de abril de 1933, el Ministro plenipotenciario de Suecia estuvo conversando personalmente con Azaña, durante el transcurso de una comida a la que asistieron también otros diplomáticos; entre ellos, el Embajador de Alemania. Azaña se quejaba del trabajo obstruccionista de la oposición. Además, informaba Danielsson que

A uno de mis colegas le dejó caer un miembro del gobierno presente en la cena que habría crisis de gobierno porque probablemente los tres ministros socialistas lo dejarían. Según ese mismo colega podría tomar el poder el Prof. Sánchez-Román, quien habría exigido como condición poder decidir libremente la lista de sus ministros, entre los que pensaba invitar a Lerroux. Se dice que las masas socialistas están dispuestas a ir a la huelga general para evitar la salida de los socialistas del gobierno ${ }^{72}$.

Tras la composición del cuarto gobierno de la República y tercero de Azaña, el 12 de junio de 1933, comentó Danielsson que era prácticamente igual que el anterior, cuya dimisión sólo había sido el resultado de la desunión de los diversos partidos republicanos y de la intromisión, "para muchos anticonstitucional", de Alcalá-Zamora ${ }^{73}$.

En septiembre, Einar Ytterberg informaba al gobierno sueco que la crisis ministerial del día 8 de ese mes se debía a que la derecha había ganado en la votación de miembros del tribunal de Garantías Constitucionales, lo que era "sorprendente, dada la influencia del gobierno en la elección de los organismos locales” con derecho al voto. Temía Ytterberg que "el desprestigio de las instituciones republicanas" pudiera "preparar el camino a una dictadura de derechas" y anunciaba la posibilidad de nuevas elecciones. No se equivocó, aunque entre medias pasaran los dos efímeros gobiernos de Lerroux y de Martínez Barrio.

Buen conocedor de la historia de España, no vaciló Ytterberg en resaltar las similitudes entre la Primera y la Segunda República española - en concreto, "la incapacidad del Parlamento de ponerse de acuerdo, a causa de durísimas luchas partidistas" - y no dudó en diagnosticar lo que estimaba que era la causa principal de "las grandes dificultades que tiene el parlamentarismo para asentarse en España”, a saber: España era un país donde "el sentido del bien común está poco desarrollado incluso entre los representantes elegidos para defender los intereses del pueblo". Aunque dice que es pronto

\footnotetext{
72 RA, UD, 1920-års dossierssystem, HP, vol. 421, despacho confidencial n. 196 de 30.IV.1933; Cfr. también AZAÑ A, Manuel, Diarios completos, Barcelona: Crítica, 2000, p. 183.

${ }^{73}$ RA, UD, 1920-års dossierssystem, HP, vol. 421, despacho n. 322 de 8.VII.1933. El texto completo de este despacho, que ofrece un resumen del desarrollo político del primer bienio republicano, aparece en el Apéndice 2 .
} 
para augurar a la Segunda República un fin similar al de la primera, insiste en que es necesario un cambio de actitud, criticando en particular la "concienzuda labor de Azaña por aplicar precipitadamente la legislación antirreligiosa, lo cual no fue precisamente una muestra de amplitud de miras" ${ }^{\text {74 }}$. Interesantes reflexiones en la pluma de un diplomático sueco que era menos afín al conservadurismo político que su jefe de misión.

En opinión de Ytterberg, la causa real del cambio de gobierno había que buscarla en la "no muy brillante gestión de los asuntos económicos por parte del gobierno". El cuadro pintado por la oposición, decía Ytterberg, era claro: las medidas agrarias habían llevado a un aumento desmesurado de los sueldos del sector; los jurados mixtos, siempre dirigidos por socialistas, habían tenido una influencia negativa en las condiciones laborales; había aumentado la lucha de clases; la gestión de la industria había sido desastrosa, etc. Y no cabía duda "de que son críticas dignas de tener en cuenta, y que el celo de los socialistas por abolir injusticias sociales con solera de siglos ha conllevado consecuencias peligrosas". A la situación de emergencia de la agricultura española, según el diplomático sueco, había contribuido también la crisis económica internacional, pero teniendo en cuenta la situación de relativo aislamiento económico de España con respecto al resto del mundo, esa explicación sola no bastaba. Sin embargo, y a pesar de que era opinión general entre los políticos que el cambio de gobierno sería un punto de inflexión para la economía española, el mundo empresarial pensaba - seguía diciendo Ytterberg - que la presencia de los socialistas en el gobierno era un factor de moderación de las numerosas huelgas organizadas por la izquierda radical. Y concluía que era de esperar que "los tres grupos marxistas, (socialistas, radical-socialistas y comunistas) se unan para dificultar al nuevo gobierno su política" 75 .

\subsubsection{La situación política española en el segundo bienio republicano}

Si durante el primer bienio republicano fueron varias las líneas principales sobre las que versó la información enviada por la Legación de Suecia al Palacio de Sofia Albertina, sede del Ministerio sueco de Negocios Extranjeros, fueron tan sólo dos las cuestiones centrales que, en un grado a veces exagerado, centraron la atención de los diplomáticos suecos en Madrid:

1) La inestabilidad política y sus riesgos para el asentamiento de la democracia.

\footnotetext{
${ }^{74}$ RA, UD, 1920-års dossierssystem, HP, vol. 421, despacho n. 431 de 17.X.1933.

75 RA, UD, 1920-års dossierssystem, HP, vol. 421, telegrama 30 de 8.IX.1933 y despachos n. 402 de 9.IX.1933 y n. 425 de 23.IX.1933.
} 
2) La revolución de octubre de 1934 y sus secuelas.

Las elecciones generales de noviembre de 1933 supusieron la llegada al poder del segundo gobierno de Lerroux (el séptimo republicano), que fue recibida, según la diplomacia sueca, con satisfacción, “con la esperanza de que España pueda tener un tiempo de calma y orden", lo que sería muy difícil con un gobierno de derechas propiamente dicho. Escribía la Legación que el "espíritu de sacrificio" de las derechas al renunciar al poder se había manifestado también en la aceptación del régimen republicano por el partido específicamente católico, Acción Popular, lo cual no quería decir que "la mayoría de los católicos o de la gente de derechas vaya a apoyar a la República si se pusiera en entredicho la forma de gobierno. Al contrario, la derecha es, en mayor o menor grado, preferentemente monárquica". Pero la cuestión monarquía/republica no era la principal en aquel momento, porque había otros problemas agudos, como la reglamentación de la situación de la Iglesia. Se esperaban negociaciones con vistas a un Concordato, pues tanto el Vaticano como los católicos españoles "se han resignado ya a la República". Los partidos centristas tenían voluntad de llegar a un acuerdo con la Iglesia, para el bien de la República, que bajo Azaña había conseguido hacer de los católicos sus enemigos mortales. Quedaba, sin embargo, por ver, si el gobierno conseguiría seguir esta línea de moderación, pues la derecha quizá no se siguiera mostrando tan complaciente. La izquierda, por su parte, estaba dispuesta a la lucha y a aprovechar el malestar social del país para recuperar sus posiciones.

La derecha y la izquierda españolas estaban - informaba Ytterberg - en fuerte pugna entre sí, y no solo por motivos ideológicos:

La frase "sentarse a la mesa del poder" es en sumo grado aplicable a los actores de la vida política española. Si el gobierno centrista fallara en llevar a cabo una política conciliadora no quedaría otra opción que un gobierno de la derecha, con consecuencias difíciles de imaginar". 76

Las elecciones de noviembre de 1933 fueron ampliamente comentadas por la diplomacia sueca. Además de lo ya expuesto, es interesante destacar que definían a la

\footnotetext{
${ }^{76}$ RA, UD, 1920-års dossierssystem, HP, vol. 421, despacho n. 539 de 22.XII.1933. La expresión tradicional utilizada por el diplomático sueco es sitta vid maktens köttgryta, literalmente "sentarse al puchero de carne del poder".
} 
CEDA como un grupo de partidos de "extrema derecha" (ytterhögerpartierna). Las elecciones se habían desarrollado de forma ordenada, en general pero con algunos actos de violencia y desórdenes en algunos lugares. Explican la victoria de la derecha como una reacción del electorado, especialmente del femenino, frente a la política radical de los gobiernos de Azaña en temas sociales y, sobre todo, religiosos: las mujeres, que "por primera vez en la historia de España utilizaban su derecho de voto, votaron a la derecha porque sus sentimientos religiosos habían sido heridos por la política laicista del gobierno de Azaña”. Así escribió Danielsson en su memoria de fin de año, añadiendo que el nuevo gobierno encauzaría la reforma agraria dentro del respeto a la propiedad privada y la cuestión religiosa se resolvería "sin conculcar las convicciones individuales"77.

De especial interés a este respecto es un despacho confidencial del 22 de noviembre, con un análisis de la situación bastante alarmante. Explicaba Danielsson que la situación podía agravarse, ya que según había sabido de "fuente bien informada", Largo Caballero había hablado de llevar a cabo una acción revolucionaria para evitar el gobierno de las derechas:

Mi informador, el cónsul general de Suecia en Madrid De La Peña, que está en contacto estrecho con el líder radical Lerroux, me dijo que Martínez Barrio había organizado una reunión entre Largo Caballero y el líder de derechas Gil Robles para discutir la cuestión. Gil Robles, viendo el peligro de guerra civil causado por la actitud socialista, había accedido en esa reunión nocturna a ceder algunos diputados a cambio de que los socialistas hicieran lo mismo a favor de algunos partidos republicanos para permitir un gobierno de centro, basado en el partido radical. Por lo que por otra parte he podido saber, la derecha no tuvo nunca intención de gobernar en solitario. Los partidos de la coalición de derechas parece recuperarán ahora su margen de acción política. La prensa seria no dice nada del juego entre bastidores. La reelección en los distritos que no han alcanzado mayoría será el 3 de diciembre. Hasta entonces, y por тиy raro que parezca, hay que contar con las manipulaciones necesarias para distribuir los escaños entre los partidos según el compromiso acordado en la reunión nocturna $^{78}$.

Como se puede apreciar aquí, De la Peña no duda en acusar a los socialistas, ya en 1933, de poner al país en peligro de guerra civil. Por otra parte, al referirse Danielsson a la manipulación de las elecciones, se ve en la necesidad de prevenir la presunta incredulidad de sus lectores del Ministerio sueco de Negocios Extranjeros, con la expresión "por muy

\footnotetext{
${ }^{77}$ RA, UD, 1920-års dossierssystem, HP, vol. 421, despachos nn. 496 de 21.XI.1933 y 561 de 31.XII.1933.

${ }^{78}$ RA, UD, 1920-års dossierssystem, HP, vol. 421, despacho n 499 de 22.XI.1933: La cursiva es nuestra.
} 
raro que parezca". Es, a nuestro entender, una señal clara de la baja estima que la República Española, en cuanto democracia, tenía a los ojos del diplomático sueco.

No fue Danielsson, sino su subordinado Ytterberg, quien informó de los incidentes revolucionarios de rasgo anarcosindicalista a partir del 8 de diciembre de ese año, insistiendo en los peligros para la República procedentes de los extremos políticos, tanto de izquierda como de derecha. Según Ytterberg, el partido socialista se había mantenido al margen, y la mayoría de la población rechazaba las acciones de "estos extremistas". El Ejército constituía un peligro, porque no se sabía con quien iba a posicionarse. De acuerdo con lo que "de buena fuente" había podido saber la Legación, "la propaganda comunista, o mejor dicho, extremista", se extendía entre los suboficiales, mientras que entre los jefes y los oficiales era el "movimiento fascista" el que parecía tener más adeptos ${ }^{79}$.

Durante el mandato del nuevo gobierno de Lerroux, el octavo gobierno republicano que comenzó el 3 de marzo de 1934, la Legación de Suecia hizo balance de la evolución de la vida política española en el primer trimestre del año, y concluía que, por su carácter de gobierno de centro-derecha, no había podido éste contar con la cooperación de otros partidos. Señalaba que también el ala izquierda del partido radical estaba descontenta con el peso de la derecha en el gobierno. Ésta prefería no formar parte del mismo por razones tácticas y la política obstruccionista de la oposición había hecho que el gobierno no hubiera hecho nada digno de mención, salvo tener que atender a la situación sociopolítica del país. El gobierno estaba contrarrestando la labor de la CNT, y en el propio partido socialista iban ganando terreno los más radicales. El moderado Besteiro había tenido que ceder su puesto en la UGT y Largo Caballero apoyaba ahora el acercamiento a la izquierda radical y el empleo de sus métodos.

Junto a esta radicalización de las izquierdas españolas, había surgido también en España un "movimiento de tipo nacionalsocialista" dirigido por "el hijo del anterior dictador Primo de Rivera”. Consideraba que no tenía demasiada importancia por el momento, al estar limitado a algunas de las clases más conservadoras, pero que podría atraer a otras clases sociales, ya que su programa incluía algunas ideas muy liberales en los aspectos sociales $^{80}$.

La situación social y económica, en opinión de la diplomacia sueca, estaba en estrecha conexión con la inestabilidad política, que se veía agravada por la falta de paz

\footnotetext{
${ }^{79}$ RA, UD, 1920-års dossierssystem, HP, vol. 421, despacho n 536 de 22.XII.1933.

${ }^{80}$ RA, UD, 1920-års dossierssystem, HP, vol. 421, despacho n. 179 de 8.IV.1934.
} 
social a la vez que esta ausencia de paz era también una secuela de la falta de estabilidad política. En mayo de 1934 informaba la Legación que el paro en España había subido en dos años de 389000 a 667000 personas, distribuido sectorialmente en un $60 \%$ en la agricultura y bosques, $8 \%$ industria, $17 \%$ en la construcción, $3 \%$ en el sector comercio, $2 \%$ en el sector transportes, y $10 \%$ en el resto. Esto se debía en parte a que España había pasado de ser un país con una emigración neta de 20000 personas al año a una inmigración neta del mismo calibre en 1932 y 1933, y a "la creciente depresión económica, con la retirada de capitales, la caída de la producción y del poder adquisitivo, y la ausencia de espíritu de iniciativa".

Sin embargo, la causa principal, que Danielsson aseguraba saber "de fuente autorizada", era la falta de paz social, la deficiente política salarial y las consecuencias de la reforma agraria. Estimaba el diplomático que aunque el paro fuera pequeño en relación a la población, suponía un problema a causa de "la falta de interés de las autoridades por dar subsidios de desempleo o adoptar medidas promotoras del empleo" y porque de los desempleados procedían la mayor parte de los extremistas que se alteraban la paz social. A pesar de ello, confiaba Danielsson en la "capacidad de los trabajadores españoles de bajar su nivel de vida hasta el mínimo posible" como garantía de que el asunto no tuviera consecuencias graves ${ }^{81}$.

Los sucesos de octubre de 1934 fueron explicados en detalle por la Legación de Suecia en un extenso despacho titulado "sobre la huelga revolucionaria en España",82. El informe comenzaba preguntándose sobre la pervivencia de la República, una cuestión que consideraba abierta. El despacho reviste gran interés, porque constituye un análisis político de primera mano y una valoración histórica aguda y relevante. Viene firmado por el secretario de la Legación, Einar Ytterberg, que, como sabemos, era menos proclive que su jefe de misión a las posturas políticas conservadoras.

Comienza el despacho refiriéndose a la actuación del Partido Socialista:

El hecho de que los socialistas se hayan decidido a recurrir a medios violentos en su lucha contra sus adversarios se debe sin duda al convencimiento de que en el marco de la República burguesa conservadora no pueden recuperar su influencia y de que España se desliza hacia la dictadura o la monarquía. Está claro que han perdido su poder y que por vías legales les resultaría imposible recuperar su posición en mucho tiempo. Además era cosa conocida que

\footnotetext{
${ }^{81}$ RA, UD, 1920-års dossierssystem, HP, vol. 421, despacho n. 241 de 14.V.1934.

${ }^{82}$ RA, UD, 1920-års dossierssystem, HP, vol. 421, despacho n. 482 de 14.X.1934.
} 
el líder del partido católico, José María Gil Robles (CEDA) ha aceptado la República sólo por razones tácticas y que su partido aceptaría un cambio de régimen sin rechistar. Respecto a los radicales de Lerroux, no era de esperar que apoyaran de forma eficaz las reformas sociales que los socialistas se habían propuesto, sino más bien era de temer que se convirtieran en un partido oportunista, que de momento apoyaría a la derecha.

Tras una detallada exposición de la rebelión asturiana, explicaba Ytterberg que la situación se había hecho preocupante por la rebelión de la Generalitat contra el gobierno de Madrid, y podría haberse tenido graves consecuencia de no haber sido por la decidida actitud del Ejército, cuyo triunfo se vio también facilitado por la pasividad de los principales líderes socialistas, "que no quisieron dar la cara públicamente".

Opinaba Ytterberg que el retorno a la normalidad llevaría tiempo, entre otras cosas por la crueldad con que se había procedido por ambas partes, revolucionarios y fuerzas del orden, con masacres injustificadas. El diplomático sueco achacaba las crueldades de la revolución a una pretendida "costumbre" española, muy en línea con el pensamiento eugenésico en boga de la época, que pretendía identificar algunos rasgos de carácter dentro de un marco racista, no exento de prejuicios, en el cual la crueldad sería rasgo especialmente presente en el mundo latino, y en particular, en España. En todo caso había que contar con que

la irritación es grande por ambas partes y tendrá que pasar bastante tiempo hasta que se empiece a calmar. Aún peor y más duradero es el 'odio de clase' que se ha generado en una lucha a muerte entre la clase trabajadora y el resto de la sociedad.

Proseguía el despacho con una detallada exposición de las causas del enfrentamiento de Cataluña con Madrid, mencionando la política unificadora de la Monarquía y la política anticatalana de las derechas republicanas, lo que había llevado a la proclamación de una República catalana dentro de la República federativa española, hecho que conllevó el arresto de los líderes de la Generalitat y del mismo Azaña, "que participó en el complot, pero que parece haber parado los planes de un golpe de Estado". La situación política de España, ahora que la rebelión había sido ahogada en sangre, era difícil de predecir, pues no parecía que pudiera durar mucho la coalición entre los radicales y la CEDA.

En particular, había que contar con un avance de las posturas reaccionarias, especialmente dentro de la oficialidad del Ejército español, siempre proclives "a la tentación de recurrir al golpe de Estado". Si los elementos de izquierda, que aún poseían 
muchos recursos, seguían su política revolucionaria había un riesgo inminente de golpe de estado militar, máxime cuando "los partidos están menos dispuestos que nunca a colaborar en bien de la nación”. En estas circunstancias, escribía Ytterberg "es difícil ver un futuro para España que no sea negro".

A la luz de los acontecimientos posteriores no se puede acusar al diplomático sueco de exageración al juzgar la realidad política española.

Quince días más tarde, más aclarada la situación, Danielsson recapitulaba sus impresiones. Había hablado con varias personas con cargos de responsabilidad, y concluía que el análisis de la situación era muy distinto de unos españoles a otros. Según unos, las desavenencias entre los radicales y la CEDA podrían preparar el camino para una dictadura militar. Otros decían que ahora que España estaba limpia de revolucionarios, habría un periodo de paz social. Danielsson pensaba que era demasiado pronto para profetizar qué pasaría. Todo estaba volviendo a la normalidad, pero se respiraba un ambiente de nerviosismo en los círculos ministeriales, a consecuencia de las desavenencias sobre las penas a imponer, sobre todo las muchas condenas a penas de muerte de los tribunales militares. Lerroux y los radicales, junto con el Presidente de la República, se inclinaban por la clemencia, mientras que la derecha era partidaria de no mostrar piedad alguna. La revolución había costado mucho en daños materiales y en vidas humanas, y "como detalle interesante", todos los políticos que en el pacto de San Sebastián de 1930 constituyeron el comité revolucionario que trajo la República, a excepción de Lerroux, estaban más o menos implicados en el movimiento revolucionario. Además, Indalecio Prieto había dicho que asumía toda la responsabilidad por la revolución ${ }^{83}$.

Asimismo escribía Danielsson que había rumores fundados de que, en caso de caer el gobierno de Lerroux, "vendría probablemente una dictadura militar bajo el popular general Franco o el general [López] Ochoa". No deja de ser significativo que la Legación de Suecia, en una fecha tan temprana como noviembre de 1934, alertara con tanta lucidez del peligro de una dictadura militar dirigida por Francisco Franco $(!)^{84}$.

El asunto de las condenas a Teodomiro Menéndez y Ramón González Peña sería seguido con detalle por la diplomacia sueca, también al más alto nivel: el propio ministro de Negocios Extranjeros, Rickard Sandler, expuso al Ministro de España en Suecia la preocupación sueca al respecto. Fiscowich se entrevistó con Sandler dieciséis veces en

\footnotetext{
${ }^{83}$ RA, UD, 1920-års dossierssystem, HP, vol. 421, despacho n. 509 de 1.XI.1934.

${ }^{84}$ RA, UD, 1920-års dossierssystem, HP, vol. 421, despacho n. 516 de 3.XI.1934.
} 
1934 y 1935, sobre todo en relación con la firma del acuerdo comercial entonces en curso y con la colaboración en política exterior, pero los sucesos de octubre no dejaron de estar presentes en las conversaciones. Fiscowich le dijo al ministro sueco que confiaba que el gobierno indultaría a los dos diputados socialistas por los que tan preocupado estaba el movimiento obrero sueco ${ }^{85}$.

El gobierno de la República dio su visión de los sucesos de octubre de 1934 en un folleto titulado "La revolución de octubre en España. La rebelión del gobierno de la Generalidad", que envió a todas las Embajadas y Legaciones con el encargo expreso de que lo hicieran llegar a sus respectivos gobiernos. La Legación lo envió a Suecia el 13 de febrero de 1935. Por otra parte, como ya comentamos en un capítulo anterior, la Legación de España en Estocolmo se ocupó de informar al gobierno sueco de los acontecimientos de octubre, aparte de estar al tanto de lo que publicaba la prensa de aquel país al respecto. Como veremos, fueron especialmente intensas las gestiones realizadas en relación con el viaje de Margarita Nelken a la capital sueca en la primavera de 1935.

Asimismo fue informado el gobierno sueco del análisis que hizo el Conde de Romanones de la revolución de octubre y sus secuelas. El informe lo dio Einar Ytterberg, en comunicación privada al barón Beck-Friis, el jefe de la Sección Política del Ministerio sueco de Negocios Extranjeros. Consideraba el diplomático sueco que la exposición de Romanones era "clara y sensata", y llamaba la atención especialmente sobre la intervención extranjera en Asturias, diciendo que las opiniones de Romanones "coinciden con las de cualquier observador imparcial" pues en España había "muchísima propaganda comunista" ${ }^{\sharp 6}$.

Finalmente, y aunque no se trate de ninguna información oficial, llegaron a Suecia otras informaciones detalladas sobre la Revolución de Asturias, en concreto a la organización sindicalista SAC. En el Archivo del Movimiento Obrero en Estocolmo existe una abundante documentación, hasta ahora apenas conocida por la historiografía. En ella se contiene una larga exposición de la Revolución de Asturias, escrita por Augustin Souchy, hombre de contacto entre la organización anarcosindicalista sueca y la CNT. No nos es

\footnotetext{
${ }^{85}$ RA, UD, 1920-års dossierssystem, Vol. 14, Utrikesministerns samtal med utländska sändebud. La conversación sobre las condenas tuvo lugar el 5 de marzo de 1935.

${ }^{86}$ RA, UD, 1920-års dossierssystem, HP, vol. 421, carta de Ytterberg a Beck-Friis de 7.XII.1934. En ella hace referencia a una carta autógrafa anterior, de 7.XI.1934.
} 
posible en el marco de este análisis, proceder a un estudio más detallado de esa documentación ${ }^{87}$.

Podemos concluir que la diplomacia sueca procuró dar una visión lo más completa posible del intento revolucionario español, mostrando una agudeza singular en su análisis de la delicada situación.

La cuestión de la suspensión del Estatuto catalán después de la revolución de octubre de 1934 fue considerada por la Legación de Suecia como uno de los problemas más difíciles que se le planteaban al gobierno de la República, pues era evidente que el pueblo catalán deseaba alcanzar una autonomía lo más amplia posible ${ }^{88}$.

Por otra parte, la decisión del gobierno de Lerroux de poner sobre el tapete la cuestión de la reforma constitucional fue ampliamente comentada por la diplomacia sueca, que no dudó en considerar la actuación de Alcalá-Zamora, al proponer la reforma constitucional, como una infracción de la Constitución - pues no le correspondía a él hacer esa propuesta, sino al gobierno o a una cuarta parte de la cámara -, aunque reconocían que muchos de los puntos del programa del gobierno conservador no podían llevarse a cabo sin reformar un texto constitucional que era "producto de los tiempos apasionados que por entonces vivía el país" ${ }^{\prime 9}$. De nuevo criticaría la diplomacia sueca al Presidente de la República en relación con la crisis gubernamental desatada a finales de marzo de 1935 , esta vez por no llamar al líder del partido más votado, Gil Robles, a formar gobierno. Refiere en esa ocasión Danielsson lo que ha sabido de "fuente de confianza" (probablemente el ya citado Cónsul general de Suecia en Madrid): Alcalá Zamora se había negado a aceptar a Gil Robles como ministro de la Guerra, tras lo cual el propio Gil Robles le habría dicho al Presidente que con su consentimiento o sin él iba a ser ministro de la Guerra, porque tenía al Ejército de su parte. La reunión fue a la una de la tarde y

a la hora de escribir estas líneas no se sabe aún nada más que el hecho de que los generales de Madrid se van a reunir esta tarde para discutir la situación. Según mi informador, Gil Robles piensa que ha llegado el momento de establecer en el país un régimen autoritario y tiene la intención de dejar que el Ejército tome el poder, disolver las Cortes y convocar elecciones, si el Presidente sigue negándose a aceptarle como Ministro de la Guerra. Mi

\footnotetext{
${ }^{87}$ ARAB, SAC 1845/E6:7 Situationen i Spanien med hänsyn till CNT (La situación española en relación con la CNT), de 8.XII.1934.

${ }^{88}$ RA, UD, 1920-års dossierssystem, HP, vol. 421, despachos n 587 de 7.XII.1934 y 633 de 31.XII.1934.

${ }^{89}$ RA, UD, 1920-års dossierssystem, HP, vol. 421, despacho n. 20 de 9.I.1935.
} 
informador describió la situación como preocupante porque podría causar una reacción de las fuerzas socialistas y republicanas de izquierdas españolas ${ }^{90}$.

Los avatares de este efímero gobierno y la remodelación que supuso la entrada de Gil Robles como ministro de la Guerra fueron seguidas minuciosamente por la Legación, que constató el creciente peso político del líder conservador español. Pensaban que era simple cuestión de tiempo el que éste llegara a ser presidente del Consejo de Ministros, pues aunque formalmente lo era Lerroux, el poder de facto lo tenía Gil Robles. La constitución de este gobierno, el número 12 de la República, fue calificada por Danielsson como una de las sorpresas que "suele traer a menudo la política española", pues el enfrentamiento entre Gil Robles y Lerroux a causa de la conmutación de la pena a Teodomiro Menéndez y Ramón González Peña, le había parecido irremediable ${ }^{91}$.

Las medidas del gobierno para paliar el paro y las reformas administrativas son presentadas en los despachos suecos como unos logros parciales. Asimismo, las causas principales de la caída del gobierno Lerroux - que en septiembre de 1935 dio paso a los gabinetes presididos por Joaquín Chapaprieta - fueron, según la Legación, las desavenencias en el seno de la coalición gubernamental sobre la cuestión catalana, la reforma de la Constitución y la política económica que debía llevarse a cabo, sin olvidar el asunto del estraperlo ${ }^{92}$.

A partir de diciembre de 1935, la atención de la Legación de Suecia, como la de todo el país, se centraría en las elecciones a Cortes de febrero de 1936, que dieron lugar a la España del Frente Popular. A este tema le dedicamos un epígrafe especial, por constituir una de las preocupaciones específicas de la diplomacia sueca.

El análisis por parte de la diplomacia sueca del segundo bienio republicano español coincide, en líneas generales, con la visión de la falta de solidaridad institucional y de inestabilidad política que, en palabras de Octavio Ruiz-Manjón, llevó a que el proyecto de modernización política que significó la Segunda República Española pudiera considerarse tocado de muerte desde el otoño de $1933^{93}$.

\footnotetext{
${ }^{90}$ RA, UD, 1920-års dossierssystem, HP, vol. 421, despacho confidencial n. 187 de 1.IV.1935. Sobre la crisis de gobierno, cfr. también Ibidem, despachos de 27 y 30.III.1935, y de 1, 2, 3, y 4.IV.1935.

${ }^{91}$ RA, UD, 1920-års dossierssystem, HP, vol. 421, despacho n. 363 de 5.VII.1935, Cfr. también telegramas de 4 y 7.V.1935; despachos de 16 y 28.IV.1935 y de 3, 4, 7 y 9.V.1935.

92 RA, UD, 1920-års dossierssystem, HP, vol. 421, despacho n. 536 de 31.X.1935; Sobre los escándalos y la dimisión del gobierno de Chapaprieta en diciembre, cfr. despachos de 4, 9 y 12.XII.1935.

${ }_{93}$ RUIZ-MANJÓN, Octavio, "La vida política en el segundo bienio republicano", en JULIÁ, Santos (coord.) República y Guerra en España (1931-1939), Madrid: Espasa, 2006.
} 


\subsection{Preocupaciones específicas de la diplomacia sueca respecto a España (1931-1936)}

¿Cuáles fueron las cuestiones más recurrentes por las que se interesó la diplomacia sueca en España durante los años de la Segunda República Española? La respuesta es clara. En primerísimo término, les preocupaba los avances del comunismo en España y las relaciones de ésta con la URSS. En un segundo plano - y en la misma línea de preocupación por el futuro de la democracia en España - el peligro de una guerra civil y/o de una dictadura militar.

A ambos aspectos nos hemos referido anteriormente de forma parcial, cuando mostramos el análisis sueco de la situación política española, al referirnos al intento de golpe de Estado militar de 1932 o a las huelgas revolucionarias presentes durante esos años; y en particular la revolución de Asturias de octubre de 1934. De forma más sistemática nos referiremos ahora a estos dos aspectos, que generaron un buen número de despachos específicos, a menudo confidenciales, por parte de la Legación de Suecia en Madrid.

\subsubsection{Los avances del comunismo y las relaciones con la URSS}

A los tres días de la proclamación de la República informaba Danielsson que la autoridad del nuevo gobierno republicano parecía ser acatada en todo el país y que los posibles peligros para el nuevo Régimen vendrían de parte de los comunistas, no de los monárquicos $^{94}$.

La Legación de Suecia mostró su preocupación por los avances del comunismo desde los albores de la República. Ivan Danielsson estaba también acreditado como Ministro de Suecia ante el gobierno portugués, y aunque residía principalmente en España tenía un estrecho contacto con el Cónsul General de Suecia en Lisboa, el noruego Simon Hansen. Fue precisamente éste quien informó a Danielsson del desasosiego de las autoridades portuguesas por la proclamación de la República en España. Según Hansen, Inglaterra había hecho gestiones en Portugal sobre una posible intervención militar portuguesa en España en caso de que España se viera amenazada por el comunismo. Al transmitir esta información a Estocolmo, señalaba Danielsson que no podía comprobar la exactitud de la misma, pero que también la prensa española había escrito que Inglaterra y Francia no se

\footnotetext{
${ }^{94}$ RA, UD, 1920-års dossierssystem, vol. 420, despacho n. 189 de 17.IV.1931
} 
mantendrían pasivas en el caso de que España se deslizara políticamente en dirección comunista. Por otra parte - escribía - era lógico que los dirigentes de la dictadura portuguesa se sintieran incómodos con la proclamación de la República en España ${ }^{95}$.

Pocos días después del 14 de abril de 1931 mantuvo Danielsson su primera entrevista con Niceto Alcalá-Zamora y le preguntó sobre el peligro del comunismo. Al igual que ya le había dicho el Ministro de Estado, Alejandro Lerroux, Alcalá-Zamora le confirmó que no creía que hubiera "peligro de una bolchevización de España, pues los socialdemócratas siempre representarán un sólido bastión contra cualquier intento de introducir métodos soviéticos en el país"96. Sin embargo, estas afirmaciones no convencieron del todo a Danielsson, que dos días más tarde, en despacho confidencial a su gobierno, escribiría que según le había confiado "uno de los más sufridos hombres del partido liberal, próximo a Romanones"

otro motivo de preocupación es el peligro comunista. A pesar de las claras declaraciones del gobierno de que no va a permitir que los comunistas desestabilicen el país, y de que aún no se ha reconocido a la URSS, está claro que el comunismo ha crecido mucho, sobre todo en Andalucía. También en la Armada hay un comienzo de agitación comunista, que ha llevado al gobierno a disolver la escuadra de maniobras.

Si España fuera amenazada por un intento de conversión comunista (y no hay que olvidar que Galán y el Comandante Franco son simpatizantes comunistas) confiaba mi interlocutor en una intervención de Inglaterra, Francia e Italia, países que no podían quedarse pasivos ante la aparición de un Estado Marioneta Soviético en el sudoeste de Europa

Y añadía que los datos facilitados por el Cónsul general de Suecia en Lisboa ratificaban el miedo inglés a que así fuera.

Al respecto, es interesante mencionar la información enviada al Ministerio de Negocios Extranjeros de Estocolmo por el Embajador sueco en Londres, barón Palmstierna, en la primavera de 1931: el político inglés Ramsay MacDonald le había comentado al Embajador que había recibido información de España sobre el aumento de la propaganda comunista. MacDonald pensaba que aún no se había llegado al punto final del proceso iniciado con la instauración de la República y podrían ocurrir muchas cosas antes de que se lograra una estabilidad real en España. Posteriormente, sin embargo, Pérez de

\footnotetext{
${ }^{95}$ RA, UD, 1920-års dossierssystem, vol. 420, despacho n. 204 de 23.IV.1931.

${ }^{96}$ RA, UD, 1920-års dossierssystem, vol. 420, despacho n. 211 de 27.IV.1931: I likhet med utrikesminister Lerroux ville Herr Alcala Zamora icke tro på någon bolschevikisk fara för Spanien, där socialdemokraterna alltid kommer att utgöra ett bålverk mot varje försök att införa sovjetmetoder i landet.
} 
Ayala había asegurado al Embajador sueco que no había peligro alguno de que "el bolchevismo" ganara terreno en España, si bien en Marruecos la labor de desgaste llevada a cabo tanto por los alemanes como por los bolcheviques era digna de tenerse en cuenta ${ }^{97}$.

Por esas mismas fechas, Danielsson envió un informe sobre la actitud de la República Española ante la URSS. En él decía que corrían nuevos vientos y la prensa de izquierdas pedía el reconocimiento inmediato de aquel país, medida que apoyaban varios miembros del gobierno provisional. Sin embargo, Lerroux le había dicho a Danielsson que el gobierno, por los muchos problemas de política interna que debía atender en primer lugar, probablemente no tendría tiempo de ocuparse de inmediato de la cuestión del reconocimiento de la URSS. Con todo, consideraba Danielsson que el asunto era muy actual, puesto que Trotsky había pedido al gobierno republicano español permiso para viajar a España. En la prensa se dijo al principio que probablemente se le permitiría entrar en el país, aunque más adelante se estimaba que era difícil que Trotsky consiguiera los permisos de transito necesarios en los diversos países de Estambul a España, y el viaje no seria posible. El gobierno español decidió esperar y la cuestión del posible establecimiento de Trotsky en España y del reconocimiento de la URSS por parte de la República debería discutirse por el gobierno que surgiera de las elecciones a Cortes constituyentes.

Danielsson pensaba que "sin llegar al pesimismo de la clase burguesa española, que considera que actualmente España está en su periodo Kerensky para acabar cayendo en manos del comunismo, sí hay que decir que la situación política es preocupante”. Un punto a tener en cuenta era la radicalización de la CNT, que había adoptado fuertes tendencias extremistas y en diversas ocasiones simpatizado con los métodos de los comunistas españoles: "Uno de sus líderes, Pestaña, que acaba de volver de Rusia, habla de que ha llegado la hora del régimen proletario"98.

Durante el verano de 1931 volvió Danielsson a hacer referencia a las relaciones hispano-soviéticas, una vez el gobierno decidió empezar las negociaciones para establecer relaciones comerciales con la URSS. Danielsson dio entonces cuenta a su gobierno de las declaraciones de Indalecio Prieto diciendo que en España no había peligro de comunismo y que era falso que la URSS quisiera hacer de España un nuevo campo de experimentación. La URSS tenía demasiados problemas internos para buscar complicaciones internacionales de este calibre. Todo parecía indicar que no habría relaciones diplomáticas por el

\footnotetext{
${ }^{97}$ RA, UD, 1920-års dossierssystem, HP, vol. 420, despachos de la Embajada de Suecia en Londres al Ministerio de Estado de Estocolmo, n. 299 de 7.V.1931 y n. 343 de 5.VI.1931.

${ }^{98}$ RA, UD, 1920-års dossierssystem, HP, vol. 420, despachos n. 230. de 7.V.1931 y n. 268 de 31.V.1931.
} 
momento, también porque la República Española no deseaba entrar en conflicto con algunas naciones sudamericanas como Argentina, muy opuesta a los contactos con la URSS. También Lerroux había hecho comentarios en el mismo sentido durante una entrevista en París ${ }^{99}$.

En diciembre de 1931, la Legación envió un despacho confidencial sobre una entrevista de Ivan Danielsson con el Ministro de Estado español Luis de Zulueta, que había tenido lugar en la Nochebuena anterior. Hablaron sobre la conferencia de desarme, y Zulueta le dijo que el gobierno español no tenía una opinión formada, aunque aprobaba el procedimiento actual y no quería retrasos, porque la República estaba totalmente a favor del desarme. Tras insistir en el pacifismo como objetivo de la política exterior española, tocaron el tema que nos ocupa:

[Zulueta] habló de la URSS y se mostró muy interesado en conocer detalles sobre las relaciones de Suecia con la URSS y especialmente sobre la política sueca contra la propaganda bolchevique. Me pareció que Zulueta personalmente no estaba interesado en promover un rápido establecimiento de relaciones diplomáticas con la URSS. Probablemente se debe a las experiencias de su antecesor en el cargo al encontrarse en Ginebra con Litvinoff, cuando [el español] le manifestó el interés de España en que el mercado ruso se abriese a los vinos y frutas españoles como contrapartida de la compra de combustibles rusos, propuesta no aceptada por Litvinoff que le dijo que los productos españoles eran de lujo y estaban prohibidos en la URSS ${ }^{100}$.

En enero de 1932, tras los "sangrientos" enfrentamientos entre trabajadores y las Fuerzas de Seguridad, informó Danielsson a Estocolmo que el Subsecretario del Ministerio de Estado español le había confiado que

estos constantes conflictos con las Fuerzas de Seguridad son un eslabón en la política sindical dirigida por la Unión Soviética, que por medio de sucesivas acciones contra las fuerzas del orden en diversos lugares del país pretende crear en el mismo una situación de desorganización que lo hiciera más receptivo a las doctrinas sindicalistas. Según mi informador, era digno de atención el hecho probado de que varios diputados socialistas de las Cortes estuvieran directamente involucrados en estos ataques al orden legal vigente en el país $^{101}$.

\footnotetext{
${ }^{99}$ RA, UD, 1920-års dossierssystem, HP, vol. 420, despachos n. 487 de 13.VIII.1931 y n. 447 de 3.X.1931.

${ }^{100}$ RA, UD, 1920-års dossierssystem, HP, vol. 420, despacho confidencial n. 584 de 26.XII.1931

${ }^{101}$ RA, UD, 1920-års dossierssystem, HP, vol. 420, despacho n. 9 de 8.I.1932.
} 
Esta información parece un tanto increíble, habida cuenta de los esfuerzos de los líderes republicanos españoles por hacer ver a los representantes diplomáticos de las democracias occidentales que en España no había peligro alguno de acercamiento al comunismo soviético, como ha quedado de manifiesto en los anteriores despachos de Danielsson. Sin embargo, no cabe dudar del dato dado por el diplomático sueco, que difícilmente se hubiera atrevido a citar su fuente con tanta precisión de no haber tenido lugar la confidencia. Cosa distinta es la exactitud o inexactitud del contenido de la misma. Sea como fuere, el Ministro Plenipotenciario de Suecia en Madrid la consideró suficientemente importante para darla a conocer de inmediato al gobierno escandinavo.

Poco después, una vez el gobierno había podido controlar la "revolución sindicalista cuyo objetivo era la implantación de la dictadura del proletariado", señalaba Danielsson que la intervención extranjera había sido reconocida por el propio Casares, según datos dados por la prensa española. Otro tipo de informaciones, como las insinuaciones del gobierno de que grupos monárquicos apoyaban los desórdenes sindicalistas, las consideraba Danielsson poco creíbles ${ }^{102}$.

No quedaría ahí la cosa. Enseguida volvía Danielsson a tomar la pluma para, de forma confidencial, dar cuenta a su gobierno de las informaciones que le había proporcionado el Cónsul General de Suecia en Madrid, el empresario Luis de la Peña. Aseguraba éste que en círculos gubernamentales se contaba con que habría más intentos de derrocar al régimen republicano por parte de los sindicalistas y que el gobierno tenía gran parte de culpa en los desórdenes públicos por no haber actuado con la suficiente firmeza contra los elementos revolucionarios, como decía haber sucedido en Manresa, donde por orden del gobierno se habría dejado escapar a la mayor parte de los revoltosos. Respecto a la Unión Soviética, decía el informe lo siguiente:

Según mi informador, la actitud ambigua del gobierno era aún más inexplicable en cuanto que el gobierno tenía pruebas fehacientes (säkra bevis) de que la Unión Soviética había tenido una parte activa en los preparativos del reciente movimiento revolucionario. El ministro de la Gobernación Casares le había dicho en persona al Cónsul General de la Peña que Trotzky había sido quien - probablemente para tratar de rehabilitarse a ojos de sus correligionarios rusos - estaba detrás de la última distribución de oro y armas rusas en el país. Por su anterior visita a España, conocía bien Trotzky las circunstancias españolas, y sus

${ }^{102}$ RA, UD, 1920-års dossierssystem, HP, vol. 420, despacho n. 55 de 30.I.1932 
directivas habían llegado a través del comunista español Andres Nin, que ha vivido una decena de años en Rusia y ha sido secretario de Trotzky.

Como prueba de la actividad de los sindicalistas mencionó finalmente el cónsul general de la Peña que en el pequeño pueblo de Cercedilla, bastante próximo a Madrid, cerca del cual tiene una finca el Cónsul General, unos interrogatorios de la población local habían sacado a la luz que unos treinta hombres del pueblo habían recibido pistolas y 250 pesetas cada uno para unirse a los líderes sindicales locales ${ }^{103}$.

Es interesante destacar que se trata de información facilitada por alguien muy cercano a Lerroux y a Casares Quiroga, y en nuestra opinión, es sintomática del ambiente en el que se movía el diplomático sueco. Al mismo tiempo, se cuida mucho Danielsson de no hacer suyas las palabras del Cónsul General, como se ve por las repetidas menciones a la persona de éste a lo largo del despacho.

Una vez más surge la pregunta: ¿Se trata de pura desinformación - intencionada o no - por parte del Cónsul General de Suecia en Madrid, o había base real en las acusaciones al país comunista?

Es interesante, al respecto, la información enviada por la Embajada de Suecia en Moscú en abril de ese año:

Puede ser interesante constatar, que la prensa local ha seguido detalladamente el desarrollo de las últimas huelgas y disturbios (oroligheterna) en España, que se presentan como frutos de la agitación enérgica de los comunistas españoles. Sin embargo, de un articulo de Pravda se deduce que el Komintern esperaba una mayor actividad revolucionaria por parte del PCE, que 'hoy por hoy cuenta con no menos de 10.000 miembros, 104

De hecho, en febrero de 1932, dirigentes del PCE habían tenido problemas con la Internacional Comunista, que acusaba a éstos de incapacidad e incluso sectarismo ${ }^{105}$.

En todo caso, el hecho cierto es que la información del oro ruso en España llegó por los canales oficiales reglamentarios a conocimiento de los responsables de la política exterior de la democracia sueca, y esa y no otra fue la explicación dada por sus diplomáticos de los disturbios de enero de 1932.

Al año de proclamarse la República, seguía preocupada la Legación de Suecia por los avances del comunismo: Era ya impensable una vuelta a la Monarquía, y los peligros para

\footnotetext{
${ }^{103}$ RA, UD, 1920-års dossierssystem, HP, vol. 420, despacho confidencial n. 57 de 2.II.1932.

${ }^{104}$ RA, UD, 1920-års dossierssystem, HP, vol. 421, misiva de Knut Lindberg de la Embajada de Suecia en Moscú al Barón Beck-Friis, Ministerio de Negocios Extranjeros de Suecia, de fecha 12.IV.1932.

${ }^{105}$ AHPCE, documentos del PCE, carpeta 13.
} 
la República provenían de las izquierdas, agitadas las masas radicalizadas por los comunistas, en opinión de Danielsson. La huelga revolucionaria convocada el 30 de mayo de 1932 mostraba claramente, según el diplomático sueco, la fuerza que estaban tomando el Partido Comunista y el anarcosindicalismo - el comunismo libertario - en España y los continuos desórdenes daban que pensar incluso "a los más acérrimos defensores del establecimiento de una oficina comercial soviética en Madrid"106.

La situación cambió un tanto, como hemos visto, tras el intento de golpe de Estado militar del general Sanjurjo en agosto de 1932. En esa ocasión, el secretario de la Legación, Einar Ytterberg, insistía en que era más probable que la República cayera a consecuencia de un pronunciamiento militar que de "una inundación sindicalistacomunista" $" 107$.

Al informar sobre los desórdenes sociales de enero de 1933, comentó Danielsson que había tenido una conversación con el Presidente de las Cortes, Julián Besteiro, a quien había preguntado si la ola de desórdenes sociales, que a menudo se convertían en "puros actos de rebeldía", no conllevaba el peligro de la difusión del comunismo en España. Besteiro le explicó que no creía que hubiera ningún peligro de comunismo, entre otras cosas porque los desórdenes eran causados principalmente por los sindicalistas, que eran en España enemigos jurados de los comunistas ${ }^{108}$.

Tras el establecimiento de relaciones diplomáticas con la URSS en julio de 1933, informaba Danielsson que, tras la negativa de Pascua a aceptar el cargo de Embajador en Moscú, se había solicitado la aprobación soviética para enviar allí a Álvarez del Vayo, un nombramiento que, según había podido saber Danielsson, no había sido del agrado de varios miembros del gobierno por las "excesivas simpatías” del candidato hacia la Unión Soviética $^{109}$.

La cuestión de las relaciones con la URSS volvió a ser objeto de la conversación que Ivan Danielsson tuvo en octubre de 1933 con el nuevo Ministro de Estado español, Sánchez Albornoz. Éste le había dado a entender que España no tenía prisa por realizar el intercambio de Embajadores y al principio podría enviarse a Moscú sólo a un Encargado de negocios. El Embajador soviético Lunachetvsky estaba gravemente enfermo en París.

\footnotetext{
${ }^{106}$ RA, UD, 1920-års dossierssystem, HP, vol. 421, despacho n. 251 de 1.VI.1932.

${ }^{107}$ RA, UD, 1920-års dossierssystem, HP, vol. 421, despacho n. 321 de 14.VIII.1932.

${ }^{108}$ RA, UD, 1920-års dossierssystem, HP, vol. 421, despachos n. 1 de 3.I.1933, 18 de 11.I.1933 y n. 28 de 13.I.1933.

109 RA, UD, 1920-års dossierssystem, HP, vol. 421, despacho n. 393 de 26.VIII.1933. Sobre las relaciones diplomáticas con la URSS, cfr. GARRIDO CABALLERO, María Magdalena, Las relaciones entre España y la Unión Soviética a través de las Asociaciones de Amistad en el siglo XX, Murcia, 2008, pp. 233-244.
} 
Danielsson sacó la conclusión de que España prefería esperar a nombrar Embajador en Moscú hasta que se solucionaran las relaciones comerciales con ese país, es decir, hasta que las exportaciones españolas a la URSS hubieran compensado en parte por las importaciones españolas de petróleo ruso. Tras el fallecimiento del Embajador soviético, todo parecía indicar que Moscú nombraría un Encargado de negocios. En una nueva entrevista de Danielsson con el nuevo Ministro de Estado el 30 de diciembre de 1933 habían vuelto a hablar de las relaciones hispano-soviéticas y Pita Romero se proponía seguir la línea de su antecesor. Danielsson sacó la conclusión de que no había peligro inmediato de competencia rusa para la exportación maderera sueca a España. ${ }^{110}$ Como se puede apreciar, tras el interés sueco por las relaciones hispano-rusas no había sólo motivos políticos, sino también comerciales.

Ya tuvimos ocasión de referirnos a la revolución de octubre de 1934 y cómo la información sobre la misma fue cubierta por la Legación sueca en Madrid. Añadiremos aquí que en octubre de 1934, el Estado Mayor de la Armada sueca recabó información acerca de las siguientes cuestiones: Las raíces internacionales de la revolución y la posible intervención de la Internacional Comunista; si había propaganda roja (sic) en el Ejército español y en caso afirmativo, qué medidas se habían adoptado al respecto; las tácticas de la revolución; las tácticas utilizadas en la represión de la revolución; y finalmente, qué se había aprendido de este conjunto de sucesos. Para contestar a la petición sueca, el Ministerio de Estado español solicitó información al Ministerio de la Guerra:

Representantes diplomáticos Suecia y Hungría, cuyos Gobiernos llevan con especial cuidado fichero internacional agitadores político-sociales, interesan apremiantemente de este Departamento relación nominal extranjeros de cualquier país cuya intervención en reciente revolución haya sido observada así en preparación como en ejecución movimiento ${ }^{111}$.

Es un dato más sobre la actitud de la socialdemocracia sueca respecto al comunismo durante los años que nos ocupan. Es una actitud común a los países nórdicos, como en los años de la guerra definirá Isabel de Palencia, Ministro de la República Española en

\footnotetext{
${ }^{110}$ RA, UD, 1920-års dossierssystem, HP, vol. 421, despacho n. 456 de 24.X.1933 y despacho confidencial n. 1 de 1.I.1934.

${ }_{111}$ RA, UD, 1920-års dossierssystem, HP, vol. 421, PM del Estado Mayor de la Armada de 10.X.1934; AGMAV, C.4, 5 .
} 
Estocolmo, al hablar de la "animadversión y recelo que hacia el comunismo experimentan todos estos países" ${ }^{\prime 12}$.

En el año 1935, curiosamente, parece ceder un tanto la preocupación específica de la Legación sueca por los avances del comunismo. En su lugar pasa a un primer plano la cuestión de la inestabilidad de los gobiernos. Esto se debe probablemente, a nuestro entender, al afianzamiento de las posiciones de la CEDA en la coalición gubernamental: en definitiva, al viraje a la derecha de la mayoría parlamentaria, ya iniciado a finales de 1933, pero que sin duda había cobrado fuerza con el fracaso del intento revolucionario de octubre de 1934. Más que el comunismo, en 1935 el espectro que se cernía sobre España era el riesgo de fascismo y/o de dictadura militar. Esto lo intuyeron con singular clarividencia los diplomáticos suecos en Madrid, en especial Ytterberg.

El hecho cierto es que el tema de los avances del comunismo aparece solamente de forma indirecta, al comentar la situación política general, durante 1935. Volvería a aparecer, con especial fuerza, en la primavera de 1936, cuando la Legación de Suecia llegó incluso a hablar de un "proyecto de bolchevización de España". La preocupación específica por el comunismo se integró dentro de una preocupación más amplia: la preocupación por la caída de la democracia en España y el riesgo inminente de una guerra civil.

\subsubsection{La España del Frente Popular y la amenaza de guerra civil}

\subsubsection{Las elecciones a Cortes de febrero de 1936}

Las elecciones de febrero de 1936 supusieron un hito importante en la historia de España y, consecuentemente, también en los análisis de la Legación de Suecia en Madrid, que a partir de entonces parecen centrarse casi exclusivamente en lo que consideraron una situación crítica para el futuro de la democracia en España ${ }^{113}$.

Ivan Danielsson describe la situación española en vísperas de las elecciones con profunda preocupación por las posibles consecuencias de la inestable situación política y de la crisis de gobierno producida con la dimisión de Chapaprieta: la situación era "grave"

\footnotetext{
112 AMAEC, PG 0197, 22675, despacho reservado de Isabel de Palencia, de 10.XI.1937.

${ }^{113}$ Para una visión más detallada, remitimos a nuestro estudio monográfico sobre Suecia y las elecciones de 1936: PEIX GELDART, Benito, "Suecia y las elecciones españolas a Cortes de 1936", en GONZÁLEZ CALlEJA, Eduardo \& NAVARRO COMAS, Rocío (coord.), La España del Frente Popular. Política, sociedad, conflicto y cultura en la España de 1936, Granada: Comares, 2011, pp. 223-240.
} 
y "amenazante", sobre todo por la intromisión del Ejército en el conflicto político ${ }^{114}$. A finales de 1935 era ya inminente la formación de un frente popular de izquierdas, mientras que el nuevo jefe del gobierno, Portela, pretendía crear un gran partido de centro, una pretensión que Danielsson pensaba que podía tener éxito, considerando que contaba con el apoyo de los gobernadores provinciales, quienes, "como es habitual en España" - decía, en clara alusión crítica al caciquismo y la manipulación de votos - "tienen muchas facilidades para influir en las elecciones". Para el diplomático sueco estaba claro que la verdadera pugna tendría lugar entre las derechas unidas y el cartel de izquierdas.

De la pesimista visión de Danielsson dan idea sus dudas sobre la permanencia de la República cuando escribe que las elecciones podrían no celebrarse debido a

complicaciones inmediatas que pudieran poner en entredicho la propia existencia del régimen actual. Cuando se piensa que la reciente crisis de gobierno es la número 28 en los cuatro años y medio de vida de la República española, no andan del todo descaminados los enemigos de la República cuando dicen que el actual sistema de gobierno no se ha caracterizado por una estabilidad merecedora de tal nombre ${ }^{115}$.

No cabe duda de a qué tipo de complicaciones se refería el Ministro Plenipotenciario sueco en Madrid: a la posibilidad de un golpe de Estado y la instauración de una dictadura militar. De hecho, en los últimos días de diciembre informaba acerca de una entrevista de Gil Robles con representantes del Ejército diciendo expresamente que "en el Ministerio de la Guerra, los principales generales le presionaron para que proclamara, en su calidad de Ministro de Guerra dimisionario, una dictadura apoyada por el Ejército" $" 116$.

Vuelve Danielsson a criticar al Presidente de la República en relación con la formación del segundo gabinete Portela, el 30 de diciembre, para salvaguardar sus propios intereses políticos, anteponiéndolos a su función constitucional de Jefe del Estado, al tiempo que deja entrever su desaprobación del gobierno por ser "no parlamentario" y

\footnotetext{
114 RA, UD, 1920-års dossierssystem, HP, vol. 422, despacho n. 620 de 13.XII.1935: "Además, los principales generales, Franco y Goded, habían dado a entender al líder del partido de derecha republicana, Miguel Maura, que el ejército no vacilaría en actuar decididamente para impedir la formación de un gobierno presidido por él (...) El Cónsul General De la Peña estaba visiblemente preocupado por la situación, pues por una parte hay que contar con la posibilidad de un golpe de estado militar y por otra hay rumores de que los líderes políticos de izquierdas están considerando la posible convocatoria de una huelga general en todo el país".

${ }_{115}$ RA, UD, 1920-års dossierssystem, HP, vol. 422, despacho n. 627 de 15.XII.1935; Cfr. también despachos n. 646 de 27.XII.1935; n. 652 de 30.XII.1935; n. 655 de 31.XII.1935 y n. 15 de 8.I.1936.

${ }^{116}$ RA, UD, 1920-års dossierssystem, HP, vol. 422, despacho n. 646 de 27.XII.1935. La cursiva es nuestra.
} 
haberse convertido en un instrumento en manos de Alcalá-Zamora ${ }^{117}$. Objeto también de las críticas del diplomático sueco fue Largo Caballero, al que consideraba un extremista poco respetuoso con la democracia por estar decidido a no aceptar el resultado de las elecciones si éstas le eran desfavorables, y estar dispuesto a tomar el poder a través de medios revolucionarios.

En enero de 1936 no creía Danielsson en las posibilidades de los partidos centristas, y hacía suyo el eslogan de la derecha de que las elecciones eran un plebiscito "a favor o en contra de la revolución y el marxismo". A juzgar por los "apasionados sentimientos ya exteriorizados en los mítines electorales”, la campaña electoral sería violenta. Informa de la creación del Frente Popular y no se atreve a pronunciarse sobre el resultado de las elecciones aunque piensa que la posición de Alcalá Zamora, "sería insostenible tanto si gana la coalición de derechas como el frente marxista" ${ }^{118}$,

Informó Danielsson que las elecciones habían tenido lugar con normalidad y buen orden, sin violencia, atribuyendo la amplia victoria del Frente popular al cambio de signo político de grandes masas del electorado español, a la inesperada participación en las elecciones de los sindicalistas y a los desafortunados «manejos» de Portela. El pueblo español había tomado una postura clara en contra del "movimiento fascista fundado por el hijo del anterior dictador Primo de Rivera" y suponía que habría un cambio sustancial de política en España. Danielsson esperaba que Azaña llegara a un acuerdo con Gil Robles que alejara el peligro de «extremismos de uno y otro lado» y resaltaba el impacto de los resultados en el mundo financiero, en las familias monárquicas - que temían "persecuciones similares a las de 1931" - y en Cataluña ${ }^{119}$. Daba datos sobre la composición del nuevo gobierno, y sobre la reducción del número de ministerios. Se hacía eco del entusiasmo popular ante la toma del poder por parte de Azaña, y del discurso de éste, describiendo vivamente el desánimo reinante en los partidos de derecha ante los resultados. Insistió también en el peligro de manipulación de las elecciones en los distritos donde se iban a repetir, diciendo que "conociendo los métodos habituales en este país cuando se trata de elecciones, no debería faltarle al gobierno ocasión de aumentar aún más su mayoría en las Cortes" ${ }^{, 20}$.

\footnotetext{
${ }^{117}$ RA, UD, 1920-års dossierssystem, HP, vol. 422, despacho n. 652, 30.XII.1935

118 RA, UD, 1920-års dossierssystem, HP, vol. 422, despacho n. 44 de 18.I.1936 y despacho n. 61 de 29.I.1936

${ }^{119}$ RA, UD, 1920-års dossierssystem, HP, vol. 422, despachos n. 90 de 17.II.1936 y n. 91, 18.II.1936

${ }^{120}$ RA, UD, 1920-års dossierssystem, HP, vol. 422, despacho n. 93, 20.II.1936. La cursiva es nuestra.
} 
A continuación - los despachos de Danielsson se habían hecho ahora casi diarios hablaba de la influencia en las elecciones de la Unión Soviética:

Se considera probado que oro ruso ha sido utilizado en abundancia durante la campaña electoral, y como ejemplo se aduce que los sindicalistas en Barcelona sólo acudieron a las urnas una vez que, dos horas antes del cierre de éstas, agitadores extranjeros bien provistos de dinero contante y sonante consiguieran convencerles para que lo hicieran ${ }^{121}$.

Por otro lado, había rumores - desmentidos por el Gobierno - de que ya se estaba fraguando un golpe de estado para instaurar, por medio del ejército, una dictadura militar, y que habían sido detenidos Francisco Franco y algunos oficiales de aviación en una base aérea cerca de Madrid ${ }^{122}$.

A finales de febrero, la Asociación de Amigos de la Unión Soviética visitaba al nuevo Ministro de Estado, Barcia, para pedirle la normalización de las relaciones comerciales y diplomáticas entre la URSS y la República Española, a la que se llegó en un breve plazo de tiempo ${ }^{123}$.

\subsubsection{La situación política y social de España en la primavera de 1936}

A mediados de marzo distaba mucho el Ministro de Suecia en España de estar tranquilo con la situación. Insistía en que situación en España era muy preocupante: Había "un proceso de fermentación" - palabras que recogerá en un titular el principal diario de Suecia, Dagens Nyheter- en amplios sectores de las masas populares y las fuerzas de extrema izquierda del país, desafiando los llamamientos del gobierno y de los dirigentes socialistas al orden y a la tranquilidad, habían comenzado una "política de violencia y de terror" con el fin de explotar al máximo la victoria en las urnas. En algunos lugares, como Canarias, se había «neutralizado el intento de los comunistas de implantar un régimen soviético". El problema era grave, según Danielsson, porque era "evidente la incapacidad de las fuerzas de orden público de evitar completamente los efectos del espíritu apasionado y revolucionario que, una vez más, ha tomado posesión de gran parte del pueblo español". La situación seguía tensa y circulaban tantos rumores que el diplomático no sabía a qué

\footnotetext{
${ }^{121}$ RA, UD, 1920-års dossierssystem, HP, vol. 422, despacho n. 100 de 24.II.1936

${ }^{122}$ RA, UD, 1920-års dossierssystem, HP, vol. 422, despachos n. n. 90 de 17.II.1936; n. 91 de 18.II.1936 y n. 93 de 20.II.1936, despacho confidencial n. 99 de 22.II.1936 y despacho n. 100, 24.II.1936.

${ }^{123}$ RA, UD, 1920-års dossierssystem, HP, vol. 422, despacho n. 115, de 2.III.1936.
} 
atenerse: ¿Se iba a "implantar en España un régimen soviético” o conseguiría Azaña, con o sin la ayuda de la derecha, parar a las masas populares radicalizadas?

Las masas obreras han reanudado su política "terrorista" - escribe a su gobierno- que puede tener consecuencias desastrosas para el país. A diario llegaban noticias de iglesias y monasterios quemados, de maltratos a personas, incluso a extranjeros, etc. Lo más preocupante era la actitud pasiva de las autoridades antes estos desmanes, prueba clara de que el gobierno de Azaña no se sentía lo suficientemente seguro. Si las cosas no cambiaban era de temer

una reacción de los adversarios políticos que, con la intervención del Ejército, puede llevar al país a la guerra civil. Un conocido político español me comentó que veía la situación con mucho pesimismo: una gran parte de la nación española se ha pasado a la izquierda política y la situación actual de España recuerda mucho a la de Rusia bajo Kerenski.

No era la primera vez que Danielsson comparaba la situación de España a la de Rusia bajo Kerenski, pero en esta ocasión menciona expresamente la posibilidad de una "guerra civil", y no solo de un golpe de Estado militar o comunista ${ }^{124}$.

El peligro comunista era, para Danielsson, muy serio, tanto como para merecer un nuevo despacho específico titulado "Avances del comunismo en España". Aunque el PCE sólo tenía 16 diputados, los seguidores de Largo Caballero en el partido socialista mostraban "tendencias bolcheviques". Se podía decir que gran parte de la masa obrera española, sobre todo en las zonas rurales, abrazaba las teorías comunistas. En las ciudades, era más común la adhesión al anarcosindicalismo. Además, se habían unido las juventudes socialistas y comunistas, que ya contaban con 100.000 miembros.

¿Por qué este aumento? Danielsson lo explica por la "actividad de agentes extranjeros". De hecho, en este momento parece que el diplomático sueco se ha dejado influir plenamente por la visión de la situación proporcionada por sus informadores más conservadores. Afirma que era "conocido" que durante las últimas elecciones, comunistas rusos provistos de abundantes medios económicos habían actuado en diversos lugares del país. Varios famosos comunistas alemanes estaban actualmente en España, según le había dicho su colega el Embajador alemán. La prensa portuguesa informaba que unos barcos rusos habían desembarcado armas y municiones en Algeciras y Sevilla para su uso en España. El Diario Vasco, por su parte, informaba que la situación española habría sido discutida en una reunión del Komintern del 27 de febrero, donde se habrían dado

${ }^{124}$ RA, UD, 1920-års dossierssystem, HP, vol. 422, despachos confidenciales n. 129 y 131 de 11.III.1936. 
instrucciones a sus representantes para que intentasen formar un gobierno proletario en España, nacionalizando la banca, minas, fabricas y vías férreas, confiscando tierras, y abandonando la zona española de Marruecos ${ }^{125}$.

El 14 de marzo tuvo que informar el diplomático sobre el intento de asesinato de Jiménez de Asúa a mano de unos "estudiantes fascistas"126. El Ministerio sueco de Estado preguntó si España se podía considerar lo suficientemente segura para los turistas suecos. La respuesta inicial fue afirmativa; pero a los pocos días, a finales de marzo, rectificó esa opinión, desaconsejó a los suecos visitar España ${ }^{127}$. Por entonces, resumía Danielsson de nuevo la actualidad política y social de la República en términos realmente sórdidos: a pesar de que había "algo más de calma" la situación seguía siendo preocupante. El gobierno retrasaba la contestación a la interpelación que le había hecho la derecha sobre las medidas que pensaba tomar para mantener el orden público, "por miedo a que la discusión parlamentaria de los excesos cometidos por los grupos revolucionarios de la izquierda y por los elementos fascistas enconen aun más la situación”. Era evidente, decía Danielsson, que "los comunistas y otros extremistas de izquierda que siguen a Largo Caballero han tomado un curso de acción que es una pura política de violencia terrorista. Según uno de mis informadores, si Largo Caballero tomara el poder, eso supondría la implantación del régimen soviético en España”. Había rumores de que los partidos republicanos se iban a unir para contrarrestar el peligro comunista, y que el ambiente entre los militares era "propicio a tomar el poder de inmediato e implantar en España un régimen dictatorial similar al de Portugal". Las elecciones locales se habían tenido que aplazar sine die por haberse encontrado casos flagrantes de manipulación de listas electorales y Azaña tenía miedo de una "sovietización" de España debido a la alianza de muchos socialistas con los comunistas $^{128}$

A primeros de abril tuvo lugar la destitución de Alcalá-Zamora como Presidente de la República. Danielsson informó de esta cuestión por telegrama, cuando acababa de enviar un análisis-resumen de la actualidad política española durante el primer trimestre de 1936: tras referirse a las elecciones, mencionaba los desórdenes públicos causados por elementos de izquierdas como respuesta a las provocaciones de los elementos fascistas, diciendo que había peligro de que se instaurase en España una dictadura militar. Alababa la decisión de

\footnotetext{
${ }^{125}$ RA, UD, 1920-års dossierssystem, HP, vol. 422, despacho n. 133 de 12.III.1936.

${ }^{126}$ RA, UD, 1920-års dossierssystem, HP, vol. 422, despacho n. 134 de 14.III.1936.

${ }^{127}$ RA, UD, 1920-års dossierssystem, HP, vol. 422, telegramas de 21 y 31.III.1936.

${ }^{128}$ RA, UD, 1920-års dossierssystem, HP, vol. 422, despachos n. 134 de 14.III.1936 y n. 176 de 4.IV.1936.
} 
Azaña, tomada tras la amenaza de los militares de tomar a su cargo el orden público, de hacer respetar las leyes, y también la de aplazar las elecciones, por el peligro de que la izquierda creara soviets locales si tomaba el poder en algunos municipios, lo que significaría "un paso adelante en su proyecto de bolchevización de España”.

Además, Danielsson trató de explicar a su gobierno - socialdemócrata - la progresiva radicalización del PSOE: donde antes había dos corrientes, "una revolucionaria, otra democrática", había pasado a haber tres: la moderada, de Besteiro; la centrista, de Indalecio Prieto y González Peña; y la revolucionaria de Largo Caballero, "cuyo objetivo de conseguir la dictadura del Proletariado por medios violentos no se diferencia en nada de las teorías comunistas". Si el partido se desintegraba en varias facciones, la mayoría seguiría al "Lenin español, como ahora llaman a Largo Caballero". La Unión de las Juventudes Socialistas con las Comunistas era buena muestra de la radicalización hacia la izquierda del PSOE. Explicaba las perspectivas ante el congreso del partido y las propuestas de Largo Caballero para cambiar los fines inmediatos del partido. Sus objetivos eran los siguientes: 1. la toma del poder por parte de los trabajadores a través de cualquier medio disponible. 2. La sustitución de la propiedad privada y cooperativa por la propiedad colectiva. En el periodo intermedio entre el capitalismo y el socialismo, la forma de gobierno sería la dictadura del proletariado. Besteiro había intentado sin éxito - informaba Danielsson - hacer ver que la propuesta de Caballero significaba convertir al PSOE en un partido comunista, y que en su lugar debería tener un programa evolutivo que, sin recurrir a la violencia, fuera alcanzando poco a poco la socialización de los medios de producción, a lo que Caballero respondía diciendo que la radicalización hacia la izquierda de los trabajadores era inevitable porque se había comprobado que la República no podía dar solución a los problemas de los trabajadores. Al mismo tiempo, parecía que las tendencias extremistas dentro del PSOE estaban presentes sobre todo en Madrid y que las organizaciones provinciales, salvo en Andalucía, no las apoyaban ${ }^{129}$.

El alarmismo de los despachos suecos respecto a la situación política y social de España fue en aumento en los meses de mayo a julio de 1936. Asimismo, durante esos meses entre el Ministerio de Estado de la República Española y el Ministerio de Negocios Extranjeros sueco, se estaba librando la batalla diplomática por alejar de España

${ }^{129}$ RA, UD, 1920-års dossierssystem, HP, vol. 422, despacho n. 178 de 7.IV.1936 y n. 219 de 25.IV.1936 
definitivamente al Ministro Danielsson, por decisión del nuevo Presidente de la República, don Manuel Azaña ${ }^{130}$.

El desarrollo político español en la primavera de 1936 está unido sin solución de continuidad, para la diplomacia sueca, con el estallido de la guerra de España en julio de $1936^{131}$.

\subsection{La política exterior de la República según la diplomacia sueca}

En acusado contraste con el detallado seguimiento que los diplomáticos suecos en Madrid llevaron a cabo respecto a la política interior de la República, llama la atención la parquedad de referencias a la política exterior de la misma. De hecho, a excepción de las relaciones hispano-soviéticas y a la actitud española ante los conflictos de Chaco y de Abisinia, en el marco de la Sociedad de Naciones - temas que analizaremos más detalladamente en el capítulo siguiente, al tratar de las relaciones bilaterales entre España y Suecia - en los despachos diplomáticos suecos aparecen pocas referencias a las relaciones de la República con otros países. Este hecho contrasta también con la actitud observada por los diplomáticos españoles en Estocolmo, que con cierta frecuencia informaron de las relaciones entre Suecia y las principales potencias del momento.

Aparte de lo relacionado a las relaciones con la Unión Soviética y de algún despacho sobre la cuestión del desarme o sobre aspectos de política comercial, la mayoría de las referencias a la política exterior de España en los informes diplomáticos suecos trata del entorno mediterráneo: Francia, Italia y, especialmente, Marruecos.

A finales de abril de 1931, todos los países con los que la España alfonsina tenía relaciones diplomáticas habían reconocido al nuevo régimen republicano ${ }^{132}$. Como era lógico, las preocupaciones más inmediatas de la República en sus primeros meses eran de orden interno más que internacional. Una cierta excepción a este respecto fueron las relaciones con Francia, con la que durante los últimos meses de la monarquía había habido

\footnotetext{
${ }^{130}$ En el capítulo 5 analizaremos en detalle esta cuestión.

${ }^{131}$ El primer despacho sueco que informa con cierto detalle de la rebelión del 18 de julio de 1936 es el n. 356 de fecha 25.VII.1936.

${ }^{132}$ RA, UD, 1920-års dossierssystem, HP, vol. 420, despacho n. 210 de 26.IV.1931.
} 
desacuerdos en materia comercial ${ }^{133}$ y la cuestión de Marruecos, donde se dejaba sentir la acción desestabilizadora de Alemania y la Unión Soviética ${ }^{134}$.

Sobre la cuestión marroquí informaba Danielsson del cambio que supuso la llegada de la República, con el nombramiento del Cónsul General en Gibraltar, López Ferrer, como Comisario general de Marruecos, y del general Cabanellas como jefe militar, pero subordinado al anterior. Citaba los rumores de la prensa extranjera de que la República Española se iba a retirar de Marruecos, que habían sido inmediata y categóricamente desmentidos por el Ministerio de Estado. España quería, eso sí, seguir el ejemplo de Francia y llevar a cabo una política más pacifista y civilizadora, favoreciendo la cooperación con los clanes locales en las zonas pacificadas. El objetivo era reducir el presupuesto a la mitad, y disminuir sustancialmente la presencia allí de las fuerzas militares españolas. A pesar de ello, parecía que un tal Ben Aziba de Tazout estaba creando dificultades a España y había miedo de que pudiera convertirse en un nuevo Abd el Krim. Una delegación marroquí había venido a Madrid para presentar al gobierno un catálogo de exigencias ${ }^{135}$.

Transmitió asimismo la Legación las declaraciones de Indalecio Prieto en el sentido de que la República Española no era imperialista y no le importaba nada Marruecos, que sólo le causaba problemas, por lo que estaba considerando solicitar que algún otro país se hiciera cargo del protectorado para poder destinar la partida presupuestaria correspondiente a la promoción de la cultura. La prensa conservadora española había protestado diciendo que eso sería el suicidio político de España, y Francia recordó que España se había comprometido en 1912 a encargarse de su zona de Marruecos y no era asunto negociable. Prieto hubo de excusarse alegando haber hablado a título personal y hecho solamente una declaración de principios $^{136}$.

La siguiente cuestión de política exterior española en los informes suecos fue la relacionada con el desarme. La política pacifista de la República fue discutida, junto a la cuestión de la URSS, en la conversación que Danielsson tuvo con el Ministro de Estado Luis de Zulueta en diciembre de $1931^{137}$. El tema volvería a ser objeto de un despacho específico, firmado por el Secretario de la Legación, Einar Ytterberg, pocos días antes de

\footnotetext{
${ }^{133}$ RA, UD, 1920-års dossierssystem, HP, vol. 420, despacho n. 170 de 10.IV.1931 y despacho n. 447 de 3.X.1931 sobre las negociaciones de Lerroux en París.

${ }^{134}$ RA, UD, 1920-års dossierssystem, HP, vol. 420, despacho confidencial n. 343 de la Embajada de Suecia en Londres, de fecha 5.VI.1931.

${ }^{135}$ RA, UD, 1920-års dossierssystem, HP, vol. 420, despacho n. 304 de 23.VI.1931

${ }^{136}$ RA, UD, 1920-års dossierssystem, HP, vol. 420, despacho n. 344 de 11.VII.1931

${ }^{137}$ RA, UD, 1920-års dossierssystem, HP, vol. 420, despacho confidencial n. 584 de 26.XII.1931.
} 
la "Sanjurjada", comentando las declaraciones de Azaña en el Parlamento sobre la política española de defensa tras la reorganización del Ejército el 30 de julio de 1932. Según Ytterberg, lo más destacable del discurso eran las frases iniciales sobre la necesidad de un ejército fuerte que permitiera a España decidir libremente su posición, de neutralidad o no, en caso de un conflicto internacional de envergadura. Mostraba Ytterberg su sorpresa de que la prensa española hubiera pasado por alto esas declaraciones, que el diplomático creía eran un aviso a Francia e Italia de que España quería tener un papel más activo en la política mediterránea y en concreto en posibles conflictos italo-franceses en la zona, apoyando "a su vecino del norte, con el que tiene tanto en común. Más de una vez se han pronunciado los círculos gubernamentales sobre la necesidad de mantener cordiales relaciones con la République amie mientras que en esos mismos círculos se mantenía el silencio sobre Italia" ${ }^{138}$.

La visita a España del Presidente del gobierno francés, en octubre de 1932, fue comentada por la Legación en el mismo sentido en que lo hizo la prensa española y extranjera, que vio en ella un intento de ganar a la República para la órbita francesa tanto en la cuestión de la defensa frente a Alemania como en el pulso con Italia por la supremacía en el Mediterráneo. Danielsson consideraba, sin embargo, que esas presiones francesas sobre España no tendrían resultado alguno, dada la política española de neutralidad $^{139}$.

Las relaciones con Francia, con todo, no eran del todo satisfactorias para la República española, en parte por la competencia en materia comercial entre ambos países y sobre todo cuando cabía el peligro de que la "República amiga" asumiese el papel de "tutora" de la española. Una muestra de ello, sobre la que informó la Legación de Suecia, fue el acto en honor del Embajador francés Herbette, en enero de 1933, en el que Miguel de Unamuno le pidió que salvara a España del peligro de guerra civil, lo que irritó profundamente a Luis de Zulueta $^{140}$.

Tras el intento de golpe de Estado del general Sanjurjo, la República procedió a efectuar cambios en las formas de acceso a los cuerpos de funcionarios. También se vio afectada la administración exterior, tras la denuncia en las Cortes de que muchos diplomáticos eran "monárquicos y reaccionarios", extremo con el que Danielsson estaba de acuerdo. La propuesta de Ley del Ministro de Estado, Luis de Zulueta, para la

\footnotetext{
${ }^{138}$ RA, UD, 1920-års dossierssystem, HP, vol. 420, despacho n. 317 de 7.VIII.1932.

${ }^{139}$ RA, UD, 1920-års dossierssystem, HP, vol. 420, despacho n. 529 de 28.XII.1932.

${ }^{140}$ RA, UD, 1920-års dossierssystem, HP, vol. 421, despacho n. 33 de 19.I.1933.
} 
democratización del Cuerpo Diplomático español que incluía la posibilidad de alejar a diplomáticos del servicio a propuesta del Ministro no fue bien vista, según la Legación de Suecia, por muchos diplomáticos españoles que veían un peligro de arbitrariedad por parte del Ministro de Estado, "que ha demostrado ser persona sectaria""141.

Hubo aún otros aspectos de la política exterior española durante el primer bienio republicano que merecieron la atención de la diplomacia sueca: lo referente a la política exterior comercial, con la decisión de la República de renegociar los tratados comerciales con otros países, eliminando la cláusula de 'nación más favorecida'. El asunto, como veremos más detalladamente en el próximo capítulo, trajo consecuencias para Suecia y preocupó hondamente tanto a los suecos como a los españoles, y fue un motivo de tensión internacional para la República ${ }^{142}$.

Con la llegada de López Oliván a Suecia se agilizaron mucho las relaciones políticas entre ambos países. Da la impresión, sin embargo, de que las iniciativas de López Oliván no siempre se debían a una estrategia definida de política exterior por parte de la República española, como se desprende, por ejemplo, de las anotaciones de Rickard Sandler sobre la conversación que tuvo con el diplomático español el 1 de junio de 1933:

El Ministro de España se presentó el 1 de junio en relación con una conversación previa con el ministro Undén sobre la posición ante la conferencia de Londres. Todavía no tenía nada definitivo que decir sobre la política de su gobierno pero confiaba en que podríamos colaborar en Londres. Él mismo va a ser miembro de la delegación [española] ${ }^{143}$

\footnotetext{
${ }^{141}$ RA, UD, 1920-års dossierssystem, HP, vol. 420, despacho n. 356 de 10.IX.1932.

${ }^{142}$ RA, UD, 1920-års dossierssystem, HP, vol. 420, despacho n. 590 de 29.XII.1931; cfr. también RA, UD, 1920-års dossierssystem, HP, vol. 421, despacho n. 560 de 31.XII.1933, donde se informa de las buenas intenciones de Pita Romero de que trataría de evitar que la política comercial española causara perjuicios a Suecia y que quería establecer una "cooperación intima con nuestro país en el terreno de la política internacional". Sin embargo, las barreras al comercio exterior no fueron solamente por parte de España, cfr. RA, UD, 1920-års dossierssystem, Vol. 14, Utrikesministerns samtal med utländska sändebud, reuniones de 29.XI.1932 y de 3.I.1933, reclamaciones de los Ministros de España en Suecia ante el Ministro sueco de Negocios Extranjeros sobre aranceles a vinos y a tabaco. Sobre los problemas y tensiones a causa de la nueva política comercial, cfr. RA, UD, 1920-års dossierssystem, HP, vol. 421, despacho n. 516 de 3.XI.1934: "También han empeorado las relaciones con Portugal, y la política comercial española: el sistema de contingentes ha causado muchos problemas, que el gobierno no ha mostrado excesivo interés en solucionar. Con España hemos tenido un problema de cierta entidad, al negarse tozudamente el gobierno español a conceder el suficiente número de licencias provisionales de importación, cuya solución ha costado dos meses de insistencia por nuestra parte. Ha habido acuerdos de España con Dinamarca, Noruega e Islandia por los que a través de compensaciones los españoles han considerado cumplida su política de nivelación del volumen de exportaciones e importaciones”. Cfr. también RA, UD, 1920-års dossierssystem, HP, vol. 421, despacho n. 633. de 31.XII.1934.

${ }_{143}$ RA, UD, 1920-års dossierssystem, Vol. 14, Utrikesministerns samtal med utländska sändebud, conversación del Ministro de Negocios Extranjeros con el Ministro de España, 1.VI.1933.
} 
De mayor entidad, en el ámbito de la política exterior de España, fue la reacción ante la toma del poder por parte de Hitler en Alemania. En esa ocasión, informó la Legación de Suecia que la prensa española - con la sola excepción de los diarios próximos a las posturas primorriveristas - criticaba claramente todas las dictaduras, y en particular lo hizo respecto al régimen nazi con "declaraciones especialmente fuertes". Unido esto a las manifestaciones ante la embajada alemana, italiana y portuguesa, se vio el gobierno de la República en la necesidad de conminar a la prensa a que se abstuviera de insultos a jefes de Estado y a representantes diplomáticos extranjeros, lo cual no fue aceptado por la prensa de izquierdas. Esto motivó, informó a Danielsson el Embajador alemán, una "relación tensa entre ambos gobiernos" [español y alemán] ${ }^{144}$. Sorprende, sin embargo, que las relaciones hispano-germanas solamente fueran objeto de un único despacho diplomático sueco.

En el primer semestre de 1935, las Cortes debatieron la política internacional de la República, y los informes suecos fueron francamente severos, llegando a decir, en síntesis, que España no estaba interesada por la política europea pero que había tenido que despertar por el acercamiento a primeros de año entre Francia e Italia, que ponía en peligro los intereses de España en el Mediterráneo. El Ministro de Estado, Rocha, había asegurado que España sería consultada en las cuestiones que afectaran a la seguridad en la zona indicada. En mayo de 1935, la interpelación parlamentaria presentada por el Conde de Romanones sobre la postura de la República Española en política internacional, motivó un nuevo debate en las Cortes, centrado en la cuestión mediterránea - sobre la vigencia o no del acuerdo de Cartagena de 1907 - y la cuestión marroquí - sobre los planes del gobierno en relación con una posible reforma del Estatuto de Tánger -, cuestiones a las que el Ministro de Estado respondió diciendo que el acuerdo de Cartagena estaba vigente y que España debía velar por la seguridad en el Mediterráneo en colaboración con Inglaterra, Francia e Italia, y reconociendo que el Estatuto de Tánger ofrecía dificultades a España pero no era aún el momento de plantear una reforma.

Por otra parte, España estaba llamada a desempeñar un papel en el seno de la Sociedad de Naciones y en relación con las Repúblicas sudamericanas. Según la Legación había podido saber "de fuente fiable", el acercamiento franco-italiano había puesto nervioso al gobierno español, que ignoraba el alcance de los acuerdos tomados por aquellas

${ }^{144}$ RA, UD, 1920-års dossierssystem, HP, vol. 421, despacho n. 139 de 30.III.1933. 
naciones, y había tomado medidas de reforzamiento militar de las Baleares y mejoras en la Armada $^{145}$.

Hubo dos conflictos internacionales, en 1935, que quedaron reflejados en la documentación diplomática sueca y española, pues ambos países quisieron saber la postura del otro al respecto. A ellos nos volveremos a referir también en el capítulo siguiente al tratar de las relaciones bilaterales sueco-españolas. Se trata del conflicto del Chaco (Paraguay-Bolivia) y del de Abisinia (italo-etiope).

Respecto al conflicto del Chaco, el Ministro de España en Estocolmo quiso saber la postura que iba a tomar Suecia, y se refirió al tema en el transcurso de dos conversaciones con el Ministro sueco de Negocios Extranjeros. Aunque dijo que la postura sueca "fácilmente podría congeniarse con la española", lo cierto es que el Sandler no supo a qué atenerse, pues al parecer el diplomático español no tenía instrucciones detalladas de su gobierno sobre cuál era la posición de la República ${ }^{146}$.

Sobre la postura española en el conflicto de Abisinia explicaba Danielsson que era de neutralidad, pero sin exponerse a enemistarse con las principales potencias implicadas, Italia e Inglaterra. Esa era la posición propugnada por el Ministro de la Guerra, Gil Robles. España prefería no irritar a Italia apoyando las sanciones que se proponían contra ella, especialmente por parte de Suecia, en la Sociedad de Naciones, aunque si se viera forzada a ello para salvaguardar el Pacto de la Sociedad, lo haría.

Además de esa postura oficial, los despachos suecos recogían también el ambiente reinante en la opinión pública española, en la que la prensa católica defendía mayormente a Italia, acusando a Inglaterra de "egoísmo", mientras que la izquierda se inclinaba por las sanciones, aunque "de una manera más moderada en sus declaraciones", si bien el PSOE había publicado un manifiesto apoyando las sanciones a Italia. En agosto, el Ministro de España en Estocolmo habló con Sandler, ministro sueco de Negocios Extranjeros sobre el tema. En septiembre, el gobierno español, que había renunciado a favor de Portugal a tener un representante en el llamado "comité de los cinco" - desautorizando así a Madariaga parecía inclinarse por la abstención en la votación de las sanciones, es decir, por el apoyo a Italia. Finalmente, optó España por prohibir la exportación de armas a Italia, pero según Danielsson reinaba en los círculos gubernamentales de Madrid un gran nerviosismo ante

${ }^{145}$ RA, UD, 1920-års dossierssystem, HP, vol. 421, despacho n. 363 de 5.VII.1935 que resume despachos de 25.I.1935 y de 15.V.1935, sobre un aumento del interés de la opinión pública española por los asuntos internacionales y la conclusión de acuerdos comerciales con Irlanda, Estonia, Uruguay y Argentina.

${ }^{146}$.RA, UD, 1920-års dossierssystem, Vol. 14, Utrikesministerns samtal med utländska sändebud, reuniones de 8.I.1935 y de 5.III.1935. 
las posibilidades de que España fuera involucrada en un conflicto armado anglo-italiano. Al final, como dijera Madariaga - en frase que Danielsson transmitió a Estocolmo -, sucedió como en la fabula del león y el cordero: se hizo la paz una vez que el primero se comió al segundo ${ }^{147}$.

Podemos concluir este apartado diciendo que la diplomacia sueca apenas se interesó por la política exterior de la República española, y cuando lo hizo, fue en general en relación con Marruecos y el Mediterráneo, o para destacar el interés por Europa y la falta de concreción de su política exterior. En efecto, los representantes de España, a juzgar por los despachos diplomáticos suecos y las minutas de las reuniones de su Ministro de Negocios Extranjeros con los diplomáticos españoles en Estocolmo, se referían con frecuencia a la política de neutralidad y pacifismo de la República, pero sin descender a detalles en el caso de los conflictos concretos: la pugna italo-francesa en el Mediterráneo, la anglo-italiana en Abisinia, etc. Aspecto éste nada sorprendente, pues se enmarca perfectamente en la línea de lo expuesto en la investigación española sobre relaciones internacionales de España en el período contemporáneo ${ }^{148}$.

\footnotetext{
${ }^{147}$ RA, Beskickningsarkivet: Madrid, F1C:41, despachos n. 451 de 30.VIII.1935; n. 456, del 12.IX.1935; n. 518 de 7.XII.1935; telegrama cifrado n. 28 de 24.XII.1935 y nota de Danielsson a Beck-Friis de 13.IV.1936. Se incluyen recortes de prensa española al respecto, principalmente del diario El Sol. Sobre las conversaciones con Sandler, cfr. RA, UD, 1920-års dossierssystem, Vol. 14, Utrikesministerns samtal med utländska sändebud, reuniones de 31.VIII, de 5.XI y de 19.XI.1935: Según Sandler, el diplomático español no tenía instrucciones claras de su gobierno respecto al tema, limitándose a hablar en términos generales de la neutralidad española y de las diferencias de actitud en la opinión pública.

${ }^{148}$ A título de ejemplo al respecto, cfr. MORALES LEZCANO, op.cit., p. 579: "la neutralidad hispana en períodos de conflictividad y guerra europea, ha traducido fielmente la asunción de que España es una pequeña potencia, que pocos intereses tiene que defender en el mundo, y que, en consecuencia, opta por la neutralidad en calidad de caparazón jurídico que la proteja de los bloques continentales en pugna".
} 



\section{Capítulo 4}

\section{SUECIA ENTRE 1931 Y 1936 SEGÚN LA DIPLOMACIA ESPAÑOLA}

La alta cultura de esta raza, (...) la hace consciente de su papel tanto en el concierto de las naciones como en la civilización del norte de Europal

\subsection{La Legación de España en Estocolmo. Los ministros de España en Suecia}

Por contraste con la continuidad de la representación diplomática sueca en Madrid, a la que hacíamos referencia en el capítulo anterior, la situación de la Legación de España en Estocolmo se caracterizó por su discontinuidad. Esto es aplicable tanto a los jefes de misión como al principal personal subalterno, y es un reflejo de la situación general de España, también a nivel de Ministros de Estado.

En los años 1931-1936 se sucedieron con rapidez los Ministros de España en Suecia: Pedro García Conde, Julio López Oliván y Alfonso Fiscowich ostentaron ese puesto. Además, durante el breve período de Oliván como jefe de misión, tuvo éste que compaginar ese puesto con otros importantes encargos diplomáticos, como fue el de presidir la delegación española ante la Conferencia Económica Mundial de Londres. Ello le llevó a estar ausente de Estocolmo con cierta frecuencia, siendo sustituido entonces por José Fernández Villaverde como Encargado de Negocios ad interim. Lo propio había tenido que hacer antes José González de Gregorio en sustitución de Pedro García Conde.

Por lo que se refiere al personal diplomático subalterno español en Suecia, el año 1931 presentó bastantes dificultades al Ministerio. Hubo varias dimisiones y nombramientos de vicecónsules honorarios, entre otros el de Helsingborg (renovación), el de Skellefteå (nuevo nombramiento) y el Cónsul de carrera en Gotemburgo (traslado desde Oslo del Cónsul en esa capital). En marzo dimitió el vicecónsul (honorario) de Estocolmo,

\footnotetext{
${ }^{1}$ José F. Villaverde, Encargado de Negocios ad interim de la Legación de España en Estocolmo, Anexo al despacho núm. 17 de 15 de enero de 1934, AMAEC R, 698, 10.
} 
Nordbeck, por un asunto del que no tenemos más referencias, pero que motivó algún escrito del Ministerio de Estado a la Legación y viceversa. Se mencionan quejas de un tal Oraz. Además, al año siguiente, parece que había irregularidades en el consulado de Gotemburgo, que llevan a la Legación a proponer su destitución.

Los cuadros siguientes dan una idea clara de la situación ${ }^{2}$ :

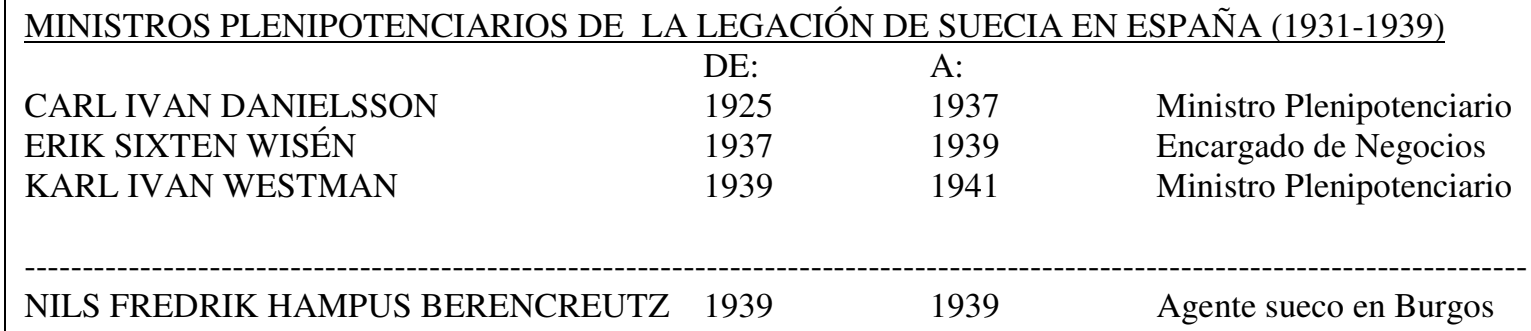

MINISTROS PLENIPOTENCIARIOS DE LA LEGACIÓN DE ESPAÑA EN SUECIA (1931-1939)

\begin{tabular}{|c|c|c|c|}
\hline & DE: & A: & \\
\hline PEDRO GARCIA CONDE & 1930 & 1932 & Ministro Plenipotenciario \\
\hline JULIO LÓPEZ OLIVÁN & 1932 & 1934 & Ministro Plenipotenciario \\
\hline ALFONSO FISCOWICH GULLÓN & 1934 & 1936 & Ministro Plenipotenciario \\
\hline ISABEL OYARZÁBAL SMITH & 1936 & 1939 & Ministro Plenipotenciario \\
\hline JOSÉ LANDECHO Y ALLENDESALAZAR & 1939 & 1949 & Ministro Plenipotenciario \\
\hline FERNANDO VALDÉS IBARGÜÉN & 1939 & 1939 & Agente Franco en Suecia \\
\hline
\end{tabular}

Y aún más evidente es la desproporción a nivel de Ministros responsables de las relaciones exteriores:

\begin{tabular}{|c|c|c|c|}
\hline & DE: & A: & \\
\hline FREDRIK RAMEL & 1930 & 1932 & Independiente liberal \\
\hline RICKARD SANDLER & 1932 & 1936 & Partido Socialdemócrata \\
\hline KARL GUSTAF WESTMAN & 1936 & 1936 & Liga agraria \\
\hline RICKARD SANDLER & 1936 & 1939 & Partido Socialdemócrata \\
\hline CHRISTIAN GÜNTHER & 1939 & 1945 & Sin afiliación política \\
\hline
\end{tabular}

\footnotetext{
${ }^{2}$ Elaboración propia a partir de datos de los archivos de los respectivos Ministerios de Asuntos Exteriores.
} 
MINISTROS DE ESTADO/ASUNTOS EXTERIORES DE ESPAÑA (1931-1939)

$\begin{array}{llll}\text { JACOBO STUART FITZ-JAMES FALCÓ } & 1930 & 1931 & \text { Sin afiliación política } \\ \text { ÁLVARO FIGUEROA TORRES } & 1931 & 1931 & \text { Partido Liberal } \\ \text { ALEJANDRO LERROUX GARCÍA } & 1931 & 1931 & \text { Partido Radical } \\ \text { LUIS ZULUETA ESCOLANO } & 1931 & 1933 & \text { Independiente } \\ \text { FERNANDO DE LOS RÍOS URRUTI } & 1933 & 1933 & \text { PSOE } \\ \text { CLAUDIO SÁNCHEZ-ALBORNOZ M. } & 1933 & 1933 & \text { Alianza Republicana } \\ \text { LEANDRO PITA ROMERO } & 1933 & 1934 & \text { Independiente } \\ \text { RICARDO SAMPER IBÁÑEZ } & 1934 & 1934 & \text { Partido Radical } \\ \text { JUAN JOSÉ ROCHA GARCÍA } & 1934 & 1935 & \text { Partido Radical } \\ \text { ALEJANDRO LERROUX GARCÍA } & 1935 & 1935 & \text { Partido Radical } \\ \text { JOSÉ MARTÍNEZ DE VELASCO } & 1935 & 1935 & \text { Partido Agrario } \\ \text { JOAQUÍN URZÁIZ CADAVAL } & 1935 & 1936 & \text { Partido Rep. Progresista } \\ \text { AUGUSTO BARCIA TRELLES } & 1936 & 1936 & \text { Izquierda Republicana } \\ \text { JUSTINO DE AZCÁRATE FLÓREZ } & 1936 & 1936 & \text { Partido Nacional Republ. } \\ \text { AUGUSTO BARCIA TRELLES } & 1936 & 1936 & \text { Izquierda Republicana } \\ \text { JULIO ÁLVAREZ DEL VAYO } & 1936 & 1937 & \text { PSOE } \\ \text { JOSÉ GIRAL PEREIRA } & 1937 & 1938 & \text { Izquierda Republicana } \\ \text { JULIO ÁLVAREZ DEL VAYO } & 1938 & 1939 & \text { PSOE } \\ \text {------------------------------------------------- } \\ \text { FRANCISCO GÓMEZ-JORDANA SOUSA } & 1938 & 1939 & \text { Militar } \\ \text { JUAN BEIGDEBER ATIENZA } & 1939 & 1940 & \text { Militar }\end{array}$

Con fecha 10 de enero de 1931, Pedro García Conde, último Ministro de la monarquía española en Suecia, informaba al Ministerio de Estado de su toma de posesión como Ministro Plenipotenciario de España en Suecia. A este diplomático le correspondería representar en Suecia a dos gobiernos españoles de muy distinto signo político: el de S.M. el Rey Alfonso XIII y el del gobierno provisional de la República Española. Tras el cambio de régimen, García Conde envió su dimisión por cable del 18 de abril. Con fecha 21 de abril, Alejandro Lerroux le reiteraba su confianza, pidiéndole que retirara la dimisión, que suponía "presentada únicamente por motivos delicadeza y no por incompatibilidad con nuevo régimen", lo que se apresura a hacer el diplomático al día siguiente ${ }^{3}$.

Pedro García Conde estaba, pues, recién llegado, cuando en España se instaura la República, y permanecería en su puesto durante más de un año. De sus informes cabe deducir que contaba con la confianza del Ministro de Asuntos Exteriores Luis de Zuluaga. El resultado de su gestión en Suecia quedó reflejado en numerosos informes al Ministerio de Estado en Madrid durante el período que le tocó dirigir la Legación de España en Estocolmo, informes han dejado un rastro documental en el libro de entrada de

\footnotetext{
${ }^{3}$ AMAEC, R 2, 19; AMAEC, PG 309, 24407: Pedro García Conde (Pravia, 1880 - Oviedo, 1952) había sido secretario de la Legación en Estocolmo de 1918 a 1919. Fue Ministro Plenipotenciario en La Paz (19291930), Estocolmo (1930-1932) y Atenas (1932-1934). Representó a España en la Conferencia de Desarme de Londres (1934-1936). Fue Embajador franquista en Roma (1936-1941), Río de Janeiro (1942-1946) y Lima (1946-1948).
} 
correspondencia del Ministerio con las representaciones españolas en el exterior, ${ }^{4}$ pero nada más: faltan, por desgracia, casi todos los correspondientes al año 1931 y parte de los de 1932 en los archivos del Ministerio. Sólo algunos de ellos se han podido encontrar, por excepción, a veces en copia incluida en legajos de índole temática, como por ejemplo los referidos a la Casa Real ${ }^{5}$. Afortunadamente, sin embargo, se conservan los telegramas enviados al Ministerio de Estado desde la Legación en Estocolmo, lo que permite cubrir algunas lagunas.

Al final de su misión en Estocolmo, Pedro García Conde recibió una condecoración sueca, la Gran Cruz de la Orden de la Estrella Polar ${ }^{6}$.

En 1932, el gobierno de la República nombró Ministro plenipotenciario en Suecia a una gran figura del mundo diplomático español, Julio López Oliván ${ }^{7}$. Su gestión en Suecia sería intensa y productiva, y no sin un deje de pena dejaría su cargo, dos años más tarde, para pasar a presidir la actividad diplomática española en Berna.

Su sucesor fue Alfonso Fiscowich ${ }^{8}$, a quien el golpe de Estado de julio de 1936 sorprendería en su puesto en Estocolmo. Al negar Fiscowich, poco más tarde, la fidelidad al gobierno de la República, la presidencia de la representación diplomática en Estocolmo pasaría a ocuparla, en difíciles circunstancias incluso desde el punto de vista material, la

\footnotetext{
${ }^{4}$ AGA, L. AE, 6402.

${ }^{5}$ AMAEC, H 1754; AMAEC R 255, 53 e; AMAEC R 341, 8, a; AMAEC, R 904.

${ }^{6}$ AMAEC, R 2656, 10 e.

${ }^{7}$ Julio López Oliván, (Zaragoza, 1891 - Madrid, 1964) tenía amplia experiencia del mundo de la diplomacia. Había comenzado su carrera en los consulados españoles del norte de África, siendo uno de los representantes españoles en la conferencia de París entre España y Francia, que en 1926 dividió el sultanato marroquí. Allí se encargó de concretar los límites de los dos protectorados español y francés, y participando un año después en las negociaciones con el Abd-el-Krim. Antes de ser destinado a Suecia, desde el inicio de la República en 1931, Oliván ocupaba la dirección de la sección política del Ministerio de Asuntos Exteriores, cargo al que accedió después de haber sido durante un año Director General de Marruecos y Colonias. En 1933, representó a la República Española en la Conferencia Mundial Económica de Londres. De 1934 a 1936 fue Ministro de España en Berna y representante de España ante la Sociedad de Naciones en Ginebra. En junio de 1936 pasó a ocupar el puesto de embajador en Londres, cargo del que dimitió a finales de agosto de ese año, según parece a consecuencia de la muerte, a manos de milicianos, de su cuñado el general Capaz. A partir de octubre de 1936 y hasta 1946, y entre 1953 y 1960 fue Secretario General del Tribunal Internacional de Justicia en La Haya. Gozó de gran prestigio internacional, por su participación en cuestiones de gran relevancia, como el caso de Nicaragua. Fue también consejero político del Conde de Barcelona, cfr. GACETA de Madrid, n. 148, de 28 de mayo de 1933, y n. 244, de 1 de septiembre de 1935; INTERNATIONAL COURT OF JUSTICE, "Case Concerning Military and Paramilitary Activities in and Against Nicaragua (Nicaragua V. United States of America): Oral arguments on jurisdiction and admissibility", United Nations Publications, 2000, s. 176;

${ }^{8}$ Alfonso Fiscowich Gullón (Madrid, 1883 - Irún, 1972) fue Ministro Plenipotenciario en Buenos Aires (1930-1933), Estocolmo (1934-1936), Cónsul General y Encargado de Negocios de España en París (194345) y Embajador en Ankara (1951-1954), cfr. AMAEC, PG 0033, 15430; ABC (Madrid), 29.VIII.1972, Nota necrológica.
} 
intelectual republicana Isabel Oyarzábal Smith ${ }^{9}$, más conocida como Isabel de Palencia, quien tuvo que iniciar su andadura iniciando un proceso jurídico para hacer desalojar por la fuerza a su antecesor. El caso quedó recogido como uno de los sucesos del año en Suecia ${ }^{10}$.

La accesión de Alfonso Fiscowich no cambió el tono general de las relaciones con Suecia, y tampoco el de los informes diplomáticos al gobierno español. A finales de julio de ese año, Fiscowich no vacilaría en enviar a las autoridades suecas el documento oficial de la Legación declarando buque pirata a un crucero que estaba en manos de los sublevados ${ }^{11}$. El cambio de rumbo y tono se produciría a partir del momento en que decidió negar su adhesión al gobierno de la República, en agosto de 1936. Fiscowich adoptó entonces la retórica propia de la España franquista.

Finalmente, al concluir la guerra española, tras haber estado unos meses el Conde de Torata como agente en Estocolmo, fue nombrado Ministro Plenipotenciario en Suecia José de Landecho y Allendesalazar ${ }^{12}$.

Un estudio del personal subalterno de la Legación de España, así como del personal de la sección comercial y de los consulados honorarios de España en otras ciudades de Suecia, sería demasiado prolijo. En general, salvo contadas excepciones - como el caso del Consulado en Gotemburgo - se limitó a los aspectos administrativos y de trámite propios del cargo y no tuvieron apenas incidencia en las relaciones sueco-españolas ni en la visión española de la realidad sueca de los años treinta. Por contraste, sus homónimos de la Legación de Suecia en Madrid, una vez empezada la guerra civil, sí tendrían un papel importante, debido a la ausencia de Madrid del jefe de la Legación.

¿De qué informaron los representantes de España en Suecia al gobierno de la República? ¿Cuáles fueron los temas básicos de interés para el Ministerio de Estado español? ¿Cuál fue, finalmente, la visión de la realidad sueca que los Ministros de España en Estocolmo transmitieron a su gobierno? Pasaremos a analizarlo sobre la base de un

\footnotetext{
${ }^{9}$ Isabel Oyarzábal Smith (Málaga, 1878 - México DF 1974), de madre escocesa, fue profesora, actriz, traductora y escritora. Casada con el dramaturgo español Ceferino Palencia Tubau desde 1909, fue pionera en España del sufragio femenino. Diputada a Cortes por el PSOE en 1931, fue representante española en Ginebra y más tarde Ministro Plenipotenciario de la República Española en Estocolmo (1936-1939), desde donde partió al exilio en México: cfr. "Isabel Oyarzábal Smith", entrada 1499, en BARRUSO BARÉS, Pedro \& MARTIN NÁJERA, Aurelio (Eds.), Diccionario biográfico del socialismo español (1879-1939), Madrid: FPI, 2010.

${ }^{10}$ Svenska Dagbladets Årsbok, 1937, p. 5.

${ }^{11}$ RA, UD, 1920-års dossierssystem, HP 36, Vol. 1504, Nota verbal de la Legación de España al Ministerio sueco de Negocios Extranjeros, de 28.VII.1936

${ }^{12}$ José de Landecho y Allendesalazar (Bilbao, 1879 - Madrid 196?), de noble ascendencia, había comenzado su carrera diplomática en 1898 y fue secretario particular de la Reina María Cristina. Posteriormente fue jefe de la Oficina española de la Sociedad de Naciones y Ministro Plenipotenciario en Belgrado y en el Cairo. Antes de ser nombrado Ministro en Suecia era jefe del Servicio Nacional (franquista) de Política y Tratados.
} 
criterio mixto cronológico-temático, como quedó expuesto en el capítulo 2 de la presente investigación.

\subsection{La política interior sueca de 1931 a 1936 según la diplomacia española}

Comenzamos nuestra exposición analizando el final del período conocido en Suecia como "la época del parlamentarismo de minorías", anterior a la llegada al poder de la socialdemocracia en 1932, para pasar después a analizar el período 1932-1936.

\subsubsection{La política interior sueca hasta la llegada al poder de la socialdemocracia}

La vida política sueca de los años veinte se había centrado en dos frentes principales: por una parte, la preconización, tanto a nivel interno, como en el de política exterior, del ideal del desarme. Por otra, los intentos de regulación de los conflictos y las relaciones laborales entre la patronal y las nuevas organizaciones obreras. En esos años se pusieron las bases del incipiente Estado de bienestar, que culminaría, con los Acuerdos de Saltsjöbaden, elemento fundamental del llamado Modelo sueco.

La crisis económica internacional de 1929 afectó pronto a Suecia y trajo consigo una crisis de gobierno en 1930. Especialmente afectadas se vieron las empresas exportadoras suecas, creció el desempleo, se debilitó la balanza de pagos y se agudizó la competencia con Inglaterra por los mercados mundiales. Cuando Inglaterra abandonó el patrón oro, la imitó Suecia inmediatamente, haciendo así su moneda mucho más dependiente de la libra esterlina, y, en consecuencia, motivando un acercamiento político al Reino Unido ${ }^{13}$.

¿Cómo vieron este período los diplomáticos españoles en Estocolmo? Para empezar, es preciso destacar que existe un problema documental, debido a la pérdida o no conservación de la mayor parte del material, por lo que no conocemos en detalle el seguimiento de la actualidad política y económica de Suecia en 1931 realizado por la Legación de España en Estocolmo. Sobre cuestiones económicas, sólo se conservan dos de los cinco despachos enviados por la Legación en la primera mitad de 1932 sobre la difícil situación económica sueca. Lo mismo sucede con los despachos sobre acuerdos suecos en materia de política exterior, de los que sólo se conserva uno, aunque sabemos que se

\footnotetext{
${ }^{13}$ Sobre la competencia con Inglaterra, cfr. NILSSON, Bengt, Handelspolitik under skärpt konkurrens: England och Sverige 1929-39 (Bibliotheca historica Lundensis vol 18), Malmö: Gleerup, 1983.
} 
informó también al Ministerio de Estado sobre un amplio conjunto de temas: la adhesión de Suecia a la Oficina Internacional del Café en febrero; el Convenio sueco-británico de Procedimiento civil; intercambios de notas entre Suecia con Rumania y Lituania; la propuesta alemana de modificación del Estatuto de Tánger; los acuerdos comerciales e impositivos de Suecia con Grecia y Turquía; la ratificación sueca del convenio de Berna y un acuerdo sueco-islandés en materia de impuestos ${ }^{14}$.

Lamentablemente falta también la mayor parte de la información enviada sobre la situación política sueca en 1931. No se conservan, por ejemplo, los informes acerca de las elecciones municipales en Suecia ni otro que comentaba la reacción en Suecia ante la nueva Constitución Española ${ }^{15}$, aunque sí uno sobre un "movimiento fascista" en Suecia, que analizaremos con más detalle al hablar de la actitud de Suecia ante el nazismo ${ }^{16}$, cuestión ésta que constituyó una de las preocupaciones específicas del gobierno de la República Española.

Afortunadamente se conservan los telegramas reservados, que tratan asuntos cuya comunicación se consideró urgente, con frecuencia la más importante. En el tema económico, la información fundamental fue la referente al abandono de Suecia del patrón oro el 27 de septiembre de 1931:

Gobierno Suecia acordó anoche suspender patrón oro. Consecuencia de ello corona se cotizó hoy con un $25 \%$ de baja, descuento ha sido elevado hasta un $8 \%$. Bolsa sigue cerrada. Prensa muestra optimismo de exportaadores anunciando restricción de importación. Conde ${ }^{17}$

La situación de vacío documental cambia a partir de comienzos de 1932. En enero informaba la Legación sobre la conferencia escandinava acerca de la situación comercial y financiera; en mayo destacaba que la difícil situación económica se había visto complicada por una aguda crisis agraria. El Gobierno estaba preocupado por el tema económico y las previsiones de déficit presupuestario para el año próximo, que se esperaba cubrir con parte de los fondos de amortización de la deuda pública y con la elevación de los impuestos sobre el alcohol. Debía fomentarse, en opinión del Gobierno, un alza moderada en los precios al por mayor, al tiempo que era absolutamente necesaria una política rigurosa ante

\footnotetext{
${ }^{14}$ AGA, L. AE 6422, pp. 168-176. Se trata del libro-registro de entradas y salidas de correspondencia del Ministerio de Estado con las Embajadas y Legaciones.

${ }^{15}$ Conocemos su existencia por el libro-registro, cfr. AGA, L. AE 6402, p.183.

${ }_{16}^{16}$ AMAEC, R 341, 8, a, despacho de 2.XII.1931

${ }^{17}$ AMAEC, R 2, 19, telegrama de 28.IX.1931.
} 
el desnivel presupuestario, ya que el arancel proteccionista de Inglaterra planteaba problemas $^{18}$.

También en enero de 1932 envió la Legación un despacho analizando la situación política y parlamentaria: los debates parlamentarios se caracterizaban, en opinión del Ministro de España, por gran tranquilidad, a pesar de las críticas al Banco de Suecia por su indecisión cuando se abandonó el patrón oro y las críticas al plan económico del gobierno. Los socialdemócratas presentaban muchas mociones en temas sociales. También se mencionaba la propuesta de prohibir las milicias voluntarias como la del teniente general Munck ${ }^{19}$.

En posteriores debates parlamentarios, los socialdemócratas habían mostrado su desacuerdo con la actitud de Suecia en la cuestión del desarme, favorable entonces a participar en organizaciones militares con el objetivo de conservar la paz ${ }^{20}$. Con ello aparece en los despachos diplomáticos de la España republicana la primera referencia a la cuestión de la defensa, que será otra de las cuestiones específicas en el resto de la década.

Los conflictos sociales habían aumentado desde principios de la década y llegaron a su punto álgido en Suecia por las mismas fechas en que se producían en España los desórdenes sociales de la quema de iglesias y conventos. Fueron los famosos sucesos de las fábricas de sulfatos y sulfitos de Ådalen, localidad de la Suecia septentrional, el 14 de mayo de 1931. Ådalen marcó un hito en la evolución política y social de Suecia.

Ese día tenía lugar una gran manifestación de aproximadamente 4.000 trabajadores, principalmente de la industria papelera, que llevaban ocho meses de huelga. Hubo choques y conflictos entre huelguistas y esquiroles, y las autoridades llamaron al Ejército para imponer el orden. El resultado fue la muerte de cinco trabajadores a consecuencia de disparos de las fuerzas del orden.

Los incidentes provocaron masivas protestas y una ola de huelgas de solidaridad tuvo lugar en todo el país. La prensa conservadora acusó a los comunistas de alterar el orden, mientras que las organizaciones de los trabajadores no dudaron en calificar los sucesos de auténtica masacre.

En esa primavera de 1931, Suecia estaba gobernada por un gobierno liberal minoritario, bajo la dirección de Carl Gustaf Ekman., dividieron el país en dos bandos y forzaron al Gobierno a tomar medidas inmediatas, como la destitución del gobernador de

\footnotetext{
${ }^{18}$ AMAEC, R 341, 8, a, informes sobre situación económica, 4 y 28-V-1932.

${ }^{19}$ AMAEC, R 341, 8, a, despacho de 26.I.1932.

${ }^{20}$ AMAEC R 341, 8, a, despacho de 23.II.1932.
} 
la región y el nombramiento de una comisión investigadora. Fue la última vez que el ejército sueco fue utilizado para asegurar el orden público en el país ${ }^{21}$.

Esa fecha, 14 de mayo de 1931, se convertiría en todo un símbolo en Suecia. A partir de entonces, el movimiento obrero y la socialdemocracia se convirtieron en los auténticos rectores de los destinos del país ${ }^{22}$.

Acerca de los sucesos de Ådalen informó la Legación de España al gobierno de Madrid el 16 de mayo y el 6 de junio ${ }^{23}$. A tenor del tono de los despachos posteriores que se conservan, es posible que unos desórdenes sociales que causaron cinco víctimas fueran considerados por la diplomacia española como asunto de poca monta, sobre todo si se comparaban con lo que era habitual en España por aquellas fechas. Sin embargo, pensamos que esto no fue así, ya que el número de despachos enviados sobre la cuestión, según se desprende de los libros-registro del Ministerio de Estado, fue considerable. Esto parece indicar que la diplomacia española en Estocolmo fue consciente de la importancia de los sucesos de Ådalen para Suecia.

A partir de entonces, y por espacio de varios meses, la cuestión social será tema frecuente en los informes de García Conde. En el primer aniversario de los sucesos de Ådalen, explicaba que las organizaciones "proletarias" habían pedido al Gobierno el nombramiento de una comisión mediadora entre patronos y obreros a fin de solucionar la huelga de los obreros de la pasta de papel, que continuaba después de muchos meses. El gobierno había concedido también una amnistía a los implicados en los sucesos de Ådalen ${ }^{24}$.

La última referencia a los mismos en los despachos diplomáticos españoles es de septiembre de 1932. Al comunicar la nueva composición del gobierno sueco, mencionaba García Conde que el nuevo ministro de Asuntos Eclesiásticos, el socialdemócrata Arthur Engberg

\footnotetext{
${ }^{21}$ Sobre el uso del ejército sueco para el control de conflictos sociales, cfr. GUILLEMOT, Agneta, "Från Sundsvall 1879 till Ådalen 1931: Om militära kommenderingar vid strejker och sociala konflikter", en ERICSSON, Tom \& GUILLEMOT, Agneta (coord.), Individ och struktur i historisk belysning, Festskrift till Sune Åkerman. Umeå, 1997.

${ }^{22} \mathrm{~A}$ comienzos de los años 1930, el movimiento obrero sueco había sufrido varias escisiones. La gran mayoría la constituía el partido socialdemócrata (SAP) y su sindicato Landsorganisationen (LO). El resto se repartía entre los anarcosindicalistas (SAC), el Partido Socialista (SP, similar al POUM español, comunistas separados de Moscú) y el Partido Comunista Sueco (SKP, prosoviético).

${ }^{23}$ Sobre los sucesos de Ådalen y la visión de los mismos en las décadas posteriores, cfr. JOHANSSON, Roger, Kampen om historien - Ådalen 1931 - sociala konflikter, historiemedvetande och historiebruk 19312000. Estocolmo: Hjalmarson \& Högberg, 2001.

${ }^{24}$ AGA, L. AE 6402, pp. 178, despachos del 16 de mayo de 1931 y del 6 de junio de 1931; AGA, L. AE 6422, pp. 168-176, despachos sobre los conflictos obreros y sus consecuencias de 14.I.32, 9, 15 y 29.II.1932, 29.III.1932, 28.VI.1932, 4 y 6.VI.1932, y 8.VII.1932.
} 
recientemente fue condenado a prisión y multas por haber calumniado en su periódico a funcionarios del Estado con motivo de los desórdenes de Ådalen (de esta circunstancia di cuenta a VE en 16 de mayo y 6 de junio de 1931 por despachos nos 43 y 51) pero se libró de ambas por haberle favorecido una amnistía general otorgada por el Rey ${ }^{25}$

Ådalen y los conflictos sociales subsiguientes fueron decisivos para la victoria electoral de la socialdemocracia en el mes de septiembre de 1932 y, con ella, para el amplio programa de reformas y legislación social que caracterizará a ese período.

En la primavera de 1932 sucedió otro hecho que, por lo que a Suecia se refiere, fue el efecto más espectacular del desastre bursátil de Wall Street en 1929. Nos referimos al llamado "asunto Kreuger", caso que catalizó el debate nacional durante largos meses, a principios de la década de los treinta.

El asunto Kreuger consistió en la ruina económica y el consecuente suicidio - hay quien dice asesinato - del mayor empresario del país, un hombre mundialmente conocido por su posesión de un monopolio de facto a nivel mundial, el del mercado de los fósforos.

En 1908, el joven empresario Ivar Kreuger había fundado, junto con el ingeniero Paul Toll, la empresa inmobiliaria Kreuger \& Toll, que pronto sería líder de Suecia en el sector. Poco después fundaría el llamado Trust de Kalmar, para ayudar a su hermano en la industria de los fósforos, y haría de ese grupo de empresas, a través de su filial americana International Match Corporation, un cuasi monopolio mundial.

Ivar Kreuger se forjó pronto una buena reputación en los mercados financieros del otro lado del Atlántico, lo que le permitió obtener préstamos en condiciones ventajosas y comprar grandes cantidades de deuda pública de diversos países a cambio de privilegios comerciales. Muy pronto, bastantes grandes empresas suecas pasarían a formar parte de su imperio mercantil, entre otras $L M$ Ericsson, Boliden, la industria cinematográfica $S F$, y la que luego sería Svenska Cellulosa (SCA). Kreuger llegó también a ser uno de los accionistas principales en empresas como SKF y Skandinaviska Kredit. Todo ello se vendría abajo con la crisis de 1929 y la consiguiente incapacidad de la banca sueca de

\footnotetext{
${ }^{25}$ AMAEC R 341, 8, a, despacho de 28.IX.1932. La figura de Engberg, ministro sueco de Asuntos Eclesiásticos de 1931 a 1939 (salvo el verano de 1936) es interesante. Fue el gran promotor de la enseñanza pública sueca, y durante su mandato se nacionalizaron la mayoría de las escuelas del país y se introdujo la "escuela obligatoria de 7 años". Un estudio reciente (BLOMQVIST, Håkan, Socialdemokrat och antisemit?: den dolda historien om Arthur Engberg, Estocolmo: Carlsson, 2001), se centra en su figura, resaltando un aspecto poco conocido: su inicial antisemitismo y su posterior antinazismo.
} 
salvar su imperio comercial. Kreuger fue encontrado muerto en su casa de París en la primavera de $1932^{26}$.

La crisis económica hizo que la banca sueca - a excepción del Stockholms Enskilda Bank de Wallenberg - exigiera como condición previa para la concesión de nuevos préstamos una total transparencia del consorcio de Kreuger, saliendo entonces a la luz importantes deficiencias e irregularidades. El Primer Ministro sueco, Carl Gustaf Ekman, se vio forzado a dimitir, según resumirá más tarde el asunto la Legación de España

como consecuencia de haberse probado había aceptado un donativo de Kreuger, sin que pudiese justificar con qué fin. Sus ministros, presididos por el de Hacienda, Sr. Hamrin, siguieron algún tiempo con objeto de probar no eran en nada responsables de la actitud del Sr. $\operatorname{Ekman}^{27}$

El asunto Kreuger fue, con diferencia, el tema concreto que más despachos diplomáticos motivó para la Legación de España en Estocolmo entre 1932 y 1934: Un total de 14. El motivo no era sólo la trascendencia de las consecuencias que trajo para la política interior sueca - especialmente el cese del presidente del gobierno, favoreciendo una victoria socialdemócrata en las elecciones de 1932 - sino también el hecho de que el propio Estado español se vio implicado, como veremos en el capítulo siguiente.

El 13 de marzo de 1932 comunicaba el Ministro de España, por telegrama, el suicidio de Kreuger:

De regreso de los EE.UU. adonde había ido en busca de crédito que le fue rehusado, se ha suicidado en Paris gran hombre negocios Suecia Kreuger, conocido por rey de los fósforos, cuyos numerosos e importantes disponibles afectan profundamente toda economía este país produciendo trágico fin enorme sensación y Gobierno provisoriamente anoche en Consejo ministros presidido por Príncipe regente ha resuelto pedir parlamento autorización para conceder moratoria a empresas consorcio Kreuger. Esta misma noche reuniráse parlamento sesión extraordinaria para examinar proposición gubernativa y otras medidas capaces evitar posible pánico mañana lunes especialmente contra clientes Banco Skandinaviska principal centro operaciones Kreuger. Probablemente bolsa será clausurada por varios días ante inminente depresión valores. Conde. ${ }^{28}$

\footnotetext{
${ }^{26}$ PARTNOY, Frank, The match king: Ivar Kreuger and the financial scandal of the century, London: Profile, 2009, passim.

${ }^{27}$ AMAEC R 698, 10, despacho n. 190 de 15.VII.1933.

${ }^{28}$ AMAEC, R 95, 15
} 
El texto del telegrama transmite con claridad la gran incidencia del suceso en la vida política sueca, provocando reuniones nocturnas extraordinarias del Gobierno y del Parlamento suecos. En sucesivos despachos se ampliaban las informaciones, explicando la precaria situación de la empresa Kreuger \& Toll, y se hacía referencia a una posible implicación de España en las irregularidades financieras encontradas en el consorcio sueco $^{29}$.

Las consecuencias del caso Kreuger para la política sueca no pasaron desapercibidas a la Legación de España. En abril mencionaba García Conde un detalle sorprendente, que no hemos visto confirmado por ninguna otra fuente. Se trataba de ciertos comentarios del líder del partido socialdemócrata sueco, Per Albin Hansson, sobre unas presuntas implicaciones del magnate Kreuger con el partido socialista de Suecia, los "socialistas de Kilbom" (comunistas separados de Moscú) ${ }^{30}$.

En el mes de agosto mencionaba el Ministro de España el caso Kreuger como la causa principal de la dimisión del presidente del gobierno sueco:

Presidente consejo ministros Sr. Ekman, de cuya honradez personal nadie duda y que fue apenas censurado cuando hace varios días devolvió comisión liquidadora quiebra Kreuger ciento cincuenta mil coronas que declaró habíale entregado Kreuger para propaganda política propio partido, ha quedado en situación extremadamente desairada ahora al verse obligado confesar verdadera suma recibida era doscientas mil coronas. Falta sinceridad o valor anterior causado natural asombro y rey interrumpiendo veraneo regresó precipitadamente hoy Estocolmo recibiendo en audiencia privada Sr. Ekman su dimisión. Acto seguido se reunió consejo de ministros sin asistir ya dimisionario, quedando designado presidente el ministro de hacienda ${ }^{31}$

En octubre informó la Legación de la encarcelación de Torsten Kreuger, el hermano de Ivar, acusado de haber permitido irregularidades como director de la empresa Högbroforsens Industri $A B$, incluida en el consorcio Kreuger \& Toll y declarada en quiebra. En marzo del año siguiente, reiteraba que la dimisión de Ekman se debía al descrédito en que había incurrido por sus sospechosas relaciones con Kreuger, al buscar su apoyo económico para su partido.

\footnotetext{
${ }^{29}$ AMAEC, R 341, 8, a, despachos de 14, 26 y 19.III.1932

${ }^{30}$ AMAEC, R 341, 8, a, despacho de 23.IV.1932.

${ }^{31}$ AMAEC, R 95,15, telegramas n. 19 y 20 de 6 y 7.VIII.1932.
} 
El asunto Kreuger no estaba aún enterrado en 1934, pues en febrero de ese año comunicó la Legación al Ministerio de Estado una noticia no confirmada, según la cual los síndicos de la quiebra Kreuger habían llevado una operación en España con las empresas de cerillas. También en el verano de ese mismo año encontramos una referencia al empréstito de Kreuger en Alemania como uno de los aspectos muy delicados en las negociaciones sobre asuntos económicos y comerciales con la Alemania de Adolf Hitler en las que Suecia se encontraba inmersa por entonces ${ }^{32}$.

\subsubsection{La política interior sueca durante el gobierno de Per Albin Hansson (1932- 1936)}

Como hemos visto, el asunto Kreuger provocó la caída del gabinete del liberal Carl Gustaf Ekman, que confesó su implicación en el asunto Kreuger y presentó al Rey Gustavo V su dimisión, anunciando la convocatoria de elecciones ${ }^{33}$.

Las elecciones de septiembre de 1932 estaban llamadas a marcar un hito en la historia de Suecia, el del comienzo de la hegemonía del partido socialdemócrata al frente de los destinos del país, prácticamente absoluta durante el resto del siglo XX.

$\mathrm{Al}$ frente del nuevo gobierno estaba Per Albin Hansson - llamado el moderno "padre de la patria" sueca - que dio nombre a toda una época, la “época de Per Albin Hansson” $(1932-1946)^{34}$.

En 1928, en un discurso que se haría famoso, había resumido el proyecto socialdemócrata para Suecia, ya formulado por el propio Hansson en $1921^{35}$ : Se trataba de elaborar una política de búsqueda del consenso, de creación de un "hogar popular", que llevaría al especial modelo de socialismo sueco, alejado de la lucha de clases para propugnar en cambio la desaparición de las mismas. Per Albin no fue entendido por todos

\footnotetext{
${ }^{32}$ AMAEC, R 341, 8, b, despachos de 28.X.1932 y de 20.III.1933; AMAEC R 850, 20, despacho de 20.VII.1934.

${ }^{33}$ AMAEC, R 95, 15, telegrama n. 20 de 7.VIII.1932.

${ }^{34}$ Per Albin Hansson (1985-1945) fue jefe del Gobierno sueco desde 1932 hasta su muerte en 1945, con excepción del verano de 1936. Había nacido en Malmö, de familia humilde, y sólo había cursado la escuela primaria. En 1903 ingresó en las juventudes socialdemócratas y comenzó su carrera política: en 1917, como destacado miembro del partido, y recién elegido diputado al Parlamento, colaboró en forzar a su rival Zeth Höglund a que abandonara el partido (dando así origen al partido comunista sueco). Hansson fue redactor jefe del diario Social-Demokraten y ministro de Defensa (a pesar de su antimilitarismo declarado) en el gabinete Edén. Tras la muerte de Hjalmar Branting fue nombrado presidente de la Junta directiva del partido y, en 1928, elegido por el Congreso socialdemócrata como presidente del partido.

${ }_{35}$ Por su gran interés para la mejor comprensión de la forma de pensar dominante en la Suecia de los treinta, reproducimos en el Apéndice 3 la parte más representativa de los llamados "discursos del hogar popular" (folkhemmets tal), en versión castellana. La traducción es nuestra.
} 
en su propio partido, pero la fuerza del pragmatismo inherente a su idea de la folkhem se abrió camino ya desde el mismo 1932, año en el que tomó las riendas del poder.

El partido socialdemócrata sueco basaría a partir de entonces su política en la idea de economía planificada y en lo que en la década de los sesenta del siglo XX vendría en llamarse "socialismo funcional": el Estado, a través de la legislación, dirigiría la economía nacional, pero dejando la propiedad en manos de los empresarios, de los "profesionales de la creación de la riqueza". Evidentemente, esto requirió la formación de un Estado muy fuerte, que establece limitaciones a la libertad individual en aras del bien de la mayoría. Este es el concepto de democracia que tenía Per Albin, y que desde entonces caracteriza a la democracia sueca: no una libertad "frente al Estado" sino una libertad "a través del Estado". Recientemente, en Suecia se ha empezado incluso a hablar de "Peralbinismo", definido como "socialismo a través de métodos conservadores"36.

Correspondió a diplomáticos subalternos, al secretario de la Legación José González de Gregorio - como encargado de negocios ad interim por ausencia de García Conde, que había cambiado de destino - mantener informado a Madrid del resultado de las elecciones de 1932.

Llama la atención, a este respecto, que el Cónsul de España en Gotemburgo, Luis Amador Sánchez, hiciera llegar su propio informe directamente al Ministerio de Estado. Se trata de un documento sorprendente, no sólo por lo excepcional del hecho en sí - ya que no es misión de los Consulados enviar informaciones políticas directamente a su gobierno si hay en el país de destino una Legación o Embajada - sino sobre todo por el contenido y tono de las informaciones, que denotan falta de profesionalidad $\mathrm{y}$ bastante desconocimiento de la realidad y de la mentalidad sueca. En él, se refería a "las elecciones al Storting" (nombre del Parlamento noruego, no del sueco, a la sazón Riksdag). Asimismo, comunicaba - erróneamente - que el partido "socialista" había obtenido la mayoría absoluta, llamaba "nazi" al partido conservador (Högerpartiet) y "religioso" al grupo de los independientes ${ }^{37}$.

Más que información se trata de verdadera desinformación. Los motivos de la misma no están claros, aunque probablemente haya que verlos en el contexto de un deseo de venganza por parte del cónsul, cuyas desavenencias con la Legación habían sido puestas de manifiesto en la propuesta de destitución del cónsul por incompetencia en el ejercicio de su

\footnotetext{
${ }^{36}$ Cfr. ERIXON, Dick, "Socialist med konservativa metoder", en Smedjan, 24.VIII.2000.

${ }^{37}$ AMAEC, R 341, 8, a, Cónsul Gotemburgo a Min. de Estado, informe de 21.VIII.1932.
} 
cargo, que la Legación había elevado al Ministerio de Estado a finales del mes de junio de $1932^{38}$.

Por su parte, la Legación informó correctamente acerca de la crisis de formación de gobierno y de su solución, con un gabinete exclusivamente socialista (léase socialdemócrata), aunque el partido no había obtenido la mayoría absoluta. Una semana de "cabildeos para resolver la crisis en burgués" no habían dado resultado. El discurso del jefe del gobierno, Per Albin Hansson, aparece narrado en detalle, resaltando que en política exterior, el gobierno apostaría por la limitación de los armamentos y de las barreras económicas. El informe español insistía en la "gran moderación" del gobierno y en la pertenencia de su presidente Hansson y de su ministro de Negocios Extranjeros, Sandler "a la escuela socialista moderada del difunto [Hjalmar] Branting"39.

En julio de 1933, José Fernández Villaverde - como encargado de Negocios ad interim por ausencia temporal del nuevo Ministro de España, Julio López Oliván - envió un extenso y detallado informe sobre el funcionamiento del sistema político sueco, dividido en dos apartados básicos:

1. El Parlamento. Organización y funcionamiento.

2. Los partidos políticos.

Constituye un resumen muy logrado de la estructura política sueca al poco tiempo de la accesión de la socialdemocracia al poder, a la vez que ofrece una breve visión histórica de los principales partidos políticos desde principios del siglo XX.

Respecto al primer punto, señalaba el diplomático que la disolución de la unión personal con Noruega, en 1905, había marcado un cambio importante en la política sueca, que adquirió desde entonces una personalidad más propia, centrándose en cuestiones como la organización de la defensa nacional, la democratización de la Constitución, la extensión del derecho electoral, y varias reformas financieras y sociales, democratización que había "sido reconocida por todos los partidos del Riksdag con rara unanimidad".

Sobre los partidos políticos, decía que el partido de derecha (conservador) tendía a favorecer los intereses de la defensa nacional, abogaba por el proteccionismo aduanero y, en las cuestiones sociales, era partidario de una política de progreso moderado. El partido agrario era "algo más izquierdista" que el conservador - del que se había escindido -

\footnotetext{
${ }^{38}$ AGA, L-AE 6422, pp. 168-176.

${ }^{39}$ AMAEC, R 341, 8, a, despacho n. 162 de 27.IX.1932.
} 
mientras que los liberales y los populares, que anteriormente estaban unidos en un solo partido y prácticamente no se diferenciaban, eran "partidos burgueses de izquierda".

Del partido obrero socialdemócrata, por su parte, decía Fernández Villaverde que

está enteramente constituido sobre una base socialista internacional y se halla estrechamente vinculado a la organización sindical obrera, que comprende en este país a la mayoría de los obreros. (...)Puede decirse que el partido en cuestión es progresista, de marcado carácter radical, pero que trabaja exclusivamente con medios parlamentarios ${ }^{40}$

Finalmente estaban los dos partidos comunistas, el de Sillén, que dependía directamente de Moscú, y el de Kilbom (llamado oficialmente Partido socialista) cuyos miembros "aunque profesan las ideas comunistas internacionales, declaran que forman un partido nacional”.

En el informe correspondiente al segundo semestre de 1933, elaborado en enero del año siguiente, tras mencionar algunos cambios en el gobierno motivados por el fallecimiento del gobernador de Estocolmo, así como las elecciones de senadores realizadas el 7 de septiembre en los distritos de Jönköping, Värmland, Gotemburgo y Bohus, se concentraba la Legación en el tema fundamental de la política sueca de 1933, el entendimiento entre el partido socialdemócrata y el segundo ganador de las elecciones de 1932, la Liga Agraria.

Este gran pacto de gobierno - llamado en Suecia kohandeln, el "tira y afloja" de 1933 - incluía compromisos acerca de las medidas a implementar para salir de la crisis motivada por el desastre de la Bolsa neoyorquina, que había disparado las cifras del paro hasta casi un $30 \%$ de la población activa. Básicamente se trataba de promover empleo público a base de créditos, idea muy inspirada en el keynesianismo británico.

El pacto fue una pieza clave en la transformación de Suecia en un Estado de bienestar: rompió romper por primera vez la política de "bloques" (partidos burguesespartidos obreros), permitió la obtención de una fuerte mayoría parlamentaria, reforzó la democracia y, al mostrar la capacidad de compromiso y de responsabilidad por la economía nacional del partido socialdemócrata, sentó las bases para el largo período de dominio político de este partido.

\footnotetext{
${ }^{40}$ AMAEC, R 698, 10, e, despacho n. 90 de 15.VII.1933, respuesta a Orden Circular del Ministerio de Estado n. $9 / 1933$.
} 
Además, el éxito obtenido a nivel económico y social, fue un antídoto frente al peligro nazi. De hecho, los partidos extremistas de inspiración nazi no tuvieron éxito alguno en la Suecia de los años treinta. Su tope máximo, alcanzado en las elecciones de 1938, fue de alrededor de 20.000 votos, tan sólo el $0,7 \%$.

Así informó la Legación acerca del pacto entre socialdemócratas y agrarios:

Los agrarios votaron los créditos que los socialistas solicitaron para socorros contra el paro y el partido gubernamental (socialista) votó las medidas proyectadas por los agrarios, encaminadas a aumentar el precio de los productos agrícolas. En general, se ha considerado esta cooperación como una cosa ocasional y que no habría de producirse durante la legislatura del año 1934. Sin embargo, en las últimas semanas se ha notado un cierto acercamiento entre ambos partidos. El Presidente del Consejo, Hansson, negocia al parecer con los agrarios para encontrar la forma de que continúe su colaboración. Estos rumores han sido confirmados últimamente por un discurso del jefe agrario, profesor Westman, que al explicar la política agraria, dijo que, para llevar a cabo su programa, había que llegar a un frente, no de cooperación burguesa, sino de cooperación ciudadana... Por lo que antecede, así como por haberse decidido la formación de un frente que evite el desarrollo del movimiento nacionalsocialista, puede preverse que los agrarios seguirán apoyando al partido socialista, actualmente en el poder, y no sería aventurado suponer que en breve entren a formar parte del Gobierno presidido por el Sr. Hansson algunos agrarios ${ }^{42}$.

Nos ha parecido oportuno resaltar este texto, porque supone una novedad respecto a las líneas básicas de la historiografía sueca, que en relación con el pacto suele destacar como causa sobre todo los aspectos económicos y sociales más que ese "frente que evite el desarrollo del movimiento nacional-socialista" al que se refiere el Encargado de Negocios de España. De hecho, desde comienzos del presente siglo existe en Suecia un debate político e historiográfico sobre las simpatías de la Liga Agraria, o al menos de bastantes de sus representantes, hacia el nazismo alemán ${ }^{43}$.

El siguiente informe semestral, firmado ya por el nuevo Ministro de España, Alfonso Fiscowich resaltaba la falta de eventos importantes en la política interior de Suecia durante el período. Lo más significativo había sido la escisión del partido socialdemócrata - con el

\footnotetext{
${ }^{41}$ MELIN, JOHANSSON \& HEDENBORG op.cit., p. 229.

${ }^{42}$ AMAEC, R 698, 10, e, despacho n. 17 de 15. I.1934. La cursiva es nuestra.

${ }^{43}$ El debate historiográfico se basa en estudios sobre los principales políticos de la Liga Agraria, cuyos estatutos vigentes en 1933 contenían un párrafo de marcado carácter racista. El debate sigue abierto, e incluso estuvo presente en la campaña electoral de elecciones al Riksdag del año 2010. El más claro defensor del antinazismo del partido agrario es BJÖRNSSON, Anders, Skuggor av ett förflutet: Bondeförbundet och trettiotalet, Lund: Sekel, 2009. Sobre la tesis contraria - que es actualmente mayoritaria - cfr. BACHNER, Henrik, Judefrågan: Debatt om antisemitism i 1930-talets Sverige, Estocolmo: Atlantis, 2009.
} 
paso de un grupo liderado por el diputado Albin al Partido Socialista (PS) - y la fusión del partido liberal con el popular, prevista para septiembre. También mencionaba un auge del nazismo, tema que comentaremos en un apartado posterior.

El informe semestral incluía un cuadro, de puño y letra de Fiscowich, sobre la postura de los partidos políticos suecos y sus "Posibilidades para el futuro". El Partido conservador, según el diplomático, contaba con elementos propios y suficientes para ejercer el poder y era considerado como el probable sucesor del actual gobierno. Acerca de los partidos liberal y popular, y de la Liga Agraria, opinaba Fiscowich que no contaban con elementos suficientes ni con una masa de opinión establecida, que les permitieran ejercer por sí solos el poder. Solamente podían, por tanto, llegar a tenerlo en el seno de coaliciones, y, en particular, se inclinaban a aliarse con el partido socialdemócrata.

Este último partido - explicaba el informe - mantenía el equilibrio de las distintas tendencias contenidas en su seno, a la hora de plantear el desarrollo de los problemas políticos, sociales y económicos de Suecia. El partido socialdemócrata contaba con elementos preparados para desempeñar la labor de gobierno, que por entonces ocupaba.

Concluía Fiscowich que el desarrollo alcanzado por el comunismo en Suecia preocupaba mucho al gobierno y a las autoridades, pero que los partidos comunistas suecos (el SKP y el SP) no constituían por el momento una fuerza de importancia, ya que su programa y los procedimientos para realizarlo encontraban resistencia en la gran masa del país ${ }^{44}$.

Con motivo de las elecciones municipales concretaba la Legación en septiembre de 1934 las posibilidades de los diversos partidos, en particular del partido popular (la llamada "izquierda burguesa" y destacaba las desavenencias de la Liga Agraria con los conservadores y con la coalición socialista de izquierda. Las elecciones se celebraban siempre, según el Ministro de España, en el marco del "espíritu ejemplar de ciudadanía de que estas gentes están compenetradas”. En marzo de 1935 informaba que la participación en las elecciones municipales había votado el $70 \%$ del electorado, y la socialdemocracia había sido sobrepasada por la izquierda socialista y comunista. Sin embargo, la colaboración entre la socialdemocracia gobernante y los partidos políticos centristas funcionaba bien, como mostraban los datos que acompañaba sobre las alteraciones en

\footnotetext{
${ }^{44}$ AMAEC, R 698, 10, e, despacho n. 151 de 15.VII.1934.
} 
distintas partidas presupuestarias. En julio actualizaba tuvo lugar la clausura de la sesión parlamentaria, y en septiembre hubo elecciones al Senado ${ }^{45}$.

En la primavera de 1936, informó Fiscowich acerca del Congreso del Partido Socialdemócrata sueco en 1936, comentando las discusiones acerca de la cuestión de la participación o no en los Juegos Olímpicos de Berlín, por aquel entonces de plena actualidad. Además, el Congreso había criticado duramente la condena en Alemania de dos marineros suecos.

Al mismo tiempo, el informe resaltaba la moderación como rasgo distintivo del partido, que le llevó a dar su voto de confianza al gobierno y su política: "La reunión ha dado ocasión de demostrar la disciplina y firme unión que existe en el partido socialdemócrata, ajeno y separado de extremismos", dirá Fiscowich ${ }^{46}$. No obstante, a las pocas semanas reconocía la existencia de algunas críticas a la política del gobierno en el seno del partido socialdemócrata, donde no todos veían con buenos ojos una política que en opinión de algunos estaba motivada en gran parte por el miedo a las grandes potencias $^{47}$.

A juzgar por la frecuencia con que el diplomático español aludía a la "moderación" de los suecos, no cabe duda que este aspecto, tan característico del país nórdico, le había impresionado, quizá aún más por contraste con la convulsa situación de España durante los años republicanos. Volvería insistir en la "moderación" al informar sobre el eco en Suecia de acontecimientos importantes en la vida política española, como las elecciones de febrero de 1936. Entonces escribió que, en Suecia, era

firme el propósito del país en huir del fascismo y sistemas análogos, y consolidar la democracia. Sin olvidar que las derechas españolas, por la excesiva significación clerical católica, no despiertan simpatías entre las derechas suecas protestantes ${ }^{48}$

En el mes de junio de 1936, tuvo lugar en Suecia una crisis gubernamental que acabaría con la caída del gobierno y la formación del que después se llamaría "el gobierno del verano de 1936", pues duró hasta las elecciones de septiembre de ese año. La crisis

\footnotetext{
45 AMAEC, R 341, 8, b, Despacho del 21.IX.1934; AMAEC, R 850, 18 e, despachos de 19.III.1935, 21.III.1935 y 7.IX.1935; AMAEC, R 720, 41 e, despacho n. 184 de 12.VII.1935.

${ }^{46}$ AMAEC, R 850, 22 e, despacho de 15.IV.1936.

${ }^{47}$ AMAEC, R 642, 1 e, despacho n. 103 de 6.V.1936.

48 AMAEC, R 850, 22, e, despacho de 22.II.1936; PEIX GELDART, Benito, "Suecia y las elecciones españolas...".
} 
motivó varios telegramas de la Legación a Madrid, dando cuenta del día a día de las posibles coaliciones ${ }^{49}$.

El 19 de junio de ese año de 1936 quedó constituido el nuevo gobierno y la crisis fue analizada en un despacho de Fiscowich al Ministerio de Estado. El gobierno de Per Albin Hansson había sido derrotado en el parlamento, por la cuestión de la reorganización de la Defensa nacional, y la proposición sobre aumento de pensiones por retiro en determinados lugares de vida cara. El Riksdag optó por la propuesta de los partidos burgueses. La estrategia de Hansson había sido la de preparar lo de las pensiones en un día para quedar bien, pues siempre era mejor caer por una propuesta de mejora social en vísperas de elecciones. Le sucede el Gabinete técnico presidido por el político del partido agrario Persson de Bramstorp ${ }^{50}$.

Los aspectos económicos y sociales aparecen, en los despachos diplomáticos españoles, frecuentemente entremezclados con informaciones de carácter político y/o comercial, por lo que no siempre es fácil tratarlos separadamente, máxime cuando, en buena medida, estos aspectos son comentados en el marco de su relación específica con los intereses económicos de España, aspecto que comentaremos en otro lugar.

Durante los últimos meses de 1932 no se envío información alguna a Madrid sobre estos aspectos. En cambio, a partir de 1933, las cuestiones económicas y/o sociales tuvieron más resonancia. En enero, la Legación informaba de la apertura de las cámaras del Riksdag y del Discurso del trono y resaltando las negociaciones con Alemania e Inglaterra sobre asuntos económicos y comerciales, así como las principales medidas propuestas: La subida del impuesto sobre la renta y las grandes reducciones de gastos. En marzo tuvo lugar una emisión de deuda pública (empréstito interior) en Suecia de 50.000 coronas que, según la Legación, curiosamente no había despertado interés ${ }^{51}$.

En abril, la Legación informaba detalladamente sobre la situación del mercado de trabajo en Suecia, dando un buen resumen de las estadísticas más relevantes: en febrero había habido 565 solicitudes por cada 100 puestos de trabajo, algo menos que el mes anterior. Informaba también de la solución del conflicto laboral en la marina mercante y del proyecto relativo al seguro contra el paro forzoso ${ }^{52}$.

\footnotetext{
${ }^{49}$ AMAEC R 615, 31, telegramas n. 23-26, de 15, 16,18 y 19.VI.1936.

${ }^{50}$ AMAEC R 850, 21, despacho de 19.VI.1936.

${ }^{51}$ AMAEC, R 341, 8, a, despachos de 12.I.1933 y 7.III.1933.

${ }^{52}$ AMAEC, R, 341, 8, a, despachos de 11.IV.1933 y de 1.IV.1933.
} 
En mayo de 1933, destacó la Legación la incidencia, a nivel político y social, de la manifestación organizada en Estocolmo por partidos de derecha y la llamada "Juventud conservadora", que definió la misma como una "manifestación de protesta contra el comunismo y la lucha de clases”. Según cálculos de la policía, habían tomado parte en ella unas 40.000 personas, que la Legación llama "reaccionarios". El almirante Lindman, jefe del partido conservador, pidió a los jóvenes que no se dejaran llevar por políticas extranjeras, en un discurso bien recibido por la prensa liberal, pero no por la prensa oficial socialdemócrata (el diario Socialdemokraten), que lo hiciera en forma un tanto irónica y mordaz. $^{53}$

La manifestación no era un asunto aislado, pues era consecuencia de las delicadas negociaciones en el el Riksdag un paquete de legislación social, en especial en relación con la política de empleo y de subsidios por desempleo, que unos días antes había motivado un telegrama del Ministro de España, Julio López Oliván, al Ministerio de Estado, en los términos siguientes:

Si en reuniones celébranse no logran ponerse de acuerdo partidos con gobierno sobre proposición ley paro forzoso es posible prodúzcase crisis inminente formándose gabinete concentración sin participación socialistas. Olivan. ${ }^{54}$

La crisis temida no llegó a producirse, por llegarse al acuerdo del partido agrario con el socialdemócrata. López Oliván lo esperaba desde hacía tiempo, pues ya a finales de abril, escribía a Madrid que había rumores de una posible reunión extraordinaria del Riksdag con el objeto de concertar acuerdos acerca del programa gubernamental para afrontar la crisis económica. El propio Presidente Hansson, sin embargo, había desmentido la convocatoria de la misma y López Oliván concluía diciendo: "Se ve claro que en el fondo están todos de acuerdo y habrá consenso". Así fue. El 1 de junio, pudo informar la Legación de la firme del importante acuerdo entre el partido socialdemócrata y la Liga agraria - el llamado "tira y afloja" - y comentar sus repercusiones económicas y sociales ${ }^{55}$.

En junio de ese año, por primera vez en la legislatura, el Parlamento sueco rechazaba una propuesta de ley, sobre expropiaciones. El motivo aducido para negar el derecho del Estado a expropiar tierras era la necesidad de fomentar la construcción de viviendas

\footnotetext{
${ }^{53}$ AMAEC R 341, 8, a, despacho de 22.V.1933.

${ }^{54}$ AMAEC, R 191, 12, telegrama n. 13 de 20.V.1933.

${ }^{55}$ AMAEC, R 341, 8, a, despacho de 29.IV.1933; AGA, L.. AE 6443, pp. 118-125, despacho de 1.VI.1933.
} 
propias. Este aspecto, y el discurso del Ministro sueco de Hacienda, en el mes de septiembre, fueron los principales aspectos comentados por la Legación de España en los meses estivales ${ }^{56}$.

A finales de septiembre hubo una la huelga del sector de la construcción, con la no aceptación, por parte de la patronal, de la propuesta de la comisión de conciliación. Los partidos de la oposición burguesa no habían visto con buenos ojos esta intervención del gobierno en el mundo laboral ${ }^{57}$.

En enero de 1934, junto a los presupuestos del Estado sueco para 1934-1935, destacaba la Legación española una serie de proposiciones de Ley presentadas por el partido conservador - todo un programa de partido - centradas principalmente en cuestiones de índole económica y social: la reducción de las obras públicas, la reducción de impuestos en relación con las testamentarías y la propuesta de congelación del impuesto especial sobre el capital y la renta, con el fin de amortizar empréstitos. Había también aspectos relacionados con la defensa (la reconstrucción de la defensa nacional y la defensa de Gotland) y se pedía la ilegalización del partido comunista por lo que entendían era "su labor de zapa". La Legación hacía también referencia al gran desarrollo experimentado en los últimos tiempos por las organizaciones obreras suecas ${ }^{58}$.

Finalmente, las cuestiones económicas y financieras estuvieron también presentes en el informe semestral de enero de 1934, en el que se anunciaba que la crisis económica empezaba a desaparecer en Suecia, hablando de la sensible mejora en la balanza comercial y la disminución del índice de desempleo. También informó la Legación de la celebración de la fiesta del Trabajo, el 1 de mayo ${ }^{59}$.

En julio de ese año constataba la Legación el final de la crisis económica en Suecia y alababa el "perfecto equilibrio y coordinación" existente entre las empresas suecas de exportación. Señalaba que los suecos estaban orgullosos de haber superado la crisis sin utilizar los procedimientos restrictivos de otros países. Fiscowich presentaba, en fin, un panorama optimista - corroborado por las estadísticas que adjuntaba - respecto a la recuperación de la economía sueca, en especial de la industria.

También la cuestión social daba síntomas de mejora, sin conflicto alguno de mayor importancia. Por otra parte, el despacho hacía un gran panegírico de la nueva legislación

\footnotetext{
${ }^{56}$ AMAEC, R 341, 8, a, despacho de 12.VI.1933; AMAEC, R 341, 8, b, despacho de 29.X.1933.

${ }^{57}$ AMAEC, R 341, 8, b, despacho de 2.X.1933.

${ }^{58}$ AMAEC R 850, 20 e, despacho de 15.1.1934; AMAEC, R 341, 8, b, despacho de 24.1.1934

${ }^{59}$ AMAEC, R 698, 10, e, despacho de 15. I.1934; AMAEC, R 341, 8, b, despacho de 2.V.1934.
} 
laboral sueca, sobre todo en materia de seguros de desempleo y la creación de un instituto nacional de empleo. Finalmente, mencionaba la aprobación de la ley que prohibía toda clase de organizaciones armadas no estatales, y de otra prohibiendo la tenencia de armas de fuego sin autorización especial, medidas ambas que Fiscowich veía como eficaces en contra del fascismo ${ }^{60}$.

Los resultados de la política reformista socialdemócrata en los años treinta fueron muy significativos: en 1934 aparecía el seguro de paro voluntario, en 1935 vio la luz la nueva Ley de Pensiones, en 1936 una ley de trabajo agrario que en la práctica implantaba la jornada de 8 horas también en el campo. En 1937 se tomaban las primeras medidas de política familiar (impulso de la natalidad) basadas en la política de ingeniería social preconizada por los esposos Gunnar y Alva $\mathrm{Myrdal}^{61}$ : el subsidio de maternidad y los préstamos estatales para la adquisición de vivienda. En 1938 se aprobó la Ley de vacaciones (dos semanas anuales) y en 1939 una ley sobre subvenciones a las pequeñas empresas.

También hubo, sin embargo, algunas leyes más polémicas hoy en día. Entre ellas, debe destacarse la Ley de Esterilización forzosa de 1934, que no fue derogada hasta 1975. El gobierno sueco fue recientemente condenado a pagar una indemnización a las decenas de miles de personas afectadas o a sus herederos ${ }^{62}$.

Concluimos esta exposición de la visión de la diplomacia española de la política interna del gobierno Hansson 1932-1936 refiriéndonos al último informe global sobre la situación de Suecia enviado por el Ministro de España en Estocolmo antes de la guerra civil. En esos momentos, la política interior sueca atravesaba un momento delicado, a consecuencia de la cuestión de la defensa - que luego comentaremos - y la cuestión de las pensiones, que enfrentó entre sí a los partidos de la coalición gubernamental. De hecho, el gobierno dimitiría y sería sustituido, durante el verano de 1936, por un gabinete en funciones, que fue el que dirigía el país cuando comenzó la guerra civil española.

El informe semestral se recibió en el Ministerio de Estado el mismo día 18 de julio de 1936. En él informaba Fiscowich sobre el cierre del parlamento sueco, sobre la nueva propuesta de ley de actividades peligrosas y sobre la situación general de la política interior.

\footnotetext{
60 AMAEC, R 698, 10, e, despacho de 15.VII.1934; cfr. también AMAEC, R 720, 41 e, despacho de 12.VII.1935.

${ }^{61}$ El punto de partida fue el libro publicado por ellos en 1934, MYRDAL, Gunnar \& Alva, Kris $i$ befolkningsfrågan, Nora: Nya Doxa, 1934/1997.

${ }^{62}$ SOU 2000:20 (SOU, Statens Offentliga Utredningar, Investigaciones Públicas Estatales).
} 
La Ley de actividades peligrosas para el Estado decretaba la imposición de castigos y sanciones contra la propagación de falsas noticias o rumores que amenazaran el orden público, incitaran a la violencia contra las personas o perturbaran conferencias o reuniones públicas. Hacía punitivo el espionaje, ampliando los supuestos del delito. La propuesta de ley incluía la posibilidad de disolución de agrupaciones o asociaciones que significaran un peligro para la seguridad del Estado, pero este aspecto no fue aprobado por el Parlamento.

El programa electoral del gobierno para las elecciones de septiembre de 1936 se centraba en los siguientes puntos: el fortalecimiento de la Defensa nacional; la consolidación del bienestar y de la buena situación económica; el desarrollo de una política de pleno empleo; la realización de una reforma tributaria en profundidad; la actualización de la política agraria; y una cooperación decidida para conservar y afirmar la paz en el mercado de trabajo, con el apoyo de las grandes organizaciones patronales y obreras.

Quedaba así allanado el camino, por parte del gobierno, para los fundamentales acuerdos de Saltsjöbaden, que en los años siguientes pondrían las bases definitivas del peculiar modelo sueco, del que fue protagonista principal el partido socialdemócrata ${ }^{63}$.

No faltan estudios que resaltan el carácter excepcional del socialismo sueco. Luebbert sostiene que la razón del diferente desarrollo de las potencias europeas durante los años treinta del siglo XX (el triunfo de regimenes fascistas en algunos y socialdemócratas en otros) no radica en la falta de polarización social de esas sociedades sino en la actitud de los líderes del movimiento obrero respecto a los trabajadores agrícolas, de forma tal que la socialdemocracia triunfó allá donde el movimiento obrero asumió como propia su causa ${ }^{64}$.

Otro autor, Berman, destaca que la socialdemocracia fue la gran ganadora del siglo $\mathrm{XX}$, venciendo al liberalismo clásico, al marxismo ortodoxo y a los primos de éste, el fascismo y el nazismo. Refiriéndose a lo que llama "la excepción sueca" explica que fue posible porque el socialismo sueco, gracias a la larga estancia a su frente de Hjalmar Branting y a su posición periférica en el ámbito europeo, fue flexible y no-dogmático. El socialismo era para Branting el paso más lógico para completar el liberalismo ${ }^{65}$.

Si a ello se añade el concepto peralbinista de "hogar popular" nos será más fácil comprender la dinámica que llevó a la creación del Estado de bienestar sueco. Johansson

\footnotetext{
${ }^{63}$ AMAEC R 850, 22 e, despacho de 30.VI.1936.

${ }^{64}$ LUEBBERT, Gregory, Liberalism, fascism and socialdemocracy, Oxford: Oxford University Press, 1996, pp. 306 y ss.

${ }^{65}$ BERMAN, Sheri, "The Swedish exception". The primacy of politics - social democracy and the making of Europe's Twentieth Century, Cambridge: Cambridge University Press, 2006, pp. 152-177.
} 
resaltó, en ese sentido, la influencia que la victoria del nacionalsocialismo en Alemania tuvo sobre la socialdemocracia sueca en los años treinta, convirtiéndola - ante el peligro del contagio de las ideas fascistas - en la gran defensora del sistema democrático imperante en Suecia.

Para Per Albin - sigue diciendo Johansson - el socialismo no era sino la democracia llevada a sus lógicas consecuencias, y supo adoptar el concepto nacionalsocialista de la "comunidad" (la Gemeinschaftideologie) a los esquemas de la retórica socialdemócrata sueca, poniéndolo en relación con el ideal de igualdad. El mensaje al pueblo sueco era claro: ni el nazismo ni el comunismo tenían nada que ofrecer que no pudiera hacer - y hacer mejor - la socialdemocracia ${ }^{66}$.

La Legación de España supo dar, no cabe duda, una visión ponderada y ajustada a la realidad del desarrollo político de Suecia en esta década tan importante para el país escandinavo, aunque a veces pueda tenerse la impresión de que los despachos de la Legación en asuntos políticos fueron más descriptivos que analíticos, especialmente en el período anterior a la llegada de López Oliván. Es posible, sin embargo, que esta impresión esté un tanto influenciada por las lagunas existentes en los fondos conservados - que afecta, como vimos, a todo el año 1931, de suma importancia para el desarrollo de la política sueca en los años sucesivos - y no debe, por tanto, considerarse definitiva.

\subsection{Preocupaciones específicas de la diplomacia española respecto a Suecia (1931-1936)}

Una vez expuestas los aspectos generales de la política interior de Suecia tal como fueron reflejados en los informes diplomáticos españoles, nos corresponde ahora analizar las cuestiones de la actualidad política sueca que fueron objeto de preocupación específica para la Legación de España en Estocolmo. Fueron básicamente dos temas: la política sueca de defensa y la actitud de Suecia ante el nazismo.

\subsubsection{La política sueca de Defensa}

La cuestión del desarme, que era uno de los temas básicos en la agenda de la Sociedad de Naciones durante el período de entreguerras, cobró particular relieve tras el acceso al poder de Adolf Hitler en Alemania y la re-militarización de ese país.

${ }^{66}$ JOHANSSON, Alf W, "Den svenska socialdemokratin och fascismen på trettiotalet : några reflexioner", en BERGQUIST, Mats, JOHANSSON Alf W. \& WAHLBÄCK, Krister (coord.), Utrikespolitik och historia, Estocolmo: Militärhistoriska förlaget, 1987, pp. 92 y ss. 
Efectivamente, los vencedores de la Primera Guerra Mundial, salvo EE.UU., se habían comprometido, tanto en el Tratado de Versalles como en el Pacto de la Sociedad de Naciones, a proceder al desarme.

En febrero de 1932 se reunió en Ginebra una Conferencia en la que participaron los miembros de la Sociedad de Naciones, junto con los EE.UU. y la URSS. No resulta sorprendente, por tanto, que la política de defensa constituyera una de las preocupaciones específicas del Ministerio de Estado de la República Española y por consiguiente de la Legación de la República en Estocolmo.

Esta cuestión fue, sin duda, el punto de conexión más claro entre la política exterior y la política interior de Suecia durante este período. La razón es fácil de entender: si ya de una manera general es evidente que la política de defensa de un país es la parte de su política exterior que más gastos presupuestarios conlleva, esto era aún más claro en el período que nos ocupa. El rapidísimo incremento de la inestabilidad internacional en el entorno cercano a Suecia durante los años treinta del siglo XX había impuesto al país la necesidad perentoria de colocar los aspectos relacionados con defensa en el primer plano de sus prioridades. Y esto, no sólo a nivel de política internacional, sino también en el orden interno, ya que la cuestión de la defensa presentaba un triple aspecto: político, económico-presupuestario y social.

La primera referencia al tema del desarme en los despachos de la Legación viene ya en el propio mes de las elecciones que dieron la victoria al partido socialdemócrata. El discurso post-electoral del Presidente del gobierno, Per Albin Hansson, incluía una declaración de la voluntad del gobierno de trabajar por la limitación de armamentos. Ya antes, en febrero de 1932, había informado la Legación del malestar en círculos socialdemócratas por las declaraciones del entonces Ministro de Negocios Extranjeros, Fredrik Ramel, a favor de una posible participación sueca en iniciativas militares europeas $^{67}$.

Sin embargo, según la Legación, no había plena unanimidad al respecto en el seno de la socialdemocracia, ya que algunos políticos de relieve, como el Ministro de Negocios Extranjeros, Rickard Sandler, no eran partidarios de un desarme completo ${ }^{68}$.

A finales de noviembre de ese año, el gobierno sueco presentó un proyecto de control del material de guerra y las reducciones en el presupuesto de defensa nacional. Se

\footnotetext{
${ }^{67}$ AMAEC, R 341,8, a, despacho de 23.II.1932

${ }^{68}$ AMAEC, R 341,8, a, despacho de 27.IX.1932
} 
pretendía imponer control gubernamental a la exportación de armas de guerra. El Ministerio de Estado español trasladó la información sin tardanza al Ministerio de la Guerra. Las medidas se completaron con la aprobación por el Parlamento sueco, en la primavera siguiente, de ciertas reducciones en el programa de instrucción de reclutas. Hubo también una moción de modernización de los cañones de campaña, que incluía la propuesta del ejército sueco de utilizar a desempleados en estos trabajos ${ }^{69}$.

En mayo de 1933, un artículo periodístico sueco que comparaba la situación estratégica de la isla de Gotland con la de Menorca mereció la atención de la Legación, que lo puso en conocimiento del Ministerio de Estado La cuestión volvería a estar presente enero de 1934 en relación con las propuestas de Ley referentes a la defensa de la isla de Gotland y a la reconstrucción de la defensa nacional ${ }^{70}$.

Tras la reapertura de los trabajos de la Conferencia Internacional del Desarme de Ginebra, a partir de octubre de 1933, la actitud de Suecia al respecto fue claramente expuesta por su Ministro de Asuntos Exteriores, Rickard Sandler. La Legación de España envió al Ministerio de Estado detallados informes y análisis de sus discursos.

No era para menos, pues las palabras de Sandler eran contundentes y sorprendentes, si se tiene en cuenta que su partido, el socialdemócrata, estaba decididamente alineado a favor del desarme, al menos en su declaración de intenciones. De hecho, la actitud real del gobierno sueco era muy distinta, y estaba motivada por

las particularidades del actual momento de la política mundial, el desgaste del gobierno y sus veladas inteligencias con los conservadores, exteriorizadas, en parte, en el ultimo presupuesto, donde en la partida de guerra no solo no aparecían reducciones sino que la cifra asignada había sido sensiblemente elevada. No se esperaban por tanto del Sr. Sandler sensacionales declaraciones de fácil aplauso popular, pero tampoco las terminantes palabras que ha pronunciado, en las que claramente asegura que cualquiera que sea la solución que se de al problema y cualquiera que sea la modalidad de su aplicación, Suecia no puede disminuir sus fuerzas defensivas. Trató la cuestión toda en forma de subido escepticismo, haciendo hincapié en la dificultad del momento presente, agravado por el régimen imperante en Alemania, que crea a su alrededor una atmosfera de desconfianza que merma las probabilidades de un acuerdo ${ }^{71}$.

\footnotetext{
69 AMAEC, R 341, 9 a, despachos de 8.XI.1932; AMAEC, R, 341, 8, a, despachos de 27.XI.1932, del 19.II.1933 y de 25.V.1933.

${ }^{70}$ AMAEC R 341, 9, a, despacho de 8.V.1933; AMAEC, R 341, 8, b, despacho de 24.I.1934.

${ }^{71}$ AMAEC, R 944, 29, despacho de 5.V.1934; cfr. también AMAEC, R 341, 9, a, despacho de 30.X.1933; AMAEC, R 698/10, despacho n. 17 de 15.I.1934
} 
La Legación concluía con la constatación del apoyo unánime de todos los partidos de Suecia a las palabras del Ministro de Negocios Extranjeros.

De la importancia del tema para España da idea el hecho de que a los pocos días, el Ministro de Estado de la República Española, Leandro Pita Romero, enviara una circular a las Legaciones de España en los países del llamado grupo de los neutrales, pidiendo que insistieran a sus anfitriones acerca de la necesidad de coordinación con los representantes de los demás países neutrales cara a una actuación conjunta en la próxima reunión de la Conferencia de Desarme ${ }^{72}$.

Una nueva referencia la encontramos en la información acerca de la importante visita a Suecia del Ministro británico de Asuntos Exteriores, A. Eden, en 1934, a la que más adelante nos referiremos con más detalle. Según el Ministro de España en Suecia, Alfonso Fiscowich, la visita estaba precisamente motivada por la semejanza de la política exterior de Inglaterra y de Suecia en el tema del desarme ${ }^{73}$.

En noviembre de 1934, la Legación enviaba un informe sobre adquisición y preparación de material defensa por parte de Suecia $^{74}$.

A la cuestión volverá a referirse Fiscowich, con mucho más detalle, en enero de 1935, en un importante informe reservado - cuyo contenido detallado expondremos al exponer la política exterior de Suecia - que respondía a la Orden del Ministerio de Estado número 129/1934 sobre la actitud que probablemente tomaría Suecia en caso de guerra en Europa. En él se decía, refiriéndose al partido socialdemócrata:

Suecia, sagaz y cautelosa, va obrando con eficacia y habilidad, pues el mismo partido que quería el desarme ahora tiene que defender el rearme ${ }^{75}$.

Al día siguiente, Fiscowich envío un estudio detallado con todos los datos que pudo conseguir relativos al estado de los medios defensivos de Suecia. Como es habitual, no revelaba sus fuentes, pero es evidente que debía ser alguien con acceso a información militar reservada ${ }^{76}$.

\footnotetext{
72 AGA, Asuntos Exteriores, Caja 523, Embajada de Estocolmo, Circular n. 10 de 22.V.1934. Agradecemos al Jefe de Sala del AGA el haber tenido acceso a esta documentación recién llegada al Archivo, que aún tenía signatura provisional y no estaba aún accesible a los investigadores.

${ }_{73}^{73}$ AMAEC, R 341, 9, b, despacho de 19.X.1934.

${ }^{74}$ AMAEC, R 341, 8 b, despacho de 17.XI.1934.

75 AMAEC, R 850, 18, despacho de 29.I.1935.

${ }^{76}$ AMAEC, R 850, 19, despacho reservado n. 29, de 30.I.1935.
} 
En el mes de julio, las consecuencias de la posición sueca en la cuestión empiezan a dejarse ver. Los propósitos de rearme y las necesidades estratégicas y defensivas de Suecia serán objeto de la atención específica de la Legación. La firma del pacto angloalemán de ese año - explicaban los diplomáticos españoles - había llevado a Suecia a considerar la posible necesidad de cesar en su política de desarme. De hecho, la aviación militar sueca había procedido a efectuar unas maniobras, y se había fortalecido la defensa de la isla de Gotland. Fiscowich estimaba que Suecia tenía capacidad de defensa, pues disponía de una red ferroviaria electrificada y una industria que el gobierno había sabido hacer independiente del capital alemán ${ }^{77}$.

En los meses siguientes, la Legación informaba sobre la ponencia y posterior promemoria de la Comisión de Defensa Nacional, señalando que había muy pocas diferencias en las cifras en litigio entre los partidos, "lo que pone de manifiesto la escrupulosidad y atención con que se manejan y administran los fondos del Estado", y dando muchos detalles técnicos sobre las unidades y necesidades de la Armada sueca ${ }^{78}$.

La información sobre temas militares llegó a descender a cuestiones de detalle cuartelero, como se ve en un despacho de noviembre de 1935 sobre las recientes maniobras militares en Escania, en el sur de Suecia. Fiscowich informaba que Suecia tenía una buena oficialidad y excelente tropa, que no había analfabetos y que eran buenos a nivel deportivo. Sin embargo, la vida en el cuartel era tan cómoda - en opinión del diplomático español que cabría preguntarse si el soldado sueco podría "resistir con la moral alta todas las eventualidades de una campaña real", especialmente teniendo en cuenta que el período de instrucción militar obligatorio era corto y que las últimas guerras en que Suecia había tomado parte habían sido las guerras contra Napoleón.

Añadía el informe que el material bélico de la Infantería no era malo, pero tenía poca arma automática, y que la artillería Bofors y Krupp, de distintos calibres y destinos, estaba en general anticuada y gastada, siendo la antiaérea casi inexistente. Contaba Suecia con algunos carros ligeros pero muy pocas armas antitanque. Cuando empezaron las maniobras, se estaba a la espera de que llegase pronto el nuevo cañón de infantería Bofors. La aviación contaba cerca de 100 aviones, en general anticuados. Respecto a los aspectos tácticos, la impresión del diplomático español era que la mayoría de los 20.000 soldados que participaron en las maniobras desconocía las características de la región de Escania,

\footnotetext{
${ }^{77}$ AMAEC, R 850, 18, despachos de 10 y de 12.VII.1935, completado el 30.VII.1935.

${ }^{78}$ AMAEC, R 850, 18, despachos de 23.VIII.1935, de 28.VIII.1935 y de 9.IX.1935
} 
diferente de las del resto de Suecia, pues echaban de menos los bosques y los lagos del resto del país ${ }^{79}$.

Como ya comentamos anteriormente, el Ministro de España en Estocolmo mencionó la cuestión de la reorganización de la Defensa nacional como la causa principal de la crisis ministerial y la caída del gobierno Hansson, en junio de $1936^{80}$.

La Legación de España había avisado ya en el mes de marzo acerca de las probables consecuencias políticas de la cuestión defensiva, manifestando la grave preocupación de las autoridades suecas por la penosa situación de Dinamarca y por el llamado "libro azul", un documento que proponía la re-militarización del archipiélago finés de Åland en el Báltico. En junio envió informes muy detallados sobre los planes de reorganización de la defensa sueca y comentó que el gobierno interino de Pehrsson-Bramstorp consideraba el rearme como uno de los objetivos prioritarios del momento ${ }^{81}$.

Para concluir, adelantamos aquí que el interés español por la política sueca de defensa siguió presente incluso durante el período en que la República estuvo en guerra, como testimonian la información enviada por Isabel de Palencia en 1938 acerca del debate en el Riksdag sobre el aumento del presupuesto de defensa ${ }^{82}$.

No resulta fácil pronunciarse sobre las razones del interés tan extraordinario de la Legación de España en Suecia por todo lo relativo a la política sueca de Defensa, pues es evidente que la República Española no veía en el país nórdico a un enemigo potencial. No consta si la abundancia de despachos estaba motivada por un interés específico del Ministerio de Estado o de la propia Legación en Estocolmo. Tampoco consta que España comprara armamento sueco en cantidades apreciables.

En todo caso, partiera la iniciativa de quien partiera, las fuentes documentales muestran con toda claridad que el Gobierno de la República Española estuvo perfectamente informado, en el período 1931-1936, de todos los pormenores relativos a la política de defensa sueca y la capacidad de este país de defenderse ante un posible ataque exterior. Todo parece indicar que, especialmente durante el período en que Alfonso Fiscowich estuvo al frente de la Legación de España en Estocolmo, la diplomacia española contaba con fuentes informadoras de confianza en altas esferas militares o políticas de Suecia.

\footnotetext{
${ }^{79}$ AMAEC, R 850, 18, despacho de 14.XI.1935.

${ }^{80}$ AMAEC, R 850, 21, despacho de 19.VI.1936.

${ }^{81}$ AMAEC R 850, 22, despachos de 6.III.1936, 26.III.1936, 16.V.1936, 6.VI.1936, 17.VI,1936 y 30.VI.1936; AMAEC R 850, 23, despacho de 5.IV.1936.

${ }^{82}$ AMAEC, R 642, 1, despacho de 19.III.1938.
} 


\subsubsection{La actitud de Suecia ante el nazismo y la Alemania de Hitler}

Acaso sorprenda un tanto que la actitud de Suecia ante el nazismo constituyera, junto con la política sueca de desarme, la gran preocupación específica de la diplomacia española respecto a la política interior sueca. En todo caso, un análisis detallado de la documentación enviada al Ministerio de Estado durante los años que nos ocupan permite afirmarlo así sin ningún género de duda.

Por otra parte, cabe entender la lógica de tal actitud, ya que el avance del nacionalsocialismo en Alemania, a partir de enero de 1933, suponía una situación nueva y profundamente amenazante para Europa en general y, de modo particular, para las potencias europeas de corte democrático - que por entonces corrían el riesgo de convertirse en la excepción más que la regla - entre las cuáles se alineaba la joven República Española.

Abordamos este tema aquí siendo bien conscientes de que no siempre es fácil separar el aspecto interno del aspecto internacional respecto al nazismo. Esto vale tanto para la ideología en cuanto tal como para el caso particular de los avances del nazismo en Suecia, país hasta entonces con profundas y seculares relaciones políticas, económicas, sociales y culturales con los demás países germánicos y muy en especial con Alemania. Es difícil, por tanto, separar pronazismo de progermanismo, o antinazismo de antigermanismo.

Además, en el caso concreto de la Suecia de la década de los treinta del siglo XX, es evidente la tensión suscitada entre la necesidad, en general profundamente sentida, de cerrar el paso en su política interna al contagio de la ideología nazi, y las exigencias de mantener un nivel de relaciones internacionales lo más cordiales posibles con su poderoso vecino, que era un socio comercial especialmente importante.

Sobre este tema han corrido ríos de tinta en la historiografía sueca, muy especialmente en los últimos veinte años, tras el hito que supuso la publicación en 1991, por la periodista Maria-Pia Boethius, de un libro titulado "Honor y conciencia" 83 , que versaba sobre la actitud sueca ante el nazismo. En él acusaba al gobierno sueco de la época, de haber ocultado a los ciudadanos las grandes concesiones de Suecia a Adolfo Hitler durante los años de la segunda guerra mundial, rayanas en el colaboracionismo.

El debate historiográfico sobre el colaboracionismo o no colaboracionismo de Suecia con el nazismo, el fascismo y, en definitiva, con la Alemania nazi, sigue abierto en el país,

\footnotetext{
${ }^{83}$ BOETHIUS, Maria-Pia, Heder och Samvete. Sverige under andra världskriget. Estocolmo: Ordfront, 1991
} 
sobre todo referido a los años de la segunda guerra mundial. Se trata también de un problema de definición y delimitación de conceptos: qué se entiende por fascismo, nazismo, y en su caso las diferencias entre uno y otro, etc. Es paradigmática, al respecto, la discusión entre Andersson y Bachner, de una parte, y Berggren de la contraria ${ }^{84}$.

La mayor parte de los estudiosos suecos parecen inclinarse hoy, en línea con el historiador israelí Bauer, por definir el nazismo como una ideología propia, distinta del fascismo ${ }^{85}$. En todo caso, no cabe duda que el nazismo alemán partía de la base de considerar Escandinavia y a sus habitantes arios como parte del mundo germánico, consideración en modo alguno ajena a la forma de pensar de bastantes suecos, como ha destacado Almgren en su libro sobre la infiltración nazi en Suecia entre 1933 y $1945^{86}$. Åmark sostiene, por su parte, que la política de cesiones ante el nazismo por parte del gobierno sueco empezó ya a partir de $1933^{87}$, opinión que no compartimos, entre otras cosas por la evidencia de la documentación diplomática española. En definitiva, el debate, como decíamos, no está cerrado.

El nazismo sueco debe verse en un doble aspecto: Uno, el que se refiere los partidos (en plural) nacionalsocialistas en Suecia; otro, el de la simpatía o apoyo al nazismo alemán por parte de sectores de la derecha política sueca.

Muy resumidamente, podemos constatar aquí que fue este segundo aspecto, el de la simpatía, incluso admiración, por el régimen de Hitler en una Alemania tan cercana a Suecia desde el punto de vista cultural y comercial, el que tendría alguna influencia práctica en la política exterior sueca, tanto por lo que se refiere a la guerra de España como a la guerra mundial. El nazismo sueco propiamente dicho, en cambio, careció de la suficiente cohesión interna y del apoyo popular necesario para constituir un peligro serio. Los pequeños grupos y partidos fascistas y nazis vieron dificultada su actuación en Suecia por la ley de prohibición del uso de uniformes políticos, lo cuál dificultó la labor

\footnotetext{
${ }^{84}$ ANDERSSON, Lars M. \& BACHNER, Henrik "Nationalsocialismen, en begreppsdiskussion", en ANDERSSON, Greger \& GEISLER Ursula (coord.), Fruktan, fascination och frändskap: det svenska musiklivet och nazismen, Malmö: Sekel, 2006; BERGGREN, Lena, "Den svenska mellankrigsfascismen - ett ointressant marginalfenomen eller ett viktigt forskningsobjekt?", Historisk tidskrift, 2002.

${ }^{85}$ BAUER, Yehuda, Förintelsen i perspektiv, Estocolmo: Natur \& kultur, 2001; cfr. ÅMARK, Klas, Att bo granne med ondskan. Sveriges förhållande till nazismen, Nazityskland och Förintelsen, Estocolmo: Bonniers, 2011, p. 23. Sobre el fascismo como ideología específica cfr. PAYNE, Stanley "The concept of fascism", en LARSEN, Stein Ugelvik, HAGTVET, Bernt \& MYKLEBUST Jan Petter (coord.) Who were the Fascists? Social roots of European fascism, Oslo: Universitetsforlaget, 1980, pp. 20 ss.; respecto a la responsabilidad de Suecia en los crímenes nazis, cfr. ANDERSSON, Lars M. \& TYDÉN, Mattias (coord.), Sverige och Nazityskland. Skuldfrågor och moraldebatt, Estocolmo: Dialogos, 2007.

${ }^{86}$ ALMGREN, Birgitta, Drömmen om Norden: nazistisk infiltration i Sverige 1933-1945, Estocolmo: Carlsson, 2005, passim.

${ }^{87}$ ÅMARK, Klas, Att bo granne med ondskan..., p. 115.
} 
proselitista de los grupos nazis, que, por otra parte, centraron su labor de propaganda a sus luchas internas, al menos durante el período 1930-1936.

La respuesta del gobierno fue la creación de una comisión parlamentaria, formada por representantes de todos los partidos representados en el Parlamento, salvo el comunista, para que procediera a investigar las actividades de las organizaciones donde hubiera sospecha de "actividades hostiles al Estado" y la proposición de medidas al respecto. El resultado fue la constatación de que el nazismo sueco no constituía un peligro serio para el sistema democrático. El peligro mayor, en opinión de muchos, venía del comunismo $^{88}$.

Pasamos ahora a analizar el seguimiento del peligro nazi en los informes diplomáticos españoles.

Como ya mencionamos anteriormente, un despacho de diciembre de 1931 informaba sobre un "movimiento fascista" en Suecia. Se basaba en una denuncia del que fuera "exjefe del partido fascista sueco, ahora pasado al comunismo" de que militares suecos habían introducido en Suecia contrabando de armas alemanas, en 1927, para la organización secreta fundada ese año por el Teniente General Bror Munck, compuesta de unos 2.000 miembros y que contaba entre sus filas con militares de alta graduación. Esta organización paramilitar afirmaba no tener finalidad política alguna, sino que solamente pretendía ser una ayuda para la policía. El jefe de policía de Estocolmo, Gustaf Hårleman, había aceptado esa colaboración.

Hasta aquí, y salvo en el dato del "pase al comunismo" del ex-líder fascista Konrad Hallgren - aspecto que no aparece confirmado en ninguna otra fuente que conozcamos - el diplomático español se limitaba a recoger las informaciones de la prensa sueca del otoño de 1931 sobre el escándalo en cuestión, cuyas repercusiones habían debilitado al gobierno sueco hasta el punto de que su presidente, Carl Gustaf Ekman, se había visto obligado a negar públicamente todo conocimiento acerca de la organización paramilitar en cuestión. Sin embargo, al final del despacho, el diplomático español incluía un párrafo - por desgracia sin citar la fuente - con una valoración un tanto novedosa, pues hasta fecha reciente no ha sido especialmente destacada por la historiografía sueca - aunque había

\footnotetext{
${ }^{88}$ Sobre esta cuestión cfr. el clásico libro de WÄRENSTAM, Eric, Fascismen och nazismen i Sverige, Estocolmo: Almqvist \& Wiksell, 1973; LÖÖW, Helena, Hakkorset och Wasakärven, Gotemburgo: Universidad de Gotemburgo, 1990; HADENIUS, Stig, Svensk politik under 1900-talet, Lund: Hjalmarsson \& Högberg, 2000.
} 
algunas indicaciones en ese sentido $^{89}$ - que tradicionalmente ha destacado el "germanismo" pero no el "nazismo" en las filas del ejército sueco. Dice así:

En general, debe reconocerse que las teorías fascistas han cundido mucho durante los últimos años entre los militares suecos, adversarios del socialismo y temerosos del comunismo. En varios regimientos los oficiales han formado subdivisiones fascistas y muchos, sin ser miembros activos, simpatizan al menos con estas ideas ${ }^{90}$.

A partir de la llegada al poder de la socialdemocracia, en septiembre de 1932, y muy especialmente a partir de comienzos de 1933, tras el establecimiento del régimen nacionalsocialista en Alemania, el tema sería de aún más candente actualidad.

Al poco tiempo de entrar en funciones el nuevo Gobierno, tuvo lugar en Estocolmo un acontecimiento que marcaba la pauta de los nuevos aires que cabía esperar de la socialdemocracia sueca ante la amenaza nazi y del que dejó constancia la diplomacia española. El acontecimiento en cuestión no fue protagonizado por ningún político de ámbito nacional, pero no por eso dejaba de tener efectos a nivel nacional. Fue la negativa del Ayuntamiento de Estocolmo, socialista, a asistir a los festejos en honor del matrimonio del Príncipe Gustavo Adolfo, hijo del príncipe heredero de Suecia y nieto del Rey Gustavo V, con la princesa Sibylla de Sajonia-Coburgo.

Las autoridades municipales de la capital sueca llegaron incluso a negarse a gastar nada en engalanar la ciudad, a pesar de que fueron recibidos en la estación de ferrocarriles de Estocolmo, a su llegada de su luna de miel en Italia el 25 de noviembre, por la Familia Real y el propio Presidente del gobierno, el socialdemócrata Per Albin Hansson. El motivo de esa actitud del Ayuntamiento, según Ministro de la Legación de España, era la "evidente simpatía del ex-soberano, padre de la joven desposada por los nazistas (sic) y su conocida amistad con Hitler" ${ }^{\prime \prime}$.

Efectivamente, el padre de la novia, Karl Edvard, era amigo personal de Hitler desde 1922 y con ocasión de la boda de su hija recibió telegramas de felicitación tanto del Führer alemán como de Göring ${ }^{92}$. Este último, por lo demás, había estado casado con la

\footnotetext{
${ }^{89}$ GUILLEMOT Agneta, "Svår omställning till demokratiskt försvar”, en Framsyn, 2004, y, de la misma autora, op. cit.

${ }^{90}$ AMAEC, R 341, 8, a, despacho de 2.XII.1931.

${ }^{91}$ AMAEC, R 341, 8, a, despacho de 28.XI.1932.

92 ERDMANN, Jürgen, Coburg, Bayern und das Reich 1918-1923, Coburgo: Druckhaus \& Rossteutscher, 1969, p. 91; SANDNER, Harald, Hitlers Herzog, Aquisgrán: Shaker Media, 2011, p. 239.
} 
sueca Carin von Kantzow desde 1923 hasta la muerte de ésta en 1931. Gustavo Adolfo y Sibylla fueron los padres del actual Rey de Suecia, Carlos XVI Gustavo.

Fue precisamente Göring el protagonista más o menos directo de otro suceso en relación con el nazismo que mereció otro despacho diplomático de la Legación de España. Göring visitó Suecia en el mes de junio de 1933 para asistir a la boda de una parienta suya, y su visita no pasó desapercibida en modo alguno para la prensa. En julio de 1933, por querella criminal presentada por la Legación de Alemania en Estocolmo, se abre procesamiento contra dos periódicos suecos de izquierda, Arbetaren y Ny Dag, por sus fuertes manifestaciones en contra de Göring y del nazismo. El órgano socialdemócrata Socialdemokraten comentó que a Suecia, de acuerdo con la legislación vigente, le había sido imposible negarse al procesamiento ${ }^{93}$. Curiosamente, el diario comunista Folkets Dagblad, que también se había distinguido por sus ataques, no fue imputado. El asunto terminó con la imposición de tres meses de presidio para el editor responsable del $N y$ $\operatorname{Dag}^{94}$.

La situación, por lo que al nazismo se refiere, había cambiado sustancialmente entre noviembre de 1932 y el verano de 1933, por el acceso al poder del partido nacionalsocialista en Alemania en enero de ese año.

La prensa sueca comentó ampliamente el nuevo gobierno alemán. En febrero, la Legación de España se hacía eco de las reacciones suscitadas en el país al respecto, citando en particular el caso del Göteborgs Handels och Sjöfartstidning, diario liberal de Gotemburgo, cuya decidida y consecuente actitud en contra del nazismo fue constante a lo largo de todo el período, y que le llegaría a ocasionar problemas con las autoridades suecas en el momento álgido del poderío nazi, entre 1940 y 1942. En enero de 1933, Göring envió un telegrama al diario exigiendo que cesara en sus críticas, llegando la Legación de Alemania también a protestar oficiosamente al Ministerio de Negocios Extranjeros sueco por la campaña del Socialdemokraten en su contra.

Aún habría más. Como la Legación de España no dejó oportunamente de informar, el propio jefe del gobierno sueco, Per Albin Hansson, hizo en un discurso de marzo de 1933 unas declaraciones que el gobierno alemán consideró ofensivas. En sustancia, lo que dijo fue que a la violencia nazi se opondría otra violencia, quizá todavía peor. Probablemente se

\footnotetext{
${ }^{93}$ AMAEC, R 341, 9, a, despacho de 12.VII.1933.

${ }^{94}$ AMAEC, R 698, 10, despacho de 15.I.1934.
} 
refiriera a la violencia comunista, pues Hansson fue siempre declarado enemigo del comunismo 95 .

En el mes de abril, tuvo lugar en el Riksdag un debate importante, por tratar cuestiones de principio, sobre el empleo de ciudadanos alemanes en instituciones del Estado sueco. Los socialdemócratas, en la prensa, abogaban porque las instituciones culturales suecas apoyaran a los representantes de la cultura alemana que eran judíos y estaban por tanto "expuestos al terror nacionalsocialista". La socialdemocracia veía un contrasentido entre repartir los premios Nobel y permanecer inactivos ante la barbarie.

El uso de los términos "terror" y "barbarie" aplicados a la política nazi sobre los judíos en fecha tan temprana como abril de 1933 no deja de ser significativo. Con todo, el senado sueco (la primera cámara del Riksdag), en una ajustada votación de 62 votos contra 59, acababa de denegar la autorización pedida por un diputado comunista para apoyar a los judíos alemanes en el sentido indicado. De todo ello informó la Legación de España al Ministerio de Estado, tema sobre el que volvería a insistir en el mes de diciembre, comentando que se esperaba la inmigración a Suecia de setenta y cinco líderes de partidos alemanes de izquierda ${ }^{96}$.

El asunto no quedaría ahí. En mayo, el gobierno de la Alemania nazi elevó una protesta oficial al gobierno sueco por las declaraciones del Ministro de Comercio de Suecia. Efectivamente, el Ministro Fritjof Ekman había criticado duramente a Hitler y a Göring. Tras la protesta alemana, el ministro dijo que la prensa había malinterpretado sus palabras presentándolas como una crítica a Alemania cuando él sólo había hablado del fascismo y del nazismo en general. El texto del discurso era en realidad una condena profética del nazismo, comparándolo con la "dictadura comunista". De todo ello informaría la Legación de España ${ }^{97}$, así como de las medidas, aprobadas también en mayo, para la represión de los movimientos subversivos. Al respecto, el Presidente del gobierno, Per Albin Hansson, dijo que en Suecia, en realidad, esa legislación no hacía falta en sentido estricto, pues eran muy pequeños los movimientos radicales. Sus palabras muestran con claridad las convicciones del insigne político sueco:

\footnotetext{
${ }^{95}$ AMAEC, R 341, 9, a, despacho de 8.III.1933.

${ }^{96}$ AMAEC, R 341, 8, a, despacho de 22.IV.1933; AMAEC, R 341, 9, a, despachos de 8.V.1933 y de 6.XII.1933

${ }^{97}$ AMAEC, R 341, 9, a, despacho de 4.V.1933.
} 
La democracia no debe confiar en primer lugar en leyes, policía y actos de autoridad: su principal defensa estriba en su capacidad de regir los destinos del pueblo en beneficio de éste $^{98}$.

A pesar de esas declaraciones de principios, no dejó Suecia de tomar medidas legislativas para evitar en la medida de lo posible el contagio de la ideología nazi. Una muy concreta fue la adopción de la Ley de Prohibición del uso de uniformes políticos. Aprobada con gran mayoría, estaba prevista como medida provisional hasta el año 1935, pero aún hoy sigue vigente y es instrumento eficaz en la lucha contra el radicalismo político, especialmente el de corte neonazi ${ }^{99}$.

Al mismo tiempo, había preocupación en Suecia, tras el fracaso de la Conferencia Económica Internacional de Londres de julio de 1933, por las posibles consecuencias de una suspensión de pagos alemana, que se vio en Suecia como una falta absoluta de formalidad. En el fondo, la preocupación era lógica, pues Suecia tenía muchos préstamos a largo plazo en Alemania, por valor de 800 millones de coronas ${ }^{100}$.

Tras la visita de Göring en junio y sus secuelas procesales, Per Albin Hansson habló una vez más sobre el nazismo en el mes de agosto, recién llegado de un viaje de recreo por el Atlántico en el yate Drottningholm, con escala, entre otros puertos, en Cádiz. El contenido del discurso no daba lugar a dudas: el jefe del gobierno sueco no se fiaba ni de los nazis ni de las derechas conservadoras. De ello daba cumplida cuenta la Legación española a las autoridades de Madrid ${ }^{101}$.

La decisión de la Unión General de Sindicatos sueca (LO), en septiembre de 1933, de declarar el boicot a los productos alemanes, aduciendo que la balanza comercial alemana ya era menos favorable que antes del advenimiento del régimen nacionalsocialista, fue criticada por la prensa conservadora, que adujo que Suecia corría el riesgo de represalias alemanas. Sin embargo, incluso el Svenska Dagbladet, diario conservador y germanófilo, se mostró muy crítico al conocerse al mes siguiente la decisión alemana de abandonar la Sociedad de Naciones. El diario Socialdemokraten se mostró alarmado por las intenciones de Hitler y recomendaba sanciones a Alemania ${ }^{102}$.

\footnotetext{
${ }^{98}$ AMAEC, R 341, 8, a, despacho de 16.V.1933.

${ }^{99}$ AMAEC, R 341, 8, a, despacho de 14.VI.1933.

${ }^{100}$ AMAEC, R 341, 9, a, despacho de 10.VI.1933.

${ }^{101}$ AMAEC, R 341, 8, a, despacho de 17.VIII.1933.

102 AMAEC, R 341, 9, a, despacho de 19.X.1933.
} 
En el mes de noviembre hubo una ola de propaganda nazi en Escandinavia, con una serie de conferencias radiadas, en sueco, organizada desde Alemania. Los diplomáticos españoles informaron que los nazis alemanes colaboraban con dinero para la difusión de sus ideas en Suecia, y hacían planes para poner en marcha un periódico sueco. Dijeron también que, en general, había poca simpatía por el Reich en la prensa y en la opinión pública, siendo especialmente crítico Ny Tid, órgano gubernamental ${ }^{103}$.

Como se ve, a partir del otoño de 1933, la actividad nazi en Suecia iba en aumento, y también las tensiones que este hecho provocaba. En noviembre, la Legación informaba de un proyecto de colaboración entre los líderes políticos conservadores de Dinamarca, Noruega y Suecia. Fue la primera vez que el líder del partido conservador danés Möller y el del sueco, Lindman, hicieron una declaración conjunta. En ella Lindman dijo que no toleraría tendencias pronazis en el seno de su partido ${ }^{104}$.

En diciembre informaba a Madrid el Encargado de Negocios ad interim de España, José F. Villaverde, que con motivo de una reunión organizada por la asociación de extrema izquierda Clarté en la Universidad de Estocolmo se habían producido disturbios relacionados con el nazismo. Era la primera vez que en el país tenía lugar un enfrentamiento entre comunistas y nazis ${ }^{105}$.

Por su parte, la Policía de Seguridad sueca, organismo responsable de la seguridad del Estado, que desde 1929 había recibido instrucciones precisas de someter a vigilancia a las personas y organizaciones extremistas, en particular las de izquierdas, empezó a dedicar más recursos al seguimiento de las organizaciones nazis que al de las comunistas ${ }^{106}$.

En enero de 1934 enviaba la Legación algunos datos sobre la actividad de las organizaciones nazis en Suecia y las medidas propuestas por el gobierno para controlarlas. El detonante fue el caso de un aviador nazi sueco llamado Wiklund que había denunciado haber sido victima de un atentado. La Policía estimó que no era cierto, sino que el atentado había sido cuidadosamente preparado por los nazis con fines de propaganda, y propuso tomar medidas contra los nazis suecos, sobre todo contra los que residían en los locales de la empresa llamada Hogar Sociedad Anónima (Hem AB). La mayoría eran obreros sin

\footnotetext{
103 AMAEC, R 341, 9, a, despacho de 25.XI.1933.

${ }^{104}$ AMAEC, R 341, 9, a, despacho de 26.XI.1933.

105 AMAEC, R 341, 8, a, despacho de 10.XII.1933.

106 ELIASSON, Ulf, I försvarets intresse: Säkerhetspolisens övervakning och registrering av ytterlighetspartier 1917-1945, Lund: Nordisk akademisk press, 2006, pp. 53 y 86. En esta época aún no estaba organizada la Policía de Seguridad (SÄPO) como entidad propia, sino que estaba encuadrada en la Policía de Estocolmo, como unidad n. 6.
} 
trabajo a los que los nazis daban alojamiento y comida a cambio de que se hicieran miembros del partido ${ }^{107}$.

Por las mismas fechas, en el resumen semestral enviado por el Encargado de Negocios de España, José F. Villaverde, se recogía en detalle la actitud de la prensa sueca en relación con el nazismo. Destacaba en particular el diplomático las llamadas del diario Social Demokraten a utilizar la tribuna de la Sociedad de Naciones para condenar el "agresivo nacional-socialismo alemán" y para no tolerar "la persecución de los judíos en Alemania, que es una evidente infracción de los principios de la misma sobre los derechos de las minorías", así como los ataques a Alemania del principal diario del país, el Dagens Nyheter, y del resto de la prensa liberal, por su actitud hacia la minoría judía ${ }^{108}$.

A pesar de todo, el nazismo no llegó nunca a ser un peligro real para Suecia. De ello se percató pronto el nuevo Ministro de España en Estocolmo, Alfonso Fiscowich, que en abril de 1934 informaba sobre las tendencias de determinados grupos políticos suecos hacia el nacionalsocialismo. El diplomático español no concedía especial importancia a las

manifestaciones de jovenzuelos alborotados que, portadores de vistosos distintivos y capitaneados por gentes de ningún prestigio, pretenden crear legiones y atraer a taconazos simpatías y adeptos, gesto sin trascendencia ni importancia

Caso distinto era, en opinión de Fiscowich, era

la actitud asumida por determinados elementos de la extrema derecha, que se han separado del partido conservador, del que formaban lucido grupo (...) declarando abiertamente sus simpatías por los procedimientos nacionalsocialistas ${ }^{109}$

Como se ve, el peligro era la captación por el nazismo de personas del entorno del ala derecha del partido conservador, en opinión de Alfonso Fiscowich. Nos parece un análisis sumamente significativo, especialmente por proceder de la pluma de un diplomático cuyas ideas políticas conservadoras le llevarían más tarde, en agosto de 1936, a negar su lealtad al gobierno de la República Española.

Y es que la opinión pública sueca, en su abrumadora mayoría, no veía con buenos ojos el nazismo triunfante en su vecino del sur. Así lo volvería a resaltar el diplomático

\footnotetext{
${ }^{107}$ AMAEC, R 341, 8, b, despacho de 12. I.1934

108 AMAEC, R 698, despacho de 15. I.1934

${ }^{109}$ AMAEC, R 341, 8, b, despacho de 1. IV.1934
} 
español al comentar en julio de 1934 los efectos en Suecia de los recientes acontecimientos en Alemania, señalando que las represiones de Hitler habían producido estupor e indignación, hasta en las derechas suecas y que la prensa se había "apartado de su acostumbrada mesura, juzgada por algunos de frialdad"110.

El tono de la prensa sueca, en efecto, se había recrudecido, y un observador cínico no dudaría en afirmar que acaso no fueran del todo ajenos a ello los aspectos puramente económicos en las relaciones con Alemania ${ }^{11}$. De hecho, la respuesta alemana no se hizo esperar, prohibiendo la entrada de varios diarios suecos como el Göteborgs Handels och Sjöfartstidningen, el Social Demokraten e incluso el mayor diario del país, Dagens Nyheter, cuyo propietario, el conocido judío Bonnier, fue objeto de particulares quejas. En el extremo opuesto del espectro político tomarán partido por Alemania el Dagligt Allehanda y el Aftonbladet ${ }^{112}$.

Con todo, a nivel institucional tuvo lugar un acuerdo económico sobre divisas entre Suecia y Alemania, cuyo texto reclamó el Ministerio de Estado de la República Española a la Legación en Estocolmo ${ }^{113}$.

En el informe semestral referido a la primera mitad de 1934, se dice que aunque la juventud sueca, en gran parte, se inclina por las ideas socialistas, el nazismo se estaba abriendo camino, como doctrina opuesta a

las ideas internacionales de tipo marxista o netamente bolchevique. Por el momento, esta tendencia se encuentra sin una organización definida, y aunque es mirada por sus contrarios con el respeto que en este país se tiene a toda opinión, no deja de preocupar al gobierno el notable desarrollo que en poco tiempo ha alcanzado ${ }^{114}$.

En el mes de noviembre de 1934 volvía Fiscowich a tomar la pluma para informar de una conferencia de carácter nazi en Uppsala, dada por Adrian Molin ${ }^{115}$, y poco después, en un despacho reservado de enero de 1935, trataba sobre la posible actitud de Suecia en caso de una conflagración militar europea:

\footnotetext{
${ }^{110}$ AMAEC, R 341, 8, b, despacho de 14. IV.1934.

${ }^{111}$ AMAEC R 850, 20 e, despachos de 16.VI y de 30.VII.1934.

112 AMAEC, R 341, 9, b, despacho de 20.VIII.1934.

${ }^{113}$ AMAEC, R 243, 12, telegrama n. 15 de 20.IX.1934.

${ }^{114}$ AMAEC, R 698, despacho de 15. VII.1934.

${ }^{115}$ AMAEC, R 341, 8, b, despacho de 21.XI.1934.
} 
Entre Alemania e Inglaterra, parece que se inclinaría por Inglaterra. Alemania cuenta a su favor el teutonismo del ejército sueco y los numerosos focos de nazismo sueco, diseminados por todo el país. ${ }^{116}$

En marzo de 1935, el Ministerio de Estado español reclamaba urgentemente de la Legación información sobre las repercusiones que hubiera tenido en el gobierno sueco la actitud de Alemania en cuanto al Tratado de Versalles, pidiendo que enjuiciase la situación y diera su opinión sobre el desarrollo del momento político ${ }^{117}$. Lamentablemente, no hemos podido encontrar la respuesta de la Legación.

Llama la atención que en el resto del año 1935 no aparezcan en la documentación otras referencias al nazismo. La explicación obvia al respecto es que la documentación de este año tampoco está completa, pero no parece que sea la razón correcta, ya que sí se conserva el registro de entrada de los documentos ${ }^{118}$, y en la lista de temas no aparece mencionado el nazismo. En cambio, como ya hemos visto, abunda la información sobre el rearme de Suecia y sobre cuestiones militares, y no faltan tampoco referencias al conflicto italo-abisinio. Quizá la explicación sea, sin más, que no había más asuntos especiales que comentar en relación con el avance del nazismo en Suecia.

La siguiente referencia al tema es de marzo de 1936, y trata de la expulsión de algunos ciudadanos suecos en represalia por la expulsión de Suecia de un nazi alemán llamado Bartel ${ }^{119}$. A los pocos días, otro informe señalaba que el Gobierno y los círculos parlamentarios juzgaban sin pesimismo la situación creada por la actitud de Alemania en política exterior, estimando que no existían argumentos jurídicos para la imposición de sanciones $^{120}$.

Sobre los resultados de los partidos nazis en las elecciones de 1936, por los avatares de la guerra española, no estará la Legación en condiciones de informar.

Nos acercamos al final de este subcapítulo singular sobre uno de los dos grandes temas que interesaron a los diplomáticos españoles en Suecia y al Ministerio de Estado de la República Española durante los años 1931 a 1936. Es evidente que, para la República, los progresos del nazismo eran un tema de preocupación, aunque fuera en un país tan alejado como Suecia.

\footnotetext{
${ }^{116}$ AMAEC, R 850, 18, despacho de 29.I.1935.

${ }^{117}$ AMAEC, R 344, 15, telegrama n. 8 de 10.III.1935, del M. de Estado a la Legación de España en Estocolmo.

${ }^{118}$ AGA, L- AE 6489, pp. 169-182.

${ }_{119}$ AMAEC, R 850, 23, despacho de 7.III.1936.

${ }^{120}$ AMAEC, R 615, 31, despacho de 11.III.1936.
} 
Por otra parte, como hemos podido observar, el interés de la Legación se concretaba en tener puntualmente informado al gobierno español de los sucesos en relación con el nazismo que quedaban reflejados en las páginas de la prensa sueca, limitándose la mayor parte de las veces a una exposición de los mismos sin mayores profundidades. Que no fue siempre fue así ha quedado claro, sin embargo, por las referencias a los avances de la ideología nazi en elementos del Ejército y en algunos grupos de la derecha política.

Resulta un tanto sorprendente la ausencia de nombres y referencias detalladas a los políticos y a las organizaciones nazis suecas, que no merecen ni siquiera una mención en el marco de las informaciones generales referidas a los partidos políticos. En cierto sentido, este silencio es, en sí mismo, altamente significativo de la poca - o nula - influencia de esos grupos en la vida política del país.

Por otra parte, no podemos descartar la existencia de información reservada que no se haya conservado y es posible que en la documentación perdida de 1931 se hiciera referencia al Partido nacionalsocialista sueco de Sigurd Furugård (Svenska Nationalsocialistiska Partiet), que se presentó entonces por vez primera a las elecciones municipales, sin conseguir apenas votos. Sea como fuere, llama la atención que la única referencia concreta a una organización nazi en los despachos españoles sea la secesión de las juventudes del partido conservador y ni siquiera los nombres de los líderes más conocidos de la extrema derecha sueca - los nazis Sigurd Furugård y Sven Lindholm y el fascista Per Engdahl - fuesen citados.

En cambio, en los informes diplomáticos españoles quedó claramente reflejada la decidida actitud antinazi del gobierno de Suecia, del partido socialdemócrata sueco y, en términos generales, del resto de la clase política y de los partidos con representación parlamentaria. Esa actitud se tradujo en eficaces medidas, tanto en política interior como exterior, para paliar y, en la medida de lo posible, tratar de evitar el riesgo del contagio de la ideología dominante en el gran vecino del sur.

\subsection{La política exterior sueca de 1931 a 1936 según la diplomacia española}

\subsubsection{Aspectos generales de la política exterior sueca 1931-1936}

Nos ocupamos a continuación de los aspectos generales de la política exterior sueca del período, desarrollada fundamentalmente dentro del marco de la Sociedad de Naciones. Desde la fundación de ese organismo internacional, Suecia adoptó un papel muy activo en 
el mismo, siendo uno de los miembros no permanentes de su Consejo durante dos períodos, de 1922 a 1926 y de 1936 a $1939^{121}$.

La política sueca en la Sociedad de Naciones siguió una triple línea: la defensa de los intereses de los países pequeños frente a las grandes potencias; el apoyo a las pretensiones de universalidad del organismo, permitiendo la entrada en él de las naciones derrotadas en la Gran Guerra; y la promoción activa de acuerdos internacionales a favor del desarme ${ }^{122}$.

Hablar de política exterior de Suecia es hablar de neutralidad y mediación. Estas son las coordenadas básicas en las que se puede resumir la actitud sueca desde las guerras napoleónicas, última vez que el país se vio directamente afectado por el flagelo de la guerra.

El tema de la neutralidad es el leitmotiv de la práctica totalidad de la historiografía sueca sobre política exterior a partir de la segunda mitad del siglo XX. Es, sin embargo, más que discutible que quepa hablar de neutralidad durante el período comprendido entre 1931 y 1936. De hecho, el debate sobre la política de neutralidad sueca ha sido reabierto con fuerza en la historiografía sueca de los últimos años ${ }^{123}$.

Esta línea estaba en consonancia con los ideales humanitarios e internacionalistas de la época, siendo a la vez, probablemente, la que mejor promovía los intereses nacionales de Suecia: la seguridad y la paz en su entorno. La consecuencia sería la posibilidad de reducción de los gastos de defensa, que en su lugar podrían dedicarse a más reformas sociales $^{124}$.

El apoyo sueco al ingreso de Alemania en la Sociedad de Naciones, a mediados de la década de los veinte, había llevado a Suecia a oponerse a la pretensión de España de obtener un puesto permanente en el Consejo de la misma, lo que motivó un conflicto diplomático de entidad. Para posibilitar un compromiso en línea con el espíritu de Locarno, Suecia cedió su propio puesto en el Consejo a Polonia ${ }^{125}$.

La posición sueca en política exterior se hizo mucho más complicada a partir de 1930: la crisis económica, y la dependencia a este respecto de Inglaterra, unidas a las

\footnotetext{
${ }^{121}$ Sobre la política exterior de la socialdemocracia sueca, cfr. HULDT, Bo \& MISGELD, Klaus (coord.), Socialdemokratin och svensk utrikespolitik: från Branting till Palme, Estocolmo: Utrikespolitiska Institutet, 1990.

${ }^{122}$ Un estudio monográfico sobre el papel de Suecia en la conferencia de desarme de 1932 en TRÖNNBERG, op. cit.

${ }^{123}$ Al respecto, cfr. ANDRÉN, op.cit.; BJÖRLIN, op.cit.; NORMAN, T., op.cit.; HANSSON, op.cit.; DAHLBERG, op.cit.; OTTOSSON, op. cit.; STEENE, op.cit..

${ }^{124}$ NORBORG, Lars-Arne, op. cit., p. 263.

${ }^{125}$ Cfr CASTIELlA, op. cit.; BLEDSOE, "The Quest for Permanencia...” y La oficina española...; ANDERSSON, I., op. cit., p. 442.
} 
vicisitudes de la vida política alemana con la entrada en escena de Adolf Hitler, ocasionaron un claro acercamiento sueco a Inglaterra. Asimismo, las relaciones con la Unión Soviética fueron motivo de tensiones, como veremos en un epígrafe posterior.

El bombardeo en 1935 de una ambulancia de la Cruz Roja sueca en Abisinia, por parte de la aviación italiana, fue también decisivo para que Suecia se apartara de su línea de estricta neutralidad y se uniera por primera vez a las sanciones decretadas contra Italia por la Sociedad de Naciones. Sin embargo, el hecho de que las grandes potencias democráticas europeas, Inglaterra y Francia, no quisieran llevar las sanciones a sus consecuencias más gravosas (por ejemplo, a la prohibición de la exportación de petróleo a Italia), llevó a Suecia y a otros pequeños países europeos a la convicción de que la Sociedad de Naciones era un instrumento sin fuerza. En 1936, Suecia hizo pública una declaración en la que anunciaba su distanciamiento de la política de sanciones y la vuelta a la política de neutralidad estricta. Más tarde, en abril de 1938, el gobierno sueco manifestó que, en caso de guerra en Europa, Suecia se mantendría neutral ${ }^{126}$.

Expondremos aquí las líneas fundamentales de la actitud de Suecia en los grandes asuntos internacionales del momento tal como fueron reflejados por la Legación de España en Estocolmo, dejando, sin embargo, para el capítulo próximo la labor específica desarrollada por Suecia como uno de los actores principales en el llamado grupo de los neutrales, donde las relaciones bilaterales con España fueron especialmente estrechas.

Por los libros de registro del Ministerio de Estado de 1931-32 sabemos de la existencia de informes, hoy perdidos, sobre la asistencia de Suecia a las conferencias internacionales de radiotelegrafía y telegrafía, sobre algunos acuerdos bilaterales de índole fiscal, aduanera o comercial suscritos por Suecia con terceros países (Islandia, Rumania, EE.UU., Brasil, Grecia y Turquía, además de la denuncia sueca de uno con Alemania) ${ }^{127}$.

A partir de 1933, tras el empeoramiento de la estabilidad internacional, por la actitud desafiante de la Sociedad de Naciones por parte fundamentalmente de la Alemania nazi, pero también de la Unión Soviética, la política exterior de Suecia pasaría a estar más presente en cuanto tal en los informes diplomáticos españoles, que no dejaron de referir puntualmente los discursos del Ministro de Exteriores sueco, ampliamente comentados, por entonces, en la prensa del país escandinavo.

\footnotetext{
${ }^{126}$ SILANDER, op. cit., passim.

${ }^{127}$ AGA, L. AE 6402, pp. 178-183; AGA, L. AE 6403, pp. 126-128; AGA, L. AE 6422, pp. 168-176.
} 
La tensión provocada por el nombramiento de Hitler como Canciller alemán se dejó sentir en Suecia desde el primer momento. El 9 de febrero de 1933, Hermann Göring protestó por la forma en que el nombramiento había sido comentado por la prensa sueca, y también se quejó de un discurso del Ministro sueco de Comercio, Ekman, muy crítico respecto al dictador alemán ${ }^{128}$.

Ello llevó a que se tomaran medidas concretas a nivel interno sueco, para evitar el contagio del fascismo, del nazismo y del comunismo. La ley de prohibición de uniformes políticos de 1933 fue, en este sentido, una indicación clara de la voluntad del gobierno. Mientras éste se alineaba claramente con Inglaterra y apoyaba la política del apaciguamiento y no-intervención, la opinión sueca se decantó vivamente en contra del fascismo y del nazismo ${ }^{129}$.

El discurso de Sandler en Gotemburgo de 29 de octubre de 1933 sobre comercio y política exterior fue especialmente importante, a juicio de la Legación de España, ya que enviaba señales claras tanto a la Alemania nazi como a las organizaciones obreras suecas. Tras citar la importancia del comercio internacional y el especial interés del gobierno sueco en proteger allende sus fronteras la producción nacional, deteniéndose en las negociaciones que precedieron a los últimos tratados suscritos por Suecia con Inglaterra y Francia, el ministro sueco habló de las relaciones con Checoslovaquia, Bélgica, África del Sur, Chile, Turquía, los EE.UU. y, finalmente, Alemania, donde las relaciones comerciales estaban especialmente tirantes.

Sandler advirtió claramente a las organizaciones obreras que un boicot de los productos alemanes era peligroso para Suecia, y que debían abstenerse de hacer política comercial al margen del poder público, añadiendo que si se le hubiese pedido su opinión personal como hombre de partido, "el socialista se hubiera declarado en esta cuestión de acuerdo con el ministro de Negocios Extranjeros". Además, en mensaje dirigido a Berlín, para que supiese la posición sueca, apoyó claramente el derecho de Dinamarca a seguir en posición pacífica de la Jutlandia del sur ${ }^{130}$.

En ese importante discurso programático, insistió el Ministro sueco de Negocios Extranjeros en la aspiración de Suecia a la paz y al mantenimiento del prestigio de la

\footnotetext{
${ }^{128}$ AMAEC R 341, 9, a, despacho de 4.V.1933, protesta del gobierno alemán contra un discurso del Ministro de Comercio de Suecia. El discurso fue, efectivamente, una condena profética del nazismo, comparándolo con la dictadura comunista soviética.

${ }^{129}$ Cfr. ÅMARK, Att bo granne med ondskan...; ALMGREN, op.cit.; NILSSON, Karl N. Alvar, Svensk överklassnazism 1930-1945, Estocolmo: Carlsson, 1996; THORSELL, Staffan, Mein lieber Reichskanzler!: Sveriges kontakter med Hitlers rikskansli, Estocolmo: Bonnier, 2006.

${ }^{130}$ AMAEC, R 341, 9, a, despacho de 30.X.1933; AMAEC, R 698/10, despacho n. 17 de 15.I.1934.
} 
Sociedad de Naciones, sin tener nada que decir a los que interpretaran esto como "sacro egoísmo". Se ocupó también del "Pacto de las cuatro potencias" y de la Conferencia de Desarme, sin olvidar una referencia a la retirada de Alemania de la Sociedad de Naciones, recordando que Alemania había entrado en ese organismo gracias a Suecia, en 1925. En suma, se trató de un discurso pacifista, como lo muestra el título bajo el que fue publicado: "Pacifismo heroico". Y refiriéndose a la atmosfera de desconfianza que Alemania creaba a su alrededor y que mermaba las probabilidades de un acuerdo, mostraba Sandler su pesimismo con el panorama internacional, aún admitiendo la posibilidad de una solución si los gobiernos de Francia y de Alemania se mostraran realmente dispuestos a lograrla, solución basada en la aceptación de un control automático y permanente y de un pacto general de no agresión. El discurso de Sandler fue unánimemente aplaudido por todas las fuerzas políticas suecas, y el Gobierno sueco lo envió, traducido al francés, a todas las representaciones diplomáticas ${ }^{131}$.

La firma de acuerdos comerciales de Suecia con otros países fue comunicada oportunamente por la Legación de España al Ministerio de Estado, siendo éste un tema de particular interés, por estar en curso negociaciones en este sentido también con España, que analizaremos en el capítulo correspondiente a las relaciones bilaterales. Sobre el acuerdo con Francia, basado en la política de contingentes o cupos de productos, similar al que se negociaba con España, se expresó críticamente el ministro Sandler en un discurso diciendo que Suecia se había visto obligada a acceder a ello ${ }^{132}$.

La Legación de España informó también del acuerdo sobre navegación entre Suecia y EE.UU. y sobre las declaraciones del nuevo Ministro de ese país en Estocolmo. El gobierno americano le había encargado conseguir la firma de un acuerdo comercial, estudiar el sistema monetario sueco, la legislación sobre restricción de bebidas alcohólicas y legislación social, añadiendo que en América se había comprendido que Suecia era un país de vanguardia y de un alto grado de cultura, del que había mucho que aprender. Por su parte, Suecia se mostraba por entonces crítica de lo que consideraba egoísmo capitalista americano, motivadas por las consecuencias del asunto Kreuger y la actitud americana en la Conferencia económica de Londres, como resaltó el ministro de Hacienda sueco en unas declaraciones de julio de $1933^{133}$.

\footnotetext{
${ }^{131}$ AMAEC, R 944, 29 e, despacho de 15.IV.1934; AMAEC, R 341, 9, a, despacho de 14.XI.1933. ${ }^{132}$ AMAEC R 341, 9, b, de 31.XII.34.

${ }^{133}$ AMAEC, R 255, 53, despacho de 11.II.31; AMAEC, R 341, 9, a, despacho de 24.VII.1933; AMAEC, R 341, 8, a, despacho de 24.VII.1933.
} 
Uno de los temas de la política exterior sueca poco conocidos hasta ahora - incluso en Suecia, donde la historiografía al respecto es escasa, salvo alguna excepción ${ }^{134}$ - es el relacionado con la actitud de Suecia ante las importantes cuestiones monetarias que fueran objeto de la Conferencia económica mundial de Londres de 1933. Al respecto, la Legación de España 1933 se hacía eco de las duras declaraciones del Ministro sueco de Hacienda, Ernst Wigforss, a su regreso de la Conferencia, lamentándose de que hubiese fracasado, por lo que calificó de egoísta actitud de Norteamérica, el proyecto de unión monetaria que Inglaterra y otros Estados, entre ellos Suecia, habían proyectado ${ }^{135}$.

La actitud de Suecia ante la Sociedad de Naciones fue tema habitual de las informaciones de la Legación de España, que calificó a Suecia de gran defensora de la Sociedad en cuanto tal, pero que se mostraba ligeramente pesimista respecto al porvenir de Europa y sentía gran preocupación por el tema del desarme y por la amenaza que Alemania suponía para la paz en Europa ${ }^{136}$.

En relación con lo que los diplomáticos españoles en Suecia llamaron "la cuestión báltica" - a la que nos hemos referido anteriormente al tratar de las relaciones de Suecia con su vecino oriental Finlandia - fue importante el viaje a Suecia, el 13 de enero de 1934, del Ministro de Asuntos Exteriores de Letonia, que propuso un pacto báltico entre Suecia, Finlandia, Letonia y Lituania para equilibrar el dominio del Báltico contra Rusia y Polonia. El asunto no prosperó, por el desinterés sueco en la cuestión. Su homónimo polaco visitará Suecia al año siguiente ${ }^{137}$.

En 1935 continuó informando la Legación a Madrid sobre las líneas generales de la política exterior sueca, aunque para entonces el cambio en la política de defensa, ya comentado, acaparaba la mayor parte de la atención respecto a la política exterior por parte de la Legación. Sin embargo, otro discurso de Rickard Sandler, que a pesar del incipiente rearme sueco seguía sin desaprovechar oportunidad de manifestar su pacifismo, fue enviado íntegro, con traducción al castellano, al Ministerio de Estado. De él son las famosas frases "nos encontramos ante el problema central de Europa: Alemania" y "son las ideologías contrarias del nazismo y del bolchevismo las que dominan el juego del

\footnotetext{
${ }^{134}$ NORMAN, T., op. cit.

${ }^{135}$ AMAEC, R 341, 8, a, despacho de 24.VII.1933

${ }^{136}$ AMAEC, R 698/10, despacho de 15.VII.1934.

${ }^{137}$ AMAEC, R 341, 9, b, despacho de 15.I.1934; AMAEC, R 850, 19 e, despacho de 4.I.1935.
} 
equilibrio de fuerzas”. También un año más tarde, en enero de 1936, reivindicó Sandler con gran "templanza" - en palabras de Fiscowich - la libertad de acción de Suecia ${ }^{138}$.

A finales de junio de 1936 envió Fiscowich al Ministerio de Estado su último informe sobre la política exterior de Suecia, donde por primera vez mencionaba que había menos unanimidad entre las fuerzas políticas suecas respecto a la postura a seguir, y que Suecia tenía miedo de ser "comparsa de los países grandes"139.

Como se desprende de lo expuesto en este epígrafe, la política exterior sueca durante los años treinta del siglo XX tuvo un gran protagonista, su Ministro de Negocios Extranjeros Rickard Sandler. Fue, sin duda, uno de los grandes políticos socialdemócratas del período de entreguerras. Sus discursos públicos iban dirigidos tanto a la opinión sueca como a la internacional, y salieron publicados en forma de libro al poco tiempo de haber sido pronunciados ${ }^{140}$.

Recientemente ha salido a la luz en Suecia una documentada biografía sobre Rickard Sandler ${ }^{141}$.

\subsubsection{Cooperación de Suecia con los otros países nórdicos}

Como es natural, uno de los aspectos fundamentales en la política exterior de Suecia es su relación con su entorno natural, el resto de los países nórdicos. Por razones de afinidad geográfica, económica, cultural e histórica, a las que se unen aspectos determinantes de carácter político como los derivados de su condición de pequeñas potencias en el marco internacional de la Europa de la época, esas relaciones constituirían un aspecto prioritario en la política internacional de Suecia durante todo el siglo XX.

Por los libros de registro de documentos del Ministerio de Estado correspondientes a 1931 y 1932, los años donde la documentación está perdida o incompleta, consta que la diplomacia española informó sobre las reuniones nórdicas para discutir el estado de la

\footnotetext{
${ }^{138}$ AMAEC, R 850, 19 e, despacho de 13.V.1935; SANDLER, Rickard, Svenska utrikesärenden: anföranden 1934-1935, Estocolmo: Tiden, 1936, pp. 89-91; AMAEC, R 850, 23 e, despacho de 20.I.1936.

${ }^{139}$ AMAEC, R 850, 23. Despacho de 29.VI.1936.

${ }^{140}$ SANDLER, Rickard, Svenska utrikesärenden...; Utrikespolitisk kringblick: anföranden 1936, Estocolmo: Tiden, 1937; Strömväxlingar och lärdomar: utrikespolitiska anföranden 1937-39, Estocolmo: Tiden, 1939.

${ }^{141}$ OHLSSON, Per T, Rickard Sandler, Estocolmo: Bonnier, 2010. Rickard Johannes Sandler (Torsåker 1884 - Solna, 1964) fue miembro de la Junta directiva del Partido socialdemócrata sueco desde 1911 hasta 1952; diputado entre 1912 y 1916; senador de 1919 a 1964; ministro de Finanzas en 1920; ministro sin cartera de 1921 a 1923; ministro de comercio en 1924-25; presidente del gobierno sueco de 1925 a 1926; ministro de Negocios extranjeros de 1932 a 1939 salvo durante el verano de 1936; y gobernador de la región de Gävleborg de 1941 a 1950. En 1909 se casó con Maria Lindberg, de la que tuvo tres hijos.
} 
economía de la primavera de 1931 - al dejarse sentir en Europa las consecuencias de la crisis de Wall Street - y de comienzos de $1932^{142}$.

El papel de Suecia en política exterior a principio de la década que nos ocupa fue analizado por José F. de Villaverde, como Encargado de negocios ad interim, en enero de 1934. Tras enumerar las que consideraba ser las tres razones básicas de la estabilidad de la política internacional sueca - su situación geográfica alejada de todo lugar conflictivo; el equilibrio de su régimen interno que hace que nadie se sienta amenazado por Suecia; y "la alta cultura de esta raza, que la hace consciente de su papel tanto en el concierto de las naciones como en la civilización del norte de Europa" - el Encargado de negocios mencionaba la "aproximación escandinava" como el aspecto de la política internacional sueca de mayor relieve en ese momento ${ }^{143}$.

El asunto no era nuevo, ya que los contactos entre los países escandinavos eran habituales, especialmente a partir de la Primera Guerra Mundial. De hecho, la Legación había informado puntualmente, en enero de 1932, de la conferencia escandinava sobre la situación comercial y financiera ${ }^{144}$.

Asimismo, el escandinavismo parecía resurgir a partir de finales de ese año. En efecto, en octubre se hablaba en Escandinavia de una posible unión entre Suecia, Noruega y Dinamarca, fundamentalmente en temas comerciales y aduaneros, pero también de colaboración en otros campos, ante el peligro nazi. En Suecia, esa propuesta - danesa - de unión comercial y política fue bien acogida. No fue así en Noruega, que estaba por entonces enfrentada con Dinamarca por la controversia sobre Groenlandia ${ }^{145}$.

El origen de esta nueva "ola de escandinavismo" - según José F. de Villaverde - fue el discurso alarmante sobre el peligro nazi del presidente del gobierno danés, en octubre de 1932, y la visita del jefe del gobierno sueco a su colega danés del mes siguiente. En esa visita se había discutido la convocatoria de una reunión conjunta nórdica sobre aspectos políticos y comerciales. Se mezclaban en esto también motivos de política militar, de necesidad por parte de los países escandinavos de garantizar su integridad territorial. Este acercamiento escandinavo venía favorecido por el acceso al gobierno en los tres países (Noruega, Dinamarca y Suecia) de partidos políticos afines, socialistas. La consecuencia podría llegar a tener efecto internacional, al "presentar unidos y compenetrados a tres

\footnotetext{
142 AGA, L. AE 6402, pp. 178-183; AGA, L. AE 6403, pp. 126-128.

${ }^{143}$ AMAEC, R 698, despacho n. 17 (informe semestral), de 15. I.1934.

${ }^{144}$ AMAEC, R 341, 9, a, despacho de 10.I.1932

145 AMAEC, R 341, 9, a, despacho de 28.X.1932.
} 
países de altísima cultura, de gran prestigio y defensores en todo momento de las ideas de paz y democracia”.

Con ocasión de un discurso del Profesor Bertil Ohlin en Copenhague sobre la cooperación nórdica, muy comentado en la opinión pública, la prensa sueca había preguntado a los principales políticos sus puntos de vista sobre el particular. El presidente del gobierno danés, el socialdemócrata Thorvald Stauning, insistía en la necesidad de una estrecha colaboración comercial entre los países nórdicos, aunque no veía factible ni una verdadera unión política ni una alianza militar formal. Por su parte, el presidente del gobierno sueco, Per Albin Hansson, confirmó que era deseable una colaboración estrecha nórdica en materias económicas, mientras que una unión política o militar no era conveniente, ya que cada país nórdico tenía el firme deseo de conservar su independencia nacional. En todo caso, según la prensa sueca, el escandinavismo estaba en auge como no lo había estado "desde la guerra mundial".

Sin embargo, a pesar de las buenas palabras respecto a un "neoescandinavismo", tanto a nivel de líderes políticos como de pensadores y articulistas - se hacía referencia a algunos libros partidistas - los logros reales eran escasos ${ }^{146}$.

El tema saldría a colación también en el informe semestral siguiente, que afirmaba la existencia del propósito de llegar a un acuerdo, pero que sólo se había llegado a tener conversaciones preliminares. Afirmaba la Legación que a Suecia, que "tiene, o pretende tener, por su organización, historia y cultura, una cierta preponderancia o hegemonía sobre los demás países nórdicos, en modo alguno le conviene comprometerse de antemano en pactos o acuerdos de tipo regional".

El Ministro de Asuntos Exteriores de Finlandia, país nórdico pero no escandinavo, había visitado Suecia, y la Legación de España insistía en la cautela y reserva de que su homónimo sueco hizo gala al manifestar que había gran cordialidad y buena disposición, pero no había acuerdo de cooperación alguno con ese país. Esa visita, igual que la de su homónimo letón, había tenido como objetivo primario la aproximación económica y cultural. Este último reflejaba además una aproximación también política entre los países bálticos y Suecia, cosa lógica, ya que era evidente la coincidencia de objetivos, basada en el temor a Rusia y, especialmente, a Alemania.

El acuerdo que se buscaba conseguir se encuadraba en el marco de las propuestas de constitución de un "bloque báltico", tema suscitado por el diputado sueco Lindhagen y que

${ }^{146}$ AMAEC, R 698, despacho n. 17 (informe semestral), de 15. I.1934. 
se había discutido en el Riksdag. La visita tenía también por objeto paliar la mala impresión causada en Suecia por ciertos ataques nacionalistas finlandeses contra el idioma sueco, co-oficial en el país ${ }^{147}$.

En septiembre, en relación con la "aproximación de los países escandinavos", especulaba la diplomacia española sobre el objeto de la Conferencia nórdica de ministros de Asuntos Exteriores que tuvo lugar en Estocolmo los días 6 y 7 de septiembre de 1934. Sugería que quizá se quisiera discutir un posible pacto anti-alemán, aunque esto era poco probable, ya que al estar presente Finlandia, de gobierno no socialista, no cabía una política común de partido (socialista). La conferencia tuvo el efecto de consolidar el liderazgo sueco en Escandinavia, pero no se concretó en propósitos de pactos o de alianzas entre los países nórdicos ${ }^{148}$.

$\mathrm{Al}$ año siguiente, tuvo lugar otra reunión de los Ministros de Exteriores nórdicos, esta vez en Oslo. Se discutieron allí - señalaba la Legación - varios aspectos de cooperación nórdica, pero no el militar, debido a los

ideales pacifistas y la orientación muy contraria al fascismo del gobierno sueco, que esperaba se resolvieran los conflictos dentro del espíritu del Pacto de la Sociedad de Naciones $^{149}$

En diciembre, las relaciones sueco-finlandesas se habían deteriorado por la insistencia finesa en buscar cooperación política y militar más concreta. Fueron necesarias unas declaraciones del jefe del gobierno finlandés en el Riksdag, indicando que los países nórdicos se encontraban unidos en su decisión de llevar a cabo una política de neutralidad ${ }^{150}$.

A finales del año 1934 transmitía la Legación de España el contenido de un discurso pronunciado por el ministro sueco de Negocios Extranjeros Rickard Sandler en Gotemburgo, el 29 de octubre de 1934. El análisis del mismo refleja bien la visión de la Legación - y en especial de su jefe, Alfonso Fiscowich - sobre la política exterior de Suecia. Respecto a la cooperación con los otros países nórdicos, afirmaba éste que Sandler se había mostrado entusiasmado por la unidad de intereses del bloque del norte, que hacía

\footnotetext{
${ }^{147}$ AMAEC, R 698, despacho n. 161 (informe sermestral) del 15. VII.1934; AMAEC, R 341, 9, b, despacho de 1.III.1934.

${ }_{148}$ AMAEC, R 341, 9, b, despachos de 5 y 9.IX.1934.

149 AMAEC, R 850, 19, e, despacho de 1.IX.1935.

${ }^{150}$ AMAEC, R 850, 19, e, despacho de 10.XII.1935
} 
innecesario un pacto regional que pudiera apartarlo de la política de neutralidad que Suecia quería mantener. Sandler declaraba estar seguro de que, en la difícil situación internacional entre paz y guerra, los países nórdicos sumarían sus esfuerzos para ponerlos al servicio de la paz. Suecia aspiraba claramente, en opinión de Fiscowich, a ser el líder del bloque nórdico, "llevándolo a la neutralidad"151.

La cuestión de la defensa fue, sin duda, uno de los principales caballos de batalla de la política sueca de los años treinta del siglo XX, tanto en política interior como exterior. En este último contexto, los intentos de cooperación con los otros países nórdicos en materia de defensa, que fueron uno de los objetivos marcados, no tuvieron éxito. Ello se debió a que cada uno de los países involucrados tenía una visión diferente de su propia situación en lo que se refiere a la seguridad. Suecia y Finlandia intentaron llegar a un acuerdo militar de cooperación sobre el archipiélago de Åland, pero la oposición soviética hizo que Suecia retirara su propuesta.

Como se puede constatar a partir de lo aquí expuesto, la diplomacia española veía a Suecia como el líder de los países nórdicos, liderazgo que utilizó para llevar a los demás al camino de la neutralidad, llevando una política exterior de "ganar tiempo", evitando en lo posible la toma de decisiones y los compromisos concreto de cooperación política y/o militar con sus vecinos nórdicos. Visión ésta que está en línea con la historiografía sueca del período, que vimos en su momento.

\subsubsection{Relaciones bilaterales de Suecia con algunos países entre 1931 y 1936}

Analizaremos finalmente las relaciones bilaterales de Suecia con algunos países, tal como fueron explicadas al Ministerio de Estado por los diplomáticos españoles en Estocolmo. Las importantes relaciones con Alemania fueron ya tratadas en un epígrafe anterior.

En la historiografía sueca se ha visto la política exterior de Suecia entre 1920 y 1935 como desprovista de grandes ambiciones, con buenas relaciones con sus vecinos y rutinarias con las grandes potencias europeas ${ }^{152}$. Veamos cómo se compagina esto con la visión dada por los diplomáticos españoles en Suecia

\footnotetext{
${ }^{151}$ AMAEC, R 341, 9, b, despacho de 31.XII.1934.

152 ÅMARK, Klas, Att bo granne med ondskan...., p.74; cfr. también LÖNNROTH, Erik Den svenska utrikespolitikens historia, Del 5, 1919-1939, Estocolmo: Norstedt, 1959, passim.
} 


\subsubsection{Inglaterra}

Como ya ha quedado de manifiesto en los epígrafes anteriores, en la política exterior sueca de los años treinta del siglo XX se produce un gran acercamiento a Inglaterra, por motivos económicos - dependencia de la corona sueca de la libra esterlina, abundante comercio, etc. - pero también políticos. No en vano se trataba de los dos sistemas parlamentarios modernos más antiguos del mundo, unidos por la afinidad democrática de sus instituciones.

Los contactos entre Inglaterra y Suecia fueron intensos en los años que nos ocupan. De la importancia de las relaciones son prueba fehaciente las dos visitas de altas personalidades británicas a Suecia: el príncipe de Gales, futuro Eduardo VIII, en octubre de 1932 y el Lord del Sello Privado, Anthony Eden, en el otoño de 1934.

La visita del príncipe de Gales, protocolaria, la explica la diplomacia española en clave comercial, como una consecuencia lógica de haberse convertido Inglaterra, por la tirantez de las relaciones comerciales de Suecia con Alemania, en el principal socio comercial del país escandinavo ${ }^{153}$.

A comienzos de 1934 explicaba la diplomacia española que el motivo "del constante deseo de Suecia de seguir en todo la política monetaria inglesa” era la ligazón fundamental entre la corona sueca y la libra esterlina, divisa ésta que constituía la principal garantía de aquella, una vez Inglaterra había abandonado el patrón oro. Según este mismo despacho, la prensa socialista sueca había comentado la Conferencia desde un punto de vista "doctrinario y de partido" mientras que la conservadora había publicado un artículo de un conocido economista, Gustaf Cassel, criticando duramente a la Conferencia y propugnando la creación de una moneda internacional, pactada entre Inglaterra, sus Dominios, Escandinavia, Sudamérica y posiblemente Japón, lo que llamó el sterling block, como medio importante de conseguir la estabilidad económica mundial ${ }^{154}$.

Si la visita del Príncipe de Gales fue de índole comercial, la de Eden, en 1934, tuvo un contenido netamente político. Alfonso Fiscowich la encuadró en el marco de la semejanza de la política exterior de Inglaterra y de Suecia en el tema del desarme, y la relacionó con el interés británico de controlar o influir la reunión de los Ministros de Exteriores nórdicos en Estocolmo. Según el diplomático español, dado que Suecia no quiere acercarse ni a Rusia ni a Alemania, parecía que Inglaterra veía la posibilidad de

\footnotetext{
153 AMAEC, R 341, 9, a, despachos del 28.IX.1932 y del 13.X.1932.

${ }^{154}$ AMAEC, R 698/10, despacho n. 17 (informe semestral) de 15.I.1934.
} 
atraer a Escandinavia a su propio círculo de influencia. Sin embargo - decía Fiscowich Suecia parecía nerviosa, y los diplomáticos acreditados en Estocolmo no sabían a ciencia cierta qué ocurría realmente, ya que circulaban rumores acerca de una posible entrevista Eden-Papen en Suecia, la URSS se sentía en la picota de la opinión pública sueca y en los medios soviéticos de Estocolmo había cundido una cierta alarma. Posteriormente, la Legación confirmó que la visita había sido en relación con la visión de Suecia como líder del grupo escandinavo, aunque resaltando que la solidaridad escandinava era muy relativa $^{155}$.

De hecho, las gestiones británicas para atraerse a Suecia a su esfera política no dejaron de tener su eficacia. Buen muestra de ello era la simpatía con que la posición de Inglaterra en la totalidad del problema se había seguido en Suecia, que quizá - según Fiscowich - exteriorizarse de nuevo en la próxima reunión de Ginebra. Se trataba del problema de la crisis italo-etíope, que fue sin duda la más grave en la que Suecia se vio implicada de modo directo, como enseguida veremos. En el conflicto, Suecia se plegó, efectivamente, a la línea inglesa, aunque mantuvo su total autonomía de acción, concretada en la imposición unilateral de sanciones ${ }^{156}$.

Fiscowich estimaba también que Suecia se inclinaría del lado inglés en caso de guerra entre las grandes potencias, pero "no apoyaría ni a Rusia ni a Francia"157. Esta frase resume muy bien el núcleo fundamental de la información de los diplomáticos españoles sobre las relaciones sueco-británicas en el período: la sintonía sueca con su vecino del Mar del Norte.

\subsubsection{Italia y el conflicto de Abisinia}

Sobre las relaciones de Suecia con la Italia fascista durante la década de los treinta del siglo XX sostiene Cantera Carlomagno, que analiza la cuestión a la luz de la documentación diplomática italiana, que durante la mayor parte de la década, Italia veía en Escandinavia un bloque de países que podrían constituir un grupo independiente en política exterior, que podría oponerse con éxito a las líneas preconizadas por Alemania, Inglaterra y la Unión Soviética. Italia consideraba que Suecia podría ser un valioso aliado para detener el expansionismo germánico.

\footnotetext{
${ }^{155}$ AMAEC, R R 341, 9, b, despachos de 19.X.1934 y de 30.XI.1934.

${ }^{156}$ AMAEC, R 344, 15, telegramas n. 16 de 31.III.1935 y n. 54 de 23.XI.1935.

${ }^{157}$ AMAEC, R 850, 18, despacho reservado de 29.I.1935.
} 
Los diplomáticos italianos en Estocolmo llegaron incluso a transmitir a Roma la impresión de que el gobierno sueco, y en particular su presidente Per Albin Hansson, hasta la crisis de Abisinia en el verano de 1935, veían con simpatía al fascismo italiano, y presentaban las reformas sociales del gobierno sueco como inspiradas en las ideas fascistas ${ }^{158}$. Sin embargo, esta visión de los diplomáticos italianos no parece congruente con la actitud de la socialdemocracia sueca ante el régimen fascista durante esos años ${ }^{159}$.

En diciembre de 1933, López Oliván envió a Madrid el texto de un artículo aparecido en el diario Social Demokraten que, según los diplomáticos españoles, exponía bien la opinión sueca sobre la actitud de Italia con respecto a la Sociedad de Naciones. Acusaba éste a Mussolini de querer convertir la organización internacional en una dictadura de grandes potencias, prescindiendo de los países pequeños. Ya en los años veinte, el presidente del gobierno sueco, Hjalmar Branting, había tomado la iniciativa en la Sociedad de Naciones en contra de Italia por el asunto de Corfú, y Suecia debía seguir oponiéndose a todo intento de relegar a las pequeñas potencias en beneficio de las grandes ${ }^{160}$.

A pesar de ser conscientes de las prevenciones suecas frente a Italia, los diplomáticos españoles señalaron que Suecia se había dejado llevar por consideraciones de política exterior, tratando de contentar a Italia, con motivo de la concesión del Premio Nobel de Literatura al italiano Luigi Pirandello. Efectivamente, la documentación diplomática, en forma de telegramas reservados, no deja lugar a dudas sobre las presiones que diversos gobiernos, entre ellos el español, ejercieron en diversas ocasiones, por vía diplomática, para tratar de influir en la concesión del premio Nobel de Literatura ${ }^{161}$.

El conflicto italo-sueco en relación con el problema de Abisinia, envenenado por el bombardeo italiano de una ambulancia de la Cruz Roja sueca en suelo africano, hundía sus raíces en el hecho de que Haile Selasie, el Emperador etíope, se había rodeado desde 1934 de asesores militares suecos para la instrucción de su ejército y su policía ${ }^{162}$.

El primer día del año 1936 se hizo público el bombardeo italiano a la ambulancia sueca, que había causado dos heridos. La opinión pública sueca acogió la noticia con irritación, y el gobierno con "extremo resentimiento por no haber recibido del gobierno italiano palabra alguna de excusa o sentimiento". El gobierno sueco consideró la actuación

\footnotetext{
${ }^{158}$ CANTERA CARLOMAGNO, Ett folk av mänsklig granit ..., pp. 11-12.

159 Cfr. por ejemplo ARGENZIANO, Mikael, "Klasskamp och kulturell inmunitet. Svenska socialisters reaktion inför den italienska fascismen 1919-1929”, en Scandia 4/1995, pp. 197-238.

${ }^{160}$ AMAEC R, R 341, 9, a, despacho de 12.XII.1933.

${ }^{161}$ AMAEC, R 243, 12, telegrama núm. 33 de 12-XI.1934; cfr. AMAEC R2, 19.

${ }^{162}$ GYLLENHAAL, Lars \& WESTBERG, Lennart, "I etiopisk tjänst 1934-1936. För lejonet av Juda", en Svenskar i Krig 1914-1945, Lund: Historiska Media, 2006, pp. 103-109.
} 
italiana como una maniobra deliberada $y$, según informaciones confidenciales que Fiscowich dice haber recibido, amenazó al italiano con llevar el asunto al Tribunal permanente de Justicia Internacional. Al final no se llevó a cabo la amenaza. El Príncipe Carlos de Suecia, presidente de la Cruz Roja sueca, publicó una dura crítica al Ejército italiano, hecho que motivó una protesta de Il Giornale d'Italia.

El conflicto dejó un abundante rastro documental en los informes de los diplomáticos españoles a Madrid, especialmente en 1935. El Ministerio de Estado preguntó en mayo de ese año a la Legación de España en Estocolmo que averiguara si Italia había tratado de impedir el suministro de armas suecas a Abisinia y qué había respondido el gobierno sueco. La respuesta había sido que Suecia no había dado aún licencia de exportación de armas, pero que quizá habían llegado allí de forma informal.

En la segunda mitad del año, la actitud de Suecia respecto a Italia, se endureció. El 18 de octubre, el gobierno sueco acordó levantar la prohibición de exportación de armas destinadas a Abisinia, manteniéndola respecto a Italia, y aplicando otras medidas financieras contra ella. Italia protestó oficialmente. Al final, Suecia apoyó las directrices inglesas en el contencioso, distanciándose de algunas propuestas francesas. Finalmente, Suecia cedería y las sanciones contra Italia serían suspendidas en julio de $1936^{163}$.

Sin embargo, el hecho de que las grandes potencias democráticas europeas, Inglaterra y Francia, no quisieran llevar las sanciones a sus consecuencias más gravosas (por ejemplo, a la prohibición de la exportación de petróleo a Italia), llevó a Suecia y a otros pequeños países europeos a la convicción de que la Sociedad de Naciones era un instrumento sin fuerza. En 1936, Suecia hizo pública una declaración en la que anunciaba su distanciamiento de la política de sanciones y la vuelta a la política de neutralidad estricta. Más tarde, en abril de 1938, el gobierno sueco manifestó que, en caso de guerra en Europa, Suecia se mantendría neutral ${ }^{164}$.

\footnotetext{
${ }^{163}$ AMAEC R 344, 15, telegrama n. 16 de M. Estado a Legación, de 14.V.1935 y respuesta por telegrama n. 22 de 15.V.1935; n. 37 de Legación de 22.VIII.1935 y respuesta de M. Estado de 29 de 27.VIII.1935; Circular reservada M. Estado n. 6; despachos n. 207 y 208 de Legación a M. Estado; telegrama n. 38 de Legación a M. Estado de 30.VIII:1935; telegramas de M. Estado a Legación, nn. 32 y 33 de 16 y 26.X.1935, respectivamente; telegramas de Legación a M. Estado nn. 41, 42, 46, 52, 53 y 54, de 18.X, 19.X, 6.XI, 15.XI., 20.XI y 23.XI.1935; AMAEC, R 698, despacho n. 33 de la Legación de España en Roma.

${ }^{164}$ AMAEC, R 615, 31, telegramas nn. 1 y 3 Legación de 10 y 15.I.1936; SILANDER, op. cit.
} 


\subsubsection{La Unión Soviética}

Las relaciones de Suecia con su vecino oriental fueron siempre extremadamente difíciles. De hecho, Suecia - con Finlandia, que fue parte de Suecia hasta 1809 - ha considerado siempre a Rusia como a su enemigo natural. A lo largo de toda su historia, ambos países han estado en pugna constante por el control del Báltico. El recuerdo de la derrota ante Rusia en Poltava en el siglo XVIII, que puso fin a las ambiciones imperiales de Carlos XII de Suecia, y la pérdida de Finlandia ante el gran país eslavo en 1809, son hitos importantes en la memoria histórica sueca.

El radical cambio de régimen en Rusia, tras la Revolución de 1917, y su desarrollo posterior durante el período de entreguerras, no supuso ningún acercamiento de posiciones entre ambos países, a pesar de que entre 1905 y 1917, muchos revolucionarios rusos se habían refugiado en Suecia y conspiraron desde ella, entre ellos el propio Lenin ${ }^{165}$.

El archivo del Movimiento Obrero sueco, en Estocolmo, contiene gran cantidad de fondos acerca de los contactos entre organizaciones suecas y soviéticas a partir de 1917, desde los archivos personales del que fuera primer cónsul soviético en Suecia, Fredrik Ström, pasando por los de Georg Branting - que en los años treinta fue abogado de la Legación soviética en Estocolmo - o los de los diplomáticos suecos en la URSS Nils Lindh y Per-Emil Brusewitz, hasta los de políticos del más alto rango, como Hjalmar Branting, Olof Palme, o los esposos Myrdal. Los fondos archivísticos ponen claramente de manifiesto la actitud sumamente positiva del comunismo sueco respecto al soviético, así como la actitud más reservada del resto del movimiento obrero, y la más hostil de la socialdemocracia, en particular por parte del presidente del gobierno Per Albin Hansson y su Ministro de Negocios Extranjeros Rickard Sandler. En esto coincidían sus correligionarios de los otros países nórdicos ${ }^{166}$.

Rickard Sandler, en particular, fue descrito por su más reciente biógrafo como "ardiente antibolchevique completamente escandalizado por la política de terror de Stalin", a la par que "fervoroso antinazi siempre opuesto a cualquier concesión a la Alemania nazi”. En el Congreso del partido socialdemócrata de 1932, había sido él quien alertara frente a la tentación de "tratar de trasplantar el experimento soviético a la realidad sueca", señalando que últimamente había seguido de modo particular lo que sucedía en la Unión

165 BJÖRKEGREN, Hans, Ryska Posten. De ryska revolutionärerna i Norden 1906-1917, Estocolmo: Bonnier, 1985.

${ }^{166}$ GOGMAN, Lars, "Tårarna kommo ofrivilligt i ögonen”, Sovjetunionen, Estocolmo: ARAB: Guía de fondos del archivo del Movimiento obrero sueco referidos a laUnión Soviética. 
Soviética y pensaba que había motivos para ser muy precavidos: "Lo que se hace en Rusia se hace en régimen de dictadura de un solo partido, algo que nunca sería posible en Suecia mientras quede la más mínima ascua de la alta estima del valor de la libertad que es patrimonio común aquí" 167 .

La fundación de la Internacional Comunista y su decisión de destruir el movimiento de los sindicatos y partidos socialdemócratas del norte de Europa, a los que llamaban a veces "social-fascistas", fueron decisivas en la consolidación de la actitud hostil de la socialdemocracia sueca respecto a la URSS y llevaría a la inclusión de las organizaciones comunistas en la lista de organizaciones sospechosas de ser "hostiles al Estado". Por ello, habrían de ser los sindicatos de corte comunista, por ejemplo el de los mineros, los que desarrollarían estrechos vínculos con su homónimo soviético ${ }^{168}$.

De nada servirá, en lo que se refiere a Suecia, el cambio de orientación soviético a mediados de década, de favorecimiento de la política de promoción de los Frentes Populares. Esa política, que tanta resonancia tuvo en Francia y en España, no tendrá éxito alguno en Suecia, por la enorme preponderancia del sindicato socialdemócrata dentro del movimiento obrero sueco, dentro del cuál todos los otros grupos (socialistas, anarcosindicalistas y comunistas) eran totalmente marginales.

Probablemente consciente de la especial rivalidad sueco-rusa, el Ministerio de Estado español envió a la Legación en Estocolmo, en los últimos meses de la Monarquía, un telegrama cifrado informando que el Gobierno español aumentaba los aranceles a Rusia respecto a la madera para favorecer las exportaciones suecas a España, y que esperaba que el gobierno sueco correspondiera con aranceles al coñac, uva y frutas franceses ${ }^{169}$.

Varios informes de la Legación en 1931 versaron sobre actividades comunistas en Suecia. En ellos se informaba acerca de un presunto caso de espionaje soviético, de una entrevista con el jefe de una delegación rusa a Estocolmo y acerca de las dificultades económicas de la Unión Soviética. También se envió un artículo ruso sobre el comunismo en España. Por ello, sorprende un tanto que el Ministerio de Estado pidiera a Suecia que cursara invitación a Rusia, en nombre del gobierno español, para la participación de éste en

\footnotetext{
${ }^{167}$ OHLSSON, Per T, op.cit., pp. 78-88, 98 y 104.

168 Sobre la actitud de la Unión de Sindicatos suecos LO respecto a los sindicatos soviéticos, cfr. VENNERSTRÖM, Ivar, Den ryska fackföreningsrörelsen (LO:s Skriftserie, 20) y OLBERG, Paul, SovjetRysslands internationella fackföreningspolitik (LO:s Skriftserie, 21), Estocolmo: LO, 1928. Sobre las impresiones acerca de la URSS de la Sección femenina del Partido socialdemócrata sueco, cfr. Morgonbris, junio 1934, y ARAB, Hulda Floods arkiv; Hilma Petterssons arkiv.

${ }^{169}$ AMAEC, R 2, 19, telegrama cifrado de M. Estado a Legación, de 14.I.1931
} 
las conferencias telegráficas de Madrid, ya que no debía ignorar Madrid que las relaciones entre Suecia y la Unión Soviética no eran precisamente amistosas ${ }^{170}$.

De todas formas, mediada la década, hubo intentos de mejorar esas relaciones, en concreto mediante un viaje de Sandler a la Unión Soviética, cuyo significado no pasó desapercibido para la Legación de España Sandler, como presidente de la Asamblea de la Sociedad de Naciones, había dado la bienvenida en enero de ese año a la Unión Soviética como nuevo miembro.

En el mismo sentido ha de entenderse la propuesta del gobierno sueco al Riksdag, a petición rusa, de la concesión de un crédito a ese país por valor de 100 millones de coronas. El crédito se inscribiría en el marco de un acuerdo comercial bilateral, en la línea de la política comercial sueca del momento. Los diplomáticos españoles informaron con sorpresa al gobierno de Madrid que el Parlamento sueco había paralizado esos planes, declarando inconstitucional la maniobra del gobierno, y que, para evitar el desaire de ver su petición desestimada por el gobierno sueco, el gobierno soviético retiró su solicitud ${ }^{171}$.

El fracaso del acuerdo comercial exacerbó aún más las diferencias entre los dos países, y en un discurso a finales de 1934, Sandler se vio obligado a defenderse de las acusaciones rusas de que Suecia estaba suministrando armas para la militarización del archipiélago finlandés de Åland y del estrecho ${ }^{172}$.

Poco antes, como ya expusimos, en relación con la visita de Eden a Suecia, había habido rumores de una posible entrevista de éste con Papen en Estocolmo. El Ministro de España en Estocolmo no dejó de constatar, al respecto, las reservas suecas respecto a Rusia $^{173}$.

Las relaciones entre Suecia y la Unión Soviética, por tanto, permanecieron distantes durante toda la década, y al final de la misma llegaron a ser aún más tensas, tras el ataque soviético a Finlandia el 30 de noviembre de 1939. Tampoco mejorarían durante los años de la segunda guerra mundial.

Como hemos podido ver, la diplomacia española no duda en resaltar el alineamiento de Suecia con Inglaterra, y su distanciamiento de las dos grandes dictaduras del momento, la Alemania hitleriana y la Rusia estalinista.

\footnotetext{
${ }^{170}$ AGA, L. AE 6422, pp. 168-176; AMAEC, R 95, telegrama de M. Estado a Legación, de 3.IX.1932.

${ }^{171}$ AMAEC R 341, 9, b, despacho de 2.III.1934

172 AMAEC R 341, 9, b, despacho de 31.XII.1934.

${ }^{173}$ AMAEC R 341, 9, b, despacho de 31.XII.1934; AMAEC R 850, 18 despacho de 29.I.1935.
} 



\section{Capítulo 5}

\section{LAS RELACIONES BILATERALES ENTRE ESPAÑA Y SUECIA DE 1931 A 1936}

Anoche, entre la gente diplomática, les tocó el turno a los más desafectos a la República: los de Italia, Argentina, Alemania... sin contar a los suecos, que son insoportables ${ }^{l}$.

\subsection{Suecia ante el cambio de régimen político en España}

Comenzamos nuestra exposición analizando la actitud tomada por Suecia ante el cambio de régimen político en España. La cuestión fundamental es si hubo o no un cambio en las relaciones diplomáticas entre ambos países con motivo del paso del sistema de gobierno de la Monarquía a la República.

\subsubsection{El reconocimiento de Suecia al gobierno de la República Española}

Luis V. Pérez Gil, al hablar del reconocimiento internacional de la Segunda República, sitúa a Suecia en el grupo de países democráticos europeos que lo hicieron "en los días siguientes" al reconocimiento de la República por parte de Francia el 18 de abril de 1931, desviándose de la línea de reserva inicial adoptada por Inglaterra ${ }^{2}$. Pero esto no es del todo exacto. En efecto, en los días siguientes a la proclamación de la República, García Conde, Ministro de la joven República Española en Estocolmo, hubo de afrontar un serio problema: la Suecia de Gustavo V mostraba una actitud recelosa y de extrema reserva hacia el nuevo régimen, que se manifestaba en la negativa inicial a reconocer al gobierno provisional de la República. Sólo tras una semana de intensos contactos diplomáticos con su consecuente tráfico de telegramas, se decidió Suecia a reconocer al gobierno republicano español ${ }^{3}$.

\footnotetext{
${ }^{1}$ AZAÑA, Manuel, Diarios completos, Barcelona: Crítica, 2000, entrada del día 30.IV.1933, p. 183.

2 PEREZ GIL, Luis V., Análisis de la política exterior de los Estados. Su aplicación a las relaciones exteriores de España durante el bienio republicano-socialista (1931-1933), La Laguna: Univ. de la Laguna, 2001.

${ }^{3}$ AMAEC, R 2, 19, telegramas cifrados de fechas 16-22 abril de 1931.
} 
En efecto, el 16 de abril informaba García Conde a Madrid que había pedido oficialmente el reconocimiento sueco del cambio de régimen y que la respuesta vendría una vez el Rey Gustavo V regresara de un viaje en el extranjero y presidiera el Consejo de Ministros al final de la semana siguiente.

Con todo, la urgencia del asunto motivó una conversación telefónica posterior del Ministro sueco de Negocios Extranjeros con la Legación de España:

Acaba llamarme Ministro Negocios Extranjeros para notificarme que después de haber visto este Soberano que regresó anoche han resuelto que próximo viernes se reuniese consejo ministros donde será reconocido de hecho gobierno provisional español aplazando reconocimiento de derecho hasta reunión Cortes constituyentes ${ }^{4}$

Tras nuevas gestiones y presiones por parte de la Legación de España, pudo García Conde escribir a los pocos días que

Apresúrome informar vuecencia que sin esperar consejo ministros viernes este gobierno ha reconocido hoy gobierno provisional republica española, según acaba de notificarme Ministerio Negocios Extranjeros. García Conde ${ }^{5}$.

Efectivamente, el ministro sueco de Negocios Extranjeros solicitó al resto del gobierno la aprobación del reconocimiento del gobierno provisional de la República el 19 de abril ${ }^{6}$.

La reserva sueca produjo estupor en las autoridades republicanas, como puso de relieve Lerroux en un nuevo telegrama a la Legación de España en Suecia, en un intento de evitar un reconocimiento meramente de hecho:

Ruégole gestione con todo tacto, si aun fuera posible, que reconocimiento de derecho sea inmediato, es decir, sin esperar reunión Cortes Constituyentes, para evitar mal efecto que produciría en esta opinión esa reserva, que hasta ahora no ha planteado ninguna otra nación. Lerroux.

La respuesta, a vuelta de correo telegráfico ese mismo día, dice:

\footnotetext{
${ }^{4}$ AMAEC, R 2, 19, telegrama cifrado de 16.IV.1931.

${ }^{5}$ AMAEC, R 2, 19, telegrama cifrado de 21.IV.1931

${ }^{6} \mathrm{RA}, \mathrm{UD}, 1920$-års dossierssystem, Vol. 12.
} 
Recibido telegrama 4 precisamente en tiempo para hacer gestión cerca de Ministerio Negocios Extranjeros he podido obtener que instrucciones telegráficas a representante Suecia en Madrid encomendándole notificación oficial a VE fuera dada manifestando únicamente que Gobierno Suecia reconocía al provisional español sin añadir palabra "de hecho"7.

A pesar de la consternación de los políticos republicanos españoles, la actitud de Suecia ante el reconocimiento de la República Española era bastante consecuente con la cauta política exterior del país, caracterizada, como veíamos en los capítulos anteriores, por la ausencia de precipitación y el deseo de conservar el mayor tiempo posible la libertad de acción en materias internacionales. Oficialmente, además, Suecia reconocía Estados, no gobiernos.

Este es el sentido, a nuestro juicio, en el que hay que enmarcar la reservada y poco entusiasta respuesta de Suecia a los sucesos del 14 de abril en España. Otra muestra de esa reserva fue la negativa sueca a enviar felicitaciones por telegrama al Presidente de la República con motivo de su toma de poder el 11 de diciembre de 1931, a pesar de la sugerencia del ministro sueco en Madrid, por telegrama cifrado, de que así se hiciera ${ }^{8}$.

De hecho, hasta un año después, no encontramos en los despachos diplomáticos suecos una actitud definida acerca lo que podríamos llamar el "asentamiento" de la República. Con ocasión del primer aniversario de la República, el Ministro sueco en Madrid decía que una vuelta a la Monarquía era impensable en ese momento, y que los peligros para la República venían de las izquierdas ${ }^{9}$, opinión ésta última que corregiría después, al informar de las claras medidas tomadas por el gobierno de la República contra los elementos perturbadores del orden, y especialmente tras la llamada Sanjurjada, que puso de manifiesto el riesgo de que la Republica cayera a causa de un pronunciamiento militar $^{10}$.

Sin embargo, esa cautela por parte de Suecia no fue obstáculo para que el país nórdico apoyara la candidatura de España a la reelección como miembro del Consejo de la Sociedad de Naciones, a finales del verano de 1931. García Conde informó que el Ministro de Negocios Extranjeros sueco, en conversación personal con él, se había expresado "con viva simpatía hacia España" y le había asegurado que votaría a favor de la

\footnotetext{
${ }^{7}$ AMAEC, R 2, 19, telegrama n. 4 del M. de Estado a la Legación de España y contestación de ésta, del 22.IV.1931. La cursiva es nuestra.

${ }^{8}$ RA, UD, 1920-års dossiersystem, DS, P 178.

${ }^{9}$ RA, UD, 1920-års dossiersystem, HP, vol. 421, despacho de 16.IV.1932

${ }^{10}$ RA, UD, 1920-års dossiersystem, HP, vol. 421, informe confidencial de 29.IV.1932 y despacho n. 321 de 14.VIII.
} 
reelección de España como miembro del Consejo de la Sociedad y animaría a sus colegas de los otros países escandinavos, Holanda y Bélgica a hacer lo propio ${ }^{11}$.

La llegada al poder en Suecia del partido socialdemócrata, en septiembre de 1932, supondría un paso más en el afianzamiento de las buenas relaciones entre los dos países, a pesar del cambio de signo del gobierno español en 1933. No insistiremos en este punto, que hemos expuesto ya anteriormente.

Finalmente, en el contexto de las reservas suecas frente a la República Española, no podemos dejar de mencionar la animosidad con la que Manuel Azaña veía a los representantes diplomáticos suecos en Madrid, y en particular a la esposa del ministro Danielsson por su actitud promonárquica, lo cual llevaría a un conflicto diplomático de entidad en la primavera de 1936.

Aunque en el fondo hubiera diferencias básicas de concepción política respecto al mejor régimen de gobierno, republicano o monárquico, el conflicto Azaña-Danielsson parece deberse en un primer momento más a una cuestión personal que a una de principio, al menos si nos atenemos a lo que dice el propio Azaña en sus diarios y al hecho de que en alguna ocasión, sobre todo durante el primer bienio republicano, el Ministro de Suecia en Madrid tuviera palabras de elogio y admiración para el político español ${ }^{12}$.

De todas formas, es cierto que, como veíamos anteriormente, la visión que dio Danielsson a su gobierno de la experiencia republicana española no fue en su conjunto positiva. Además, por nacimiento y formación, está claro que los Danielsson eran personas de actitudes claramente monárquicas y conservadoras.

Por su parte, los diplomáticos españoles tuvieron siempre para el diplomático sueco el trato deferente y cordial propio de la profesión, como quedó de manifiesto, por citar sólo un ejemplo, en el interés mostrado por el Subsecretario de Estado por la salud de la Sra. Danielsson, operada de un cálculo renal en $1932^{13}$.

De lo que no cabe dudar, en cualquier caso, es que Manuel Azaña no podía soportar a Ivan Danielsson, y en particular a la esposa de éste. Así, en la anotación del diario de Azaña 30 de abril de 1933, se incluye el siguiente relato:

\footnotetext{
${ }^{11}$ AMAEC, R 2, 19, despacho de 28.VIII.1931

${ }^{12}$ RA, UD, 1920-års dossiersystem, HP, vol. 421, despacho de 14.VIII.1932, donde Danielsson califica a Azaña de "gran hombre de Estado".

${ }^{13}$ AMAEC R 95, 15, telegramas n. 4 de M. Estado a Legación y n. 16 de Legación España a M. Estado, de 11. VII.1932.
} 
Anoche, entre la gente diplomática, les tocó el turno a los más desafectos a la República: los de Italia, Argentina, Alemania... sin contar a los suecos, que son insoportables. Ella, la ministra, raya en lo impertinente, de monárquica que es. Se atrevió a preguntarle a Ramos por qué nos habíamos empeñado en hacer la carretera de Alicante a la playa de San Juan (la carretera de la obstrucción), que no hace falta para nada. Y otras muchas tonterías. Le he encargado a Ramos que escriba a López Oliván, nuestro ministro en Suecia, a ver si se puede conseguir el relevo de esta señora Danielson. La grosería de la Danielson llega a esto: cuando López Oliván fue nombrado ministro en Suecia, estuvo en visita de cortesía en la Legación sueca, y dijo a la señora que se alegraba mucho de ir destinado a Estocolmo. "Lo creo", contestó la Danielson ${ }^{14}$.

A primera vista, el asunto podría no ser más que una anécdota. Sin embargo, es muy llamativo el hecho de que el jefe del gobierno de la República Española incluya a los representantes diplomáticos de un país como Suecia, de honda raigambre democrática y en ese momento gobernado por un partido socialista, entre los diplomáticos "más desafectos a la República”, y los mencione junto con los de países como Argentina, la Italia fascista y la Alemania nazi (!).

Además, el asunto no quedaría ahí. La gestión encargada por Azaña se vio frustrada, al poco tiempo, por el cambio de gobierno en España. Y no deja de ser significativo que, a la vuelta de Azaña al poder, en la primavera de 1936, el asunto Danielsson no hubiera caído en el olvido por lo que a aquel se refiere. De hecho, y tras reiterados intentos de la Legación de España, especialmente tras el nombramiento de Azaña como Presidente de la República, el gobierno sueco acordó la sustitución de Danielsson. El telegrama cifrado dirigido al Subsecretario de Estado de la República Española el 25 de abril de 1936 lo expone claramente:

Descifre vuecencia personalmente. Recibo hoy carta confidencial 18 corriente. Gobierno tomando en consideración sugestiones tiene acordado sustitución. Ha iniciado preliminar combinación para llevarla cabo primeros julio próximo. Ignorando todavía interés proyecto en marcha. En vista de tal disposición he creído deber evitar dar a gestión realizada hoy carácter nueva petición reiterada, limitando la pregunta sobre propósito gobierno Suecia respecto persona aludida. He observado se comprende y comparte aquí punto de vista del Gobierno de la Republica, hallándose dispuestos todas facilidades y agradecido modalidad presente caso, esperando a mi vez lograré aprobación. Fiscowich ${ }^{15}$

\footnotetext{
${ }^{14}$ AZAÑA, Manuel, Diarios completos, Barcelona: Crítica, 2000, entrada del día 30.IV.1933, p. 183.

15 AMAEC R 615, 31, telegrama cifrado n. 15 del 25.IV.1936. Al respecto, cfr. también PETRI, op. cit., p. 38.
} 
Sin embargo, Suecia no dejaría de tomar una represalia diplomática al respecto, al no enviar ningún representante de rango a la ceremonia de nombramiento presidencial de Azaña, no permitiendo siquiera la asistencia del Ministro de su Legación, el propio Danielsson, ignorando todas las gestiones diplomáticas españolas al respecto e incluso haciéndolo saber así al Ministerio de Estado mediante comunicación del Subsecretario sueco de Exteriores, en lugar del Ministro ${ }^{16}$. De hecho, al nuevo presidente de la República Española no le llegó ni siquiera un telegrama de felicitación desde Estocolmo, ni se le deseó suerte. Aparte de lo ya dicho, sentó mal en Suecia que Azaña enviara a Suecia su carta de presentación como Presidente tan sólo una vez empezada la guerra y, además, con errores de protocolo ${ }^{17}$.

Es posible, con todo, que el desplante diplomático no fuera tanto el resultado de una acción diplomática deliberada como consecuencia de una negativa directa por parte de Ivan Danielsson a cumplimentar personalmente a Azaña. Así parece sugerirlo la existencia de un telegrama del Ministerio sueco de Negocios Extranjeros conminando a Danielsson a asistir, anterior a las gestiones oficiales que acabamos de referir ${ }^{18}$.

Sin embargo, por lo expuesto - y por la evolución posterior de los acontecimientos parece que, por lo que a la esposa del diplomático sueco se refiere, la prevención de Azaña en su contra estaba justificada. Nos referimos aquí a un tema del que hasta ahora no se ha ocupado, que sepamos, la historiografía sueca, a saber: las acusaciones a la Sra. Danielsson de simpatías hacia los países del Eje, que fueron la causa de la declaración de su esposo como persona non grata en Egipto durante la Segunda Guerra Mundial, forzando al gobierno sueco a su sustitución.

Al respecto, hemos encontrado en los archivos suecos documentación en forma de una carta confidencial del Foreign Office británico del 20 de abril de 1942, que lo indica claramente, añadiendo que ya Azaña había procedido antes a su "expulsión" de España.

Asimismo, consta que el asunto de la expulsión de España fue sacado a la luz por el diario sueco Arbetaren el 6 de marzo de 1953, citando como fuente a un diplomático alemán llamado Welczek, que habría escrito que Danielsson fue expulsado de España por Azaña a causa de la antipatía de éste y de su esposa por los gobiernos de izquierdas de la República Española, citando además unas presuntas confidencias de Salazar a Danielsson que era también Ministro de Suecia ante Portugal - sobre la ayuda que ese país pensaba

\footnotetext{
${ }^{16}$ AMAEC R 615, 31, telegramas n. 19 y 20, Legación Estocolmo a M. Estado, del 8.V.1936

${ }^{17}$ RA, UD, 1920-års dossiersystem, P 178, telegrama n. 10 b y despacho n. 233 de 10 .V.1936.

${ }^{18}$ RA, UD, 1920-års dossiersystem, P 178, telegrama a Danielsson.
} 
prestar a Franco. Sin embargo, el Ministerio sueco de Negocios Extranjeros desmintió esa información como "totalmente errónea"19.

Pensamos que las acusaciones de simpatía con el nazismo hacia Danielsson no tienen base real, sin que ello quiera decir que no tuviera una actitud crítica hacia la República Española, pues sí la tenía.

En consonancia con lo que exponíamos en el capítulo anterior al tratar del nazismo en Suecia, consideramos más plausible hablar, en el caso de Danielsson, de progermanismo más que de nazismo, pues ése es el perfil propio de la gente de su clase, al menos por lo que se refiere al período que ahora mismo nos ocupa, 1931-1936. Además, su labor en Budapest en 1944 a favor de los judíos húngaros perseguidos por el nazismo alemán le valió el título póstumo de "Justo entre las Naciones", lo cual encaja mal con las acusaciones de simpatizar con el nazismo ${ }^{20}$.

Tema distinto es la actuación posterior de Danielsson en los años de la guerra española - donde la evidencia muestra una clara decantación del diplomático por la causa franquista, como tendremos ocasión de comentar más en detalle al analizar las relaciones de Suecia con la España de Franco - y su actividad diplomática en Egipto durante los primeros años de la Segunda Guerra Mundial.

A pesar de esta frialdad inicial en las relaciones entre la República Española y Suecia, la situación cambiaría pronto, como manifestó López Oliván en febrero de 1934:

El advenimiento de la República en España, si tal vez ha podido ser visto con recelo y disgusto por la Corte, ha despertado, por el contrario, una curiosidad viva y simpática en los medios políticos, sobre todo de la izquierda y, principalmente, en el socialismo, que asume en estos momentos la gobernación del Estado ${ }^{21}$.

\subsubsection{Alfonso XIII y Suecia tras la instauración de la República Española}

El cambio de régimen en España conllevó incluso algunas dificultades protocolarias. La bandera española no pudo ondear en el edificio de la Legación en Suecia hasta que llegó una bandera republicana desde Madrid ya pasado el verano de $1931^{22}$. Otro ejemplo concreto fueron las cuestiones relacionadas con las condecoraciones mutuas

\footnotetext{
${ }^{19}$ RA, UD, P1:167, expediente personal de Ivan Danielsson, Ministerio sueco de Negocios Extranjeros.

${ }^{20}$ Database of Righteous among the nations, www.yadvashem.org. (visto el 3.X.2012).

${ }^{21}$ AMAEC R, 860, 74, despacho n. 46 de 15.II.1934.

${ }^{22}$ AGA, L. AE 6402, pp. 178
} 
intercambiadas entre Suecia y España con ocasión de los viajes oficiales de los monarcas respectivos al otro país al final de la década anterior, que puso fin al enfrentamiento diplomático entre Suecia y España de 1926.

Ese enfrentamiento había tenido lugar a consecuencia del veto sueco, para favorecer a Alemania, a que España ocupara un lugar permanente en el Consejo de la Sociedad de Naciones. Suecia no quería que España consiguiese la permanencia, porque temía que Polonia obtuviese el mismo derecho, envenenando así las relaciones con Alemania, que quería ingresar sola en la Sociedad de Naciones y en el Consejo ${ }^{23}$.

El viaje de Alfonso XIII a Suecia tuvo lugar en 1928, en devolución de la visita de Gustavo V a España. Salió de Bilbao el 10 de septiembre, llegó a Estocolmo el 14 y cinco días después partió del puerto de Gotemburgo con destino a Escocia ${ }^{24}$.

Con motivo del viaje, se canjearon numerosas condecoraciones, que motivarían inconvenientes de carácter protocolario durante años. Un caso singular sucedió en 1932 cuando, con motivo de la firma del acuerdo de navegación aérea entre Suecia y España, el Ministro de Estado de la República Española, Luis de Zulueta, quiso conceder a su homónimo sueco saliente, el barón Ramel, una de las dos máximas condecoraciones españolas - que eran entonces la Gran Cruz de Isabel la Católica y la recién instaurada Orden de la República - a cambio de recibir la mayor condecoración sueca, la Gran Cruz de Vasa, que la Casa Real sueca no quiso conceder en un principio.

La historia en sí no tiene mayor trascendencia, pero es de algún modo significativa de la fría actitud de Suecia frente a la República Española hasta el acceso al poder de la socialdemocracia. El ministro sueco prefirió la Orden de Isabel la Católica a la de la República y Zulueta, ofendido, decidió no aceptar la sueca ${ }^{25}$.

De más entidad, sin duda, fueron los contactos de Alfonso XIII con Suecia, que motivaron bastante correspondencia entre el Ministerio de Estado de la República Española y la Legación de España en Estocolmo durante los años 1931-1932. El motivo fue doble: el viaje del ex-Rey a Suecia en el verano de 1931, donde - en contra de su costumbre - hizo declaraciones a la prensa, y la presunta implicación de Alfonso en el llamado asunto Kreuger.

\footnotetext{
${ }^{23}$ AGA, Asuntos Exteriores, Caja n. 523, Estocolmo, carpeta 1; CASTIELLA, op. cit.; BLEDSOE, "The Quest for Permanencia:..." y "La oficina española...," p. 123.

${ }^{24}$ AGA, Asuntos Exteriores, Caja n. 5262. Se conservan imágenes filmadas de la llegada por mar al Palacio Real de Estocolmo, que fue inmortalizada también en un cuadro del pintor alemán Alexander Kircher (18671939), entonces de visita en la capital sueca, cfr. TYDÉN-JORDAN, Astrid, "Kungamötet på strömmen", Populär Historia, 3/2000, Estocolmo: LRF Media.

${ }^{25}$ AMAEC, R, 2656, 10, telegramas entre M. Estado y Legación en Estocolmo, 15-23.IX.1932.
} 
Por razones obvias, la República Española quiso mantenerse bien informada sobre las actividades del depuesto rey Alfonso XIII, que a efectos oficiales había pasado a ser Don Alfonso de Borbón. No es de extrañar, por ello, que el Ministro de España en Estocolmo informase inmediatamente al Ministerio de Estado al hacerse público, por la prensa sueca, que el que fuera Rey de España había visitado Suecia en el curso de un crucero por el norte de Europa.

Acompañado por el duque de Miranda, Alfonso XIII, que se hacía llamar duque de Toledo, llegó a Estocolmo el 14 de agosto y permaneció dos días en la capital como invitado del príncipe Carlos - hermano del rey Gustavo V, por entonces ausente del país y su esposa la princesa Ingeborg, y por el Consejero de la Legación de Alemania y esposa, Príncipes de Erbach Schönberg. También se entrevistó con el príncipe heredero de Suecia, Gustavo Adolfo, que se acercó para este fin a Estocolmo desde Malmö, hecho que fue duramente criticado en la prensa socialista sueca.

Luego, Alfonso XIII siguió viaje a la isla sueca de Gotland, donde un periodista sueco del conocido diario conservador Svenska Dabgladet, consiguió una entrevista con él, valiéndose de un subterfugio, ya que el ex rey no las concedía. El artículo periodístico, del que la Legación de España envió copia al Ministerio de Estado, pone en boca del ex Rey las siguientes palabras:

Todas las noticias sobre mi abdicación son falsas. Es verdad que había pensado abdicar en mi tercer hijo, don Jaime, pero no he firmado ningún documento. Para el porvenir de España existen dos posibilidades: Estados Unidos, como en Norteamérica y en Alemania, o centralización como en Francia, algo que exigen los habitantes del Sur de España(...) Mi colaboración en la solución del problema será mínima, pues de los 1.500 candidatos designados por las elecciones del 28 de julio apenas veinte eran monárquicos.

Así dice la traducción enviada por la Legación al Ministerio de Estado. El texto sueco del artículo original, sin embargo, contenía una palabra que los diplomáticos españoles no incluyeron en su traducción, probablemente por las implicaciones de la misma: en lugar de "mi colaboración será mínima" el artículo original dice "quizá sea". ¿Consideraba Alfonso XIII su abandono del poder como una situación provisional? Todo parece indicar que así era. 
También dijo Alfonso XIII que había temido por su familia, al salir de España, pero que "los contratiempos accidentales no le habían aniquilado", frase que el periodista decidió utilizar como titular de su noticia ${ }^{26}$.

No fue esa la única vez que la Legación de España en Estocolmo tuvo que ocuparse de asuntos relacionados con el depuesto monarca. Ya antes había enviado un informe, que se ha perdido, sobre los bienes de la Corona, el 11 de junio de $1931^{27}$.

Posteriormente, un nuevo informe trataba sobre las repercusiones en Suecia de un supuesto manifiesto del ex Rey de España, exponiendo los comentarios aparecidos en la prensa sueca los días 27 y 28 de febrero de 1932, que fueron por lo general bastante escuetos. La única excepción, según el informe de García Conde, fue el órgano de los socialistas, que "publica un artículo muy fuerte contra don Alfonso, censurándole duramente por su nefasta actuación como Rey" ${ }^{28}$. La noticia había aparecido en la prensa.

La otra gran cuestión en la que la persona de Alfonso XIII se vio implicada fue el llamado asunto Kreuger, al que ya nos referimos con detalle en el capítulo anterior.

Tras el telegrama inicial sobre el suicidio de Kreuger, siguieron varios despachos ordinarios y más detallados sobre el asunto ${ }^{29}$. En ellos se hacía referencia, entre otras cosas, a una posible implicación de España en las irregularidades financieras encontradas en el consorcio sueco y a la precaria situación de la empresa Kreuger \& Toll. A los pocos días, García Conde se vio en la necesidad de enviar otro telegrama especificando en qué consistía la presunta implicación de España en los asuntos del magnate sueco:

Irregularidades sospechadas primero confirmadas luego por despacho 47 y 56 resultan mayores de cuanto pudiera imaginarse concretándose nuevamente y más gravemente a medida comisión investigadora publica resultados de sus trabajos. Hoy han sido detenidos tres altos empleados por haberse comprobado complicidad bajo dirección Kreuger en falsificación obligaciones estado italiano por trescientos millones de coronas. Acaba de denunciarse haber sido descubierto en caja caudales particular Kreuger copia traducida al inglés de contrato firmado en enero 1925 por general Primo de Rivera en nombre gobierno español y Kreuger en representación compañía Continental Investments comprometiéndose éste a entregar 180 millones de pesetas en dos años al 16\% interés a condición de resarcirse totalmente empréstito e intereses mediante beneficio monopolio Fósforos que le sería concedido en 1927.

\footnotetext{
${ }^{26}$ AMAEC, R 904, 50, despacho. n. 77 de 19.VIII.1931; AMAEC H 3397.

${ }^{27}$ AGA, L. AE 6402, pp. 178, despacho de 16.VI.1931.

${ }^{28}$ AMAEC, R 904, 50, despacho n. 35 de 3.III.1932.

${ }^{29}$ AMAEC, R 95, 15; AMAEC R 341, 8, a, telegramas cifrados de la Legación de España al M. Estado de 14, 26 y 19.III.1932.
} 
Ha sido encontrado también copia certificación Primo de Rivera extendida en nombre Gobierno español en Madrid 1926 declarando que citada compañía había pagado 5 millones de pesetas y su saldo acreedor era 124 millones. En libros contabilidad misma Cía. figura una sección denominada "cuenta España en suspenso" con una partida de 165 millones de francos suizos pagados a España en concepto empréstito. Aún no ha sido comprobado falsedad ambos documentos pero se supone resultarán tan apócrifos como los citados títulos italianos de que Kreuger se prevalecía para realizar balances fantásticos y dar sorprendente y decisiva solidez a sus empresas facilitando así emisión acciones y obligaciones. García Conde. ${ }^{30}$

El telegrama despertó el interés del Ministerio de Estado, o acaso éste hubiera sido ya despertado por otra vía, pues parece que hubo cruce de telegramas al respecto. El 16 de abril, el Ministerio de Estado solicitó informes sobre los contratos de Kreuger con España. Al día siguiente, García Conde informaba, a vuelta de telegrama, que la prensa sueca había comentado el asunto sin añadir ninguna mención especial, a excepción del diario Socialdemokraten que dijo "haberse encontrado un recibo del Rey de España por cinco millones" 31 .

Al mes siguiente, el 18 de mayo, el propio Ministro de Estado de la República, don Luis de Zulueta, pedía por escrito a García Conde informaciones sobre si en el activo del consorcio Kreuger figuraban acciones del monopolio español de cerillas y si el ex-rey o personas afines estaban involucrados.

García Conde tomó entonces contacto con un miembro de la Comisión investigadora de la quiebra de Kreuger, nada menos que Wallenberg, uno de los empresarios más poderosos de Suecia, a quien afirmaba conocer personalmente. El dato es muy significativo, pues es un reconocimiento claro de una de las fuentes de información de la Legación de España en Suecia. ${ }^{32}$ No puede hablar Conde con Wallenberg por estar en una reunión, pero sí con "otra persona significativa que sigue de cerca los trabajos".

El día 20 contestaba el diplomático que, tras hablar con el presidente de la comisión investigadora del asunto Kreuger, el Profesor Fehr, no parecía que el monopolio español de cerillas, ni el ex-rey, ni ninguna persona afín estuvieran involucrados; algo que confirmó al día siguiente en otro telegrama cifrado, una vez consultados todos los miembros de la comisión investigadora de la quiebra. Quedaba así cerrado el tema de las presuntas implicaciones de la España de Alfonso XIII con el magnate sueco ${ }^{33}$.

\footnotetext{
${ }^{30}$ AMAEC R 341, 8, a., telegrama de 16.IV.1932

${ }^{31}$ AMAEC R 341，8, a, telegrama n. 9 de 17.IV.1932.

${ }^{32}$ AMAEC R 341, 8, a, telegrama cifrado de 19.IV.1932

${ }^{33}$ AMAEC R 341, 8, a, telegramas n. 13 y 14 de 20 y 21.IV.1932.
} 
Si la Legación de España en Estocolmo se interesó por Alfonso XIII, aún en mayor medida lo hizo la diplomacia sueca, y en particular la Legación sueca en Madrid, cuyo jefe, Ivan Danielsson, había forjado estrechos contactos con círculos monárquicos españoles. Además de la abundante correspondencia en relación con el cambio de régimen, expuesta en otro capítulo de este estudio, cabe destacar el seguimiento de las cuestiones relativas al ex-monarca en los meses que siguieron a su salida de España.

Una fuente documental de primera mano, no conocida en España, es el testimonio enviado a su gobierno por el Ministro de Suecia en Londres, el barón Palmstierna, a los dos días de la instauración de la República en España, informando del malestar de la Casa Real británica por la actitud de Alfonso XIII. Señalaba que no iban a apoyarle en manera alguna. Según Palmstierna, un miembro de la familia Real británica le había dicho que el rey Jorge había advertido seriamente al rey Alfonso de que la situación en España era peor de lo que se imaginaba. Asimismo, la Reina Victoria Eugenia había insistido a su esposo en que cambiara su estilo autocrático de gobierno si quería evitar una catástrofe ${ }^{34}$.

Por su parte, el Ministro sueco en Madrid informó cumplidamente en esos días de la salida del Rey al exilio, de su manifiesto al pueblo español, etc. En mayo, se hizo eco de una entrevista a Alfonso XIII en el diario ABC y de la decisión del Fiscal del Estado de encausar al ex-monarca. Y en el mes de julio tuvo una entrevista personal con el Edecán de Su Majestad, el duque de Miranda, que fue franco con el diplomático sueco y le dijo que no veía más solución para el futuro de España que una dictadura.

Miranda le comentó también a Danielsson que los informes que él y el Rey habían recibido antes de las elecciones municipales del 12 de abril eran tan optimistas que no dieron crédito a las voces de alarma y el resultado fue una completa sorpresa para el Rey. El Rey sabía que Miranda le había dicho a Danielsson en vísperas de las elecciones que no había ningún motivo de preocupación. El despacho de Danielsson sobre esta conversación acababa informando que la Familia Real vivía en Fontainebleau y que las hijas del Rey iban a casarse con los hijos del infante Alfonso de Orleans.

En agosto, Danielsson informó de los rumores de la abdicación del rey Alfonso XIII en favor de don Juan, que fueron desmentidos tras su publicación por parte de la prensa. Sin embargo, según el diplomático, Lerroux le había dicho que sabía que la abdicación se había firmado. En el mismo despacho, la Legación de Suecia comunicaba las intenciones

\footnotetext{
${ }^{34}$ RA, UD, 1920-års dossierssystem, HP Vol. 420, despacho n. 222 de la Embajada de Suecia en Londres, 16.IV.1931.
} 
del ex-monarca de hacer un crucero por el Báltico y visitar, entre otros puertos, Estocolmo, viaje del que informó en detalle, como vimos, la Legación de España en Suecia.

En otoño de ese año tuvo lugar la petición de responsabilidades a Alfonso XIII por sus medidas de gobierno, y la información sobre el tema dada por la Legación de Suecia en Madrid no podía ser más exhaustiva. Comentaba con todo detalle las conclusiones de la comisión parlamentaria encargada de la investigación y el debate parlamentario subsiguiente, diciendo que las derechas españolas no se habían atrevido a protestar por miedo a la aplicación de la Ley en defensa de la República y hacía referencia a la "apasionada acusación del presidente de la Comisión investigadora, el sectario diputado socialista radical Galarza, jefe de la policía de seguridad"35. Al enviar, días después, el texto oficial sobre la sentencia condenatoria al ex-rey que la Legación había recibido del Ministerio de Estado pedía instrucciones a su gobierno sobre cómo debía contestar, a lo que se le respondió desde Estocolmo que se diera sencillamente acuse de recibo de la información.

Finalmente, en marzo de 1932 volvía Danielsson a nombrar a Alfonso XIII, al comentar el posible origen de los rumores en círculos monárquicos españoles y en la prensa extranjera de un acercamiento de las dos ramas rivales de la Casa de Borbón española ${ }^{36}$.

A partir de ese momento, desaparecen las referencias al ex Rey de España por parte sueca.

\subsection{La colaboración entre España y Suecia en la Sociedad de Naciones}

\subsubsection{Neutralidad $y$ pacifismo como claves comunes de la política exterior de España y de Suecia}

El papel en política internacional de los países considerados como potencias pequeñas o medianas cambió de forma clara a partir del nacimiento de la Sociedad de Naciones, donde la diplomacia multilateral ocupaba un lugar prevalente. El gran objetivo del Pacto era garantizar la seguridad y la paz, sufrió un revés importante a partir del fracaso de la Conferencia de Desarme, a mediados de los años treinta. Ello llevó a varios

\footnotetext{
${ }^{35}$ RA, UD, 1920-års dossierssystem, HP Vol. 420, despachos n. 186 de 15.IV.1931; 189 de 17.IV.1931; n. 237 de 10.V.1931; 245 de 17.V.1931; 325 de 8.VII.1931; 394 de 6.VIII.1931; 517 de 16.XI.1931; 532 de 20.XI.1931.

${ }^{36}$ RA, UD, 1920-års dossierssystem, HP Vol. 420, despachos n. 556 de 8.XII.1931 y 119 de 24.III.1932.
} 
de esos países, entre ellos Suecia y España, a adaptar su política internacional, pasando de lo que podríamos llamar un pacifismo societario - basado en la defensa a ultranza del Pacto de la Sociedad de Naciones - a un pacifismo neutralista. Esa nueva actitud quedó especialmente de manifiesto tras la crisis ítalo-etíope, la guerra de España y el expansionismo de la Alemania nazi en los años inmediatamente anteriores a la segunda guerra mundial.

Por lo que a España se refiere, un primer paso dentro de la "reconexión" con Europa en el primer tercio del siglo XX fue la atención especial a su ámbito propio, el Mediterráneo e Hispanoamérica, constituyendo esto, según Neila Hernández y Pereira Castañares, el eje central de la política exterior española durante el reinado de Alfonso XIII. Quedaba así de manifiesto la posición periférica que la España alfonsina ocuparía en el sistema internacional de la paz armada y en el de Versalles ${ }^{37}$. Se trataba de buscar aliados a nivel regional y ser neutral a nivel continental.

Las consecuencias de esta "mediterraneidad" de España en el contexto de la Sociedad de Naciones, y viceversa - la influencia de la Sociedad de Naciones en la política mediterránea española - es materia bien estudiada en la historiografía española ${ }^{38}$ y no necesita aquí de ulterior comentario.

Con la llegada de la República, aparecería un nuevo estilo de política exterior, centrando los esfuerzos por europeizar a España, objetivo primordial de los dirigentes republicanos, en el desarrollo de una política pacifista en Ginebra ${ }^{39}$. La Sociedad de Naciones fue vista con un carácter finalista por las nuevas élites republicanas, en expresión de Francisco Quintana ${ }^{40}$.

\footnotetext{
${ }^{37}$ PEREIRA CASTAÑARES, Juan Carlos \& NEILA HERNANDEZ, José Luis, "La España de Alfonso XIII en el sistema internacional de la posguerra (1919-1931)”, Historia Contemporánea 34, 2007, pp. 117-154; p. 137; cfr. también PEREIRA CASTAÑARES, Juan Carlos, Las relaciones bilaterales entre España y la Gran Bretaña durante el reinado de Alfonso XIII (1919-1931), Madrid: UCM, 1986.

${ }^{38}$ Cfr., entre otros, NEILA HERNANDEZ, José Luis, "La mediterraneidad de España en las relaciones internacionales del periodo de entreguerras (1919-1939)", Cuadernos de Historia Contemporánea, 19, Madrid: Universidad Complutense, 1997, pp. 15-54; SUEIRO, Susana, "España, potencia mediterránea 1898-1930", en España, Europa y el Mediterráneo, Bulletin d'Histoire Contemporaine de l'Espagne, n. 27, 1998, Aix-en-Provence: Université de Provence, pp. 55-110.

${ }^{39}$ NEILA HERNANDEZ, José Luis, "España y la Sociedad de Naciones: un tránsito historiográfico inacabado". Cuadernos de Historia Contemporánea, 2003, n. Extraordinario, pp. 49-67.

${ }^{40}$ QUINTANA NAVARRO, Francisco: "La política exterior española en la Europa de entreguerras: cuatro momentos, dos concepciones y una constante impotencia", en TORRE GÓMEZ, Hipólito de la (coord.) Portugal, España y Europa. Cien años de desafío (1890-1990), Madrid: UNED, 1991, pp. 64-65.
} 
No faltan los estudios sobre el papel de España y la Sociedad de Naciones ${ }^{41}$, a los que remitimos al lector, ya que en estas páginas nos limitamos a estudiar únicamente las relaciones bilaterales con Suecia que se dieron dentro de ese marco.

Por parte sueca, tampoco faltan estudios sobre la política del país dentro de la Sociedad de Naciones. Como veremos luego en más detalle, la historiografía sueca es unánime en presentar la política sueca en este período dentro de las coordinadas que tratamos en este apartado: una política pacifista, de marcado carácter prosocietario - es decir, de apoyo decidido al Pacto de la Sociedad de Naciones - hasta el momento de la crisis de Abisinia en 1935; y un claro cambio de rumbo a partir de esa fecha, a favor de una política estricta de neutralidad ${ }^{42}$.

Sea como fuere, tanto España como Suecia coincidían en las cuestiones de principio ante los trabajos de la Sociedad de Naciones: pacifismo prosocietario y neutralidad. Otra cosa sería las posibilidades de hecho para ambos países de no alinearse con ninguna de las grandes potencias. También en esto, Suecia y España, como pequeñas potencias, estaban en situación parecida. La orientación pacifista fue recogida por la Constitución de la Segunda República Española, por lo que a España se refiere, y por el programa de gobierno del partido socialdemócrata sueco en las elecciones de 1932.

Como señala Quintana Navarro, la República, en cuanto pequeña potencia miembro de la Sociedad de Naciones, debía actuar como leal mantenedora del sistema de seguridad colectiva vigente. En este sentido, la República apostó claramente por buscar la colaboración de las pequeñas potencias democráticas europeas, el straight eight, entre las que se encontraba Suecia. Tras el fracaso de la conferencia de desarme, la postura española oscilaría en parte, buscando un acercamiento a las grandes potencias cercanas, en particular a Francia, pero también a Gran Bretaña - a la que apoyaría claramente en la crisis de

\footnotetext{
${ }^{41}$ Además de las obras generales sobre la política exterior española y las ya citadas, cfr. BLEDSOE, Spain in the League of Nations, 1919-1931, Florida State University, 1972; NEILA HERNANDEZ, José Luis, "Amanecer sin mediodía en la política exterior democrática de la Segunda República: transición sin consolidación" en Aportes, 47, XVI (3/2001), pp. 4-22 y 48, XVII (1/2002), pp. 88-102; PÁEZ-CAMINO, Feliciano: "Manuel Azaña y la política exterior de la Segunda República española", en Bile 10, 1990, pp. 6978; PALOMARES LERMA, Gustavo, "La política exterior española: de la Dictadura de Primo de Rivera a la Guerra Civil" en CALDUCH CERVERA, Rafael (coord.), La política exterior española en el siglo XX, Madrid: Ciencias Sociales, 1994, pp. 46-70; TUSELL, Javier \& GARCIA QUEIPO DE LLANO, Genoveva, El dictador y el mediador, Madrid: CSIC, 1986.

${ }^{42}$ LÖNNROTH, op. cit.,; BERGQUIST, Mats, "Sverige och Nationernas Förbund", Statsvetenskaplig Tidskrift, 1970, pp. 130-152; OTTOSSON, op. cit.; TINGSTEN, op. cit.; ÅMARK, Makt eller moral...; HULDT \& MISGELK, op. cit.,; BERGQUIST, Mats \& JOHANSSON, Alf W, Säkerhetspolitik och historia: essäer om stormaktspolitik och Norden under sjuttio år: vänbok till Krister Wahlbäck, Estocolmo: Hjalmarson \& Högberg, 2007; cfr. también SILANDER, op. cit., que analiza en detalle el debate sueco en torno a la Sociedad de Naciones y la neutralidad.
} 
Abisinia -, para volver al fin a buscar la colaboración con los neutrales del "grupo de los seis" a partir de 1936. Personaje principal de todo este esfuerzo diplomático fue Salvador de Madariaga ${ }^{43}$.

Por otra parte, el debate sobre si la España de los años treinta del siglo XX debía considerarse una potencia pequeña o mediana sigue estando presente en la historiografía española. Pérez Gil, basándose sobre todo en la afirmación de Madariaga en sus memorias de que España, por ser vocal semipermanente del Consejo de la Sociedad de Naciones, no podía ser considerada una pequeña potencia, califica a España como potencia media ${ }^{44}$. A nosotros no nos parece decisivo este argumento, pues el hecho de que España fuera reelegida varias veces a uno de los puestos no permanentes del Consejo se debió, en cada caso, a diversos factores, no necesariamente vinculados a la consideración del país como potencia de tipo medio. Nos parece que, a la luz de la documentación nórdica examinada, España era considerada en estos años, por parte de los otros países europeos, más como pequeña que como mediana potencia. En todo caso, el debate no deja de ser, a nuestro entender, una cuestión de importancia marginal.

Analizaremos a continuación, a partir de la documentación diplomática, la preparación y desarrollo de las iniciativas comunes hispano-suecas a favor de la paz, en el marco del llamada "grupo de los neutrales", y el papel jugado por los diplomáticos españoles en lo que fue un intento de establecer unas relaciones especiales entre los dos países, como líderes del grupo mencionado, para garantizar la toma de postura común en la Sociedad de Naciones. El resultado, como veremos, no fue del todo satisfactorio, al menos en lo que a España se refiere.

\subsubsection{Iniciativas comunes hispano-suecas a favor de la paz: El "grupo de los neutrales"}

\subsubsection{El acercamiento entre los neutrales y el memorándum conjunto de 1934}

En este marco de promoción de la paz internacional a través de la Sociedad de Naciones se inscribe la iniciativa que, en palabras de Berdah, supuso el primer impulso

\footnotetext{
${ }^{43}$ QUINTANA NAVARRO, Francisco, "Salvador de Madariaga, diplomático en Ginebra (1931-1936). La película de la política exterior de la Segunda República”, Historia Contemporánea 15, 1996. pp. 107-124. El "grupo de los seis" eran Suecia, Noruega, Dinamarca, Bélgica, Holanda y Luxemburgo, las naciones neutrales en la Primera Guerra Mundial que habían firmado el acuerdo de Oslo de 1932. El straight eight o "grupo de los ocho"agrupaba a las anteriores más Espana y Checoslovaquia. Más detalles en el epígrafe siguiente.

${ }^{44}$ PEREZ GIL, op. cit., p. 143 y ss.
} 
internacional de la República ${ }^{45}$ : la coordinación de las declaraciones de política exterior entre los países europeos que fueron neutrales en la Primera Guerra Mundial en vistas a presentar un frente común frente a las grandes potencias.

En 1932, seis países firmaron en la capital de Noruega una Convención sobre cooperación en materia comercial: la llamada Convención de Oslo. Aparte de su situación geográfica en el norte de Europa, todos tenían en común también el hecho de haber sido neutrales en la Gran Guerra. Se trataba de Suecia, Noruega, Dinamarca, Holanda, Bélgica y Luxemburgo. Pronto serían conocidos en círculos diplomáticos como "el grupo de los seis", "las potencias de Oslo" o "los ex neutrales". España, también neutral en la guerra, no formaba parte del grupo. Sin embargo, a partir de 1932, cuando Zulueta accedió a la cartera de Estado de la República, hubo un intento concreto por parte de España para pasar a formar parte del grupo en cuestión y para tomar una posición de líder dentro del mismo.

La diplomacia española empezaría a hablar del "grupo de los ocho" (los seis de Oslo, más España y Checoslovaquia), y posteriormente del "grupo de los neutrales", al que Azaña se referiría después, bastante despectivamente, como el "chisme" que "se inventó Madariaga" ${ }^{46}$. La historiografía española ha resaltado el papel "preponderante" de España en este grupo, en el que se incluye a Suecia ${ }^{47}$. Como veremos, esta visión no es compartida en absoluto por la historiografía sueca.

En un estudio reciente, Jean-Francois Berdah se refiere con cierto detalle a la iniciativa común de los neutrales. Según este autor, Luis de Zulueta sabía que España, durante la Conferencia de Desarme ${ }^{48}$, había colaborado con otras siete naciones que no se podían llamar pequeñas porque figuraban, por su elevada cultura y progreso social, a la cabeza de la civilización. La diplomacia española se mostró, en efecto, extraordinariamente activa durante las semanas siguientes (marzo 1933).

$\mathrm{Su}$ postura, ostensiblemente a favor de los esfuerzos pacifistas de la Sociedad de Naciones, coincidía con la de los estados neutrales, como Dinamarca, Suecia, Noruega, Suiza, Bélgica y los Países Bajos. Sin embargo, la iniciativa de los neutrales en el tema del desarme no fue bien recibida por las grandes potencias, y el propio Zulueta se vio obligado a reconocer que de los países neutrales, como España, Holanda o los Estados escandinavos,

\footnotetext{
${ }^{45}$ BERDAH, op. cit., p. 424.

46 AZAÑA, Manuel, Obras completas, vol. IV, Madrid: Centro de Estudios Políticos y Constitucionales, 2007, p. 609.

${ }^{47}$ En este sentido se pronuncian NEILA HERNANDEZ, "La mediterraneidad de España...”; EGIDO LEÓN, op. cit., pp. 104 y ss.; QUINTANA, Francisco, España en Europa...,, pp. 71-77 y 127-150.

${ }^{48}$ La Conferencia de Desarme fue una iniciativa de las Sociedad de Naciones en 1932 y 1933, en la que participaron además loe EE.UU. y la Unión Soviética. No consiguió llegar a ningún acuerdo.
} 
solo se podría conseguir que adoptaran posturas o medidas discriminatorias en caso de un conflicto europeo, si Inglaterra y EE.UU. daban ejemplo de ello.

Según el análisis de Berdah, España, después de que Bélgica y Checoslovaquia abandonaran el grupo de los ocho, se mostraba reticente a aceptar las posturas conciliadoras en el seno de la Sociedad de Naciones. Tropezó entonces con las reacciones un tanto circunspectas de los diplomáticos daneses, suecos y holandeses, preocupados por la forma que Madrid deseaba dar a esta concentración de países neutrales ("¿alianza o pacto escrito?"). Insiste en la imprecisión de las cuestiones formuladas por el ministerio de Estado, lo que motivó un cierto caos.

No obstante - sigue diciendo Berdah - la iniciativa de crear un grupo de neutrales dentro de la Sociedad de Naciones, cobró un nuevo impulso a mediados de diciembre de 1933 a instancias del nuevo ministro de Estado, Pita Romero, y del Secretario de ese Ministerio, José María Doussinague ${ }^{49}$, y respondía a la línea de neutralidad de la política exterior española y a las exigencias de la opinión pública.

Sin embargo, ante las reticencias de Suecia y de Dinamarca, se convino seguir las ideas de López Oliván, que concluía en la necesidad de proceder a un análisis minucioso y detallado de los puntos de vista sostenidos por estos gobiernos. Pese a esa iniciativa española, la tentativa emprendida por Suecia a principios de 1934 de relanzar la idea de una acción común dentro de la Sociedad de Naciones y la voluntad de Noruega de recuperar a Bélgica para el grupo, terminaron perturbando los planes españoles.

Efectivamente - explica Berdah - estas iniciativas podían poner en peligro el carácter profundamente neutralista de la alianza común. Por su parte, Doussinague, de tendencia germanófila, quería excluir a Checoslovaquia y a Bélgica. Inglaterra proponía pactar con Hitler sobre el desarme, y al final los países neutrales se plegaron a las propuestas inglesas. Suecia sugirió "realizar un esfuerzo en la siguiente sesión de la conferencia, apoyándose, si fuera posible, en una declaración común que diga que los gobiernos de España, Suecia, Suiza y Países Bajos están de acuerdo con las conclusiones formuladas en la nota británica y que se pronunciaban a favor de un desarme sustancial".

En su análisis expone Berdah con precisión el dilema en el que se encontraba España: aceptar la postura inglesa en el desarme, más conciliadora con Alemania, suponía un choque con las posturas de Francia, tema espinoso para España. Igualmente, y según

\footnotetext{
${ }^{49}$ José María Doussinague y Teixidor (1894-?), diplomático de profesión, era por entonces Subsecretario del Ministerio de Estado. Fue Embajador español en Chile y posteriormente Director General de Política Exterior en el Ministerio de Asuntos Exteriores de la España de Franco.
} 
declaraciones de Pita Romero al Embajador francés, una intervención de las pequeñas potencias podría ser contraproducente, por lo que España quiso asegurarse de la postura de los países neutrales y encargó a López Oliván que hiciera gestiones cerca del Gobierno sueco, para modificar el memorándum común, lo cual no fue aceptado por Suecia.

Finalmente, el memorándum de los países neutrales, presentado por Sandler en la Sociedad de Naciones el 14 de abril de 1934, fue el fruto de una colaboración hispanosueca sin precedentes. Según Berdah, al adherirse el gobierno de la República, por recomendación de su ministro en Estocolmo, López Oliván, a las ideas del ministro sueco de Exteriores de favorecer una reglamentación del rearme que de hecho estaba teniendo lugar, consiguió España arrastrar a Noruega y Dinamarca a una declaración común ${ }^{50}$.

Por su parte, la historiografía sueca no coincide con Berdah respecto a la autoría de esta iniciativa de acción común, sosteniendo que no habría sido española sino sueca. De hecho, la intervención de España en el manifiesto de los neutrales es prácticamente ignorada en la historiografía sueca. Un estudio de Carlgren, basado en documentos diplomáticos suecos, sostiene que la iniciativa de acción común fue propuesta sueca. Según este autor, el gobierno sueco, y en particular el ministro de Negocios Extranjeros Rickard Sandler, trabajaron intensamente - aunque sin éxito - para conseguir al menos un acuerdo entre los países pequeños para la reducción de las partidas presupuestarias sobre gastos militares, que hubiera pedido servir de modelo a las grandes potencias ${ }^{51}$.

En el mismo sentido se expresa Zetterberg en su semblanza del diplomático sueco Carl Hamilton, que fue el primer representante de Suecia en la Sociedad de Naciones. Zetterberg caracteriza a Hamilton como el diplomático "realista", en contraste con el "idealista solidario" Sandler. Dice este autor que los países neutrales del grupo de Oslo constituían en la primera mitad de la década de los años treinta una fuerza política en la Sociedad de Naciones, pero que perdieron esa posición en la segunda mitad a consecuencia del incremento de la tensión.

A partir de 1934, con Rickard Sandler como ministro de Negocios Extranjeros, se avivó la política sueca, basada en el apoyo en las democracias occidentales, en los países

\footnotetext{
${ }^{50}$ BERDAH, op. cit., pp. 80 y 117-134.

51 CARLGREN, Wilhelm, "Karl Ivan Westman", en ARTEUS, Gunnar \& LEIFLAND, Leif (coord.), Svenska diplomatprofiler under 1900-talet, Estocolmo: Probus, 2001, pp. 133 y s.
} 
neutrales del grupo de Oslo y en la cooperación nórdica, a favor de la paz internacional dentro del marco de la Sociedad de Naciones ${ }^{52}$.

También Ohlsson destaca el protagonismo del Ministro sueco de Negocios Extranjeros en la iniciativa de los exneutrales. Según este autor, Sandler siguió con la política internacional activa de Undén, queriendo reunir los países menores sobre la base del grupo de $\mathrm{Oslo}^{53}$.

Finalmente, un estudio monográfico sobre la labor de Suecia en la Sociedad de Naciones en 1935, centrado en la actitud sueca en la crisis italo-etíope y en la militarización de Renania, no sólo considera a Suecia el motor y artífice de la "declaración del 1 de julio" - conocido como el Manifiesto de los Siete - sino que prácticamente ni siquiera menciona a España, cuya participación en la declaración común habría sido fruto de la colaboración entre los países nórdicos y Holanda, uniendo las ideas del holandés De Graeff con los planes de Madariaga. Nos referimos a la tesis doctoral de Ingemar Ottosson, que resulta fundamental para entender los entresijos del debate sueco sobre política exterior a mitad de los años treinta del siglo XX.

Esta política era el resultado de un compromiso entre las dos tendencias fundamentales en la clase política sueca: la que propugnaba en primer lugar la búsqueda de la paz a través de la solidaridad activa en la Sociedad de Naciones - llamada por el autor "escuela de opinión 1" - y la línea "defensiva" - "escuela de opinión 2" - que propugnaba una neutralidad estricta ${ }^{54}$.

El estudio de la documentación diplomática hispano-sueca respecto a la iniciativa en cuestión, permite matizar la visión de la historiografía, resaltando su origen español - de Pita Romero, Doussinage, López Oliván y Madariaga - que Suecia hizo suya, desplazando a España. En todo caso, queda claro el papel fundamental desarrollado por el ministro de España en Suecia, López Oliván, persona por otra parte acostumbrada a representar a España en los foros internacionales, por su sucesor Fiscowich $\mathrm{y}$, sin duda de manera especial, por Salvador de Madariaga.

López Oliván, en efecto, vio claramente y alentó las posibilidades que ofrecía un acercamiento a nivel político entre Suecia y España. Es muy posible que esa colaboración hubiera llegado a ser más estrecha aún de haber podido permanecer López Oliván más

\footnotetext{
52 ZETTERBERG, Kent, "Carl Hamilton”, en ARTEUS, Gunnar \& LEIFLAND, Leif (coord.), Svenska diplomatprofiler under 1900-talet, Estocolmo: Probus, 2001, pp. 157-164.

${ }_{53}$ OHLSSON, op. cit., pp. 80s.

${ }^{54}$ OTTOSSON, op. cit., passim, especialmente pp. 164-168 y 245-249.
} 
tiempo a la cabeza de la representación diplomática española en Estocolmo. No pudo ser, pues le encomendaron a finales de 1933, junto con el sueco Östen Undén - figura clave de la política exterior sueca de neutralidad - diversas misiones internacionales. Fue López Oliván uno de los tres expertos neutrales a los que hubieron de ocuparse, por sentencia permanente del Tribunal de La Haya, de la tarea de resolver la situación de las zonas de Alta Saboya en lo referente al régimen aduanero e intercambio comercial. También fue nombrado delegado suplente de la Asamblea de la Sociedad de Naciones en Ginebra ${ }^{55}$.

La primera reunión de López Oliván con el Ministro sueco de Negocios Extranjeros, Rickard Sandler, tuvo lugar el 7 de marzo de 1933, y tuvo carácter meramente protocolario y de representación. Fue en una reunión posterior, el 1 de junio de ese año, cuando la iniciativa española de colaboración en el marco de la Sociedad de Naciones se discutió entre ambos por primera vez. Rickard Sandler anotó en su promemoria de la reunión, que López Oliván le había visitado tras haber tenido una reunión con Undén, para tratar de la actitud a tomar en la Conferencia de Londres y le había dicho que, aunque aún no tenía datos concretos sobre la postura del gobierno español, esperaba que ambos países pudieran colaborar en la capital británica.

A finales de enero y primeros de febrero de 1934, López Oliván mantuvo una reunión confidencial con Sandler a la que siguieron varias reuniones con Östen Undén, que actuaba como ministro de Negocios Extranjeros en funciones, por encontrarse Sandler en el extranjero. Fue en esas reuniones donde se concretaron los detalles de la acción conjunta sueco-española que dio lugar al manifiesto de los neutrales del mes de abril. Los ministros suecos dejaron por escrito información detallada de esas reuniones ${ }^{56}$. Se trata de una documentación de sumo interés para el tema que nos ocupa y que no nos consta sea conocida en España.

Sobre la reunión del 27 de enero de 1934 entre Sandler y López Oliván, escribió el Ministro sueco que había sido a iniciativa del representante español para tratar de la iniciativa española - el subrayado es nuestro - de adopción de propuestas comunes por parte del grupo de países neutrales con intereses comunes en la Sociedad de Naciones. Según Sandler, Oliván había hablado ya de esta iniciativa con Undén, mientras estuvieron juntos en Montreux.

\footnotetext{
${ }_{55}^{55}$ AMAEC R 191, 12, telegramas de M. Estado a Legación de España, n. 14 y 15, de 4.IX.1933.

${ }^{56}$ RA, UD, 1920-års dossierssystem, HP, Vol. 1; HP Vol. 14, Utrikesministerns samtal med utländska sändebud.
} 
Oliván quería deshacer el malentendido sobre la forma con que la iniciativa española se había planteado en Oslo y Copenhague. No se trataba - explicaba el diplomático español, de forma confidencial, a Sandler - de crear un grupo de países exneutrales ante la evolución de los acontecimientos en Europa, sino más bien de sondear de modo informal las posibilidades de cooperación entre España, los países nórdicos y Suiza, en lo referente sobre todo al Pacto de la Sociedad de Naciones y a su posible revisión.

Según López Oliván, la necesidad de trabajar por el desarme estaba clara, dadas las circunstancias políticas del momento, y en este sentido los países en cuestión estaban ya colaborando con éxito. Sandler, por su parte, le expuso a López Oliván que esa cooperación podía extenderse a dos países no mencionados por éste, pero con los que Suecia ya venía cooperando, Finlandia y Bélgica, a lo cuál respondió López Oliván que no creía que España tuviera inconveniente en extender la cooperación también a Finlandia.

Sandler dejó constancia expresa, en el texto que comentamos, de que eso lo había dicho el diplomático español por propia iniciativa, sin que por parte del Ministro sueco hubiera habido ningún compromiso de proceder a la cooperación solicitada por España, aunque sí le había dicho que, de entrada (prima vista) la idea española parecía interesante. Acordaron que Oliván pediría al gobierno copias de las respuestas danesa y noruega y que mantendría informado a Undén, en ausencia de Sandler, sobre el asunto.

El 30 de enero, se reunió López Oliván con Undén, y en el promemoria de esa reunión escribió éste que el motivo era discutir, según lo acordado el sábado anterior con el Ministro de Exteriores, la iniciativa española de cooperación entre los países ex neutrales. El diplomático español le explicó que había recibido el encargo de su gobierno de plantear a Suecia la misma iniciativa que ya le había explicado a Undén, en relación con Noruega y Dinamarca, en Montreux en noviembre último. Por el desarrollo de los acontecimientos, al gobierno español le parecía conveniente que la cooperación empezara por discutir la posible revisión del pacto de la Sociedad de Naciones.

López Oliván quería conocer la posición de Suecia ante la iniciativa, sabiendo que era cuestión delicada proponer la constitución de un grupo de seis excluyendo a Bélgica y Checoslovaquia, miembros del grupo de los ocho. Por otra parte, era evidente que estos dos países, por sus relaciones con los países de la Entente, tenían intereses propios y por ello parecía deseable excluirlos de la cooperación. Dijo que Sandler había nombrado a Finlandia como un posible socio y que no veía que España se fuera a oponer. Respecto a la forma de cooperación, el español manifestó estar abierto a cualquier propuesta sueca. 
Undén le comentó a López Oliván que personalmente le parecía de gran interés la idea de mantener conversaciones previas entre los Estados ex neutrales para concertar una acción común ante una posible revisión del Pacto de la Sociedad de Naciones. Era un tema sobre el que los países exneutrales, por su falta de intereses propios, podrían ayudar a desbloquear la falta de acuerdo de las grandes potencias. Pero le parecía difícil, por ser asunto muy delicado, el excluir de esas conversaciones a dos países que ya formaban parte de un grupo ya existente para consultas mutuas dentro de la Sociedad. No obstante, era medida justificada si se trataba de discutir cambios al Pacto de la Sociedad, por tratarse de un asunto en el que esas naciones tenían intereses divergentes.

A continuación, Oliván sugirió a Undén el siguiente plan de procedimiento: Que Suecia y España empezaran por discutir entre ellas el tema del Pacto de la Sociedad de Naciones - la cursiva es nuestra - y una vez llegado a un acuerdo preliminar, ponerse en contacto con los demás países. Según Oliván, nadie se sorprendería, ni vería peligro alguno, en caso de conversaciones entre España y Suecia. También se podría proceder de la misma forma en otras cuestiones, como la cuestión austríaca y la del Sarre. Undén prometió pensarlo y contestarle.

El 1 de febrero tuvo lugar una nueva reunión entre López Oliván y Undén, por iniciativa del sueco. Tras haberlo consultado con el Ministro de Exteriores, Undén le dijo a Oliván que consideraban "muy acertada" la iniciativa española y que Suecia estaba interesada. Respecto al procedimiento, el gobierno sueco veía con buenos ojos empezar las negociaciones con el español. No obstante, teniendo en cuenta las estrechas relaciones de Suecia con sus vecinos nórdicos, a Suecia le parecía necesario informarles al respecto y no presentarles los temas como acordados de antemano. López Oliván contestó que entendía la posición sueca y que la propuesta española era sólo por razones de eficacia.

A la pregunta del diplomático español sobre la posibilidad de incluir en el Grupo de los Seis a Bélgica y Finlandia, Undén le dijo que respecto a Finlandia quedaba el asunto abierto, ya que en ocasiones tenía ese país intereses distintos de los suecos en la Sociedad de Naciones, pero que a Suecia le interesaba fomentar las relaciones con su vecino. Sobre Bélgica, la opinión particular de Undén era que dependía del tipo de gobierno que tuviera en cada momento, porque bajo algunos gobiernos las posturas belgas se acercaban más a las holandesas y escandinavas mientras que bajo otros apoyaban a Francia, como ahora con Ryman. López Oliván se mostró de acuerdo con este análisis. 
Dos días más tarde, el 3 de febrero, sin esperar el regreso del Ministro Sandler, previsto para el 5, Undén y López Oliván se volvieron a reunir. Sobre esa reunión escribió Undén que habían tratado en primer lugar el memorándum holandés, que Oliván veía en general con buenos ojos aunque no entendía la distinción que hacían lo holandeses entre el Pacto y el tratado de paz. A ese respecto, a ambos les parecía deseable una reforma del Pacto, quitando las referencias a los "aliados" y al "tratado" en los artículos 4 y 5 del Pacto, lo cual tendría un importante efecto psicológico aunque fuera un mero cambio redaccional.

Sobre la composición del Consejo, pensaba López Oliván que su gobierno no estaría en contra de que hubiera cambios. Personalmente era de la opinión de que constaba de demasiados miembros, aunque dejó entrever que era cuestión un tanto delicada y era partidario de no tomar la iniciativa en ese tema. Con ello se mostró de acuerdo Undén. Sobre los cambios previstos al Pacto que la Asamblea veía en principio con buenos ojos, como la inclusión del pacto de Kellogg en el mismo, le parecía a López Oliván que una iniciativa del grupo de los ex neutrales era oportuna. Undén propuso incluir una sugerencia de añadido al Pacto permitiendo al Consejo y a la Asamblea invitar, por mayoría simple, a terceros países a intervenir ad casum en los trabajos de la Sociedad. Esto ya había sucedido en relación con el conflicto de Manchuria, si bien con la oposición de Japón. A López Oliván le pareció acertada esta sugerencia.

Undén resumió el contenido de la propuesta española de la manera siguiente: El gobierno español aspiraba a una acción coordinada de España, Holanda, los países escandinavos y Suiza para discutir posibles cambios del Pacto de la Sociedad de Naciones y como manifestación de estos Estados de su voluntad de ejercer una política exterior independiente e imparcial, proponiendo que la Asamblea de la Sociedad de Naciones procediera a una revisión del Pacto.

López Oliván confirmó que así era y añadió que las acciones coordinadas se podrían extender a otras cuestiones, como las relacionadas con las minorías. Sugirió además coordinar el modo de informar a los demás países nórdicos para no dar la impresión de que en el fondo se trataba sólo de lograr su asentimiento a cuestiones que Suecia y España ya habían decidido de mutuo acuerdo. El diplomático español expuso también que se partía de la base que la creación de este grupo de consultas no requería base escrita ni nombre alguno, pero que la convocatoria de una reunión conjunta sería necesaria. Undén insistió en 
que personalmente estaba a favor de todas estas propuestas pero que el acuerdo no era definitivo hasta que no lo confirmara el Ministro de Exteriores.

El 8 de febrero, estando ya de vuelta en Estocolmo el Ministro Sandler, tuvo lugar una nueva reunión entre éste y López Oliván. En su promemoria de la conversación, escribió Sandler que le había comunicado al diplomático español su conformidad con los presupuestos para las deliberaciones sueco-españolas según lo acordado con Undén, y que ahora se trataba de prepararse, mediante ellas, ante las posibles alteraciones del Pacto de la Sociedad de Naciones. No se trataba, en opinión de Sandler, de crear ningún grupo político de Estados, sino de concertar políticas comunes ante cuestiones concretas.

Sandler expuso a López Oliván la intención del gobierno sueco de poner a Noruega y Dinamarca al corriente de estas conversaciones sueco-españolas, y de seguir manteniéndolas informadas al respecto. Sugirió al diplomático español que elaborase una lista de las cuestiones que él pensaba que debían abordarse, al plantearse la reforma del estatuto de la Sociedad de Naciones. Si fuera posible, deseaba Sandler poder tener una última reunión con López Oliván antes de la marcha de éste, y esperaba poder comunicarle entonces cómo veían los noruegos y daneses las posibilidades de cooperación según la iniciativa española. López Oliván se mostró de acuerdo y pidió que, "para no avergonzar" a los daneses y noruegos, el Ministro sueco les explicara las conversaciones entabladas con España como el resultado lógico del especial trato que, en el marco de las misiones internacionales recibidas, López Oliván tenía con Undén. Acordaron además que López Oliván escribiría la lista de cuestiones pedidas por Sandler en colaboración con Östen Undén.

También se pusieron de acuerdo en seguir las conversaciones sueco-españolas, manteniendo Suecia informados a los otros dos países escandinavos, mientras que López Oliván, que se trasladaba en breve a Suiza, sondearía al gobierno de ese país al respecto. La próxima reunión sueco-española podría tener lugar en breve, y que sería bueno hacerlo en Ginebra para dejar claro que la colaboración se refería a cuestiones de la Sociedad de Naciones.

Terminadas estas conversaciones, y antes de dejar su destino de ministro español en Suecia, López Oliván envió un informe específico al Ministerio de Estado sobre las relaciones políticas entre España y Suecia, de sumo interés, donde aboga claramente por el estrechamiento de las mismas. Quizá para resaltar más su punto de vista, dice que había que partir de la inexistencia de relaciones políticas entre ambos países, "salvo la 
simpatizante hacia un régimen de ideales muy semejantes, atenuada últimamente, hay que decirlo, con la salida de los socialistas en España”. Opina López Oliván que a España no le interesa alinearse con las grandes potencias, ni con ninguna de ellas en particular, por lo que

habría que orientar el fomento de las relaciones políticas con las pequeñas potencias europeas, libres de compromisos políticos a su vez y cuyos ideales sean la paz y la cooperación internacional. Esta política, además de ser, al parecer, la conveniente para España, habría de permitirle, en su día, ser la primera de las pequeñas potencias y preparar su eventual neutralidad ante un conflicto europeo. Suecia figura en ese grupo y (...)se llegará a la conclusión de que el fomento de las relaciones políticas con este país es conveniente y necesario para la acción política internacional de España.

Respecto a los medios para llevar a cabo ese acercamiento, propone Oliván que la acción no sea sólo con Suecia, sino también con los otros países similares (Noruega, Dinamarca, Países Bajos, Suiza...); que no debía caracterizarse políticamente, y que los objetivos debían estar impregnados de "moral internacional" (defensa de la Sociedad de Naciones, cooperación internacional, etc). Además, la acción política debía complementarse con una acción económica y cultural y España no debía asumir, en modo alguno, ninguna especie de hegemonía. López Oliván estimaba que esta política ya estaba iniciada y que, además, la situación política de Suecia en esos momentos, y su afán por cambiar su política internacional tradicional de cercanía a Alemania, eran muy favorables $^{57}$.

Como se desprende de lo anteriormente expuesto al referir las conversaciones entre López Oliván y Sandler/Undén, el diplomático español había pedido al Ministerio de Estado, a finales de enero, copias de las respuestas de los diferentes gobiernos afectados (Dinamarca, Noruega, etc.) a la nota enviada por España relativa a la constitución de un "grupo de neutrales" ${ }^{\text {". }}$. El 1 de febrero llegó la contestación de Pita Romero, informándole que había puesto en antecedentes al representante de Suecia en Madrid, y que

las comunicaciones recibidas de los representantes diplomáticos en los países en cuestión revelaban interés, solidaridad y deseo de esos gobiernos de que dicha cuestión siga

\footnotetext{
${ }^{57}$ AMAEC, R 860, 74, despacho de 15.II.1934.

${ }^{58}$ AGA, Asuntos Exteriores, Caja 523, carpeta 10, telegrama n. 2 de 29.I.1934, cifrado de 1.II.34
} 
adelante precisándose y concretándose, correspondiendo por tanto VE continuar camino trazado proponiendo o ejecutando iniciativas. Pita ${ }^{59}$

A vuelta de correo, contestaba López Oliván al Ministro de Estado:

Ministro Negocios Extranjeros me ha comunicado hoy que aprueba resultado conversaciones que he mantenido con Sr. Undén. Gobierno sueco muéstrase favorable a constitución grupo sin carácter político cuya primera finalidad sería cambiar impresiones sobre oportunidad dar conocer su criterio sobre reforma Pacto Sociedad. Aún caso no se estimara oportuno lanzar iniciativa, gobiernos representados en grupo tratarían concertar criterio para mantenerlo unido en eventual reforma. Ministro Negocios Extranjeros propónese comunicar resultado conversaciones a otros dos gobiernos escandinavos. Si se obtiene adhesión de ellos y de Holanda y Suiza se concertaría reunión en Ginebra mes de marzo.

Por el momento estimo convendría informar a nuestros representantes en Copenhague y Oslo dándoles cuenta esta información encargándoles que, a reserva comunicaciones ulteriores, gobierno sueco les informara directamente resultado mis conversaciones con $\mathrm{Sr}$. Undén. Hasta no conocer respuesta esos gobiernos convendría aplazar gestiones con Holanda y Suiza. Ministro me ha rogado prepare con Sr. Undén lista cuestiones examinar y aplace en consecuencia mi salida de aquí hasta día 18 lo que me he permitido hacer a reserva instrucciones VE. Agradeceré VE envío urgente copias respuestas recibidas de gobierno danés, noruego y holandés. Oliván ${ }^{60}$

La documentación analizada muestra claramente, a nuestro juicio, quién tenía la iniciativa en la formación del grupo de los neutrales: la República Española, a través de su ministro en Estocolmo, López Oliván. Llamado éste a misiones internacionales, hubo de dejar por entonces Estocolmo, y fue sustituido por Alfonso Fiscowich, a quien correspondió proseguir las gestiones.

En abril, el nuevo ministro en Estocolmo informaba al Ministerio de Estado del importante discurso del Ministro sueco de Negocios Extranjeros, que acababa de salir para Ginebra, explicando que en él había dado seguridades de que Suecia no pensaba reducir sus fuerzas defensivas y se había mostrado pesimista sobre el resultado de la reunión, aunque sin negar que había una vaga posibilidad de llegar a un acuerdo. Las manifestaciones de Sandler habían sido favorablemente acogidas en Suecia por los partidos

\footnotetext{
${ }^{59}$ AGA, Asuntos Exteriores Caja 523, carpeta 10, telegrama cifrado de M. Estado a Legación España, de1.II.34.

${ }^{60}$ AGA, Asuntos Exteriores Caja 523, carpeta 10, telegrama cifrado n. 3 de Legación España a M. Estado, 2.II.34.
} 
de la oposición. Los países pequeños, aunque jurídicamente fueran iguales en el seno de la Sociedad de Naciones - según Sandler - no tenían más remedio que tener en cuenta los intereses de los grandes ${ }^{61}$.

Tras la intervención en la asamblea de la Sociedad de Naciones del Ministro de Negocios Extranjeros de Suecia en representación del grupo de los neutrales, exponiendo el famoso memorándum, informaba el representante español en Estocolmo que la prensa sueca, en especial la socialdemócrata, lo había presentado "como si la iniciativa hubiera sido tomada por Suecia”, resaltando además el acendrado pesimismo de los comentarios y las acusaciones a Alemania como principal culpable del fracaso de la iniciativa, pero también a Francia e Inglaterra por no haber sido capaces de ponerse de acuerdo ${ }^{62}$. Dos meses más tarde, en un análisis más ponderado, decía Fiscowich:

Las discusiones de Ginebra han despertado aquí el mismo interés universalmente sentido y aunque los asuntos ventilados no afectan a problema alguno vital para Suecia, ni el fondo de las mismas ha de tener para ella especial repercusión, ha podido no obstante observarse la marcada atención con que se han seguido sus deliberaciones, acentuada, como es natural, al intervenir en nombre de los seis países neutrales el Sr. Sandler, dejándose adivinar un puntillo de satisfecha vanidad ante el papel preponderante que dentro de este grupo ha desempeñado. Mucha ha sido la información a este respecto, pero escasos los comentarios que por cuenta propia han hecho los centros políticos y la prensa. No es de extrañar esta reservada actitud si se recuerdan las declaraciones efectuadas por el propio Sr. Sandler pocos días antes de la reunión de abril (despacho n. 78) en las que hábilmente contentó las aspiraciones de los partidos de derechas sobre la defensa nacional.

Este reconocimiento del punto capital del programa conservador llevado a cabo por un ministro socialista ha puesto punto en boca a las tendencias extremas de uno y otro lado, sin contar con la prudencia y el recato con que se tratan aquí los asuntos de carácter internacional. El tiempo transcurrido de abril aquí no ha servido para modificar el escepticismo con que ha mirado el Sr. Sandler el posible éxito de la conferencia, puesto otra vez de manifiesto en forma mas viva que su reserva acostumbra, en conversación mantenida conmigo el día anterior a su partida $^{63}$.

En el informe semestral, el diplomático español resumía la intervención de Sandler en la Sociedad de Naciones insistiendo en la actitud sueca de pesimismo e incluso de escepticismo ante el futuro de la Sociedad, pero destacando al mismo tiempo el "verdadero

\footnotetext{
${ }^{61}$ AMAEC R 243, 12, telegrama n. 9 de 8.IV.1934; AMAEC R 944, 29, despacho n. 78 de 11.IV.1934.

${ }^{62}$ AMAEC R 944, 29, despacho de 17.IV.1934.

${ }^{63}$ AMAEC, R 944, 29, despacho de 12.VI.1934.
} 
entusiasmo con que el actual titular del Ministerio de Negocios Extranjeros, Sr. Sandler, acogió la propuesta española del grupo de países neutrales", considerando que mientras siga al frente de la política exterior sueca iba a ser esa la base de su orientación en lo relativo a la Sociedad de Naciones ${ }^{64}$.

Esa declaración no tuvo mayores consecuencias, pero fue una manifestación de intenciones consensuada, dada por los países neutrales, frente a las grandes potencias de la Sociedad de Naciones.

\subsubsection{Los conflictos del Chaco y Abisinia}

A partir de esta iniciativa común, los contactos entre España y Suecia, en el marco de la cooperación en la Sociedad de Naciones, se intensificaron, como puede verse tanto en relación con el conflicto del Chaco como con el de Abisinia.

En agosto de 1934, la República Española buscó el apoyo sueco para ser reelegida como miembro del Consejo de la Sociedad de Naciones. El resultado de las gestiones a este respecto lo resumió Alfonso Fiscowich diciendo que Sandler le había reiterado la simpatía que le inspiraba la gestión de España en el Consejo de la Sociedad de Naciones, a pesar de que, por una cuestión de principio, Suecia se oponía a toda reelección. Así lo había hecho en el caso de Polonia, aunque al final le dio su voto favorable. El Consejo de Ministros sueco trataría el tema a finales de agosto. En septiembre comunicó Fiscowich que Sandler estaba a punto de viajar a Ginebra donde deseaba tratar con los delegados españoles el asunto de la reelección, para ver la manera de aunar el principio sueco con el deseo de apoyar a España ${ }^{65}$.

En contrapartida, Suecia confiaba en la cooperación de España en el conflicto del Chaco, en el que Suecia había tomado partido contra la actitud de Paraguay. Los telegramas del representante de España en Estocolmo no dejan lugar a dudas:

Negativa Paraguay aceptar propuesta Sociedad Naciones ha disgustado profundamente este gobierno que convencido necesidad despejar equivoca situación considera indispensable caso persistir negativa ejercer presión. Estudia actualmente medios apropiados realizarla, no descartando posibilidad presentar cuestión embargo, prefiere ponerse previamente acuerdo Ginebra contando valiosa cooperación España ${ }^{66}$.

\footnotetext{
${ }^{64}$ AMAEC, R 698, 10, despacho n. 151 de 15.VII.1934.

${ }^{65}$ AMAEC, R 243, 12, telegramas n. 19 de 8.VIII.1934 y n. 23 de 5.IX.1934.

${ }^{66}$ AMAEC, R 344, 15, telegrama n. 1 de 9.I.1935.
} 


\section{Y al poco tiempo:}

Ministro negocios extranjeros me expresa su desorientación y perplejidad sobre puntos convendría tratarse Ginebra en cuestión Chaco, observando persiste su actitud energía respecto Paraguay. Consciente interés y prestigio España aquel continente estimaría conocer antes reunión criterio vuecencia ${ }^{67}$

Como es sabido, el asunto del Chaco quedó eclipsado por el anuncio de la Alemania nazi, el 16 de marzo de 1935, de su intención de incumplir el Tratado de Versalles con la creación de la Wehrmacht. Al respecto informaba Fiscowich que, de una conversación confidencial con el Ministro sueco de Negocios Extranjeros, se desprendía que la medida no le había sorprendido demasiado porque el gobierno sueco conocía "el verdadero desenvolvimiento de la política alemana". A pesar de todo, Sandler estimaba que no agravaba especialmente la situación política europea. Sandler le comunicó también a Fiscowich que no había recibido sugestión alguna extranjera, ni había estudiado todavía cómo actuar en Ginebra, limitándose a paliar la alarma de la prensa recomendando en comunicación oficiosa la oportunidad de una reunión internacional para tratar abiertamente la cuestión del armamento sin dificultar la labor con juicios apasionados ${ }^{68}$.

Sin embargo, el optimismo inicial cedió pronto. Con objeto de preparar la reunión extraordinaria de Ginebra, los ministros escandinavos de Asuntos Exteriores, a iniciativa del danés, acordaron reunirse en Copenhague para cambiar impresiones. Es una prueba más de la prioridad que para Suecia tenía la cooperación nórdica, a pesar de la iniciativa española en relación con el Grupo de los Seis, pues el Ministro español no fue invitado. En particular, se apreciaba en los ministros nórdicos una clara simpatía por la posición inglesa ante el problema, esperando saber la impresión que había causado la visita de unos agentes ingleses a Rusia ${ }^{69}$.

A su vuelta de Copenhague, Sandler le explicó a Fiscowich que el comunicado de la reunión había sido premeditadamente vago, para no dar la impresión de que se tenía una propuesta concreta de solución, pues, en opinión de Sandler, era tarea de los países reunidos en Copenhague no interesados directamente en el conflicto. Según Sandler, no era fácil fijar la actitud a tomar, hasta saber cuál sería el tema central de la reunión de Ginebra:

\footnotetext{
${ }^{67}$ AMAEC, R 344, 15, telegrama n. 8 de 6.III.1935.

${ }^{68}$ AMAEC, R 344, 15, telegrama n. 13 de 20.III.1935.

${ }^{69}$ AMAEC, R 344, 15, telegrama n. 16 de 31.III.1935
} 
la violación jurídica del Tratado de Versalles - con la posibilidad de emitir un voto de censura de la misma - o la organización de la seguridad y los armamentos.

Confidencialmente, Sandler informó al representante español que Dinamarca haría una propuesta a los países del grupo neutral, sugiriendo adoptar una actitud de reserva, no formulando ningún punto de vista hasta conocer la propuesta que harían en Ginebra los países interesados. A la vez, los neutrales deberían esforzarse para que el problema fuera presentado de una manera que permitiera a la Sociedad de Naciones llegar a un acuerdo. El objetivo sería la sustitución de la política de armamentos por una convención basada en el derecho universal reconocido ${ }^{70}$.

España no tenía nada que objetar a esta política, y el Ministro sueco de Negocios Extranjeros no dejó de manifestar su agrado por el estrechamiento de la colaboración sueco-española en Ginebra ${ }^{71}$. Incluso el Parlamento sueco se hizo eco de esta satisfacción, concretándose ésta en una interpelación al Ministro, en la Primera Cámara, solicitando que se llevara a cabo una "política exterior fuerte de los países pequeños bajo el liderazgo sueco", citando, como ejemplo a seguir, el memorándum de los neutrales del mes de abril como propuesta común en Ginebra de las delegaciones danesa, holandesa, suiza, española y sueca ${ }^{72}$.

La colaboración con España funcionó sólo en parte en relación con el grave conflicto abisinio, que trajo como consecuencia para Suecia - la cual habría de quedarse prácticamente sola en su postura de sanciones a Italia - el cambio de curso de su orientación política exterior de defensa a ultranza de la Sociedad de Naciones a una neutralidad radical.

El 22 agosto de 1935, Fiscowich reiteraba al Ministerio de Estado cual era la actitud sueca ante el conflicto abisinio, tema del que había informado detalladamente en despachos anteriores. La intransigencia de Italia en París y las persistentes alusiones de la prensa italiana a la intención de Suecia de defender los principios de la Sociedad de Naciones habían agudizado la hostilidad sueca hacia Italia, preocupando al gobierno la situación, que iba de ser el tema primordial de una reunión de los ministros de Exteriores de Suecia, Dinamarca, Noruega y Finlandia en Oslo, el 28 de agosto.

El objetivo de ese encuentro era llegar a un acuerdo común sobre la postura a adoptar en la próxima reunión de la Sociedad de Naciones en Ginebra. De forma reservada,

\footnotetext{
${ }^{70}$ AMAEC, R 344, 15, telegrama n. 17 de 5.IV.1935.

${ }^{71}$ AMAEC, R 344, 15, telegrama n. 20 de 13.IV.1935.

${ }^{72}$ SANDLER, Rickard, Svenska utrikesärenden..., pp. 73 ss.
} 
Sandler ofreció a Fiscowich la posibilidad de señalarle orientaciones, reiterando su simpatía y su interés por mantener los contactos con España. Inmediatamente, el Ministerio de Estado contestó agradeciendo el interés sueco por mantener los contactos con España, y anunciando que el delegado español se pondría en contacto con el sueco para coordinar la política a seguir.

La reunión de Oslo constató la gravedad del momento y la desorientación de las grandes potencias, acordando unánimemente tratar de resolver el conflicto dentro del espíritu del Pacto de la Sociedad de Naciones. La actitud italiana fue estimada por los ministros reunidos como preocupante y amenazadora. Fiscowich no ocultaba su sorpresa ante la enérgica actitud sueca de tratar por todos los medios de hacer cumplir a Italia los compromisos del Pacto ${ }^{73}$.

Sin embargo, en el caso de Abisinia no se llegaría a una postura común por parte de los neutrales, y Suecia se quedó sola en su decisión de enfrentarse frontalmente a Italia dentro del marco del Pacto de la Sociedad de Naciones. La actitud española aparece claramente expuesta en la documentación enviada por la Legación de Suecia en Madrid al Ministerio sueco de Negocios Extranjeros.

Según esa documentación, el hombre clave respecto a la postura española - basada en mantener una actitud neutral, evitando todo enfrentamiento con Inglaterra y con Italia era el ministro de la Guerra, Gil Robles. Se mencionan las críticas de la prensa católica española a la postura inglesa, considerada "egoísta", pero se dice que España no está dispuesta a imponer sanciones a Italia, política que sólo el PSOE había apoyado públicamente. En una carta privada de Ivan Danielsson al barón Beck-Friis, jefe de la sección política del ministerio sueco de Negocios Extranjeros, resumía aquel la crisis italoetíope citando las palabras de Madariaga al respecto: "Fue la fabula del león y el cordero. Se hizo la paz una vez que el primero se había comido al segundo"74.

Fiscowich dio cuenta detallada a Madrid acerca de las medidas tomadas por Suecia contra Italia, consistentes en embargo de armas y sanciones económicas. El conflicto sueco-italiano se agudizó, a consecuencia de ello, en las últimas semanas del año, con el bombardeo de la ambulancia de la Cruz Roja sueca por la aviación italiana. El 23 de noviembre informaba Fiscowich del anuncio sueco de las medidas a Italia, realizado a

\footnotetext{
${ }^{73}$ AMAEC, R 344, 15, telegramas n. 37 de 22.VIII.1935 y n. 38 de 30.VIII.1935.

${ }^{74}$ RA, UD, Beskickningsarkivet: Madrid, F1 C, Vol. 41, despachos n. 451 de 30.VIII.1935 y 456 de 12.IX.1935; Nota de Ivan Danielsson a Beck-Friis, 13.IV.1936.
} 
través de un documento breve que "no contiene palabra alguna de amistad o consideración" 75 .

Sandler se mostró inflexible respecto a la posición sueca en un discurso público, pero en una conversación privada con Fiscowich, le confió que el interés de Suecia como pequeño Estado y la intransigencia que había manifestado en el conflicto italo-etíope habían colocado al país en una situación embarazosa. El ministro veía la situación con "extremo pesimismo"76.

\subsubsection{El "Manifiesto de los Siete”}

Con esto llegamos al acto final de las relaciones específicas de Suecia con la República Española dentro del marco de la cooperación entre los países neutrales, que llevaría al llamado "Manifiesto de los Siete", del 1 de julio de 1936.

La génesis del manifiesto, en línea con el "Manifiesto de los Seis" de 1934, se encuentra en la crisis de Renania, consecuencia de la militarización de esa zona de Alemania. Al día siguiente de la flagrante violación del Tratado de Versalles que supuso el paso del Rin en Colonia por las tropas alemanas el 7 de marzo de 1936, telegrafió Fiscowich al Ministerio de Estado:

Gobierno y círculos parlamentarios juzgan sin pesimismo situación creada por actitud Alemania estimando no existen argumentos jurídicos imposición sanciones. Cambio impresiones países Grupo coinciden. Delegado Dinamarca en consejo sociedad naciones reflejará este criterio en forma acaso similar a la observada en reunión motivada por rearme alemán $^{77}$

El Gobierno de la República Española quiso tomar contacto enseguida con Suecia en vistas a una declaración común. En mayo, el Secretario de la Legación de España en Estocolmo, Oyarzábal, confirmó el aprecio del gobierno sueco por el interés de España, y especificó que Sandler se reuniría con la delegación española en Ginebra el 9 de ese mes ${ }^{78}$.

En el transcurso de esa reunión, que tuvo lugar entre el 9 y el 12 de mayo de 1936, el representante español, Madariaga, entregaría a los neutrales un memorándum, que serviría

\footnotetext{
75 AMAEC, R 344, 15, telegramas n. 41, 42, 43 y 44 de 18, 21, 28, y 30.X.1935; Ibid., n. 46 de 6.XI.1935; AMAEC R 344, 15, telegrama n. 54 de 23.XI.1935.

${ }^{76}$ AMAEC, R 850, 19, despacho de 20.XI.1935; AMAEC, R 344, 15, telegrama n. 56 de 18.XII.1935.

${ }^{77}$ AMAEC R 615, 31, telegrama n. 8 de 11.III.1936.

78 AMAEC R 615, 31, telegramas n. 17 y 18 de 2 y 5.V.1936, y telegrama de Augusto Barcia a Legación España n. 17, de 4.V.1936.
} 
de base de la declaración común de los mismos. El Ministerio sueco hizo un amplio resumen del contenido del memorándum de Madariaga para someterlo al trámite de aprobación por el Comité de Política Exterior (utrikesnämnden) ${ }^{79}$.

El memorándum partía de la necesidad que se hacía sentir, a la luz de los dieciséis años transcurridos desde 1920, de reformar el Pacto de la Sociedad de Naciones. Las ideas de Madariaga, según el resumen sueco, eran las siguientes:

Se trataba de reformar la Sociedad, no para hacerla jurídicamente más perfecta, sino políticamente más efectiva. Pensaba Madariaga que sería preferible hacerlo sin necesidad de proceder a una reforma formal del texto del Pacto. Era importante mantener el equilibrio entre las distintas disposiciones del Pacto, pero por otra parte, el sistema de ratificaciones de las alteraciones al texto del Pacto era tan complicado, que un texto revisado no podría entrar en vigor en un plazo corto. Además, el dejar inalterado el texto del Pacto permitiría verlo como el objetivo a lograr a largo plazo, aunque las necesidades políticas no permitieran aplicarlo tal cual en el momento actual.

Por otra parte, estimaba Madariaga que no se podía aplicar el Pacto mientras la Sociedad de Naciones no fuese universal y las circunstancias políticas permitieran aplicar todos los artículos de manera equitativa. La falta de universalidad actual era evidente y no precisaba de comentario alguno.

Sobre el equilibrio entre los distintos artículos del Pacto, parecía también evidente que una aplicación completa del artículo 8 (limitaciones al rearme nacional) era el presupuesto político y jurídico para la aplicación de las sanciones obligatorias del artículo 16. En opinión de Madariaga, los países miembros estaban en su perfecto derecho de, reservarse frente al artículo 16 en ciertas condiciones, mientras la falta de universalidad y las circunstancias políticas no permitieran una completa aplicación del artículo 8.

La propuesta del español era que algunos países (los neutrales), a partir del razonamiento jurídico expresado, se reservaran frente a la obligatoriedad de aplicar el artículo 16 respecto a zonas políticas y geográficas lejanas de su esfera de intereses y, una vez fuera de juego el mismo, declararan que lo aceptaban respecto a las zonas políticas y geográficas en las que tuvieran un interés específico.

Esto permitiría, en opinión de Madariaga, la formación de pactos regionales y alianzas dentro del marco de la Sociedad de Naciones. En la situación vigente entonces, la suspensión total del artículo 16 permitiría la creación de grupos político-militares

\footnotetext{
${ }^{79}$ RA, UD, 1920-års dossierssystem, HP, Vol. 5 Utrikesnämnden, orden del día 12.VI.1936.
} 
(militärpolitiska grupper, en la expresión sueca utilizada), algo que comportaba una serie de peligros evidentes. En cambio, su supresión parcial en el sentido indicado, haría que las posibles acciones militares quedaran sujetas ipso facto al control del Consejo de la Sociedad de Naciones. El sistema se podría completar dando a aquellos países que quisieran mantenerse al margen del sistema ginebrino, la posibilidad de adherirse al artículo 11 sobre consultas internacionales en caso de conflictos, y revisando para ello la praxis vigente que exigía unanimidad en la aplicación de los artículos 10 y 11, lo cual en la práctica los hacía ineficaces.

Madariaga proponía poner el acento en las disposiciones de la Sociedad de Naciones sobre la prevención de conflictos armados en lugar de centrarse en las sanciones a los Estados que incumplieran el Pacto. Mientras se siguiera contemplando el Pacto como un sistema de sanciones, será inefectivo, porque conducía automáticamente, en la práctica, a la aplicación de medidas violentas.

Esa política preventiva, tal como la veía Madariaga, tendría dos partes importantes: la primera era la aceptación de la necesidad de una política colectiva, como presupuesto para conseguir una seguridad colectiva. No era realista exigir a cada país que se hiciese responsable de tomar medidas por su cuenta para solucionar unas situaciones, en cuya génesis nada había tenido que ver. La acción solidaria del artículo16 debía ampliarse, por tanto, a una solidaridad en la actividad política y diplomática.

La segunda parte era el fortalecimiento del artículo 11, no imponiendo sanciones por su incumplimiento - ya que entonces se convertiría en otro artículo 16 - sino desarrollando en su seno un conjunto de medidas preventivas, lo cual era el núcleo de la Convención de 1931 sobre medidas preventivas de la guerra.

Todo esto podía llevarse a cabo - creía Madariaga - sin excesivas complicaciones jurídicas. El proceso cabía dentro del marco de la soberanía nacional de los Estados miembros. Cualquier Estado o grupo de Estados estaba facultado para poner en marcha el sistema mencionado, sin más formalidades que comunicar su decisión a la Secretaria de la Sociedad de Naciones. Madariaga proponía que el grupo de Estados neutrales enviara un documento conjunto en tal sentido, lo cual daría especial peso a la iniciativa.

El memorándum de Madariaga no era vinculante para el gobierno español, que sin embargo se mostró dispuesto a discutir el asunto con otros gobiernos del grupo de los neutrales, en base a este memorándum u otro similar. Los gobiernos de los países neutrales aceptaron este planteamiento, y de ahí surgió el "Manifiesto de los Siete", el comunicado 
común de los Ministros de Asuntos Exteriores de Dinamarca, Finlandia, Holanda, Noruega, Suiza y España, que se publicó en Ginebra el 1 de julio de 1936.

La obra básica de la historiografía sueca sobre la historia de la política exterior del país menciona la "reunión de las siete potencias en Ginebra el 9 de mayo de 1936" como el gran intento de adopción de una política neutral común en el marco de la Sociedad de Naciones ${ }^{80}$.

Las ideas de Madariaga las hizo Suecia suyas, como se pone de manifiesto en el borrador de documento a enviar al Secretario General de la Sociedad de Naciones que los ministros nórdicos discutieron en su reunión de Copenhague, el 20 de agosto de 1936. Suecia no estaba dispuesta, de todos modos, a dejarse involucrar en un sistema de sanciones militares en caso de ataque a un Estado miembro.

En todo caso, el interés por crear una Convención de Neutrales continuó hasta el comienzo de la guerra mundial. En 1937, lamentaba el ministro sueco de Exteriores no poder contar con el representante español, al que, por la situación de guerra existente en España, se había visto más oportuno no convocar, esperando que en el futuro pudiera participar $^{81}$.

El Ministro de Negocios Extranjeros sueco no se equivocaba: la relación especial de España con Suecia en cuanto miembros principales del grupo de los neutrales, comenzada por la República, continuaría en el período inmediatamente siguiente a la guerra civil española, siendo el interlocutor, en ese momento, la España de Franco. La guerra mundial vendría a truncar esas relaciones, si bien no de manera inmediata: hubo tiempo para un conato de declaración común sueco-española llamando a la paz incluso después del comienzo de la contienda. Pero esto es ya otra historia, que expondremos en un capítulo posterior, al analizar las relaciones de Suecia con la llamada "España nacional".

No es fácil juzgar con precisión el alcance y significación de esta política exterior sueco-española en el marco de la Sociedad de Naciones. El conocido historiador sueco Klas Åmark, en su reciente estudio sobre la relación de Suecia con el nazismo, califica a la Suecia de entreguerras como un país sin apenas ambiciones de política exterior, que se limitaba a mantener buenas relaciones con sus vecinos y relaciones rutinarias con las potencias europeas, sin una agenda importante. Estima que en la Sociedad de Naciones,

\footnotetext{
${ }^{80}$ LÖNNROTH, op. cit., p. 144.

${ }^{81}$ RA, UD, 1920-års dossierssystem, HP, Vol. 5 Utrikesnämnden. Guión del discurso del Ministro de Negocios Extranjeros en la reunión de la Comisión de Exteriores, 4 de marzo de 1937.
} 
Suecia apenas se hizo notar, ocupada solamente en conseguir su objetivo primordial: no verse involucrada en una guerra ${ }^{82}$.

A la luz de lo expuesto anteriormente, no nos parece justa esta afirmación. Por el contrario, la documentación diplomática analizada parece sugerir que el papel de Suecia y en cierta medida también, por qué no decirlo, el de España, fue un papel activo, de interés e iniciativa responsable por crear y mantener, en la medida de sus posibilidades, un ambiente que facilitara la colaboración en el seno de la Sociedad de Naciones para tratar así de evitar la guerra que todos veían, por aquel entonces, como una amenazadora y real posibilidad.

\subsection{Intereses bilaterales específicos entre España y Suecia}

Dejando a un lado los grandes temas de la política internacional, nos corresponde ahora centrarnos en los intereses bilaterales específicos entre ambos países que fueron objeto de la gestión propia de la Legación de cada país en la capital del otro. En primer lugar, nos ocuparemos de los informes diplomáticos sobre la visión del propio país en el país de destino, para analizar luego cuáles fueron los principales temas específicos objeto de las gestiones diplomáticas encargadas a los representantes de España en Suecia y de Suecia en España.

\subsubsection{La imagen del propio país en el país de destino}

Es práctica normal, en el mundo diplomático, informar a sus gobiernos sobre la imagen que la opinión pública del país de destino, en especial tal como es reflejada en la prensa. En este sentido, y por razones obvias, el interés de la prensa sueca por los asuntos de España aumentó claramente a partir del cambio de régimen en España.

Como ya sabemos, la documentación diplomática española referida a 1931 y 1932 está muy incompleta, por lo que en muchos casos no nos queda otra referencia que la contenida en los libros-registro de entradas y salidas de las Embajadas y Legaciones. Por él sabemos, por ejemplo, de la existencia de varios despachos sobre el impacto en Suecia, a nivel de imagen, de graves sucesos de la actualidad política española. Normalmente, los comentarios en estos despachos, a juzgar por los existentes de fechas posteriores, son parcos, limitándose a enviar recortes de prensa en los que se ha nombrado a España, con un

\footnotetext{
82 ÅMARK, Klas, Att bo granne med ondskan..., pp. 74-77 y 114s.
} 
breve resumen de los mismos o, en casos de especial interés, con la traducción correspondiente.

Durante 1931 y 1932, además de lo ya señalado respecto a Alfonso XIII, consta, por los libros-registro, que la Legación informó en bastantes ocasiones sobre el impacto en Suecia de los principales sucesos de la actualidad política española: en julio de 1931, remitía artículos de prensa suecos sobre España; en diciembre, un despacho sobre la recepción de la Constitución Española; en abril de 1932, primer aniversario de la República, varios despachos: uno acerca de una entrevista de un periodista sueco con Niceto Alcalá-Zamora, otro informando acerca de un artículo ruso sobre el comunismo en España, un tercero acerca de un artículo sueco sobre el proyecto de Ley Agraria y otro más sobre la política española en general, ampliado a primeros de mayo con otro sobre la situación en España.

En junio adjuntaba un artículo de prensa sobre desórdenes sociales en España y en julio otro artículo sobre la reforma de la enseñanza primaria en España. En agosto, informaba del tratamiento dado en la prensa sueca a la "Sanjurjada", y en octubre comentaba el especial interés del órgano oficial de la prensa socialdemócrata, el Socialdemokraten, sobre los asuntos españoles. Finalmente, declaraciones atribuidas a politicos españoles, en noviembre de 1932 se daba cuenta de declaraciones que la prensa sueca ponía en boca de algunos políticos españoles ${ }^{83}$.

Quizá lo más interesante sobre la imagen de España en torno al primer aniversario de la República sea la información que envió García Conde al Ministerio de Estado con carácter estrictamente confidencial relativa a una conversación que había tenido con su colega francés en Estocolmo, en la que éste le contó el contenido de la información que el Embajador francés en Madrid había enviado a su gobierno. A través del Ministro de Francia en Suecia, la visión francesa del primer año de la República se difundió, es de suponer, en los círculos diplomáticos, y a través de ellos en los círculos políticos de Estocolmo.

Según esa información, los españoles eran considerados por los franceses como muy fatalistas, habiendo empleado el Embajador francés en Madrid el símil de un tren que descarrila. Los españoles no estaban acostumbrados a la democracia, y eso podría dar al traste con la República. Elogiaba el francés a Azaña, quien en los primeros seis meses

\footnotetext{
${ }^{83}$ AGA, L- AE 6403, pp. 126-128, despacho n. 254 de 1931; AGA, L- AE 6422, pp. 168-176, despachos n. 54, 57, 61, 70, 78, 126, 138, 170, 204 de 1932.
} 
había conseguido librar a la República de los pronunciamientos y en los seis siguientes había sabido dar valientemente la cara por la democracia. Veía posibilidades claras de que Azaña consiguiera juntar a los partidos republicanos en torno a sí mismo, con detrimento de los socialistas. Suponía probables las elecciones generales para principios de 1933. Hablaba del deseo de los socialistas de dejar responsabilidades de gobierno por el descontento que había en sus afiliados por los ataques anarcosindicalistas y comunistas.

Respecto a la economía, decía el Embajador de Francia que el alza de la peseta tras la emisión de deuda pública por valor de 500 millones de pesetas, el equilibrio del presupuesto, la buena cosecha anunciada y la prosperidad industrial catalana, hacían que el país estuviera mejor que hacía un año. El embajador francés sentía, a pesar de todo, un cierto temor por el nuevo nacionalismo español, resucitado por el advenimiento de la República. Le parecía, de todas formas, que la prensa francesa debería mostrar más afecto a los españoles ${ }^{84}$.

La siguiente remesa de envíos de artículos periodísticos suecos sobre España, por parte de la Legación en Estocolmo, coincide con el nuevo cambio de gobierno en la República, en 1933. Aparte de información sobre la crisis del gobierno español y sobre las elecciones en general, hay varios despachos sobre impresiones recibidas por periodistas suecos en sus viajes a España ${ }^{85}$.

También de ese año es un despacho sobre un viaje de estudios a Suecia de funcionarios municipales extranjeros, entre ellos algunos españoles (todos catalanes), del que se hizo eco la prensa sueca con una entrevista a la española Maria Soteros, esposa de un abogado de Barcelona, que alabó la reforma escolar española ${ }^{86}$. Y en febrero de 1934, el principal diario conservador de Suecia entrevistó al Ministro saliente de España en Estocolmo, López Oliván ${ }^{87}$.

Es bastante significativa la presencia en los medios de comunicación suecos de los representantes diplomáticos de España durante toda la década. Tras la caída de Barcelona, a principios de 1939, aparecieron entrevistas con los representantes diplomáticos en Estocolmo de ambas zonas de España; y al comienzo de la década, el anuncio del cambio de Ministro, de García Conde a López Oliván, ya había sido objeto de interés por parte de

\footnotetext{
${ }^{84}$ AMAEC R, 341, 9, a, despacho confidencial de García Conde a Luis de Zulueta, 18.VII.1932.

${ }^{85}$ AGA, L- AE 6443, pp. 118-125.

${ }^{86}$ AMAEC R 341, 9, a, despacho de 31.VII.1933.

${ }^{87}$ AGA, L-AE 6464, pp. 143-152, entrevista con López Oliván en el Svenska Dagbladet.
} 
la prensa sueca. De hecho, en esa ocasión, García Conde había pedido explicaciones al Ministerio de Estado, pues la prensa sueca había anunciado su futuro destino:

Toda esta prensa anoche y hoy publica nombramiento ministro aquí López Olivan y mío cónsul general Atenas. Como varias redacciones extrañadas ha solicitado por teléfono aclaración esto ultimo que a mí mismo me sorprende, hube contestarles que única noticia oficial recibida era mi traslado de Ministro Atenas. ${ }^{88}$

También se conservan los llamados inventarios de intereses españoles en Suecia. Los correspondientes a 1931 y 1932 se centran casi exclusivamente en asuntos comerciales. El inventario de 1933 informaba del número de españoles residentes en Suecia, un total de ocho personas, a la par que mencionaba el alto porcentaje que correspondía al mercado español dentro de las exportaciones suecas. El del año 1934 daba la cifra total de catorce españoles en Suecia: diez en Estocolmo y cuatro en Gotemburgo ${ }^{89}$.

De mayor interés para el tema que nos ocupa son las informaciones contenidas sobre la imagen de España en Suecia en los informes semestrales. En el correspondiente a la segunda mitad 1933, firmado por José F. Villaverde como Encargado de negocios de España ad interim, la Legación incluyó un subapartado titulado "actitud y noticias de la prensa referentes a España”. En él se menciona una larga serie de artículos sobre España escritos por un conocido periodista sueco, Gösta Attorps, que había participado en un viaje para periodistas extranjeros organizado por el Patronato Nacional de Turismo español. El tenor de estos artículos, en los que el periodista contaba sus impresiones sobre España, era en general halagüeño para España aunque alguno de ellos había sido algo irónico. Esos artículos habían contribuido a hacer más eficaz la campaña que desarrollaba en Suecia el Patronato Nacional del Turismo.

Por otra parte, el diario Social Demokraten había publicado el 2 de septiembre un artículo muy elogioso sobre la labor de la República en materia de enseñanza. Y respecto a la actualidad política española, la Legación destacaba las informaciones aparecidas en el ese mismo diario atribuyendo el triunfo electoral de las derechas españolas a la desunión de las izquierdas, al alto porcentaje (40\%) de votos por distrito exigido por la Ley electoral española para dar la victoria a un partido y al voto femenino. Las mujeres españolas, para

\footnotetext{
${ }^{88}$ AMAEC R 191, 12, telegrama n. 3 de 9.I.1933.

89 AMAEC, R 720, 41 e, despacho n. 59 de 9.IV.1932; despacho n.14 de 25.I.1933; despacho n. 2 de 2.I.1934; despacho n. 10 de 15.I.1935.
} 
el diario socialdemócrata sueco, carecían de experiencia política, y estaban todavía bajo la influencia clerical.

Añadía además la Legación que, en los últimos meses, el Social Demokraten comentaba la política española "en tonos de menor simpatía de lo que hasta el presente venía haciendo". Por su parte, el diario conservador Nya Dagligt Allehanda había publicado un artículo sobre el nuevo "régimen de derechas en España" con el "carácter sensacional que, debido a la escasez de noticias, suele imprimir a sus publicaciones".

El periodista socialista sueco Sigfrid Hansson, que había hecho un viaje a España subvencionado por el sindicato sueco LO para estudiar el movimiento obrero español, dio algunas entrevistas a la prensa sueca al volver, entre otros al Dagens Nyheter, donde, "aunque algunos de sus conceptos adolezcan de la rapidez de la visión, habrán sido desde luego leídos con gran interés". De ello también se hacía eco la Legación.

Finalmente, aparecían en el informe semestral referencias a los artículos de los principales diarios, Svenska Dagbladet y Dagens Nyheter, sobre las elecciones españolas. En suma - concluía Villaverde - durante 1933, España y su política habían sido seguidos con mayor interés por parte de la prensa sueca de lo habitual en años anteriores, "y si bien ésta, como todas las prensas, está a veces mal informada, si se toman en consideración los muchos factores que nos separan de la mentalidad escandinava, podemos afirmar que los términos empleados han sido en general de simpatía"90.

Por su parte, López Oliván, en un despacho específico sobre las relaciones políticas hispano-suecas antes de dejar su cargo en Estocolmo, tras descalificar las relaciones entre ambos países durante el tiempo de la monarquía como "de carácter efímero y de un interés puramente dinástico", afirmaba también que los medios políticos suecos veían con simpatía a la República Española ${ }^{91}$.

En el primer informe semestral de 1934, el Ministro de España en Estocolmo, respecto al tema que nos ocupa, se centraba en el interés que despertaba en Suecia todo lo relacionado con el turismo en España. Un buen número de intelectuales suecos había participado en los cursos de verano de Santander. Consideraba importante el diplomático fomentar este tipo de relaciones, pues contribuiría a "mantener en alza constante la curiosidad y el interés que en este sentido existe por nuestro país". Aprovechaba Fiscowich para pedir mayor rapidez en las contestaciones y mayor exactitud en las informaciones

\footnotetext{
${ }^{90}$ AMAEC R 698, 10, despacho n. 17 de 15.I.1934.

${ }^{91}$ AMAEC R, 860, 74, despacho n. 46 de 15.II.1934.
} 
dadas a consultas de suecos por el Patronato Nacional de Turismo, "ya que dada la psicología de los suecos en este sentido, estiman mucho todo cuanto a puntualidad y minuciosidad se refiere".

Sobre la actitud de la prensa y las noticias referentes a España, informa que los grandes diarios suecos suelen traer casi todos los días noticias del desarrollo de los acontecimientos políticos españoles, limitándose de ordinario a dar la información sin comentarios. Últimamente mereció especial atención "el problema de Cataluña". 92

En el segundo semestre de ese año, sin embargo, la Revolución de Asturias fue motivo de preocupaciones para el Ministerio de Estado y la Legación en Estocolmo en lo concerniente a la imagen de España en Suecia. Ya en el mes de marzo, una Circular del Ministerio de Estado a las Embajadas y Legaciones insistía en la necesidad de fomentar las buenas relaciones con los directores de los principales diarios para que no publicaran "noticias exageradas sobre España"93. Del tipo de informaciones a que se refería el Ministerio de Estado da idea el artículo publicado por el diario comunista Ny Dag el 14 de marzo de ese año, titulado "España Fascista o España Comunista: un camarada sueco nos explica la situación", del cual se conserva copia incluso en el Archivo de la Policía de Seguridad sueca ${ }^{94}$.

Un telegrama de Fiscowich mostraba claramente su desconcierto:

Prensa publica acontecimientos españoles especialmente actos sin detallar actitud del gobierno central. Ante interés esta opinión juzgo conveniente poseer alguna información al respecto que calme actual desorientación ${ }^{95}$.

El tráfico de telegramas entre Estocolmo y Madrid a este respecto fue intenso durante ese mes de octubre: el día 9 informaba Fiscowich que la prensa sueca había comentado la noticia basándose en parte en la versión oficial de los acontecimientos que se había dado a conocer desde el Ministerio de Estado, pero añadiendo otras informaciones de origen diverso, que hablaban de un "recrudecimiento de la extensión de los disturbios".

El 14 de octubre, la prensa sueca publicó la versión dada por el Gobierno de la República:

\footnotetext{
92 AMAEC R 698, 10, despacho n. 151 de 15.VII.1934.

${ }^{93}$ AGA, Asuntos Exteriores, Caja 523, Carpeta 10, Circular n. 5 de 21.III.1934 de M. Estado

${ }^{94} \mathrm{RA}, S \ddot{A} P O$, Vol. 489.

95 AMAEC R 243, 12, telegrama n. 24 de 7.X.1934.
} 
La tranquilidad en España es casi absoluta puesto que movimiento revolucionario ha sido dominado en todo el territorio con sola excepción provincia Asturias. Pueblos esta provincia donde se habían hecho fuertes rebeldes han sido ya invadidos por fuerzas leales ejército quedando completamente pacificados Oviedo, Gijón Avilés y otros lugares. Sólo queda un foco de revolucionarios en zona Mieres, si bien se ha producido ya desmoralización entre rebeldes que en número considerable abandonan armas y se presentan autoridades. En dicha cuenca minera se espera que pueda restablecerse completamente normalidad dentro plazo no superior 48 horas. En resto España la vida ha quedado totalmente normalizada: todos los gremios de trabajadores han acordado reintegrarse al trabajo. Huelga había sido ya dominada por medidas autoridades gubernativas y militares que aseguraron todo momento circulación trenes y vehículos y prestación servicios públicos Después acuerdo gremios obreros reintegrarse trabajo dicha huelga ha terminado totalmente. Samper ${ }^{96}$.

El hecho de estar por entonces en juego importantes intereses comerciales y culturales que provocaron tensiones en las relaciones hispano-suecas influyó sin duda en el interés del gobierno de la República Española por tratar de paliar las consecuencias negativas para la imagen de España que producían las informaciones de la prensa extranjera sobre los sucesos de Asturias y Cataluña.

En febrero de 1935 tuvo lugar un nombramiento en Suecia que tendría consecuencias para las relaciones entre ambos países: el diplomático Christian Günther, que durante la guerra mundial sería Ministro sueco de Negocios Extranjeros. Günther fue nombrado Subsecretario de Negocios Extranjeros en sustitución de Hamilton, que se fue de Embajador a Dinamarca. Fiscowich le conocía bien, y comentó que Günther hablaba español muy bien ${ }^{97}$.

Este dato era positivo para la imagen de España. El negativo, al menos para la imagen que el gobierno de la República quería dar entonces, fue el viaje que por las mismas fechas hiciera la diputada española Margarita Nelken a los países escandinavos, que comentaremos en un epígrafe posterior, y que motivó cierta correspondencia entre la Legación en Estocolmo y el Ministerio de Estado.

A finales de ese año hay una referencia a una película de cine que el Ministerio de Estado consideró ofensiva para España. En Suecia se exhibió bajo el nombre de "El Carnaval español”, pero según el ministro de España estuvo poco tiempo en cartelera ${ }^{98}$.

\footnotetext{
${ }^{96}$ AMAEC R 243, 12, telegramas n. 26 y 27 de 9 y 15.X. 1934; AGA, Asuntos Exteriores, Caja 523, Carpeta 10 .

${ }^{97}$ AMAEC R 850, 18 e, despacho de 3.II.1935.

${ }^{98}$ AMAEC R 344, 15, telegrama n. 45 de 2.XI.1935.
} 
En febrero de 1936, con motivo de las elecciones españolas, volvió Fiscowich a referirse a la imagen de España en Suecia, dando cuenta de los comentarios de la prensa al respecto $^{99}$, diciendo que el resultado de las mismas, para la opinión pública sueca, había puesto de manifiesto el propósito del país de huir del fascismo y sistemas análogos ${ }^{100}$.

El resto de esa primavera, las noticias sobre la actualidad política española en la prensa sueca no dejaron de estar presentes, y los sucesos del mes de julio, como es lógico, pusieron a España en primera línea de la política internacional. La influencia en Suecia, a nivel de opinión pública, fue inmensa, como veremos en detalle en la segunda parte de este trabajo.

Hemos referido hasta aquí los informes de los diplomáticos españoles que se refieren a la imagen de España en Suecia. De la imagen de Suecia en España, en cambio, no hemos dicho nada. La razón es que - sorprendentemente - no hemos encontrado en la documentación sueca nada relevante a este respecto. Si partimos de la base de que la imagen del propio país en el país de destino suele constituir una preocupación básica de las representaciones diplomáticas, no deja de resultar sorprendente la despreocupación sueca al respecto.

El tema aparece en los documentos suecos sólo muy esporádicamente y sin especiales análisis. La razón, probablemente, haya que buscarla en el propio hecho en sí, la ausencia de información interpretada en la línea del argumentum e silentio: Si no se escribió más es porque no había más que decir. Pensamos que esto es congruente con el hecho de que, a nivel de opinión pública, el conocimiento e interés por la actualidad sueca era prácticamente inexistente.

\subsubsection{La gestión diplomática de los asuntos bilaterales sueco-españoles}

\subsubsection{Asuntos comerciales}

Acerca de las relaciones comerciales entre España y Suecia existe una obra monográfica fundamental, fruto de uno de los Encuentros históricos hispano-suecos que mencionamos en su momento, y en la que se recogen dos estudios de particular interés sobre los años anteriores a la guerra civil española: el de Kent Olsson sobre el comercio

\footnotetext{
99 Para una visión más detallada al respecto cfr. PEIX GELDART, "Suecia y las elecciones españolas...". ${ }^{100}$ AMAEC R 850, 22 e, despacho de 22.II.1936.
} 
hispano-sueco en el siglo XX; y los de Cantera Carlomagno sobre ese mismo comercio de 1870 a $1940^{101}$.

Cantera resalta la importancia de Suecia en el ámbito comercial mundial, ya que no en vano eran los países escandinavos, tomados en su conjunto, los exportadores más importantes del mundo después de Estados Unidos, Inglaterra y Alemania, en esos momentos. Cantera señala las dificultades que tuvo Suecia durante los años treinta para la exportación, motivadas por las medidas proteccionistas que se habían adoptado en el país para tratar de paliar los efectos de la crisis económica, y que conllevaron a su vez dificultades para la importación, dado el principio de reciprocidad entonces habitual en los tratados comerciales. Por eso eran tan importantes las negociaciones de ese tipo de tratados. Las estadísticas citadas ayudan a comprender muy bien el alcance e importancia de este comercio hispano-sueco.

En el período 1923-1935 se diversificaron las exportaciones suecas a España, incluyendo nuevos productos industriales como estufas, motores, turbinas, bombas hidráulicas, aspiradoras, etc., aunque la madera y la pasta de papel siguieran siendo los principales productos de la exportación sueca a España durante la década de los treinta, un $80 \%$ del total ${ }^{102}$.

$\mathrm{Al}$ respecto, dice Olsson:

El valor añadido del comercio de mercancías nos muestra una imagen con un gran excedente para Suecia. Pueden apreciarse fácilmente en la figura las dos depresiones a principios de los años 1920 y en 1930. Al mismo tiempo es evidente que la Guerra civil española hizo disminuir el comercio hasta unos niveles muy bajos en la segunda mitad de los años $1930^{103}$

La tabla siguiente muestra claramente el flujo de mercancías entre España y Suecia a partir de 1920:

\footnotetext{
${ }^{101}$ RAMOS SANTANA, Comercio y navegación ...

102 CANTERA CARLOMAGNO, Marcos, "El comercio hispano-sueco de 1870 a 1940: Algunos rasgos generales", en RAMOS SANTANA (coord.), Comercio y navegación entre España y Suecia (Siglos X-XX), Cádiz: Fundación Berndt Wistedt, pp. 493-505, p. 488; CANTERA CARLOMAGNO, Sverige och spanska $\ldots$, pp. 50-64 y $80-82$

103 OLSSON, Kent, "El comercio entre España y Suecia en el siglo XX: las consecuencias del cambio industrial”, en RAMOS SANTANA, Alberto, (coord.), Comercio y navegación entre España y Suecia (Siglos X-XX), Cádiz: Fundación Berndt Wistedt, pp. 493-505; la gráfica aparece en p. 497.
} 


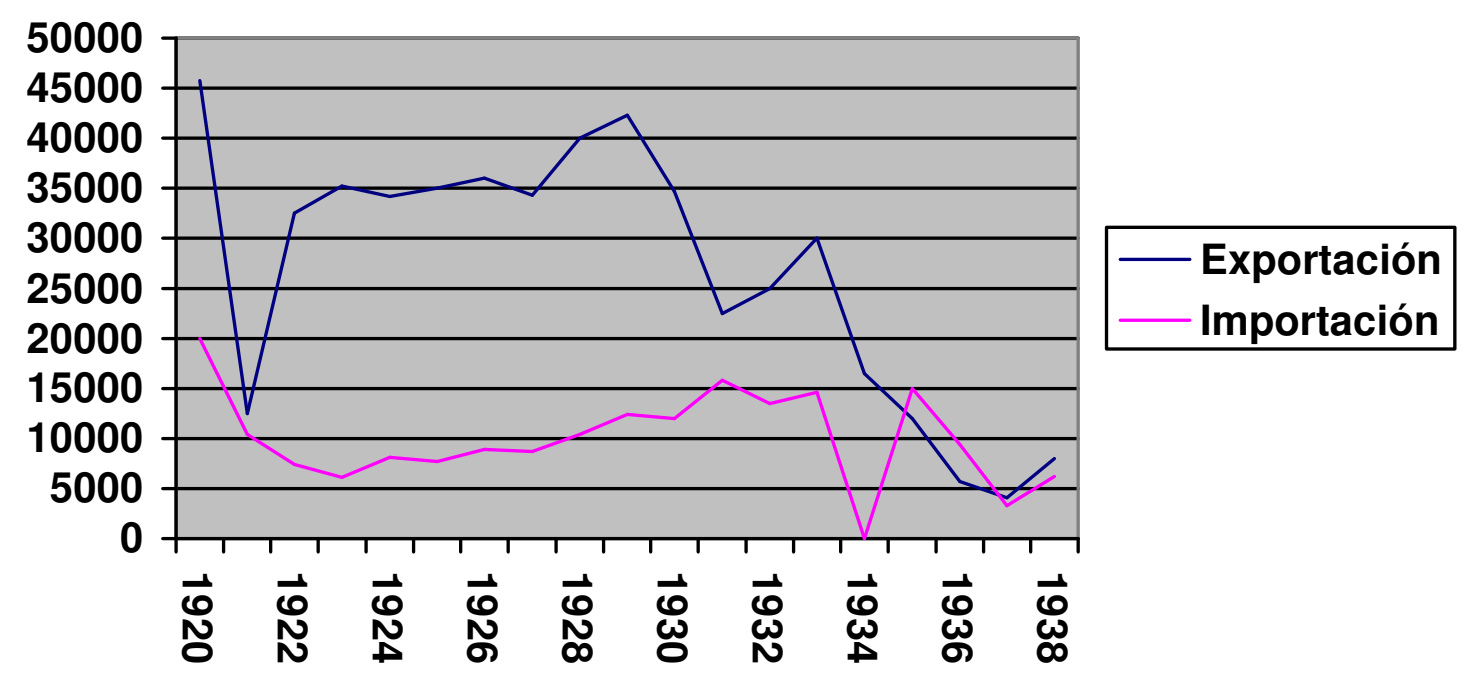

Fuente: Handel, SOS (recogida por Olsson). Los datos están en miles de coronas suecas.

Las relaciones comerciales entre España y Suecia fueron muy importantes en el período 1931-1936. De la extensión e importancia de esas relaciones, en especial por lo que se refiere a la exportación sueca a España, es testimonio patente la gran cantidad de cónsules y vicecónsules que cada país tenía en el otro, durante los años treinta. España tenía representación consular en Estocolmo, Gotemburgo, Malmö, Skellefteå, Luleå, Gävle, Sundsvall, Söderhamn y Härnosand: es decir, a lo largo y ancho de la geografía sueca. Suecia contaba con un Cónsul General en Madrid; con cónsules en Barcelona, Cádiz, Alicante, Bilbao, Canarias y Mallorca; y con vicecónsules en Vigo, Madrid, Alicante, Santander, San Sebastian, Sanlúcar de Barrameda - Antonio Maestre, que luego sería condenado a muerte por los militares sublevados - y Gijón.

Más adelante, durante la guerra civil, las autoridades de Burgos compilaron una relación exhaustiva de todos los cónsules y vicecónsules extranjeros que trabajaban entonces en territorio español. Según ella, en 1938 Suecia tenía cónsules o vicecónsules honorarios en Almería, Barcelona, Bilbao, Jerez de la Frontera, La Coruña, Las Palmas de Gran Canaria, Málaga, San Sebastián, Santa Cruz de Tenerife y Santander, además de un cónsul en Cádiz - compartido con Dinamarca en la persona del danés Cordt Bay - y un vicecónsul en Sevilla ${ }^{104}$.

Presentamos aquí las relaciones comerciales y culturales entre España y Suecia en el período que nos ocupa fijándonos sobre todo en su incidencia en la gestión diplomática al más alto nivel, y en cuanto fue objeto principal de numerosas reuniones entre los jefes de

${ }^{104}$ AMAEC, R 790, 3. 
la Legación de España en Estocolmo y el Ministro sueco de Negocios Extranjeros. En este marco, nos centraremos en lo relacionado con la firma del acuerdo comercial entre ambos países, que fue una cuestión de primera magnitud

Como ya apuntamos, las medidas proteccionistas tomadas por Suecia a partir de 1931 ocasionaron dificultades a las exportaciones españolas. Hay un telegrama para el ministro de España en Estocolmo, firmado por Azaña en diciembre de 1931, comunicándole que en caso de que las proyectadas subidas de los aranceles afectaran a determinados productos (especialmente vinos, generosos, brandy y frutas), el gobierno español adoptaría medidas de represalia. Ese mismo mes, un decreto autorizaba al gobierno de la República a contingentar importaciones de determinados artículos, y se ordenaba al Ministro en Estocolmo comunicar al gobierno sueco que esas medidas no iban en contra de Suecia, sino que eran generales. Si productos suecos se vieran afectados, el gobierno español estaba dispuesto a negociar en base al criterio de reciprocidad ${ }^{105}$. Poco después, el Ministro de España en Estocolmo insistió, siguiendo instrucciones de su gobierno, en las protestas y demandas españolas en relación con las cuotas o contingentes de exportación que Suecia había impuesto respecto a vinos, frutas y conservas. El Ministerio de Negocios Extranjeros sueco aseguró que los productos españoles más importantes no serían sometidos a las medidas proteccionistas ${ }^{106}$.

En el mes de noviembre de ese año, la amenaza de subir los aranceles al corcho motivó una nueva visita del Ministro de España al Ministro sueco de Negocios Extranjeros, alegando el malestar de España, para la que ya era desfavorable la balanza comercial con Suecia, máxime cuando la importación de madera sueca por parte de España era considerable. El ministro dio largas ${ }^{107}$.

Las gestiones tuvieron éxito en el sentido de que no se adoptó ninguna disposición legal en un principio, pero la campaña, originada por los fabricantes de tapones de corcho suecos contra la competencia extranjera (es decir, la española y portuguesa) dejó sentir sus efectos durante los años siguientes, pues el único comprador de tapones españoles, el monopolio de bebidas alcohólicas Vin- och Spritcentralen, dejó de comprar a España. De hecho, el 18 de mayo de 1934 subiría el arancel al doble ${ }^{108}$.

\footnotetext{
105 AMAEC R 2, 19, telegrama de Azaña a Conde, 2.XII.1931 y telegrama de Luis de Zulueta a García Conde de 24.XII.1931.

${ }^{106}$ AMAEC R 95, 15 cruce de telegramas entre M. Estado y Legación Estocolmo, de 8. y 16.I.1932.

${ }^{107}$ AMAEC R 95, 15 telegrama n. 33 de Legación a M. Estado, de 30.XI.1932

108 AMAEC R 698, 10, despacho n. 17 de 15.I.1934.
} 
Aunque al final no llegó Suecia a subir los aranceles a productos españoles, en 1933 se cernían nubes sobre el horizonte comercial hispano-sueco: el Sindicato de agricultores suecos pedía medidas proteccionistas, por lo que España se vio en la necesidad de actuar para asegurar unas condiciones no desfavorables. Le correspondió a Fiscowich llevar a cabo una intensa gestión diplomática al respecto. Comenzó con una campaña a favor de la venta de naranjas a base de reducciones de precio, que dio como resultado un aumento de las cantidades importadas, pero con una disminución en el importe total. El establecimiento en Estocolmo y Gotemburgo de una casa exportadora española (Planelles y Granell) favoreció las exportaciones. También se iniciaron gestiones, a través de la sección comercial, para la venta de potasas españolas, y hubo intentos de rebajar los aranceles a algunos productos, como las uvas ${ }^{109}$.

En julio, a petición del Ministerio de Estado, la Legación de España informó detalladamente sobre la organización del comercio exterior en Suecia, en vistas a las negociaciones comerciales en curso. El Ministerio sueco de Negocios Extranjeros, a través de su sección comercial, impartía instrucciones a las misiones diplomáticas, recibiendo de estas una amplia correspondencia al respecto. Para tomar acuerdos y resoluciones, el Ministerio de Negocios Extranjeros estaba asistido por las dos entidades autónomas subvencionadas por el Estado, la Asociación de Exportadores y la Dirección General de Comercio e Industria, encargadas respectivamente de estudiar las necesidades del comercio y de redactar estadísticas.

Suecia tenía agregados comerciales en Berlín, Madrid, París, Washington y Cairo dependientes de las Legaciones en dichas capitales, así como Cámaras de comercio en Inglaterra, Australia, EE.UU., Francia y Polonia. Suecia enviaba además, por tiempo ilimitado, a unos agentes encargados de realizar estudios sobre materias especiales, que se comprometían a facilitar informes periódicos. En Madrid, el Secretario Comercial era Einar Ytterberg ${ }^{110}$.

Empezaba así una larga pugna, que duraría más de un año, entre la diplomacia española y las autoridades suecas, para conseguir unas condiciones comerciales más favorables a España, de forma similar a las que había obtenido Francia, ante el disgusto

\footnotetext{
${ }^{109}$ AMAEC R 243, 12, telegrama n. 18 de M. Estado a Legación, de 9.XI.1934; AMAEC R 698, 10, despacho n. 151 de 15.II.1934.

110 AMAEC, R 242, 12, telegrama n. 18 de Legación a M. Estado, de 19.I.1934.
} 
evidente de Rickard Sandler, el ministro de Exteriores sueco ${ }^{111}$, que acabaría en el acuerdo provisional alcanzado en agosto de 1935, con buenos resultados iniciales ${ }^{112}$.

El camino fue arduo y se caracterizó por los intentos suecos de no ceder a las presiones españolas, demorando en el tiempo la llegada a un acuerdo mediante el procedimiento de retrasar sus respuestas a las demandas españolas. Finalmente, en julio de 1935 cuando la República Española aumentó su presión diplomática tanto en Madrid como en Estocolmo, se consiguió por fin llegar a un acuerdo.

Los hitos principales de la negociación fueron los siguientes:

1) Exigencia española de llegar al equilibrio, o al menos disminuir el desequilibrio, de la balanza de pagos con Suecia, en octubre de 1934.

2) Negativa sueca a renegociar una rebaja de los aranceles a los productos españoles, en noviembre 1934. El Ministro de España manifiesta su descontento por esta medida y ejerce nuevas presiones diplomáticas.

3) Envío de una Nota verbal del Ministerio de Estado a la Legación de Suecia en Madrid presentando las aspiraciones españolas, el 6 de marzo de 1935. Suecia no contestó a la misma.

4) Insistencia del Ministro de España ante las autoridades suecas, que responden con buenas palabras pero sin hacer propuestas concretas, a finales de mayo de 1935 .

5) Negociación del Ministerio de Estado con la Legación sueca en Madrid, que concluye con la aceptación parcial, por parte sueca, de las demandas españolas. Tiene lugar una tensa entrevista del Ministro de España en Suecia con las autoridades suecas, a comienzos de julio de 1935.

6) Nuevas concesiones suecas, comunicadas por la Legación sueca en Madrid al Ministerio de Estado, que no son aceptadas por éste, que insiste en conseguir mejores condiciones; Suecia no quiere admitir la exigencia española de reservarse el derecho de denuncia unilateral del acuerdo, en julio de 1935.

7) Acuerdo final, con la aceptación por parte sueca de las exigencias españolas a cambio de una declaración confidencial por parte española de que sólo denunciará el acuerdo en caso de fuerza mayor ${ }^{113}$.

\footnotetext{
${ }^{111}$ AMAEC R 341, 9, b, despacho de 31.XII.34, discurso de fin de año de R. Sandler.

${ }^{112}$ AMAEC R 602, 5, despacho de 5.I.1937, de Fiscowich al gobierno de Burgos.

${ }^{113}$ AMAEC R 243, 12, telegrama de M. Estado a Legación, n. 16, de 25.X.1934; telegrama reservado n. 34, de Legación a M. Estado, de 16.I.1934; AMAEC R 344, 15 n. 9 de Legación a M. Estado de 12.III.1935; n18 de M. Estado a Legación, de 31.V.1935; n. 25 de Legación a M. Estado de 1.VI.1935; n. 20 de M. Estado a Legación de 2.VII.1935; n. 29 de M. Estado a Legación de 20.VII.1935; n. 30 de Legación a M. Estado de
} 
Concluía así, de manera muy favorable para España, la negociación de un acuerdo comercial que, de no haber sido truncado por la guerra civil, tenía visos prometedores para la exportación española.

\subsubsection{Asuntos culturales}

En materia cultural, la Segunda República Española consiguió logros indiscutibles, no sólo a nivel de la política interior sino también en política exterior. En efecto, la Junta de Relaciones Culturales, reformada en 1931, había dado un buen impulso a la política cultural española en su vertiente exterior, en tres direcciones fundamentales:

1) Atención a las necesidades escolares de la emigración española, con la creación de escuelas en algunos países y del Instituto Hermenegildo Giner de los Ríos para la enseñanza secundaria fuera de las fronteras españolas.

2) Fomento del conocimiento de la lengua y la civilización españolas en otros países, con la creación y financiación de una treintena de Lectorados de Español en Universidades extranjeras, dos de ellos en Suecia.

3) Intensificación de los vínculos culturales con los países hispanoamericanos.

Además, se fomentaron las conferencias de intelectuales españoles en el extranjero, los envíos de libros a centros culturales de otros países, las exposiciones de arte y recitales musicales y el intercambio cultural de toda índole, a través de instituciones como la Universidad Internacional de Santander ${ }^{114}$.

Por lo que se refiere a Suecia, parte de los esfuerzos realizados en la segunda de las direcciones mencionadas se concretaron en las gestiones para tratar de influir en la Fundación Nobel para la concesión del premio Nobel de Literatura a un español. En 1931 se presentó la candidatura de Menéndez Pidal por parte de veintisiete miembros de la Real Academia de la Lengua Española, y García Conde realizó algunas gestiones: pidió obras del autor para poderlas dar a miembros de la Academia sueca, pero sólo recibió un ejemplar, de lo cual se quejaba el Ministro de España en Estocolmo al Ministerio de Estado.

17.VII.1935; n. 32 de Legación a M. Estado de 24.VII.1935; n. 33 y 34 de Legación a M. Estado de 7.VIII.1935; n. 26 de M. Estado a Legación de 10.VIII.1935 y n. 35 de Legación a M. Estado de 8.VIII.1935; La documentación sueca correspondiente se encuentra en RA: Beskickningsarkivet: Madrid, E1, vol. 4 y 5.

${ }^{114}$ DELGADO LÓPEZ-ESCALONILLA, Lorenzo, "Las relaciones culturales de España en tiempo de crisis: de la II República a la Guerra Mundial”, Espacio, Tiempo y Forma, Serie V, Historia Contemporánea, t. 7, 1994, pp. 259-294. 
La Real Academia Española no consiguió su objetivo, al contrario que la Academia francesa, que logró la nominación de Sully Prudhomme en 1901. Al final, el Premio Nobel de 1931 fue concedido a título póstumo al sueco Karlfeldt. García Conde comentó que con ese premio se deseaba remediar la difícil situación económica en que se encontraba la familia del escritor sueco ${ }^{115}$.

Los intentos de presión política y nacional respecto a la concesión del Premio Nobel de Literatura no eran nuevos: de hecho, ya en 1922, con la concesión a Jacinto Benavente, el Comité de la Fundación dejó entrever que las presiones españoles habían sido fuertes ${ }^{116}$.

Un nuevo intento tuvo lugar en 1934, cuando se logró que fueran nominados Ramón Pérez de Ayala y, de nuevo, Menéndez Pidal. Esta vez, el descontento español por la concesión del Nobel a Luigi Pirandello quedó reflejado en la correspondencia diplomática del Ministerio de Estado con la Legación. Así comentó Fiscowich el nombramiento:

A través extremada reserva actuación comités parece compartían probabilidades Finlandia Sillanpää y Francia Paul Valery. Descartado últimamente primero ante medida Finlandia contra idioma sueco y logrado mayoría corriente antifrancesa surgió candidatura Pirandello, cuya visita pasado año Estocolmo fue adecuada propaganda sin olvidar actual destacada situación política Italia. Una vez mas ha pesado en elección estudio consideración toda índole independiente muchos de los méritos artísticos y condiciones particulares candidato $^{117}$

Al año siguiente tenía bastantes posibilidades la candidatura de Miguel de Unamuno, pero el premio se declaró desierto. También en este caso hubo cierta correspondencia al respecto entre el Ministerio de Estado y la Legación de España ${ }^{118}$.

De mayor interés y eficacia práctica que las presiones para la concesión del Nobel a un español, fue la iniciativa de López Oliván de organizar, en colaboración con la Sociedad Hispano-Sueca, una gira de Antonio Pastor, titular de la Cátedra Cervantes de la Universidad de Londres, por universidades escandinavas. Se celebraron numerosos actos en Estocolmo y Uppsala, con gran asistencia de público, especialmente universitario ${ }^{119}$.

\footnotetext{
115 AMAEC R 2, 19, telegramas de 3.II.1931 y 8.X.1931.

116 SVENSÉN, Bo, "The Nobel Prize in Literature: Nominations and Reports 1901-1950". Nobelprize.org. 14 Apr 2012 http://www.nobelprize.org/nobel_prizes/literature/articles/svensen/

${ }^{117}$ AMAEC R, 243, 12 telegrama n. 33 de 12.XI.1934.

${ }^{118}$ AMAEC R 344, telegramas n. 47, 50 y 51 de 6, 13 y 14.XI.1935.

${ }^{119}$ AMAEC R, 698, 10, despacho n. 17 de 15.I.1934.
} 
En marzo de 1934 se fundó en Gotemburgo el Círculo Sueco-español, para la aproximación cultural entre ambos países, y en octubre se invitó al Agregado cultural español en París a dar unas ponencias en Suecia. En general, se dio un impulso importante a la enseñanza del español en Suecia, durante estos años, tanto a nivel de enseñanza media - donde el español fue incluido por primera vez en el curriculum obligatorio del Liceo femenino de Estocolmo - como a nivel universitario ${ }^{120}$.

Destaca en este campo el Lector de Español de las Universidades de Estocolmo y Uppsala, Joaquín Herraiz, que daba habitualmente conferencias sobre temas españoles, y que más adelante, con el comienzo de la guerra civil, tomó un papel activo en contra de la República Española. En febrero de 1935 se aprobó, por la Junta de Relaciones Culturales, el desdoblamiento en dos del lectorado, quedando Herraiz como Lector de Estocolmo y ocupando provisionalmente el lectorado de Uppsala, hasta el nombramiento de un nuevo lector, cosa que no pudo llevarse a cabo debido a la guerra civil ${ }^{121}$.

Además tuvo lugar en Estocolmo, en la primavera de 1935, una exposición de literatura española, con la presencia de Gustavo Gili, en cuya gestación y gestión tomó parte muy activa la Legación de España, llegando incluso el Ministro de España a adelantar fondos de su propio bolsillo para el buen éxito de la misma. Más tarde informó con satisfacción de la asistencia a la inauguración de la exposición de los Príncipes Regentes de Suecia y de altas personalidades de la vida cultural del país ${ }^{122}$.

En suma, la gestión de los asuntos culturales por parte de la Legación de España, siguiendo las pautas generales de la política exterior de la República en la materia, consiguió un conjunto de resultados apreciables.

\subsection{Contactos entre líderes políticos y sindicales españoles y suecos}

Una exposición de las relaciones políticas bilaterales entre Suecia y España no estaría completa sin una referencia, aunque sea somera, a los contactos personales entre los líderes políticos y sindicales de ambos países. A ello se refiere este último apartado, en el cual presentamos, sin pretensiones de exhaustividad, algunos de los contactos más

\footnotetext{
${ }^{120}$ AMAEC R 698, 10, despacho n. 151 de 15.VII.1934; despacho n. 127 de 18.VI.1934.

${ }^{121}$ AMAEC R 344, 15, telegramas n. 1 y 2 de M. Estado a Legación, de 23.I. y 13.II.1935.

${ }^{122}$ AMAEC R 344, 15, telegramas n. 3, 9, 10, 11 y 13 de M.Estado a Legación, en febrero y marzo de 1935; telegrama n. 18 de Legación a M. Estado de 6.IV.1935.
} 
relevantes durante el período que nos ocupa, que merecieron la atención de los representantes diplomáticos.

Visto el tema en su conjunto, constatamos, no sin cierta sorpresa, que en los archivos utilizados no hay referencias a contactos institucionales de entidad entre los partidos y sindicatos suecos y españoles, con la clara excepción del sindicalismo de corte anarquista (CNT - SAC). En ese caso, los contactos fueron de una intimidad y una sintonía sin paralelo en la Europa de la época. Los fondos documentales existentes en el Archivo de la SAC, dentro del Archivo del Movimiento Obrero sueco, son de una extensión e interés considerables, y bien merecen estudios monográficos por parte de la historiografía.

También encontramos material en sobre la SAC en el Centro Documental de la Memoria Histórica. Presentamos una primera aproximación al tema en la ponencia titulada "Sindicalistas suecos en los archivos de Franco", en un congreso de historiadores del mundo obrero en el sur de Suecia, cuyas actas serán publicadas próximamente ${ }^{123}$, y esperamos poder tener ocasión de volver más detenidamente esta cuestión, aparte de lo que ya veremos más adelante en relación con el período 1936-1939.

Podemos constatar además que el desinterés por la colaboración institucional fue mutuo, aunque quizá hubo más interés por mantener esos contactos por parte de las organizaciones españolas que por las suecas: un ejemplo típico es la tardanza - más de diez años, desde los primeros contactos - del sindicato mayoritario sueco Landsorganisationen (LO) en manifestar su apoyo a la UGT española, y las reservas expresadas respecto a la misma por los dirigentes de la LO incluso después de haberlo hecho.

En los archivos del Partido Socialista sueco (Comunista no alineado con Moscú) de Kilbom no consta ningún tipo de contacto con organizaciones políticas o sindicales españolas $^{124}$.

Tampoco aparecen referencias a contactos en los archivos de los partidos comunistas sueco y español, aunque es conocido que Vittorio Codovilla y José Diaz pasaron por Estocolmo y París de regreso a España desde Moscú el 22 de enero de $1936^{125}$.

En los archivos del PSOE y la UGT, en la Fundación Pablo Iglesias, apenas hay referencias a contactos institucionales entre estas organizaciones y sus homónimas

\footnotetext{
123 PEIX GELDART, Benito, "Svenska syndikalister $i$ Francos arkiv", ponencia en el Congreso de Historiadores del Mundo Obrero, en Landskrona, Suecia (26-27.V. 2011), cuyas actas serán publicadas en breve.

${ }^{124}$ ARAB, Socialistiska Partiet, Korrespondens, vol. E 1: 7; E 1: 14; E1: 18; E1: 23.

125 ARAB, VP Kommunistiska partiet, Serie ÖS, vol. 4-7; Archivo del PCE, Docs PCE y Díaz, José, caja 8/3/2; ELORZA \& BIZCARRONDO, op. cit., p. 265.
} 
nórdicas. Aparte de algunos contactos con el Partido socialdemócrata finlandés de julio de 1933, por lo que se refiere a Suecia solamente hemos encontrado una petición de carteles de propaganda por parte de las Juventudes Socialdemócratas suecas a sus homónimas españolas, de 1934, y las cartas de invitación - y respuesta, excusándose - al PSOE para que enviase observadores al importante Congreso del Partido socialdemócrata sueco de $1936^{126}$.

Aunque los contactos institucionales fueron muy parcos, existieron algunos a nivel personal. Especialmente buenos fueron los contactos con Suecia de algunas altas personalidades de la República, como Luis Jiménez de Asúa o Niceto Alcalá-Zamora. Más problemáticos fueron otros, como el de Margarita Nelken, cuyo ciclo de conferencias en Escandinavia estuvo a punto de causarle problemas graves al PSOE en el seno de la Internacional socialista.

Es interesante el hecho de que los contactos personales entre algunos líderes españoles y suecos no seguían necesariamente las líneas de la política del partido. Así por ejemplo, el Presidente de la República, Niceto Alcalá-Zamora, conservador, le dijo personalmente al Ministro de Suecia en Madrid que tenía gran amistad con Hjalmar Branting, el fundador del Partido Socialdemócrata sueco ${ }^{127}$.

Luis Jiménez de Asúa fue probablemente el político republicano español con mayores conexiones con Suecia. Se remontaban éstas a los años de la Primera Guerra Mundial, cuando el joven Jiménez de Asúa estuvo realizando una estancia de estudios en Suecia con el famoso Catedrático sueco de Derecho Penal de la Universidad de Lund, Johan Thyrén $^{128}$.

Desde entonces, y hasta 1931, la relación entre ambos juristas, aunque con altibajos, fue de una sincera amistad, que iba más allá de lo meramente profesional. En el archivo personal de Johan Thyrén, en la Universidad de Lund, se conservan 43 cartas de Jiménez

\footnotetext{
${ }^{126}$ FPI-AH-23-2; FPI-AH-73-28; FPI-AH-73-11.

${ }^{127}$ RA, UD, 1920-års dossierssystem, Vol. 420, despacho n. 211 de 27.II.1931.

${ }^{128}$ Johan Karl Vilhelm Thyrén, llamado "el mago de Lund", fue una gran figura del mundo jurídico sueco. Fue miembro de la Real Academia de las Ciencias, parlamentario independiente liberal entre 1909 y 1917, rector de la Universidad de Lund de 1916 a 1926 y Ministro de Justicia en el gabinete Ekman de 1926 a 1928. Había sido discípulo - al igual que Jiménez de Asúa - del fundador de la llamada Escuela Moderna o Sociológica del Derecho Penal, Franz von Liszt. Thyrén fue el autor del proyecto de Código penal sueco que fue sustancialmente aprobado. La actriz de Estocolmo Anna Carolina Widforss (1891-1950), que era novia por entonces de Jiménez de Asúa, le puso en contacto en 1915 con Thyrén. Anna Widforss se casó en 1923 con el ingeniero sueco Oskar David Zetterholm: cfr. WESTRIN, Theodor (red.), Nordisk familjebok (2 ed.), Estocolmo: Nordisk familjeboks förlag, 1919, voz "Thyrén, Johan Karl Vilhelm", p. 1226. Respecto a Anna Widforss cfr. SSA, Sveriges Dödbok version 5, Sveriges befolkning 1900, Stockholms rotemansarkiv/ Widforss.
} 
de Asúa, la primera del 5 de septiembre de 1915 y la última del 5 de octubre de 1931. En esta última, Jiménez de Asúa insiste a su amigo sueco en que está esperando “con ansiedad" noticias sobre la adopción legislativa en Suecia de la nueva figura penal ideada por Thyrén, las “multas de jornal diario" (dagsböter) - según la cuál la cuantía de las penas pecuniarias no se determinan en cantidades fijas de dinero sino de días - una figura que pasará desde entonces a formar parte del sistema penal sueco. Jiménez de Asúa mantuvo también cierto trato con el líder socialdemócrata Hjalmar Branting ${ }^{129}$.

El hijo de éste, el senador Georg Branting, sería entre 1936 y 1939 el contacto principal entre la clase política sueca y la España Republicana. Abogado de su Legación en Estocolmo, fue presidente del Comité sueco de ayuda a España, adonde viajó frecuentemente. En uno de esos viajes estuvo con Manuel Azaña, quien recogió así la visita del sueco:

16 agosto 1937: En Valencia, muchas visitas. Entre otras, la del senador sueco Branting, a quien ya había recibido en Madrid el verano pasado. Viene a España con frecuencia, con motivo de las funciones de socorro a los niños y su envío al extranjero, que realiza una organización internacional de la que forma parte. Hemos hablado un buen rato. Considera que nuestra causa es también la de los países escandinavos. En su país, el ochenta por ciento de la opinión pública está a nuestro favor. Damos algunas vueltas al comité de Londres, al de la reunión de Ginebra, etc. Branting se fía de todo esto tan poco como yo. Respecto de lo que pudiera hacerse en la Sociedad de Naciones, me dice que el Gobierno de su país tiene que seguir la política de Londres $^{130}$.

Luis Jiménez de Asúa seguiría en contacto con Suecia durante los años de la guerra civil, cuando se ocupaba desde Praga, en colaboración con Isabel de Palencia, Ministro de España en Estocolmo, de conseguir apoyos y abastecimiento para la República. También con ese objeto viajarían a Estocolmo en 1937 y 1938 otros líderes socialistas españoles, como Ramón González Peña y Belarmino Tomás. Este último se había encargado de coordinar los contactos entre la UGT y su homónima sueca $\mathrm{LO}^{131}$.

En los fondos archivísticos suecos ha quedado constancia de algunos contactos anteriores entre la poderosa organización sindical sueca, LO, y la UGT. Se conserva una

\footnotetext{
${ }^{129}$ Archivo de la Universidad de Lund, UB, Samling Thyrén J.C.W, serie II, cartas de Jiménez de Asúa; FPI, Catálogo de los archivos documentales del Partido, vol. 2, anexos e índices.

${ }^{130}$ AZAÑA, Diarios..., p. 1096.

${ }^{131}$ AMAEC R 577, 4; FPI-AH-54-72; AMAEC R 1058, telegrama de la Legación al M. Estado n. 11 de 30.XI.1937; AMAEC R 634, 17, de M. Estado a Legación en Estocolmo, de 17.I.1938; ARAB, Landsorganisationen i Sverige (LO), 2964/E 9A:16.
} 
carta de Largo Caballero de 1923, agradeciendo pero declinando la invitación a participar en un aniversario del sindicato sueco. También hay una petición a éste de información detallada sobre su funcionamiento, que Largo Caballero quería conocer.

Tampoco al Congreso de la LO en Estocolmo de 29 de agosto a 4 septiembre de 1926 asistió ningún representante español, según informa otra carta de Largo Caballero. En 1928 hay una petición de dinero de la UGT a la LO, para publicaciones y una invitación reiterada a que la LO envíe representantes al Congreso de la UGT, que no es oída por la organización sueca, a pesar de que Largo Caballero insistiera en que la presencia de algún representante sueco supondría un gran espaldarazo para la UGT. En contrapartida, el 21 de mayo de 1931 enviaba Wenceslao Carrillo sus excusas por no poder enviar representantes al Congreso de la LO de agosto de ese año.

Por fin, la larga lista de invitaciones concluye con una aceptación: Wenceslao Carrillo invitó el 30 de agosto de 1932 a la LO al XVII Congreso, en octubre de ese año, y la organización sueca aceptó, siendo el propio presidente de la misma, Edvard Johansson, el que contestó diciendo que asistiría él mismo, acompañado por el camarada Bäcklund.

A su regreso a Estocolmo, los dirigentes suecos escribieron un amplio dossier titulado “El XVII Congreso de la LO española, Madrid 14-23 de octubre de 1932”, donde se describen con todo lujo de detalles las discusiones del Congreso. Se trasluce en él una cierta admiración, no exenta de asombro, por algunas de las exigencias del Congreso, como el descanso semanal de 36 horas seguidas, los 15 días de vacaciones pagadas, y que el Parlamento discutiera inmediatamente la cuestión del control de las empresas por parte de los trabajadores.

Hay algunas expresiones en el dossier sueco que manifiestan asombro ante el carácter apasionado de las discusiones: "faltas de mesura y control", "le hicieron callar a gritos", "el alboroto llegó a un grado tal que Mora tuvo que abandonar la tribuna de oradores", etc. Ha quedado en el dossier constancia expresa de la exigencia del Congreso del establecimiento de relaciones diplomáticas con la URSS. Al mismo tiempo, muestra Johansson su sorpresa por unas declaraciones de Eggert, representante del sindicato alemán, sobre las pocas posibilidades que Hitler tenía de ganar las elecciones en Alemania $^{132}$.

Sin embargo, el contacto político español con Suecia que tuvo más repercusiones a nivel diplomático durante el período que estudiamos fue, sin duda, el viaje que realizó

${ }^{132}$ ARAB, Landsorganisationen i Sverige (LO), 2964/E 9A:16. 
Margarita Nelken por los países escandinavos en marzo de 1935. Había sido invitada por el Socorro Rojo para dar una serie de conferencias sobre la situación de España después de la revolución de octubre de 1934.

Se conserva una carta del líder anarcosindicalista Augustin Souchy informando que en los momentos anteriores al viaje, Margarita Nelken había tomado contacto con él:

Por último, un detalle que no deja de ser interesante: la señora Margarita Nelken, que estuvo en Estocolmo, habló conmigo antes de viajar para pedirme recomendaciones. Al parecer no sabía que pertenezco a la CNT. Pero no acudí a la cita siguiente donde íbamos a concretar detalles sobre el asunto. Entonces tomó ella contacto con el banquero judío sueco Aschberg, que parece estar en París, y viajó. He oído que está satisfecha de su viaje a Suecia y que consiguió reunir dinero ${ }^{133}$.

El representante de la CNT no fue el único en informar sobre el viaje de Nelken a Escandinavia. De hecho, éste captó el interés tanto de la diplomacia española en Estocolmo como de la misma Policía de Seguridad sueca ( $S A ̈ P O)$, que conservó en sus archivos el texto taquigrafiado de la conferencia titulada "sobre las luchas de octubre y la represión española" que a través de intérprete impartió la política española el 1 de marzo de $1935^{134}$.

El 25 de febrero informaba Fiscowich al Ministerio de Estado sobre el proyectado viaje diciendo que presumiendo que éste obedecía a un plan premeditado para lograr ayuda moral y material de los medios afines suecos, había puesto sobre aviso al Ministro de Negocios Extranjeros de la "personalidad de la interesada". El 26 encargaba a Fiscowich el Ministerio de Estado que le tuviera al corriente de todo.

El 28 contestaba el Ministro en Estocolmo que desde el día anterior se encontraba Margarita Nelken en Estocolmo, que su viaje lo realizaba por cuenta del Socorro Rojo, siendo patrocinado en Suecia por "un de Comité de señoras que, sin pertenecer a partido alguno, se había ocupado en otras ocasiones de casos internacionales de análoga tendencia”. Señalaba que la prensa comunista publicaba la entrevista sin hacer comentarios y presentaba el viaje como una misión de carácter humanitario a favor de los obreros de Asturias y de los indultos de González Peña y otros, en cuyo sentido había recibido Fiscowich dos peticiones de centros obreros.

\footnotetext{
${ }^{133}$ ARAB, SAC 1845/ E6:7, Carta a Jensen, Paris, 14.III.1935.

${ }^{134}$ RA, S̈̈PO, Vol. 489.
} 
Añadía también el diplomático que la legislación sueca, por su liberalidad, impedía suspender las conferencias, pero que él había insistido, sin embargo, en que no se tolerasen extralimitaciones y se cuidaran especialmente las noticias en la prensa. En la conferencia trató Margarita Nelken ante ciento ochenta personas en forma acostumbrada el tema objeto de su propaganda, reclamando ayuda internacional para poner término a la situación de España.

Según el diplomático español, la falta de organización y la pugna entre los diferentes partidos de izquierdas suecos habían restado trascendencia al viaje, logrando, no obstante, lo que la Internacional reclamaba de todos ellos: que pidieran clemencia al gobierno español ${ }^{135}$

El 2 de abril salió Nelken para Copenhague, donde el viaje tomó pronto otro cariz: en efecto, el líder de los socialdemócratas daneses, Alsin Andersen, tuvo un enfrentamiento fuerte con Nelken por entender que ella defendía a la Unión Soviética, colaboraba con los comunistas daneses, y había calumniado a los socialdemócratas al acusarles, en un artículo publicado en Suiza y comentado por la prensa danesa, de faltar a "su deber de solidaridad" por haber criticado "los horrores de Rusia" tras el asesinato de Kirov, pero no haber hecho lo propio respecto al "terror blanco" en España.

Como respuesta a la furibunda carta de protesta de Andersen a la Internacional Socialista, Margarita Nelken se defendió en términos no menos fuertes, acusando al danés de actuación frenética e intransigente. Adujo que su colaboración con los comunistas se debía al hecho de que el Partido Socialista Obrero Español había aceptado la misma en la lucha por los intereses de la clase obrera y lamentaba la "deplorable impresión" que en su opinión causaba la negativa de la socialdemocracia nórdica a hacerlo. Según ella, la presencia de los políticos socialistas suecos Lindhagen y Branting en la conferencia que dio en Estocolmo era prueba de que no todos los socialistas nórdicos pensaban como Andersen.

El Partido Socialista Obrero Español dio cuenta a la Internacional Socialista de la respuesta de Nelken a Andersen, suavizando las expresiones, pero al mismo tiempo resaltando que Margarita Nelken no llevaba mandato alguno del Partido en su viaje a los países nórdicos, que había efectuado sin informar a la Comisión Ejecutiva del mismo ${ }^{136}$.

\footnotetext{
${ }^{135}$ AMAEC R 344, 15, telegramas entre Legación España y M. Estado, diversas fechas de febrero y marzo 1935.

${ }^{136}$ FPI-AH-73-38.
} 
El viaje a Estocolmo dejó huella en Margarita Nelken. De hecho, se refiere a él desde el exilio, en dos artículos escritos en México sobre temas culturales, donde dice que Estocolmo es "una de las capitales de más alta cultura en el orbe, una de las ciudades más bellas y refinadas del viejo mundo"137.

No hay constancia, en la documentación que hemos analizado, de ningún otro contacto entre líderes políticos españoles y suecos en el período de nuestra investigación.

A la vista de los resultados, ha quedado patente la escasez de contactos, lo que sin duda parece confirmar las palabras de López Oliván en la cita que exponemos al principio de este capítulo: que las relaciones políticas entre España y Suecia eran consideradas excelentes porque eran en realidad inexistentes. Fueron los diplomáticos, en particular López Oliván y Madariaga, y no los políticos, los que mantuvieron el contacto entre ambos países, siendo los protagonistas de la cooperación internacional sueco-española en el marco de la Sociedad de Naciones, primero en el grupo de los Ocho y posteriormente en el "de los Seis" o de los Neutrales. Y en cierta medida lo hicieron, cabría decir, a pesar de los políticos.

${ }^{137}$ AHN, Diversos Títulos Familias, 3251, N. 229; 3254, N. 70. 



\section{GUERRA, INTERVENCIÓN Y NO INTERVENCIÓN}

Cada hombre es un mundo. Este proverbio clásico es aplicable en sumo grado a los españoles y a su individualismo, que en ocasiones llega a extremos absurdos. Mutatis mutandis, esas palabras pueden también aplicarse a España como nación, ya que es un mundo aparte, un mundo fundamentalmente hostil a toda influencia extranjera, y con toda seguridad lo seguirá siendo ${ }^{l}$.

Pocos países habrán dado prueba de su simpatía por el pueblo español en la proporción que Suecia ${ }^{2}$.

\footnotetext{
${ }^{1}$ Palabras de Nils F. H. Berencreutz, agente de Suecia ante la España de Franco en 1938-39, RA, Beskickningsarkivet: Madrid, F1 C Vol 48, despacho confidencial n. 359 de 16.III.1939. Las palabras "Cada hombre es un mundo" están en español, en el original sueco.

${ }_{2}^{2}$ Palabras de Isabel de Palencia, Ministra Plenipotenciaria de la República Española en Suecia, AMAEC R 1785, 13, despacho n. 190 de 27.VII.1938.
} 



\title{
Capítulo 6
}

\section{SUECIA Y LA REPÚBLICA ESPAÑOLA DE 1936 A 1939}

\begin{abstract}
"En la pugna entre una dictadura negra y un régimen popular, nuestra postura está clara de antemano, a pesar de que el régimen popular español no esté asentado y aún no haya podido garantizar un orden democrático" ${ }^{p}$
\end{abstract}

\subsection{La guerra civil española según la diplomacia sueca}

Per Albin Hansson, que en el momento de pronunciar las palabras arriba citadas no era presidente del gobierno sueco, explicaba así su apoyo, por cuestiones de principio, a la República Española. En el mismo discurso, aprovechaba para dar también un toque de atención a las bases de su partido acerca de los peligros de seguir una política de Frente Popular: "que tomen nota aquellos que entre nosotros propugnan un frente popular".

En su discurso se incluían palabras de crítica hacia Largo Caballero por "considerar al gobierno del Frente Popular sólo como un período transitorio", señalando además que la situación en que España se veía entonces no era sólo culpa de los enemigos del gobierno democrático español, sino "también, y no en menor medida, de sus propios partidarios". Cantera Carlomagno resalta acertadamente que en este discurso se resume muy bien el dilema al que habrían de enfrentarse los socialdemócratas suecos durante los años posteriores, a saber: la necesidad de prestar su apoyo en España a las mismas fuerzas contra las que se enfrentaban en Suecia, comunistas, anarcosindicalistas, trotskistas y otros grupos revolucionarios ${ }^{2}$.

El 21 de julio de 1936, el principal diario del país, Dagens Nyheter, independiente liberal, se posicionó de forma clara ante los sucesos de España, apostando por una neutralidad a ultranza:

"a fin de cuentas, probablemente sea indiferente quién gane. Las dos partes en conflicto en España son como dos tensores en pugna: pueden destruirse uno al otro, pero no salvarse a sí

\footnotetext{
${ }^{1}$ HANSSON, Per Albin, Discurso "La tragedia española" (Den spanska tragedin) en Social-Demokraten, 22.VII.1936.

${ }^{2}$ CANTERA CARLOMAGNO, Sverige och spanska..., p. 42.
} 
mismos... ahora sólo queda espacio para la violencia. La cuestión pendiente es si el resultado de esta lucha será una dictadura negra o una roja””.

Lógicamente, tal visión de la contienda no era compartida por la prensa sueca de izquierdas, salvo una notoria excepción: el diario Frihet (Libertad), órgano de las juventudes socialdemócratas, dudaba de que una victoria del Frente Popular supusiera necesariamente una victoria de la democracia, ya que "la excesiva sed de venganza destruirá probablemente las posibilidades de la democracia en España"4. Per Albin Hansson se sintió obligado a salir al paso de la misma, diciendo que la guerra era "la lucha de un pueblo contra la reacción".

Curiosamente, la visión del Dagens Nyheter y del articulista de Frihet, tan contraria a la mayoritaria en la opinión pública sueca, coincidía en gran parte con la de quien sería el primer secretario de la Legación de Suecia en Madrid una vez terminada la guerra y futuro Embajador sueco tras la caída del régimen franquista, Lennart Petri ${ }^{6}$.

Este diplomático sueco veía la guerra española como un conflicto interno español, no como el fruto de una conspiración nazi-fascista o comunista. Petri pensaba que, en realidad, se trataba de

una guerra entre el clericalismo y el anticlericalismo, la monarquía y la República, la democracia y el totalitarismo y, en algunos lugares, entre ricos y pobres. El desprecio salvaje e inhumano por la ley y la justicia fue más o menos el mismo en ambas partes. La diferencia era que los franquistas no ocultaban su fin ni los medios para lograrlo, mientras que el bando gubernamental quería hacerse pasar por legítimo y democrático incluso después de haber echado por la borda toda su carga democrática y de que el poder hubiera caído en manos de los anarquistas y los comunistas (...) En realidad, era una lucha entre la peste y el cólera ${ }^{7}$.

Pero ¿cómo vieron la guerra civil los diplomáticos suecos en España durante los tres años de duración de la misma? A pesar de la inestable situación producida por los cambios

\footnotetext{
${ }^{3}$ Dagens Nyheter, 21.VII.1936.

${ }^{4}$ Frihet, n. 16, 15.VIII.1936.

${ }^{5}$ Social-Demokraten, 15.VIII.1936.

${ }^{6}$ Lennart Petri (1914-1996) empezó su carrera diplomática en 1938. Fue Secretario de Legación en Madrid (1939-41), Buenos Aires (1943), Lima (1944-45) y Paris (1049-54); Consejero de Embajada en Moscú (1955-58) y Embajador de Suecia en Rabat (1958-62), Peking (1963-69), Viena (1969-76) y finalmente Madrid (1976-80). Sus memorias (cfr. PETRI, op. cit.), recogen muchos datos de interés sobre sus períodos en España.

7 BERGQUIST, Lars, "Lennart Petri", en ARTEUS, Gunnar \& LEIFLAND, Leif (Eds.), Svenska diplomatprofiler under 1900-talet, Estocolmo: Probus, 2001, p. 400.
} 
de domicilio y personal de la Legación, la guerra civil y la actualidad política española fue seguida celosamente por los diplomáticos suecos, en especial en lo referente a la España republicana. En la zona franquista, hasta el intercambio de "agentes" a finales de 1938, el seguimiento pudo hacerse sólo a través de los Cónsules, en su mayoría honorarios.

Entre el 15 de julio y el 31 de diciembre de 1936, la Legación operó sucesivamente en San Sebastián, Zarauz, Hendaya, San Juan de Luz y Lisboa. Al estallar la guerra, el Ministro, Ivar Danielsson, estaba en Lisboa, a punto de regresar a Estocolmo y finalizar su destino en España; el Secretario de la Legación, Erik Wisén, en San Sebastián.

Sin haber podido comunicar con Madrid, el 20 de julio informaba Wisén de la situación, a medida que iba llegando información desde algunos consulados suecos. El Cónsul en Barcelona escribía que la ciudad había sido tomada por milicianos, que vestían "como en los cuadros de la Revolución francesa". El de Cádiz se quejaba de que había perdido contacto con los cónsules honorarios de su jurisdicción y los de Vigo y Las Palmas - ambos ciudadanos británicos, y cónsules también del Reino Unido - tomaban partido por los militares golpistas. Éste último, Bellamy, pedía con insistencia el envío a Canarias de un buque de guerra sueco para salvaguardar los intereses de los suecos.

Desde Lisboa envió Danielsson una carta manuscrita al barón Beck-Friis, del Ministerio sueco de Negocios Extranjeros, donde expresaba su temor de que hubiera desórdenes y excesos por parte de "los extremistas", si Azaña caía. En Portugal se confiaba en una victoria de los generales. Tras ello, cesó la misión de Danielsson en España ${ }^{8}$. A partir de ese momento será Wisén quien, como Encargado de Negocios, esté al frente de la Legación de Suecia en España.

Durante el primer mes a contar desde el 18 de julio de 1936, las noticias recibidas en Estocolmo por canales diplomáticos fueron fragmentarias y un tanto confusas, pero en todas se destacaba la inusitada brutalidad - "salvaje" (barbariskt) es el adjetivo usado más frecuentemente - de esos primeros momentos, y la falta de control, por parte de las autoridades republicanas, de los elementos más extremistas que habían tomado el poder en las calles. El 7 de agosto estaban en curso negociaciones entre los países nórdicos para ver la respuesta común a adoptar ante informaciones recibidas de los diplomáticos daneses en Madrid. Señalaban éstos que el gobierno legítimo había sido sustituido por un "régimen soviético" y que en Madrid reinaba "una total anarquía".

\footnotetext{
${ }^{8}$ RA, UD, 1920-års dossierssystem, vol. 1504 y RA, UD, Beskickningsarkivet: Madrid F1c:42.
} 
En el mismo sentido informó el cónsul sueco en Madrid, Axel Olsén ${ }^{9}$, en llamada telefónica del 10 de agosto, diciendo que el gobierno perdía terreno y se estaba formando "un régimen comunista con comités de diverso tipo".

El jefe de la Legación sueca, por su parte, informaba desde Zarauz y, más tarde, Hendaya, que la situación era caótica también en el norte de España - donde, según el cónsul sueco en Bilbao, la población no sentía el más mínimo entusiasmo por la guerra - y los diplomáticos huían a San Juan de Luz. Mencionaba que Navarra era el "bastión del fascismo español" y que los soldados de los ejércitos sublevados habían sido reclutados por la fuerza por "sus oficiales fascistas", aunque durante la última semana, en Zarauz, el Frente Popular había encarcelado "a multitud de personas" ". Alababa también a Indalecio Prieto, cuyo discurso en Madrid había sido

por su moderación, una grata excepción a los comunicados engañosos y a los boletines de una y otra parte, que diariamente anuncian victorias exageradas. Los excesos de los milicianos han sido terribles en toda España durante estos primeros días desde el comienzo de la guerra, pero parece que el gobierno y las autoridades locales empiezan a conseguir evitar abusos y someter a los milicianos a disciplina militar ${ }^{11}$.

Sin embargo, a los pocos días se vio obligado a reconocer que el gobierno había perdido el control de los milicianos, que incluso habían tratado de entrar en los edificios diplomáticos y habían cometido muchos desmanes ${ }^{12}$.

No deja de tener su interés el que un diplomático como Wisén, que tanta labor humanitaria haría después a favor de la República Española y cuya esposa tenía amistad

\footnotetext{
${ }^{9}$ Axel Olsén era Consejero-Delegado de la filial en España de la empresa sueca Electrolux, y vicecónsul sueco en Madrid hasta el 22.IX.1936 (cfr. RA, UD, 1920-års dossierssystem, HP 36, Vol. 1504), en que decidió abandonar España. En Suecia, fue elegido por el agente franquista en Estocolmo, en 1938, hombre de contacto con las empresas de la España de Franco, por tener, en palabras del Conde de Torata, "una actitud positiva hacia los nacionales", cfr. RA, UD, 1920-års dossierssystem, Vol. 1523, Del III, PM de Berencreutz de 1.IX.1938.

${ }^{10}$ RA, UD, 1920-års dossierssystem, HP 36, Vol. 1504, despachos n. 357, 360, 361 y 364, todos de los primeros días de agosto de 1936. El 15 de agosto de 1936 se trasladó la Legación a Hendaya.

${ }_{11}^{11}$ RA, UD, 1920-års dossierssystem, HP 36, Vol. 1504, despacho n. 362 de 14.VIII.1936.

${ }^{12}$ RA, UD, 1920-års dossierssystem, HP 36, Vol. 1504, despacho n. 369, de 21.VIII.1936. Respecto a las brutalidades cometidas por los milicianos, se conserva en el archivo del Ministerio sueco de Negocios Extranjeros, un autógrafo sin firmar, al pie de un recorte de un diario sobre una manifestación en Estocolmo a favor de la República en la que se exhibió una pancarta llamando a Franco "perro sanguinario", que dice: "¿Cómo habría que llamar entonces al miliciano (literalmente Valenciaman, "hombre del gobierno de Valencia') que le cortó el cuello a mi mejor amigo español con un hacha y con la misma herramienta cortó los antebrazos a su hermana, una mujer de singular belleza exterior e interior?". Se desconoce el autor del comentario, pero parece claro que era uno de los diplomáticos suecos en España (Wisén o, probablemente, Danielsson).
} 
con líderes republicanos españoles, al explicar la confrontación española y sus razones internas - con particular énfasis en la evolución política durante los años 1931 a 1936 -, lamente la falta de democracia en España y llegue a decir que "la victoria de la izquierda supondría una España bolchevizada" ${ }^{\text {13 }}$.

Cabe preguntarse, sin embargo, sobre la base de estos temores de - por decirlo con palabras de la época - "bolchevización" de España. Es posible que en ellos influyera la información de la Legación sueca en la capital soviética, firmada por un gran conocedor de la situación española: el secretario de Embajada Einar Ytterberg, que había pasado de la Legación en Madrid a la Legación en Moscú. Informaba Ytterberg de la colecta obligatoria de dinero organizada en lugares de trabajo y en entidades oficiales soviéticas a favor de la República Española, y escribía lo siguiente:

Los sucesos de España se han seguido con extrema atención en Moscú, ya que España, a pesar de su lejanía, ocupa un lugar importante en el horizonte mental comunista, y aquí se ponen muchas esperanzas en la revolución española, confiando en las palabras de Lenin de que España sería el primer país después de Rusia donde triunfaría el comunismo, debido a su atraso en lo material y en lo social ${ }^{14}$.

Una carta de la Legación sueca en Berna, del 28 de agosto, informaba de la llegada a España del representante soviético Rosenberg, diciendo que iba a ser "la eminencia gris del gobierno republicano", y pocos días después, el cónsul sueco en Madrid, Olsén, con ayuda de sus colaboradores españoles, enviaba un informe de diez páginas titulado "La revolución española”, donde se volvía a insistir en la radicalización del país hacia el comunismo.

El informe fue escrito con ocasión del cambio de gobierno del 4 de septiembre, que dio el poder a Largo Caballero. Wisén comentó que el gobierno entrante era de extrema izquierda y comentó con ironía unas declaraciones del gobierno republicano en el sentido de que la República Española, por su parte, estaba haciendo todo lo posible por humanizar

\footnotetext{
${ }^{13}$ RA, UD, 1920-års dossierssystem, HP 36, Vol. 1504, despacho confidencial n. 375 de 26.VIII.1936. En ese mismo despacho informa que una buena parte del oro del Banco de España se había mandado a Francia para comprar con él material bélico.

${ }^{14}$ RA, UD, 1920-års dossierssystem, HP 36, Vol. 1504, despacho n. 310 de la Legación de Suecia en la Unión Soviética, de 6.VIII.1936.
} 
la guerra. El gobierno había dado una respuesta negativa al ofrecimiento de mediación que días antes le había formulado el Cuerpo Diplomático ${ }^{15}$.

Las declaraciones del gobierno, según Erik Wisén, "son realmente llamativas, especialmente cuando en la lucha por Irún hemos podido ver a los milicianos en retirada prender fuego a gran parte de la ciudad y fusilar a una cantidad considerable de rehenes civiles".

Wisén desaconsejaba además una vuelta de la Legación a Madrid porque ello "sería en estos momentos poco prudente desde el punto de vista político, dado el carácter comunista y socialista-radical del gobierno de Madrid y que la suerte de la guerra parece inclinarse cada vez más del lado de los rebeldes"16.

En su informe trimestral, el primero desde el comienzo de la guerra, explicaba Wisén que un golpe de Estado militar era esperado, pero su transformación en guerra civil no lo era: ésta había sorprendido incluso a los militares, que no esperaban la resistencia ofrecida por los milicianos. La guerra se preveía larga, según Wisén.

Este es el primer despacho en el que aparece la expresión "nacionalistas" para designar a los sublevados - que rechazaban el calificativo de "rebeldes" - y el primero en el que se hace referencia a sus planes de guerra.

Según las informaciones de Wisén, el gobierno de Francisco Largo Caballero - a quien el diplomático sueco califica de "político extremista" - apenas tenía poder efectivo, ya que éste estaba en manos de las milicias anarquistas y comunistas, o, en Cataluña y el País Vasco, de las autoridades autonómicas.

Tras mencionar noticias del Cuerpo Diplomático acreditado en Madrid - la ruptura de relaciones de Uruguay con la República, la llegada del embajador soviético, etc. -, explicaba las depuraciones de funcionarios, el establecimiento de los tribunales populares, las medidas tomadas en relación con el esfuerzo bélico y al establecimiento unilateral de clearing para el comercio con España por parte de Suiza, Finlandia y Suecia.

Se detallaba asimismo la organización del incipiente Estado franquista, con el nombramiento de Franco como generalísimo y jefe de Estado y de gobierno, un "poder

\footnotetext{
${ }^{15}$ RUBIO, Javier, Asilos y canjes durante la guerra civil española, Barcelona: Planeta, 1979, p. 376: "El jefe de la misión sueca, junto con los de Bélgica, Checoslovaquia, Finlandia, Francia, Inglaterra, Italia y Holanda ofrecen sus servicios de mediación para humanizar la guerra, en 21 agosto 1936."

${ }^{16}$ RA, UD, 1920-års dossierssystem, HP 36, Vol. 1504, despachos n. 383, 387 y 388, y carta de Wisén a Beck-Friis, jefe de sección del M. sueco de Negocios Extranjeros: todos de la primera semana de septiembre de 1936).
} 
absoluto típico de una dictadura militar". De la toma de San Sebastián por las tropas franquistas y de la brutal actuación de éstas informó Wisén en un despacho posterior ${ }^{17}$.

A mediados de octubre de 1936, la Legación de Suecia en Moscú modificó el sentido de sus informaciones iniciales respecto a las intenciones soviéticas, haciéndose eco de la opinión común en el Cuerpo Diplomático acreditado en la capital rusa sobre la falta de interés por parte de las autoridades soviéticas por involucrarse a fondo en la guerra de España: aunque estaban éstas decididas a combatir el fascismo, no parecía que tuvieran un plan determinado, como lo probaba el hecho de que el telegrama de Stalin al PCE del 15 de octubre había sido una completa sorpresa en el Secretariado soviético de Asuntos Exteriores, según sabía la Legación “de fuente confidencial y segura”.

Parecía incontestable el hecho de que "el verdadero regente del país" tomaba sus decisiones sin informar siquiera a los que habían de ponerlas en práctica, aunque en el caso del telegrama a José Díaz había "obrado de manera impulsiva" sin tener un plan premeditado.

En opinión de Erik Gyllenstierna, el Ministro de Suecia en Moscú, las autoridades soviéticas, "a pesar de las bravatas en la prensa", no estaban dispuestas a romper definitivamente con las potencias del Comité de No Intervención ni a enfrentarse frontalmente a Alemania. Respecto a la ayuda soviética a la República en forma de material bélico se mostraba el Ministro especialmente prudente, mencionando que los datos que tenía al respecto provenían de fuentes alemanas, y por tanto, no podían ser consideradas como objetivas.

Sin embargo, el hecho de que un número considerable de pilotos rusos hubieran sido condecorados por servicios a la Patria era una señal de la ayuda enviada. Asimismo, a la luz de las estadísticas comerciales soviéticas, se podía entrever la magnitud de la ayuda concedida a la República ${ }^{18}$.

\footnotetext{
${ }^{17}$ RA, UD, 1920-års dossierssystem, HP 36, Vol. 1504, despacho n. 420 de 14.X.1936: despacho n. 426 y carta del Cónsul sueco en Canarias sobre el fusilamiento de políticos republicanos.

18 RA, UD, 1920-års dossierssystem, Vol. 1504, despacho n. 258 de la Legación sueca en Moscú, de 22.X.1936 e Ibidem, Vol. 1505, despachos en el mismo sentido de fecha 29.X, 2 , 4 y 5.XI.1936, y despachos de 12.I.1937 y 21.III.1937. Ya dos meses antes, en telegrama del 14 de agosto de 1936, había mencionado el Embajador británico en Moscú la sorpresa y el desagrado que la noticia del estallido de la guerra causó a las autoridades soviéticas: "Las reacciones soviéticas ante la guerra civil española han sido, en la mayor parte de los casos, casi tan inevitables que apenas si hay que añadir algo a mis telegramas sobre el tema. Aún cuando la guerra parece que terminará probablemente en el establecimiento de un régimen comunista en el país, no creo que la noticia de su estallido pueda haberla recibido con menor entusiasmo el gobierno soviético. El del señor Casares Quiroga era probablemente bastante bueno para el Kremlin en las circunstancias actuales y aquí no puede recibirse con alegría ningún enturbamiento de la escena europea que proporcione a Alemania la oportunidad de intervenir. Por ello la prensa soviética, aunque desde el comienzo otorgó una gran
} 
También desde las Embajadas suecas en Berlín y París se enviaban informó al Ministerio de la ayuda soviética a la República y la alemana a la España franquista: La Legación sueca en París escribía el 2 de diciembre que, según "un embajador de una gran potencia” (¿Inglaterra? ¿Estados Unidos?), era evidente que la República había recibido mucha ayuda por parte de la Unión Soviética - motivando que Francia le pidiera a este país más precaución - y que Italia y Alemania iban a incrementar la suya a Franco.

Por su parte, entre noviembre de 1936 y enero de 1937, la Legación sueca en Berlín informó detalladamente de las relaciones entre Hitler y Franco. Tras anunciar el envío de "un submarino alemán y una unidad de aviación" a España, informaba que según "una fuente extraordinariamente segura", Alemania estaba considerando el envío de dos divisiones para ayudar a Franco pero estaba algo indecisa por tener dudas sobre la capacidad de Franco de formar gobierno.

Sobre este delicado asunto, recogía también unas declaraciones del Embajador italiano en Berlín poniendo en duda la capacidad militar de Franco ("no era ningún Napoleón”). Según el representante sueco en Berlín, Wirsén, circulaban rumores de que la oposición del General von Fritsch a una mayor intervención alemana en la guerra de España era el motivo de su sustitución al frente de la Legión Cóndor por el "nazi von Reichenau"19.

El 18 de febrero de 1937 se estableció la Legación de Suecia en Valencia, y una semana después informaba Wisén desde esta ciudad a Estocolmo acerca de los bombardeos de Barcelona y Valencia, y sobre la situación militar y política en la España republicana, lamentando que continuase siendo realidad la escasa influencia del gobierno frente a "las organizaciones revolucionarias" y que fueran precisamente los partidos republicanos y la UGT, "el núcleo del Frente Popular", los que menos influencia tenían. Incluso en las altas esferas militares había desunión, como las discusiones sobre las responsabilidades por la caída de Málaga ponían de manifiesto. Por otra parte, la

cobertura a la guerra civil, haciendo gala de los inevitables sesgos en cuanto a la selección de noticias del extranjero, no dio signo alguno durante las primeras semanas de que el gobierno de Madrid pudiera esperar algo más que simpatía platónica por parte de la Unión Soviética". El texto del telegrama está recogido, entre otros, en VIÑAS, Ángel, El oro de Moscú: Alfa y Omega de un mito franquista, Barcelona: Grijalbo, 1979, y ESPADAS BURGOS, Manuel "El contexto de una conmemoración", en REQUENA GALLEGO, Manuel (coord.) La guerra civil española y las brigadas internacionales, Cuenca: Universidad de Castilla-La Mancha, 1998, pp. 15-28.

${ }^{19}$ RA, UD, 1920-års dossierssystem, HP 36, Vol. 1505, despacho de la Legación sueca en París de 2.XII.1936; despachos de la Legación de Suecia en Berlín de 7.XI.1936, y 27.XI.1936, telegrama cifrado de 15.XII.1936, y despachos del 3, 5, 12 y 16.I.1937. 
seguridad ciudadana había aumentado, aunque seguía habiendo ejecuciones por las noches, escribía el diplomático ${ }^{20}$.

En el mes de marzo aparece en los despachos suecos la aportación de las Brigadas Internacionales por primera vez con cierto detalle, así como las dificultades del gobierno de Valencia con los anarquistas catalanes. Wisén reiteraba que el error de base había sido dar armas a las milicias populares en julio del año anterior, aunque reconocía que, dadas las circunstancias, el gobierno no tenía otra opción si quería dominar la sublevación. El resultado estaba a la vista, ya que, a pesar de sus buenas palabras, las milicias populares que aún se caracterizaban por sus luchas por el poder y su desunión interna, aunque quizá en algo menor grado que unos meses antes - no prestaban su apoyo real y efectivo al gobierno de la República. ${ }^{21}$

La apelación del gobierno vasco "al mundo civilizado" por el bombardeo de Guernica, los graves sucesos de Barcelona, los rumores de crisis de gobierno con la posibilidad de que Indalecio Prieto llegara a presidir el Consejo de Ministros y las disposiciones sobre intervención estatal en la industria privada, dominaron las informaciones de la Legación de Suecia en mayo de 1937.

Llama la atención, sin embargo, la parca información y la escasez de detalles que dio la Legación tanto sobre Guernica como sobre los enfrentamientos en Barcelona, limitándose prácticamente a constatar este último hecho como un paso más - aunque más difícil que otros - en los intentos sistemáticos del gobierno por controlar la situación general y a las organizaciones revolucionarias en particular, llevados a cabo a lo largo del primer semestre de $1937^{22}$.

Más atención mereció el incidente del Deutschland y el consiguiente bombardeo de Almería. Wisén comunicó a Estocolmo que, según había sabido a través del Encargado de Negocios inglés, los aviones republicanos habían bombardeado el buque sin provocación por parte de éste ${ }^{23}$.

\footnotetext{
${ }^{20}$ RA, UD, 1920-års dossierssystem, HP 36, Vol. 1505, despacho n. 26 de 24.II.1937. Sobre la situación militar en Madrid, cfr. ibidem, despacho n. 30 de 27.II.1937.

${ }^{21}$ RA, UD, 1920-års dossierssystem, HP 36, Vol. 1505, despachos n. 36, 41, 45 y 46, de 8, 13, 17 y 19.III.1937.

${ }^{22}$ RA, UD, 1920-års dossierssystem, HP 36, Vol. 1506, telegramas de 29.IV.1937, 6.V.1937 y 14.V.1937; despachos N. 67, 72 y 78 de 14, 15 y 31.V.1937; cfr. también despacho n. 114 de 8.VII.1937.

${ }^{23}$ RA, UD, 1920-års dossierssystem, HP 36, Vol. 1506, carta confidencial de Wisén a Beck-Friis, de 8.VI.1937, y despacho n. 100 de 29.VI.1937, donde menciona expresamente a Indalecio Prieto como el responsable de la orden de ataque al Deutschland. Sobre las repercusiones del incidente en la URSS, Alemania, Inglaterra y Francia informaron a Estocolmo las Legaciones de Suecia en esos países.
} 
En su análisis del gobierno saliente de Largo Caballero, escribía Wisén que le había tocado presidir el Consejo de Ministros durante

el peor periodo de todas las revoluciones, el de la destrucción irracional. La memoria de los sucesos sangrientos, los crueles abusos y las trágicas injusticias contra personas singulares acaecidos durante su gobierno quedarán para siempre unidos a su nombre. Ocho meses no han sido suficientes para calmar las pasiones que fueron desatadas en su día y el gobierno de Largo Caballero no ha podido realizar intentos serios de reconstrucción. Por eso, no parece correcto hacer cargar al primer gobierno revolucionario de la República española con toda la culpa de lo ocurrido ${ }^{24}$.

En el otoño de 1937 pudo constatar Wisén que el nuevo gobierno de la República, con Negrín al frente, al que apoyaban socialistas, comunistas y republicanos moderados, había conseguido controlar a las organizaciones de milicianos anarquistas y libertarios y restablecer el orden constitucional.

Por otro lado, la situación material había empeorado, a consecuencia de la adversa situación militar para la República, y las duras palabras de Álvarez del Vayo y de la prensa republicana española contra Inglaterra no parecían - pensaba Wisén - la mejor táctica a emplear para conseguir ayuda de las democracias europeas. En 1938 volvería a insistir Wisén en lo absurda que era - en su opinión - la actitud crítica con Inglaterra que adoptaba la prensa y sobre todo el gobierno de la República ${ }^{25}$.

Al cumplirse un año del comienzo de la guerra, constataba Wisén que solamente Indalecio Prieto había previsto una guerra de tanta duración, y estimaba como causas de la misma la desunión existente entre los distintos grupos políticos - curiosamente incluye también aquí a la España de Franco, hablando de desunión entre falangistas, requetés,

\footnotetext{
${ }^{24}$ RA, UD, 1920-års dossierssystem, HP 36, Vol. 1506, despacho n. 99 de 26.VI.1937, informe político del primer y segundo trimestre de 1937. Gran parte del mismo está dedicado a la situación financiera y comercial de la República. El escaso intercambio comercial con Suecia se había basado en compensaciones. Menciona asimismo la ayuda humanitaria sueca, en diversas modalidades, a España, a la que nos referiremos en un futuro capítulo.

${ }^{25}$ RA, UD, 1920-års dossierssystem, HP 36, Vol. 1506, despachos n. 114 de 8.VII.1937 informe político del primer y segundo trimestre de 1937; n. 179 de 12.X.1937, informe del tercer trimestre de 1937; n. 154 de 9.IX.1937; RA, UD, 1920-års dossierssystem, HP 36, Vol. 1507, despacho n. 154 de 9.IX.1938. Sobre la intervención extranjera durante el otoño de 1937 y las desavenencias entre Franco y Mussolini sobre la política a seguir se recibieron en Estocolmo varios despachos de las Legaciones de Suecia en Italia, Francia y Portugal. Desde la Legación sueca en Portugal se envió el informe en inglés de la situación militar elaborado por el agregado militar "de una gran potencia" (probablemente Estados Unidos o Inglaterra), donde se califica a Franco de "pésimo estratega". Esa misma fuente dijo también que la guerra española era una guerra entre el proletariado y las clases altas, cfr. RA, UD, 1920-års dossierssystem, HP 36, Vol. 1506, informe de 16.I.1938.
} 
militares y monárquicos - y sobre todo a la intervención extranjera. Suecia se había visto afectada en sus Cónsules: de los treinta que tenía en España al comenzar la guerra, uno había muerto, dos estaban en la cárcel y catorce habían abandonado sus puestos ${ }^{26}$.

Con ocasión de los rumores del traslado del gobierno de la República a Barcelona, Erik Wisén obtuvo una entrevista con José Giral, y tras ella informó a su gobierno de los motivos que aconsejaban el traslado de la capital a Barcelona. Entre ellos destacaba el mejor control de la capacidad industrial catalana con vistas al esfuerzo bélico, y la creciente desconfianza hacia los sindicalistas catalanes, cuyo programa tenía en materia social un gran parecido - según Wisén - con el de los falangistas, lo que hacía temer posibles acuerdos futuros entre esos grupos.

Wisén no creía, sin embargo, que el gobierno ganara mucho con el traslado a Barcelona, pues lo único que, en su opinión, podía ayudar a mejorar la delicada situación, era una posible desunión de las organizaciones políticas de la España de Franco o bien un cambio decisivo en la situación internacional, que moviera a las democracias a intervenir a favor de la República. Tanto lo primero como lo segundo no parecía viable, especialmente tras la unificación de la Falange con los Requetés en el bando franquista y la actitud cada vez más positiva del Reino Unido hacia la España de Franco ${ }^{27}$.

Durante el primer semestre de 1938, se ocupó el diplomático de transmitir a Estocolmo algunas declaraciones más destacadas de líderes políticos españoles, tales como el discurso de Negrín en el acto de apertura de la nueva sesión de las Cortes o lo que en una conversación privada le había dicho el Ministro de Estado sobre la situación militar (Teruel, frente de Aragón, etc.).

También informó sobre la carta colectiva del episcopado español - que se publicó también en sueco - y el cese del Ministro de Justicia, Irujo, por "haber llevado a cabo una política demasiado agresiva a favor de la restauración del culto público".

Sin embargo, fueron los bombardeos de las ciudades catalanas los que ocuparon el primer plano en los informes diplomáticos suecos. A ellos se refería Wisén calificándolos de "horribles" y de "comienzo del final de la guerra civil". Añadía que ya no quedaba duda alguna sobre quién ganaría la guerra. Describió con especial detalle el bombardeo de Granollers. Los bombardeos despertaron en Suecia el interés de muchas personas, entre

\footnotetext{
${ }^{26}$ RA, UD, 1920-års dossierssystem, HP 36, Vol. 1506, despacho n. 120 de 19.VII.1937. Trataremos el asunto de los cónsules suecos en un epígrafe posterior.

${ }^{27}$ RA, UD, 1920-års dossierssystem, HP 36, Vol. 1506, despacho n.184 de 20.X.1937; RA, UD, 1920-års dossierssystem, HP 36, Vol. 1507, despacho n. 192 de 10.XI.1937.
} 
ellas de los Servicios de Inteligencia militar, que deseaban enviar observadores militares a las dos zonas de España para estudiar el funcionamiento de las defensas antiaéreas y los efectos de los bombardeos modernos en ciudades indefensas.

El Ministerio sueco de Negocios Extranjeros desaconsejó vivamente el asunto y una petición a las autoridades militares españolas de "experiencias" al respecto obtuvo respuesta negativa ${ }^{28}$.

La prensa internacional, el Gobierno británico y las organizaciones obreras suecas acusaban a la España de Franco de bombardear ciudades sin objetivos militares. Consultado al efecto por su gobierno, Erik Wisén respondió que no era cierto que los bombarderos de la España franquista bombardearan ciudades sin objetivos militares, pues en la mayoría de los casos sí los había. El problema era más bien que

los bombarderos, con una indiferencia criminal, no se han concentrado con cuidado y precisión en bombardear sus objetivos específicos y en cambio suelen volar a una altura excesiva desde la que es imposible acertar con precisión. Las bombas parecen ser arrojadas más bien al azar, y muy raramente ha sido derribado ningún bombardero. Sin embargo, hay que decir que los gubernamentales también tienen su parte de culpa en los terribles efectos de los bombardeos sobre la población civil, porque con mucha frecuencia hay polvorines, fábricas de armamento, depósitos de material militar y otros objetivos militares, en las zonas céntricas de las ciudades. Además, es bastante corriente y se ha podido comprobar varias veces, por ejemplo, en Barcelona, que transportes de tropas y armamento hagan escalas largas a lo largo de las calles principales de las ciudades, e incluso es conocido que habitualmente se dejan vagones de tren cargados de material bélico en vías férreas en el centro de las ciudades. Es evidente, de todas formas, que el bombardeo de ciudades abiertas, y especialmente con la cobardía y el cinismo con el que se hacen aquí, deben ser calificados como actos de salvajismo y de táctica de guerra no permitida, y toda persona en sus cabales no puede dejar de apoyar al gobierno británico en su decisión de poner coto al asunto" ${ }^{\text {29 }}$.

Suecia había accedido a la propuesta británica de participar en la comisión para el control de bombas, en línea con el deseo de Inglaterra de que en ella hubiera representantes de países "no identificados con ninguna de las dos partes en lucha en España”. El país escandinavo tuvo ciertas reticencias en hacerlo, a causa de la falta de

\footnotetext{
${ }^{28}$ Respecto a los distintos asuntos aquí mencionados cfr. RA, UD, 1920-års dossierssystem, HP 36, Vol. 1507, despachos nn. 21, 22, 23, 25, 28, 31, 40, 41, 43, 44, 53, 98 y 106, todos del primer semestre de 1938, y n. 129 de 4.VIII.1938.

${ }^{29}$ RA, UD, 1920-års dossierssystem, HP 36, Vol. 1507, despacho "estrictamente confidencial" n. 107 de 11.VI.1938.
} 
interés mostrada al respecto por los EE.UU., pero la Embajada británica había informado ya al gobierno de la República que habría militares suecos, noruegos e ingleses y éste había aceptado el plan, por lo que Suecia decidió colaborar. Al final no fue posible, porque Franco se negó a aceptar a representantes noruegos o suecos en la comisión ${ }^{30}$.

En septiembre informó Wisén de los resultados de los controles efectuados por la comisión en algunas ciudades republicanas - que en cierta medida parecían haber influido en el claro descenso de los bombardeos a objetivos civiles - así como de los ataques aéreos a Palamós y Caldetas ${ }^{31}$.

También se hizo eco la Legación de Suecia de los rumores de un golpe de Estado por parte del Ejército republicano, ante el peligro de una toma del poder por parte de grupos anarquistas ${ }^{32}$.

Otros temas que merecieron su interés fueron la clara toma de partido a favor de Indalecio Prieto que mostraban los informes que se recibían del Agregado militar "de una gran potencia", y la intención de los ejércitos franquistas de avanzar hacia el mar, con los correspondientes planes de contraofensiva del gobierno republicano ${ }^{33}$.

En julio, tras mencionar la visita a Negrín del capitán sueco Liljehöök, de la organización internacional de ayuda a los huérfanos españoles - en la que Negrín le había hablado de condiciones mínimas a exigir para el fin de la guerra - envió Wisén a Estocolmo un nuevo balance de la situación: a dos años de comenzada la guerra, había hambre y miseria en la retaguardia republicana, mientras el gobierno de Negrín procuraba apoyarse en los sindicatos mayoritarios, a veces sin mucho éxito. Informaba también de los Trece puntos del presidente del Consejo de Ministros republicano ${ }^{34}$.

En el otoño siguiente, informó la Legación de Suecia sobre las dificultades que el gobierno de Negrín tenía con la CNT-FAI, los intentos de disminuir la influencia comunista en el Ejército popular, y la postura española ante la cuestión checoslovaca. Sobre esta última cuestión estimaba el diplomático sueco que la solución dada a la misma

\footnotetext{
${ }^{30}$ RA, UD, 1920-års dossierssystem, HP 36, Vol. 1507, telegrama cifrado de la Legación de Suecia n. 18 de 28.VI.1938 y nota de la Embajada britanica adjunta al escrito de Söderblom a Wisén del 9.VII.1938

${ }^{31}$ RA, UD, 1920-års dossierssystem, HP 36, Vol. 1507, despachos nn. 149 y 152, de 12 у $15 . I X .1938$ y despacho n. 217 de 27.XII.1938. En Palamós fue destruida la fábrica sueca Wicander.

${ }^{32}$ RA, UD, 1920-års dossierssystem, HP 36, Vol. 1507, telegrama cifrado de 23.III.1938

${ }^{33}$ RA, UD, 1920-års dossierssystem, HP 36, Vol. 1507, informe del Agregado militar de 27.III.1938, despacho n. 60 de 2.IV.1938 y despacho n. 81 de 4.V.1938.

${ }^{34}$ RA, UD, 1920-års dossierssystem, HP 36, Vol. 1507, despacho n. 107 de 5.VII.1938. Sobre la carestía de alimentos y combustible, cfr. también despachos n. 151 de 12.IX.1938 y n. 185 de 11.XI.1938.
} 
en el acuerdo de Münich podía tener consecuencias para España, aunque no especifica a qué consecuencias se refiere ${ }^{35}$.

A partir de finales de 1938, se puede constatar una menor actividad de la Legación, motivada probablemente por el intercambio de "agentes" entre Suecia y la España de Franco en octubre de 1938, ya que el agente sueco en Burgos empezó también a informar de los asuntos españoles. La Legación en Barcelona, que se trasladó a Perpignan el 30 de enero de 1939, se limitó prácticamente a informar de la marcha de las operaciones militares y del desarrollo de los acontecimientos que conducirían al final de la guerra ${ }^{36}$.

No hemos hecho referencia aquí, sin embargo, a lo que constituyó numéricamente el núcleo más numerosos de los despachos suecos a Estocolmo durante la guerra civil: los referentes a la información sobre cuestiones militares puntuales, situación de los frentes de guerra, y rumores de todo tipo respecto a la marcha de la guerra. La razón no es otra que su carácter extremadamente sobrio, puntual y meramente informativo, sin análisis adicionales de especial interés. La diplomacia sueca, sencillamente, no quiso o no se atrevió a hacer conjeturas cualificadas sobre cuestiones militares, salvo la constatación, repetida a menudo durante la segunda mitad de la guerra, de que sólo circunstancias excepcionales podrían evitar la derrota final de la República ${ }^{37}$.

El otro gran conjunto de informes lo constituye todo lo relacionado con la participación de brigadistas suecos en la contienda, la protección a los intereses de los suecos residentes en España y las numerosas gestiones relacionadas con la mediación en el intercambio de presos y con la evacuación de refugiados en los edificios de la Legación. Estos aspectos los analizaremos en un apartado posterior.

Al final de la guerra, hacía balance Wisén de la situación en que se encontraba la República Española, con el paso del poder supremo "de Azaña a Negrín y finalmente a Miaja". En su análisis, criticaba fuertemente a la República porque, según decía, "había tolerado, por no decir estimulado, los numerosos desórdenes y actos de violencia llevados

\footnotetext{
${ }^{35}$ RA, UD, 1920-års dossierssystem, HP 36, Vol. 1507, despacho n. 148 de 25.VIII.1938, n. 155 de 19.IX.1938 y n. 175 de 18.X.1938; carta de Wisén del 7.XII.1938.

${ }^{36}$ RA, UD, 1920-års dossierssystem, HP 36, Vol. 1507, despacho n. 5 de 3.I.1939 sobre la ofensiva franquista en Cataluña, n. 13 de 30.I.1939 sobre el traslado de la Legación a Perpignan, telegrama de 16.I.1939 sobre derrota inminente de la República, despacho n. 19 de 2.II.1939 sobre la caída de Barcelona, telegrama de 3.II.1939 sobre presiones anglo-francesas para conseguir la rendición de la República, carta de 6.II.1939 sobre la situación política y militar, despacho n. 39 de 20.II.1939 sobre caída de Cataluña y paso a Francia de 163100 civiles y 180000 soldados según cifras francesas (55000 soldados regresaron a la España de Franco).

${ }^{37}$ En Apéndice 4 recogemos, a manera de ejemplo, el texto completo del despacho n. 30 de la Legación de Suecia en Valencia sobre la defensa de Madrid, de 27.II.1937, (RA, UD, 1920-års dossierssystem, HP, vol. 1505).
} 
a cabo por los partidos extremistas tanto de la derecha como de la izquierda". Asimismo, explicaba que el Dr. Negrín no habría buscado el apoyo del Partido Comunista si las circunstancias no le hubieran obligado a ello, idea sugerente, ya que ratifica las más recientes aportaciones de la historiografía española sobre la actitud de Negrín frente al apoyo comunista ${ }^{38}$.

\subsection{Suecia y la política de no intervención}

En el apartado anterior expusimos las primeras reacciones de la prensa sueca a los sucesos de julio en España. La primera gran manifestación en Suecia a favor de la España republicana tuvo lugar el 28 de julio de 1936, organizada por un comité llamado JanssonMineur (dos marinos suecos en prisión en Alemania por su oposición al nazismo), de iniciativa comunista pero con representantes de varios partidos y organizaciones obreras ${ }^{39}$. El partido socialdemócrata sueco (SAP) y la Unión General de Sindicatos (LO) aprobaron el 1 de agosto sus primeras ayudas a España a través del Fondo de Solidaridad Internacional $^{40}$. Por su parte, el gobierno provisional sueco presidido por Axel PehrssonBramstorp - que rigió Suecia desde el 19 de junio de 1936 hasta el nombramiento del nuevo gobierno de Hansson surgido de las elecciones de septiembre, el 28 de ese mes - se mantenía a la expectativa.

El desarrollo general de los acontecimientos desde la decisión inicial del jefe del gobierno francés, Leon Blum, el 20 de julio de 1936, de vender armas a la República en cumplimiento del tratado franco-español al respecto, hasta el establecimiento del Pacto de no intervención, es bien conocido. El 7 de agosto, el gobierno francés preguntó al sueco si estaba dispuesto a adherirse a una declaración prohibiendo la exportación de armas. La primera medida sueca fue retirar a la fábrica Bofors, el 11 de agosto, el permiso general de exportación del que gozaba, y el día 13 se informó al gobierno francés que Suecia aceptaba adherirse al Pacto de no intervención ${ }^{41}$. La decisión fue muy criticada por el partido

\footnotetext{
${ }^{38}$ RA, UD, 1920-års dossierssystem, HP 36, Vol. 1507, despacho n. 61 de 14.III.1939. Sobre la actitud de Negrín, cfr. VIÑAS, Ángel, El honor de la República..., pp. 371-519, especialmente p. 517.

39 Social-Demokraten, 29.VII.1936.

40 ARAB, SAP, Verkställande utskottet (Comité directivo)1.VIII.1936; ARAB, Landsorganisationen $i$ Sverige (LO), Landsekretariatet (Secretaría general), 1.VIII.1936.

${ }^{41}$ RA, UD, 1920-års dossierssystem, HP 430: B, acta de la sesión conjunta de los Ministerios de Comercio y Negocios Extranjeros del 13.VIII.1936; comunicación del Ministerio de Comercio a la Autoridad Superior Aduanera y comunicación al Ministro de la Legación de Francia de 13.VIII.1936.
} 
socialista (SP), el comunista (SKP) y los sindicalistas (SAC), además de por algunos políticos del ala izquierda del partido socialdemócrata ${ }^{42}$.

Curiosamente, el 4 de septiembre de 1936 salió en España un artículo de prensa, titulado "Suecia, país amigo" "43, donde se decía que el país escandinavo era el "único amigo" de la República, y que había rehusado adherirse al Pacto de no intervención.

No quedaría ahí la cosa, pues el Ministerio de Estado, con motivo de esa noticia, preguntó oficialmente a la Legación de Suecia en España si era cierto lo que allí se decía respecto a la no adhesión de Suecia. El diplomático sueco deshizo el malentendido.

La cuestión de la no intervención estaba, de todas formas, sobre el tapete, pues precisamente en esos días había enviado Wisén a Estocolmo un despacho explicando la impresión - muy crítica hacia Francia - que tenían los miembros del Cuerpo Diplomático que se encontraba en Hendaya acerca del cumplimiento por parte de ese país del Pacto de no intervención, a saber: que Francia estaba ayudando mucho a la República, en contraposición con lo acordado en el mismo.

También en esa misma semana tuvo que responder Wisén a la cuestión que se le había planteado acerca de la presunta amenaza, por parte de los militares sublevados, de utilizar gas venenoso en la guerra. El gobierno sueco había sido animado a intervenir para evitar la amenaza de guerra química. Wisén contestó que no estaba probado que los rebeldes hubieran hecho esa amenaza, "es sólo lo que dice Branting" 44

La adhesión de Suecia a la política de no intervención fue apoyada por la mayoría de la clase política sueca, el partido socialdemócrata y los llamados "partidos burgueses" (conservadores, liberales, agrarios, etc.), y fue ratificada, sin discusión parlamentaria, al llegar de nuevo al poder la socialdemocracia con el apoyo de la Liga Agraria, Bondeförbundet, el 28 de septiembre de 1936. Los partidos a la izquierda del socialdemócrata (socialistas, comunistas y sindicalistas) estaban en contra y no cesaron en su oposición a la misma durante toda la contienda.

El gobierno sueco tardó algunos meses en hacer efectivas todas las exigencias de las grandes potencias en el Comité de No Intervención. El representante sueco ante el mismo era el Embajador en Londres, Palmstierna, que había recibido instrucciones de mantenerse

\footnotetext{
${ }^{42}$ Cfr. Ny Dag, Folkets Dagblad y Arbetaren, 14.VIII.1936.

${ }^{43}$ Frente Popular, 4.IX.1936.

${ }^{44}$ RA, UD, 1920-års dossierssystem, HP 36, Vol. 1504, despachos n. 392, 393 y 394, de 8, 10 y 11.IX.1936.
} 
a la expectativa en las discusiones sobre la prohibición de voluntarios internacionales y de procurar evitar que se prohibieran las colectas de fondos con destino a España ${ }^{45}$.

Es probable que influyeran en esta actitud las dudas que, ya desde el comienzo, tuvo Suecia acerca de la sinceridad de otros países representados en el Comité: a finales de septiembre de 1936, Suecia había exigido al Comité que se pronunciase acerca de si era posible seguir vendiendo armamento sueco a Portugal, hecho que suscitó alarma en las esferas diplomáticas y políticas de este país, como se desprende de la documentación confidencial portuguesa al respecto $^{46}$. Al final, Suecia suspendería, al menos oficialmente, sus exportaciones de armas a este país.

El 27 de enero de 1937, a resultas de algunas interpelaciones parlamentarias, explicó Westman, ministro de Justicia, que el gobierno apoyaba la política de no intervención, pero que eso no implicaba la prohibición de prestar ayuda humanitaria, que, por el contrario, era muy conveniente ${ }^{47}$.

El debate parlamentario sueco de febrero de 1937 acerca de la adhesión de Suecia a la política de no intervención en España y sus consecuencias prácticas ha sido estudiado con mucho detalle por Lundvik ${ }^{48}$, a quien seguimos en esta exposición: En cumplimiento de lo acordado por el Comité de No Intervención de Londres, el gobierno sueco presentó al Riksdag la ley "sobre medidas para impedir la participación de voluntarios en la guerra civil española", que criminalizaba todo intento de reclutamiento y de prestación de servicio de armas en España. La ley fue aprobada el día 5 de marzo de 1937 y estaría en vigor hasta el 28 de febrero de 1938, pero tres días antes de esa fecha su vigencia fue prorrogada por un año ${ }^{49}$.

Lundvik distingue dos líneas básicas en el debate parlamentario sueco. Por un lado, estaba la línea de los "moralistas", compuesta sobre todo por políticos del ala izquierda del partido socialdemócrata como Branting. Ström y algunos líderes de la Unión de Sindicatos

\footnotetext{
${ }^{45}$ Sobre el delegado sueco en el Comité narra Howson la siguiente anécdota: "En el transcurso de tales altercados, el barón Erik Palmstierna, el delegado sueco, entraba a veces en una especie de trance, pues se hallaba a la sazón redactando su libro Los horizontes de la inmortalidad, en el que registraba sus conversaciones con "mensajeros del otro mundo", y siempre que estos espíritus le hablaban a él se concentraba al máximo en lo que decían para poder anotarlo después. Cuando apareció su libro, en 1938, ya había alcanzado la edad de la jubilación, y el gobierno sueco, temiendo que sus instrucciones pudieran no ajustarse a las de los mensajeros, lo relevó de su puesto", cfr. HOWSON, Gerald, Armas para España. La historia no contada de la guerra civil española, Barcelona: Península, 2000, p. 169.

${ }^{46} \mathrm{CDMH}$, Colección Armero, 10/4, Memorándum reservado portugués respecto a pregunta de Suecia en Comité de No Intervención.

${ }^{47}$ RA, UD, 1920-års dossierssystem, HP 36, B, vol. 1510: Cartas de Beck-Friis a Palmstierna de 7.X.1936 y a Söderblom de 8.X.1936. RA, Justitiedepartamentet, Huvudarkivet, F 10 B, vol. 7.

${ }^{48}$ LUNDVIK, Solidaritet och partitaktik..., pp. 155-178.

${ }^{49}$ SFS (Svensk författningssamling, BOE sueco), 1937, nn. 61-63.
} 
LO. Esta línea atacaba la política de no intervención por considerarla un sometimiento pragmático a la política anglo-francesa en contra de las exigencias de la justicia.

Per Albin Hansson y Rickard Sandler no sentían la menor comprensión por esta postura, ya que consideraban que creaba dificultades para la política exterior de neutralidad de Suecia - cuyo objetivo principal era mantener a Suecia al margen de una posible guerra mundial - y, a la larga, podía llevar también a la pérdida de las elecciones para el partido socialdemócrata, si la opinión pública sueca notaba la división entre el gobierno y las bases del partido.

La otra línea de oposición a la política de no intervención - según Lundvik - fue la llamada "línea de las armas", es decir, la de los que apoyaban el envío de armas a la República. Esta fue la línea seguida por el partido comunista sueco (SKP), la organización sindicalista SAC - con gran influencia anarquista - y el partido socialista (SP). El SKP se vio forzado, sin embargo, a apoyar oficialmente la no intervención cuando la URSS se adhirió al sistema de controles del Comité de No Intervención, aunque ya en abril de 1937 volvía a mostrarse crítico con la política del gobierno sueco ${ }^{50}$.

Los comunistas, socialistas y sindicalistas suecos no cesaron en sus campañas a favor de un cambio en la política sueca que permitiera la venta de armas a la República Española. En total, 351 organizaciones de trabajadores suecos enviaron un escrito al gobierno exigiendo esa posibilidad. De ellas, 163 eran organizaciones locales de la SAC, que protestaron al mismo tiempo contra los planes de intercambiar agentes comerciales con la España de Franco. Per Albin Hansson las desechó, aduciendo que la acción no inspiraba confianza ya que el texto de todas ellas era el mismo. Hubo también 12 organizaciones centrales de sindicatos que lo hicieron. Las restantes fueron, en su mayoría, organizaciones vinculadas al partido comunista ${ }^{51}$.

A pesar de ser Suecia un país pequeño, tanto el Reino Unido como Francia buscaron desde el primer momento el apoyo sueco a su política de no intervención, probablemente por la importancia de su industria armamentística y por el prestigio como país neutral y democrático del que gozaba el país escandinavo.

\footnotetext{
${ }^{50}$ El debate interno en el seno de los partidos comunista y socialista respecto a la postura a tomar ante la política de no intervención ha sido objeto de sendos estudios monográficos llevados a cabo por Claes-Göran Jönsson ("SKP y el movimiento sueco a favor de España") y Bernt Kennerström ("El partido socialista y la guerra civil española: la difícil cuestión de principios"), publicados en JÖNSSON \& KENNERSTRÖM, $o p$. cit.

${ }^{51}$ La mayoría están archivadas en RA, UD, 1920-års dossierssystem, HP 36, G1, Vol. 1524. Cfr. también LUNDVIK, Solidaritet och partitaktik..., p. 177. Sólo una pequeña minoría fueron de organizaciones socialdemócratas (entre ellas, el distrito del partido en Estocolmo y en Bofors, y el Club Juvenil Socialdemócrata de Eriksdal).
} 
Buen ejemplo de ello es la reunión que las delegaciones británica, sueca y francesa tuvieron el 11 de noviembre de 1936 en casa de Joseph Avenol, Secretario General de la Sociedad de Naciones, para preparar un borrador de resolución sobre la cuestión española a someter a los demás países miembros del Consejo el día siguiente. Asimismo, por iniciativa franco-británica, el Bureau International pour le Paix propuso a Suecia como posible mediador, junto con los demás países escandinavos, Holanda y Bélgica, en el conflicto español ${ }^{52}$.

Suecia se mantuvo fiel a su política de no intervención durante los años que duró la guerra, pero sin tener una voz especialmente activa en el seno del Comité o de la Sociedad de Naciones, limitándose a mantener el status quo, en estrecho contacto con los otros países nórdicos.

En consonancia con esta política, Suecia no quiso pronunciarse durante la reunión extraordinaria sobre España de la Sociedad de Naciones en agosto de 1937, y en septiembre presentó a ésta la decisión tomada en sus discusiones con los demás países nórdicos que tuvieron lugar en Estocolmo el 18 y 19 de agosto. La decisión era unívoca: los países nórdicos apoyaban en todo la política de no intervención.

En las negociaciones, había sido precisamente Per Albin Hansson quien se había opuesto a una propuesta noruega que había pedido que se considerase la posibilidad de permitir la venta de armas a la República. Per Albin opinó que era preferible esperar primero a ver cómo funcionaba la política de No Intervención, y que sólo si ésta fracasaba se podría considerar la posibilidad de "apoyar a las fuerzas que están a favor de una intervención en España" ${ }^{\text {53. }}$.

Isabel de Palencia confirmó en varias ocasiones la firmeza de la postura sueca en la llamada cuestión española. En 1937 comunicó al gobierno de la República la actitud negativa de la socialdemocracia sueca respecto a la posibilidad de una acción conjunta de la II y III Internacionales a favor de España. En julio de 1938, escribía que Suecia prefería a las democracias pero que no se manifestaba "en modo alguno hostil a los que por su sistema de gobierno tienen forzosamente que resultarle menos comprensivos y comprensibles".

\footnotetext{
${ }^{52}$ RA, UD, 1920-års dossierssystem, HP 36 A, Vol. 1505, PM confidencial de K.I.Westman de 12.XI.1936 y propuesta del Bureau International pour le Paix.

${ }^{53}$ RA, UD, 1920-års dossierssystem, HP 36 A, Vol. 1506; WAHLBÄCK, Krister \& BLIDBERG, Kersti (eds.), Protokoll från den nordiska arbetarrörelsens sammankomster 1932-1946, möte i Stockholm 18-19 augusti 1937, p. 121 y s.
} 
Seguía diciendo Palencia que el apoyo a la política de neutralidad del gobierno en la opinión pública era, "en general, incondicional”, y en también lo era en la prensa sueca, salvo en la de extrema izquierda. Respecto a la clase política, señalaba:

En cuanto a los partidos políticos, su apoyo a la política internacional del gobierno es incondicional por parte de los gubernamentales: Social Demócratas y Agrarios (...) Por lo que se refiere a los partidos de derecha (...) su apoyo al gobierno entraña críticas por considerar que la política internacional que mantiene es demasiado avanzada ${ }^{54}$.

Por su parte, las Legaciones de Suecia en las principales capitales de Europa mantuvieron informado al gobierno sueco sobre la actitud de los diversos países frente a la política de no intervención. Suecia estaba al tanto, por ello, de la falta de aplicación estricta de lo acordado, no sólo por lo que se refiere al apoyo militar y armamentístico por parte de Alemania, Italia y la Unión Soviética, sino también a la laxa actitud británica respecto al apoyo portugués a la España franquista, y a la francesa respecto a los transportes de voluntarios y armas a través de su territorio ${ }^{55}$.

La existencia de desavenencias en el seno del Comité de no intervención no era asunto nuevo. Las complicadas negociaciones en ese foro fueron discutidas en la reunión del Comité de Asuntos Exteriores (Utrikesnämnden) - comisión del Parlamento sueco compuesta por diputados de ambas Cámaras y de todos los partidos, repartidos en proporción al número de escaños en el Riksdag - el 10 de septiembre de 1937.

Los parlamentarios suecos pasaron revista a los principales asuntos relacionados con el tema desde la promulgación de la ley sueca de prohibición de voluntarios del 8 de marzo 1937 y su entrada en vigor el 19 de abril de ese año: la retirada de Alemania e Italia de las tareas de control el 23 de junio y la propuesta franco-británica de encargarse de hacerlo con la ayuda de observadores neutrales a bordo; la negativa de Alemania e Italia a esa propuesta y la contrapropuesta hecha por ellas de que se concediera a ambas partes el estatuto de beligerante y que se acabaran los controles; la solución de compromiso británica del 14 de julio, que propugnaba terminar con las patrullas, pero mantener la presencia de controladores en los puertos españoles y en los barcos de los países miembros del Comité de no intervención, junto con el reconocimiento de una beligerancia parcial y la

\footnotetext{
${ }^{54}$ AMAEC R 642, 2, despacho n. 162 de 23.VI.1937; AMAEC R 1785, 13, despacho n. 190 de 27.VII.1938.

${ }^{55}$ RA, UD, 1920-års dossierssystem, HP 36 A, Vol. 1505, despacho de la Legación sueca en Moscú de 4.XI.1936; despachos de la Legación en Londres de 18 y 27.XI.1936; despacho n. 467 de la Legación en España de 30.XI.1936.
} 
evacuación de los extranjeros; y por fin, la suspensión de controles fronterizos por parte de Portugal el 30 de junio y por Francia el 13 de julio. La experiencia acumulada desde entonces mostraba la necesidad de mejorar el sistema.

Sin embargo, no fueron estas dificultades sino, sobre todo, el juego diplomático británico encaminado a tratar de alejar a la Italia fascista de la Alemania nazi, secundado por Francia, lo que más influyó en la actitud del gobierno sueco, porque conllevaba, en la práctica, la falta de compromiso serio por hacer cumplir a rajatabla el Pacto de no intervención.

Ese descontento sueco con la pasividad del Comité, y en particular las dificultades para conseguir la retirada de las tropas extranjeras de España llevaría, a largo plazo, a la salida de Suecia del subcomité especial que dirigía el trabajo del Comité de no intervención, el 23 de noviembre de 1938.

Para entonces, Suecia ya había intercambiado agentes con el gobierno del general Franco y había comenzado la retirada de los brigadistas internacionales. El Comité de no intervención estaba ya obsoleto ${ }^{56}$.

En el fondo de todo, sin embargo, subyacía la reticencia de Suecia por alinearse decididamente con la línea defendida por una u otra de las grandes potencias, ante el temor de que ello la llevase a verse involucrada en la gran conflagración que se preveía podía azotar en breve a Europa y al mundo. La directiva del partido socialdemócrata estaba totalmente decidida a evitar tal escenario aunque ello supusiera verse obligado a llevar una política internacional que no estaba en la línea de los sentimientos y convicciones de la mayor parte de sus miembros ${ }^{57}$.

A pesar de las grandes simpatías que la causa republicana despertaba en la gran mayoría de la clase obrera y de la clase media sueca, triunfó la disciplina de partido y el pragmatismo tradicional de la política exterior del país escandinavo. Por ello, y por la firme decisión de la socialdemocracia sueca - que eran el partido y el sindicato absolutamente mayoritarios - de no colaborar en absoluto con los comunistas o con otras organizaciones que colaboraran con éstos, no consiguió el movimiento obrero sueco unirse en un frente común en apoyo de la República. Cabe, por tanto, aplicar también a Suecia lo

\footnotetext{
${ }^{56}$ RA, UD, 1920-års dossierssystem, HP 36 B, Vol. 1515, cartas de Beck-Friis a Prytz (representante sueco en el Comité desde el verano de 1938), de 23.XI.1938 y respuesta de 25.XI.1938. Sobre la retirada sueca del Comité de no intervención, cfr. AMAEC, R 1785, 13 e, despachos n. 350 y 364 de 17 y 30.XI.1938, de la Legación de España en Estocolmo.

${ }^{57}$ ARAB, SAP, Acta de la reunión del Comité de cooperación LO-SAP de 7.V.1938. Cfr. también JÄNDEL, op. cit., p. 145 y LUNDVIK, Solidaritet och partitaktik...., p. 178.
} 
que escribió Miralles acerca de la actitud de los partidos franceses de izquierda, que no fue favorable a la República excepto en el campo de la solidaridad ${ }^{58}$.

La decisión de las organizaciones socialdemócratas suecas (partido SAP y Unión sindical LO) de evitar hacer causa común con los comunistas y socialistas había sido definitivamente ratificada en el Congreso del partido del mes de mayo de $1936^{59}$. Apostaban así los socialdemócratas suecos por un programa de reformas graduales y de búsqueda del consenso, cuando fuera necesario, con los denominados partidos burgueses.

Aunque tradicionalmente las cuestiones internacionales solían influir poco en las campañas electorales suecas, en el caso de 1936, la situación internacional, y en particular la europea - en la que la evolución de España era un aspecto importante - influyeron, sin duda, en esta decisión de la socialdemocracia sueca, ratificando el convencimiento de ésta de que la línea a seguir era la ya iniciada de búsqueda del consenso, y no del enfrentamiento, con los adversarios políticos liberales y conservadores.

En parte, seguían esta misma línea también otros partidos socialdemócratas europeos dentro de la II Internacional, que no veían con simpatía la presencia de representantes del PSOE y la UGT en el Comité Internacional de Coordinación de las ayudas a España de inspiración frentepopulista ${ }^{60}$.

\subsection{Las relaciones diplomáticas de Suecia con la República Española de 1936 a 1939}

Por las circunstancias de la guerra, la actividad diplomática entre España y Suecia fue conducida de modo diverso por sus respectivas Legaciones en el país receptor. En líneas generales, se puede afirmar que los contactos diplomáticos sobre las cuestiones de fondo

\footnotetext{
${ }^{58}$ MIRALLES, Ricardo, "El duro forcejeo de la diplomacia republicana en París. Francia y las Guerra civil española", en VIÑNA, Angel, (coord.), Al servicio de la Republica, Madrid: Marcial Pons, 2010, pp. 121154 , p. 122.

${ }^{59}$ Cfr. WAHLBÄCK, \& BLIDBERG (Eds.), op. cit., p. 106: Politisk rapport från SAP till Nordiska samarbetskommitténs möte i Köpenhamn (informe político del Partido socialdemócrata sueco).

${ }^{60}$ Sobre la actitud contraria de la socialdemocracia sueca respecto a una posible acción conjunta de la II y III Internacionales a favor de España, cfr. AMAEC R 642, 2 e, despacho n. 162 de 23.VI.1937, y SKOUTELSKY, op. cit., p. 132 y s.: "dominada por la socialdemocracia de los países del norte y el Labour party británico, que rechazaban toda unidad de acción con la Internacional Comunista contra el fascismo y $a$ fortiori para España, se encontraba [la Internacional socialista] muy dividida". Sobre la repercusión de la guerra española en la estrategia electoral sueca de 1936 hemos seguido básicamente el análisis de LUNDVIK, Solidaritet och partitaktik..., pp. 36-42 y 111-113, que nos parece acertado. Cfr. también artículos en los diarios suecos Nya Daglig Allehanda, de 9.VIII.1936; Svenska Dagbladet, de 17.VIII.1936 y Aftonbladet de 8.VIII.1938. Otros autores suecos, por el contrario, sostienen que la guerra civil española no tuvo ninguna influencia en la campaña electoral sueca de 1936, cfr. TINGSTEN, op. cit., p. 193.
} 
que afectaban a ambos países fueron preferentemente desarrollados a través de la Legación de la República en Estocolmo.

Esto tiene su explicación lógica en el hecho de la paz y estabilidad reinantes en Suecia, que permitían un desarrollo normal de la vida diplomática. La Legación de Suecia en España, en cambio, estuvo en situación excepcional durante toda la guerra: su jefe de misión, Erik Wisén, era sólo Encargado de Negocios en lugar de Ministro (como era el caso de Isabel Oyarzábal de Palencia en Estocolmo), y además tuvo que dirigir la Legación desde domicilios provisionales (San Sebastián, Zarauz, Hendaya, Valencia, Barcelona y finalmente Perpignan), a menudo con dificultades de contacto con sus funcionarios subalternos y con el edificio de la Legación en Madrid, que albergaba cerca de doscientos refugiados políticos.

La guerra, y los conflictos concretos a los que dio lugar, también en relación con los intereses de Suecia, hicieron que la actividad de la Legación sueca ante la República Española fuera difícil y en general orientada a la resolución de problemas concretos relacionados con los refugiados, y a la defensa y protección de los súbditos y de los intereses suecos amenazados por la conflagración bélica.

Al mismo tiempo, como es lógico, la actividad de información al gobierno sueco sobre el desarrollo de la guerra recayó en la Legación de Suecia en España, ya que la recibida del gobierno de la República a través de la Legación española en Estocolmo era una visión necesariamente parcial. A esa labor de información nos hemos referido ya al comienzo de este capítulo.

\subsubsection{La actividad diplomática de la Legación de Suecia en Madrid}

A punto de terminar la guerra, los Servicios de Información de la España de Franco elaboraron un informe titulado "Actuación de algunas Embajadas y Consulados acreditados ante el gobierno rojo". Es significativo que Suecia aparezca en el tercer lugar de esa lista, detrás de Gran Bretaña y Francia. En él se lee

SUECIA: Tuvo asilados en Madrid y los evacuó a todos. Conducta general correcta. No ha tenido asilados rojos. Su amistad con el Gobierno, discreta. Elemento indeseable entre el personal, la esposa del encargado de Negocios extranjeros (sic) Sra. Wisén, amiga íntima de algunos cabecillas rojos y denigradora de los españoles nacionalistas. Suecia se dedicó 
especialmente a proteger colonias infantiles, como la que bajo sus auspicios estaba instalada en

Teyá (Barcelona) ${ }^{61}$.

Moral Roncal ha escrito que las autoridades republicanas respetaron estrictamente la inmunidad de los edificios diplomáticos suecos durante toda la guerra, por ser considerado un Estado amigo. "De esa manera - escribió - resultó sintomático que ninguna propiedad de ciudadanos suecos fuera dañada o expropiada, salvo la fábrica AGA situada en el sur de la capital, la cual fue saqueada por los milicianos y cuyos daños fueron evaluados en 100.000 pesetas, 62 .

Esta información no es correcta. El dato procede de la nota verbal enviada por Suecia en 1942 en respuesta a las preguntas del Ministerio de Asuntos Exteriores de la España de Franco, recogida en la Causa General ${ }^{63}$. Sencillamente, Suecia no dijo la verdad, probablemente para evitar las consecuencias que el hacerlo podría tener en una dictadura donde la represión política estaba en pleno vigor, o acaso por solidaridad - aunque fuera tardía - con la República. En todo caso, queda aquí patente una vez más la escasa credibilidad de la Causa General franquista como fuente histórica si no es contrastada con otras fuentes.

La actividad de la Legación de Suecia en Madrid durante la guerra civil se centró en dos aspectos básicos:

1. La labor humanitaria de asilo a refugiados y de mediación en canjes de presos.

2. La protección de los intereses suecos en la España republicana.

Por suponer el primero de estos dos aspectos una intervención - aunque fuera de carácter humanitario - en la guerra civil, lo analizaremos en el capítulo correspondiente, y nos centraremos ahora en el segundo.

Ya en agosto de 1936 tuvieron lugar los primeros conflictos diplomáticos entre Suecia y la República Española después de comenzada la guerra. El detonante fue el allanamiento de las prerrogativas del vicecónsul sueco en Alicante, Manuel Prytz, ciudadano sueco, que incluían la expropiación de su domicilio. Las protestas suecas fueron inmediatas, y ante la falta de arreglo inmediato de la situación, subieron de tono hasta

\footnotetext{
${ }^{61}$ AMAEC R 832, 1, informe del 2.III.1939.

${ }^{62}$ MORAL RONCAL, Antonio Manuel, Diplomacia, humanitarismo y espionaje en la Guerra Civil española, Madrid: Biblioteca nueva, 2008, p. 494, basado en AHN (hoy en CDMH), Causa General, vol. Embajadas y Legaciones, L. 1563, nota verbal de la Legación Real de Suecia con referencia a nota del Ministerio de Asuntos Exteriores de 27 de octubre de 1941, Madrid, 23 de abril de 1942, pp. 305-306.

${ }^{63}$ AHN, Causa General de Madrid, Embajadas y Legaciones, L. 1563, paquete 10, doc. 4 (actualmente trasladada al CDMH).
} 
concluir en un cruce de telegramas al máximo nivel, el Ministro de Negocios Extranjeros sueco y el Ministro de Estado español. Álvarez del Vayo aseguró a su colega sueco que el Ministerio del Interior había dado orden estricta a las autoridades de Alicante de restituir inmediatamente las prerrogativas del vicecónsul ${ }^{64}$.

El asunto no quedaría definitivamente solucionado, ya que en 1937, La Legación de Suecia se volvió a dirigir al Ministerio de Estado en relación con el automóvil que también le fuera incautado al vicecónsul Prytz:

A principios del mes de diciembre de 1936 durante la ausencia del vicecónsul, algunos miembros de la CNT se introdujeron en su domicilio donde se encontraban los archivos consulares con los colores suecos y se apoderaron de su coche bajo pretexto de que lo llevarían a Málaga para utilizarlo en los servicios de guerra. Como resulta del telegrama del 21 de diciembre de 1936, enviado por R. Sandler, Ministro de Negocios Extranjeros de Suecia a S.E. Sr. Alvarez del Vayo, la violación del domicilio de un funcionario consular sueco ha sido inmediatamente denunciada. Todas las investigaciones hechas por la legación para encontrar el coche en cuestión no han tenido ningún resultado y es preciso, pues, considerarlo como perdido. Por tanto, M. Prytz se reserva el derecho de reclamar una indemnización correspondiente al valor de su coche (...) que estima en la suma de 30.000 pesetas."65

Al año siguiente, la Legación se vio en la necesidad de solicitar el indulto de un pariente del vicecónsul, Hugo Prytz, condenado a 14 años de prisión como enemigo de la República, a lo que el Ministerio de Justicia español responde diciendo que el interesado debía solicitar personalmente el indulto del Tribunal Supremo ${ }^{66}$.

El caso del vicecónsul Prytz no fue un asunto aislado. Lo mismo le sucedió al vicecónsul sueco en Gijón, aunque la protesta formal sueca no llegó, en este caso, hasta el 29 de diciembre de 1937. He aquí la relación de los hechos, tal como lo describió la Nota Verbal de la Legación de Suecia:

El 22 de julio de 1936, el viceconsulado de Suecia en Gijón ha sido atacado por un grupo de individuos armados, conducido por un tal Nicolás Abasolo, el cual pretende que han disparado del piso alto de la casa. Sin embargo, se ha demostrado después que no ha sido ése el caso. El vicecónsul Juan de Jove y Corrales ha solicitado la protección de las autoridades locales pero sin

\footnotetext{
${ }^{64}$ RA, UD, 1920-års dossier, HP 36, vol. 1504; AMAEC R 588, 120, cruce de telegramas entre los Ministros de Estado español y sueco de Negocios Extranjerosde 21 y 26.XII.1936.

${ }^{65}$ AMAEC R 889, 88, nota de la Legación de Suecia de 30.IX.1937.

${ }^{66}$ AMAEC R 634, 25, nota de 19.XI.1938.
} 
ningún resultado. Cuando más tarde los mismos individuos volvieron llevando dinamita con intención de hacer volar la casa, el cónsul tuvo que huir al campo con su familia.

El 13 de agosto, el hijo del cónsul, secretario del viceconsulado, fue asesinado y su cadáver despojado. Después, el consulado ha sido registrado dos veces a pretexto de que había asilados en el local. Después las llaves del consulado han sido confiscadas para instalar allí las oficinas de un sindicato. El cónsul ha protestado contra esta intrusión y las llaves fueron devueltas a las veinticuatro horas. Don Juan de Jove puede aportar testigos de todos estos hechos, entre otros su vecino el cónsul de la Gran Bretaña. No ha podido hacer antes un informe de estos hechos a causa de la censura. El gobierno de Suecia se reserva el derecho de precisar mas tarde en sus reclamaciones este asunto ${ }^{67}$.

Ya desde los primeros momentos de la guerra, los suecos residentes o con intereses en España se sintieron amenazados. La mayor parte de ellos abandonó España, o al menos la zona bajo el control de la República Española. El Ministro de Estado español, Augusto Barcia, se había visto en la necesidad de dar garantías acerca de las personas y los bienes de los ciudadanos suecos ${ }^{68}$. La Legación de Suecia tomó entonces bajo su protección diecinueve domicilios particulares de ciudadanos suecos en Madrid: Uno de ellos pertenecía a un misionero protestante llamado Ståhlberg, compuesto de dos habitaciones y capilla, que habían sido destrozadas por los milicianos ${ }^{69}$.

A pesar de las buenas palabras de Augusto Barcia al comenzar la guerra, lo cierto es que en varias ocasiones más se vio la Legación de Suecia en la necesidad de protestar por atentados contra la propiedad de suecos residentes en España. Tal fue el caso de la requisa de los automóviles de los ciudadanos suecos G. Tunell (confiscado en Gijón el 23 de septiembre de 1936) y J. Nordbeck (en Llacuna, Villafranca del Penedes), o del repetido allanamiento de morada del domicilio barcelonés del ciudadano sueco Övergård en febrero de 1937, además de los daños ya citados a las empresas suecas AGA en Madrid y Wicander en Barcelona.

Había habido también algún conflicto motivado por la apropiación indebida de bienes, a una empleada del hospital sueco-noruego de Alcoy, y a los niños huérfanos del orfelinato sueco de Denia. De la influencia de estos hechos en el comercio sueco-español

\footnotetext{
${ }^{67}$ AMAEC R 889, 85, Nota Verbal de la Legación de Suecia de 27.XII.1937. Respondió el Ministerio el 10 enero de 1938 diciendo: "se ha dado traslado a las autoridades competentes". Cfr. también RA, UD, 1920-års dossierssystem, HP 36, vol. 1507.

${ }^{68}$ RA, UD, 1920-års dossierssystem, HP 36, vol. 1504: El telegrama de Barcia en ese sentido llegó a Estocolmo el 12.VIII.1936). Sobre la seguridad de las personas y de los bienes suecos cfr. también AMAEC R 749, 87-89.

${ }^{69}$ RA, UD, Beskickningarkivet: Madrid, F1 C Vol. 47.
} 
da idea el temor manifestado en 1938 por la conocida empresa sueca Skandia, que había recibido un pedido de motores y combustible por parte del gobierno español y estaba preocupada por la posibilidad de que les fueran expropiados si los enviaban antes de recibir el pago por ellos ${ }^{70}$.

La Legación se ocupó también de ayudar a sus conciudadanos y a los familiares de éstos a salir de España cuando así lo requerían. No fueron excepción, en este sentido, ni siquiera los voluntarios suecos de las Brigadas Internacionales que deseaban ser repatriados, incluso en contra de los deseos de sus superiores ${ }^{71}$.

En cambio, no aparecen en los fondos archivísticos suecos intentos de mediación o liberación de presos suecos no pertenecientes a las Brigadas Internacionales ${ }^{72}$.

Los conflictos diplomáticos relacionados con la detención de cónsules honorarios no fueron infrecuentes durante los primeros meses de la guerra civil. Suecia no fue una excepción, y tuvo que protestar enérgicamente ante las autoridades de ambos bandos, especialmente ante las de la España de Franco $^{73}$.

Además de los problemas citados con los vicecónsules en Alicante y Gijón, hay que mencionar también al vicecónsul sueco en Denia, Carbonell, que al principio de la guerra se pasó a la zona franquista por sentirse amenazado. Un primo suyo fue condenado a muerte por traición a la República por un tribunal de Valencia el 9 de mayo de 1938.

\footnotetext{
${ }^{70}$ AMAEC R 889, 89 Nota verbal de la Legación de Suecia de 23.IX.1937 sobre automóvil de G. Tunell; AMAEC R 889, 87 Nota verbal del 31.VIII.1938 sobre automóvil de J. Nordbeck: Las autoridades españolas respondieron que la incautación se debía a que sus ocupantes se dedicaban a adquirir ganado sin estar provistos de la autorización correspondiente; AMAEC R 889, 90, Nota verbal de la Legación de Suecia de 12.III.1937 sobre domicilio de Övergård: Suecia pidió, en este caso, una compensación de 75.000 coronas suecas, ya que había "objetos de plata y porcelana de los siglos XVII y XVIII, tapices orientales, una colección de armas de oro y plata, tapicerías, una veintena de pinturas valiosas, muebles preciosos de estilo antiguo y moderno, una biblioteca y un gran piano Stenway”. El gobierno de la República contestó que el asunto estaba poco claro, la Policía había intervenido bien la segunda vez que hubo allanamiento de morada, que parte de los objetos habían sido rescatados por el cónsul de Suecia y que la casa esta incautada por la Generalitat. Sobre el hospital sueco-noruego y el orfelinato sueco de Denia, cfr. AMAEC R 577, 4; sobre Skandia, cfr. RA, Beskickningsarkivet: Madrid, F1 C Vol. 47, carta de Skandia al Ministerio Sueco de Asuntos Exteriores, de 22.VI.1938. Sobre el hospital sueco-noruego y el orfelinato sueco de Denia, cfr. AMAEC R 577, 4.

${ }^{71}$ RA, UD, 1920-års dossierssystem, HP 36 H, Vol. 1525.

${ }^{72}$ Consta que había algunos suecos presos en España, cfr. CDMH, PS-Madrid 672, 2, "Relación de súbditos extranjeros existentes en los distintos establecimientos dependientes de esta Dirección General que se envía al Sr. Jefe del SM conforme interesa en escrito 24 del pasado septiembre": aparecen un sueco llamado Sven Landström, "detenido para expulsión" y una sueca de 41 años Agueda Amanda Johnsson, en la prisión de Cartagena, el 15 de enero 1938.

${ }^{73}$ MORAL RONCAL, Diplomacia, humanitarismo...., p. 149, donde menciona que numerosos cónsules honorarios fueron asesinados en los primeros meses de la guerra. Por lo que se refiere a Suecia, en el capítulo correspondiente comentaremos las dilatadas negociaciones diplomáticas con las autoridades franquistas para tratar de salvar la vida del vicecónsul sueco en Sanlúcar de Barrameda y liberar de la prisión al vicecónsul en Coruña.
} 
También los vicecónsules suecos en Madrid tuvieron múltiples problemas relacionados con su labor en relación con los refugiados en la Legación sueca en Madrid y edificios anexos. Las relaciones de uno de ellos, Gumersindo Vallejo, con las actividades de la llamada quinta columna en Madrid parecen fuera de toda duda, como veremos en un capítulo posterior. Al año de comenzar la guerra, catorce de los treinta cónsules o vicecónsules suecos de antes de la guerra habían abandonado sus puestos, voluntariamente o a la fuerza, uno había muerto y dos estaban prisioneros ${ }^{74}$.

Otros dos conflictos diplomáticos tuvo la Legación de Suecia con las autoridades republicanas en 1936: la protesta contra la captura del barco sueco Gallia por el español Libertad, y el asunto de las barricadas junto al edificio de la Legación en plena batalla de Madrid. Suecia temía que la existencia de barricadas y armas en las cercanías del edificio de su representación diplomática en la madrileña calle de Zurbano atrajeran las bombas de la aviación franquista hacia la zona. Ante la falta de respuesta a la Nota oficial enviada por la Legación al Gobierno español, el Ministro sueco de Negocios Extranjeros envió un telegrama directamente a la Junta de Defensa de Madrid exigiendo que las retiraran ${ }^{75}$.

Hubo asimismo tres conflictos, de orden diplomático, que tuvieron una cierta entidad: El primero de ellos fue motivado por la violación del correo diplomático sueco en 1937, cuando una carta y un "pliego" enviados por el Ministerio de Negocios Extranjeros de Suecia, con los sellos oficiales de dicho Ministerio y la indicación de ser correo diplomático fue "censurado por las autoridades postales de España"76.

El segundo fue un caso inverso: el traspaso de algunas decenas de refugiados de la Legación de Suecia a la de Panamá - con cesión a este último país de la responsabilidad por el local de la Legación de Suecia del Paseo del Cisne, dedicado a albergar refugiados sin haberlo puesto en conocimiento del gobierno de la República. Éste mostró su descontento a la Legación sueca, pero el hecho no tuvo más consecuencias ${ }^{77}$.

\footnotetext{
${ }^{74}$ RA, UD, Beskickningarkivet: Madrid, F1 C Vol. 44 y Vol. 45; RA, UD, 1920-års dossier, HP 36 A, Vol. 1505 e ibídem, Vol. 1506, despacho n 120 de 19.VII.1937.

${ }^{75}$ RA, UD, 1920-års dossierssystem, HP 36, Vol. 1504 sobre el Gallia y RA, UD, 1920-års dossierssystem, HP 36, Vol. 1505, nota al gobierno y telegrama de Sandler a la Junta de Defensa de Madrid de 19.XI.1936. La ruptura del protocolo diplomático que el envío de este telegrama denota muestra la importancia que el gobierno sueco daba al asunto. Las Embajadas de Turquía y Finlandia, situadas en la inmediata vecindad de la sueca, solicitaron a las autoridades franquistas la extensión de la "zona neutral" para que comprendiera la zona donde estaban las Legaciones sueca, noruega, turca y finlandesa, cfr. AGMAV, C.2330, L. 39, Cp. 102. ${ }^{76}$ AMAEC R 889, 84 Nota verbal de la Legación de Suecia de 29.XII.1937.

${ }^{77}$ AMAEC R 673, 13, Nota verbal del Ministerio de Estado a la Legación de Suecia, de 12.VIII.1937. Cfr. también RA, UD, Beskickningarkivet: Madrid, F1 C Vol. 44.
} 
El tercero fue con la Generalitat catalana, y tenía relación con el deseo de las autoridades de controlar la casa de acogida de niños de Teyá, iniciativa de la esposa de Erik Wisén. El asunto terminó con un decreto de la Generalitat en septiembre de 1938 sometiéndola a la inspección de las autoridades republicanas españolas, en contra de los deseos de los suecos ${ }^{78}$.

Puede dar la impresión, de lo que antecede, que las relaciones entre las autoridades de la República Española y la Legación de Suecia estuvieron plagadas de conflictos. Esto es sólo verdad en parte. Las autoridades españolas, en general, procuraron actuar de forma correcta. La mayor parte de las desavenencias fueron causadas por elementos incontrolados de las milicias. En otros casos, como en lo relacionado con las personas a las que la Legación de Suecia había dado asilo, las gestiones con las autoridades republicanas fueron bastante premiosas, y a pesar de las quejas en privado de Erik Wisén acerca de la ineficacia de la burocracia española se consiguió evacuar a la mayoría de los refugiados en un plazo relativamente breve. Parece también claro que las autoridades gubernamentales y las del Ministerio de Estado - Indalecio Prieto, en particular, es un ejemplo claro - procuraron mantener las mejores relaciones posibles con Suecia, al que seguían viendo como "país amigo",79.

\subsubsection{La actividad diplomática de la Legación de España en Estocolmo}

Entre el 18 de julio de 1936 y el 8 de agosto de ese año continuó presidiendo la Legación de España en Estocolmo su titular, Alfonso Fiscowich Gullón. En esas semanas, su única aportación a la República fue la comunicación a las autoridades suecas de la declaración por las republicanas españolas de un buque español, en manos de los militares rebeldes, como barco pirata. El 27 de julio afirmaba su lealtad y la de la "totalidad funcionarios mis órdenes" a la República: El secretario Oyarzabal, el Agregado comercial Viada y el secretario comercial Dafonte. Ninguno de ellos mantendría esa lealtad por mucho tiempo. El 31 de julio de 1936, Fiscowich fue nombrado, por el gobierno

\footnotetext{
${ }^{78}$ RA, UD, Beskickningsarkivet: Madrid F1 C,Vol. 49. Sobre el orfelinato de Teyá, cfr. capítulo 8.

${ }^{79}$ RA, UD, Beskickningsarkivet: Madrid F1 C Vol. 42, agradecimiento de Wisén al Gobernador Civil de San Sebastián por su ayuda; RA, UD, Beskickningsarkivet: Madrid F1 C Vol. 45, telegramas entre Wisén e Indalecio Prieto de noviembre de 1937 sobre repatriación de heridos suecos; RA, UD, Beskickningarkivet: Madrid, F1 C Vol. 44 y Vol. 47, cartas varias de Wisén a diversos funcionarios del Ministerio sueco de Asuntos Exteriores. Respecto al agregado comercial Viada y al secretario comercial Dafonte, cfr. FPI-AH80-14.
} 
republicano español, Encargado de Negocios en Berlín, pero el 8 de agosto retiró su lealtad a la República y el 11 de ese mes se adhirió al bando franquista ${ }^{80}$.

$\mathrm{Su}$ sucesora fue Isabel Oyarzábal Smith, conocida en Suecia como "Madame Palencia”. Durante un tiempo pareció que iría a Estocolmo López Ríos, para el que se había solicitado repetidamente el placet sueco. En septiembre de 1936, Bernardo Giner de los Ríos informó a Estocolmo del cambio de planes.

Según informaciones de Alfonso Fiscowich a la Junta de Burgos, el gobierno sueco de Pehrsson-Bramstorp había dilatado la concesión del placet a López Rey por querer mantenerse a la expectativa respecto a los acontecimientos de España y por ver con simpatía la causa franquista. En esa misma línea, el Ministerio sueco habría dado orden al vicecónsul en Madrid, Axel Olsén, de regresar a Suecia. Las gestiones de Fiscowich, a través de sus contactos en el Ministerio sueco de Negocios Extranjeros, Günther y Danielsson, destinadas a tratar de impedir o, al menos, retrasar la llegada de Isabel de Palencia, no dejaron de ser eficaces.

No obstante, probablemente la razón principal del retraso en la llegada del nuevo Ministro plenipotenciario español fuera más bien la imposibilidad física de hacerlo, ya que se encontraba en su viaje por Norteamérica en busca de apoyo para la República, acompañada por Marcelino Domingo y el sacerdote Luis Sarasola. Ante la amenaza de la posible caída de Madrid, el gobierno de la República envió a Suecia a dos funcionarios subalternos, Francisco Ugarte y Jesús Navascués, llegando incluso a pedir el placet para este último como Encargado de Negocios ${ }^{81}$.

Isabel de Palencia llegó a Estocolmo el 27.XII.1936 y se hospedó en el Grand Hôtel, ante la imposibilidad de hacerlo en el edificio de la Legación, que Fiscowich se negaba a abandonar $^{82}$.

\footnotetext{
${ }^{80}$ Fiscowich lo comunicó el 28.VII.1936, cfr. RA, UD, 1920-års dossierssystem, HP 36 A, Vol. 1504. Como es sabido, todos los Embajadores y Ministros de España que lo hicieron, al comienzo de la guerra, tuvieron que responder de ello ante los tribunales especiales franquistas al acabar la guerra. Cfr. también AMAEC $\mathrm{R}$ 584, 16, telegrama n. 33 de 27.VII.1936 y AMAEC, PG 0033, 15430, expediente personal de Alfonso Fiscowich, telegramas de Fiscowich al gobierno de Burgos de 12.VIII.1936, 5, 17 y 21.I.1937 y escrito al General Franco de 13.III.1937. Un informe confidencial de la Secretaría de Estado de Burgos, de 4.VIII.1936, califica la presencia de Fiscowich como Encargado de Negocios de la República Española en Berlín de "situación pintoresca en extremo", cfr. AMAEC R, 614,5. Sobre la actitud de Fiscowich, cfr. también CASANOVA, Marina, La diplomacia española..., pp. 45 y 247.

${ }^{81}$ AMAEC R 615, 31, comunicación al Ministro sueco de Negocios Extranjeros de 29.IX.1936; AMAEC R 602 , 5, despachos nn. 2, 3, 17, 21, 23, 25, 26, 30, 31 y 48, de A. Fiscowich a la Junta de Defensa Nacional de Burgos, de fechas comprendidas entre agosto de 1936 y enero de 1937.

${ }^{82}$ AMAEC R 577, 4, telegrama n. 38 de Isabel de Palencia al Ministerio de Estado, de 27.XII.1936. Cfr. también AMAEC PG 0033, 15430.
} 
La nueva Ministra de España comenzó inmediatamente su ofensiva para poder disponer del edificio de la Legación, insistiendo ante el Ministerio de Negocios Extranjeros y acudiendo a los tribunales suecos a través del que sería el gran valedor de la República en Suecia, el senador Georg Branting ${ }^{83}$, que era abogado también de la Legación soviética en Estocolmo.

La actitud de las autoridades suecas en el conflicto con Fiscowich, si bien desde el punto de vista formal fue completamente correcta - ya que Isabel de Palencia tenía la razón jurídica de su parte, como único representante del gobierno legítimo de España - no deja de llamar un tanto la atención, pues de hecho no se consiguió desalojar a Fiscowich hasta varias semanas más tarde. Es significativo que los representantes franquistas dijeran expresamente que el gobierno sueco quería "dar largas" a Isabel de Palencia. Christian Günther, el Secretario general del Ministerio de Asuntos Exteriores, a quien correspondía exigir a Fiscowich que abandonara la Legación, trató de ganar tiempo pidiendo a Isabel de Palencia que tuviera paciencia ${ }^{84}$.

Finalmente, tras la declaración firme de las autoridades suecas de que la Ministra de la República española tenía derecho a ocupar el edificio, cedió Fiscowich el mismo el 24 de enero de 1937. Pese a ello, la Legación no volvió a la normalidad hasta el traslado efectivo de domicilio de Isabel de Palencia y hasta la llegada de Aurelio Romeo, el nuevo Secretario de la Legación, que llegó a Estocolmo en marzo de 1937.

Ya en enero había solicitado la Ministra el nombramiento de un nuevo cónsul para Gotemburgo - el anterior, Manuel Becerra, no se había mantenido leal a la República - y el del canciller Ernesto Dethorey Camps como Cónsul extraordinario ${ }^{85}$.

A pesar de las dificultades en relación con la sede de la Legación, lo cierto es que Isabel de Palencia ejerció sus funciones de Ministro Plenipotenciario de España en Estocolmo desde el mismo momento de su llegada. El 4 de enero de 1937 escribía informando de su audiencia con el Rey Gustavo V, que

\footnotetext{
${ }^{83}$ Sobre la actividad de Georg Branting a favor de la República, cfr. capítulo 8. En el archivo privado de Branting en el del Movimiento Obrero de Estocolmo se conserva una carta manuscrita de Isabel de Palencia, anunciandole que pronto le prepararía las cartas para "el asunto comercial", cfr. ARAB, Georg Brantings arkiv 90/11 brev från Palencia (carta de Palencia), 24.II.1937.

${ }^{84}$ AMAEC R 602, 5, despacho de Fiscowich n. 17 de 10.X.1936 e informe de 21.XI.1936. Christian Günther habría sido el sucesor de Danielsson como Ministro Plenipotenciario sueco en España de no haber estallado la guerra.

${ }^{85}$ AMAEC R 642, 2, despacho n. 57 de 8.III.1937; CANTERA CARLOMAGNO, Sverige och spanska..., p. 79; Diario Dagens Nyheter de 8.I.1937. El abogado de Fiscowich fue Dick Bergman. Toda la prensa sueca defendió el derecho de la nueva Ministra de España a ocupar la Legación, cfr. AMAEC R 577, 4, despachos de la Legación de España nn 4, 6 y 7 de 9, 11 y 14.I.1937.
} 
prolongó la audiencia algún tiempo y me pidió noticias acerca de la situación de España, lamentándose de los males acarreados por la guerra. Me preguntó si eran ciertas las noticias referentes a la ayuda prestada por ciertas naciones: Italia y Alemania, y sobre todo Rusia. Me expreso sus deseos de que la amistad entre España y Suecia se mantenga como hasta aquí dentro de los términos de una gran cordialidad y yo le exprese por mi parte los votos de nuestro país en el mismo sentido ${ }^{86}$

En poco tiempo, la Legación de España se convirtió en lugar de encuentro de todos aquellos grupos, muy numerosos en la sociedad sueca, que querían dar su apoyo a la República española, en especial el Comité sueco de Ayuda a España, cuya labor analizaremos en un capítulo posterior. La causa republicana, defendida con palabras más que con hechos por los representantes del gobierno sueco, vio crecer a nivel popular un gran movimiento de solidaridad, especialmente entre la población trabajadora sueca.

La actividad propagandística de la Legación, dentro de sus limitadas posibilidades logísticas y de escasez de personal, fue considerable. De cuando en cuando, se podía contar en Estocolmo con la presencia de personalidades españolas, como el rector de la Universidad de Madrid Jose Gaos ${ }^{87}$ o el Consejero de Economía de la Generalitat ${ }^{88}$.

Otras personalidades españolas que visitaron Suecia durante los años de la guerra civil fueron: el anarquista nacionalizado español Augustin Souchy (a establecer contactos y buscar fondos, agosto 1936), el director del Observatorio de Madrid, Pedro Carrasco (reunión de la Unión Astronómica Internacional, agosto de 1938); Julio López Oliván (asistencia al entierro de Åke Hammarskjöld, julio de 1937); Ramón González Peña y Belarmino Tomás (reunión con la directiva de la LO, noviembre de 1937); el vicepresidente de la UGT Edmundo Domínguez (agosto de 1938, congreso de la Federación de Sindicatos de la construcción); y Horacio Prieto, de la directiva de la CNT (congreso de la SAC, septiembre de 1938). También fue invitada Dolores Ibarruri, pero no pudo acudir ${ }^{89}$.

\footnotetext{
${ }^{86}$ AMAEC PG 0197, 22675 despacho n. 1 de 4.I.1937. La diplomacia republicana española procuró cumplir con delicadeza el protocolo previsto en lo referente al trato con el Rey de Suecia. En este sentido, cfr. AMAEC R 588, 120, felicitación del Ministro de Estado, Giral, por la onomástica del Rey, el 6 de junio de 1937. El Rey Gustavo V, por su parte, se sirvió de estos contactos para intervenir a favor de algunos refugiados políticos españoles, cfr. AMAEC R 673, 13 y Capítulo 8 de este estudio.

${ }^{87}$ AMAEC R 602, 5, despacho n. 42 de Fiscowich, de 15.XII.1936; RA, SÄPO, Vol. 489.

${ }^{88}$ AMAEC R 577, 4, despacho n. 27 de la Legación de España, de 2.II.1937

${ }^{89}$ ARAB, SAC, 1845/ E6:7; AMAEC R 634, 29; AMAEC R 634, 19, despacho n. 184 de Legación de España de 21.VII.1937; AMAEC R 634, 17, información del Ministerio de Estado a la Legación en Estocolmo de 17.I.1938; R 642, 2 e despacho n. 226 de 17.VIII.1938: Edmundo Domínguez recibió 20.000
} 
Además, invitado por el Ministro sin cartera Östen Undén, visitó Suecia Salvador de Madariaga, que pronunció dos conferencias y fue entrevistado por el diario conservador Svenska Dagbladet. En esa ocasión dijo Madariaga que "en la actualidad ninguna de las dos partes contendientes en mi país desea saber de mí (...). Déjeme olvidar todo lo que sea política activa para volver a ser un particular" 90 .

En febrero de 1937, Isabel de Palencia se ocupó de reorganizar la marcha normal de la Legación y de su Sección Comercial ${ }^{91}$. Por aquellas fechas, aconsejó a Pascual Tomás que si la UGT quería desarrollar su propaganda en Suecia buscara el apoyo de la Unión de Sindicatos sueca LO, puntualizando que, caso de negarse ésta a colaborar, habría otras organizaciones que sí lo harían ${ }^{92}$.

En la primavera de 1937, la Ministra de España en Estocolmo se mantuvo en estrecho contacto con su esposo, el empresario y dramaturgo Ceferino Palencia Tubau (1882-1963), por entonces Ministro de España en Riga, y ambos a su vez con Luis Araquistáin. Por aquel entonces, estaban en marcha varios intentos de compra de armamento en Suecia, Finlandia y los países bálticos - en especial, lo relativo al llamado caso del vapor Allegro que tuvieron consecuencias inesperadas ${ }^{93}$.

El 15 de febrero de ese año, Madame Palencia había tenido la primera entrevista con el Ministro sueco de Negocios Extranjeros, Rickard Sandler, con ocasión de una de las audiencias generales que éste concedía a los jefes de misión en Estocolmo. Hablaron de la guerra. La diplomática española aseguró que no había peligro de que cayera Madrid y que no tenía nada que objetar a los acuerdos del Comité de No intervención de Londres.

kr y fue entrevistado por el diario Social-Demokraten; AMAEC R 1058, 11 e; CDMH, PS-Madrid 663/44; AMAEC R 634, 22, carta de la Subsecretaría de Propaganda a Kulturfronten de 27.X.1938 sobre invitación a Dolores Ibarruri.

${ }^{90}$ AMAEC 602, 5, informe de Gabriel Dafonte al Secretario de Relaciones Exteriores en Salamanca, de 3.II.1937.

${ }^{91}$ Sus gestiones dificultaron la actividad del antiguo secretario comercial, Gabriel Dafonte, pasado al campo rebelde: En carta a su colega en Noruega, Campuzano, también al servicio de la España de Franco, contaba Dafonte las dificultades que tenía para recibir telegramas y cartas, ya que "Doña Pendón [calificativo ofensivo con el que designaba a Isabel de Palencia] había dado orden de que todo lo que fuese a su oficina, en su nombre sueco o español, le fuera entregado". Dafonte amenazó a las autoridades suecas de Correos y Telégrafos con acudir a los tribunales si no le entregaban correspondencia dirigida a su nombre a la Secretaría comercial de España. Al final, adoptaron éstas la decisión de preguntar a los interesados, antes de entregar la correspondencia, a cual de los representantes comerciales iba dirigida, al republicano o al franquista, lo que Dafonte calificó de "una solución salomónica, y por tanto judía", cfr. AGA 54/5290 carta de Dafonte a Campuzano de 20.V.1937. Aparte de la burda expresión antisemita referida, contenía la carta otras palabras soeces y ofensivas.

${ }^{92}$ FPI-AH-54-72.

${ }^{93}$ Sobre el caso Allegro, cfr. el epígrafe correspondiente al material bélico sueco en el capítulo sobre la intervención sueca en la guerra civil española. Isabel de Palencia se quejó de que la prensa sueca lo había tratado de forma sensacionalista, cfr. AMAEC R 634, 9. Sobre la correspondencia entre Luis Araquistáin y los Palencia, cfr. FPI-ALA-98-27 y FPI-ALA-98-28. 
También le dijo a Sandler que no debería haber problemas para la evacuación de los refugiados en la Legación de Suecia en Madrid.

El 9 de marzo volvió Palencia a estar presente en la audiencia semanal con Sandler, pero sin intervenir. Sí lo haría dos semanas después, el 23 de marzo, cuando, en nombre del gobierno de la República pidió el apoyo del gobierno sueco a la petición de reunión extraordinaria sobre España del Consejo de la Sociedad de Naciones para tratar de la violación por parte de Italia del artículo 10 del Pacto.

Sandler le aseguró que lo plantearía al gobierno pero que, en su opinión, se obtendrían mejores resultados en el Comité de Londres y que la cuestión debería ventilarse primero allí; opinión que la diplomática española, según dejó escrito el Ministro sueco, afirmó comprender plenamente. El despacho enviado por la Ministra de España informando sobre esta reunión añade, además, la insistencia de Sandler en la necesidad urgente de retirada de España todas las tropas extranjeras ${ }^{94}$.

Durante los dos años siguientes, Isabel de Palencia se entrevistó en varias ocasiones más con el Ministro sueco de Negocios Extranjeros.

En la audiencia del 4 de mayo de 1937, se quejó de la actividad llevada a cabo por algunos españoles simpatizantes de la causa rebelde en Estocolmo: uno, llamado O'Connor, que había estado refugiado en la Legación sueca en Madrid, tenía contactos con la España de Franco y con Portugal; otro, Joaquín Herraiz, Profesor titular (Lector) de español de la Universidad de Estocolmo, incluso recorría la capital sueca luciendo la bandera roja y gualda en su coche. Isabel de Palencia había prohibido a su personal hacer ondear en sus vehículos la bandera republicana, con excepción del automóvil oficial de la Legación.

En conversación posterior, del 1 de junio, Sandler le manifestó sus condolencias por los "trágicos sucesos de los últimos días" (el incidente del Deutscheland y el bombardeo de Almería) y le dijo que esperaba que el gobierno español no hiciera nada que agravase la situación y dificultase una solución. Palencia "repitió la versión española sobre los bombardeos" y le dio las seguridades que pedía ${ }^{95}$.

\footnotetext{
94 RA, UD, 1920-års dossierssystem, HP Vol. 14, Utrikesministerns samtal med utländska beskickningschefer 1935-1937; AMAEC R 577, 4, despacho n. 78 de 23.III.1937. Suecia, en atención a las particulares circunstancias por las que pasaba España, acabó apoyando la candidatura de ésta, cfr. AMAEC R 642, 2, despacho n. 57 de 8.III.1938.

${ }^{95}$ HP, 1920-års dossierssystem, HP Vol. 14, Utrikesministerns samtal med utländska beskickningschefer 1935-1937; AMAEC R 642, 2 despacho n. 98 de 4.VI.1938 y AMAEC R 634, despacho n. 138 de 1.VI.1937.
} 
Tras otra entrevista en agosto de 1937 para pedir el apoyo sueco a la reelección de España al Consejo de la Sociedad de Naciones, volvieron a verse el 8 de marzo de 1938 para tratar de algunos trámites burocráticos relacionados con el personal de la Legación y denunciar más violaciones del Pacto de No Intervención por parte de las potencias que ayudaban a la España de Franco.

A finales de 1938 tuvieron lugar dos reuniones más, una el 25 de octubre para pedir que Suecia recapacitase antes de seguir el ejemplo noruego y danés de intercambiar agentes con la España de Franco, apelando al daño que ello haría a la reputación de Suecia en la España republicana. Sandler aprovechó esa ocasión para presionar a la diplomática española insistiendo en el deseo del gobierno de Suecia de conseguir permiso para la evacuación de los militares refugiados en la Legación sueca en Madrid.

La última reunión, de noviembre de 1938, cuando ya Suecia había intercambiado agentes con el gobierno de Burgos, puso sobre el tapete las recientes medidas suecas de contraespionaje - motivadas, al parecer, por haberse encontrado ramificaciones del espionaje alemán en Dinamarca en las ciudades suecas de Malmö, Helsingborg y Gotemburgo - y sobre cuestiones comerciales relacionadas con el bloqueo de capitales.

Durante la misma, se quejó también Isabel de Palencia ante Sandler de algunos artículos ofensivos para la Sra. de Azaña, aparecidos en publicaciones de la propaganda franquista en Suecia ${ }^{96}$.

En junio de 1937, la Legación de España en Estocolmo intervino activamente en las gestiones para conseguir "víveres" para la República. Ello motivó una intensa correspondencia entre la Legación y el Ministerio de Estado sobre créditos anulados y otros problemas monetarios. Sin embargo, a juzgar por las informaciones de los representantes franquistas un año más tarde, el sistema de compra de víveres de la Legación republicana parecía funcionar. Por otra parte, las organizaciones de extrema derecha hacían propaganda contraria, y el Secretario de la Legación, Aurelio Romeo, llegó a quejarse de una campaña nazi en Suecia en contra de Isabel de Palencia ${ }^{97}$.

96 RA, UD, 1920-års dossierssystem, HP Vol. 14, Utrikesministerns samtal med utländska beskickningschefer 1935-1937 y AMAEC R 1785, 13 e, despacho n. 350 de 19.XI.1938, donde Palencia se queja de la actitud distanciada de Sandler. Cfr. también Ibidem, despacho n. 330 de 12.XI.1938 sobre la entrevista con Möller, ministro sueco de asuntos sociales, quien le dijo confidencialmente que estaba considerando dimitir. Sobre el asunto del espionaje nazi, cfr. FPI-ALJA-450-1, copia del despacho n. 365 de Isabel de Palencia al Ministro de Estado, de 30.XI.1938 y sobre la propaganda franquista, cfr. AMAEC R 1785, 13 e, despachos 368 y 377 de diciembre de 1938.

${ }^{97}$ AMAEC R 577, 4, despachos n. 150 de 18.VI.1937; n. 154 de 21.VI.1937, n 161 de 22.VI.1937 y n. 165 de 30.VI.1937. AMAEC R 1048, 34 informe n. 104 del Conde de Torata de 21.XII.1938, señala que."parece existir una especie de crédito abierto y anticipos a cuenta de frutas que vienen a través del organismo llamado 
En julio, la República creó un consulado honorario en Gotemburgo, que sería ocupado por Gustaf Theofil Vickman, que había colaborado con el Socorro Rojo internacional y había estado varias veces en España. Con él, funcionaban consulados honorarios españoles en las ciudades suecas: Estocolmo, Gotemburgo, Malmö, Gävle, Söderhamn, Härnosand, Sundsvall, Skellefteå y Luleå ${ }^{98}$.

Entre los meses de abril de 1937 y enero de 1938 tuvo lugar, por iniciativa de las organizaciones suecas de ayuda a la España republicana con el apoyo de la Legación, una serie de exposiciones de arte moderno español en las principales ciudades de Suecia, y también en Oslo. La colección consistía en "130 números, compuesta de óleos, acuarelas, aguafuertes, dibujos, litografías y esculturas" $"$.

La actividad de la Legación en 1937 que consiguió un mayor impacto propagandístico a favor del esfuerzo bélico de la República fue la celebración de una Semana de España en noviembre de ese año. Tuvo ésta lugar en diversas ciudades suecas y fue promocionada como un acto "en homenaje al heroico Madrid".

Consistió en una serie de actos culturales y mítines de personas destacadas de las organizaciones de Ayuda a España, como Georg Branting, el profesor Israel Holmgren, o algunos brigadistas internacionales suecos venidos de los frentes de guerra. Fue organizada en colaboración estrecha con el Comité de Ayuda a España, y recibió amplia cobertura por parte de la prensa. En ella se presentó la pieza teatral de Brecht titulada Les fusils de Madame Carrar, y se publicó un pequeño libro, titulado A Madrid, al que contribuyeron veinticinco autores. Constituyó indudablemente un gran éxito propagandístico ${ }^{100}$.

El viaje de una delegación de miembros del Parlamento sueco a España para asistir a la apertura de las Cortes españolas a comienzos de 1938 fue otro gran éxito de la labor propagandística de la Legación republicana en Estocolmo. Asistieron cinco: Branting, Sandegård, Tengström, Andersson y Österström.

A su vuelta a Estocolmo, escribieron artículos y dieron conferencias ante personas "de muy diversas tendencias políticas, llevando al ánimo de todos el convencimiento de la justicia de nuestra Causa y la seguridad de nuestra victoria (...) Fue particularmente

Transfer y de la Stockholms Enskilda Bank, que es el Banco de la Legación Roja, perteneciente a la familia Wallenberg, que aunque parezca raro protegen todas las operaciones de los rojos". Sobre la campaña nazi contra Isabel de Palencia cfr. AMAEC 577, 4, despacho n. 152 de 18.VI.1937.

${ }^{98}$ AMAEC R 556, 24, despacho n. 172 de 10.VII.1937 y AMAEC R 602, 5.

99 AMAEC 642, 1, Anejo al despacho n. 209 de 7.VIII.1938.

100 AMAEC R 1069, 25 e despacho n. 224 de 29.IX.1937; AMAEC R 1069, 25 e, despacho n. 250 de 18.XI.1937 y AMAEC R, 642, 2, despacho n. 57 de 8.III.1938; ARAB, Georg Brantings arkiv, 90/29, Report of the Swedish Committee for Aid to Republican Spain, presentado en la Conferencia Internacional de la Oficina Internacional de Ayuda a la Infancia, París, 21-22 de julio de 1938. 
interesante el discurso del diputado liberal [Tengström] por la fría objetividad con que emprendió el viaje a España y la emocionada sinceridad con que está hablando".

Además, y como culminación de esos actos de apoyo, el jefe del gobierno sueco, Per Albin Hansson, aceptó asistir a una comida en la Legación ${ }^{101}$.

También se facilitaron desde la Legación los viajes a España de periodistas afines, que a su vuelta pudieran escribir artículos aprovechables en la labor de propaganda a favor de la República. En especial, y con la idea de contrarrestar los efectos negativos para la República ocasionados en la opinión pública sueca por la Carta colectiva del Episcopado español de 1 de julio de 1937, la Legación organizó el viaje a España de un grupo de suecos, entre los que se encontraban la periodista Barbro Alving, la abogada Sonja Branting-Westerståhl y el también periodista Ragnar Casparsson ${ }^{102}$.

En los meses de abril, mayo y junio de 1938, Isabel de Palencia viajó a otros países: Inglaterra, Suiza, Finlandia - donde también estaba acreditada como Ministra de España -, Noruega y Letonia, en relación con gestiones para buscar ayuda para la República ${ }^{103}$.

Tras el verano de 1938, en el que un buen número de voluntarios suecos perdieron la vida en la Batalla del Ebro ${ }^{104}$, pasó a primer plano la cuestión de la retirada de las Brigadas Internacionales, en la que estuvieron muy directamente involucrados algunos militares suecos.

En septiembre de ese año era ya inminente el acuerdo entre Suecia y la España de Franco sobre intercambio de agentes. Como ya expusimos, Isabel de Palencia se entrevistó varias veces sobre el particular con el Ministro sueco de Negocios Extranjeros, y también llegó a entrevistarse con el propio jefe del gobierno, Per Albin Hansson, el 18 de octubre de 1938. El resultado de esas conversaciones no fue en modo alguno favorable a la causa

\footnotetext{
101 AMAEC R 642, 2, despacho n. 42 de 22.II.1938; AMAEC R 1058, 11 e, despacho de 25.I.1938; AMAEC R 642, 1 e, despacho de 2.II.1938; AMAEC R 642, 2, despacho de 12.II.1938.

${ }_{102}$ AMAEC R 1069, 25 e, despacho n. 206 de 23.VIII.1937, sobre la conveniencia de invitar a periodistas suecos visitar España, "quizá la Sra. Sonia Branting y algún pastor protestante”. Cfr. también LUNDBERG, op.cit., p. 141.

${ }^{103}$ AMAEC R, 1785/13, despacho n. 190 de 27.VII.1938; AMAEC R 642, 2 despachos n. 104, 131 y 132 de mayo de 1938; AMAEC R 1058, 11; Sobre la presentación de credenciales en Finlandia y los problemas con su antecesor allí, Gómez-Acebo, también pasado a la España de Franco, cfr. AGA 54/12047 despacho de G. Acebo de 15.XII.1937; AMAEC R 1785, 13, despachos n. 380 y 383, de 10.XII.1938; AMAEC PG 0197, 22675, informe reservado de 10.XI.1937.

${ }^{104}$ Cfr. NILSSON, Torbjörn, "Ebro. Spanienfrivilligas sista strid", en Guide till svensk historia i Europa, Estocolmo:Wahlström \& Wistrand, 2002, p. 196.
} 
republicana, que Suecia consideraba ya perdida, como lo prueba su retirada del Comité de No Intervención pocas semanas después ${ }^{105}$.

Tanto la Ministra de España en Estocolmo como los Secretarios de la misma, especialmente Feduchy, que sustituyó a Romeo en el primer trimestre de $1938^{106}$, procuraron desarrollar una amplia labor de representación acudiendo a congresos y otros actos culturales y aprovechándolos para hablar de la guerra civil española.

Asimismo, distribuyeron gran cantidad de material propagandístico: 4.139 envíos en el primer semestre de 1938, en español, inglés, alemán o sueco (aunque éstos últimos fueron pocos, porque los traducidos en España a este idioma "estaban mal” y no cumplían su objetivo, según informó la Legación.

Se quejaba ésta, además, de la adversa situación para la propaganda republicana ocasionada por "la enorme propaganda realizada por el enemigo en los primeros meses de la rebelión", y por las prevenciones suecas frente a España:

La gran distancia que separa a Suecia de nuestro país; mas a medir por diferencias de temperamento que de kilómetros y que en el pasado ha hecho surgir barreras de incomprensión entre ambos, no es fácil de salvar en poco tiempo ${ }^{107}$.

Por lo que se refiere a las relaciones comerciales, en cambio, apenas tuvo éxito la labor de la Legación. De hecho, los contactos comerciales fueron mayores con la España de Franco, como tendremos ocasión de exponer en el capítulo correspondiente. Incluso en algún caso hubo problemas serios, que terminaron en los tribunales suecos.

En diciembre de 1937, el Tribunal Supremo sueco condenó a la Oficina comercial de la Legación de España, y solidariamente al Agregado comercial Francisco Ugarte, a pagar 188.350 coronas a la firma Handelsbolaget Elof Hansson, Göteborg. El asunto estaba relacionado con un encargo de la Oficina comercial de pasta de madera con destino a la República que no se había pagado a su debido tiempo. La Oficina comercial se negó a pagar, y la Audiencia Provincial de Estocolmo (Svea Hovrätt) decretó el embargo de todos los créditos existentes en el Comité de clearing (en los bancos Handelsbanken, Göteborgs

\footnotetext{
${ }^{105}$ AMAEC R 577, 4 despacho n. 268 de 20.IX.1938, donde acusa a los "elementos industriales" de ser la causa del paso dado por Suecia, nombrando en particular a R. von Heidestam, de la empresa AGA; AMAEC, R 1785, 13 e, despachos n. 303, 350 y 364 de 18.X , 17.XI y 30.XI.1938, de la Legación de España en Estocolmo.

${ }^{106}$ Para los traslados y destinos durante la guerra civil de los diplomáticos fieles a la República, cfr. VIÑAS, Al servicio de la República..., Apéndices 14 y 15, pp. 473-508.

${ }^{107}$ AMAEC R, 1785/13, despacho n. 190 de 27.VII.1938 e "Informe de la Representación de la República en Estocolmo. Agosto 1938. Labor realizada".
} 
Bank, Skandinaviska Kreditaktiebolaget y Stockholms Enskilda Bank) a favor de dicha Oficina comercial o de Ugarte. El Tribunal consideró que la Oficina comercial ejercía un monopolio en el comercio exterior de España.

Al final, la representación comercial republicana no tuvo más remedio que cumplir la sentencia ${ }^{108}$.

Finalmente, ya a punto de terminar la guerra, tuvo lugar en Suecia un suceso anecdótico, pero, que sepamos, inédito en el mundo diplomático español durante los años de la guerra: el hecho de que los jefes de las representaciones diplomáticas de la República Española y de la España de Franco asistieran, uno al lado del otro, a un acto oficial representando a España.

No parece que el asunto fuera premeditado, aunque tampoco cabe descartarlo sin más. El evento en cuestión fueron los funerales por el Papa Pío XI, en el templo católico de Santa Eugenia, en Estocolmo. Así lo relata el Conde de Torata, que había recibido invitación del Vicario apostólico sueco, monseñor Müller:

La Señora de Palencia se presentó en la iglesia sin ser invitada, y como no había puestos fijos, su presencia no dio lugar a ningún incidente, pero el Padre que hacía de acomodador tuvo la desgraciada idea de sentarla a mi lado. Al salir, hizo colocar el coche de la Legación frente a la puerta, con la bandera republicana colocada sobre las aletas ${ }^{109}$

Podemos resumir este apartado señalando que, a la luz de lo aquí expuesto, las relaciones diplomáticas de Suecia con la República Española durante los años de la guerra civil pueden calificarse de correctas y a la vez distanciadas. La razón fue probablemente la firme decisión sueca por mantener a toda costa la neutralidad del país frente al juego de las grandes potencias, rehuyendo todo conflicto con Alemania, Gran Bretaña, la Unión Soviética y Francia. Esta actitud contó con el apoyo mayoritario de la opinión pública, aunque creara problemas de conciencia a gran parte de los miembros y electores del Partido mayoritario, el socialdemócrata.

Las bases del movimiento obrero, por su parte, no dejaron de criticar esta actitud, las socialdemócratas de manera muy velada, debido a la disciplina de partido y a consideraciones prácticas, las comunistas y sindicalistas de manera abierta y clara.

108 AMAEC R 1058, 11, despacho de 16.XII.1937; AMAEC R 1785, 13 despacho n. 190 de 27.VII.1938 y despacho n. 331 de 12.XI.1938; AMAEC R 634, 15. Cfr. también CANTERA CARLOMAGNO, Sverige och spanska..., pp. 80-84.

${ }^{109}$ AMAEC R 1058, 11, despacho del Conde de Torata al gobierno de Burgos, de 22.II.1939. 
Esta actitud sueca fue recibida con incomprensión y desengaño por los republicanos españoles. Las duras palabras de Indalecio Prieto en un discurso del 28 de agosto de 1937, cuando declaró no entender cómo los líderes de partidos socialistas extranjeros que de palabra se mostraban tan entusiasmados con la causa republicana, luego como gobernantes "se tiraban a nuestro cuello para ahogarnos" fueron recogidas, con acritud apenas contenida, en las memorias de un conocido brigadista sueco ${ }^{110}$.

La actitud oficial del gobierno socialdemócrata sueco respecto a la guerra española había sido ya expuesta con gran claridad en el importante discurso en la ciudad de Norrköping del Ministro de Negocios Extranjeros, Rickard Sandler, el 23 de noviembre de 1936:

Respecto a la tragedia española, ya tuve ocasión de expresar mi opinión de que no debían mezclarse nuestros asuntos interiores con cuestiones extrañas. De lo que entonces dije, quiero subrayar ahora especialmente dos puntos de vista: uno se refiere a la democracia, y el otro a la formación de frentes ideológicos. No es posible tomar partido por uno de los frentes en el problema español, y sostener al mismo tiempo los principios democráticos, por ser dos cosas que se contradicen.

Se puede lamentar profundamente que el camino de España a un orden social moderno y democrático vaya a través de convulsiones tan sangrientas y crueles y que el desarrollo parezca por ahora tan incierto, pero no debe afirmarse que el destino de la democracia en el mundo se resuelva en las luchas callejeras de Madrid. Este depende de la manera de solucionar sus propios asuntos de los Estados democráticos y de su voluntad de defenderse de ataques tanto materiales como inmateriales. Pero a ese fin es de la mayor importancia que la democracia afirme su idiosincrasia y no se coloque en la situación de tener que elegir entre dictaduras de distintos matices. Sobre este punto debe haber una absoluta claridad.

No significa esto que los Estados democráticos tengan que aislarse y renunciar al trato con los países regidos por dictaduras, que es un corolario de la necesidad de colaboración en este planeta. Si, por ejemplo, en el curso de los trabajos internacionales se presentan proyectos para la organización de la paz, que consideramos buenos y prácticos, no nos impide colaborar con ellos el hecho de provenir de la Unión Soviética o eventualmente de Alemania. Pero si se nos ofrece formar parte de un bloque, ya sea anticomunista o antifascista, cuyo único fin es la derrota del extremo opuesto, nos negaremos terminantemente ${ }^{111}$.

\footnotetext{
${ }^{110}$ MATTSON, op. cit., p. 94.

${ }^{111}$ SANDLER, Rickard, Utrikespolitisk kringblick.... Hemos utilizado la traducción española realizada por A. Fiscowich, cfr. AMAEC 602, 5, despacho n. 33 de Fiscowich al gobierno de Burgos, de 24.XI.1936.
} 
Posteriormente, volvió a insistir Sandler en que la guerra española era producto del enfrentamiento de "dos minorías"112. Esta visión distanciada y reacia a tomar partido decididamente por alguna de las partes en contienda persistió a lo largo de toda la guerra, a pesar de las palabras que escribió Isabel de Palencia en su informe semestral de julio de 1938:

Persiste desde luego el deseo de mantenerse estrictamente dentro de los límites fijados por el Comité de No Intervención al que se halla adherida Suecia (...). Pero el evidente fracaso de dicha política, la cada vez más clara comprensión de lo que es nuestra lucha y la franca admiración que en las esferas gubernamentales y los medios obreristas y democráticos inspira nuestro tenaz heroísmo a la vez que el ansia de que no triunfen sistemas de gobierno que indefectiblemente habían de conducir a toda Europa al desastre, son causa de que la simpatía por el Gobierno Español y la Causa que defiende nuestro pueblo gane terreno de día en día (...)

Sin la influencia que ejerce la política inglesa en todos estos países es probable que el Gobierno sueco se hubiera visto a veces tentado a abandonar su apoyo a las normas no intervencionistas, pero tentado nada más. El temor a la guerra y el uso admirable que de tal espectro hace Gran Bretaña no le hubieran permitido ir más allá de su deseo o convertir a este en acción ${ }^{113}$.

El análisis de Isabel de Palencia, que consideramos correcto, no hace sino confirmar las palabras del Embajador americano Claude Bowers citadas por Enrique Moradiellos: "Me da la impresión de que hace meses se tomó la decisión de sacrificar la democracia en España en beneficio de la paz de Europa" ${ }^{114}$.

\subsection{La actualidad política sueca según la diplomacia española}

Podría pensarse que las cuestiones relacionadas con la guerra civil monopolizaban el tiempo y los recursos de la Legación de España en Estocolmo y, mutatis mutandis, de la representación de la España de Franco en la capital de Suecia. Sorprende, sin embargo, que esto no fuera así, y que aun en tiempo de guerra funcionaran los procedimientos ordinarios que regulaban la actividad de las representaciones diplomáticas. Aunque, lógicamente, los asuntos relacionados con el esfuerzo bélico tuvieron prioridad, siguieron éstas informando acerca de la actualidad política tanto en el aspecto de la política interna como de la política exterior.

\footnotetext{
${ }^{112}$ AMAEC R 642, 2 e, despacho n. 124 de 21.V.1937, que informa acerca del discurso de Sandler.

${ }^{113}$ AMAEC R, 1785/13, despacho n. 190 de 27.VII.1938.

${ }^{114}$ MORADIELLOS, Enrique, El reñidero de Europa..., p. 164.
} 


\subsubsection{La política interior sueca de 1936 a 1939}

Aunque la política exterior sueca suscitó mayor interés en los diplomáticos españoles estacionados en Suecia, los principales avatares de la actualidad interna sueca fueron también objeto de despachos y análisis al Ministerio de Estado.

Entre julio y diciembre de 1936 no contó la República con representante en Estocolmo, ya que Fiscowich no se mantuvo leal al gobierno. Hasta la llegada de Isabel de Palencia siguió éste ocupando el edificio de la Legación de España e informando sobre la realidad sueca a sus superiores, ahora de la Secretaría franquista.

Durante el verano de 1936, la situación política de Suecia era de total interinidad, tras la dimisión por razones tácticas del gobierno socialdemócrata-agrario de Per Albin Hansson. Existía un gobierno en funciones, dirigido por el líder del partido agrario Axel Pehrsson-Bramstorp, y compuesto por 12 miembros, seis de los cuáles eran funcionarios sin afiliación política.

El gobierno de Pehrsson-Bramstorp no tomó iniciativa legislativa alguna, y respecto a España mantuvo una actitud inicial expectante, que, al parecer, evolucionó en septiembre hacia unas mayores simpatías por la España franquista. Su misión era ejercer las funciones de gobierno hasta el nombramiento del que saliera elegido en las elecciones parlamentarias del 20 de septiembre, que dieron una amplia mayoría al partido socialdemócrata.

Por no haber por aquel entonces en Estocolmo diplomáticos leales a la República, no existen más informes españoles de las mismas que el enviado por Fiscowich al gobierno franquista, que en su momento comentaremos.

El primer despacho que se ocupó expresamente de cuestiones de política interior sueca tras el restablecimiento del funcionamiento normal de la representación diplomática de la República en Estocolmo, fue un detallado informe sobre la política monetaria de Suecia, firmado por Aurelio Romeo del Valle como Encargado de Negocios ad interim, por ausencia temporal de Isabel de Palencia. El motivo fue la existencia de rumores acerca de un posible abandono por parte de Suecia del bloque de la libra esterlina - vigente desde julio de 1933 - con una consiguiente revaluación de la corona sueca. El objetivo era controlar la inflación, medida que las organizaciones obreras veían con buenos ojos, al contrario que las empresas exportadoras. La política económica expansionista de Suecia 
desde 1933 había dado buenos resultados, permitiendo un desarrollo de las industrias domésticas ${ }^{115}$.

Otros aspectos de la economía de Suecia comentados por la Legación de España en Estocolmo fueron la circulación fiduciaria en Suecia, la conferencia para la colaboración económica nórdica, un informe sobre el nivel económico sueco y las medidas preventivas del gobierno ante la posibilidad de una crisis económica ${ }^{116}$.

En el informe anual de 1937, enviado por Isabel de Palencia en marzo del año siguiente, se dedican varias hojas a analizar la situación política interior de Suecia.

Resalta el informe la ausencia de problemas sociales, por ser Suecia "el pueblo que ha logrado alcanzar el nivel de vida más elevado de nuestra época", gracias a la prolongada etapa de paz disfrutada, la temprana resolución de los problemas de distribución de la tierra y al "arraigo que en el país tienen las ideas democráticas".

La situación económica seguía siendo muy satisfactoria: las finanzas públicas habían mostrado un superávit de 66,81 millones de coronas, las reservas de divisas del Banco Central, el Riksbank, habían aumentado, y prácticamente todos los indicadores de la economía habían experimentado mejorías. Para Isabel de Palencia, la situación social y económica señalada era la causa de que la situación política del país fuera "de una envidiable estabilidad".

El gobierno socialdemócrata-agrario contaba con amplia mayoría parlamentaria (89 de los 150 senadores y 151 de los 230 diputados). La política interior llevaba "un ritmo ordenado y pacífico sin que no obstante se limiten ni mucho menos las posibilidades de avance social", como lo probaba el número e importancia de las reformas legislativas del año: la Ley de Extranjeros (facilitando el derecho de asilo y los derechos de los refugiados), la Ley de Asistencia a la Maternidad, Ley de Asistencia a la Infancia (con subsidios a las familias numerosas), la Ley de Seguros de Enfermedad, Ley de subsidios estatales para viviendas, la "Ley de ayuda a familias necesitadas que necesitan cuidar animales domésticos", etc. ${ }^{117}$.

En el informe semestral siguiente, último de este tipo elaborado por Isabel de Palencia, se insistía en las mismas ideas. La paz social de Suecia, sin parangón en el mundo, se debía, según la Ministro de España, a la prosperidad económica, la escasa

\footnotetext{
115 AMAEC R 544,7, despacho n. 159 de 22.VI.1937.

${ }^{116}$ AMAEC R 642, 3, e, despachos n. 300 de 13.X.1938, n. 280 de 4.X.1938, n. 90 de 26.IV.1938 y n. 45 de 25.II.1938

${ }^{117}$ AMAEC R 642, 2, despacho n. 57 de 8.III.1938.
} 
población y "la sabia política de reorganización económica" del gobierno socialdemócrataagrario.

De hecho, en el primer semestre de 1938 sólo había habido dos conflictos laborales, el lockout de la asociación de hoteleros y el de las empresas tipográficas, ambos solucionados por acuerdo entre las partes. La situación económica había empeorado algo respecto a 1937, con un descenso del nivel de precios y de las reservas de divisas, pero tanto la importación como la exportación apenas se habían visto afectadas y el intercambio comercial de Suecia con el extranjero había seguido en expansión.

La situación política, por su parte, seguía siendo de "absoluta estabilidad", sin cambio alguno en la composición del Parlamento o del gobierno ${ }^{118}$, aunque había un cierto movimiento en torno a las elecciones municipales, y pequeñas críticas al gobierno dentro de la socialdemocracia, por su actitud demasiado temerosa de las grandes potencias.

La actividad de reformas legislativas había seguido su curso, con leyes reguladoras de la enseñanza, de protección del trabajo realizado por ciegos, prórrogas de varias leyes y decretos anteriores (sobre prohibición de uniformes políticos, prohibición de reclutamiento en la guerra de España, apoyos estatales a la exportación, etc.), leyes de mejora de las condiciones y seguros sociales de los presos, de los obreros y de los parados (en especial la Ley de vacaciones pagadas, estableciendo un mínimo de un día libre por mes trabajado), la Ley de créditos de vivienda a familias numerosas y la Ley de Aborto en determinados $\operatorname{casos}^{119}$.

Otros informes puntuales trataron de las relaciones entre los partidos suecos de extrema derecha y la pérdida de terreno del nazismo en Suecia, la proclamación del 1 de mayo como fiesta civil, y sobre el Congreso de las Juventudes Socialdemócratas de Suecia $^{120}$

Además, como es lógico, informó la Legación de una reforma de la Constitución sueca: la modificación de la Ley de Sucesión al Trono permitiendo al heredero casarse con un plebeyo con permiso del Rey y consultado el gobierno, y la creación de una nueva Comisión de Asuntos Exteriores de 16 miembros, sustituyendo el sistema anterior ${ }^{121}$.

\footnotetext{
${ }^{118}$ Posteriormente hubo ligeros ajustes, cfr. AMAEC R 642, 1, e, despachos n. n. 247 de 3.IX.1938, n. 282 de 4.X.1938, y n 382 de 14.XII.1938; AMAEC R 1785, 13 e, despacho n. 263 de 19.IX.1938.

119 AMAEC R, 1785/13, despacho n. 190 de 27.VII.1938; AMAEC 642, 1, e, despacho n. 103, de 6.V.1938; AMAEC R 642, 2, despachos diversos;

${ }^{120}$ AMAEC R 642, 1 e, despacho n. 72 de 24.III.1938 y despacho n. 382 de 4.X.1938; AMAEC R 1783, 24 e, despacho n. 191 de 28.VII.1938; AMAEC R 1069, 25 e despacho n. 219 de 20.XI.1937.

${ }^{121}$ AMAEC R 577, 4 despacho n. 53 de 18.II.1937.
} 
De mayor importancia a este respecto tuvo, debido a su tema específico más que al hecho de ser el último de los dedicados a la política interior de Suecia por parte de la Legación de España en Estocolmo, un despacho del 28 de diciembre de 1938, que lleva por título "Acuerdo entre las organizaciones obreras y patronales para la solución de los conflictos de trabajo". Se trata del importante Acuerdo de Saltsjöbaden, hito fundamental y base del desarrollo del llamado Modelo Sueco ${ }^{122}$.

En realidad, se trató de un conjunto de acuerdos adoptados en 1937-38 en la localidad de Saltsjöbaden, cercana a Estocolmo, entre la central de las organizaciones patronales (SAF) y la Unión de Sindicatos (LO). El acuerdo principal, fue firmado el 20 de diciembre de 1938, fijando las reglas del juego del mercado laboral sueco.

El acuerdo ponía fin a las negociaciones iniciadas en mayo de 1936 para encontrar un medio de limitar los conflictos laborales por medio de acuerdos directos previos, libremente negociados, entre trabajadores y empresarios. Isabel de Palencia hizo un buen resumen del contenido y alcance del mismo:

El arreglo prevé la creación de un llamado "Comité del Mercado de Trabajo", en el cual estarán representadas por tres miembros cada una las organizaciones obreras y patronales. Corresponderá a este comité la tarea de decidir en última instancia los conflictos de interpretación a que dé lugar la aplicación del nuevo acuerdo general. (...)

Los puntos principales del nuevo arreglo para el tratamiento de los conflictos son: la negociación en dos instancias antes de plantear una huelga o lock-out, la necesidad de que una huelga o un lock-out en una determinada empresa sean autorizados por el sindicato obrero o asociación patronal correspondiente, y la obligación para los patronos de comunicar con anticipación a los sindicatos los despidos individuales o reducciones de personal que se propongan practicar. Finalmente, el acuerdo presta atención especial a las consecuencias de los conflictos sociales, tanto en lo que se refiere a las represalias por participación activa en huelgas como a los perjuicios que huelgas y lock-outs puedan irrogar a terceros no directamente interesados, siempre con el propósito de eliminar las represalias y reducir los perjuicios de que se trate.

\footnotetext{
${ }^{122}$ Sobre los Acuerdos de Saltsjöbaden y el Modelo Rehn-Meidner como estrategia de política laboral propia del Modelo sueco, cfr. ROSAL CRESPO, Mario del "Los límites del socialismo reformista: el caso de Suecia. Una aproximación crítica al Modelo Rehn-Meidner desde una perspectiva histórica (1932-1983)", trabajo de Investigación bajo la dirección de Xabier Arrizabalo, Madrid: UCM, 2007; LANE, Jan-Erik (ed), Understanding the Swedish Model, Londres, Frank Cass, 1991; GUSTAFSSON, Bo, "Foundations of the Swedish Model" en The Nordic Journal of Political Economy (NOPEC), $\mathrm{n}^{\circ}$ 22, 1995, pp. 5-26. La bibliografía en sueco sobre los Acuerdos de Saltsjöbaden es lógicamente muy amplia y no procede detallarla aquí. Mencionaremos tan sólo algunos títulos básicos: CASPARSSON, Ragnar, Saltsjöbadsavtalet i historisk belysning, Estocolmo: Tiden, 1966; EDLUND, Sten E. (ed.), Saltsjöbadsavtalet 50 år: forskare och parter begrundar en epok 1938-1988, Estocolmo: Arbetslivscentrum, 1989; y el reciente estudio de LUNDH, Christer (red.), Nya perspektiv på Saltsjöbadsavtalet, Estocolmo: SNS förlag, 2009.
} 
Concluía la Ministra resaltando la buena acogida del acuerdo por la prensa socialdemócrata y burguesa, y el descontento de "los órganos comunistas y socialistas revolucionarios" $" 123$.

En suma, aunque no lo dijera expresamente, del conjunto de las informaciones enviadas por Isabel de Palencia acerca del desarrollo del sistema político, económico y social de Suecia, no cabe duda de que consideraba al país escandinavo como un modelo a seguir, especialmente en lo referente a la legislación social y laboral.

\subsubsection{La política exterior sueca de 1936 a 1939}

La política exterior de Suecia fue objeto de mayor atención por parte de la Legación de España en Estocolmo. No podía ser de otra manera, en una Europa convulsionada por las tensiones causadas por los regímenes totalitarios y la política apaciguadora llevada a cabo por las democracias.

La actividad del Ministro sueco de Asuntos Exteriores, Rickard Sandler, fue durante este período muy intensa, con abundantes reuniones de trabajo con sus colegas de los demás países nórdicos y viajes a Ginebra, Bruselas, París, Londres, Kaunas, Riga, Tallinn, Helsinki, Berlín y Moscú. La política sueca de neutralidad estuvo presidida por un objetivo fundamental: evitar que el país se viera envuelto en una guerra.

El fortalecimiento de los lazos que unían en política exterior a Suecia con los demás países firmantes del Convenio de Oslo estuvo en primer plano. El 3 de marzo de 1937 tuvo lugar una reunión de los mismos en La Haya, de carácter comercial, pero ante la cual Sandler había declarado que se trataba de favorecer la acción común de las pequeñas democracias europeas en los foros internacionales. Era, en definitiva, un intento de reforzar la política ya iniciada a mediados de década, con la participación entonces también de España, tal como expusimos en un capítulo anterior.

En el verano de 1938 volvieron a reunirse los representantes de los países del Grupo de Oslo en Copenhague, para dar consistencia a la neutralidad nórdica. Según la Legación de España, parte del movimiento obrero sueco se oponía a esta política pero "en forma débil y esporádica"124.

\footnotetext{
${ }^{123}$ AMAEC R, 642, 1, despacho n. 402 de 28.XII.1938.

${ }^{124}$ AMAEC R 577, 4, despacho n. 60 de 3.III.1937; AMAEC R 642, 2, e, despachos n 129 de 30.V.1937, despacho n. 177 de 16.VII.1938 y n. 189 de 27.VII.1938. El Ministro de Asuntos Exteriores finlandés visitó Estocolmo a continuación de la reunión de Copenhague, cfr. AMAEC R 1783, 24 e, despacho n. 193 de 30.VII.1938.
} 
Los viajes del Ministro Sandler a varias capitales europeas ${ }^{125}$ fueron comentados por la Legación en el sentido expuesto, de ser intentos de fortalecimiento de las relaciones con los países cercanos y de intereses afines, a través de relaciones comerciales y discusiones políticas.

En relación con el viaje a Londres especulaba la Legación sobre la posibilidad de que se hubiesen tratado de la necesidad de un sistema de seguridad colectiva.

El estrechamiento de la cooperación nórdica, y especialmente de las relaciones con Finlandia, dio un paso adelante con la reunión de cuatro ministros nórdicos de Asuntos Exteriores en Helsinki en abril de 1937, donde además se discutieron cuestiones relacionadas con la defensa, con la idea de favorecer la política de desarme. También se gestó allí una protesta común nórdica ante las autoridades de Burgos por los apresamientos de barcos mercantes nórdicos.

El viaje a Berlín fue, en palabras de Sandler, "un alto en el camino a Ginebra", pero Isabel de Palencia entendía que su objeto era más bien apaciguar a la opinión pública derechista de Suecia, molesta por el proyectado viaje a Moscú. El viaje no tuvo el efecto deseado, pues Sandler fue muy criticado por la prensa alemana, que le acusó de estar formando, en unión con Inglaterra, un bloque nórdico antialemán. Por su parte, el viaje a las capitales bálticas podía "tener gran influencia en la afirmación de las tendencias democráticas”, en opinión de la Ministra de España.

Acompañado de la Ministra rusa en Estocolmo, Alexandra Kollontai, visitó Sandler la Unión Soviética en julio de 1937. Sobre ese viaje escribió Isabel de Palencia que Suecia se iba alejando cada vez más de la influencia alemana y aproximándose políticamente a Inglaterra, pero quería mantener buenas relaciones con un país tan potente como era la URSS. El Ministro Sandler inauguró la línea aérea Estocolmo-Moscú, facilitando el correo entre Londres y Moscú.

En su resumen anual de 1937, dedicaba Isabel de Palencia varias páginas a analizar la política exterior de Suecia. Consideraba la Ministra que Suecia era "el espíritu animador" de la política de reforzamiento de los lazos de unión de los países pequeños del norte de Europa, entendiendo que se estaba gestando la formación de un grupo defensivo contra

\footnotetext{
${ }^{125}$ AMAEC R 577, 4, despacho n.71 de 29.III.1937, n. 103 de 27.IV.1937, n. 134 de 29.V.1937 y n. 174 de 10.VII.1937. Cfr. también AMAEC R 642, 2 e, despacho n. 136 de 3.VI.1938 sobre la visita a Estocolmo del Ministro polaco de Asuntos Exteriores.
} 
posibles intervenciones bélicas. Las relaciones con Finlandia, por la cuestión de la militarización del archipiélago de las islas Åland, eran especialmente importantes ${ }^{126}$.

Por otra parte, Suecia no cesaba de proclamar su intención de atenerse a una estricta neutralidad ante cualquier conflicto internacional. En esta política, contaba el gobierno sueco con la adhesión prácticamente unánime de la prensa del país, con la sola excepción de la comunista, y de los partidos políticos principales y la opinión pública, "fuertemente unida en cuanto al mantenimiento de la neutralidad".

Era precisamente este "sentimiento general adverso a todo lo que pueda implicar un riesgo para la paz" la razón última de la actitud sueca en la política internacional. El largo período de paz que había vivido Suecia (150 años) y el bienestar económico eran un freno frente a cualquier tentación de desviarse de la política de neutralidad. Asimismo comentaba la Ministra de España - existía un gran temor a los conflictos, a la vez que había un convencimiento general de que la guerra no podría evitarse a largo plazo, y por eso se admitían los aumentos en los gastos de defensa.

Respecto a otros países, Suecia seguía cultivando sus tradicionales relaciones cordiales con Francia y había aumentado sus relaciones con Argentina y Méjico. En Europa defendía con fuerza la democracia y el pacifismo, y respecto a la URSS, quizá motivada - según el análisis de Isabel de Palencia - por sentirse Suecia defraudada ante la debilidad mostrada por Inglaterra, "que fue siempre considerada por Suecia como su guía y como defensora de los pueblos pequeños", había modificado su tradicional política contraria a Rusia. No obstante, la situación de Suecia era difícil pues sus aceros eran codiciados por las grandes potencias, especialmente Alemania, a la que Suecia temía pero a la que estaba unida por intereses económicos

ya que dicho país adquiere enormes cantidades de hierro sueco dándose el extraño caso de que mientras diariamente salen trenes cargados de mineral para Alemania, Suecia intensifica sus preparativos de defensa contra un posible ataque por parte de su comprador, realizado con el producto de sus propias minas ${ }^{127}$.

Respecto a la Sociedad de Naciones, permanecía Suecia fiel a su actitud de apoyo leal, aunque éste se había hecho menos ferviente por el desencanto sueco ante las

\footnotetext{
${ }^{126}$ Sobre la fortificación de las islas Åland cfr. AMAEC R 642, 2, despacho n. 37 de 15.II.1937 y AMAEC R, 1785, 13, despacho n. 256 de 15.IX.1938.

${ }^{127}$ AMAEC R 642, 2, despacho n. 57 de 8.III.1938. Sobre el debate parlamentario en relación con los gastos de defensa, cfr. AMAEC R 642, 1, despacho de 9.III.1938.
} 
indecisiones del organismo internacional. Suecia tenía la impresión de que las grandes potencias manipulaban a la Sociedad para favorecer sus propios intereses.

A medida que pasaban los meses, el descontento sueco con la Sociedad, y el miedo a que el fiel cumplimiento de sus obligaciones respecto a la aplicación de sanciones derivadas del Pacto la llevaran a un enfrentamiento con alguna de las grandes potencias, motivaron un cambio en la política sueca: el intento de encontrar un medio de quedar eximida de esas obligaciones, empeño para el que buscó y logró la colaboración de los países del grupo de Oslo, Holanda, Bélgica, Luxemburgo y los demás nórdicos.

En esta política contaba el gobierno sueco con el apoyo prácticamente total de los partidos políticos y de la opinión pública: los empresarios sólo se dejaban llevar por consideraciones económicas y comerciales, mientras que "la clase media, el pequeño burgués e incluso el campesino se interesa poco por estas cuestiones (...) y su única preocupación es que no haya guerra. Puede el gobierno tomar todas las medidas que crea conveniente, llevar a cabo alianzas con quien le parezca con tal de que el espectro de la guerra se mantenga a la necesaria distancia”.

Por otra parte, presionada por peticiones de asilo por parte de judíos austriacos, temerosa de que su riqueza minera fuera causa de una agresión bélica, y a la vez deseosa de mantener a un tiempo buenas relaciones con todos y una estricta neutralidad, se encontraba Suecia en una situación precaria, que le hacía sentir la necesidad de incrementar su propio presupuesto de defensa, sobre todo aérea.

Para todo ello, era fundamental para Suecia el cultivo de buenas relaciones con las grandes potencias, Alemania, Inglaterra, Rusia y Estados Unidos. En relación con ésta última opinaba Palencia que el viaje del Príncipe Heredero sueco a América para celebrar el tercer centenario de la llegada de la primera colonia sueca al territorio americano había servido para intensificar vínculos ${ }^{128}$.

Las relaciones de Suecia con Alemania eran especialmente complicadas, y las quejas de las autoridades nazis con motivo de las críticas de la prensa sueca eran frecuentes. Especialmente críticas fueron las reacciones de la opinión sueca ante los incidentes en Alemania de febrero de 1938 - que dieron a Hitler el control de la Wehrmacht - y la entrevista de éste con el canciller austríaco Kurt von Schuschnigg. Aún más, si cabe, lo fueron tras la tristemente célebre Noche de los Cristales Rotos del 9 al 10 de noviembre de

\footnotetext{
${ }^{128}$ AMAEC R 1785, 13, despacho n. 190 de 27.VII.1938. Sobre la preparación militar sueca en relación con la crisis europea, cfr. AMAEC R 642, 2, e, despacho n. 276 de 30.IX.1938. Con Inglaterra se llegó a un acuerdo naval, cfr. AMAEC R 642, 2, e, despacho n. 5 de 4.I.1939.
} 
1938, y el gobierno sueco se vio forzado a exigir de la prensa que practicara la autocensura para no exponer a Suecia a represalias alemanas, especialmente cuando el acuerdo de clearing comercial entre ambos países estaba a punto de firmarse ${ }^{129}$.

De forma velada, pero eficaz, se había preocupado Alemania por mostrar su fuerza ante Suecia: el Ministro del Interior alemán visitó Suecia en 1937 y tanto la Luftwaffe como la marina de guerra alemana hicieron acto de presencia en territorio sueco. La prensa sueca no dijo nada, pero en círculos políticos se comentó el asunto, según Isabel de Palencia ${ }^{130}$

La retirada de Suecia del Comité de No Intervención y los claros discursos del Ministro de Negocios Extranjeros sueco, criticando a las grandes potencias por considerar a los pequeños Estados como figuras de ajedrez han de entenderse a la luz de esta difícil e insegura relación de Suecia con la Alemania de Hitler en 1938.

En un informe conservado en el archivo de Luis Jiménez de Asúa en la Fundación Pablo Iglesias se describe la posición de Alemania con respecto a Suecia en términos inequívocos:

Sandler en su discurso se declaró asimismo contra las desvergonzadas pretensiones de Alemania con respecto a Suecia, interpuestas en los últimos tiempos. El Representante alemán ha dado a entender a Suecia que en caso de una guerra, con la cual se puede contar, y en la que Inglaterra tomara parte contra Alemania, Suecia habría de ser utilizada como punto de "apoyo" para los submarinos alemanes, marina de guerra, etc. a fin de romper el bloqueo; y también como estación de aprovisionamiento de carbón, petróleo, etc. Se pretende obtener seguridades de que Suecia entregará sus metales a Alemania. El discurso de Sandler puede considerársele como una llamada de auxilio ${ }^{131}$.

A la vista de los acontecimientos posteriores, queda patente la clara visión que tuvieron los responsables de la política exterior de Suecia, en la preguerra, sobre los peligros a que se exponía el país por parte de su poderoso vecino al sur del Báltico. Suecia consiguió evitar la guerra, pero fue al precio de hacer grandes concesiones a Alemania, viéndose forzada a no interrumpir sus exportaciones de mineral de hierro a ese país y

129 AMAEC R 642, 2, e, despacho n. 46 de 26.II.1938; AMAEC R 1785, 13 e, informe sobre Circular del gobierno sueco de 1.X.1938. Sobre el acuerdo sueco-alemán de clearing, cfr. AMAEC R 642, 3, e, despacho n. 374 de $9 . X I I .1938$

${ }^{130}$ AMAEC R 642, 2, e, despacho n. 240 de 6.XII.1937; AMAEC R 634, 30, desp. n. 154 de 23.VI.1938 y despacho n. 198 de 31.VII.1938

131 FPI-ALJA-449-10, informe n 973 de 1.XII.1938, "Posición de Alemania con respecto a Dinamarca y Suecia". Sobre los discursos de Sandler acerca de la neutralidad sueca, la actitud a seguir en la Sociedad de Naciones, y la política inglesa y la crisis europea, cfr. AMAEC R 1785, 13 e, anexos a despachos de 29.VIII.1938, 11.XI.1938 y 22.XII.1938. 
teniendo que permitir el paso de tropas alemanas por territorio sueco: viajes de permiso a Alemania de soldados estacionados en Noruega y, sobre todo, el paso de la División acorazada Engelbrecht de Noruega a Finlandia en junio de 1941.

Queda también patente la agudeza de análisis de los diplomáticos españoles acreditados ante el gobierno de Suecia sobre las prioridades que el país escandinavo tenía en política exterior, y su clarividencia respecto a las consecuencias que de ahí se derivaban, tanto en relación con la guerra de España como con la gran conflagración mundial que se estaba fraguando: Neutralidad a ultranza y pragmatismo feroz, acercamiento y apoyo a la política inglesa en tanto en cuanto ésta no pusiera en entredicho el único objetivo fundamental de la política exterior de Suecia, a saber: el de evitar a cualquier precio y por cualquier medio que el pueblo sueco sufriera los horrores de la guerra. 



\title{
Capítulo 7
}

\section{SUECIA Y LA ESPAÑA DE FRANCO DE 1936 A 1939}

\begin{abstract}
Ministro de Negocios extranjeros me dice que aprecia altamente iniciativa S.E. el Jefe del Estado que este gobierno está dispuesto a secundar por todos sus medios. Ha añadido celebra ver a España entre países que desean contribuir terminación actual catastrofe y día de mañana quizás puedan lograrlo ${ }^{1}$
\end{abstract}

\subsection{La diplomacia sueca respecto a la España de Franco hasta el intercambio de agentes}

En cierta medida, la actitud de Suecia ante la España franquista durante la guerra civil española ha sido ya puesta de manifiesto en estas páginas, al tratar en el capítulo anterior de la postura sueca en el Comité de No Intervención de Londres y de las relaciones del país escandinavo con la República Española. Además, la intervención humanitaria y militar sueca en la guerra, por lo que se refiere a ambas zonas de España, será objeto de análisis en el capítulo siguiente.

Nos corresponde ahora analizar de manera más específica cómo se desarrollaron las relaciones diplomáticas entre Suecia y la parte de España no controlada por el Gobierno de la República, desde julio de 1936 hasta el final de la década que nos ocupa. Para ello, expondremos en primer lugar los contactos oficiales y oficiosos suecos con las autoridades franquistas hasta el intercambio de agentes a finales de 1938; en un segundo momento, la actividad del agente sueco en la España nacional y las gestiones conducentes al reconocimiento oficial del 31 de marzo de 1939; en tercer lugar, comentaremos la actividad política, diplomática y propagandística de la representación de la España franquista en Suecia y cómo fue vista la actualidad sueca por los diplomáticos franquistas, para pasar finalmente a tratar de las relaciones entre Suecia y España durante el resto del año 1939.

Por razones prácticas, como ya mencionábamos en los capítulos introductorios, utilizamos en este estudio la expresión "España de Franco" o "España franquista" para

\footnotetext{
${ }^{1}$ José de Landecho y Allendesalazar, Ministro Plenipotenciario de España en Suecia, telegrama n. 43 de 4.IX.1939, sobre respuesta sueca a la propuesta española de hacer un llamamiento común por la paz en Europa, en AGA, Asuntos Exteriores, Caja n. 523, carpeta 11.
} 
referirnos a la autodenominada España Nacional o Estado Español, aunque técnicamente no sea correcto para el período entre el 18 de julio y el nombramiento de Franco como “jefe del gobierno del Estado español”, el 1 de octubre de 1936.

\subsubsection{La labor de información de la diplomacia sueca acerca de la España de Franco}

Durante los primeros días después del 18 de julio, como expusimos en el capítulo anterior, los diplomáticos suecos en España sólo pudieron informar de la confusa situación a partir de lo que pudieron colegir en los ambientes diplomáticos de Lisboa y San Sebastián, donde estaban Karl Ivan Danielsson y Erik Wisén. De la situación en el resto de España, incluido Madrid, las únicas informaciones disponibles fueron en esos primeros momentos las enviadas por los cónsules de Suecia, titulares algunos, honorarios la mayoría.

Con fecha 30 de julio de 1936, la Junta de Burgos notificó al Ministerio de Negocios Extranjeros de Estocolmo que habían tomado el poder².

Por esas mismas fechas informaba el cónsul de Dinamarca y Suecia en Cádiz que el orden se había restablecido en Cádiz y Sevilla. Sobre la situación en sus respectivas ciudades llegaron también informes de otros cónsules, y en algunos casos de empresarios suecos en fuga, como el relato de atrocidades en Barcelona que el ingeniero William Svensson hizo en la prensa sueca. En Madrid fue el vicecónsul y empresario sueco Axel Olsén quien se encargó de informar sobre el desarrollo de los acontecimientos.

En bastantes casos, las informaciones eran favorables a los militares: en Las Palmas, el cónsul honorario británico-sueco, presentó la rebelión militar como el triunfo de los españoles partidarios del orden frente al desorden de corte comunista, mientras que el vicecónsul en Vigo, también compartido con Gran Bretaña, describía en agosto la guerra con la palabra "cruzada" y exoneraba a los rebeldes de las acusaciones de crueldad: "Aunque es verdad que los líderes del movimiento bolchevique, una vez detenidos, han sido sentenciados en consejos de guerra, tengo certeza de que no se pueden atribuir al gobierno militar actos de crueldad arbitraria”. Según el vicecónsul, las autoridades franquistas deseaban "un reconocimiento no oficial" (unofficial recognition), añadiendo que la mayoría de los jóvenes españoles "están de parte de los generales”3.

\footnotetext{
${ }^{2}$ RA, UD, 1920-års dossierssystem, HP 36, Vol. 1504, telegram från Cabanellas om att de tagit makten, (telegrama de Cabanellas comunicando que han tomado el poder), Burgos 30.VII.1936

${ }^{3}$ RA, UD, 1920-års dossierssystem, HP 36 A, Vol. 1504, informes varios.
} 
Poco tiempo después, tras el establecimiento del gobierno de Largo Caballero, el Secretario de la Legación, Erik Wisén, desaconsejaba el regreso de los diplomáticos suecos a Madrid diciendo que "sería en estos momentos poco prudente desde el punto de vista político, dado el carácter comunista y socialista-radical del gobierno de Madrid y que la suerte de la guerra parece inclinarse cada vez más del lado de los rebeldes"4.

A partir de septiembre de 1936, y muy especialmente tras el traslado del gobierno de la República a Valencia - que conllevó también el de la Legación sueca, ahora con Wisén como Encargado de Negocios - y hasta el nombramiento de un agente sueco ante las autoridades de Burgos, en el otoño de 1938, el seguimiento por parte sueca de los asuntos relacionados con la España franquista se llevaría a cabo también por otras vías, aunque, como es lógico, la Legación de Suecia ante la España republicana enviaba las noticias que recibía. Las principales vías alternativas de información fueron las siguientes:

1. La Legación de Suecia en Portugal, a cuyo frente estuvo Carl Ivan Danielsson (hasta 1937) y Lennart Rappe (1937-38). Carl Ivan Danielsson recibió también el encargo de "trabajar en el Ministerio de Negocios Extranjeros en asuntos referidos a España" del 3 de octubre de 1936 al 31 de marzo de $1937^{5}$.

2. Las Legaciones de Suecia en otros países europeos, en especial la Legación en Berlín y la Legación en Roma. Con frecuencia, las noticias sobre la España franquista provenían de las conversaciones de los diplomáticos suecos con sus colegas, o con miembros de los gobiernos alemán e italiano.

3. Los cónsules y vicecónsules de Suecia radicados en el territorio controlado por la España de Franco. En especial, el Cónsul General Luis de la Peña, que durante la guerra fijó su domicilio en casa de unos parientes en Valladolid, actuó desde allí como agente oficioso de Suecia ante las autoridades franquistas. Sin embargo, como veremos, esta fuente de información no parece haber sido especialmente utilizada ni valorada a partir de enero de $1937^{6}$.

4. Los empresarios suecos con intereses en la España franquista. Algunos, como Åkerman y Olsén, eran también vicecónsules de Suecia, o lo habían sido.

\footnotetext{
${ }^{4}$ RA, UD, 1920-års dossierssystem, HP 36 A, Vol. 1504, carta de Wisén a Beck-Friis, 9.IX.1936.

${ }^{5}$ RA, UD:s kalender 1961, Register över Sveriges beskicningschefer hos främmande makter från 1720 till ca 1960 (Calendario del Ministerio de Negocios Extranjeros de 1961, registro de los Jefes de las representaciones diplomáticas suecas ante potencias extranjeras de 1720 a 1969), pp. 243-275; RA, UD: P1: 167, expediente personal de Carl Ivan Danielsson.

${ }^{6}$ RA UD, 1920-års dossierssytem, HP 36 A, vol. 1508, despacho n. 141 de 30.VIII.1938; RA, UD, Beskickningsarkivet: Madrid, F1 C Vol. 44; Ibidem, F1 C Vol 45, carta de Luis de la Peña al Ministro sueco Rickard Sandler. Cfr. también Archivo Municipal de Valladolid, R 98, hoja 941.
} 
En octubre, escribió Erik Wisén que el general Franco había recibido “poderes absolutos, típicos de una dictadura militar", sugería el traslado de la Legación a Lisboa y animaba a considerar "la postura que Suecia quería adoptar frente a los nacionalistas"7.

Ya para entonces habían llegado a conocimiento sueco las primeras noticias directas acerca de las durísimas represalias franquistas en algunos lugares, especialmente en el País Vasco - donde los cónsules suecos hablaron de "duro ajuste de cuentas" - y también en Canarias, donde según el cónsul sueco en Santa Cruz de Tenerife, el inglés Bellamy, "muchas personas han sido fusiladas (no sé cuántas, porque no se publica su número) y bastante gente ha sido deportada a Río de Oro e Ifni”. Al mismo tiempo llegaban también al Ministerio en Estocolmo noticias de la situación en Madrid, a través de un empresario sueco $^{8}$.

En noviembre parecía cercano el final de la guerra si las tropas franquistas tomaban la capital de España ¿Qué pensaba acerca de todo esto el gobierno sueco? El único dato que hemos encontrado sobre la cuestión está recogido en una anotación a lápiz, sin firma, en el archivo del Ministerio de Negocios Extranjeros: "Información transmitida al jefe del gobierno, que ha remitido a la decisión del gobierno anterior y se ha negado a dar opinión alguna acerca de si hay motivos o no para cambiar nuestra postura"9.

Siempre cauto, Per Albin Hansson prefería no pronunciarse ni comprometerse a nada, sino esperar a ver el resultado de los acontecimientos. Coincidía en esto con las grandes democracias europeas, sobre cuya postura ante el gobierno franquista escribió por entonces la Legación de Suecia que, incluso aunque cayera Madrid, se mostraban indecisas debido a sus intereses comerciales en la España republicana, particularmente en Barcelona ${ }^{10}$.

Tras el reconocimiento del régimen de Franco por los gobiernos alemán e italiano, las autoridades del nuevo Estado enviaron dos escritos a las autoridades suecas. Uno de ellos iba en papel membretado de la Legación de España en Suecia e informaba sobre las cuestiones referentes a correos y telégrafos con la zona franquista. El otro fue enviado directamente desde la Secretaría de Relaciones Exteriores de la España de Franco al Ministerio sueco de Negocios Extranjeros para denunciar la presunta exportación ilegítima de objetos de arte españoles. Ninguno de ellos fue registrado formalmente en el Archivo

\footnotetext{
${ }^{7}$ RA, UD, 1920-års dossierssystem, HP 36 A, Vol. 1504, despacho n. 420 de 14.X.1936 y 425 de 21.X.1936. ${ }^{8}$ RA, UD, 1920-års dossierssystem, HP 36 A, Vol. 1504, despacho n.426 y 434 de 22.X.1936; RA, UD, 1920-års dossierssystem, HP 36 A, Vol. 1505, carta de W. Kempe al Ministerio sueco de Negocios Extranjeros.

${ }^{9}$ RA, UD, 1920-års dossierssystem, HP 36 A, Vol. 1505, anotación a lápiz en el informe al presidente del gobierno sueco.

${ }^{10}$ RA, UD, 1920-års dossierssystem, HP 36 A, Vol. 1505, despacho n. 453 de 22.XI.1936.
} 
del Ministerio sueco, pero consta, por anotaciones a lápiz, que el segundo causó una cierta preocupación. Otras informaciones, relativas al bloqueo de puertos republicanos en Cataluña y otros lugares por parte de la flota franquista, fueron recibidas a través de Erik Wisén ${ }^{11}$.

A partir de 1937 la recepción por parte de las autoridades suecas de documentos o comunicaciones de la España franquista fue haciéndose más habitual. En febrero pidió permiso de residencia en Suecia un español con pasaporte expedido por la España franquista, el 28 de junio llegó la petición oficial de Franco de ver reconocidos los derechos de beligerancia; en julio se recibe información del consulado sueco en Canarias sobre las normas vigentes para visitas de extranjeros al archipiélago; y de septiembre data un documento con nombres de responsables de diversos departamentos franquistas, entre ellos Sangróniz ${ }^{12}$.

Por su parte, la prensa sueca de tendencia conservadora se hacía eco de las noticias aparecidas en la prensa de la España franquista. El diario Stockholms Tidningen, que según Isabel de Palencia tenía "franca tendencia germánica", tenía incluso un propio corresponsal en la zona controlada por el gobierno de Burgos, Karl Olof Hedström. Además, durante los primeros meses de la guerra estuvo presente en esa zona otro periodista sueco, Kjell Strömberg, que fue entrevistado por la BBC - junto con Barbro Alving "Bang", corresponsal en la zona republicana - en mayo de 1937. En esa entrevista describió con colores vivos su experiencia de la España de Franco ${ }^{13}$.

Las Legaciones de Suecia en otros países también enviaron información referente a la España franquista. Como casi siempre se trataba de datos recibidos en conversaciones con otros diplomáticos, a menudo de segunda o tercera mano, cuya exactitud dependía de la credibilidad que tuviera la fuente originaria. Tampoco cabe ignorar, por otra parte, que la circulación de rumores en los ámbitos diplomáticos no siempre es sincera por parte de quienes los ponen en circulación. Con todo, y considerando el prestigio de la neutralidad y seriedad de Suecia en asuntos internacionales, este tipo de confidencias no dejan de tener su interés.

\footnotetext{
11 RA, UD, 1920-års dossierssystem, HP 36 A, Vol. 1505 escritos a las autoridades suecas y RA, UD, Beskickningsarkivet: Madrid, F1 C Vol. 41, despachos de la Legación de Suecia en Lisboa n. 457 y 468.

${ }^{12}$ RA, UD, 1920-års dossierssystem, HP 36 A, Vol. 1505 y Vol 1506.

${ }^{13}$ AMAEC R 1785, 13, despacho n. 190 de la Legación de España en Estocolmo, de 27.VII.1938; AMAEC R 4002, 6, despacho n. 17 de la representación franquista en Estocolmo, de 18.IV.1938; KB, SMDB, entrevista de la BBC a los corresponsales de guerra en España, mayo 1937.
} 
Algunas de esas informaciones son anecdóticas, como por ejemplo la enviada por la Legación sueca en Varsovia acerca de los rumores del nombramiento del "perezoso Ministro de España [en Varsovia], Francisco Serrat y Bonastre" como Ministro de Asuntos Exteriores franquista. Otras fueron de mayor interés político, como las enviadas en febrero y marzo de 1938, desde la Legación de Suecia en Roma sobre la presencia de armamento sueco en la guerra civil y desde la Legación en París asegurando que fue la oposición alemana e italiana lo que impidió la toma de Madrid por Franco ${ }^{14}$.

Aparte de las informaciones enviadas por las Legaciones suecas en Berlín y Roma acerca del reconocimiento al gobierno de Franco por parte de los gobiernos alemán e italiano en el otoño de 1936, la de Berlín envió frecuentemente detalles de la ayuda alemana a Franco, al igual que la de París. La Legación en Roma, por su parte, informó de las fricciones entre los dirigentes fascistas italianos y la España de Franco, mencionando además que, según confidencias de diplomáticos británicos, la victoria de Franco era segura y Gran Bretaña no la veía con malos ojos ${ }^{15}$.

La documentación diplomática sueca ratifica así lo ya conocido acerca de la actitud británica frente a Franco, tal como se describe, entre otras fuentes, en los despachos de Pablo de Azcárate, que arrojan mucha luz sobre el particular: Inglaterra no sentía especial temor ante una victoria franquista porque confiaba en que las necesidades económicas y comerciales de Franco tras la guerra pusieran a éste en manos del poderío financiero británico $^{16}$.

No procede concluir este apartado sin resaltar un aspecto importante, que los fondos diplomáticos suecos corroboran por defecto, a saber: la falta de información fidedigna y concreta sobre la política interior de la zona de España bajo la autoridad de Francisco Franco. Sorprende, en efecto, esa carencia de análisis acerca de qué estaba ocurriendo en la España franquista. La explicación obvia es la ausencia de relaciones diplomáticas oficiales, pero no deja de ser sintomático el hecho de que lo que podríamos llamar "infrautilización" de los cónsules honorarios suecos residentes en la España de Franco en cuanto posibles informadores. Es posible que los dirigentes de la política exterior sueca no confiaran

\footnotetext{
${ }^{14}$ RA, UD, 1920-års dossierssystem, HP 36 A, Vol. 1507, despacho de la Legación sueca en Roma de 18.II.1938 y despacho de la Legación sueca en París de 16.III.1938.

${ }^{15}$ RA, UD, 1920-års dossierssystem, HP 36 A, Vol. 1505, despacho de la Legación sueca en Varsovia de 8.X.1936; despacho de la Legación sueca en Berlín de 27.XI.1936, telegrama de 15.XII.1936, y dos despachos confidenciales en la primera semana de enero de 1937; despachos de la Legación sueca en París de 28.XI y 2.XII.1936; despachos de la Legación sueca en Roma de julio de 1937.

${ }^{16}$ VIÑAS, El honor de la república..., Apéndice documental 1: Pablo de Azcárate sobre la actitud británica hacia la República, pp. 5-13.
} 
demasiado en su credibilidad, tras los informes laudatorios de los sublevados recibidos inicialmente de algunos cónsules. Por otra parte, no podía escapar a la perspicacia sueca las limitaciones que se derivaban de la férrea censura vigente en la zona franquista.

\subsubsection{Cuestiones bilaterales y conflictos diplomáticos suecos con la España de Franco}

Analizamos a continuación los contactos diplomáticos entre Suecia y la España franquista derivados de las cuestiones bilaterales de mayor interés así como de las situaciones en que los intereses suecos fueron motivo de conflictos con las autoridades de la incipiente dictadura.

Entre los primeros, cabe destacar los contactos en relación con la evacuación de las personas refugiadas en las dependencias de la Legación de Suecia en Madrid y locales anejos, y otros canjes de personas.

El fondo de la doble cuestión mencionada, el asilo ofrecido por Suecia a refugiados políticos que temían por su vida en Madrid y la labor de mediación sueca en canjes de presos serán objeto de un apartado específico en el capítulo dedicado a la intervención sueca en la guerra de España. Nos limitaremos aquí, por tanto, a describir muy someramente las gestiones que en relación con esos asuntos realizaron los diplomáticos suecos ante las autoridades franquistas.

Dos personajes fueron claves en este aspecto: Carl Ivan Danielsson y Luis de la Peña, el anterior Ministro y el anterior Cónsul General de Suecia en España.

Carl Ivan Danielsson desarrolló, a distancia, una importantísima labor humanitaria a favor de los refugiados políticos y de familiares de españoles que por cualquier motivo tenían una especial vinculación con Suecia. Esta labor fue preludio de otra que le valió compartir con sus subordinados Per Anger y Raoul Wallenberg un monumento situado frente a la Legación sueca en Budapest, en reconocimiento a su heroica labor humanitaria en defensa de la población judía de la capital húngara ${ }^{17}$.

Del interés de Danielsson por los refugiados españoles, y no sólo por los protegidos bajo pabellón sueco, sino también por otros, ha quedado constancia expresa en varias

\footnotetext{
${ }^{17}$ La labor de Danielsson y de Anger en la acción de salvamento de judíos en Budapest - que pasó bastante desapercibida en Suecia durante muchos años, pues fue Raoul Wallenberg el diplomático sueco más conocido en este sentido, en parte debido al trágico fin de éste en las cárceles soviéticas - ha sido puesta de manifiesto por LEVINE, op. cit., pp. 383-391.
} 
fuentes franquistas. La Cruz Roja Nacional escribió a la Secretaria de Relaciones Exteriores de la España de Franco que

Se complace en comunicarle que el antiguo representante de Suecia en Madrid se ocupa con interés de la suerte de nuestros compatriotas refugiados en dicha Legación de Noruega, incluso de los militares, cuya evacuación es mas difícil y que este interés podría contrarrestar la negativa que para esos efectos parece deducirse del nombramiento que acaba de hacer el gobierno de Noruega como Encargado de Negocios de su país en Valencia al Sr. Erling Ness ${ }^{18}$.

Por su parte, Luis de la Peña, que residía por entonces en la zona franquista, se involucró personalmente en las gestiones para conseguir el canje de un grupo de militares refugiados en la Legación sueca en Madrid por militares republicanos prisioneros en la España de Franco. En esas gestiones participaron también activamente el canciller de la Legación de Suecia Gunnar Björck, el Encargado de Negocios Erik Wisén y algunas personas más. Los diplomáticos suecos pidieron al español por escrito que procurara entrar en contacto con las autoridades de la España de Franco para discutir el intercambio de prisioneros, diciéndole que eran conscientes que no sería tarea fácil porque los asilados suecos cuyo canje se trataba conseguir eran "militares, algunos del Estado Mayor y otros oficiales de la Marina". Además, De la Peña debía realizar las gestiones sin "dar la impresión de ser representante oficial de Suecia". También debía colaborar en otras gestiones en cooperación con la Comisión de intercambio de prisioneros dirigida por el Coronel Mosley, en concreto el intercambio del hijo del general Goded, a propuesta del vicecónsul sueco en Baleares, por Odón de Buen del Cos, gestión que se concluyó con éxito ${ }^{19}$.

Los contactos en relación con este último caso no fueron del completo agrado del Cuartel General del Generalísimo, que prohibió al Comandante Militar de Baleares hacer gestiones al respecto, exigiendo que las mismas se hicieran a través de la Cruz Roja ${ }^{20}$.

No fue ese el caso de los refugiados militares de la Legación de Suecia, que hubieron de esperar en los locales de la misma hasta el final de la guerra. Otros países, como

\footnotetext{
${ }^{18}$ AGA, Asuntos Exteriores, Caja 5290, Carpeta. 4, despacho n. 90 de la representación franquista en Oslo de 29.VII.1937.

${ }^{19}$ RA, UD, 1920-års dossierssystem, HP 36,Vol. 1522, correspondencia entre la Legación de Suecia y el Cónsul General De la Peña, cartas de 28.II, 10.III y 22.III.1938. RA, Beskickningsarkivet: Madrid, F1 C Vol. 44, carta "estrictamente confidencial" de Gunnar Björck a Erik Wisén de 31.V.1938; RA, UD, 1920-års dossierssystem, HP 36, Vol. 1508, despacho n. 141 de la Legación de Suecia en España de 30.VIII.1938.

${ }^{20}$ AGMAV C. 2328 , L.54, cp. 84, comunicación del Cuartel General del Generalísimo a Comandancia Militar de Baleares, de 27.XI.1936.
} 
Francia, sí consiguieron de las autoridades republicanas permiso para evacuar a todos sus refugiados, y sorprende que no lo hicieran en el caso de Suecia. Consta que José López Rey había propuesto a José Giral, al llegar éste al Ministerio de Estado, que se denegara el permiso de salida a los militares refugiados en Embajadas y Legaciones de países "de los que se sospechara que, tras la evacuación, romperían relaciones diplomáticas con la República", pero esto no parece aplicable en el caso de Suecia ${ }^{21}$.

¿Cabe acaso pensar que, a pesar de todo, la negativa de las autoridades republicanas se basara en este criterio? Si así fue, cabe preguntarse por qué desconfiaba la República de un país considerado, por la opinión pública y por sus propios representantes diplomático, como amigo y simpatizante de su causa. Esta posibilidad parece, por tanto, harto improbable, aunque es cierto que ya Manuel Azaña, en 1933, había incluido a los representantes diplomáticos suecos, junto a los alemanes, italianos y argentinos, en el grupo de "los más desafectos a la República" 22.

Otro campo que motivó contactos entre las autoridades suecas y las franquistas entre julio de 1936 y octubre de 1938 fue el apresamiento o la detención de barcos mercantes suecos por parte de la Armada franquista. La mayor parte tuvieron lugar en 1937, y motivaron en cada caso una protesta oficial del gobierno sueco ante las autoridades de Franco.

El riesgo de apresamiento por parte de la Armada franquista de barcos extranjeros que trajeran carga procedente de puertos republicanos españoles había sido ya claramente señalado por Erik Wisén en marzo de 1937, que sugirió a su gobierno la conveniencia de enviar el buque de la Marina de guerra sueca Gotland a aguas españolas, pues supondría un poderoso elemento disuasivo ${ }^{23}$.

El 24 de abril el gobierno sueco ordena a su Encargado de Negocios en España que presente protesta formal ante Franco, junto a los Ministros de Noruega y Finlandia, por la captura de los barcos suecos Mauritz, Brita, Lechistan, Hedda y Valencia, que habían sido apresados y conducidos a Ceuta para su inspección. Posteriormente habría de hacerse lo propio por la detención de los barcos Iberia y Valencia (el 28 de abril de 1937), Gallia y Bernicia (el 18 de junio de 1937), Massilia y Andalusia (el 15 de julio de 1937) y de nuevo el Bernicia (el 8 de septiembre de 1937). Las protestas fueron cursadas al representante

\footnotetext{
${ }^{21}$ AMAEC R, 672, 1, inforne de José López-Rey a Giral de 5.VI.1937, continuacion de otro de fecha 24.V.1937. Cfr. también MORAL RONCAL, Diplomacia, humanitarismo..., p. 48.

${ }^{22}$ AZAÑA, Diarios..., anotación del 30.IV.1933, p. 783.

${ }^{23}$ RA, UD, Beskickningsarkivet: Madrid, F1 C, Vol. 41, despacho n. 33 de 3.III.1937 y telegramas cifrados n. 11 y 37 de 4. III. 1937 y 5.V.1937, respectivamente.
} 
diplomático de Franco en Lisboa, Nicolás Franco, que contestó contemporizando. Además, en diciembre de 1938, se presentó una lista de agravios por los que la naviera Svenska Lloyds exigía compensación de las autoridades franquistas ${ }^{24}$.

Sin embargo, el conflicto más importante de Suecia con la España franquista durante el período que nos ocupa fue el relacionado con la detención y condena de dos vicecónsules honorarios suecos en localidades de la España franquista: El vicecónsul en Coruña y su homónimo en Sanlúcar de Barrameda.

El vicecónsul sueco en Coruña, Cornide, era cuñado de Casares Quiroga, y según el hijo del cónsul, y el propio Encargado de Negocios sueco Erik Wisén en su información al Ministerio de Negocios Extranjeros sueco, esa era la causa real de su encarcelamiento por las autoridades franquistas. Esa opinión no era compartida por el cónsul sueco en Vigo, Oxley, ciudadano inglés y cónsul también de Gran Bretaña en esa ciudad. Según Oxley, que fue quien notificó la detención de Cornide, el motivo había sido la desafección de éste, demostrada por su participación en un ataque de elementos de izquierdas a la estación de radio local. El cónsul en Vigo propuso la sustitución de Cornide como vicecónsul sueco por Henry Guyatt como vicecónsul honorario. Suecia aceptó esta sugerencia y, a juzgar por la carencia de documentación subsiguiente respecto al asunto, parece haberse desentendido de la suerte de Cornide ${ }^{25}$.

El otro caso mencionado tuvo mayores consecuencias y condujo a contactos diplomáticos al más alto nivel: los generales Franco y Queipo de Llano por parte de la España franquista, Martínez Barrio por parte de la España republicana y el Príncipe Carlos de Suecia y el Ministro de Negocios Extranjeros Rickard Sandler, por parte sueca.

El detonante fue el arresto, consejo de guerra y condena a muerte del vicecónsul sueco en Sanlúcar de Barrameda, el concejal de Izquierda Republicana Antonio Maestre. Fue el Cónsul de Suecia y Dinamarca en Cádiz, el danés Bay, quien en diciembre de 1936 informó a la Legación de Suecia del arresto de Maestre por motivos de "persecución política”. La Legación le pide que haga lo posible por liberarlo. Las gestiones de Bay no

\footnotetext{
${ }^{24}$ RA, UD, 1920-års dossierssystem, HP 36 F, Vol. 1522; RA, UD, Beskickningsarkivet: Madrid, F1 C, Vol. 41, instrucciones del Ministerio sueco a Wisén de 24.IV.1937 y carta confidencial del Ministerio a Wisén de 7.V.1937, con copia de escrito de 29.IV.1937 del representante de Franco en Lisboa al Cónsul General de Suecia; RA, UD, Beskickningsarkivet: Madrid, F1 C Vol 48, PM de 27.X.1937 y lista de la Svenska Lloyds de 20.XII.1938.

${ }^{25}$ RA, UD, 1920-års dossierssystem,, HP 36 A, Vol. 1504, telegrama de 23.IX.1936 e informe confidencial de 30.IX1936 del Cónsul sueco en Vigo a la Legación de Suecia y subsiguiente comunicación de la Legación a Estocolmo.
} 
tuvieron éxito y el 19 de diciembre informaba por telegrama que Maestre iba a ser fusilado el lunes siguiente y solicitaba la intervención urgente de la diplomacia sueca.

En la misma tarde del 19 de diciembre, el Ministro de Suecia solicita por telegrama su liberación al gobierno de Burgos, desde la Legación en Lisboa. Al día siguiente, el Ministro sueco de Negocios Extranjeros ratificó esa petición por medio de un telegrama personal al Comité de Defensa Nacional de Burgos y otro al General Queipo de Llano.

Las autoridades franquistas contestaron, a través de la Cruz Roja, el día 23, diciendo que se había aplazado la ejecución de la sentencia. Entretanto, el Cuartel General del Generalísimo había solicitado del Ejército del Sur información urgente de las circunstancias del caso.

El 28 de diciembre contestó Queipo de Llano a Rickard Sandler que la condena no era definitiva y que el asunto estaba en tramitación. El 18 de enero se comunicó que el asunto estaba "en suspenso" y el Ministro sueco de Negocios Extranjeros volvió a escribir a Queipo de Llano, el 19 de enero de 1937, en castellano, pidiendo por favor que no fuera condenado, ya que "según tenemos entendido, la única causa de detención es su afiliación política”.

Entretanto, el Cónsul sueco en Cádiz proseguía sus gestiones ante Queipo de Llano. En un nuevo informe de la situación enviado a la Legación sueca en Lisboa, corrige los datos que había dado al principio, diciendo que había estado equivocado sobre el vicecónsul, y que éste en realidad era un activista político republicano en toda regla, siendo el coordinador de toda la actividad de la resistencia antifranquista en Sanlúcar de Barrameda.

En otra carta del 25 de enero de 1937 dirigida al Cónsul General de Suecia dice que canjearlo por un prisionero franquista de igual categoría era imposible porque "todos los de esa categoría ya han sido ejecutados”. Queipo de Llano propuso entonces al Cónsul sueco en Cádiz el canje de Maestre por la propia hermana del general, prisionera en Alicante.

La diplomacia sueca se dirigió entonces al gobierno de la República con el ruego de que aceptara el canje propuesto. Las gestiones se dilataron y el 10 de abril, el Príncipe Carlos de Suecia, como Presidente de la Cruz Roja, envió otro telegrama a Queipo de Llano solicitando gracia para Maestre.

Finalmente, Martínez Barrio comunicó el 11 de mayo de 1937 a los diplomáticos suecos que el gobierno de la República no autorizaba el canje de Antonio Maestre por la 
hermana de Queipo de Llano. Se trata de la última referencia sobre el particular en la documentación diplomática sueca ${ }^{26}$.

No fue ésta la única vez que la diplomacia sueca intercedió por la vida de algún español ante las autoridades franquistas. Un caso similar sucedió con el hermano del ingeniero sueco Christian Scharfausen, representante en España de la gran empresa sueca Skandia, en septiembre de 1936. Ésta se dirigió al Ministerio Sueco de Negocios Extranjeros pidiendo que gestionase la mediación del Rey Gustavo V, en su calidad de Almirante de la Armada Española, para que éste intercediera ante Franco para salvar la vida del hermano de Scharfausen, el Teniente de navio Oscar Scharfausen, naturalizado español, "que fue obligado por los republicanos en Cartagena a tomar el mando de un submarino una vez que su hermano (ambos nacidos de madre sueca), el Teniente de Navio Guillermo murió bajo tortura ante sus ojos”. El submarino había sido hundido por las tropas de Franco. El gobierno sueco trasladó la petición al Príncipe Carlos, que se mostró favorable a la intervención y dispuesto a hacer gestiones de palabra con las autoridades de Burgos. Nada más consta en los archivos suecos al respecto. ${ }^{27}$.

También hubo algún caso en que ciudadanos suecos tuvieron problemas con las autoridades de la España franquista ${ }^{28}$.

Los casos de los vicecónsules suecos Cornide y Maestre en la España de Franco tuvieron su contrapartida, como ya vimos, en las dificultades que otros vicecónsules honorarios suecos tuvieron con las autoridades republicanas. La diferencia fue que no hubo allí condenas a muerte, si bien el hijo del vicecónsul sueco en Gijón, empleado del viceconsulado, fue asesinado por milicianos. También el vicecónsul honorario sueco en Denia pidió ayuda a la Legación para poder pasarse a la España franquista, y consiguió hacerlo $^{29}$.

En el verano de 1937, las autoridades franquistas suprimieron en su zona la franquicia a los Cónsules extranjeros de países que no hubieran reconocido al gobierno de

\footnotetext{
${ }^{26}$ RA, UD, 1920-års dossierssystem, HP 36, Vol. 1525, telegramas e informes del Cónsul sueco en Cádiz Cordt Bay en relación con el "asunto Sanlúcar", copias de los telegramas de Sandler y del Príncipe Carlos a las autoridades franquistas y respuestas de éstas; RA, UD, 1920-års dossierssystem, HP 36, Vol. 1505, telegrama de 18.I.1937; RA, UD, Beskickningsarkivet: Madrid, F1 C, Vol. 44, intento de canje de Maestre por la hermana de Queipo de Llano; AGMAV, C. 2306, Libro 11, carpeta 3, solicitud de información del Cuartel General del Generalísimo al General Jefe del Ejército del Sur.

${ }^{27}$ RA, UD, 1920-års dossierssystem, HP 36, vol. 1525, telegrama de Skandia al Ministerio de Negocios Extranjeros, de 22.IX.1936.

${ }^{28}$ RA, UD, 1920-års dossierssystem, HP 36, vol. 1525: Carta de Danielsson al cónsul sueco en Tenerife sobre la ciudadana sueca Bagge, acusada en relación con asesinato de Machado, y asunto de la expulsión de la enfermera sueca Fredriksson del Hogar Sueco de Acogida de Niños de Guetaria.

${ }^{29} \mathrm{RA}, \mathrm{UD}, 1920$-års dossierssystem, HP 36, vol. 1505 y vol. 1525.
} 
Franco $^{30}$. Esto afectaba a los cónsules suecos. Luis de la Peña recibió del Ministerio sueco de Negocios Extranjeros órdenes expresas de abandonar sus gestiones, que proseguirían a través de otros canales ${ }^{31}$.

A partir de entonces, solamente el vicecónsul en San Sebastián, Andres Åkerman, tendrá un cierto protagonismo en las relaciones entre Suecia y la España de Franco ${ }^{32}$.

Aparte de interesarse por personas perseguidas, fue Åkerman hombre de contacto de la clase empresarial sueca con la España de Franco, y hombre clave en las presiones ejercidas por ésta frente a su gobierno para tratar de conseguir un intercambio de agentes comerciales y finalmente el reconocimiento oficial del nuevo régimen, como veremos en el apartado siguiente. En cierta ocasión, el Ministerio sueco de Negocios Extranjeros se sintió obligado a aclararle, por medio de Carl Ivan Danielsson, cuál era la política sueca de neutralidad y a recordarle la falta de simpatía que el país escandinavo sentía por el fascismo $^{33}$.

Por su parte, las Fuerzas Armadas suecas mostraron interés por enviar observadores a la España de Franco con el objeto de estudiar los aspectos técnico-militares de la guerra. Sin embargo, se encontraron con la negativa de las autoridades franquistas y con la de su propio Ministerio de Negocios Extranjeros: el Cuartel General del Generalísimo desestimó la solicitud del Ejército sueco de enviar al capitán Patrik Gyllenhammar como observador, y el Ministerio sueco de Negocios Extranjeros respondió al jefe del Servicio sueco de Inteligencia militar, C. Adlercreutz, que no era procedente tratar de enviar un oficial a la España de Franco para el estudio de las defensas antiaéreas. La misma respuesta recibió el

\footnotetext{
${ }^{30}$ AGMAV, C. 1264, cp 14;

${ }^{31}$ RA, UD, 1920-års dossierssystem, HP 36, vol. 1506, carta de Wisén a Söderblom (Ministerio sueco de Negocios Extranjeros) de 28.VIII.1937, con anotación marginal a lápiz que explica que Danielsson escribió “el 8 de agosto al Cónsul General Peña comunicándole que el gobierno sueco ha entablado negociaciones con el gobierno español para el canje de los restantes 21 refugiados de la Legación. Peña debe abstenerse de toda gestión al respecto". Ya en marzo, el Ministerio sueco de Negocios Extranjeros había escrito una carta a Luis de la Peña prohibiéndole presentarse a las autoridades franquistas como representante del gobierno sueco, cfr. RA, UD, Beskickningsarkivet: Madrid F1 C Vol. 45, carta a L. De la Peña de 10.III.1938.

${ }^{32}$ Las autoridades franquistas elaboraron el siguiente informe sobre Andrés Åkerman: "Vicecónsul de Suecia, nacio en Murcia, nacional sueco por parte de sus padres. Reside en España desde hace muchos años. Desde hace tres en San Sebastian. Católico, sus hijos estudian en el Colegio de Santa María. Referente a sus ideas politicas, no se ha significado nunca en ellas en nuestra nación, demostrando actualmente su preferencia por nuestro glorioso movimiento nacional. Goza de excelente reputación personal lo mismo en los centros diplomáticos que en los comerciales. Muy bien relacionado en nuestras esferas nacionales, observando dentro de ellas una conducta irreprochable", AMAEC R 790, 3.

${ }^{33}$ RA, UD, 1920-års dossierssystem, HP 36, vol. 1505, mensaje de Danielsson a Åkerman.
} 
capitán de la aviación sueca Beckhammar, que quería "ir a estudiar al frente de guerra español, preferiblemente en la zona blanca"34.

Es posible que, a pesar de todo, los militares suecos consiguieran su objetivo, según indicios contenidos en algunas fuentes, especialmente un despacho del representante franquista Gabriel Dafonte de julio de 1938, preguntando sobre un presunto viaje a España de ciertos militares suecos bajo la pretensión de ser delegados de la Cruz Roja, burlando así la prohibicion de las autoridades de Burgos al denegar éstas la solicitud del capitán Patrik Gyllenhammar. Este hecho, sin embargo, fue desmentido por el Cuartel General de Franco $^{35}$.

\subsection{El intercambio de agentes entre Suecia y la España de Franco}

A medida que avanzaba la guerra civil, se hacía cada vez más presente a los ojos de las autoridades suecas la necesidad de proceder a una regularización de sus relaciones con la España de Franco. El gobierno de Burgos controlaba una parte cada vez mayor del territorio español y era evidente que desconocer oficialmente este hecho podría tener graves consecuencias, especialmente en el aspecto comercial, para Suecia. Contribuía a ello, además, la fuerte presión en este sentido ejercida por la Secretaría de Relaciones Exteriores de la España de Franco.

Un hito fundamental en este contexto fue la decisión británica de proceder al intercambio de agentes con la España insurgente. Las gestiones al respecto entre los gobiernos de Burgos y Londres, que habían sido paralizadas en parte por la cuestión de los submarinos italianos en el Mediterráneo, cobraron nueva fuerza tras el éxito de la Conferencia de Nyon, y concluyeron con resultado positivo con la firma de un acuerdo comercial el 4 de octubre y el intercambio de agentes el 11 de noviembre de $1937^{36}$.

\footnotetext{
${ }^{34}$ AGMAV, C. 2305, L. 10, Cp. 11; RA, UD, 1920-års dossierssystem, HP 36, vol. 1507, Ministerio a Adlercreutz, febrero de 1938; RA, UD, 1920-års dossierssystem, HP 36, vol. 1519, carta de Beckhammar. La decisión de no autorizar la visita de agregados militares afectaba a aquellos paises que no hubierna reconocidon al régimen, cfr. AGA 54, Caja 12048, Legajo 12, comunicación de Antonio Sangróniz a Jose R. Gómez-Acebo, jefe de la representacion franquista en Helsinki, sobre las razones por las que no se accede al deseo del General Oesch, Jefe del Estado Mayor finlandés, de enviar un Agregado militar al Cuartel General de Franco.

${ }^{35}$ AMAEC R 1058, 11, despacho de 23.VII.1938 del representante franquista en Estocolmo e informe reservado de 21.VIII.1938 del Cuartel General del Generalísimo.

${ }^{36}$ MORADIELLOS, Enrique, La perfidia de Albión: El gobierno británico y la Guerra Civil Española, Madrid: Siglo XXI, 1996, pp. 210-215.
} 
A partir de entonces, la posibilidad de emular al gobierno británico comenzó a ser considerada por las autoridades suecas. En este proceso tuvo una influencia fundamental las presiones ejercidas en tal sentido por parte del mundo empresarial sueco.

\subsubsection{Las presiones del mundo empresarial sueco a favor de la España de Franco}

El comienzo de la guerra civil había asestado un golpe importante a las relaciones comerciales entre Suecia y España, que habían sido de cierta entidad antes de la guerra. No obstante, no se interrumpieron éstas por completo, y a pesar de las dificultades siguió habiendo un cierto intercambio comercial, también entre Suecia y la zona de España ahora controlada por el gobierno de Burgos. Los principales productos eran celulosa y madera.

Según datos publicados en el diario Social-Demokraten en noviembre de 1937, la situación comparada de la balanza de pagos hispano-sueca* era la siguiente ${ }^{37}$ :

\begin{tabular}{lcc} 
Importación de la zona republicana & 9,7 & 4 \\
Importación de la zona franquista & 5,1 & 3,4 \\
Exportación a la zona republicana & 9,6 & 2,4 \\
Exportación a la zona franquista & 18,9 & 3,2 \\
\hline
\end{tabular}

*En millones de coronas suecas.

Según la Asociación General Sueca de Exportadores (SAE), en noviembre de 1936 las empresas exportadoras suecas tenían créditos impagados en España por un valor total de casi veintitrés millones de coronas ${ }^{38}$. Este hecho, unido al fuerte descenso del comercio hispano-sueco en 1936, llevó a Erik Nylander ${ }^{39}$, director de la Asociación, a considerar, en junio de 1937, la posibilidad de enviar a España un representante de los empresarios suecos.

Entre julio y septiembre de 1936, la mayor parte de los empresarios suecos residentes en la zona de España que permaneció leal al gobierno republicano abandonaron ésta, y algunos se establecieron en la otra zona. A finales de agosto sólo quedaban en zona

\footnotetext{
${ }^{37}$ RA, UD, Beskickningsarkivet: Madrid, F1 C Vol 48, export/import Sverige-Spanien enl SocDem 17 nov 1937.

${ }^{38}$ RA, SAE, Svenska varufordringar i Spanien i november 1936; RA. UD., Beskickningsarkivet: Madrid, F1 C Vol. 47, contiene una lista de las principales empresas con intereses en España: Electrolux, Aga Baltic, Atlas Diesel, ASEA, De Lavals Ångturbin, Skandia Verken, Svenska Kullagerfabriken, Svenska Ackumulator, Elektriska svetsnings, Svenska Maskinverken.

${ }^{39}$ Erik Nylander (1885-1958) fue director de la Asociación Sueca de Exportadores desde 1915 a 1941. Fue también diputado del partido conservador (Höger) entre 1918-1941. Fue después Gobernador de Gotland, cfr. Tidens kalender 1941: almanack och uppslagsbok, Estocolmo, 1940, p. 121.
} 
republicana dos de los once jefes de las grandes empresas suecas con intereses en Madrid, y las empresas suecas confiaron la defensa de sus intereses, e incluso de sus activos, al Ministerio sueco de Negocios Extranjeros ${ }^{40}$.

Las empresas suecas que deseaban seguir comerciando con España tenían, además, la dificultad inherente al transporte de las mercancías hacia la zona de la que se tratara. A pesar de que Isabel de Palencia criticara a la Svenska Lloyds por haber adoptado una postura de "franca hostilidad hacia la República", poniendo sus barcos a disposición de transportes destinados a la España de Franco pero no a la República, no parece que esto fuera exacto. Según la estadística de la Asociación de Navieras, en 1936 llegaron solo ocho barcos a puertos de la España franquista (cinco a Sevilla, uno a Huelva y dos a Ceuta) frente a cuarenta que lo hicieron a puertos republicanos ${ }^{41}$.

El bloqueo franquista de los puertos republicanos motivó, como hemos visto, el apresamiento de varios barcos suecos. La Asociación de Navieras suecas pidió al gobierno sueco el envío de buques de guerra para la protección de los mercantes suecos en aguas españolas, petición que fue apoyada también por la Asociación de Exportadores (SAE) ${ }^{42}$.

Poco después, el armador Anders Smith escribió al Ministerio de Negocios Extranjeros sueco pidiendo que se regularizaran las relaciones con la España de Franco, porque la situación actual era lamentable para el comercio sueco, ya que muchos marineros se negaban con frecuencia a tripular barcos con destino a los puertos franquistas ${ }^{43}$.

A partir del mes de octubre de 1937, regularizadas las relaciones comerciales entre el Reino Unido y la España franquista, las presiones del mundo empresarial sueco sobre su

\footnotetext{
${ }^{40}$ RA, UD, 1920-års dossierssystem, HP 36, vol. 1525, PM de 28.VIII.1936 del Ingeniero Wöhler de la Lavals ångturbin; Cartas de ASEA a los consulados suecos a través del Ministerio de Negocios Extranjeros; PM de 18.XII.1936 sobre arresto de un empleado de AGA y su familia por presuntas simpatías con el bando sublevado; carta de Orrefors Bruks AB al Ministerio de Negocios Extranjeros; carta de la empresa Axelsson Johnsson a la Legación de Suecia en España acerca de una mina de su propiedad en Galicia; RA, UD, Beskickningsarkivet: Madrid F1 C Vol. 47, petición de ayuda de la Elektriska Svetsningsbolaget en asunto sobre reclamación de capitales. Muchos de esos asuntos no se resolvieron hasta el final de la guerra, cfr. RA, UD, 1920-års dossierssystem, HP 36, vol. 1520.

${ }^{41}$ La opinión de Palencia se encuentra en AMAEC R 642, 2 despacho n. 57 de 8.III.1838. La insistencia del representante de la Svenska Lloyds en España, August Siljeström, de que el gobierno sueco debería regularizar sus relaciones con el gobierno de Burgos (cfr. CANTERA CARLOMAGNO, Sverige och spanska..., p. 75) parece ratificarlo. En su contra, sin embargo, cfr. RA, UD, Beskickningsarkivet: Madrid, F1 C Vol 48, PM de 18.XI.1938, donde la Svenska Lloyds se niega a aceptar la declaracion exigida por la España franquista comprometiéndose a abstenerse de comerciar con los puertos republicanos españoles, e Ibidem, reclamaciones de la Svenska Lloyds al gobierno de Burgos por la detención de barcos.

${ }^{42}$ RA, UD, 1920-års dossierssystem, HP 36, vol. 1522, diarienr. 630, carta de la Svenska Rederiförbundet, de 20.IV.1937; RA, UD, 1920-års dossierssystem, HP 36, vol. 1507.

${ }^{43}$ RA, UD, 1920-års dossierssystem, HP 36, vol. 1522, PM de Anders Smith de 7.VII.1937; Cfr. también AMAEC R 1058, 11, despacho de 16.XII.1937 sobre el abandono por parte de la Federación sueca de obreros maritimos del boicot contra los puertos de la España franquista.
} 
gobierno se intensificaron. El archivo de la Asociación General sueca de Exportadores (Svenska Allmänna Exportföreningen, SAE) permite seguir al detalle el contenido de las discusiones en el seno de la Asociación sueca de Exportadores y hacerse cargo de los argumentos expuestos en las cartas que diversos grupos de empresarios enviaron pidiendo la regularización de las relaciones. Entre éstos se encontraban los representantes de las principales empresas suecas (Electrolux, Atlas Diesel, ASEA, AGA, etc). Cantera Carlomagno dedicó una atención preferente a estos aspectos en su estudio sobre Suecia y la guerra civil española ${ }^{44}$.

En suma, los empresarios suecos consideraban que Franco se perfilaba como el futuro vencedor de la guerra y que en esas circunstancias era imperativo que Suecia no sufriera represalias ni desventajas comerciales por no haber regularizado a tiempo sus relaciones con el nuevo Estado. Las ventajas comerciales que el acuerdo comercial entre los gobiernos de Burgos y Londres daba a la Gran Bretaña asustaron a las clases empresariales de media Europa, que no dudaron en actuar. Los empresarios noruegos enviaron un representante a Burgos, Nils Jacobsen, y Francia siguió el ejemplo británico el 7 de diciembre de $1937^{45}$.

Aunque eran conscientes de la imposibilidad política de que el gobierno sueco reconociera oficialmente al de Burgos, los empresarios suecos exigían - por carta a Sandler de finales de octubre de 1937 - el inicio de conversaciones para llegar a un acuerdo que fuera al menos parcialmente satisfactorio. El 8 de noviembre de 1937, los empresarios fundaron un Comité específico para los contactos con España, bajo la presidencia de Rolf von Heidenstam ${ }^{46}$.

Sus argumentos eran de índole comercial y no política, al contrario de los que el vicecónsul Åkerman y un grupo de suecos residentes en España comunicaban en una carta al Ministerio sueco de Negocios Extranjeros, presentando a la República como régimen violento con el que la democracia sueca no podía tener nada en común y solicitando que se reprochara a la prensa sueca sus ataques al régimen de Franco y el reconocimiento del mismo por parte del gobierno sueco:

\footnotetext{
${ }^{44}$ RA, SAE, Huvudarkivet, Övriga dossierer (archivo principal, expedientes varios), vol. 4-6; CANTERA CARLOGMAGNO, Sverige och spanska...), pp. 67-78.

${ }^{45}$ RA, UD, 1920-års dossierssystem, HP 36, vol. 1522.

${ }^{46}$ RA, SAE, Huvudarkivet, Övriga dossierer, vol. 4, copia de la carta a Sandler de 23.10.1937; Ibidem, vol. 6, acta de las reunión del órgano directivo de la SAE de 5.XI.1937 y relato de la reunión del Comité para España de 8.XI.1937.
} 
Tenemos el firme convencimiento de que nuestro sistema sueco de gobierno no tiene nada en común con el régimen violento, que desde el comienzo de la guerra civil está vigente en la zona de España controlada por el gobierno de Valencia, y opinamos además que el alzamiento nacional [sic: nationella rensningen] surgió en virtud de una poderosa opinión popular motivada por las circunstancias caóticas que reinaban en el país en la primera mitad del año 1936. No tenemos la más mínima duda de que el general Franco cuenta hoy con el apoyo de la inmensa mayoría del pueblo español, a ambos lados del frente" ${ }^{\text {47 }}$.

El asunto no deja de tener su interés, pues será precisamente Åkerman la persona elegida por los empresarios suecos como su representante para centralizar todas las cuestiones comerciales con la España de Franco. El jefe de la Sección comercial del Ministerio sueco de Negocios Extranjeros, Stig Sahlin, opinaba que ese cargo podría ser ocupado por un cónsul. En la duda sobre la persona a elegir, von Heinestam quiso saber la opinión del Ministro Rickard Sandler, que al parecer fue terminante en su negativa a dotar a la persona en cuestión de ningún tipo de encargo oficial y prohibió todo tipo de iniciativas privadas en relación con el reconocimiento del régimen franquista.

A pesar de ello, el comité de los empresarios se puso en contacto con el representante franquista en Estocolmo, Gabriel Dafonte, y encargó a Åkerman que se pusiera en contacto con las autoridades comerciales de Burgos. Éste, en lugar de hacerlo así, se puso directamente en contacto con Antonio Sangróniz, e insistió ante sus poderdantes en la necesidad de presionar al gobierno sueco a llevar a cabo negociaciones a nivel político, pues ya era demasiado tarde, en su opinión, para quedarse en un plano solamente comercial. La SAE mostró, con todo, un cierto temor de ejercer demasiada presión ${ }^{48}$.

Así, por partida doble, a través de Åkerman en San Sebastián y Dafonte en Estocolmo, comenzaron las gestiones destinadas a conseguir un reconocimiento oficial, al menos a nivel de intercambio de agentes, entre Suecia y la España de Franco.

Aparte de la presión directa por parte de la SAE, llegaron por aquellos días al Ministerio sueco cartas de empresarios suecos singulares, todas en el mismo sentido. Una carta de Arthur Spanberg, miembro del Comité de la Cámara de Comercio sueca en Francia, insistia en la necesidad de regularizar el comercio para evitar las "trabas de

${ }^{47}$ RA, UD, 1920-års dossierssystem, HP 36, vol. 1522, carta de los suecos residentes en España, de 11.XI.1937.

${ }^{48}$ RA, SAE, Huvudarkivet, Övriga dossierer, vol. 6, Referat från spanska kommitténs sammanträde, 10.XI.1937 y 24.XI.1937; Ibidem, PM de 15.12.1937; RA, SAE, Huvudarkivet, Övriga dossierer, vol. 5, carta de Åkerman al SAE de 29.XI.1937; RA, UD, 1920-års dossierssystem, HP 36, vol. 1522, carta de Åkerman al Ministerio de Negocios Extranjeros; AMAEC R 602, 5, informes de Dafonte de 27.X y 12.XI.1937; CANTERA CARLOGMAGNO, Sverige och spanska..., pp. 69-71. 
lentitud" que imponían las autoridades de la España franquista franquistas en los asuntos comerciales. Otra carta, de Leje y Thurne en nombre de las empresas Stora Kopparbergs Bergslags $\mathrm{AB}$, Kopparberg $\mathrm{AB}$, Hofors Sågverk $\mathrm{AB}$ y Vifstavarvs $\mathrm{AB}$, pedía el establecimiento de relaciones con Franco cuanto antes ${ }^{49}$.

Dos semanas más tarde, un grupo importante de asociaciones y otras entidades comerciales de Suecia - Jernkontoret, Svenska cellulosaföreningen, Svenska trämasseföreningen, Svenska trävaruexportföreningen, la Asociación de Mayoristas Sveriges grossistförbund, la Asociación de Navieras suecas Sveriges redareförening y la propia SAE - insistía en lo mismo, quejándose de la situación comercial de Suecia por no entrar en tratos con el gobierno de Burgos y pidiendo "medidas inmediatas para el comienzo de negociaciones con las autoridades de Burgos para conseguir un acuerdo comercial y de transporte marítimo que de la manera más amplia posible asegure los intereses económicos actuales y futuros de nuestro país"50.

También hubo quien se dirigió al Rey en el mismo sentido, y quien trató de conseguir trato preferencial en la España franquista alegando su apoyo a la causa. El cónsul sueco en Sevilla propuso incluso la creación en Suecia de una empresa similar a la HISMA alemana ${ }^{51}$.

A pesar de las reticencias oficiales a regularizar las relaciones comerciales, siguió habiendo comercio entre Suecia y la España franquista, incluso con organismos oficiales como compradores, por ejemplo la Junta General de Adquisiciones ${ }^{52}$.

Los exportadores suecos siguieron ejerciendo presiones, especialmente tras los acuerdos comerciales que Holanda y Noruega firmaron con el gobierno de Burgos en julio y agosto de 1938, respectivamente. A propuesta del empresario sueco Patrik Falkman,

\footnotetext{
${ }^{49}$ RA, UD, 1920-års dossierssystem, HP 36, vol. 1522, cartas de Spangberg y Leje/Thume a Sandler, de 4.XII.1937.

${ }^{50}$ RA, UD, 1920-års dossierssystem, HP 36, vol. 1522 y RA, SAE, Huvudarkivet, Övriga dossierer, vol. 4, carta de la SAE y otras organizaciones comerciales al Ministerio de Negocios Extranjeros, de 21.XII.1937.

${ }^{51}$ RA, UD, 1920-års dossierssystem, HP 36, vol. 1522, carta del conde Jens af Trampe al Rey de Suecia, 13.XII.1937: AGA, Asuntos Exteriores, Caja 5290, carta de Hans S. Johansson, de Karlstad, a Felipe Campuzano, representante franquista en Noruega, de 14.IX.1937, pidiendo carta de recomendacion y visado en reconocimiento a "nuestros sentimientos y trabajos por la España nacional". Johansson era director de la empresa Material \& Productos para la avicultura, y otras empresas de Tortosa. Campuzano le respondió: "lamento mucho no poder atender a lo que solicita por ser contrario al nuevo espíritu de la España Nacional y a las instrucciones existentes sobre estos casos", carta de 29.IX.1937; RA, UD, 1920-års dossierssystem, HP 36, vol. 1523, carta de J.E. Östlund de 25.I.1938 y carta de 1.III.1938 del cónsul sueco en Sevilla al director Böhman de Gotemburgo.

${ }^{52}$ AHN, FC_Presid_Gob_Adquisiciones, 52 y 53, Estado Español, Junta general de adqusiciones: varios expedientes sobre importación de material de la Swenska Kullagerfrabriken de Gotemburgo para el Servicio de Recuperacion de Automóviles; AMAEC R 1107, 1, carpeta 1, telegrama a Dafonte respecto a compras oficiales, 21.VII.1937.
} 
residente en San Sebastián y yerno de Carl Ivan Danielsson, los exportadores suecos eligieron el 24 de agosto a Axel Olsén, ex-vicecónsul sueco en Madrid y ejecutivo de la Electrolux, como su representante y hombre de contacto en Burgos, con el visto bueno del Ministerio sueco de Negocios Extranjeros (según consta en una anotación escrita a mano en los archivos del mismo). Y en el mes de octubre la insistencia de la SAE, de empresarios singulares, y de los cónsules suecos en España adquirió ya tonos apremiantes $^{53}$.

Durante todo ese tiempo, el asunto se discutió también a nivel diplomático, como veremos a continuación. Los actores principales en esas negociaciones, por parte española, fueron los representantes de la España de Franco en Estocolmo, Gabriel Dafonte al principio, y Fernando Valdés, el Conde de Torata, a partir del 1 de septiembre de 1938. Por parte sueca, el Ministerio de Negocios Extranjeros y el propio jefe del gobierno, Per Albin Hansson.

\subsubsection{La negociación diplomática sobre el intercambio de agentes}

La posición sueca de no querer entrar en trato oficial alguno con la España de Franco siguió firme a lo largo de 1936 y 1937. Como vimos, solamente tras el cambio de actitud de Inglaterra y el establecimiento por este país de relaciones con Franco a nivel de intercambio de agentes, a finales de 1937, se planteó en Suecia la posibilidad de seguir ese ejemplo.

De acuerdo con la SAE, Gabriel Dafonte había escrito a sus superiores en noviembre de 1937, explicando el ambiente en Suecia tras intercambio de agentes entre Burgos y Londres, y abogando por un trato de favor hacia Suecia que, en contra de la política habitual exigida por el gobierno franquista, permitiera el intercambio de agentes puramente comerciales sin matiz político, habida cuenta de la presión que el gobierno socialdemócrata sueco tenía por parte de su propia opinión pública y de sus sindicatos. Dafonte pensaba - y no se equivocó - que Suecia, “a pesar de ser uno de los países que más ajustan su política a

\footnotetext{
${ }^{53}$ RA, SAE, Huvudarkivet, Övriga dossierer, vol. 6, Referat från spanska kommitténs sammanträde, RA, UD, 1920-års dossierssystem, HP 36, vol. 1522, despachos de la Legación sueca en Oslo de 9.VIII.1938, anotación manuscrita sobre nombramiento de representante de los exportadores; Ibidem, carta de la SAE de 6.X.1938, carta del cónsul sueco en Valencia de 15.X.1938 y carta de Axel Olsén a la SAE de 27.X.1938; AMAEC R 1108, 1 telegrama del Conde de Torata de 24.XII.1938; RA, UD, Beskickningsarkivet: Madrid F1 C Vol 48, carta de P. Falkman de 12.X.1938 presionando para que los barcos con bandera bicolor pudieran entrar en puertos suecos.
} 
la de Inglaterra", sería una de las últimas potencias europeas que reconociera a la España de Franco ${ }^{54}$.

La Legación de Suecia en Oslo (Noruega), en una nota "estrictamente confidencial" de finales de noviembre de 1937, mencionaba que el gobierno y la Comisión de Asuntos Exteriores del Parlamento habían considerado la posibilidad de seguir el ejemplo inglés, pero temían la reacción de la opinión pública. Alguien había dicho en el parlamento que el gobierno sueco había tenido contactos de sondeo con Dafonte, el representante de Franco en Suecia. El embajador sueco solo reconoció que había habido contactos a través de un empresario sueco afincado en San Sebastián. El 1 de diciembre, Beck-Friis desmintió esas informaciones ${ }^{55}$.

En el mes de enero, un diputado conservador interpeló en el Parlamento sueco al gobierno acerca de la situación en que se encontraban las relaciones entre Suecia y la España de Franco, expresando el temor de que los intereses suecos pudieran resultar perjudicados en el caso que tales relaciones no se restablecieran. En su contestación, el Ministro Sr Sandler manifestó que el asunto estaba siendo estudiado por "los centros administrativos competentes".

Al informar a Sangróniz sobre este particular, Dafonte proseguía:

Las palabras del Sr. Sandler confirman las indicaciones del que suscribe contenidas en anteriores despachos sobre el particular, dando además, según cabía esperar, estado publico y oficial a las gestiones pendientes. En relación con este asunto me permito reiterar a V.E. mi ruego sobre la conveniencia de recibir lo antes posible contestación a los anteriores despachos a partir del n. 43 de fecha de 26 noviembre último (...). En los centros administrativos a que el Sr Sandler hizo referencia se lamentaban, precisamente el día antes del debate en cuestión, o sea anteayer, de no tener todavía orientación por parte de las autoridades nacionales españolas $^{56}$.

La respuesta llegó el 26 de enero, y no dejaba lugar a dudas: Consultado el propio Franco, la decisión era no dar trato de favor a Suecia, por lo que los agentes a intercambiar no habrían de tener carácter comercial, sino político, con los mismos derechos, salvo el nombre, de los representantes diplomáticos de otros países ${ }^{57}$.

\footnotetext{
${ }^{54}$ AMAEC R 1051, 13, despachos n. 4 y 43 de Gabriel Dafonte, de 12. y 26.XI.1937, respectivamente.

${ }^{55}$ RA, UD, 1902-års dossierssystem, HP 36, Vol. 1522, nota de la Legación sueca en Oslo de 27.XI.1937.

${ }^{56}$ AMAEC R 590, 23, Dafonte a Sangróniz, 18.I.1938.

57 AMAEC R 1051, 13, Sangróniz a Dafonte, 26.I.1938; RA, UD, 1920-års dossierssystem, HP 36, vol. 1523, comunicado de Sangróniz, 3.II.1938.
} 
Dafonte no quiso, o no se atrevió, a comunicar esto a las autoridades suecas e intentó un doble juego a fin de conseguir el objetivo previsto, alterando para ello, en su traducción al sueco, las instrucciones recibidas. A la vez, trató de convencer a las autoridades de Burgos de la imposibilidad de exigir a Suecia un intercambio de representantes a nivel político. Alegó la división interna del gobierno sueco al respecto, motivada por las informaciones que éste recibía de Erik Wisén - el Encargado de Negocios sueco ante la República - quien, según Dafonte, habría desaconsejado un acercamiento de Suecia a Franco para quedar bien ante los socialistas del gobierno sueco, a pesar de tener "simpatías secretas" por la causa franquista. Estas acusaciones no tenían fundamento ${ }^{58}$.

Cantera Carlomagno sospecha que ese doble juego fue la causa de la sustitución de Dafonte por Fernando Valdés, Conde de Torata, como representante de la España franquista en Estocolmo, en el verano de 1938. Es posible que así fuera, aunque nos inclinamos más bien por atribuirlo a la insistencia de Isabel de Palencia ante el Ministerio de Negocios Extranjeros, que exigió la retirada del pasaporte diplomático - y del consiguiente permiso de residencia en Suecia - a Dafonte. La noticia fue comunicada al interesado de forma oficiosa a través de Danielsson. Además, la Legación republicana en Estocolmo había iniciado procedimiento judicial penal en contra de Dafonte por presunta apropiación indebida de fondos, y en esas circunstancias se hacía difícil la permanencia de éste en Estocolmo 59 .

El gobierno sueco recabó información de sus Embajadas y Legaciones acerca del estado de la cuestión de la relación de los diversos países con el régimen franquista.

El Encargado de Negocios en Portugal, Lennart Rappe, a quien correspondía más directamente el seguimiento de la actualidad política de la España franquista, informó de la llegada de Teotonio Pereira, "un destacado fascista" pero no especialmente pro-franquista, como Embajador de Portugal, en lo que Rappe consideraba un intento de Salazar de alejar de Portugal a Pereira. Informaba también de las negociaciones sobre establecimiento de relaciones comerciales entre Polonia y la España de Franco, según le había comunicado su colega polaco en Lisboa. También Hungría, Austria y Suiza - la cual tenía un representante inoficial en Burgos - estaban en tratos similares.

El Ministro holandés en Lisboa había comunicado a Rappe que Holanda tenía un agente general en San Sebastián que estaba preparando la posible cooperación comercial

\footnotetext{
${ }^{58}$ AMAEC R 1051, 13, despacho n. 7 de Dafonte, 10.II.1938.

${ }^{59}$ CANTERA CARLOGMAGNO, Sverige och spanska..., p. 78; AMAEC R 602, 5, informe de Dafonte de 1.IX.1938; AMAEC R 577, 4, "Hechos ocurridos en oficina comercial de España en Estocolmo".
} 
con la España de Franco, y el agente oficioso de ésta en Holanda, según el ministro, "era especialmente bien recibido" en el Ministerio de Asuntos Exteriores. Finalmente, mencionaba que Winkelmann, el Ministro finés en Lisboa, que lo había sido también en Madrid, había pedido "con insistencia" a su gobierno que procediera a establecer relaciones con Franco ${ }^{60}$.

Con esas y otras informaciones, el Ministerio de Negocios Extranjeros elaboró un informe del estado de la cuestión, que en resumen decía lo siguiente:

Reino Unido - Al menos desde julio 1937 en regular contacto con Franco, a través de su Embajada en Hendaya. El 11 noviembre, acuerdo de intercambio de agentes. Exportación británica a la España de Franco, enero - septiembre de 1937, dos millones de libras esterlinas.

Francia - contacto a través de su consulado general en San Sebastián y otros consulados. Acuerdo comercial con Franco en noviembre de 1937.

Suiza- Ha establecido cuatro consulados en la España de Franco y ha dado exequatur provisional a un cónsul franquista en Suiza. En noviembre, acuerdo entre los exportadores suizos y la España de Franco. Relaciones íntimas.

Portugal - Intensas relaciones, con un Embajador de alto rango en Salamanca.

Holanda -- experto comercial en Salamanca desde noviembre de 1937

Polonia -- contacto a través del Ministro polaco en St. Jean de Luz. Idem Yugoslavia

Noruega -- ha considerado encargar a su cónsul en Bilbao empezar negociaciones para acuerdo comercial

Dinamarca y Finlandia -- de momento, han dicho a sus exportadores que no procede

Según la Representación franquista en Lisboa, han reconocido a Franco: Alemania, Italia, Japón, Portugal, Albania, Hungría, Nicaragua, S. Salvador, Vaticano, Guatemala,

De facto: Inglaterra, Checoslovaquia, Rumania, Turquía, Yugoslavia ${ }^{61}$

Como ya mencionamos, la cuestión de las relaciones con la España de Franco se discutió en el Comité parlamentario de Asuntos Exteriores (Utrikesnämnden) y en el propio Parlamento, en el marco de las discusiones sobre la No Intervención. En ellas, el

\footnotetext{
${ }^{60}$ RA, UD, Beskickningsarkivet: Madrid, F1 C Vol. 48, cartas de Rappe a Beck-Friis, de 14 y 29.XII.1937.

${ }^{61}$ RA, Utrikesnämnden, Vol. 4, orden del díadel 12.I.1938 y pro memoria de 8.I.1938 sobre las relaciones de algunos países con la España de Franco (también recogido en RA, UD, Beskickningsarkivet: Madrid, F1 C Vol. 48, PM ang vissa staters handelsförbindelser med Francospanien); RA, UD, Beskickningsarkivet: Madrid, F1 C Vol. 48, despacho de la Legación de Suecia en París de 1.II.1938.
} 
partido conservador apoyó la postura de neutralidad del gobierno pero se mostró también partidario de regularizar cuanto antes las relaciones comerciales con Franco ${ }^{62}$.

El gobierno sueco encargó entonces al organismo administrativo competente en materia comercial, el Kommerskollegium, un estudio de la cuestión, que estuvo listo en marzo de 1938, y recomendaba al gobierno un seguimiento de la cuestión, en colaboración con los otros países nórdicos, pero sin especiales prisas, pues estimaba que la falta de un acuerdo comercial con Franco no era tan desastroso para los intereses comerciales suecos como querían hacer ver los exportadores ${ }^{63}$.

El tema de la representación de los países nórdicos ante la España de Franco fue tratado también en la reunión de los Ministros de Asuntos Exteriores de estos países en Oslo el 5 y 6 de abril de 1938. Para entonces, el Parlamento noruego había ya aprobado, en reunión secreta, la propuesta del gobierno de nombrar a uno de sus cónsules honorarios como "representante no diplomático" ante Franco. Dinamarca y Finlandia se mantenían a la expectativa, y Sandler insistió en que esa actitud era la correcta, especialmente porque un cambio de actitud tras las recientes éxitos militares de la España franquista sería mal recibido por la opinión pública. ${ }^{64}$

Poco a poco, sin embargo, fue aumentando el nivel de contactos e informaciones entre Suecia y la España de Franco: En julio informaba Dafonte sobre la presencia de agentes comerciales de Noruega y Suecia en España; en agosto, el Instituto sueco de Estadística aceptó intercambiar informaciones con su homónimo en la zona franquista; el 11 de septiembre, el diario Stockholms Tidningen publicó un reportaje sobre la situación en la retaguardia franquista elaborado por un periodista sueco que viajó allí; y el discurso de Franco el 18 de julio de 1938 quedó recogido en el archivo del Ministerio sueco de Negocios Extranjeros ${ }^{65}$. Por las mismas fechas, sin embargo, la España de Franco se negaba a aceptar controladores suecos en la Comisión internacional de control de bombas ${ }^{66}$.

\footnotetext{
${ }^{62}$ LUNDVIK, Solidaritet och partitaktik..., p. 162.

63 RA, Utrikesnämnden, Vol. 4, informe del Kommerskollegium al Ministro de Negocios Extranjeros, 14.III.1938.

${ }^{64}$ RA, Utrikesnämnden, Vol. 4, negociaciones en la reunión de Ministros de Asuntos Exteriores en Oslo, 56.IV.1938.

65 AMAEC R 634, 19 Despacho n. 166 de 6.VII.1938; AMAEC R 1058, 11, despacho de 2.VIII.1938 y extracto de prensa de 12.IX.1938; RA, UD, Beskickningsarkivet: Madrid, F1 C, Vol. 93, discurso de Franco del 18 de julio de 1938.

${ }^{66}$ RA, UD, Beskickningsarkivet: Madrid F1 C Vol 48, copia de la Nota de la Embajada británica adjunta al envio de Söderblom a Wisén del 9.VII.1938.
} 
Con mucha discreción, a través del cónsul danés Hedegaard, recibió el gobierno sueco información precisa sobre la postura de las autoridades franquistas en relación con Suecia. El danés se entrevistó en España con el ministro de Industria y Comercio Juan Antonio Suanzes, y éste le dijo que la España franquista no tenía inconveniente en comerciar con Suecia, pero que al mismo tiempo sería "denigrante" tener relaciones comerciales con un país que ignoraba "la existencia de la España Nacional". En consecuencia, no se prohibiría el comercio con Suecia pero no se le daría ningún tipo de trato de favor.

Según Suanzes, el gobierno sueco no ejercía control alguno sobre la prensa de su país, y ésta presentaba siempre a la República como una democracia, "no siendo verdad", ya que en realidad era un "régimen puramente anarquista y comunista dirigido por la Unión Soviética". Suanzes manifestó tener conocimiento de que los soviéticos habían hecho mucha propaganda en Suecia a favor de la República, empleando mucho dinero en ello. Sabía también que entidades privadas suecas habían mandado mucho dinero a la España republicana, aunque "por lo que yo sé, el Estado sueco no ha ayudado directamente a los rojos ni con armas ni con fondos públicos y España lo recordará".

Y en mensaje directo al gobierno sueco, le dijo Suanzes a Hedegaard lo siguiente:

Podemos comprender que Suecia no haya reconocido antes a Franco porque habéis considerado el asunto desde un punto de vista estrictamente comercial. No sabíais quién ganaría y por tanto, como financieros prudentes, no habéis querido tomar partido ni por uno ni por otro para no estropear vuestras perspectivas de futuro si apostabais mal. Pero lo que no puedo comprender es que ahora, en que ya no podéis tener ninguna duda sobre quién va a ganar, sigáis ignorándonos. Y de esto solo os pueden venir perjuicios.

$\mathrm{Si}$ ahora dierais muestras de al menos reconocer que existimos, seríais recibidos con nuestra máxima confianza y buena voluntad. En ese caso favoreceríamos por todos los medios el comercio entre nuestros países y quizá tendríais un estatuto mejor que el de muchos países que ya han reconocido nuestra existencia, porque ambas partes necesitamos el comercio entre nuestros países. Pero si seguís mostrando esta actitud negativa, debemos considerarla como un acto hostil a España, y deberíamos trataros en consecuencia (...)

No miramos mal a Suecia, y deseamos unas buenas relaciones con vuestro país, al que tenemos gran consideración, pero no podemos recibir y dar las gracias si persistís demasiado tiempo en mostrarnos una actitud puramente hostil ${ }^{67}$

\footnotetext{
${ }^{67}$ RA, UD, 1920-års dossierssystem, HP 36, vol. 1523, informe de 18.VII.1938 del cónsul danés Hedegaard. Las palabras de Suanzes aquí recogidas no son originales, sino traducción nuestra del texto en sueco del informe de Hedegaard.
} 
La entrevista del cónsul danés estaba en el marco de los estrechos contactos entre los países nórdicos y su deseo de proceder de común acuerdo en las cuestiones importantes de política exterior.

A finales de agosto de 1938, Fernando Valdés, Conde de Torata, sustituyó a Gabriel Dafonte como representante de la España de Franco en Suecia. El 5 de septiembre tomó posesión del archivo de la representación. Venía de Inglaterra, donde había trabajado a las órdenes del Duque de Alba, representante de Franco en Londres.

Valdés informó a su gobierno del nombramiento de Axel Olsén, como representante de los exportadores suecos, añadiendo que pese a su carácter de representante privado, era de algún modo un buen canal del Ministerio de Negocios Extranjeros sueco para establecer contactos oficiosos con las autoridades de Burgos. Las autoridades franquistas decidieron, de acuerdo con Valdés, evitar los contactos con Olsén, incluso a nivel oficioso, para evitar que el intercambio de agentes fuera sólo a nivel comercial en lugar de político $^{68}$.

El 12 de octubre, el Ministerio sueco de Negocios Extranjeros hizo saber discretamente a los círculos interesados que Suecia estaba interesada en negociar un acuerdo de intercambio de agentes. Al día siguiente, el 13 de octubre, Valdés propuso al gobierno sueco un acuerdo similar al que se había firmado con Holanda el 27 de julio anterior. El mismo día escribían desde San Sebastián en el mismo sentido el vicecónsul Åkerman y un grupo de suecos residentes en España. Pocos días antes, la SAE había enviado un nuevo escrito al Ministerio pidiendo lo mismo. Además, Noruega había llegado a un acuerdo el 9 de agosto y Dinamarca lo haría el 29 de octubre ${ }^{69}$.

Por su parte, la Legación de la República española en Estocolmo no cejaba de presionar en contra, ante el Ministerio de Negocios Extranjeros y el Gobierno sueco. El Ministro de Asuntos Sociales le prestó su apoyo, Per Albin Hansson le consoló con buenas palabras pero no le prometió nada, y Sandler le dijo que, aunque personalmente no deseaba entablar relaciones con Franco, no hacerlo era difícil, una vez que los demás países nórdicos ya habían dado ese paso. En el fondo, había también cuestiones

\footnotetext{
${ }^{68}$ AMAEC R 1051, 13, despacho n. 10 del Conde de Torata de 7.IX.1938; Ibidem, carta de Jordana a Suanzes, de 24.X.1938.

${ }^{69}$ RA, UD, 1920-års dossierssystem, HP 36, vol. 1523, carta de Beck-Friis a Heidenstam (Ministro de España en Finlandia y hermano del presidente del Comité para España de la SAE), de 12.X.1938; Ibidem, nota del Conde de Torata al Ministerio sueco de Negocios Extranjeros, de 13.X.1938; RA, UD, 1920-års dossierssystem, HP 36, vol. 1524, carta de Åkerman y suecos residentes en España, de 13.X.1938; RA, SAE, Huvudarkivet, Övriga dossierer, vol. 4, carta de la SAE de 4.X.1938.
} 
económicas en juego, pues Suecia había aprobado créditos a España y las autoridades franquistas habían declarado que no reconocerían ningún crédito que se concediera a la zona republicana salvo que fuera para ayudar a simpatizantes de su causa a llegar a la propia zona desde la republicana ${ }^{70}$.

Además, un gran número de organizaciones de izquierda, especialmente las vinculadas a la SAC y al Partido comunista sueco, enviaron al gobierno cartas de protesta contra los planes de intercambiar representantes con el gobierno de Franco. La mayoría utilizaba un texto estándar, distribuido por los órganos centrales de gobierno de las organizaciones obreras en cuestión. El volumen de cartas tuvo la suficiente entidad para provocar un comentario del propio jefe del gobierno, Per Albin Hansson explicó en la revista interna del partido socialdemócrata que había recibido docenas de cartas de protesta pero que la credibilidad de las mismas quedaba en entredicho porque todas estaban cortadas por el mismo patrón y su texto era idéntico. Hansson pidió a los remitentes que no se olvidaran de los intereses de Suecia, explicándoles que, aunque las relaciones comerciales con la España de Franco nunca se habían interrumpido, era esencial regularizarlas ${ }^{71}$.

El 3 de noviembre, el Conde de Torata fue llamado al Ministerio de Negocios Extranjeros, donde se le informó que Suecia había decidido intercambiar agentes en las mismas condiciones que lo había hecho Holanda. El 16 de ese mes pedía Valdés a Burgos poderes para poder firmar el acuerdo. El 18 de noviembre se reunió el Comité de Asuntos Exteriores del Parlamento (Utrikesnämnden) para discutir el asunto. En él, el Ministro de Comercio negó que fueran motivos económicos los que llevaban al gobierno a proponer este paso, sino el hecho de que los demás países nórdicos ya lo habían dado. Y el día 25 el gobierno sueco aprobó el intercambio de agentes con la España de Franco ${ }^{72}$.

El gobierno sueco trató por todos los medios de calmar el agitado estado de la opinión pública sueca, que recibió la noticia con pesar y descontento manifiestos,

\footnotetext{
${ }^{70}$ RA, UD, 1920-års dossierssystem, HP 36, vol. 1522, PM 6.XII.1937; Ibidem, vol. 1519; Ibidem, Vol. 1523, notas de la Legación de España de 25.X. 1938 y 18.XI.1938 y PM de 19.XI.1938, de Isabel de Palencia a Rickard Sandler sobre la reunión entre ambos del 18.XII); AMAEC R 1785, 13, despachos n. 303 y 306 de 18 y 26.X.1938, n. 330 y 331 de 12.XI.1938 y n. 350 de 19.XI.1938

${ }^{71}$ RA, UD, 1920-års dossierssystem, HP 36, vol. 1524, opinionsyttringar (opiniones), ejemplar del boletín SAP, Information $n r$ 23, 1938; AMAEC R 1785, 13, despacho n. 387 de la Legación de España, de 19.XII.1938.

${ }^{72}$ AMAEC R 1108, 1, y AMAEC R 622, 27 telegramas de Valdés a Burgos de 16.XI.1938 y contestación del 17.XI.1938; RA, Utrikesnämnden, Vol. 4, Memorialprotokoll från utrikesnämndens sammanträde (Acta de la reunión del Comité de Asuntos Exteriores), de 18.XI.1938; RA, UD, 1920-års dossierssystem, HP 36, vol. 1523, intercambio de notas de 26.XI.1938 con Valdés sobre el intercambio de agentes.
} 
insistiendo en que de ninguna manera suponía un reconocimiento oficial del régimen franquista. La opinión pública en general, y especialmente el movimiento obrero, no se dejaron impresionar por esos argumentos y consideraron la medida una claudicación en toda regla ${ }^{73}$.

\subsubsection{El agente sueco en Burgos y el reconocimiento oficial del gobierno franquista por Suecia}

La misión en la España de Franco de Nils Berencreutz, agente sueco ante el gobierno de Burgos, empezó con muy mal pie. En su primera visita a las autoridades franquistas de Asuntos Exteriores, Berencreutz se entrevistó con Ginés Vidal y con el conde de Casas Rojas. Ambos se lamentaron ante el diplomático sueco de la ayuda francesa a la República y dijeron que Franco tenía ya contactos en toda Europa. Le manifestaron su "sorpresa" ante el hecho de que el agente de Suecia no llevara cartas de presentación del Ministro de Negocios Extranjeros, sino de un funcionario de menor rango del Ministerio, Erik Boheman. Éste, valga la expresión, se hizo el sueco ${ }^{74}$.

Aunque el intercambio de notas entre los gobiernos de Burgos y Estocolmo acerca del intercambio de agentes fue del 26 de noviembre, hubo un cierto retraso en el reconocimiento oficial de los agentes: Berencreutz fue reconocido como agente sueco en Burgos el 20 de diciembre de 1938, y el conde de Torata como representante de Franco en Suecia el 22 de diciembre. No obstante, el agente español exigió posteriormente a Estocolmo una carta de presentación de Berencreutz firmada por el Ministro sueco de Negocios Extranjeros ${ }^{75}$.

Al llegar a España recibió Berencreutz una carta de un sueco residente en Sevilla, solicitando un puesto de trabajo en la nueva Agencia sueca. Lo consiguió, y Henrik Björkander comenzó así a trabajar como canciller de la misma el 30 de enero de $1939^{76}$.

La misión de Berencreutz en España duró poco, pero no por eso dejó el Agente de enviar información detallada sobre la situación en el país. En febrero enviaba un largo despacho, fruto de sus conversaciones con Luis de la Peña y de la lectura de la prensa

\footnotetext{
${ }^{73}$ AMAEC R 1785, 13 despacho n 363 de 3.XII.1938 sobre la prensa sueca en relación con el intercambio de agentes con la España de Franco; CANTERA CARLOMAGNO, Sverige och spanska..., pp. 103 y s.

${ }^{74}$ RA, UD, Beskickningsarkivet: Madrid, F1 C Vol 48. Nota confidencial de Berencreutz al Ministerio sueco de Negocios Extranjeros, de 7.I.1939; RA, UD, 1920-års dossierssystem, HP 36, vol. 1523, despacho de Berencreutz 1.II.1939.

${ }^{75}$ RA, UD, 1920-års dossierssystem, HP 36, vol. 1523, Nota Verbal del Conde de Torata al Ministerio sueco de Negocios Extranjeros, de 16.I.1939.

${ }^{76}$ RA. UD, Beskickningsarkivet: Madrid, F1 F: 6.
} 
local, sobre el asunto de las reservas de oro del Banco de España. En él escribía lo siguiente:

Me contestó que tenía datos completamente seguros sobre el particular, y que en diciembre de 1938 quedaban alrededor de 80 millones de pesetas-oro de los 2.300 a 2.400 millones que había al principio de la guerra. Además de los 80 millones, en Francia había una deposición de 250 millones de pesetas, que sin embargo estaban empeñadas como garantía de un préstamo anterior $(\ldots)$

A los representantes oficiales de la República en Méjico y Washington se había enviado la cantidad de 64 y 75 millones de pesetas respectivamente; a París, 194 millones (L. Araquistáin) y 210 millones (A. de Albornoz); a Londres 61 millones en tres partidas distintas, y 350 millones se habían enviado en avión al extranjero. Además, se habían enviado otros 663 millones más al extranjero, especialmente a Rusia, y finalmente se habían enviado 250 a Francia (Mont de Marsant). Se dice además que las compras en Méjico han sido un mal negocio, ya que el material de guerra recibido de allí era totalmente anticuado y deficiente.

Lo que queda actualmente de las reservas de oro parece estar situado en Francia, ya que según la prensa vespertina había llegado hoy a Le Perthus una serie de camiones con milicianos en fuga, y en la frontera francesa se descubrió que llevaban lingotes de oro y plata por favor de algunos cientos de millones de francos, que han sido incautados por las autoridades francesas. Según los soldados, se trataría de las últimas reservas de oro del Banco de España ${ }^{77}$.

A partir de enero de 1939 hay ya más correspondencia entre Estocolmo y Burgos que entre Estocolmo y Caldetas-Barcelona (sede del Encargado de Negocios sueco ante la República, Erik Wisén).

En febrero informó Berencreutz que Franco temía una intervención militar francesa en septiembre de 1938, durante la ofensiva franquista a Cataluña, y que había planes concretos para la evacuación de San Sebastián en caso de haberse producido ésta. Mencionaba también que la España de Franco estaba sumamente irritada con Francia por su apoyo a la República. Asimismo, informaba que las autoridades de Burgos habían desestimado propuestas de créditos provenientes de Inglaterra, Francia, Bélgica y los

\footnotetext{
${ }^{77}$ RA, UD, Beskickningsarkivet: Madrid, F1 C, Vol. 43, despacho n. 106 de 8.II.1939. Según el balance del Banco de España, el 30.VI.1936 las reservas ascendían a 2.202 millones de pesetas-oro (cfr. Gaceta de Madrid, 1.VII.1936). No entraremos aquí, por exceder el ámbito del presente estudio, en un análisis de esta cuestión, exhaustivamente estudiada en la historiografía española, fundamentalmente por Pablo Martín Aceña, Enrique Moradiellos, Francisco Olaya Morales, y, sobre todo, VIÑAS, Ángel, El oro español en la Guerra Civil, Madrid: Instituto de Estudios Fiscales, 1976; El oro de Moscú, Barcelona, Grijalbo, 1979; y, más recientemente, El escudo de la República. El oro de España, la apuesta soviética y los hechos de mayo de 1937, Barcelona: Crítica, 2007.
} 
EE.UU., y que la peseta contaba como única base los 250 millones de pesetas-oro que se habían encontrado depositados en Francia ${ }^{78}$.

También en el mes de febrero envió Berencreutz un telegrama cifrado sobre los intentos de obtener, con ayuda francesa e inglesa, una paz negociada. Asimismo, envió varios despachos, con informes acerca del avance y conquista franquista de Cataluña, la Ley de responsabilidades políticas, la promesa de que no se condenaría a quien no tuviera "delitos de sangre", la difícil situación alimenticia y la caótica situación de la frontera franco-española, las dificultades con los exiliados, etc. En uno de esos despachos pedía autorización para ofrecer ayuda sueca para la atención de los que volvían a la España franquista. El Parlamento sueco acababa de aprobar una donación de millón y medio de coronas para ayuda humanitaria a los exiliados que regresaran a España. El 27 de febrero informaba sobre la represión franquista en Barcelona y el volumen de la intervención extranjera a favor de la España de Franco ${ }^{79}$.

A primeros de marzo, Berencreutz daba cuenta de los últimos acontecimientos políticos, el caos reinante, la toma del poder por la Junta de Defensa, los rumores sobre el paradero de Negrín, etc. Durante los últimos días de marzo de 1939, aumentó aún más la frecuencia de despachos en los que el Agente sueco en la España de Franco trataba de mantener a su gobierno informado del curso de los acontecimientos. El 24 informaba por telegrama de los rumores de la capitulación de Madrid, el 27 envía un despacho sobre el comienzo de la ofensiva nacional sobre Madrid y al día siguiente sobre la entrada de las tropas franquistas en la capital ${ }^{80}$.

Aparte de esta labor informativa, hubo Berencreutz de ocuparse, como diplomático, de un aspecto delicado de las relaciones entre Estocolmo y Burgos: las gestiones para la liberación de los voluntarios suecos a favor de la República que habían caído prisioneros del Ejército franquista. El asunto venía de lejos, pues el gobierno sueco llevaba tiempo intentando conseguir el canje de varios prisioneros suecos por otros italianos, a través de la Legación republicana en Estocolmo y la sueca en Barcelona.

A primeros de febrero seguían los intentos de canje, a través de la Legación sueca ante la República española y de Berencreutz en San Sebastián - a través del Marqués de

\footnotetext{
78 RA, UD, 1920-års dossierssystem, HP 36, vol. 1523, despacho confidencial de 2.II.1939 y despacho "estrictamente confidencial" de 13.II.1939, ambos de Berencreutz.

${ }^{79}$ RA, UD, 1920-års dossierssystem, HP 36, Vol. 1508, despachos de 6, 7, 9, 10, 14, 17, 20 y 27.II.1939; AMAEC R 1039, 21.

${ }^{80}$ RA, UD, 1920-års dossierssystem, HP 36, Vol. 1508, telegrama cifrado de 10.III.1939 y despachos de Berencreutz de 3, 6, 7, 24, 27, 28 y 30.III.1939.
} 
Rialp - pero con el colapso del aparato del Estado republicano sólo quedaba tratar de conseguir la puesta en libertad de los mismos. Según los datos disponibles, se trataba de diecinueve personas, la mayoría en el campo de concentración de prisioneros de San Pedro de Cardeña. Se conserva bastante correspondencia de Berencreutz al respecto. No tuvieron el éxito deseado y hubo que esperar hasta el final de la guerra ${ }^{81}$.

Mientras tanto, ¿cuál era la actitud de Suecia respecto a un posible reconocimiento de iure del gobierno franquista?

Desde primeros de año, tras la caída de Cataluña y el exilio del gobierno republicano, muchos países se apresuraban a reconocer al gobierno de Franco o estaban en vías de hacerlo. Por entonces, el Ministro sueco en Lisboa solicitó permiso de su Ministerio de Negocios Extranjeros para hacer una visita oficial a Nicolás Franco, Embajador del gobierno de Burgos en Lisboa. Ya se ha encontrado con él privadamente, y el español había mostrado "el máximo respeto" por el gobierno socialdemócrata sueco ${ }^{82}$.

Las Embajadas suecas mantenían a Estocolmo al tanto de todo. El 14 de febrero lo hizo Suiza, y Berencreutz informaba el 21 de febrero que se esperaba el próximo reconocimiento por parte de Inglaterra y de Francia - reconocimiento que llegaría pocos días después -, así como del hecho que las autoridades franquistas habían solicitado a Noruega que también lo hiciera ${ }^{83}$.

En un despacho posterior comentaba Berencreutz que Francia e Inglaterra, sabiamente, no habían querido imponer condiciones a los españoles a cambio de un reconocimiento, y añadía:

Parece ser experiencia general cuando se negocia con españoles que raramente se obtienen buenos resultados si se intenta atarles con cláusulas específicas o mediante argumentos razonados. La mentalidad española se siente herida por este tipo de actitud, que considera una muestra de falta de confianza, y un intento de pisotear su libertad individual y de

\footnotetext{
${ }^{81}$ RA, UD, 1920-års dossierssystem, HP 36, Vol. 1507, despacho n. 389 de 27,IX.1938, de la Legación de España en Estocolmo; RA, UD, 1920-års dossierssystem, HP 36, Vol. 1508, despachos de Berencreutz de 3 y 10.II.1939 y cartas del mismo mes; RA, UD, 1920-års dossierssystem, HP 36, Vol. 1522, informe de 23.II.1939 sobre intento de intercambio de diez prisioneros suecos; Ny Dag, 1.III.1939, lista de presos en poder de Franco: Knut Danielsson de Landskrona, Harry Eriksson, de Gyttorp, Stig Nordström de Norrköping, Albin Engvall de Bollsta bruk, Harry Karlsson de Hasslö, Egon Nilsson de Trelleborg, Uno Flemström de Kramfors, Hugo Åberg de Storfors, Nils Helgesson de Karlstad, Einar Risto de Luleå, Karl Wettergren de Gotemburgo, Tage Källblad de Orsa, Artur Karlsson de Karlstad, John Eriksson de Sandviken, Gunnar Hallman de Ljusdall, Lars Berggren de Gävle, Eskil Eriksson de Håbo-Tibble, Kurt Einar Levander de Halmstad y Kurt Sörensen de Holmsund.

${ }^{82}$ RA, UD, 1920-års dossierssystem, HP 36, vol. 1523 sobre los contactos en Lisboa.

${ }^{83}$ RA, UD, 1920-års dossierssystem, HP 36, vol 1524, despachos de varias Embajadas y Legaciones suecas sobre el particular.
} 
su derecho a decidir por sí mismos. Es más eficaz adoptar una postura que muestre confianza en la parte contraria, apelando de ese modo a su caballerosidad como si ésta fuera un axioma indiscutible ${ }^{84}$.

Los ministros nórdicos se reunieron en Helsinki, y el 22 de febrero hicieron público un comunicado diciendo que seguirían una línea común "en la cuestión española". El 2 de marzo informaba el conde de Torata que el Parlamento había tratado el asunto y, en respuesta a una interpelación, Sandler había reiterado que en Helsinki los países nórdicos habían considerado conveniente adoptar una actitud de expectativa. El gobierno sueco seguía con interés el desarrollo de la situación en España pero no daría ningún paso diplomático sin ponerse en contacto con los demás países nórdicos ${ }^{85}$.

Y el 6 de marzo tuvo lugar una agitada discusión en el Comité parlamentario de Asuntos Exteriores (Utrikesnämnden), en el que los representantes conservadores abogaron por el reconocimiento inmediato al gobierno de Franco ante la oposición de los socialdemócratas, entre ellos el propio Ministro de Negocios Extranjeros, Rickard Sandler. Éstos dijeron que Suecia no necesitaba apresurarse a reconocer al gobierno franquista como gobierno de iure de España, porque aún controlaba la República parte del territorio español y no se había rendido. Además, los intereses suecos en España no eran lo suficientemente grandes para justificar tal medida ${ }^{86}$.

Tres días antes de la reunión del Utrikesnämnden, Berencreutz había insistido en la necesidad de que Suecia reconociese al gobierno franquista pues de lo contrario se vería afectado el comercio sueco. Las autoridades de Burgos presionaban también con fuerza y el Svensk-spanska nyhetsbulletin, la revista de propaganda franquista en sueco, daba una lista de de gobiernos que ya habían reconocido de iure al de Burgos y pidiendo a Suecia que se uniera a ellos ${ }^{87}$. Sin embargo, preguntada Suecia por Finlandia sobre el particular, aquella había respondido que no lo haría hasta que Madrid no fuese tomado por las tropas franquistas y existiese "un gobierno legal" $"$.

\footnotetext{
${ }^{84}$ RA, UD, 1920-års dossierssystem, HP 36, Vol. 1508, despacho de 7.III.1939.

${ }^{85}$ AMAEC R 1050, 2, despacho de Conde de Torata n. 64 de 2.III.1939.

${ }^{86}$ RA, Utrikesnämnden, Vol. 4, Memorialprotokoll från utrikesnämndens sammanträde (Acta de la reunión del Comité de Asuntos Exteriores), de 6.III.1939; RA, UD, 1920-års dossierssystem, HP 36, Vol. 1524, PM angående erkännande av Franco-regeringen såsom Spaniens regering de jure, (Promemoria sobre el reconocimiento del gobierno de Franco como gobierno legal de España), 31.III.1939

${ }^{87}$ RA, UD, 1920-års dossierssystem, HP 36, Vol. 1524, despacho de Berencreutz de 3.III.1939; Svenskspanska nyhetsbulletin, $\mathrm{n} .221$ del 31.III.1939.

${ }^{88}$ AMAEC R 1050, 2, información recibida del agente franquista en Helsinki, José Gómez-Acebo.
} 
También las organizaciones suecas a la izquierda del partido socialdemócrata seguían haciendo oír su voz, tratando de impedir el reconocimiento del régimen franquista por Suecia. El diario Social Demokraten, en articulo de fondo firmado por su director y titulado "Violencia, mentira y traición", había atacado duramente a la prensa conservadora que abogaba por el reconocimiento, y también a Inglaterra y a Francia, declarando que el reconocimiento al rebelde Franco "nunca puede hacerse demasiado tarde" 89.

Un ejemplo típico del tono empleado es la siguiente carta de la sección local de la SAC en Sigtuna, cerca de Estocolmo:

La Asamblea Anual de la Organización Sindicalista Local de Sigtuna el 3 de febrero de 1939 decidió enviar este mensaje al gobierno:

Habida cuenta de que parece completamente inútil protestar contra la postura profascista adoptada por el gobierno socialdemócrata frente a la España gubernamental, favoreciendo a los bandidos Franco, Mussolini y Hitler, la Organización Sindicalista Local de Sigtuna desea inquirir por cuánto tiempo piensa el gobierno socialdemócrata mantener su actual postura pro-fascista.

Al mismo tiempo, esta Organización pregunta a la clase obrera sueca por cuánto tiempo va ésta a seguir permitiendo este modo de actuar reaccionario.

Exigimos muestras de simpatía en forma de armas para España ${ }^{90}$.

A mediados de marzo, una delegación de hombres de negocios suecos fue a hablar con Sandler para solicitar el reconocimiento de iure del gobierno de Franco por parte de Suecia. A pesar de ello, a la luz de las experiencias anteriores y del silencio sobre el tema en la prensa socialdemócrata, el conde de Torata no se atrevía ni siquiera entonces a asegurar que el país escandinavo así lo haría ${ }^{91}$.

Finalmente, el 31 de marzo tuvo lugar el reconocimiento, por parte de los países escandinavos. En las discusiones en el seno del gobierno al respecto, Per Albin Hansson había dicho, según el ministro de Justicia Carl Gustaf Westman: "el asunto está bastante claro, si no se tienen en cuenta los aspectos sentimentales" 92 .

\footnotetext{
${ }^{89}$ Social-Demokraten, 5.II.1939.

${ }^{90}$ RA, UD, 1920-års dossierssystem, HP 36, Vol. 1524, opinionsyttringar, Sigtuna Lokala Samorganisation (opiniones, cooperativa sindical de Sigtuna).

${ }^{91}$ AMAEC R 1051, 13, despacho n. 81 del Conde de Torata de 22.III.1939.

92 RA, UD, 1920-års dossierssystem, HP 36, Vol. 1524, PM angående erkännande av Franco-regeringen såsom Spaniens regering de jure, 31.III.1939 (promemoria sobre el reconocimiento de jure del gobierno de Franco); AMAEC R 1051, 13, despacho n. 85 del Conde de Torata de 1.IV.1939; WESTMAN, Carl Gustaf, Politiska anteckningar april 1917- augusti 1939, (Ed. W M Carlgren), Estocolmo: Kungl. Samfundets handlingar, 1987, p. 187.
} 
El día 31 de marzo, el Conde de Torata comunicaba por telegrama a las autoridades franquistas el reconocimiento sueco, y el día 1 se hizo cargo de la Legación de España ${ }^{93}$.

\subsection{La actividad de la representación de la España franquista en Suecia}

En el capítulo anterior mencionamos el proceso que terminó con la retirada de la adhesión a la República por parte de todos los diplomáticos españoles residentes en Estocolmo. El Ministro, Alfonso Fiscowich, lo hizo el 8 de agosto pero seguiría actuando como Ministro de España, defendiendo ya los intereses de la España de Franco, hasta que hubo de ceder el edificio de la Legación a Isabel de Palencia a finales de enero de $1937^{94}$.

La labor política y diplomática de Fiscowich, durante esos meses, estuvo concentrada en justificar ante el gobierno sueco la legitimidad de la rebelión militar española y en tratar de impedir las buenas relaciones entre Suecia y la República Española.

Inicialmente, Fiscowich pareció tener éxito, pues el gobierno provisional de Axel Pehrsson Bramstorp decretó su neutralidad y, si hemos de creer las declaraciones del propio Fiscowich a su gobierno, hacia el final de su mandato tenía una actitud positiva ante la causa de la España franquista. A finales de agosto, Fiscowich escribía al Presidente de la Junta de Defensa Nacional de Burgos un despacho, que no deja lugar a dudas.

Según Fiscowich, el gobierno sueco continuaba manteniendo una actitud favorable hacia "nuestra causa", aunque lo hiciera con reserva y prudencia, debido a sus compromisos internacionales. Esa actitud se traducía, en la práctica en el intento de "ir relajando los lazos que le unen al Gobierno de Madrid", dando orden al cónsul Olsén de abandonar Madrid - dato que reservadamente hizo saber al diplomático español el Ministerio de Negocios Extranjeros - y procurando dilatar al máximo la concesión del placet al nuevo Ministro de España en Estocolmo que habría de sustituir a Fiscowich, solicitada por telegrama el 26 de agosto:

Por el propio Secretario general del Ministerio de Negocios Extranjeros, sé que este telegrama no recibirá contestación, y que caso de insistencia, se buscará una fórmula que, sin entrar en discusiones de principio, evite el que sea acreditado un representante del Gobierno de Madrid con el solemne y alto carácter de Ministro Plenipotenciario. Se desea y se aspira a

\footnotetext{
93 AMAEC R 1050, 2, telegrama n. 6 de 31.III.1939.

94 AMAEC, PG 0033, 15430, expediente personal de Alfonso Fiscowich, telegramas de Fiscowich al gobierno de Burgos de 12.VIII.1936, 5, 17 y 21.I.1937 y escrito al General Franco de 13.III.1937; AMAEC R 642, 2, despacho n. 57 de 8.III.1938.
} 
demostrar que no habiendo representación alguna de Suecia en Madrid no es necesario ni oportuno que la tenga Madrid en Estocolmo ${ }^{95}$.

Quince días más tarde, enviaba Fiscowich más detalles respecto a la actitud del gobierno sueco:

Es tanto más de apreciar este favorable ambiente cuanto que para formarse y mantenerse han tenido que desaparecer buen número de prejuicios de orden jurídico y religioso que en principio retardaron la consolidación del actual criterio. El Gobierno, cerca del que yo trabajo con más asiduidad y más de cerca, fue el primero en quedar impuesto de la verdad, y fue asimismo el que se adelantó a formar su criterio respecto a las ventajas que en la lucha llevaban los nacionalistas. ${ }^{96}$

¿A qué prejuicios se refería el diplomático español? Sin duda a los derivados de la no legitimidad del bando rebelde, del carácter no democrático del mismo, y su pretensión de presentarse como un régimen católico, todas ellos factores propicios a inspirar un fuerte rechazo en los ambientes suecos.

Por otro lado, era consciente Fiscowich que las cosas cambiarían con la llegada del nuevo gobierno que habría de surgir de las elecciones del 20 de septiembre, el socialdemócrata, ante el cual - decía en el mismo despacho - había que "prepararse a luchar y a convencer".

No se equivocaba Fiscowich respecto al cambio de actitud que tendría lugar tras las elecciones. El nuevo gobierno socialdemócrata sueco dejaba ya ver "la duplicidad de la política que ha seguido siempre el partido que está hoy en el poder". Sin embargo, el Presidente del Gobierno, Per Albin Hansson, "recia personalidad de especial capacidad y relieve", había asegurado a una persona de confianza del diplomático español que "Suecia no quiere comprometerse en ningún sentido; desea permanecer alejada de las repercusiones del conflicto español"97.

En octubre, el gobierno sueco concedió su placet a Isabel de Palencia como Ministra Plenipotenciaria de la República Española en Estocolmo. En el despacho que envió con tal motivo, Fiscowich escribía que era una nueva "prueba de la doblez de la política" del partido socialdemócrata. A la vez, concretaba quiénes habían sido las personas

\footnotetext{
${ }^{95}$ AMAEC R 602, 5, despacho n. 2 de 28.VIII.1936 de Fiscowich a la Junta de Defensa Nacional de Burgos. Por su importancia, reproducimos el texto completo de este despacho en el Apéndice 5.

${ }^{96}$ AMAEC R 602, 5, despacho n. 3 de Fiscowich, de 14.IX.1936.

${ }^{97}$ AMAEC R 602, 5, despacho de Fiscowich n. 19 de 12.X.1936.
} 
responsables de la postura pro-franquista del anterior gobierno: "Inspirador de ella fue el Soberano, y firme sostén de la misma el Departamento de Negocios Extranjeros, y dentro de él, mi interlocutor el Sr. Günther" ${ }^{\circ 8}$.

Sin embargo, ello no fue obstáculo para que Fiscowich continuara su labor de boicotear en lo posible la llegada de la nueva Ministra de España. Aprovechando su amistad con Günther, sembró dudas sobre la idoneidad de Isabel de Palencia como representante de España en Suecia, basándose en que ésta había retrasado su incorporación a su nuevo destino por estar realizando un viaje propagandístico por Norteamérica.

Fiscowich pone en boca de Günther la frase "el gobierno sueco no desea la llegada del agente rojo y espera que no vendrá", pero al mismo tiempo no se tomaron por parte sueca más medidas que pedir informes a la Legación de Suecia en EE.UU. sobre el viaje en cuestión. También Beck-Friis y Danielsson, cuando las tropas franquistas estaban a las puertas de Madrid, apoyaron los esfuerzos de Fiscowich para tratar de retrasar la llegada de Isabel de Palencia ${ }^{99}$.

Respecto a la actitud del Rey de Suecia, es interesante destacar que el 25 de octubre fue invitado el matrimonio Fiscowich, por el Intendente Mayor de Palacio, a una comida a la que asistiría Gustavo V. Según el relato que el diplomático hizo de la misma, su esposa - cuya familia tenía estrecha relación con la familia de la difunta Reina de Suecia - estuvo sentada al lado del Rey, que le deparó muchas atenciones y le manifestó sus vivas simpatías, invitándola a beber por "nuestra España". De sobremesa, "en larga conversación", el Rey trató con Fiscowich sobre la situación de España y le dijo: “comprenderá que nosotros no podemos ser los primeros en reconocerles, pero ya verá Vd. cómo no llegará a venir [Isabel de Palencia]"100.

Sorprendentemente, el contenido de estos despachos es desconocido, o ha sido ignorado, en la historiografía sueca acerca del papel de Suecia en la guerra civil española, y también en la española. Es evidente que, incluso si se acepta una buena dosis de exageración en las informaciones de Fiscowich - pues no cabe duda de que era especialmente importante para el diplomático resaltar el valor de sus propias gestiones, dando así prueba de su adhesión a la causa que había decidido representar -, no hay duda de que dejan en muy mala posición al gobierno de Pehrsson-Bramstorp, al Rey Gustavo V,

\footnotetext{
98 AMAEC R 602, 5, despacho de Fiscowich n. 21, de 17.X.1936.

${ }^{99}$ AMAEC R 602, 5, despachos de Fiscowich n. 23, de 23.X.1936, n. 30 de 12.XI.1936, n. 31 de 21.XI.1936 y n. 48 de 19.XII.1936.

${ }^{100}$ AMAEC R 602, 5, despacho confidencial de Fiscowich n. 26, de 26.X.1936. Sobre la intervención directa del Rey Gustavo V a favor de algunos refugiados españoles, cfr. capítulo 8.
} 
a los más altos funcionarios del Ministerio de Negocios Extranjeros y, aunque en menor medida, también al nuevo gobierno socialdemócrata. Es más, de haberse sabido entonces en Suecia, el hecho hubiera podido tener graves consecuencias para el futuro político de los involucrados.

Aparte de sus gestiones para tratar de impedir o retrasar el funcionamiento normal de las relaciones diplomáticas de Suecia con la República española, mientras pudo hacerlo, Fiscowich siguió trabajando por los intereses de la España franquista en Suecia desde su posición oficiosa. Una de las primeras actuaciones de las que ha quedado constancia fue la denuncia ante el Ministerio sueco de Negocios Extranjeros de las gestiones destinadas a la compra de armas para la República que llevaban a cabo en Suecia el Ministro de Méjico, Pérez-Gil y Ortiz, y el anarquista germano-español Augustin Souchy ${ }^{101}$.

Asimismo, a comienzos de octubre, Fiscowich puso en guardia al "Sr. Jefe del Gobierno del Estado español" del interés de algunos anticuarios suecos por antigüedades españolas, y consiguió sustraer a la atención de la prensa el paso por Estocolmo de Marcelino Pascua, camino de su destino diplomático en Moscú, además de hacer que fuera vigilado por la policía sueca durante toda la duración de su estancia en territorio sueco ${ }^{102}$.

Gran parte de la actividad de Fiscowich, como más tarde de la de Dafonte, al frente de la representación de la España de Franco en Suecia se concentró en temas relacionados de una u otra forma con la guerra civil. Un aspecto concreto, en diciembre de 1936, fue el seguimiento de las gestiones en Escandinavia de José Weissberger destinadas a la obtención de materias primas para la República española, pero también incluyeron alguna gestión de abastecimiento de la propia zona de España, como la propuesta de compra de sacos de campaña para las tropas a una empresa sueca de la ciudad de Arboga, cuyo director, Harald Wallin, se había puesto en contacto con Fiscowich ${ }^{103}$.

A mediados de diciembre informó Fiscowich por primera vez del reclutamiento de jóvenes suecos para las Brigadas Internacionales. También lo hizo al Ministerio sueco de Negocios Extranjeros, como ya hiciera en septiembre, cuando denunció algunos intentos de compra de armas para el esfuerzo bélico republicano. Al parecer, algunas personas, por error o desconocimiento, se habían dirigido directa y personalmente a la Legación para pedir visado. Mencionaba la actividad de los sindicalistas y las gestiones reservadas que hacía la policía sueca por encargo del gobierno. Hasta la fecha, "de acuerdo con las

\footnotetext{
${ }^{101}$ AMAEC R 602, 5, despachos de Fiscowich n. 3 y 5, de 20 y 26.IX.1936, respectivamente.

102 AMAEC R 602, 5, despachos de Fiscowich n. 16 de 7.X.1936 y n. 17 de 10.X.1936.

103 AMAEC R 602, 5, despachos de Fiscowich n. 39 y 41 de 5 y 7.XII.1936, respectivamente.
} 
investigaciones de la policía", habían partido unos sesenta suecos, y algunos judíos alemanes refugiados en Suecia, y el gobierno, que había recibido quejas de "no pocos de los familiares de los expedicionarios", estaba estudiando las posibilidades de combatir el reclutamiento.

El dato es interesante, pues refleja el conocimiento que Fiscowich tenía de asuntos reservados suecos, especialmente relacionados con la labor policial. También Dafonte los tenía, pues en el verano de 1937 informó del paso por Estocolmo de turistas rusos, estonios y bálticos, que en realidad prentendían alistarse en las Brigadas Internacionales, sin que la policía sueca pudiera intervenir ${ }^{104}$.

También hubo algunos ofrecimientos para combatir en los ejércitos franquistas, que Fiscowich, de acuerdo con las instrucciones recibidas por la Orden Circular del 10 de octubre de 1936, se limitó a recoger y comunicar. Entre ellas hubo algunas de gente con conocimientos militares (un experto en artillería y un oficial de reserva de la Aviación, "especialista en bombardeos y con quinientas horas de vuelo"105

A partir de enero de 1937, tras verse obligado a entregar la Legación a Isabel de Palencia, Fiscowich abandonó Suecia. Las autoridades suecas le prestaron la ayuda adicional de acoger a sus familiares como refugiados en la Legación sueca en Madrid, y uno de ellos, Ricardo Valera Fiscowich, fue evacuado a Bélgica a cargo del erario sueco ${ }^{106}$.

A partir de entonces, fue Gabriel Dafonte, el antiguo Agregado Comercial de la Legación, quien tomó el relevo al frente de la representación oficiosa de la España franquista en Suecia. En el apartado anterior expusimos la actividad de Dafonte en relación con las gestiones tendentes a conseguir el intercambio de agentes. Veremos ahora algunos aspectos del resto de su gestión.

Uno de los campos fundamentales de la representación franquista en Suecia era la labor de información y propaganda de su causa ${ }^{107}$. Para ello debía coordinar la labor que algunos individuos afines a la misma hacían en el país escandinavo, en particular el Delegado de Prensa y Propaganda, Joaquín Herraiz, representante en Suecia de Falange Española. Herraiz había sido Lector de Lengua Española en la Universidad de Estocolmo,

\footnotetext{
${ }^{104}$ AMAEC R, 602, 5, despacho de Fiscowich n. 44 de 16.XII.1936; RA, UD, 1920-års dossierssystem, Vol, 1504, carta de Fiscowich a Günther de 22.IX.1936; informe de Dafonte de 31.VIII.1937.

${ }_{105}$ AMAEC R, 602, 5, despacho de Fiscowich n. 49 de 21.XII.1936.

106 RA, UD, 1920-års dossierssystem, Vol, 1525, carta de Fiscowich al Ministerio sueco de Negocios Extranjeros de 16.VIII.1936. En este legajo hay documentación diversa sobre las medidas que tomaron las autoridades suecas para proteger a la familia del diplomático español. También hay documentación sueca en otros volúmenes del mismo archivo, especialmente los Vol. 1522, 1504 y 1505.

${ }^{107}$ El 23 de julio de 1937 acusó recibo de $50 £$ para ese fin, cfr. AMAEC R 4002, 6.
} 
y por entonces prestaba servicios en la Legación de Chile en Suecia, pero recorría Estocolmo con la bandera bicolor española en la aleta de su vehículo. Este desafuero había motivado la protesta expresa de Isabel de Palencia ante el Ministerio de Negocios Extranjeros, y algún que otro despacho de ésta al Ministerio de Estado. Herraiz era el redactor jefe del boletín propagandístico franquista Svensk-spanska nyhetsbulletin. De todas formas, las actividades de Herraiz fueron a veces demasiado lejos, ya que un despacho del Conde de Torata califica sus actividades de "perniciosas", y a Herraiz de individuo "peligroso",

Otro propagandista de la causa franquista que quedó ampliamente reflejado en la documentación diplomática fue un refugiado español llamado O'Connor. Había recibido asilo en la Legación sueca en Madrid al comienzo de la guerra y fue evacuado a Suecia en la primavera de 1977. Isabel de Palencia se quejó ante Sandler de los contactos que, desde Suecia, hacía con la España de Franco a través de Portugal ${ }^{109}$.

También colaboraban suecos en estas labores de propaganda. En los archivos se mencionan, como gente que apoyó la causa franquista, algunos nombres de personas de prestigio en el país. Algunos de ellos aparecen también en la historiografía sueca como simpatizantes también de la Alemania nazi.

Aparte de los funcionarios, diplomáticos y empresarios mencionados en apartados anteriores, destacan los nombres del pionero de la aviación sueca Douglas Hamilton, del historiador Carl Grimberg, de la baronesa Beata Maria Bonde, del profesor Samuel Hybinette, del ejecutivo del corcho Hjalmar Wicander, del escritor Ernst C:son Bredberg, del conde Erik von Rosen - que publicó artículos favorables a la España franquista en la prensa conservadora sueca - y del vicecónsul honorario de España en Estocolmo Arvid Sjöberg. Éste último contestó con un “¡Viva España!, ¡arriba España!” a la carta conminatoria de Isabel de Palencia en la que le prohibía seguir ejerciendo sus funciones de vicecónsul. Hubo también otros suecos implicados en negocios de contrabando de armas y/o de espionaje a favor de la España de Franco ${ }^{110}$.

\footnotetext{
108 AMAEC R 344, 15, telegrama n. 2 del Ministerio de Estado a la Legación de España en Estocolmo, de 13.II.1935; RA, UD, 1920-års dossierssystem, HP Vol. 14, Utrikesministerns samtal med utländska sändebud, informe de la reunión de Palencia con Sandler de 4.V.1937; AMAEC R 634, 19, despachos de la Legación de España de 31.VII.1938 y 10.XII.1938; AMAEC R 1785, 13, despachos n. 368 y 377 de XII.1938; AMAEC R 4002, 6, despachos del Conde de Torata de 9.I y 6.III.1939.

${ }^{109}$ RA, UD, Huvudarkivet, C 3 B: 273, 1937-38, telegramas cifrados n. 34 y 40; RA, UD, Huvudarkivet, C 3 B: 271, despacho estrictamente confidencial n. 61; HP Vol. 14, Utrikesministerns samtal med utländska sändebud, informe de la reunión de Palencia con Sandler de 4.V.1937.

${ }^{110}$ AMAEC R 4002, 6, despacho n. 17 del Conde de Torata de 19.IX.1938; AGMAV C. 2305, L. 10 cp. 15; AMAEC R 1058, 11, carta de 25.I.1938 de Isabel de Palencia a Arvid P. Sjöberg; AMAEC R 1039, 21,
} 
En colaboración con el escritor Ernst C:son Bredberg, la representación franquista en Suecia publicó un libro titulado El rebelde Franco y el gobierno legítimo: la tragedia española en los documentos rojos y blancos. El libro fue declarado de interés por la oficina anti-Komintern en Berlín. Asimismo, el marqués Lage Staël von Holstein, autor de varios libros, escribió otro sobre España titulado ¿Qué será de España? Las posibilidades de mediación ${ }^{111}$.

Dentro de las actividades de propaganda y contra-propaganda, merece destacarse también el aprovechamiento de la ausencia temporal de Isabel de Palencia - en misión puntual ante la Sociedad de Naciones en Ginebra - hecho por Dafonte en la prensa sueca, presentándolo como una marcha definitiva de Estocolmo de la Ministra ${ }^{112}$.

Asimismo, fue un triunfo propagandístico la asistencia de un representante de la Sociedad Española de Autores y Compositores, llamado Morcillo, al Congreso de la Confederación Internacional de esas organizaciones, en lugar de Isabel de Palencia, que se quejaba del hecho diciendo que Morcillo “ de paso hacía la apología del rebelde Franco" y que, en ese foro, la causa republicana sólo podía ser defendida por Francia, "y eso con la falta de entusiasmo que desde la guerra ponen a veces sus representantes en mantener nuestros derechos cuando se trata de asuntos crematísticos"113.

Un detalle anecdótico en las relaciones entre Burgos y Estocolmo, en relación con las actividades de propaganda y el mundo de la cultura, fue la petición de asistencia hecha por el gabinete de prensa franquista al "Instituto Nobel", poco después de comenzada la guerra, para conocer la suerte que había sufrido el premio Nobel de Literatura Jacinto Benavente. El Ministerio de Negocios Extranjeros sueco se negó a intervenir, pero no tuvo inconveniente en que lo hiciera la Academia Sueca. No se pudo averiguar nada, y al final serían las autoridades franquistas las que, el 27 de abril de 1939, informaran a Suecia que Benavente se encontraba "en buena salud y en paz con el régimen"114.

donativos de Suecia; FPI-ALJA-450-1, informe de Isabel de Palencia, sobre la cuestión del espionaje. Sobre el contrabando de armas cfr. el apartado correspondiente del capítulo 8. Acerca de las simpatías con la Alemania nazi de personas de los ambientes culturales suecos, cfr. LÖÖW, Heléne, Nazismen i Sverige 19241979: pionjärerna, partierna, propagandan, Estocolmo: Ordfront, 2004 y ÅKERLUND, Andreas, "De svenska universiteten och nazismen", Historisk Tidskrift (Sweden) 129:1, 2009, pp. 65-72.

${ }^{111}$ AMAEC R 1058, 11, despacho de 2.V.1938; BREDBERG, Ernst C., Rebellen Franco och den lagliga regeringen: den spanska tragedin i röda och vita dokument, Estocolmo: Svea Rikets förlag, 1938; STAËL VON HOLSTEIN, Lage, Vad blir det av Spanien? En medlings möjligheter, Estocolmo: Fritzes Bokförlag, 1938.

${ }^{112}$ AMAEC R 602, informe de Dafonte de 14.III.1938.

113 AMAEC R 1785, 13, despacho de la Legación de España de 28.VI.1938.

${ }^{114}$ RA, UD, 1920-års dossierssystem, HP 36 Vol 1525 y RA: UD, Beskickningsarkivet: Madrid, F1 C, Vol. 48. 
En agosto de 1937, informaba Dafonte de un hecho singular ocurrido días antes: la presentación por parte del partido socialista sueco (los comunistas independientes de Moscú), de una carta de protesta a la Legación de la República Española en Estocolmo por el encarcelamiento de militantes de "nuestra fraternal organización española P.O.U.M., así como de los partidos sindicalistas y anarquista", en lo que el diario pro-nazi Aftonbladet definió como "verdadera ironía del destino, el que la Legación antifascista se vea obligada a recibir un escrito de severa crítica de sus principales simpatizantes en Suecia". La prensa sueca, salvo el diario citado, silenció el asunto, a pesar de los esfuerzos de Dafonte de divulgar la noticia ${ }^{115}$.

A finales de octubre de 1937, el Comité sueco de Ayuda a España de Gotemburgo acordó proponer el envío del periodista y senador socialdemócrata Rickard Lindström como observador a Asturias, para entonces ya en poder de Franco, para valorar sobre el terreno la ayuda que se necesitaba como consecuencia de "los graves sufrimientos a que se ve sometida la desgraciada población civil del Norte de España después de la victoria de los rebeldes". Dafonte informó de esas intenciones, que por razones obvias no se convirtieron en realidad, aunque muchas organizaciones suecas presionaron al gobierno sueco para que fuera él quien solicitara el envío del observador ${ }^{116}$.

En noviembre de 1937 informó Dafonte del viaje a Suecia de Salvador de Madariaga y de la repercusión mediática de la Semana Española de Estocolmo organizada por la Legación republicana. La mayor parte de la prensa conservadora, por sugerencia de Dafonte, no publicó nada, mientras que el principal diario del país, el Dagens Nyheter, daba amplia cobertura al evento, si bien publicó en el mismo número una fotografía de Franco tras la conquista de Gijón. Ese diario, que según Dafonte era el que "con más tesón ha defendido a los marxistas españoles, hasta el extremo de falsear abiertamente la verdad", estaría ahora convencido de la victoria final de los Ejércitos franquistas ${ }^{117}$.

La visita de parlamentarios suecos a Barcelona fue anunciada por Dafonte a las autoridades de Burgos, y también, lógicamente, la decisión del Parlamento sueco de prorrogar por un año la ley que prohibía a los suecos combatir en España ${ }^{118}$.

En mayo, comentó que la manifestación del 1 de Mayo en Estocolmo había sido la menos concurrida de los últimos años. En ese informe, Dafonte incluía un comentario que

\footnotetext{
115 AMAEC R 602, 5, informe de Dafonte de 17.VIII.1937.

${ }^{116}$ AMAEC R 602, 5, informes de Dafonte de 1.XI.1937, 3 y 5.XI.1937.

117 AMAEC R 602, 5, informes de Dafonte de 2 y 3.XI.1937.

${ }^{118}$ AMAEC R 1058, 11, e, informes de Dafonte de 25.I.1938 y 24.II.1938
} 
había oído, con un punto de vista un tanto llamativo, si no fuera porque expresiones similares habían aparecido también en los despachos diplomáticos de la Legación de la Italia fascista en Suecia: "si el Sr. Per Albin Hansson hubiera nacido veinte años más tarde sería el mejor líder de una Suecia nacionalista”. Cabe pensar, como apuntó Malmborg, que la expresión es una muestra de la concepción egocéntrica del mundo típica de los regímenes totalitarios ${ }^{119}$.

En el verano de 1938, la empresa Norddeutscher Lloyds Svenska Aktiebolag en colaboración con el diario conservador Svenska Dagbladet organizó un viaje turístico sueco a la España franquista, hecho insólito sin parangón en la zona republicana. El Ministerio sueco de Negocios Extranjeros no tuvo inconveniente en autorizar el viaje si los suecos interesados obtenían visado de la representación franquista. Fue el último asunto en que estuvo implicado Dafonte, que abandonó Suecia para trasladarse a Bilbao y trabajar en el ministerio franquista de comercio e industria ${ }^{120}$.

El 5 de septiembre comunicó Fernando Valdés, Conde de Torata, que se había hecho cargo de la representación de la España franquista en Suecia. El día 11 fijó el domicilio oficial de la misma e inmediatamente comenzó a enviar nuevos informes a Madrid. Entre ellos, merecen destacarse el relativo a las actividades de propaganda republicana en Estocolmo, con motivo de la asistencia de dos delegados de la CNT y FAI, Horacio Prieto y Manuel Mascarell, al congreso de la SAC en Estocolmo. En él se proyectó la película propagandística La lucha del pueblo español por el pan y la libertad. Los anarquistas españoles dieron lectura a un escrito de Ricardo Sanz, jefe de la division 26, columna Durruti, dirigido a los trabajadores suecos agradeciendoles su ayuda. Daba cuenta también del llamamiento del Comité femenino para los Niños de España y de la propaganda negativa que su presidente, Anna Lena Elgström había hecho en un semanario sueco en relación con el hogar sueco de Guetaria ${ }^{121}$.

A finales de 1938 y comienzos de 1939, Valdés siguió de cerca - informando de todo ello a Burgos - los esfuerzos del Comité sueco de Ayuda a España por recopilar fondos para la ayuda humanitaria a niños y refugiados españoles. Consiguieron entre cuarenta y cincuenta mil coronas semanales, por término medio. Informaba también de un

\footnotetext{
119 AMAEC R 1058, 11, e, informe de Dafonte de 1.V.1938; CANTERA CARLOMAGNO, Ett folk av mänsklig granit..., p. 11 y s.; AF MALMBORG, Niklas, "Sverige i det fascistiska...", p. 162.

${ }^{120}$ AMAEC R 1108, 11, e, informe de 7.VI.1938 y AMAEC R 634, 19 despacho 181 de 20.VII.1938.

${ }^{121}$ AMAEC R 1108, 11, e, despachos del Conde de Torata de 11.XI, 21.IX y 18.X.1938. Respecto al hogar de Guetaria, cfr. capítulo 8. Sobre la visita de los anarquistas españoles a Suecia, cfr. PEIX GELDART, "Svenska syndikalister...",
} 
"empréstito" a favor de la España republicana, una especie de crédito abierto y anticipos a cuenta por la exportación de frutas. El banco implicado era el Stockholms Enskilda Bank, "que es el banco de la Legación roja, perteneciente a la familia Wallenberg, que aunque parezca raro protegen todas las operaciones de los rojos". Valdés les informó que el Estado español no garantizaría esos créditos ${ }^{122}$.

Otro asunto del que se ocuparon los representantes de la España de Franco en Suecia fue la información a su gobierno acerca de las menciones a España en la prensa sueca. Los últimos informes a este respecto son del Conde de Torata, diciendo que a finales de 1938 eran bastante esporádicas las referencias a España: mítines de brigadistas internacionales a su regreso, publicación de declaraciones de políticos republicanos españoles, etc. ${ }^{123}$.

En el capitulo anterior se incluye un apartado sobre la realidad política sueca en los informes de la Legación de España en Estocolmo. Procedería ahora hacer lo propio respecto a los informes de los representantes de Franco en Suecia acerca de la actualidad política del país escandinavo. Sin embargo, no hemos encontrado material suficiente para hacerlo así.

Sorprendentemente, el contraste con la actitud observada por los representantes de la República en Suecia, no podía ser mayor. Durante los años de la guerra civil, los representantes franquistas no parecen haberse preocupado en absoluto por informar acerca de la política interior sueca. Solamente hicieron alguna referencia a la política internacional de Suecia en cuanto ésta repercutía en la cuestión española.

Las elecciones suecas del 20 de septiembre de 1936, lógicamente, sí fueron comentadas por el representante franquista, por entonces Alfonso Fiscowich. Las elecciones dieron el triunfo, como era de esperar, al partido socialdemócrata, y el diplomático español comentó al respecto - utilizando ya un lenguaje imbuido de retórica franquista - que se trataba de un partido "socializante por evolución, independiente de la III Internacional, sin obedecer a los dictados soviéticos" y cuyos procedimientos en el interior se ajustaban a los de "una severa democracia, condenando toda violencia" pero al que sus intereses llevaban a "aceptar como bueno en otros países lo que en el suyo rechaza". No obstante, el partido había "hecho constar de modo terminante que gobernaría alejado de extremismos anarquizantes y subversivos".

\footnotetext{
${ }^{122}$ AMAEC R 1048, 37 e, despachos de 21.XII.1938, y de 6 y 13.II.1939; Las gestiones para hacer llegar a buen destino los fondos recaudados en Suecia para ayuda humanitaria a España dio lugar a muchos quebraderos de cabeza, viéndose involucrada también la diplomacia sueca, cfr. RA, UD, 1920-års dossierssystem, Vol. 1520. No entraremos aquí en esta cuestión, que excede del ámbito del presente estudio.

${ }^{123}$ AMAEC R 4002, 6, despachos del Conde de Torata n. 17, 22 y 39 de 19.XI, 26.IX y 15.X.1938.
} 
Atribuía Fiscowich el triunfo electoral a la "perfecta organización" del Partido socialdemócrata y a la exitosa política desarrollada en el cuadrienio anterior, que había llevado a Suecia "con una política ordenada y prudente a un cierto estado de bienestar económico". Los partidos de corte nacionalsocialista, pese a un aumento de votos, no habían conseguido escaños ${ }^{124}$

En diciembre de 1936 informaba Fiscowich que, excepcionalmente, Suecia no se había puesto de acuerdo con los otros países nórdicos ante la convocatoria de reunión del Consejo de la Sociedad de Naciones a propuesta del gobierno de Valencia. Sandler, miembro del comité para la reforma del Pacto de la Sociedad, asistiría a la misma, y en la cuestión española "va a observar y decidir sobre el terreno lo que considere oportuno". Según Fiscowich, un fruto de la reunión, en la que estuvieron presentes sólo dos ministros de Exteriores, Sandler y del Vayo, fue que el sueco sacó una mejor impresión de la situación del gobierno de la República ${ }^{125}$.

En 1937 y 1938, hay pocos despachos específicos de los representantes franquistas sobre cuestiones internas suecas. Por otra parte, es cierto que, desde la marcha de Fiscowich y hasta la llegada del Conde de Torata, no hubo en el país representantes con rango diplomático alguno. Éste último, además, estuvo sólo pocos meses al frente de la representación española, y fueron meses donde la cuestión del intercambio oficial de agentes y posteriormente del reconocimiento oficial del gobierno franquista monopolizó en la práctica todos sus esfuerzos.

Los únicos aspectos de la política interna sueca de los que informó Fernando Valdés al gobierno de Burgos, aparte de transmitir el discurso de año nuevo del Rey y uno de Sandler, fueron el gran triunfo socialdemócrata en las elecciones municipales y provinciales suecas, de septiembre de 1938, el indulto a los suecos de las Brigadas Internacionales a finales de octubre de 1938 - donde escribía que "el gobierno, que tanto simpatiza con estos elementos, se precipitó a indultarlos" - y la nueva Ley de Extranjería de febrero de 1939. El resto de las informaciones de política sueca se centraron en la política internacional: el discurso de comienzo de año del Rey, el convenio sueco-finlandés sobre el archipiélago de Åland y los comentarios de la prensa sobre el conflicto germanochecoslovaco. Además, informó a fondo de la repercusión mediática en Suecia de la liberación de Barcelona, enviando copia del artículo del Dagens Nyheter, con las

\footnotetext{
${ }^{124}$ AMAEC R 602, 5, despacho de Fiscowich n. 6, de 22.IX.1936.

${ }^{125}$ AMAEC R 602, 5, despachos de Fiscowich n. 37 de 4.XII.1936 y n. 47 de 19.XII.1936.
} 
declaraciones de los representantes en Estocolmo de ambas zonas de España, el propio Valdés e Isabel de Palencia ${ }^{126}$.

Asimismo, en otro despacho sobre la prensa sueca en relación a España, hay un párrafo más general dedicado a la política internacional del país escandinavo. Con él ponemos fin a este capítulo:

Durante la semana pasada la prensa se ha dedicado especialmente a ocuparse de la peligrosa situación internacional, comentándose en general favorablemente la decisión del Primer Ministro británico de trasladarse a Alemania para conferenciar directamente con el Führer. Sin embargo, en cierta prensa liberal, se nota un tono, si no de crítica, de reserva, y el Dagens Nyheter de esta capital de fecha 13 del corriente, en su artículo de fondo, aprovecha la ocasión para hacer elogios de la política de Eden, recordando sus distintas fases, y al hacerlo así, elogia también su actitud frente al problema español. En el artículo se argumenta en forma tal que se hace creer a los lectores que los males actuales son debidos exclusivamente a la impericia de los que recogieron la herencia dejada por el ex-Jefe del Foreign Office. ${ }^{27}$

\subsection{Las relaciones diplomáticas entre Suecia y España de abril a diciembre de 1939}

Terminamos nuestro recorrido por las relaciones diplomáticas entre España y Suecia en la década de los años treinta del siglo XX con una mirada a la situación de la inmediata posguerra española, el período que va desde el 1 de abril de 1939 y el final de ese año. Fue, sin duda, un período crucial, no sólo por el cambio de régimen político en España sino sobre todo por la situación internacional, con el comienzo de la segunda guerra mundial en septiembre de 1939.

Hemos tenido ocasión de constatar la ambivalente actitud adoptada por el gobierno de Suecia frente al nuevo régimen emergente en España, que culminó con el intercambio de agentes a finales de 1938 y con el reconocimiento oficial del gobierno del general Franco como gobierno español de jure el 31 de marzo de 1939, tan sólo unas horas antes del final oficial de la guerra civil española.

Es bien conocido, por otra parte, que las relaciones de Suecia con la España de Franco fueron difíciles. Esto se manifestó claramente a partir los tiempos del bloqueo diplomático internacional a su régimen tras la guerra mundial, culminando en el grave conflicto diplomático del 28 de septiembre de 1975, cuando el Presidente del Gobierno

\footnotetext{
${ }^{126}$ AMAEC R 1058, 11, despachos de 21.IX.1938, 3 y 29.X.1938, 3.XI.1938, 7, 16 y 27.I.1939, y 14.II.1939
}

${ }^{127}$ AMAEC R 4002, 6, despacho n. 17 del Conde de Torata, de 19.IX.1938. 
sueco, Olof Palme, llamó "asesinos de mierda" (Satans mördare) a Franco y su gobierno, y retiró a su Embajador de Madrid ${ }^{128}$. Pero, ¿cómo fueron las relaciones sueco-españolas recién terminada la guerra civil?

A los tres días del final de contienda, el Ministro de Suecia en Lisboa transmitía a Estocolmo un informe, elaborado por fuentes francesas, sobre las atrocidades cometidas por los vencedores en Barcelona. Allí se hablaba de une sourde terreur: Según el informe, a las veinticuatro horas de la caída de Barcelona, todos los alemanes y los judíos habían recibido la visita de la policía, y la Gestapo alemana había establecido sus propias cárceles, La Policía franquista, "dirigida por la Gestapo" hace lo que quiere, sin informar al gobierno". El Príncipe Carlos de Suecia se propuso entonces escribir a Franco pidiéndole que tratara con "humanidad" a los republicanos, pero considerando detenidamente el asunto, dudaba sobre la oportunidad de hacerlo. Berencreutz le sugiere que no lo haga, porque podría ser malinterpretado $^{129}$.

Poco después, la Legación sueca en Lisboa informó también acerca de los voluntarios portugueses en la guerra civil, los "Viriatos", dando la cifra de 500 oficiales y un total de 12.000 hombres, de los cuales 5.000 habrían muerto en la contienda. Estas cifras coinciden con las que aporta Anthony Beevor, bastante superiores a las de otras fuentes, como los 8.000 de Christopher Othen ${ }^{130}$.

Una semana después del reconocimiento oficial del régimen por parte de Suecia, las autoridades franquistas solicitaron el placet para un nuevo Ministro de España en Suecia, ya que Fernando Valdés, a petición propia, fue destinado a Finlandia. Las gestiones fueron rápidas y el 21 de abril, recibido el placet sueco, tomó posesión de la Legación de España el nuevo Ministro, José de Landecho y Allendesalazar. Presentó sus cartas credenciales el día 25 y sería Ministro de España en Suecia hasta $1949^{131}$.

Por las mismas fechas fue Berencreutz sustituido en Burgos por el nuevo Ministro de Suecia en España, Carl Ivan Westman. Este diplomático sueco era hermano del Ministro de Justicia Carl Gustaf Westman, que había sido Ministro de Negocios Extranjeros durante el verano de 1936. Hasta su nombramiento como Ministro en España, Carl Ivan Westman

\footnotetext{
${ }^{128}$ ARAB, Olof Palmes arkiv (archivo de Olof Palme), Vol. 2.4.0:068. El famoso discurso se encuentra reproducido en múltiples medios audiovisuales en Internet.

${ }^{129}$ RA, UD, 1920-års dossierssystem, Vol. 1523, informe de la Legación de Suecia en Lisboa, de 4.IV.1939 y documentación sobre posible protesta del Príncipe Carlos.

${ }_{130}$ RA, UD, 1920-års dossierssystem, Vol. 1523, informe de la Legación de Suecia en Lisboa, de 13.VI.1939; BEEVOR, Antony, op. cit,, p. 123; OTHEN, op. cit., p.79.

${ }^{131}$ AMAEC R 622, 27; OCHOA BRUN, op. cit., apéndice 1, repertorio diplomático: listas cronológicas de representantes.
} 
había sido Ministro sueco en Berna, y había desempeñado también una parte muy activa en la labor de la Sociedad de Naciones en Ginebra. No recibió su nombramiento para Madrid con gran entusiasmo, pues consideraba que su anterior misión en Suiza, donde había sido portavoz de una política sueca contraria al régimen de Franco, era un factor que podía influir negativamente en su misión. Por otra parte, Madrid no era un puesto de importancia para la diplomacia sueca ${ }^{132}$.

Uno de los puntos pendientes en las relaciones entre Burgos y Estocolmo era llevar a término las gestiones iniciadas por Berencreutz con el Marqués de Rialp para conseguir la libertad de la docena y media de brigadistas internacionales suecos hechos prisioneros por el Ejército franquista. Entretanto, habían aparecido nuevos nombres. Alguno, como Knut Björck o Lars Berggren, estaba preso en prisiones provinciales, pero la mayoría, estaban en el campo de concentración de San Pedro de Cardeña, donde uno de ellos, Isak Mattson, había fallecido ${ }^{133}$.

Puede resultar llamativo el conocimiento detallado que tenían las autoridades suecas acerca de los brigadistas internacionales apresados por Franco, teniendo en cuenta que en Suecia existía una prohibición legal de alistarse en ellas. Aparte de otras consideraciones que expondremos en el apartado correspondiente, basta constatar aquí que la Policía de Seguridad sueca estaba muy bien enterada de todo, en algunos casos incluso a través de informaciones directamente recibidas de la Gestapo ${ }^{134}$.

La mayoría fueron puestos en libertad en el mes de abril, y a finales de agosto de 1939 tan sólo quedaban tres: Erik Dahl, Kurt Levander y Lars Berggren. Los dos primeros fueron liberados en septiembre y el último hubo de esperar hasta 1940, y exigió la intervención directa del Ministro de Exteriores, el general Beigbeder ${ }^{135}$.

Otra cuestión bilateral entre Suecia y España, de la que se ocupó fundamentalmente el Ministro de España en Estocolmo, fue el intento español de conseguir el apoyo sueco

\footnotetext{
${ }^{132}$ CARLGREN, op. cit., pp. 138

${ }^{133}$ RA, UD, 1920-års dossierssystem, Vol. 1523, documentación sobre presos, de 6.IV, 23.IV y 6.V.1939; RA, UD, Beskickningsarkivet: Madrid, F1 C, Vol. 46.

${ }^{134}$ RA, SÄPO, Vol. 493, tyska säkerhetspolisens chef (Gestapo) till Stockholms dito (Lindell), "Lista över svenska medborgare som har setts $i$ Spanien" (Jefe de la policía de seguridad alemana Gestapo a Lindell, jefe de la de Estocolmo, lista de ciudadanos suecos que han sido detectados en España). Sigue una lista de 13 nombres con las fechas en que fueron vistos, entre febrero de 1937 y marzo de 1938. Entre ellos está el citado Isak Matsson, con la indicación de que era judío. Sobre otros aspectos, cfr. el apartado correspondiente a los brigadistas suecos en el Capítulo 8 .

${ }_{135}$ AMAEC R 1058, 11, e, despacho de la Legación de España de 3.V.1939; AMAEC R 1051, 104 e, Nota de la Legación de Suecia en España de 28.VIII.1939; Ibidem, despacho n 267 de la Legación de España en Suecia, de 30.IX.1939; Ibidem, escrito reservado del Cuartel General del Generalísimo, sección 2 n. 11403, sobre denegación de permisos para visitar los campos de concentración; Ibidem, carta del Ministro de Asuntos Exteriores Beigbeder al Ministro del Ejército, de 13.III.1940.
} 
para la candidatura de un juez español al Tribunal de La Haya. Las gestiones se realizaron con algo grado de confidencialidad. Tras El 7 de julio se entrevistó Landecho con Sandler, que le dijo que el gobierno sueco apreciaba la propuesta de acuerdo mutuo porque mostraba el interés del Gobierno español por el Tribunal permanente de La Haya y discutiría el asunto en Consejo de Ministros.

El 14 de julio, el Ministro sueco comunicó al diplomático español la aceptación del gobierno sueco al plan propuesto, diciendo expresamente que el acuerdo debería mantenerse estrictamente confidencial: Suecia y España presentarían cada uno su propio candidato al Tribunal y darían su apoyo a la candidatura del otro, cuando el asunto se planteara en la Conferencia de Oslo de finales de agosto ${ }^{136}$.

El asunto perdería su actualidad al no poderse celebrar la reunión del Tribunal en septiembre de 1939, por el comienzo de la guerra. En diciembre, se decidió no proceder, por el momento, a la renovación del mismo ${ }^{137}$.

Una vez más, un proyecto de colaboración entre España y Suecia quedaba en nada a consecuencia del estallido de una guerra, esta vez la mundial. Tema que, en sí mismo, invitaba de nuevo a la colaboración entre ambos países, en cuanto tradicionalmente neutrales. Efectivamente, tras el ataque de la Alemania nazi a Polonia, no tardarían en concretarse intentos de colaboración, como enseguida veremos.

La posición de Suecia ante la tensa situación internacional provocada tras la desmembración de Checoslovaquia y la creación del Protectorado alemán de Bohemia y Moravia en marzo de 1939, ocupó un puesto central en la atención de la Legación de España en Estocolmo.

La actitud agresiva y expansionista de la Alemania nazi, su poderoso vecino, llevó a los políticos suecos a proclamar con fuerza la política de estricta neutralidad que Suecia estaba firmemente decidida a implementar. Así lo hizo Sandler en su discurso en Fredriksten, en unión con sus colegas escandinavos, en junio de 1939, cuando ya Dinamarca había firmado un acuerdo de no agresión con Alemania.

El Ministro de Justicia, C.G. Westman, hizo lo propio en un discurso del mes de julio detallando la postura de Suecia ante la situación en el Báltico, y lo haría de nuevo, el 2 de agosto, en declaración conjunta con Sandler publicada por la prensa, en el sentido de que

\footnotetext{
${ }^{136}$ AMAEC R 622, 27, telegramas n. 27, 32, 33, 34, 35, 36 de 29.VI, 1, 3, 7, 11 y 14.VII respectivamente, y telegrama n. 39 de 23.VIII.1939.

${ }^{137}$ SOCIEDAD DE NACIONES, Diario Oficial, 1939, Records of the 20th Ordinary Session of the Assembly of the League of Nations, Plenary Meetings, p. 6; pp. 494, 500 y ss.
} 
Suecia se desentendía del conflicto ruso-finlandés motivado por la actitud de Rusia respecto de las islas Åland. De todo ello, así como del debate parlamentario sueco sobre la Sociedad de Naciones, y las relaciones de Suecia con la recién creada República de Eslovaquia, daba cuenta la Legación de España ${ }^{138}$.

Tras el cambio de gobierno en España del 9 de agosto de 1939, Landecho informó de los comentarios que sobre el nuevo gobierno habían aparecido en la prensa sueca, en particular el Stockholms tidningen, el Social-Demokraten y el Dagens Nyheter. El de este último había sido, en opinión de Landecho, "muy mesurado", pero en general el tono crítico había sido predominante. El diplomático achacaba el motivo de esa actitud a una presunta "incapacidad fundamental de los suecos para hacerse cargo de cualquier realidad a la que no que estén acostumbrados”. El Dagens Nyheter analizaba la situación española haciendo referencia a la presencia de muchos intereses enfrentados que sólo se mantenían unidos gracias a "la autoridad dictatorial del Jefe del Estado". Unas semanas antes, el mismo diario había denunciado ya las disensiones internas en la España franquista, la persecución despiadada de los vencidos y el sometimiento a Italia y Alemania ${ }^{139}$.

El 27 de agosto, Albin Hansson, el presidente del Consejo de Ministros, hizo pública la actitud sueca. Sobre sus palabras informó la Legación de España por telegrama:

En reunión pública pronunció ayer tarde presidente consejo ministros alocución expresando voluntad Suecia guardar neutralidad no habiéndose disuelto parlamento por estar tomando medidas necesarias existencia provisiones principalmente productos alimenticios suficientes largo tiempo, con lo cual ha intensificado intercambio con los demás países Norte pueda soportar bien aislamiento. Ha sido prohibida exportación e importación numerosos productos que no afectan nuestro comercio y cuya lista envío por correo. Han sido reforzadas Marina, Aviación y Artillería de costa. Reina gran nerviosismo en población que procura hacer gran acopio de víveres ${ }^{140}$.

Al día siguiente, Landecho detallaba en un despacho las medidas tomadas por Suecia en previsión de una guerra. Reinaba en Suecia una actitud de nerviosa expectativa y pesimismo ante la crisis internacional. En previsión del conflicto, que se veía como inevitable, había procedido Suecia a la prohibición de importación y exportación de mercancías sin licencia.

\footnotetext{
${ }^{138}$ AMAEC R 1058, 11, despachos de 2, 15 y 20.VI.1939; despacho de 11.VII.1939 y del 2.VIII.1939.

139 AMAEC R 1058, 11, despachos de 14 y 18 de agosto de 1939; AMAEC R 4002, 6 e, despacho de 13.VII.1939.

${ }^{140}$ AMAEC R 622, 27, telegrama n. 40 de 28.VIII.1939
} 
En la Primera Guerra Mundial Suecia había exportado a Alemania una gran cantidad de artículos no solo suecos sino también de otros países, con el resultado conocido de que los aliados extendieron a Suecia el bloqueo a que habían sometido a Alemania. Suecia quería ahora evitar esa situación, que había conllevado hambre por la necesidad de racionar los alimentos. Buscaba ahora una "neutralidad negociada", que permitiera la exportación de hierro y madera a ambos bandos a cambio de otros productos ${ }^{141}$.

Inmediatamente después de la invasión de Polonia y la declaración de guerra a Alemania por parte de Francia e Inglaterra, Landecho informaba de la postura sueca. El gobierno sueco había declarado su neutralidad "en la guerra anglo-franco-alemana" y "en la germano-polaca”. Alemania había manifestado al gobierno sueco que deseaba mantener sus relaciones comerciales con Suecia en toda su extensión. El gobierno sueco accedió declarando su intención de sostener relaciones comerciales con todos los beligerantes y dando garantías de no tomaría unilateralmente medidas restrictivas mientras se respetase su neutralidad e integridad. El gobierno alemán prometió respetar la inviolabilidad e integridad de Suecia siempre que ésta se mantuviera absolutamente neutral ${ }^{142}$.

Dos días antes, la Legación de España había comunicado al Ministerio sueco de Negocios Extranjeros el contenido de la circular n. 23 de su homónimo español, el llamamiento de Franco a la paz y a impedir la extensión del conflicto, aduciendo la experiencia de la guerra española y resaltando la "hondísima e insuperable perturbación en la economía del mundo" que una internacionalización de la guerra supondría. El gobierno sueco contestó que apreciaba altamente la iniciativa española y que estaba dispuesto a secundarla con todos sus medios, ya que celebraba "ver España entre los países que deseaban contribuir a la terminación de la actual catástrofe" ${ }^{\text {"143 }}$.

Ello dio lugar a intensos contactos entre el Ministro de España en Estocolmo y el Ministro sueco de Negocios Extranjeros Rickard Sandler. El 13 de septiembre, con ocasión de la audiencia general al Cuerpo Diplomático acreditado en Estocolmo, tuvo lugar una entrevista entre ambos, donde el diplomático español propuso una declaración conjunta hispano-sueca apelando a la paz. Landecho informó que Sandler le manifestó estar dispuesto a atender la indicación del gobierno español pero estimaba que

\footnotetext{
${ }^{141}$ AMAEC R 1058, 11, despachos de 25 y 29.VIII.1939.

${ }^{142}$ AMAEC R 622, 27, despacho n. 237 y telegrama n. 42 de 4.IX.1939.

${ }^{143}$ AGA, Asuntos Exteriores, Caja n. 523, cp. n. 11 y 12; AMAEC R 622, 27, telegrama n. 43 de 4.IX.1939.
} 
dado desarrollo de los acontecimientos era preferible atenerse espíritu llamamiento y no su letra por lo que propone publicación nota oficiosa cuyo sentido general seria expresar alto aprecio este gobierno hace aquella iniciativa y su satisfacción ver España al lado países que procuran conciliación, cuya redacción definitiva estaría encomendada a director política y a mí ${ }^{144}$.

Según la versión sueca de la entrevista, en cambio, la propuesta de alterar el texto original del llamamiento de Franco fue iniciativa del diplomático español. Deja entrever así, entre líneas, que el gobierno español deseaba la publicidad positiva que se derivaría de un reconocimiento sueco de las intenciones pacifistas y mediadoras de España pero sin comprometerse excesivamente. He aquí el texto escrito por Sandler sobre la entrevista:

El Ministro de España me transmitió el deseo de su gobierno de recibir una respuesta pública a su llamamiento del principio de la guerra. Le expliqué que yo estaba dispuesto a colaborar en un comunicado desde aquí. Él dijo que en ese caso sería bueno citar el llamamiento español de una manera general, ya que había sido elaborado antes del estallido de la guerra de las grandes potencias, por lo que su texto no respondía a la situación actual. Le dijo que, naturalmente, era mejor dar en la declaración el contenido fundamental de la respuesta oral que yo le había comunicado. Le expuse que una declaración de ese tipo sólo tendría el efecto deseado si se redactaba de tal modo que la respuesta sueca y el comunicado español estaban en total sintonía. Declaró comprender mis puntos de vista y acordamos que la redacción final se concretaría entre él mismo y el consejero Söderblom ${ }^{145}$

Cuatro días antes había tenido lugar la apertura de la reunión extraordinaria del Parlamento, donde el Rey de Suecia había dado un discurso afirmando la voluntad de Suecia de mantener su neutralidad e independencia, y su deseo de sostener relaciones amistosas con todos los beligerantes. Además, había añadido que los países neutrales tenían intereses comunes y su actitud "tendría gran importancia para la terminación de las hostilidades" $" 146$.

Eran palabras que invitaban a retomar el viejo discurso de la colaboración de los países neutrales, que tan presente había estado en la concepción de la política internacional

\footnotetext{
${ }^{144}$ AMAEC R 622, 27, telegrama n. 46 de 13.IX.1939.

${ }^{145}$ RA, UD, 1920-års dossierssystem, HP 14, Utrikesministerns samtal med utländska beskickningschefer 1938-1952, allmänna mottagningen den 13 september 1939 (audiencia general del 13 de septiembre de 1939).

${ }^{146}$ AMAEC R 622, 27, telegrama n. 44 de 9.IX.1939.
} 
de la República española en el seno de la Sociedad de Naciones. El gobierno franquista retomaba ahora esta tradición.

El tema fue objeto de discusión en la siguiente audiencia general de Sandler a los jefes de misión en Estocolmo, con motivo del torpedeamiento de dos buques suecos, que había producido viva preocupación e indignación en el país. Suecia formuló una protesta a Berlín basándose en que la celulosa no figuraba en la lista alemana de productos considerados como contrabando. Inglaterra había ofrecido a Suecia protección para sus barcos mercantes, pero Alemania había hecho saber a Estocolmo que aceptar esa propuesta sería considerado acto hostil. Sandler indicó en la reunión la conveniencia de que los países neutrales mantuvieran contacto entre sí para la mejor defensa de sus derechos. Sandler escribió también que el Ministro español "subrayó de nuevo el interés de España por la cooperación entre los países neutrales en materias de interés común". Landecho estaba preocupado por el tráfico comercial entre Suecia y España. Sandler respondió que no tenía constancia de ningún problema al respecto ${ }^{147}$.

Hasta entonces, Suecia no se sentía amenazada por las listas inglesas y alemanas de artículos considerados contrabando, porque su comercio con Alemania se efectuaba por el mar Báltico y en todo caso confiaba en llegar a un acuerdo con Inglaterra para que ésta, a cambio de recibir ciertas mercancías suecas, no pusiera trabas a la importación de determinados productos procedentes de países neutrales. Esperaba Suecia que este método de llegar a acuerdos puntuales con Inglaterra y Alemania le daría mejor resultado que abordar el asunto en términos de principio, lo cual podía ser interpretado como inclinación por alguna de las partes, poniendo así en entredicho su neutralidad. El asunto había funcionado bien hasta el 25 de septiembre ${ }^{148}$.

A menos de un mes de comenzada la guerra se había ya hecho evidente, sin embargo, que las relaciones comerciales no podrían seguir como hasta entonces. La autoimpuesta prohibición sueca de exportación o importación de productos sin licencia previa conllevó problemas para el comercio con España, por necesidades de tonelaje y de adaptarse a las exigencias impuestas por los grandes países beligerantes, especialmente Alemania. Ésta exigía de los armadores suecos la garantía del país neutral al que iban destinadas sus

147 AMAEC R 622, 27, telegrama n. 53 de 26.IX.1939; HP, UD, 1920-års dossierssystem, HP 14, Utrikesministerns samtal med utländska beskickningschefer 1938-1952, allmänna mottagningen den 26 september 1939 (audiencia general de 26.IX.1939).

${ }^{148}$ AMAEC R 622, 27, telegrama n. 44 de 9.IX.1939, n. 49 de 18.IX.1939 y n. 52 de 25.IX.1939. 
mercancías de que no las reexportarían. Igual exigencia impuso a los armadores españoles Inglaterra $^{149}$.

Este es el contexto en el que hay que encuadrar las conversaciones entre José de Landecho y Rickard Sandler sobre una declaración común de los países neutrales ante los beligerantes. En una nueva reunión entre ambos, del 10 de octubre, el diplomático español recabó conocer la opinión sueca sobre la nota española acerca del contrabando que pocos días antes había puesto en conocimiento del gobierno sueco, para su información. El sueco le agradeció la deferencia y le manifestó su aprecio por el hecho de que España, en ella, hubiera sacado a colación el tema de las relaciones comerciales entre los países neutrales. También le dijo que, por su parte, Suecia estaba considerando la forma y momento adecuados para dar a conocer sus opiniones al respecto.

Tres semanas más tarde, en una nueva reunión, el Ministro de España, "además de sacar a colación la obligatoria cuestión sobre Finlandia, volvió a insistir en su antiguo tema de enviar una nota de protesta a las naciones beligerantes, en conformidad con los usos del derecho de gentes". Sandler le contestó que Suecia seguía considerando con interés esa posibilidad pero que lamentablemente había que tener en cuenta que la cuestión había perdido actualidad y que a efectos prácticos se ganaría probablemente más por medio de acuerdos comerciales que con argumentaciones jurídicas ${ }^{150}$.

La cuestión "sobre Finlandia" a la que se refería Sandler no era otra que la tensa situación creada a consecuencia de las exigencias soviéticas respecto a este país, que conducirían al ataque ruso a Finlandia del 30 de noviembre de 1939 que dio comienzo a la Guerra de Invierno, de 100 días de duración, durante los que el país escandinavo resistió con gallardía el embate de su enemigo, muy superior en potencia militar.

El 12 de octubre comunicaba Landecho a sus superiores que había gran inquietud en Suecia, tanto en las esferas gubernamentales como en la opinión pública, ante el peligro de

\footnotetext{
${ }^{149}$ AMAEC R 622, 27, telegramas de la Legación de España n. 45 de 11.XI.1939, sobre prohibición sueca de exportación de mercancías; n. 46 de 16.IX.1939 sobre importacion de uvas españolas; n. 47 de 17.IX.1939 sobre posibilidades de comercio con Suecia, y respuesta del Ministerio español de Comercio e Industria de 29.IX.1939; n. 58, de 18.X.1939, sobre protesta española por subida sueca del impuesto de alcohol; telegramas del Ministerio español de Asuntos Exteriores a la Legación, n. 43 de 27.X.1939 sobre bloqueo de cuentas de intercambio; n. 44 y 46 de 8 y 18XI.1939 sobre comercio con la Guinea española,y contestación de la Legación por telegrama n. 66 de 21.XI.1939; telegramas de la Legación al Ministerio n. 68 y 69 de 30.XI.1939 y contestación de éste de 2.XII.1939 sobre certificados garantizando la no reexportación de mercancías suecas; telegramas del Ministerio a la Legación n. 52 de 4 .XII.1939 y n. 53 de 6.XII.1939, y respuesta de la Legación, n. 75de 6.XII.1939, sobre garantías suecas de no reexportación de productos españoles.

${ }^{150}$ RA, UD, 1920-års dossierssystem, HP 14, Utrikesministerns samtal med utländska beskickningschefer 1938-1952, allmänna mottagningen den 10 oktober 1939; allmänna mottagningen den 31 oktober 1939 (audiencia general de 31.X.1939).
} 
una posible agresión soviética a Finlandia, lo cual podría suponer que Suecia se viera envuelta en el conflicto. Suecia había tomado precauciones militares, procediendo a una "movilización disimulada". El día siguiente anunciaba que habría una cumbre de Jefes de Estado de los países nórdicos en Estocolmo, señalando que en "círculos autorizados" suecos se había comentado que el gobierno inglés había respondido negativamente a la pregunta del sueco sobre si podía contar con su apoyo en caso de que Suecia sufriera una agresión rusa ${ }^{151}$.

La cumbre de Jefes de Estado terminó con buenas palabras de solidaridad, de afirmación de la voluntad nórdica de mantenerse neutrales y de apoyo moral para Finlandia, pero quedó claro que no se había hecho ningún propósito de intento de mediación. Cinco semanas más tarde, la guerra era un hecho, y Finlandia se encontró sola. Según Landecho, las noticias de la ruptura de hostilidades en Finlandia habían causado gran impresión en Suecia, pues era creencia general que "el gobierno soviético se limitaría a presión económica y guerra de nervios".

Añadía que no era probable que Suecia prestase apoyo militar directo aunque sí suministraría armas, voluntarios, etc., como de hecho ocurrió. La opinión pública sueca estaba muy alarmada por los rumores de que Rusia aspiraba a las minas de hierro suecas y a algún puerto noruego y de que Alemania tenía también reivindicaciones respecto a Escania, la región sur de Suecia ${ }^{152}$.

La postura sueca en el conflicto ruso-finlandés fue confirmada por Per Albin Hansson el 3 de diciembre, en el que reafirmó una vez más la voluntad de neutralidad de Suecia y manifestó que la colaboración entre los países nórdicos solo tenía fines pacíficos $^{153}$.

Por las mismas fechas, la prensa alemana lanzó fuertes ataques contra el Ministro de Negocios Extranjeros sueco, Rickard Sandler, a quien acusaban de ser un obstáculo para las buenas relaciones entre Suecia y el Tercer Reich. Esos ataques tuvieron como consecuencia inmediata la sustitución de Sandler, el 13 de diciembre de 1939, por un

\footnotetext{
${ }^{151}$ AMAEC, R 622, 27, telegramas n. 55 de 12.X.1939 y n. 57 de 13.X.1939.

${ }^{152}$ AMAEC, R 622, 27, telegramas n. 60 de 22.X.1939 y n. 70 de 1.XII.1939. Suecia llegó a solicitar armas españolas para enviarlas a Finlandia, cfr. AMAEC R 622, 27 telegramas n. 79 y 80, de la Legación de España, de 18.XII.1939: "Firma Hegas, entidad sueca creada para suministrar armas Finlandia, solicita urgentemente ofertas siguientes. Primero: hasta doscientos cincuenta mil fusiles bayoneta calibre 7,62 usado Rusia q suponen cogidos rojos, con mil tiros cada. Segundo, cañones 75 cualquier ejercito con 3000 tiros cada. Tercero: Pistolas ametralladoras 9 milímetros Schmeisser; Cuarto, municiones 9 milímetros Parabellum. Preguntan cantidad y precios. Finlandia propone pago divisas libres pero agradecería parte fuera madera y pasta. Asegura esta resuelto problema tránsito".

${ }^{153}$ AMAEC, R 622, 27, telegrama n. 73 de 4.XII.1939.
} 
nuevo Ministro de Negocios Extranjeros sin afiliación a ningún partido político. El elegido era Christian Günther, el diplomático de carrera que en 1936 habría sido Ministro de Suecia en Madrid de no haber estallado la guerra civil y fue luego Secretario del Ministerio de Negocios Extranjeros sueco, donde como vimos tuvo un importante papel en las relaciones de Suecia con la España de Franco. Günther fue el Ministro sueco de Negocios Extranjeros hasta el 31 de julio de $1945^{154}$.

Llegados a este punto, nos queda tan sólo por comentar brevemente la visión general que, los diplomáticos suecos en Madrid, el Ministro Karl Ivan Westman, y el consejero de la legación Lennart Petri, transmitieron acerca de la España de Franco de la inmediata posguerra. Westman fue Ministro de Suecia en Madrid de 1939 a 1945, a excepción del período 1941-42 en que fue destinado a Finlandia. Petri fue secretario de 1939 a 1941, y volvería a España muchos años después, como primer Embajador sueco ante la recién instaurada democracia española, de 1976 a 1980.

En sus memorias, publicadas en 1996, Lennart Petri describió en tonos vivos sus experiencias en la España de 1939, su primer destino diplomático. Nada más llegar a Burgos, acompañó a Westman a Madrid, para asistir al desfile de la victoria, el 19 de mayo de 1939. Tras narrar las peripecias del viaje, narra Petri detalladamente la visita de inspección que hicieron al edificio de la Legación de Suecia en Madrid. Al parecer, estaba por dentro en un estado penoso y seguía ocupado por el canciller Björck, la novia de éste, y un buen número de personas, antiguo personal de servicio de Danielsson, un antiguo chófer de la Legación que había sido miliciano y participado en los tristemente célebres "paseos", etc.

Westman presentó credenciales en Burgos el 27 de mayo. Petri destacó la forma elegante en la que Westman evitó alzar su brazo en el obligatorio saludo fascista, haciendo en su lugar un saludo con su sombrero emplumado. La persona de Franco, con quien Westman pudo conversar un rato en francés, no impresionó a los diplomáticos suecos.

La Legación de Suecia hubo de ocuparse de ayudar a los ciudadanos suecos que se habían visto perjudicados en sus bienes durante la guerra civil. La Legación, como todas las demás representaciones diplomáticas en España, no recibió autorización para trasladarse a Madrid hasta finales de año, lo cual - unido a otros aspectos derivados de la situación del país tras la guerra, como el mal funcionamiento del correo - influyó en sus actividades. Dos ejemplos sintomáticos aduce Petri al respecto: tras el ataque soviético a

${ }^{154}$ AMAEC, R 622, 27, telegrama n. 71 de 4.XII.1939 
Finlandia, la Legación no recibió ningún tipo de información de su gobierno; y tras el relevo de Sandler por Günther como Ministro de Negocios Extranjeros sólo recibieron una corta información por telegrama pero para los detalles hubieron de esperar dos semanas ${ }^{155}$.

Al acabar la guerra, el régimen franquista se enfrentaba a un difícil panorama en el que debía sortear los abundantes problemas de tipo político, económico y social que tres años de guerra civil habían traído consigo. La situación y la importancia geopolítica y militar de España cambiarían radicalmente a partir del comienzo de la guerra mundial.

Correspondería a Westman estar al tanto, e informar a Estocolmo, acerca de las posibilidades de que España se adhiriera a los países del Eje. Westman pensaba que esa posibilidad era bastante remota, a pesar de las simpatías falangistas por Alemania e Italia y de las presiones de Hitler y Mussolini, porque España realmente no se encontraba en condiciones para afrontar una nueva guerra sin arriesgarse a una gran catástrofe económica y social.

En general, Westman se mostró crítico del régimen franquista, pero su visión no fue totalmente negativa. Informó de los enormes conflictos económicos y sociales, y de la resistencia de las clases altas a las reformas. El propio Franco, pensaba Westman, parecía convencido de la necesidad de reducir la tensión social y la Falange unificada, a pesar de todo, representaba la única fuerza organizada con una visión de futuro.

La historia reciente de España mostraba que tanto un régimen dictatorial como uno democrático habían tenido dificultades para establecer una forma de gobierno más o menos estable. Al final de su misión española, en marzo de 1941, concluía Westman que el régimen difícilmente sobreviviría una derrota de las dictaduras europeas en la guerra mundial $^{156}$.

Ponemos aquí punto final a este análisis de las relaciones de Suecia con la España de Franco durante los años treinta del siglo XX. A la luz de lo expuesto, se puede afirmar que las relaciones fueron más positivas de lo que, a la vista del desarrollo posterior de las mismas, y del masivo apoyo de la opinión pública sueca a la República española en guerra, cabría esperar. La Suecia oficial se mantuvo en una actitud de expectativa, cultivando contactos oficiosos y comerciales de bastante entidad con la España de Franco y, en suma, desarrollando una política, en consonancia con la británica, que podríamos llamar de estudiada neutralidad.

\footnotetext{
${ }^{155}$ PETRI, Lennart, op.cit., 32-52.

${ }^{156}$ RA, UD, 1920-ärs dossierssystem, Vol. 423, informes varios de Westman, mayo 1939- marzo 1941; CARLGREN, op.cit., p. 139.
} 
Hemos podido constatar también que, tras la guerra, las relaciones sueco-españolas fueron buenas durante 1939. Incluso hubo algunas tentativas de acciones diplomáticas conjuntas, en el espíritu de la colaboración entre los países neutrales tan en boga antes de la guerra civil, y que la República había fomentado.

En el capítulo siguiente expondremos detalles de la intervención de Suecia en la guerra de España, a favor de ambos bandos en litigio, aunque lo fuera de manera desigual, pues el apoyo popular sueco a la causa republicana era masivo.

Sorprende un tanto, por todo ello, que las relaciones entre Suecia y la España franquista anteriores a la condena internacional del régimen español al finalizar la segunda guerra mundial hayan sido completamente ignoradas hasta ahora por la historiografía sueca. Esto es aún más sorprendente, si se piensa en los contactos que uno de los héroes suecos de la época de la guerra mundial, Raoul Wallenberg, y su jefe en la Legación sueca en Budapest, el gran amigo de la España franquista Carl Ivan Danielsson, tuvieron con el Ministro de España en la capital húngara, Ángel Sánchez Briz, y el "cónsul” Giorgio Perlasca, de los cuales no hay referencia alguna, hasta muy recientemente ${ }^{157}$, en la historiografía sueca.

${ }^{157}$ LEVINE, Paul, op.cit., 2011, el único que menciona a Perlasca, muestra también su sorpresa al respecto. 



\section{Capítulo 8}

\section{LA INTERVENCIÓN DE SUECIA EN LA GUERRA CIVIL ESPAÑOLA}

La tercera parte de los quinientos suecos que lucharon por la democracia española entre 1936 y 1938 murió en el empeño. Lo dieron todo en Madrid, Jarama, Guadalajara, Brunete, Teruel, Aragón, Ebro. Caminante: ¡Detente! Recuérdales con orgullo ${ }^{1 .}$

\subsection{La ayuda humanitaria sueca a la España en guerra}

La actividad humanitaria sueca durante la guerra civil española, especialmente aunque no de manera exclusiva - a favor de la República, fue muy considerable, y se concretó en dos aspectos fundamentales: por un lado, en el asilo diplomático y la mediación en canjes de presos, y por otro en la ayuda económica, sanitaria y a la infancia. El primer aspecto supuso en la práctica una cierta intervención a favor de la España franquista, al proteger a personas amenazadas o perseguidas en la zona de España que permaneció leal al gobierno legítimo de la Segunda República (especialmente en Madrid).

El segundo aspecto, como veremos, favoreció de manera preponderante a la España republicana. Con todo, los motivos que llevaron a Suecia a intervenir, tanto en un sentido como en otro, fueron claramente humanitarios, aunque evidentemente hubo también consideraciones de carácter político, especialmente claras en el apoyo al esfuerzo bélico de la República.

\subsubsection{El asilo diplomático y la mediación en canjes de presos}

Curiosamente, durante bastante tiempo, la historiografía española no pareció dar demasiada importancia a los aspectos relacionados con el asilo diplomático y la mediación en canjes de presos llevados a cabo por las Embajadas y Legaciones extranjeras durante la

\footnotetext{
${ }^{1}$ Inscripción en la base de La Mano, monumento a los voluntarios suecos en la guerra civil española, en Estocolmo. La traducción es nuestra.
} 
guerra civil española. En los últimos años, no obstante, esta situación ha cambiado un tanto, especialmente gracias a los estudios de Moral Roncal ${ }^{2}$.

Como ha señalado acertadamente este autor, la magnitud del asilo, con cifras conocidas cercanas a las once mil personas, y la contratación, por las Embajadas y Legaciones o por el personal de las mismas, de locales anejos para poder albergar a sus refugiados, constituyen hechos sin precedentes en la historia de la diplomacia internacional $^{3}$.

Aunque en algunas representaciones diplomáticas, como por ejemplo en la Embajada de Chile, los beneficiarios de esta práctica del asilo fueron tanto personas perseguidas por las autoridades republicanas como, en un momento posterior, por las autoridades franquistas, esto no fue así en el caso de Suecia, que sólo acogió refugiados políticos que estaban amenazados en el Madrid republicano. Únicamente aquellas personas que tenían alguna vinculación especial con Suecia, como los cónsules honorarios o sus familias, constituyeron una excepción a esta regla general. La solicitud de refugio en la Legación sueca por parte de algunos representantes del Estado Mayor republicano en marzo de 1939 fue denegada por las autoridades suecas' al igual que otras peticiones de asilo en Suecia cursadas por algunos grupos republicanos, como un colectivo de médicos ${ }^{4}$.

Tampoco las organizaciones obreras suecas se prestaron a ayudar de esta forma a sus correligionarios españoles: la SAC, por ejemplo, respondió a la solicitud de ayuda de la CNT para que sus dirigentes pudieran refugiarse en Suecia diciendo que les gustaría poder ayudar pero que Suecia tenía

un gobierno con mayoría socialdemócrata cuya policía vigila las fronteras más que nunca y se encarga de que no entre ningún obrero revolucionario en el país. Podemos añadir al respecto que antes no hacía falta visado para que entraran en Suecia personas con pasaporte

\footnotetext{
2 Merece especial mención su reciente obra MORAL RONCAL, Diplomacia, humanitarismo..., donde analiza una por una la labor humanitaria llevada a cabo por cada Representación diplomática. A Suecia, sin embargo, le dedica solamente cuatro páginas escasas (pp. 494-497), que recogen lo sustancial del tema que nos ocupa, aunque con algunos errores, sin duda debido a la escasez de fuentes documentales que pudo consultar, entre las que no se encuentra ninguna sueca.

3 MORAL RONCAL, Antonio Manuel, "El asilo diplomático como condicionante de las relaciones internacionales de la República durante la guerra civil”, en Congreso La guerra civil Española 1936-1939, Sociedad Estatal de Conmemoraciones Culturales, 2006, p. 1.

${ }^{4}$ Cfr. RA, UD, Beskickningsarkivet: Madrid F1 C Vol. 44, y AMAEC R 1787, 18.
} 
español, pero tras la caída de Barcelona, el gobierno sueco ha publicado un decreto imponiendo el visado a todos los viajeros procedentes de España ${ }^{5}$.

La mayor parte de los Embajadores y Ministros plenipotenciarios en España habían abandonado Madrid días antes del 18 de julio de 1936, y se habían trasladado, como era costumbre entonces, a San Sebastián, donde se encontraba durante los veranos el llamado "Ministerio de Jornada". Por esa razón, salvo alguna excepción, quedó al cargo de las sedes diplomáticas en Madrid el personal subalterno: secretarios de Embajadas y Legaciones, cónsules o cancilleres, cónsules honorarios y personal administrativo. Fueron éstos quienes dieron cobijo y asilo a miles de personas, siguiendo el ejemplo y la inspiración de los Embajadores de Chile y Argentina - y de algún modo, amparados por ellos -, con la aceptación tácita del Ministerio de Estado, a cuyo frente estaba Augusto Barcia.

Fueron especialmente activos, como es bien sabido, el Cónsul de Noruega, Felix Schlayer, de nacionalidad alemana; y el agregado comercial de la embajada rumana, Henry Helfant. Ambos tuvieron una relación directa con los diplomáticos suecos ${ }^{6}$.

Danielsson, estaba a punto de abandonar su cargo en España en julio de 1936 y se había trasladado a Lisboa, capital en la que estaba también acreditado como Ministro de Suecia en Portugal, y Erik Wisén estaba en San Sebastián hasta que fue evacuado a San Juan de Luz, el 14 de agosto en el buque de guerra alemán Albatros.

El edificio madrileño de la Legación, que estaba situado en la calle Zurbano ${ }^{\circ} 25$, quedó a cargo de funcionarios subalternos, como el vicecónsul Olsén y el español Gumersindo Vallejo, hasta que el diplomático Gunnar Björck pudo hacerse cargo de la Legación. A ellos les correspondió gestionar las peticiones de asilo de diversas personas en los locales de la Legación? ${ }^{7}$.

Durante los primeros días después del 18 de julio, la atención de la diplomacia sueca se centró especialmente en la evacuación de los suecos residentes en España que quisieran

\footnotetext{
${ }^{5}$ ARAB, SAC 1845/ E6:10. Es de suponer que a la CNT le resultaría un tanto llamativo el respeto por las leyes que, a tenor de la respuesta recibida, animaba a sus camaradas de la organización anarcosindicalista sueca.

${ }^{6}$ La labor desarrollada al efecto por los diplomáticos en Madrid tuvo éxito en muchos casos. Según Cervera, consiguieron 19 concesiones de libertad de las checas hasta febrero de 1937, 288 de prisiones (45 denegadas y 58 en trámite), 32 absoluciones en tribunales populares, inútil en 4 casos y 12 en gestión. Sin aval, lograron 214 libertades en los tribunales frente a 24 denegaciones. Hallaron el paradero de 388 personas e indagaron sobre 165 que no pudieron encontrar. Fracasaron en 393 gestiones sobre asesinatos, desaparecidos o acusados de fascistas, cfr. CERVERA, op. cit., p. 352

${ }^{7}$ RA, UD, 1920-års dossierssystem, HP 36, Vol. 1525, hjälp åt enskilda, comunicado de prensa del Ministerio sueco de Negocios Extranjeros y documentos varios de julio de 1936.
} 
abandonar el país. Para ello, el Ministerio sueco de Negocios Extranjeros tomó contacto el 25 de julio con su homónimo alemán, y le pidió su apoyo logístico, que obtuvo sin dificultad. Ello no fue obstáculo para que días después, el Ministerio sueco diera orden a la Legación en Madrid de dar asilo en la misma a dos judíos alemanes que tenían relación con Suecia. El 26 de agosto, a través de Barcelona, abandonaron España por esta vía 68 suecos, entre ellos el cónsul Olsén, uno de cuyos últimos actos como tal fue interceder por la vida del hijo de una ciudadana sueca, que había sido apresado por los milicianos ${ }^{8}$.

Por otra parte, no tardaron en llegar a la Legación, ya a finales de julio y en los primeros días de agosto, algunas peticiones de asilo, entre ellas las del cónsul sueco en Málaga, que solicitó asilo para su familia, y otras personas, entre ellas varios militares.

Suecia autorizó, en primer lugar, que se acogiera en la Legación a los familiares de los cónsules suecos, y también a la familia del Ministro Plenipotenciario español en Suecia, Alfonso Fiscowich, que el 14 de agosto así lo había solicitado, en Estocolmo, al Ministerio sueco de Negocios Extranjeros ${ }^{9}$.

A primeros de septiembre, las puertas de la Legación de Suecia en Madrid se abrieron para un grupo de suecos y varias docenas de ciudadanos españoles. Seguirían llegando refugiados hasta el mes de marzo de 1937. En total, llegaría a haber 174. De ellos, 66 fueron alojados en la Legación propiamente dicha y 108 en el local que se alquiló para este fin, como anexo de la Embajada, en la Calle del Cisne n. 13.

Diez de ellos eran ciudadanos suecos, cinco alemanes, dos polacos, uno lituano y el resto españoles. Entre ellos había veintiún militares, que darían muchos quebraderos de cabeza a los diplomáticos suecos. Veintisiete refugiados eran menores de dieciocho años, incluidos algunos bebés de pocos meses, y veinticuatro eran parientes del Cónsul General de Suecia, Luis de la Peña, que se había trasladado a Valladolid ${ }^{10}$. Aparte de los refugiados

\footnotetext{
${ }^{8}$ RA, UD, 1920-års dossierssystem, HP 36, Vol. 1525, hjälp åt enskilda (ayuda a particulares), consulta al Ministerio alemán de Asuntos Exteriores de fecha 25.VII.1936, promemoria interno de 29.VII.1936, promemoria del 22.VIII.1936 e informe del Consulado sueco en Barcelona de 26.VIII.1936. La prensa alemana presentó la ayuda logística prestada a Suecia para la evacuación como un acto de sometimiento sueco a la protección alemana, lo que motivó las lógicas protestas de Estocolmo.

${ }^{9}$ RA, UD, 1920-års dossierssystem, HP 36, Vol. 1525, hjälp åt enskilda, carta del cónsul sueco en Málaga y nota reservada de Otto Johansson (funcionario del Ministerio sueco de Negocios Extranjeros) al Encargado de negocios sueco en Dinamarca para que éste se pusiera discretamente de acuerdo con su homónimo alemán ("que está al tanto de todo") a fin de llevar a buen término lo solicitado por Fiscowich. Cfr. también ibidem, instrucciones a la Legación sueca en Madrid.

${ }^{10}$ RA, UD, Beskickningsarkivet: Madrid, F1 C Vol. 45 y AMAEC R673, 13. Cfr. también CERVERA, op.cit., p. 379. Incluimos en el Apéndice 6 las listas completas de los asilados en la Legación sueca en Madrid y en el anexo de la Calle Cisne n. 13.
} 
“oficiales", durante algún tiempo se atendió también desde la Legación a otro grupo de refugiados en la calle Miguel Angel n. $17^{11}$.

Gumersindo Vallejo era el hombre de contacto entre los asilados y la Legación de Suecia, ya que muchos de ellos entraron en la misma gracias a su mediación. Vallejo era un hombre de personalidad singular, que consiguió un nombramiento de Cónsul sueco ad interim, lo que le permitió seguir llevando a cabo sus actividades. No tardaría, sin embargo, en causar serios problemas a la Legación, por sus claras simpatías por los sublevados; unas simpatías que, según todo parece indicar, no se quedaron sólo en eso.

Los primeros problemas de que tenemos constancia surgieron por el arresto de dos amigos de Vallejo, uno de ellos empleado de la filial española de la empresa sueca Electrolux, que Vallejo había ocultado en el piso - vacío - del vicecónsul Olsén. La Legación defendió a Vallejo pero trató de obtener de éste garantías de que no se involucraría más en gestiones a favor de los sublevados. De todas formas, la policía tenía los ojos puestos en Vallejo, y requería la entrega de las armas de los militares refugiados en la Legación ${ }^{12}$.

Mientras se ultimaban las gestiones para proceder a la evacuación de los refugiados, la Legación de Suecia escribió a Gumersindo Vallejo, prohibiéndole expresamente, en nombre del Gobierno sueco, que admitiera a más refugiados en la Legación. Vallejo no hizo caso, y Erik Wisén, el Encargado de negocios sueco, no dudó en informar a Estocolmo de las "manipulaciones" de Vallejo, cuya "posición política era demasiado conocida" ya que era un "colaborador activo de los nacionales", solicitando que fuera despedido ${ }^{13}$. A pesar de que a partir de entonces cesó la actividad directa de Vallejo con

\footnotetext{
${ }^{11}$ RA, UD, 1920-års dossierssystem, HP 36, Vol. 1521, informe del cónsul sueco en Barcelona Emil Beckmann, de 13.II.1937.

${ }^{12}$ RA, UD, Beskickningsarkivet: Madrid Fl C Vol. 47, carta de Björck a Wisén, de 15.X.1936: Tras darle cuenta de los hechos, escribía: "Me pidió que le acompañara a visitar al comisario general del Servicio de Seguridad para clarificar el asunto. Es bueno que se dé cuenta de la necesidad de terminar con una situación insostenible y sería deseable que firmara algún documento declarando que se abstendrá de comprometer a la Legación y a sí mismo. Problemas como los de estos últimos días deberían evitarse en el futuro. Está claro que [Vallejo] ha cometido errores y tonterías, que nos han causado muchos perjuicios, pero no puedo saber sus motivos íntimos, es posible que sean nobles en conformidad con su forma de vida, y por ello no quiero dar un juicio condenatorio de su conducta, antes bien, siento compasión de él." Cfr. también RA, UD, Beskickningsarkivet: Madrid F1 C Vol. 47, carta de Björck de 4.V.1937, elogiando la labor realizada por Vallejo y Helfant a favor de la Legación.

${ }^{13}$ RA, UD, Beskickningsarkivet: Madrid, F1 C Vol. 45, carta de la Legación de Suecia a G. Vallejo de 30.III.1937; telegrama cifrado al Ministerio de Negocios Extranjeros sueco de 14.IV.1937 y carta confidencial a Christian Günther - que durante la segunda guerra mundial sería Ministro sueco de Negocios Extranjeros - de 19.IV.1937: Entre otras cosas, escribe Wisén que en el edificio de la Legación y en el Anexo de la Calle Cisne "han sucedido algunas cosas que es mejor que nuestro país desconozca" (som det för vårt land är förmånligast att icke ha något kännedom om).
} 
los refugiados, no dejó la Legación de Suecia de tener problemas con su personal español ${ }^{14}$.

Tras las gestiones de rigor, realizadas por Wisén y Johansson - enviado al efecto por el Ministerio de Negocios Extranjeros de Estocolmo - el 4 de abril de 1937 se pudo proceder a la evacuación de los refugiados: por carretera hasta Valencia. Allí embarcaron en un buque que los llevó hasta Marsella y posteriormente llegaron a Bruselas, donde fueron internados, a cargo de las autoridades suecas hasta el final de la guerra. Los refugiados que estaban en edad militar habían tenido que firmar un documento en el que se comprometían a no escapar y a no adherirse a los sublevados.

Wisén dejó constancia de las dificultades que supuso la evacuación, debido a "la delicada situación del gobierno de Valencia ante su opinión pública, que está extremadamente en contra de estas evacuaciones", y le decepcionó profundamente que todos los refugiados incumplieran su compromiso, porque abandonaron Bélgica en cuanto pudieron para regresar a la otra zona de España ${ }^{15}$.

Hubo, sin embargo, un grupo de refugiados que no obtuvo permiso de las autoridades republicanas para la evacuación. Se trataba de los 21 militares, la mayoría de alta graduación, que cobijaba. A partir de entonces, Suecia no cejó en su intento de tratar de conseguir su evacuación. Intentó conseguir, en primer lugar, que fueran aceptados por la Legación de Noruega.

Al fracasar esa iniciativa, procuró conseguir el canje de los mismos por militares republicanos prisioneros en la España de Franco, gestiones que realizó a través del Cónsul General sueco Luis de la Peña. Complicaba las gestiones el hecho de que Suecia quería hacerlas de manera oficiosa, sin reconocer formalmente a De la Peña como su representante en Burgos, aunque era evidente que las autoridades de aquel gobierno así lo consideraban, y también que en el transcurso de las mismas varió el número de militares, pues siete de ellos abandonaron por decisión propia la Legación y uno de ellos, teniente

\footnotetext{
${ }^{14}$ RA, UD, Beskickningsarkivet: Madrid F1 C Vol. 44, carta de Björck informando de que el peluquero de la misión, un tal Nicasio Garrido, era espía, y también el portero Antolín. Cfr. también RA, UD, Beskickningsarkivet: Madrid F1 C Vol. 47, carta de Björck de 14.I.1939 sobre el conflicto entre la Legación y Helfant/Vallejo en relación con los víveres que éstos compraban a la empresa sueca Viking para el abastecimiento de comida a los refugiados de las Embajadas y Legaciones. Respecto a las actividades del Socorro Azul y del Socorro Blanco en relación con los refugiados, y al espionaje franquista en el Madrid de la guerra civil, cfr. HEIBERG, Morten \& ROS AGUDO, Manuel, La trama oculta de la guerra civil. Los servicios secretos de Franco, 1936-1945, Barcelona: Crítica, 2006, p. 186-190.

${ }^{15}$ RA, UD, 1920-års dossierssystem, HP 36, Vol. 1521, despacho n. 49 y carta confidencial de Wisén a Beck-Friis, de 9.IV.1937; RA, UD, 1920-års dossierssystem HP 36, vol. 1522 y 1525, correspondencia entre autoridades suecas y Luis de la Peña, febrero-marzo 1938. Cfr. también MORAL RONCAL, Diplomacia, humanitarismo..., p. 405.
} 
coronel Luis Rodríguez Pascual, fue objeto de trato de favor por intervención directa del Rey Gustavo $\mathrm{V}^{16}$, que estaba interesado en conseguir su liberación cuanto antes porque le conocía personalmente (Rodríguez Pascual había sido ayudante de Alfonso XIII).

El asunto fue llevado con la máxima discreción por la Legación de Suecia: las autoridades republicanas propusieron su canje por el teniente coronel Francisco Angulo, pero no llegó a llevarse a cabo porque Rodríguez Pascual llegó a la otra zona de España "por otro procedimiento". Los trece militares restantes no consiguieron abandonar la Legación hasta el final de la guerra ${ }^{17}$.

Además de por los militares refugiados en su Legación, Suecia se interesó también en otros canjes, y en alguno de los mismos tuvo éxito, por ejemplo, el del hijo del General Goded por Odón de Buen del Cos, a iniciativa del Cónsul sueco en Barcelona y con la colaboración de la diplomacia británica ${ }^{18}$.

La presencia de estos militares en la Legación de Suecia motivó fuertes críticas al gobierno sueco por parte de la prensa de izquierdas del país. El diario Ny Dag escribió que "el Ministerio de Negocios Extranjeros salva a franquistas" y que "los refugiados en la Legación son en su mayoría fascistas". Para el diario Arbetaren la actividad de la Legación de Suecia en Madrid suponía un escándalo mayúsculo: la Legación era, según el diario, "un nido de fascistas" y el Ministerio mentía para ocultar la realidad de las cosas ${ }^{19}$.

No le faltaba parte de razón a la prensa, pues lo cierto es que el Ministerio de Negocios Extranjeros sueco estaba sobre aviso del tema, y de hecho intervino rápidamente, en gestión particular ante el director del diario Ny Dag, a fin de parar las habladurías ${ }^{20}$.

La relación entre la Legación de Suecia en Madrid y los periodistas suecos no fue fácil: hubo problemas por la negativa de la Legación a que dos periodistas - que habían

\footnotetext{
${ }^{16}$ El Rey Gustavo V se empeñó también personalmente en la liberación de la tenista Josefa Chavarri, lo cual fue gestionado a través de la Legación española en Estocolmo, cfr. AMAEC R 673, 13.

17 AMAEC R 673, 13; RA, UD, Beskickningsarkivet: Madrid F1 C Vol. 45; y RA, UD, 1920-års dossierssystem, HP 36, Vol. 1522: Se conserva correspondencia al efecto entre Luis de la Peña y el Ministro Rickard Sandler, así como entre Wisén y funcionarios del Ministerio de Negocios Extranjeros sueco. Entre líneas se deja entrever que la evacuación de Rodríguez Pascual no fue llevada a cabo por conductos legales, cfr. RA, UD, Beskickningsarkivet: Madrid F1 C Vol. 44, carta "estrictamente confidencial" de G. Björck a E. Wisén de 31.V.1938, y notas autógrafas de Wisén a funcionarios del Ministerio de Negocios Extranjeros. Se conserva también una carta de los militares españoles refugiados al Rey Gustavo $\mathrm{V}$, felicitándole por su cumpleaños.

${ }^{18}$ RA, UD, 1920-års dossierssystem, HP 36, Vol. 1506, informe del viceconsulado sueco en Palma de Mallorca de 11.X.1937 y RA, UD, Beskickningsarkivet: Madrid F1 C Vol. 44, donde se dan más detalles; AGMAV C. 2328, L. 54, cp. 84

${ }^{19}$ Artículos en Ny Dag y en Arbetaren del 6.IV.1937.

${ }^{20}$ RA, UD, 1920-års dossiersystem, HP 36, Vol. 1504, telegrama de la Legación sueca en Bruselas de 3.II.1937 informa que según Camille Hyusmans, recién llegada de Madrid, gran parte de los refugiados en la Legación de Noruega, la de Bélgica y la de Suecia conspiran a favor de los rebeldes.
} 
venido a Madrid empezada la guerra y pretendían vivir en la Legación - se alojaran en ella: Se trataba de la conocida periodista Barbro Alving - alias Bang - del Dagens Nyheter y de Viola Wahlstedt Markelius del Social Demokraten ${ }^{21}$.

Barbro Alving, que ya se había dado a conocer como corresponsal en las Olimpiadas de Berlín, se quedó unos meses en España y pudo informar detalladamente de las condiciones en la España republicana ${ }^{22}$. La Legación estaba entonces haciendo gestiones para evacuar a un grupo de heridos suecos de las brigadas internacionales, y la intromisión de la prensa sueca no fue vista con buenos ojos por los diplomáticos. En sus informes al Ministerio de Asuntos Exteriores, Wisén no ocultó su irritación con el periodista Ernst Roos, de Karlstad, por dificultar la operación, además de por no haber devuelto un préstamo de dinero que había pedido al propio Wisén. Por fin, el asunto se solucionó por intervención directa de Indalecio Prieto ${ }^{23}$.

Del estudio de la documentación sueca se desprende que el asilo ofrecido por la Legación de Suecia a personas amenazadas en Madrid tuvo motivos humanitarios, no políticos. La entrada de los refugiados en la Legación fue facilitada por personajes secundarios, en ausencia de los diplomáticos responsables, aunque el anterior Ministro plenipotenciario, Danielsson, tuvo su parte en el asunto ${ }^{24}$.

\footnotetext{
${ }^{21}$ RA, UD, 1920-års dossiersystem, HP 36, Vol. 1505. Barbro Alving fue acusada por la Legación de falta de lealtad, pues se le había permitido alojarse provisionalmente en la Legación a condición de que no publicara nada sobre las condiciones en la misma. Sus artículos en la prensa motIvanon una protesta al periódico, y el Dagens Nyheter contestó negando que Alving fuera su corresponsal, ya que tenía "distinta opinión que el periódico y probablemente esté este allí invitada por el gobierno español" (PM de 15.XI.1936). El diario prometió no publicar los artículos de Alving sin el visto bueno del Ministerio de Negocios Extranjeros.

${ }^{22}$ Sobre Barbro Alving cfr. también sus memorias en ALVING, Barbro \& Ruffa, Bang om Bang, Möklinta: Gidlunds förlag, 2009; la biografía de CANTERA CARLOMAGNO, När Alving...; e YRLID, op.cit. Las impresiones de Barbro Alving y del corresponsal sueco en la España franquista Kjell Strömberg fueron recogidas en una entrevista de radio conjunta en la BBC londinense en mayo de 1937 (cfr. KB, SMDBarkivet, SR.Minnen 2009-09-25, entrevista del 13.V.1937 en la BBC con Barbro Alving y Kjell Strömberg).

${ }^{23}$ RA, UD, Beskickningsarkivet: Madrid, F1 C Vol. 45, cartas de Wisén a Staffan Söderblom (funcionario del Ministerio sueco de Negocios Extranjeros) de 4.X.1937 y contestación de Wisén a la carta de Svenska sjöfolksförbundet de 19.X.1937. cfr. ibidem, telegrama de Wisén a Prieto de 22.XI.1937 y respuesta de éste de 23.XI.1937. El pasaporte colectivo del 1 de enero de 1938, con fotos de los brigadistas heridos que se repatriaban, se ha conservado. Eran Per Olof Ahlstrand, Hjalmar Björnstad, Malte L Eldh, Lars Larsson, John albin Malmqvist, Rudolf Nilsson, Gustav Ottosson, Bertil Sommelius, Eric Svensson, John Svensson, Sixten Olsson (Rogeby) y Hjalmar Stridsberg.

${ }^{24}$ Carl Ivan Danielsson ayudó mucho al Cónsul noruego Schlayer en la labor con los refugiados. Cfr., AGA, Asuntos Exteriores, Caja 5290 despacho n. 90 de la representación franquista en Oslo de 29 julio 1937, e informe de la Jefatura suprema de la Cruz Roja de la España franquista a la Secretaria de Relaciones Exteriores de Burgos, de 26.VI.1937: "Se complace en comunicarle que el antiguo representante de Suecia en Madird se ocupa con interés de la suerte de nuestros compatriotas refugiados en dicha legacion de Noruega, incluso de los militares, cuya evacuacion es mas dificil y que este interés podria contrarrestar la negativa que para esos efectos parece deducirse del nombramiento que acaba de hacer el gobierno de Noruega como encargado de neg de su pais en Valencia al Sr Erling Ness”. Cfr. también MORAL RONCAL, Diplomacia, humanitarismo..., pp. 494-497.
} 
Al respecto, la Ministra de España en Suecia, Isabel de Palencia, no pudo sino lamentar el hecho de que el pabellón sueco hubiera dado cobijo a "espías y fascistas" 25.

\subsubsection{La ayuda material sueca a la España en guerra}

El otro gran campo de la actividad humanitaria sueca durante la guerra civil fue la ayuda económica, sanitaria y a la infancia, que se canalizó principalmente a través del llamado Comité Sueco de Ayuda a España (Svenska hjälpkommittén för Spanien, que en lo sucesivo citaremos por sus siglas suecas SHfS), conocido popularmente en Suecia como la Spanienhjälpen, la "Ayuda a España”. Esta organización se convertiría en el primer gran movimiento de solidaridad internacional del movimiento obrero sueco.

\subsubsection{El Comité Sueco de Ayuda a España}

Isabel de Palencia dejó escrito un gran panegírico de la actividad del SHfS:

El Comité sueco de Ayuda a España desarrolló una actividad incansable de apoyo a las mujeres y niños españoles en mucha mayor medida de lo que cabría esperar del tamaño y del número de habitantes del país. Cuando yo todavía estaba al cargo de la Legación presentó el senador Georg Branting, presidente del Comité, un proyecto especialmente interesante para liberar de los campos de concentración franceses a algunos miles de refugiados, campesinos españoles, y transportarlos a Méjico bajo vigilancia sueca. Pero el plan quedó en nada por el estallido de la guerra europea ${ }^{26}$.

El Senador Georg Branting ${ }^{27}$ fue el hombre clave del SHfS y el contacto más importante con el que pudo contar la Legación de la República Española en Estocolmo durante la guerra civil. Ya hemos tenido oportunidad de comentar su actuación como abogado de la Legación en el pleito entablado contra el anterior Ministro de España en

\footnotetext{
${ }^{25}$ LUNDBERG, op.cit., p. 32. Isabel de Palencia no aceptó el asilo político que le fue ofrecido por el Gobierno sueco al terminar la guerra, cfr. KOLLONTAI, Aleksandra, Aleksandra Kollontajs dagböcker 1930-1940 (Los diarios de Aleksandra Kolllontai de 1930 a 1940), Estocolmo, 2008, p. 580.

${ }^{26}$ PALENCIA, Isabel de, Spanien mot friheten (Smouldering freedom), Estocolmo: Medén, 1946, p. 44.

27 Georg Branting (21.IX.1887-6.VII.1965) fue un político sueco del ala izquierda del partido socialdemócrata. Miembro de la Cámara Alta (primera cámara) del Parlamento sueco (1932-1961) e hijo del conocido político socialdemócrata y primer Ministro sueco en los años veinte, Hjalmar Branting. Fue fundador del Banco Sueco-Soviético y conocido abogado de Estocolmo. Por su postura cercana a las ideas comunistas y su decidido apoyo a la causa de la República Española - la Compañía sueca del Batallón Thäelmann en la XI Brigada Internacional llevó su nombre - tuvo que abandonar su puesto en la Junta Directiva del partido socialdemócrata sueco. Según datos recientemente publicados, durante la segunda guerra mundial, Georg Branting llevó a cabo actividades de espionaje para la NKVD soviética bajo el sobrenombre "Senator". Cfr. ENGLUND, Peter, "Om Sven, Senator och Orestes", prólogo al libro de AGRELL, Wilhelm, Venona: spåren från ett underrättelsekrig, Lund: Historiska Media, 2003.
} 
Estocolmo para desalojar a éste de los locales de la Legación. En cuanto representante del SHfS viajó con frecuencia a la España republicana, durante la guerra, y al menos en dos ocasiones se entrevistó con Manuel Azaña, que en sus Diarios escribió de él lo siguiente:

En Valencia, muchas visitas. Entre otras, la del senador sueco Branting, a quien ya había recibido en Madrid el verano pasado. Viene a España con frecuencia, con motivo de las funciones de socorro a los niños y su envío al extranjero, que realiza una organización internacional de la que forma parte. Hemos hablado un buen rato. Considera que nuestra causa es también la de los países escandinavos. En su país, el ochenta por ciento de la opinión pública está a nuestro favor. Damos algunas vueltas al comité de Londres, al de la reunión de Ginebra, etc. Branting se fía de todo esto tan poco como yo. Respecto de lo que pudiera hacerse en la Sociedad de Naciones, me dice que el Gobierno de su país tiene que seguir la política de Londres ${ }^{28}$.

La fundación y actividad del SHfS es un tema detalladamente estudiado en la historiografía sueca. El Partido Socialdemócrata sueco (SAP) y la Unión de Sindicatos (LO) había dado los primeros pasos llamando a una gran colecta de fondos a favor de España, como resultado del apoyo de la Segunda Internacional y de la Internacional de Sindicatos al gobierno de la República Española en las Conferencias de París en el verano de $1936^{29}$. Por iniciativa comunista surgió asimismo el Comité de Coordinación de la ayuda humanitaria internacional a España, uno de cuyos miembros era Georg Branting.

Por su parte, la SAC, en estrecho contacto con la CNT durante los años anteriores a la guerra ${ }^{30}$, trató de aunar esfuerzos con las otras organizaciones vinculadas al movimiento obrero sueco para ayudar a España, aunque solamente consiguió unirse con el SP, el partido comunista sueco independiente de Moscú.

El resto de las organizaciones, especialmente las vinculadas a la socialdemocracia sueca, no mostraron interés oficial alguno por unirse a una acción de ayuda conjunta, ya que no les aportaba nada especial - por bastarse a sí mismas en cuanto agrupadoras de la

\footnotetext{
${ }^{28}$ AZAÑA, Obras..., p. 1096, anotación de 16.VIII.1937.

${ }^{29}$ Además de la aportación una aportación directa de 50.000 coronas suecas que la Unión General de Sindicatos LO dio al Fondo Internacional de Solidaridad, los sindicatos dependientes de la misma también reunieron fondos, así como las organizaciones dependientes de la central sindicalista de tipo anarquista, SAC. cfr. LUNDVIK, Solidaritet och partitaktik..., p. 52 y ss.

${ }^{30}$ En el Archivo del Movimiento Obrero sueco (ARAB) existe abundante y detallada documentación sobre estos contactos, que bien merece un estudio monográfico especial, ya que excede del ámbito del presente trabajo. De especial interés para el estudio de la actividad de la CNT antes de la guerra civil y durante la contienda son los legajos ARAB, SAC, 1845/ E6:7 y 1845/ E6:10; ARAB, Albert Jensen, 275/7; y ARAB, SAC, SAC-berättelser 1937-39, "Den spanska kampen" (Memorias de actividades de la SAC 1937-1939, "la lucha española").
} 
mayor parte del movimiento obrero sueco - y para evitar acusaciones de connivencia con el comunismo ${ }^{31}$.

Sin embargo, algunos políticos del ala izquierda del partido socialdemócrata - Georg Branting con su hermana y su madre, el director de periódico Zeth Höglund, los catedráticos Israel Holmgren y Herbert Tingsten, etc. - mostraron una actitud más abierta hacia las ofertas de los comunistas y socialistas de colaboración a favor de España, y el 9 de octubre de 1936 fundaron el SHfS, al que pronto se unieron también los sindicalistas de la SAC. No tardaron en organizarse comités locales, por iniciativa del SHfS, que llegaron a ser más de doscientos en noviembre de $1936^{32}$.

Durante los años de la guerra civil española, el SHfS llevó a cabo en Suecia una intensa labor propagandística a favor de la República española - reuniones, mítines, manifestaciones, recogida de firmas, actos culturales, etc. - y una colecta de fondos destinados a prestar ayuda humanitaria a la España en guerra. Los pormenores de su actividad en Suecia han sido descritos en detalle en la historiografía sueca ${ }^{33}$.

El SHfS consiguió, sin duda, canalizar la opinión pública sueca en un movimiento sin precedentes de solidaridad internacional. Sin embargo, desde el punto de vista estrictamente económico, las cantidades reunidas fueron modestas - en total, alrededor de 5.700.000 coronas - sobre todo si se comparan con las recolectadas para Finlandia en 1939-40, que fueron muy superiores ${ }^{34}$.

\footnotetext{
${ }^{31}$ LUNDVIK, Solidaritet och partitaktik..., p.55-57. Por otra parte, las esperanzas de la CNT de conseguir ayuda de sus correligionarios suecos en forma de material de guerra se vieron pronto desengañadas, cfr. carta de Augustin Souchy al secretario general de la SAC, John Andersson en agosto de 1936, y la contestación de éste, en ARAB, SAC, 1845/ E6:7.

${ }^{32}$ ARAB, SHfS, Spanienhjälpen (La ayuda a España), Actas. Cfr. también LUNDVIK, Solidaritet och partitaktik..., p.58-61 у p. 75-77.

${ }^{33}$ Aparte de la clásica obra de LUNDVIK tantas veces citada cfr. SVENSKA HJÄLPKOMMITTÉN FÖR SPANIEN, Spanienhjälpen: en redogörelse över Svenska Hjälpkommitténs för Spanien verksamhet under tiden 9 oktober 1936-31 augusti 1938, Estocolmo: SHFS, 1938; LUNDBERG, op.cit., pp. 109.126; WEIJDEGÅRD, Nils, "Spanienhjälpen - några minnesbilder", en HELGESON Patrik, JÄNDEL Richard, WEIJDEGÅRD Nils (coord.), iNo pasarán!: spanska inbördeskriget och uppgörelsen med fascismen. Linköping: Nixon, 2008, pp. 110-122; MATTSON, op. cit.; Sobre la participación del partido comunista sueco en el SHFS cfr. JÖNNSON, Claes-Göran, "SKP och den svenska spanienrörelsen", en Arkiv, 4,/1973, Lund: Sociologiska Institutionen.

${ }^{34}$ El jornal medio de un obrero sueco en 1936-38 estaba en torno a las 11 coronas suecas, cfr. LUNDVIK, Solidaritet och partitaktik...., p. 93. Las cifras oficiales dadas por el SHFS en su momento (cfr. SHFS, Spanienhjälpen: en redogörelse över Svenska Hjälpkommitténs för Spanien verksamhet under tiden 9 oktober 1936 - 31 augusti 1938, Estocolmo: SHFS, 1938, pp. 55-59) contienen algunas partidas un tanto llamativas: por ejemplo, 25000 coronas en 1937 en concepto de "regalos de Navidad a los niños españoles", cifra casi equivalente a la empleada en material sanitario y a la destinada a sueldos y gratificaciones. Si se tiene en cuenta que costaba 40 coronas mensuales apadrinar un niño en los hogares españoles, parece inevitable plantearse la pregunta sobre el tipo de regalos al que la partida se refiere (¿acaso material bélico?). Contribuye asimismo a ello el hecho de que no existen recibos por esos gastos, como el propio Branting
} 
Al mismo tiempo, no cabe olvidar que no todas las ayudas a España fueron canalizadas a través del SHfS, como era el caso de las cantidades recolectadas por la SAC o por el sindicato $\mathrm{LO}^{35}$. Las ayudas oficiales de los organismos públicos, por su parte, fueron distribuidas preferentemente a través de la Cruz Roja ${ }^{36}$.

También hubo ciertos intentos de hacer llegar fondos de ayuda a través de las grandes empresas suecas con intereses en España, aunque éstas se mostraron a veces reticentes, y en algún caso apoyaron directamente al bando sublevado ${ }^{37}$.

La Legación de España en Estocolmo tuvo siempre palabras de alabanza para la labor de recogida de fondos del $\mathrm{SHfS}^{38}$.

¿A qué fueron destinados esos fondos? Una parte de los mismos fue destinada a víveres, en forma de alimentos, medicinas y otras mercancías para aliviar las necesidades en la España republicana. Al menos en un caso, en Santander, consta que fueron entregados personalmente a las autoridades competentes por representantes suecos del SHfS, Stefan Oljelund y Nils Holmberg, que dejaron constancia por escrito de sus impresiones. En algunos casos, la generosidad sueca fue inmediata, como en el caso del

reconoce en carta a Holmgren de 27.I.1937: "no hemos recibido recibos [por los regalos a los niños], al parecer no se estila hacerlo" ("det tycks inte gå till på det sättet"), cfr. ARAB, Georg Brantings arkiv 90/11.

${ }^{35}$ La Unión de Sindicatos (LO) organizaba sus propias colectas, que hacía llegar al Fondo de Solidaridad Internacional, cfr. ARAB, Landsorganisationen LO, Landssekretariatet, directiva del 26.X.1936. La SAC enviaba dinero directamente a la CNT. Del agradecimiento español por las ayudas ha quedado rastro documental, cfr. ARAB, SAC 1845/ E6:7, carta de la UGT al Comité de la SAC de Estocolmo, y carta de Horacio Prieto a la SAC: "Somos deudores de reconocimiento y admiración a vuestra organización, que con sentimiento noble y solidario con la revolución española ha dado pruebas de sentir común y capacidad de cooperación hasta ahora desconocidas en la historia del proletariado" (Madrid, 26.IX.1936).

${ }^{36}$ RA, UD, 1920-års dossiersystem, HP 36, vol. 1519. Como dato curioso, se conserva un informe "estrictamente confidencial" del Ministro de Suecia en España, Erik Wisén, de fecha 3 de junio de 1937, desaconsejando al gobierno sueco colaborar con la Cruz Roja española porque, según el diplomático, ésta no era imparcial, sino que favorecía a la España republicana escondiendo armas y de otras maneras. Respecto a las ayudas oficiales suecas entre enero y marzo de 1939, cfr. RA, UD, 1920-års dossiersystem, HP 36, vol. 1520 , humanitär verksamhet.

${ }^{37}$ AMAEC R 1048, 34 (expediente titulado "Suministros rojos, guerra civil española" de la Representación franquista en Estocolmo): en 23.I.1938 informa de la reunión de Branting con la Commission internationale de Ravitaillement des populations civiles d'Espagne, que había mandado una circular a empresas suecas pidiendo dinero, y también señalaba que otras empresas suecas ayudaban a la International Cooperative Alliance y a The Kenfig Pool Co., que enviaba paquetes de alimentos para España. Cfr. también las quejas de Isabel de Palencia contra la Svenska Lloyd, en AMAEC R 642, 2, despacho n. 57 de 8.III.1938; y la negativa de las empresas $A G A$ y Electrolux a ayudar a distribuir fondos reunidos por las organizaciones obreras de Suecia, en RA, UD, 1920-års dossiersystem, HP 36, Vol. 1525.

${ }^{38}$ Un ejemplo entre muchos en AMAEC R 1785, 13: "El pueblo sueco no cesa en su labor humanitaria para con la España Republicana. Södertälje ha reunido 40.000 coronas para España, unas 3.000/habitante". Cfr. también AMAEC R 642, 2, despacho de 8.III.1938, n. 57, donde la Legación escribe que los donativos de los partidos de izquierda suecos a la República son proporcionalmente superiores a los otorgados por cualquier otro país, con la excepción de la URSS. 
envío de víveres a Bilbao en el vapor Sil, para el que se recogieron 200.000 coronas en Estocolmo y Gotemburgo en tan sólo veinticuatro horas ${ }^{39}$.

Sobre los envíos de mercancías informaron cumplidamente las representaciones diplomáticas de ambas zonas españolas en Estocolmo. Un ejemplo paradigmático fueron las gestiones de Ernst Toller para obtener viveres para España:

Dice Estocolmo: Num 3. Comunista alemán Ernst Toller organiza paises escandinavos colecta a favor ancianos, niños, mujeres ambas partes españolas como preliminar campaña EEUU ayuda democracia roja España roja. Prensa publica declaración de que estuvo en ambos frentes. Aunque supongo no es cierto, ruego vuecencia se sirva decirme con urgencia si puedo desmentirlo asi como que este autorizado a enviar fondos a la España Nacional. Colecta se anuncia como apolítica pero se hace de acuerdo con Comité Suecia ayuda España roja intimamente relacionada con Legacion roja ${ }^{40}$.

Por otra parte, los servicios franquistas de espionaje llevaron a la detención y reconocimiento de muchos barcos suecos con mercancías para la España republicana: el Bernicia fue detenido 3 veces, el 14.V.37, 30.V.37 y 2.IX.37, con pulpa de madera, 2337 toneladas de fosfatos y pulpa de madera; el Brissen el 8.III.1937 y el Britta el 16.III.37, con esparto y carbón, respectivamente; el Greth el 13.XI.1936 con patatas, el Hedda el 21.III.38 con esparto, el Hildur 21.III.38 con carga no especificada, el Iberia en 3 ocasiones (24.IV.37, 9.X.37 y 8.XII.38) con naranjas, 1.400 toneladas de pasta de papel y efectos varios; el Lechistan el 15.IV.37 con algodón, fruta y minerales; el Massilia el 4.VII.37 con madera; y el Valencia en 5 ocasiones (el 18.IV.37, 24.II.37, 1.I.38, 31.I.38 y 4.VI.38) con naranjas, tortas de cacahuetes, pasta de madera y carga sin especificar ${ }^{41}$.

El gobierno sueco protestó ante las autoridades españolas por estas detenciones de barcos suecos ${ }^{42}$.

\footnotetext{
${ }^{39}$ CDMH, PS-Santander E, 100; AMAEC R 577,4, copia del despacho n. 125 de la Legación de España en Estocolmo, de 22.V.1937.

${ }^{40}$ AMAEC R 1108, 1, telegrama cifrado n. 396 de la Embajada española en Berlin, de 21.X.1938; cfr. también AMAEC R 634, 17 despacho n. 311 de 30.X.1938.

${ }^{41}$ AGMAV C.2063, Cp. 80/5, 8, 10 y 15. También informó el SIFNE de la recogida de carga en Hamburgo por el vapor sueco Robert; de la llegada a Port Vendres del Gnydia con 600 toneladas de pasta de papel en 1936 (cfr. AGMAV, C.2481, Cp.13/13 y 25); de la presencia en Port Vendres el 15.1.37 del barco sueco Scania (procedente de Gotemburgo llevando 1100 ton de pasta de papel para Barcelona) y del Scarp en septiembre de 1937 con cargamento de madera; así como de la intención del SKfS de enviar víveres a Bilbao en un barco sueco el 29.IV.1937 (cfr. AGMAV C.2472, Cp. 18).

${ }^{42}$ RA, UD, Beskickningsarkivet: Madrid F1 C Vol 48, PM angående svenska regeringens protester emot franco-styrkornas övergrepp på svenska fartyg (Promemoria sobre las protestas del gobierno sueco contra los
} 
Aparte de los víveres, la ayuda principal se concretó en dos tipos de iniciativas, que constituyeron la principal aportación humanitaria sueca a la España en guerra: el hospital militar sueco-noruego de Alcoy, y las casas de acogida de niños huérfanos en Francia y en España (Denia, Teyá y Guetaria).

Georg Branting dejó escrito en su cuaderno de trabajo, después de una exposición detallada de la labor del SHfS, las siguientes palabras: “¿Qué es todo esto? ¡Algo nuevo! Nada de revoluciones, sino actividad organizada"43.

\subsubsection{El hospital sueco-noruego de Alcoy}

Una parte importante de la actividad humanitaria sueca consistió en ayuda sanitaria, en forma de ambulancias y, en colaboración con los organismos de Ayuda a España noruegos, el hospital sueco-noruego de Alcoy ${ }^{44}$. La iniciativa empezó a gestarse en enero de 1937, cuando Nils Silverskiöld (1888-1957), médico de ideas izquierdistas, de familia noble, conocido ortopeda y profesor universitario sueco, recibió el encargo del SHfS de organizar un hospital de campaña en la España republicana.

Tras reunirse con el Comité noruego en Estocolmo, el 3 de febrero de 1937, se acordó llevar a cabo esta iniciativa como actividad conjunta, repartiéndose equitativamente gastos y personal. Establecidos los contactos con las autoridades del Ministerio de Sanidad, dirigido por Federica Montseny, se determinó aceptar la propuesta española de equipar un hospital grande, de seiscientas a mil camas. Al final, el número total fue de alrededor de setecientas. El costo total para Suecia fue de 285.000 coronas para el hospital en sí y 130.000 coronas en material sanitario (incluidas ocho ambulancias), a lo que hay que añadir otras dieciocho ambulancias proporcionadas por la Unión de Sindicatos (LO).

El hospital fue inaugurado el 25 de abril de 1937, en presencia del Ministro español de Estado, Álvarez del Vayo, que el 12 de abril de ese año había escrito al SHfS una carta personal de agradecimiento por el hospital ${ }^{45}$.

El personal escandinavo que se desplazó a Alcoy para atenderlo estaba constituido por una treintena de personas, entre médicos y enfermeras. El gerente y jefe de personal

asaltos a barcos suecos por las tropas de Franco), de 27.X.1937, y RA, Beskickningsarkivet: Madrid, F1 C, Vol. 41.

${ }^{43}$ ARAB, Georg Brantings arkiv 90/29, cuaderno manuscrito a lápiz.

${ }^{44}$ Recientemente han aparecido varios estudios sobre el hospital sueco-noruego de Alcoy: MYKLEBUST, \& BENEITO LLORIS, op. cit.; BALLESTER \& BENEITO LLORIS, op. cit.; BENEITO LLORIS, Ángel, El Hospital Sueco Noruego de Alcoi durante la Guerra Civil Española, Alcoy: Alfa Ediciones Gráficas, 2004.

${ }^{45}$ RA, UD, 1920-års dossierssystem, HP 36 Vol 1519; BENEITO LLORIS, op.cit.; LUNDVIK, Solidaritet och partitaktik..., p. 101 y s. 
fue un militar sueco, de familia aristocrática, el capitán Natt och Dag ${ }^{46}$. La diplomacia franquista en Estocolmo dejó clara constancia del asunto, informando que Branting estaba en París con una comisión que llevaba a España un equipo completo para un hospital quirúrgico de 100 camas que el SHfS ponía a disposición del gobierno español.

Cuatro médicos y ocho enfermeras acompañaban a los cuatro camiones que transportaban lo necesario para la instalación del hospital, el cual sería "gestionado por la

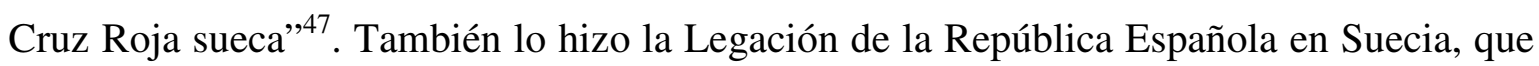
informó que el Dr. Nils Silverskiöld había estado dos veces en España y tenía "simpatía indudable por la causa leal". La Legación se ocupó de coordinar los contactos entre el SHfS y las autoridades españolas, y de agasajar convenientemente a los directivos del Comité $^{48}$.

La labor a la que se enfrentó el Dr. Silverskiöld no fue fácil. El 19 de mayo de 1937 llegaban al hospital los primeros heridos del frente y enseguida se llenó, especialmente del personal de la XI Brigada Internacional, en la que prestaban servicio la mayoría de los voluntarios escandinavos. Tras su regreso a Suecia, Silverskiöld se convirtió en un gran benefactor de los brigadistas suecos, a quienes proporcionó asistencia médica gratuita, y en ocasiones ayudó económicamente.

En sus cartas al SHfS desde Alcoy, Silverskiöld criticó severamente a la burocracia española, a la que acusaba de falta de capacidad organizativa, lamentándose en particular de que envíos de medicamentos llegaran a direcciones equivocadas sin que las autoridades españolas reaccionaran. Finalmente, el 20 de agosto de 1937, el Hospital pasó a manos españolas, aunque el personal escandinavo seguiría trabajando allí durante unos meses. El general Julio Bejarano, a quien correspondió dar las gracias a Nils Silverskiöld por sus servicios, no dudó en calificar al hospital sueco noruego como un "establecimiento modelo"49.

\footnotetext{
${ }^{46}$ En los archivos suecos se conserva un ejemplar del contrato entre el Gobierno de la República y el Director del Hospital, Dr. Silversköld, en RA, UD, Beskickningsarkivet: Madrid F1 C, Vol. 49. También se conservan los informes del capitán Natt och Dag a las autoridades militares suecas acerca de sus experiencias en: Consideraba "catastrófica" la formación militar del Ejército republicano, que "se caracteriza por la teoría de que sólo un ataque lleva a la victoria final. Esto es, por otra parte, típico de la mentalidad española" (RA, Krigsarkivet, Fst.Und., Ivan Holmquist arkiv, vol. 2/Natt och Dag).

47 AGMAV C.2472, cp. 18; y también AMAEC R 1048, 34 donde se informaba sobre la labor del Comité de ayuda a España: Sus colectas a favor de la España republicana proporcionaban entre 1500 a 2000 coronas diarias, aparte del donativo de LO de 100000 coronas, con el que se habían comprado 25 ambulancias y se había financiado un refugio de niños en Francia, el hospital de Alcoy y envíos de víveres.

${ }^{48}$ AMAEC R, 577, 4, despachos n. 55 de 8.III.1937; n. n 68 de 10.III.1937 y n. 125 de 22.V.1937.

49 ARAB, SHfS, Spanienhjälpen, p. 25 s.; OLSSON, op. cit., p. 196 y s; LUNDBERG, op. cit., pp- 113-120. Las relaciones con las autoridades españolas, no obstante, debieron dejar bastante que desear: Por ejemplo, la
} 
El hospital sueco-noruego, bajo su nuevo nombre de Hospital Militar Base, siguió funcionando hasta el 16 de octubre de 1938, cuando sufrió daños durante un bombardeo de la aviación franquista, y tuvo que ser desalojado. Este hecho pasó inicialmente desapercibido para la prensa sueca. Posteriormente, esa prensa acusaría a las autoridades de la España franquista de haber bombardeado el hospital a propósito, extremo que el Ministro de Suecia en España, Wisén, no dudó en desmentir ${ }^{50}$.

El Hospital sueco-noruego de Alcoy fue una contribución humanitaria importante, por parte de Suecia, pero también suponía una cierta intervención en la guerra, a favor de uno de los bandos. En la España de Franco, ciertamente, no hubo ningún hospital semejante financiado con dinero escandinavo, aunque también se recibió una cierta ayuda sanitaria, principalmente en forma de envío de material quirúrgico sueco. Además, un informe habla de la ayuda prestada por el profesor Hybbinette y la baronesa Beata Maria Bonde:

Hybbinette y su esposa, gracias a la propaganda que en los círculos médicos hizo la baronesa Beata Maria Bonde, que ha pasado largos periodos en España Nacional ocupándose de Hospitales, han reunido importantes donativos para los hospitales militares. Los fabricantes suecos [de material quirúrgico] han renunciado a ganancia y han vendido a precio de coste. También han contribuido Wikander, que controla el comercio del corcho en Suecia, y el Conde Eric von Rosen simpatizante con nuestra causa, que escribió un articulo a favor de la España nacional. También la viuda de Mitjana ${ }^{51}$.

\subsubsection{Los hogares infantiles suecos en España}

Aparte del hospital sueco-noruego de Alcoy, la principal aportación humanitaria sueca a la guerra de España fueron los hogares infantiles establecidos a partir de 1937 para acoger a niños españoles. Llegó a haber hasta diez de estas casas en territorio francés, y tres en España: dos en la zona controlada por el gobierno de la República - una en Denia y otra en Teyá (cerca de Barcelona) - y una en la España de Franco (Guetaria).

\footnotetext{
Legación de Suecia tuvo que reclamar la devolucion de 3000 pts que las autoridades habían quitado a la señora Hansson, empleada del hospital sueco-noruego, cfr. AMAEC R 577, 4, correspondencia con Legación de Suecia 1936-37. Se pueden ver fotografías del hospital y de su personal en SEPÚLVEDA LOSA, Rosa María, Las brigadas internacionales. Imágenes para la historia, Albacete: Universidad de Castilla-La Mancha, 2006.

${ }^{50}$ RA, UD, 1920-års dossierssystem, HP 36, Vol. 1519.

${ }^{51}$ AMAEC R 1039, 21, despacho de 10.II.1939.
} 
En el establecimiento y en la atención de estas casas de acogida de niños, el SHfS pudo contar con la eficaz colaboración de la organización creada en diciembre de 1936 por algunas mujeres suecas de distinto origen y afiliación política - una de ellas era Maja Sandler, esposa del Ministro sueco de Asuntos Exteriores -, el Svenska kvinnokommittén för Spaniens barn ("Comité sueco de mujeres a favor de los niños de España”, SKfSB).

La presidencia de este comité de mujeres fue ocupada por una conocida escritora y activista de los derechos de la mujer, Anna Lenah Elgström (1884-1968) ${ }^{52}$. Se crearon comités locales para recoger fondos, que luego harían llegar a su destino a través de la Cruz Roja Internacional y otros organismos internacionales de ayuda a la infancia. Las colectas se llevaron a cabo a través de la organización de conferencias, fiestas, proyecciones cinematográficas, envíos de hojas de propaganda a la prensa, y especialmente por medio de anuncios en la revista Husmodern.

La organización quiso ser políticamente neutral desde el principio, y prestó su apoyo a niños españoles necesitados de las dos zonas de la España en guerra. Según datos de la diplomacia franquista en Suecia, en septiembre de 1938, el SKfSB había gastado “62.000 coronas en la España Nacional y 180.000 en la roja"53.

En la primavera de 1937, cuando se produjo la avalancha de refugiados vascos a Francia, entre los que se encontraban muchos niños, era grande, el SKfSB y el SHfS trataron de conseguir la evacuación a Suecia de 500 niños españoles, y de las numerosas gestiones, idas y venidas del asunto ha quedado amplia constancia documental.

El SKfSB trató incluso de conseguir el apoyo personal del Rey de Suecia para que el gobierno accediera a la propuesta de Isabel de Palencia (Ministra de la República en Suecia) de transportar a los niños hasta Suecia en un barco español, lo cual dio lugar a un escrito del Ministerio de Asuntos Exteriores al Rey solicitándole que hiciera oídos sordos al respecto.

El gobierno se mostró dispuesto a pagar los gastos de manutención de los niños hasta el fin de año, pero a condición de que se quedaran en Francia, y no vinieran a Suecia. El Ministerio de Asuntos Exteriores propuso la concesión, a tal efecto, de una ayuda oficial a

\footnotetext{
${ }^{52}$ En los archivos particulares depositados en la Biblioteca Real de Suecia de Ellen Hagen (KB, Ellen Hagens samling, L87:14) y de Anna Lenah Elgström (KB, Gustaf Collijns och Anna Lenah ElgströmCollijns samling, L94:246-262) se conservan copias de las actas de reuniones y de la contabilidad del Comité, así como bastantes cartas y documentos relacionadas con el SKfSB: KB, Gustaf Collijns och Anna Lenah Elgström-Collijns samling, L94:246-262.

${ }^{53}$ Nya Dagligt Allehanda, "Mujeres suecas ayudan a niños españoles necesitados", 16.I.1937; RA, UD, 1920-års dossierssystem, HP 36 A, Vol. 1519, anotación del 12.V.1937. AMAEC R 1058, 11, infome del representante de Franco en Suecia de 26.IX.1938.
} 
la Cruz Roja de 50.000 coronas suecas. Ante esta situación, la Legación de España procuró presentar el asunto como un fait accompli, informando que los 500 niños estaban ya a bordo de un barco y en camino hacia Suecia. Isabel de Palencia había hablado con Georg Branting, que le prometió ayuda.

En realidad, los niños estaban en Burdeos, al cuidado provisional de un sacerdote católico llamado Dieppe. Tras diversas gestiones, las autoridades suecas consiguieron alojamiento en Francia para ochenta de ellos, y pidieron a Dinamarca que se ocupara de recibir los restantes. Dinamarca se ofreció a hacerlo si el Gobierno de la República les pagaba la cantidad de 50000 coronas danesas, lo cual no fue aceptado por los españoles.

Branting volvió entonces a presionar al gobierno sueco para que los recibiera en Suecia, pero la Embajada sueca en París, preguntada por éste, desaconsejó el asunto comentando que los niños vascos eran difíciles de educar, tenían tendencia al latrocinio (sic) e iban a crear muchos problemas, como se había visto en Inglaterra.

El gobierno sueco informó a Branting que la decisión sobre la recepción en Suecia de los niños vascos era competencia exclusiva del gobierno y que la decisión era negativa. De nada sirvieron las gestiones de las organizaciones de izquierdas para intentar cambiarla (Branting llegó incluso a pedir por teléfono a Per Albin Hansson, el jefe del gobierno sueco, que aceptara recibir al menos 100 niños). Al final, el gobierno sueco, que desde el primer momento se había mostrado reacio a recibir en Suecia a los niños vascos, consiguió que otras naciones se hicieran cargo de los mismos, o se ocupó de ellos en casas propias, pero situadas fuera de Suecia (en Francia y España) ${ }^{54}$.

Desde el establecimiento del primer orfelinato o casa de acogida de niños en el Chateau de la Brévière, Compiègne (Francia), propiedad de un matrimonio sueco, hasta la entrega a las autoridades españolas de los orfelinatos de Denia, Guetaria y Teyá, acabada la guerra, algo más de un millar de niños españoles fueron atendidos por personal y dinero sueco. La financiación se hizo en buena parte a través de un sistema de apadrinamiento de

\footnotetext{
${ }^{54}$ RA, UD, 1920-års dossierssystem, HP 36, Vol. 1519, telegrama de 29.VI.1937, escrito del Partido Socialista sueco de 5.VII.1937, informes de la Embajada sueca en París, PM de conversación telefónica Hansson/Branting de 30.VIII.1937 y escrito del Ministerio de Negocios Extranjeros al Rey de Suecia de 11.IX.1937. Cfr. también AMAEC R 602, 5 despacho de 19.VII.1937 de la diplomacia franquista en Estocolmo y AGA, Asuntos Exteriores, Caja 5290, informe de 22.VII.1937 del representante en Oslo, explicando que 500 niños rechazados por Suecia habían sido ofertados a Noruega.
} 
niños: 55 coronas/mes costaba ser padrino de un niño en los hogares infantiles franceses y 40 en los españoles 55 .

Los dos primeros hogares infantiles suecos en España estuvieron, respectivamente, en Denia (zona republicana) y en Guetaria (una vez ocupada la zona por la España de Franco). Para dirigir el "hogar sueco para los niños españoles" de Denia, los comités suecos buscaron a una persona con experiencia de España, Manghild Olsson ${ }^{56}$, que trabajó en él desde su constitución en 1937 hasta septiembre de 1938. El hogar siguió funcionando hasta el final de la guerra, cuando pasó a las autoridades españolas.

Se conserva en Suecia un apreciable número de dibujos y grabados infantiles, realizados por los niños acogidos en estos hogares, expresando su agradecimiento al país escandinavo y reflejando los horrores de la guerra. Bastantes fueron presentados en una exposición sobre los niños españoles realizada en Estocolmo en 1938. Algunos han sido publicados, en el libro de Kajsa Rothman ${ }^{57}$ titulado Barnen ritar om kriget ("Los niños hacen dibujos sobre la guerra"), que fue distribuido por toda Suecia ${ }^{58}$.

A las organizaciones suecas involucradas en la ayuda a los niños españoles no siempre les resultó fácil el contacto con las autoridades españolas. Tanto con las republicanas como con las franquistas hubo enfrentamientos, alguno de ellos serios. En concreto, y por lo que respecta a las autoridades republicanas, Federica Montseny llegó a renunciar a recibir la ayuda monetaria extraordinaria que el gobierno sueco donaba en 1937 porque los suecos habían dejado claro que la ayuda se repartiría entre las dos zonas de España.

\footnotetext{
${ }^{55}$ VIEDMA, Lucy, “La guerra civil española 1936-1939”, presentación y guía de fondos documentales sobre el tema en el Archivo del Movimiento Obrero de Estocolmo, p. 3; ARAB, SHfS, Verksamhetsberättelserl Redogörelser, (Memorias de actividades) de 1938 y 1939.

${ }^{56}$ Frida Magnhild Olsson había nacido en 1903 en Hedemora (Suecia) y había sido empleada del hogar en familias suecas afincadas en España de 1926 a 1928. Realizó después estudios de enfermería, en Estocolmo, especializandose en atención de niños: RA, Landsarkivet i Härnösand, Magnhild Olssons samling (Archivo Territorial de Härnösand, colección Magnhild Olsson).

${ }^{57}$ Kajsa Rothman, hija de un periodista de Karlstad, fue la primera voluntaria sueca en la guerra civil. Fue una de las grandes propagandistas de la causa de la República Española en Suecia. En el verano de 1936 trabajaba en una agencia de turismo en Barcelona y el mismo día 19 de julio se ofreció voluntaria para la Cruz Roja. Posteriormente se encargaría de las emisiones en lengua sueca de Radio Madrid. Su actividad, en especial sus visitas a los frentes de guerra, despertó algunas sospechas en el SIM, que temía que pudiera ser una espía de Franco. No parece que esas sospechas tuvieran fundamento. Cfr. LUNDBERG, op. cit., pp. 120123; GYLLENHAAL \& WESTBERG, "I spansk tjänst...", p. 113 y s.; GUSTAFSSON \& KARLSSON, $o p$. cit., pp. 49-53. Sobre las presuntas labores de espionaje de Kajsa Rothman cfr. PETROU, Michael, Renegades: Canadians in the Spanish Civil War. Vancouver: University of British Columbia Press, 2008, pp. 164-167

${ }^{58}$ Los dibujos se encuentran en RA, Landsarkivet i Härnösand, Magnhild Olssons samling y en ARAB, colección Spanska inbördeskriget (Guerra Civil Española), Svenska hjälpkommittén för Spanien, Knut Olssons arkiv.
} 
En la documentación sueca ha quedado constancia del estupor - y consiguiente daño para la imagen de la República en Suecia - que causó esta negativa republicana a aceptar ayuda humanitaria para niños huérfanos para privar así a los niños de la otra zona de una ayuda equivalente ${ }^{59}$.

Por lo que respecta a las autoridades franquistas, la empleada sueca al cargo del hogar infantil sueco "Villa San José" de Guetaria, Srta. Fredriksson, tuvo fuertes enfrentamientos verbales con una de las dirigentes locales de Falange española, lo que llevó a la expulsión de aquella de la España franquista. Esas dificultades fueron sólo un preludio de las que habría al final de la guerra, al llegar el momento de efectuar el traspaso al Auxilio Social de los hogares infantiles suecos de Guetaria y Denia ${ }^{60}$.

Además de los hogares infantiles de Guetaria y Denia, existió uno en Cataluña en la localidad de Teyá, que acogió a 125 niños y tenía adosada una escuela a la que asistían además 400 niños en calidad de alumnos externos. Empezó en 1938 como comedor para 325 niños y hogar para 120 niños de 4 a 12 años, por iniciativa de Alexandra Wisén, esposa del Ministro plenipotenciario de Suecia en España, Erik Wisén. El superintendente de la iniciativa fue Eric Svensson. Por otra parte, Kajsa Rothman, que ya había colaborado en el establecimiento y desarrollo del hogar infantil de Suecia en Denia, ayudó también a organizar éste de Teyá.

Georg Branting donó 10000 coronas suecas para la iniciativa y el hogar sueco de Teyá fue visitado el 22 de junio de 1938 por la Sra. de Alvarez del Vayo y la Sra. de Azcárate, amigas de Alexandra Wisén. Celebraron el cumpleaños del rey de Suecia, al que 260 niños españoles regalaron una carpeta con sus nombres, el escudo sueco y el catalán, y un texto de felicitación en ambos idiomas.

La casa de Teyá estuvo en funcionamiento desde el comienzos de 1938 hasta la toma de Barcelona por las tropas de Franco, el 15 de marzo de 1939. Esta iniciativa le costó a

\footnotetext{
${ }^{59}$ RA, UD, 1920-års dossierssystem, HP 36, Vol. 1519, documentación sobre la ayuda a los niños españoles; AMAEC R 602, 5, despacho de 13.IV.1937: "La Montseny ha renunciado ante el Sr Knut Hanner, que estuvo en Abisinia con la ambulancia sueca, a la ayuda para los niños españoles republicanos, porque Suecia también quería ayudar a los niños nacionales".

${ }^{60}$ RA, UD, 1920-års dossierssystem, HP 36, Vol. 1519, documentación sobre la ayuda a los niños españoles; RA, UD, Beskickningsarkivet: Madrid F1 C, Vol. 43, correspondencia entre Mercedes Sanz Bachiller, delegada nacional del Auxilio Social (Valladolid) y Marie Pictet, del Hogar sueco (Villa San Jose, Guetaria) en abril de 1939. Cfr también AMAEC R 1058, 11, carta desde Burgos a Carlos Lopez Doriga de 20.X.1938, mencionando un artículo de la Sra. Elgström (presidente del SKfSB) y señalando que la Srta. Bonde, "de una de las mejores familias de Suecia" se proponía "contrarrestar la propaganda negativa que la Elgström hace del orfelinato de Guetaria".
} 
Alexandra Wisén el calificativo de "elemento indeseable", con que la calificaron las autoridades franquistas después de la guerra ${ }^{61}$.

Los hogares suecos de acogida de niños fueron traspasados a las autoridades españolas al terminar la guerra. Fueron, sin duda, una aportación humanitaria importante orientada hacia el sector más inerme de la población española del momento, los niños huérfanos y abandonados a causa de la guerra.

\subsection{La ayuda militar sueca a la España en guerra}

\subsubsection{Los voluntarios suecos al servicio de la República Española}

La ayuda militar sueca a la España en guerra no fue, en modo alguno, ayuda oficial. En todos los casos, se trató de voluntarios, que además se arriesgaron, por hacerlo, a una pena de prisión, ya que a partir de marzo de 1937, la participación en la guerra civil española era conducta punible. Ello no fue obstáculo para que un número considerable de jóvenes suecos se hicieran presentes en los frentes de guerra españoles. A continuación presentaremos algunos datos sobre este colectivo, en tres apartados: su aportación al esfuerzo bélico, la actitud de las autoridades suecas frente a ellos, y su actividad tras el retorno a su patria

\subsubsection{La aportación bélica de los voluntarios suecos}

La aportación al esfuerzo bélico de la Segunda República Española y a la lucha contra el fascismo internacional de los más de quinientos Spanienkämpar ("luchadores por España") - como pronto fueron conocidos popularmente los voluntarios suecos de las Brigadas Internacionales - es en Suecia un punto de referencia en los estudios históricos sobre el siglo XX, incluso a nivel de la enseñanza escolar. Esto resulta quizá poco conocido en España. De hecho, en Suecia hay abundante bibliografía sobre los brigadistas suecos.

\footnotetext{
${ }^{61}$ RA, UD, Beskickningsarkivet: Madrid F1 C, Vol. 49, carta de Wisén a Branting de 8.III.1938. Informe de Wisén de 21.III.1938. Cfr. también AMAEC R 832, 1: "Elemento indeseable entre el personal, la esposa del encargado de Negocios extranjeros Sra. Wisén, amiga íntima de algunos cabecillas rojos y denigradora de los españoles nacionalistas. Suecia se dedicó especialmente a proteger colonias infantiles, como la que bajo sus auspicios estaba instalada en Teyá (Barcelona)". Sobre las relaciones de la Sra. Wisén con las autoridades republicanas, en RA, UD, Beskickningsarkivet: Madrid, F1c:49, sólo se conserva una carta de trámite de Alexandra Wisén a Julián Zugazagoitia pidiendole que le permita contratar un cocinero para el hogar de Teyá, ya que todos los hombres estaban movilizados.
} 
El deseo que tenían muchos jóvenes suecos de prestar su apoyo a la democracia y a la lucha antifascista en España fue canalizada por los partidos y sindicatos de izquierda, en especial por el Partido Comunista sueco y por los sindicalistas de la SAC, y se concretó en lo que pronto se conocería como Brigadas Internacionales.

En estas páginas pretendemos, a la luz de las más recientes aportaciones de la historiografía sueca y de los fondos archivísticos que se han abierto recientemente a la investigación - en especial, el de la Policía de Seguridad sueca - dar una visión general de la aportación de los voluntarios suecos a la República Española. Al retirarse los brigadistas de España, en el otoño de 1938, las autoridades suecas suspendieron la aplicación de la ley que desde marzo de 1937 prohibía el alistamiento de suecos en las brigadas bajo pena de prisión.

Si consideramos que Suecia fue uno de los países que más voluntarios envió a las Brigadas Internacionales en proporción al tamaño de su población, llama la atención el vacío historiográfico sobre el papel de los voluntarios suecos por lo que a España se refiere. Salvo el artículo de Erik Norling en una revista militar - que recoge sustancialmente los resultados de la historiografía sueca existente -, otro artículo breve de Michiko Murai y alguna aportación reciente nuestra ${ }^{62}$, en la bibliografía española sobre las Brigadas sólo se encuentran referencias puntuales a los suecos, al referirse a los voluntarios escandinavos englobados en los contingentes alemanes de la XI Brigada Internacional.

Muy distinta es la situación en Suecia, donde la bibliografía al respecto es prolija ${ }^{63}$ incluso sin contar con la larga lista de publicaciones que contienen las memorias o cartas de los antiguos brigadistas suecos.

El número total de voluntarios suecos se sitúa actualmente en 530-540, la mayoría de ellos miembros del Partido Comunista sueco o de las Juventudes Comunistas, según el libro de la asociación de exbrigadistas La causa de España fue la nuestra, ${ }^{64}$ aunque las

\footnotetext{
${ }^{62}$ NORLING, op. cit., pp. 127-133; MURAI, Michiko, "Los voluntarios suecos y escandinavos en la guerra civil española, una aproximación lingüística", en CELADA, Antonio R., PASTOR GARCIA, Daniel y LÓPEZ ALONSO, Rosa María (Eds.), Las Brigadas Internacionales: 70 años de memoria histórica, Salamanca: Amarú, 2007, pp-.299-305; PEIX GELDART, Benito, "Efter Spanien. De svenska frivilligas hemkomst" en Arbetarhistoria 1/2012, Estocolmo: ARAB.

${ }^{63}$ LUNDVIK, Solidaritet och partitaktik...; CANTERA CARLOMAGNO, Sverige och spanska...; GYLLENHAAL \& WESTBERG, "I spansk tjänst...”; ERICSON, Lars, Svenska frivilliga. Militära uppdrag i utlandet under 1800- och 1900-talen, Lund: Historiska Media, 1996; LUNDBERG, op. cit.; NILSSON, op. cit; OLSSON, Folke, "Solidaritetens soldater", en HELGESON, Patrik; JÄNDEL, Richard \& WEIJDEGÅRD, Nils, (coord.), No pasaran!: Spanska inbördeskriget och uppgörelsen med fascismen, Linköping: Nixon, 2008, pp. 153-213; ERICSON WOLKE, "Frivilliga i strid”, en Populär Historia 7/2006.

${ }^{64}$ GUSTAFSSON \& KARLSSON, op.cit., passim, especialmente p. 62.
} 
listas hasta ahora publicadas contienen 501 nombres $^{65}$ y algún estudio hable de $550^{66}$. Hay que tener en cuenta, sin embargo, que no todos lucharon en las Brigadas Internacionales, algunos lo hicieron como partisanos en los grupos anarquistas u otras formaciones ${ }^{67}$.

No es fácil llegar a conclusiones definitivas respecto al número real de brigadistas, pues las listas disponibles presentan diferencias, datos parciales e inexactitudes. Por otra parte, los fondos archivísticos tampoco son unánimes en lo que se refiere a cifras y nombres. Al regreso de los voluntarios en 1938-39 el Comité de apoyo creado en Suecia pidió ayuda al Ministerio sueco de Negocios Extranjeros para intentar averiguar más datos de los desaparecidos y muertos, manejando en esa ocasión las siguientes cifras: 305 repatriados suecos, 25 repatriados a Suecia de nacionalidad no sueca, y 153 que no habían regresado (72 desaparecidos, 62 muertos, 19 prisioneros) ${ }^{68}$.

Los contactos de la España nacional en Estocolmo comunicaron en 1938 la cifra aproximada de 650 o 450 voluntarios, según las diversas fuentes ${ }^{69}$. Además, en el Centro Documental de la Memoria Histórica, diseminados en muchos legajos y expedientes, se encuentra un cierto número de referencias a los suecos.

La documentación más interesante al respecto es probablemente la de de los Servicios de Inteligencia. Es interesante y detallada, pero hasta muy recientemente no ha estado abierta a la investigación, y aún hoy lo está con restricciones. Lundvik no pudo consultarla para su tesis doctoral sobre Suecia y la guerra civil española, a excepción de algunos datos estadísticos ${ }^{70}$. Nosotros sí hemos podido tener acceso a la misma, y con ella, y los datos encontrados en otros archivos, incluidos el Centro Documental de la Memoria Histórica de Salamanca y el Archivo General Militar de Ávila, podemos completar las listas de brigadistas aparecidas hasta ahora ${ }^{71}$.

La cifra total que aportamos es de 552 brigadistas suecos, a los que hay que añadir al menos cerca de 20 nombres más como probables, además de 40 extranjeros residentes en

\footnotetext{
${ }^{65}$ LUNDBERG, op. cit., pp. 158-171; LUNDVIK, Solidaritet och partitaktik..., pp.197-203.

${ }^{66}$ KVALØY, Arve, Norske frivillige i den spanske borgekrig, Oslo: Universidad de Oslo, 1996. En el mismo sentido, un artículo de GYLLENHAAL, Lars, "Skandinaviska bataljonen Hans Beimler", publicado en http://www.smb.nu/index.php/militara-artiklar/andra-vaerldskriget/1442-skandinaviska-bataljonen-hansbeimler, visto el 30 marzo de 2009.

${ }^{67}$ JÄNDEL, op. cit., p. 32.

${ }^{68}$ RA, SÄPO, Vol. 497, p. 1348.

${ }^{69}$ AGMAV, C.2472, Cp. 18, exp. 5 (650); AMAEC R 1048, 37 (450). Esta última es la fuente primaria, la primera parece un error de transcripción.

${ }^{70}$ LUNDVIK, Solidaritet och partitaktik..., p. 115.

${ }^{71}$ Cfr. Apéndice 7 "Listas de Voluntarios Suecos en la Guerra civil Española".
} 
Suecia y un grupo de voluntarios que no llegaron a España porque antes de hacerlo fueron interceptados por las autoridades suecas o de los países de tránsito.

Aparte de los más de 150 comunistas declarados que aparecen en las listas publicadas hasta la fecha, consta que al menos ocho pertenecían al partido Socialista de izquierda (Socialistiska Partiet), y al menos diez eran sindicalistas de la SAC, mientras que la afiliación al partido gubernamental socialdemócrata sólo consta de siete de ellos ${ }^{72}$.

No faltaron, por otra parte, los que no estaban afiliados a ningún partido, e incluso se encuentra el nombre de algún aristócrata, aunque más del $95 \%$ pertenecían a la clase trabajadora, con una edad media de 28 años $^{73}$. Geográficamente, provenían de todo el país, aunque dos quintas partes procedían de las dos principales ciudades, Estocolmo y Gotemburgo.

Aproximadamente un tercio de ellos murieron luchando por la República en el campo de batalla o en las cárceles de los sublevados, según las estimaciones comúnmente aceptadas en la actualidad. Al menos cuatro de ellos fueron comisarios de las Brigadas Internacionales, seis fueron jefes de compañía, dos mandaron provisionalmente un batallón, y al menos diecinueve lucharon como guerrilleros o partisanos en las unidades que los soviéticos llamaban spetsnaz.

Uno de ellos, Per Ericsson, fue instructor de brigadistas y guardaespaldas de diversas personalidades, concretamente de Grigori Mijailovitch Shtern, alto asesor militar soviético en España en 1937-1938, y de Dolores Ibárruri durante el verano de 1938 $8^{74}$. Otro, Sven Brännström, manifestó poco antes de morir haber servido a las órdenes de un alto cargo de la NKVD en España, el Mayor Leonid Alexandrovich Eitingon ${ }^{75}$.

A finales de 1936, los voluntarios suecos pertenecían en su mayoría a la $3^{\text {a }}$ compañia de fusileros del Batallón Ernst Thäelmann - mandada por Ragnar Skotte, un subteniente del ejercito sueco, comunista - que a principios de 1937 pasó de la XII a la XI Brigada, que recibió también el nombre de Thäelmann, o al batallón alemán Edgar André. Ambos batallones entraron en combate en el Jarama en febrero de 1937, y participaron después en la batalla de Guadalajara.

\footnotetext{
${ }^{72}$ LUNDVIK, Solidaritet och partitaktik..., p.123. Debe tenerse en cuenta, sin embargo, que este autor sólo pudo determinar con certeza la afiliación política de 207 brigadistas, de la lista de 501 nombres que presenta. ${ }^{73}$ OLSSON, op.cit., p. 182 y s.

${ }^{74}$ GYLLENHAAL \& WESTBERG, “I spansk tjänst...”, pp. 126 y 150-160; LUNDVIK, Solidaritet och partitaktik..., p. 123 y ss. Muchos de estos datos se recogen también en otras obras.

${ }^{75}$ BRÄNNSTRÖM, op.cit., pp. 35 y ss.
} 
Algunos suecos estuvieron también presentes en los combates de Brunete ${ }^{76} \mathrm{y}$ Belchite, y en varios lugares del frente de Aragón. Allí, los escandinavos fueron reasignados al batallón "12 de febrero", mayoritariamente austriaco, aunque poco después se pudo formar un batallón escandinavo-español, de nombre Hans Beimler, compuesto por cuatro Compañías (sueca, danesa, noruega y española). La sueca recibió el nombre del senador socialista sueco Georg Branting, abanderado de la causa de la República Española en Suecia, abogado de la Legación de España en Estocolmo y presidente del Comité de Ayuda a España. Estuvieron presentes en la batalla del Ebro. De los aproximadamente ochenta suecos que participaron, la mitad cayó en combate, diez fueron hechos prisioneros y el resto resultó herido ${ }^{77}$.

Por encargo oficial del batallón Thäelmann, la noruega Lise Lindbæck escribió en 1938 un pequeño libro sobre el mismo que en 1939 fue publicado en sueco con el título $\mathrm{La}$ brigada internacional $^{78}$ en el que mencionaba que la compañía Georg Branting, del batallón escandinavo de la XI Brigada Internacional, había sido la primera en pasar el Ebro durante la ofensiva de 1938 , dato que, a pesar de no ser correcto $^{79}$, ha sido y es aún hoy motivo de gloria para el movimiento obrero sueco. En definitiva, poco importa la hora exacta en que pasaron el Ebro.

Algunos voluntarios suecos se convirtieron pronto en personajes de leyenda, al menos para las masas obreras de Suecia. Tal fue el caso del estudiante de teología de la Universidad de Uppsala Olle Meurling, que fue considerado durante mucho tiempo como el primer sueco que había muerto en los frentes de batalla españoles, o de la ya mencionada Kajsa Rothman, la primera voluntaria sueca ${ }^{80}$.

También hubo voluntarios suecos en otras unidades, por ejemplo en las guerrillas de corte anarco-sindicalista. Una figura señera entre este grupo de voluntarios fue el sindicalista Nils Lätt (1907-1988), que estuvo en la columna Durruti y realizó una gran labor de propaganda en Suecia. Su nombre aparece repetidamente en los archivos,

\footnotetext{
${ }^{76}$ En Brunete mostró la XI Brigada una "brillantez excepcional". Así escribió el general Walter (el asesor ruso Sverchervsky) en un informe, cfr. RADOSH, HABECK \& SEVOSTIANOV, op. cit., pp. 512-540, en especial p. 521.

${ }_{77}$ NORLING, op.cit., pp. 128-129; cfr. también ERICSON WOLKE, op.cit., passim.

${ }^{78}$ LINDB ÆCK, Lise, Internationella Brigaden, Estocolmo: Solidaritet, 1939.

${ }^{79}$ El batallón alemán-escandinavo formaba parte de la 35 División, y al parecer fueron precedidos en el paso del Ebro por unidades de la 11 División, cfr. AGMAV, C.2114, exp. 7

${ }^{80}$ LUNDBERG, Lennart, op. cit., pp. 44 y 120-123; NORLING, op.cit., p. 128. El primer sueco que murió en España fue E. Wedin, en el frente de Madrid, el 11.IX.1936.
} 
incluidos los fondos del Centro Documental de la Memoria Histórica de Salamanca ${ }^{81}$. También sirvieron algunos suecos en la XV Brigada Internacional (Abraham Lincoln) y en otras unidades republicanas.

En general, los voluntarios suecos constituyeron un grupo muy motivado e ideológicamente homogéneo, y el número de desertores no fue alto, aunque ciertamente hubo algunos que se desilusionaron o que cambiaron de opinión al llegar a España ${ }^{82}$. La mayoría de los voluntarios coinciden en señalar la cohesión entre ellos, en su lucha antifascista, aunque hubiera disputas entre sindicalistas y comunistas ${ }^{83}$.

\subsubsection{La actitud de las autoridades suecas frente a los voluntarios}

El teniente coronel sueco Olof Ribbing, miembro de la comisión enviada por el Comité de No Intervención para el control de la retirada de voluntarios de las Brigadas Internacionales, decidida por el gobierno de la República en el otoño de $1938^{84}$, escribió en una revista sueca en febrero de 1939 sus impresiones de los voluntarios a repatriar. Entre otras cosas, decía que para los suecos era un motivo de orgullo poder decir que eran bienvenidos a su país de origen después de haber luchado en España ${ }^{85}$.

El hecho de que esto fuera así es prueba manifiesta de la simpatía y actitud positiva hacia los voluntarios suecos por parte del pueblo de Suecia y, también, de las autoridades suecas. En efecto, los voluntarios sabían que podrían regresar a su país sin problemas, a pesar de que, desde el punto de vista legal, eran en Suecia reos de delito castigado con seis

\footnotetext{
${ }^{81}$ CDMH, PS-Madrid 321/2, Nills (sic) Lätt. Este voluntario sueco dejó escritas sus experiencias de la guerra de España en varios libros: LATT, Nils, Nisse Lätt. En svensk anarkist berätta. Minnesbilder ur Nisse Lätts liv som agitator och kämpe för de frihetliga idéerna, redigerad av Hakan Forshult, Goteborg: Nisse Latts minnesfond, 1993; LATT, Nils, Som milisman och kollektivbonde i Spanien, Estocolmo: Federativ, 1938.

${ }^{82}$ Fuentes del Ministerio sueco de Negocios Extranjeros nombran 10 desertores, uno de los cuales fue fusilado. De todas formas, al tratarse de voluntarios, no es fácil definir qué se entiende por "desertor", entre otras cosas porque no era infrecuente que las autoridades de las Brigadas licenciaran a brigadistas que habían perdido la motivación. Sobre los desertores suecos, cfr. LUNDVIK, Solidaritet och partitaktik..., pp. 125127, que cita las fuentes archivísticas fundamentales. Cfr. también RA, SÄPO, Vol. 494, sobre los desertores Yngve Andersson, Stenberg, Ahlstrand y Norrblom. En general, los desertores eran socialistas o sindicalistas, descontentos con el predominio comunista en las Brigadas.

${ }^{83}$ SJÖSTEDT, Brev till en broder..., p. 24s., menciona las palabras del voluntario Segerson: "Entre los voluntarios se hablaba muy poco de las distintas opiniones que cada uno tenía. Al hablar de política se procuraba evitar las disputas partidistas. Lo más importante era la unidad en la lucha contra el fascismo. En la cartilla militar, en la casilla Ideas Políticas, escribíamos solamente antifascista (...) Pero había una profunda desconfianza mutua entre anarquistas y sindicalistas de un lado y marxistas del otro".

${ }^{84}$ Sobre la repatriación de voluntarios suecos informaron los servicios de la España franquista en Estocolmo, comentando también que el General sueco Bruno Jalander, presidente de la Comisión encargada de la repatriación, era persona poco afín a los sublevados españoles, cfr. AMAEC R 1785, 13. En el informe en cuestión, de 13.X.1938, hay una anotación marginal encargando se comience "un archivo de militares de todo el mundo, registrando sus simpatías políticas, etc. Debe ser absolutamente reservado".

${ }^{85}$ Svensk Tidskrift, febrero de 1939. Citado en LUNDBERG, op.cit., p. 134. La traducción es nuestra.
} 
meses de cárcel por haber prestado servicio de armas en España contra la prohibición legal expresa que entró en vigor el 26 de febrero de 1937, que dejaba incluso fuera de la ley cualquier tipo de viaje a España sin permiso expreso del gobierno ${ }^{86}$.

Esas disposiciones legales no fueron aplicadas en la práctica. El gobierno, una vez decidida por la República la repatriación de los voluntarios, decidió proceder a la abolición de la pena incurrida por los brigadistas por el delito de participación armada en la guerra española, dejándola sin efectos prácticos ${ }^{87}$.

Mientras estuvo vigente la prohibición del reclutamiento de voluntarios, la policía hizo tímidos esfuerzos por detenerla y llevar a los tribunales los casos de reclutamiento que llegaban a su conocimiento, aunque tenía buen conocimiento de los canales por las que se realizaba, especialmente el club obrero comunista de Gotemburgo ${ }^{88}$.

Por otra parte, la Legación de Suecia en España llevó a cabo, en la medida de sus posibilidades, un seguimiento de los voluntarios suecos en el país. Quizá lo más llamativo a este respecto sea el hecho de que, lejos de perseguir a los voluntarios, les prestó a ellos y

${ }^{86}$ CANTERA CARLOMAGNO, Sverige och spanska...., p. 48.

87 SFS 1938, n. 623. La Ley había sido promulgada en febrero de 1937 (cfr. SFS 1937, n. 61-63) y comunicada inmediatamente al Gobierno español por la Legación de Suecia en Madrid (cfr. RA, UD, Beskickningsarkivet: Madrid F1 C Vol. 45). Sobre los debates en el Parlamento antecedentes a la misma, tras la interpelación del diputado del partido conservador Von Seth, cfr. AMAEC R 642, 2 despacho n. 12 de 17.I.1937. Un año después, en febrero de 1938, el Parlamento sueco había prorrogado la prohibición por un año, pero eso no bastó para parar el reclutamiento, como señalaba la representación franquista en Estocolmo: Los interesados burlaban a la policía para ir a España, a través de las centrales de reclutamiento en las distintas capitales nórdicas y se servían, entre otras cosas, de barcos pequeños que llevaban personas y armas de contrabando a puertos de Bélgica, Holanda y Francia. Los voluntarios de Suecia firmaban un contrato de servicio por 4 ó 5 meses, y recibían un jornal de 20 pts diarias en el frente y 10 en la retaguardia, billete pasaporte y 75 pts. (cfr. AMAEC R 1058, 11, despacho de 24.II.1938).

${ }^{88}$ Sobre el papel del Club obrero de Gotemburgo cfr. RA, SÄPO, Vol. 495, PM de 27.XII.1937. Sobre la actividad policial en relación con el reclutamiento, cfr. RA, SÄPO, vol“. 493, PM confidencial de 15.XII.1936; Ibidem, vol. 494, informe de la policía danesa de 29.IV.1937; Ibidem, Vol 495, informes varios; Ibidem, Vol. 496, informe de la policía de Gotemburgo de 4.VII.1938 y menciones al interrogatorio al Senador comunista Senander; Informes de junio de 1938 de la Policía de Örebro, Sundsvall y Linköping. Por otra parte, no era infrecuente que los fiscales no siguieran adelante con las denuncias, a pesar de que el reclutamiento, activo o pasivo, para la guerra de España, era punible: cfr. por ejemplo Ibidem, vol. 496, caso de los desertores Malmkvist y Liljeroth, y del partisano y espía Hugo Andersson Blixtsköld (PM confidencial del 19.XI.1938). Por su parte, la diplomacia franquista en Suecia y Alemania informó cumplidamente de las Centrales de reclutamiento y su funcionamiento, cfr. AMAEC, R 1058, 11. 
a sus familiares toda la ayuda que estuvo a su alcance ${ }^{89}$. Asimismo, procuró mantenerse informada del número de voluntarios presente en cada momento ${ }^{90}$.

Las organizaciones creadas por diversos actores del movimiento obrero sueco para la ayuda a la España republicana se emplearon a fondo para dar la bienvenida a los Spanienkämpar, en diciembre de 1938. Un papel fundamental a este respecto fue el desempeñado por el Frontkämparnas stödfond (Fondo de Apoyo a los luchadores del Frente), creado en octubre del 1937 por iniciativa comunista para apoyar económica y materialmente a los voluntarios suecos en España y en cuya Junta Directiva había dos conocidos brigadistas suecos, repatriados tras haber resultado heridos en la guerra civil. La poderosa central sindical socialdemócrata LO y las juventudes socialdemócratas apenas prestaron apoyo a esta organización, que fue la que organizó el transporte y recepción en Suecia del gran contingente de voluntarios que llegó en diciembre de $1938^{91}$.

El contingente en cuestión, formado por 174 brigadistas suecos, 6 alemanes ${ }^{92}$ y 22 finlandeses de camino a su país, llegó a Suecia el 8 de diciembre de 1938, siendo recibidos como héroes del movimiento obrero sueco.

Las palabras del líder de la izquierda socialista Zeth Höglund, en el diario Socialdemokraten del mismo día, se han hecho famosas:

Han honrado el nombre de Suecia, han honrado a su clase, la clase trabajadora, y han honrado a la democracia. Y por esta hazaña, nosotros les hemos amenazado con pena de prisión mediante una ley que nos fue impuesta por la política de no intervención ${ }^{93}$.

\footnotetext{
${ }^{89}$ Los ejemplos son muy numerosos, sin que haya quedado rastro en la documentación sueca ninguna excepción a este modo de proceder. Tanto los voluntarios como sus familiares no dudaban en acudir a la Legación de Suecia ante situaciones de necesidad, llegando incluso la Legación a transmitir cartas a los brigadistas en el frente (cfr. AMAEC R 749, 161; AMAEC R 749, 87; Y especialmente, RA, UD, Beskickningsarkivet: Madrid F1 C Vol. 45, donde se reflejan las gestiones realizadas por la Legación en relación con los voluntarios. Un caso entre muchos fue el relacionado con el voluntario Bertil Sommelius, de 16 años, cuya familia trató de repatriar a través de la Legación.

${ }^{90}$ Las fuentes reflejan la poca claridad al respecto, cosa lógica si se tiene en cuenta que el reclutamiento era ilegal. La Legación da diversas cifras en distintos momentos: La más aproximada es de abril de 1938, donde señalaba que en la primavera de 1937, el número de voluntarios era de alrededor de 400 voluntarios, de los que tras muertes, deserciones y repatraciones quedarían unos 100. En los primeros meses de 1938 habrían llegado otros 100, según la Legación (cfr. RA, UD, Beskickningsarkivet: Madrid F1 C Vol. 45, telegramas cifrados de 18.IV.1938). En junio, y sobre la base de nuevos informes recibidos, comunicó primero la cifra de 600 y posteriormente la de 860, aunque señalando que le parecían exageradas (cfr. ibidem, telegrama de 2.VI.1938 y despacho n. 100 de 10.VI.1938).

${ }_{91}$ LUNDVIK, Solidaritet och partitaktik..., p. 127 y s.

92 Consta que, al menos, 19 ciudadanos extranjeros, residentes en Suecia - en su mayoría alemanes participaron como voluntarios en la guerra de España: cfr. RA, SÄPO, vol. 496, lista över spanienfrivilliga som tidigare var politiska flyktingar $i$ Sverige- Por no ser ciudadanos suecos, sus nombres no fueron reflejados en las listas de voluntarios suecos hasta ahora publicadas. Según datos del Comité de Apoyo (cfr. RA, SÄPO, vol. 497), se trataba de 25 personas.
} 
En los meses siguientes, enero a octubre de 1939, en pequeños grupos, regresaron el resto de los brigadistas: en enero los heridos, que llegaron en barco a Gotemburgo, a finales de abril 16 voluntarios que estaban presos en las cárceles de la llamada España nacional. Otros dos presos no pudieron hacerlo hasta el 15 de octubre y el último, Lars Berggren, de Gävle, hasta el 28 mayo de 1940ㄴ․

La prensa sueca mencionó el dilema que para la conciencia moral de la Suecia democrática supuso la participación de voluntarios suecos en la guerra civil española, al tener que compaginar la simpatía por la causa antifascista con las exigencias derivadas de los acuerdos internacionales de Suecia en el Comité de No Intervención:

A veces se tenía la impresión de que las centrales de reclutamiento para España - en especial algunos centros de agitación comunista - se dirigían a jóvenes inexpertos que no se daban mucha cuenta de en qué se estaban metiendo. Ese ha sido uno de los motivos de la actitud distanciada y posteriormente adversa hacia el reclutamiento, por parte de la opinión pública y de las autoridades. Otro motivo fue de orden político, por las exigencias del Pacto de No Intervención... Al respecto, Sandler hubo de pronunciarse no sólo como funcionario público, sino como representante de la socialdemocracia y de todos los partidos suecos responsables. Sin embargo, muchos se han visto en un serio conflicto de conciencia.

La situación creada por la colaboración directa de Alemania e Italia con Franco ha sido horrible. Al concluir ahora la historia de las Brigadas Internacionales, los voluntarios suecos se encuentran en la ventajosa posición de quien puede regresar a un país que les recibe con los brazos abiertos y con buenas posibilidades de trabajo. Aquí no se repetirá la historia de 1918 (con la persecución a los voluntarios blancos). Se respetará el convencimiento que llevó al frente a los voluntarios, y no hay más que hablar. Con una sola condición: Si los voluntarios de España intentan propagar doctrinas y costumbres españolas en Suecia, se colocarán en una posición muy desafortunada ${ }^{95}$.

\subsubsection{Los brigadistas tras su regreso a Suecia}

Si a cualquier combatiente en una guerra larga le espera un difícil período de readaptación a la vida civil, con más motivo sucede esto en el caso de los brigadistas

\footnotetext{
${ }^{93}$ Social-Demokraten, 11-XII-1938. La traducción es nuestra.

${ }^{94}$ ERICSON, op.cit., p. 95; CANTERA CARLOMAGNO, Sverige och spanska...., pp. 112 y s.

${ }^{95}$ Dagens Nyheter, 8.XII.1938. Hay copia en RA, SÄPO, Vol 496.
} 
suecos, que habían abandonado sus puestos de trabajo voluntariamente para ir a luchar contra el fascismo en un país lejano ${ }^{96}$.

Por documentación del Archivo del Movimiento Obrero en Estocolmo constan los grandes problemas económicos, de salud, y de preocupación por su reinserción al trabajo que tenían los brigadistas. Cerca de la mitad de ellos habían resultado heridos y tenían limitada su capacidad de trabajo, y prácticamente todos ellos carecían por completo de medios económicos. Para paliar sus necesidades más inmediatas, la Organización Nacional de Sindicatos $(L O)$, el Fondo de Apoyo a los luchadores del Frente (Stödfonden) y el Comité sueco de Ayuda a España les proporcionó ayuda en forma de ropa y dinero para comer $^{97}$.

Los marinos encontraron trabajo más fácilmente, aunque, como todos, tuvieron que enfrentarse a la desconfianza de sus patronos, temerosos de que los recién llegados, por sus ideas comunistas, fueran un motivo de conflicto en sus empresas ${ }^{98}$.

A consecuencia de la declarada política anticomunista del gobierno socialdemócrata sueco, los brigadistas fueron objeto de especial atención y vigilancia por parte de los servicios de inteligencia, tanto la Policía de Seguridad, (SÄPO) como el Servicio de Inteligencia Militar ${ }^{99}$.

El jefe del Servicio de Inteligencia militar sueco durante los años de la segunda guerra mundial, C. Adlercreutz, recogió en un promemoria la acción de su Servicio contra los excombatientes suecos en España. En él se recogen las siguientes frases:

Hay sobrados motivos para sospechar que aquellos que en su día se alistaron en las Brigadas Internacionales han quedado tan firmemente atrapados en las garras del Comintern, que ya no tienen posibilidad alguna de librarse de ellas.

Unos cuantos veteranos de la guerra de España continuaron su formación - incluso una formación especial - en la Unión Soviética, donde su presencia se ha podido comprobar ${ }^{100}$.

En 1942, la Policía de Seguridad sueca elaboró un amplio informe sobre los brigadistas suecos, con un análisis de la guerra civil española en general, así como de la

\footnotetext{
${ }^{96}$ Una visión más detallada sobre los brigadistas internacionales suecos tras el regreso a su país en PEIX GELDART, Benito, "Efter Spanien: De svenska spanienfrivilligas återkomst”, en Arbetarhistoria 1:2012, Estocolmo: ARAB, 2012.

${ }^{97} \mathrm{JÄNDEL}$, op.cit, p. 33.

${ }^{98}$ LUNDBERG, op.cit., p. 137 y s.

${ }^{99}$ Sobre la actividad de los Servicios de Inteligencia suecos al respecto, cfr. ELIASSON, op. cit.

${ }^{100}$ RA, Krigsarkivet, C.Adlercreutz arkiv: Aktionen mot Spanienkämparna, citado en GYLLENHAAL \& WESTBERG, “I spansk tjänst...”, p. 338.
} 
implicación de la Internacional Comunista, con informes detallados de las personas y métodos implicados en el reclutamiento de voluntarios en Suecia. A esa información se adjuntaban las listas de los brigadistas, distribuidas por lugares de procedencia y/o residencia, los datos de su afiliación política y el grado de su implicación en las Brigadas $^{101}$. El informe comienza con un análisis de la guerra civil española, basado en la obra en dos volúmenes - el primero de 1938 - sobre la misma preparada por la Sección histórica del Estado Mayor de la Defensa sueco ${ }^{102}$.

Especialmente durante el período de vigencia del pacto Ribbentrop-Molotov, todos los que participaban activamente en las organizaciones comunistas suecas fueron sometidos a estrechos controles y registros por parte de la policía sueca. No faltan testimonios al respecto por parte de los interesados, por ejemplo el de Greta Segerson, esposa de uno de los brigadistas, y activista comunista al igual que su esposo Bengt, sobre la redada policial anticomunista del 10 de febrero de 1940, que tuvo lugar en toda Suecia $^{103}$.

Las dificultades de algunos antiguos brigadistas con la Policía de Seguridad sueca seguirían incluso después de 1945, en forma de escuchas telefónicas e interrogatorios ${ }^{104}$.

Durante la Segunda Guerra Mundial, muchos voluntarios de la guerra de España fueron movilizados por el Ejército sueco, como lo fue la mayor parte de los suecos varones menores de 45 años en condiciones de efectuar servicio de armas. Tras la invasión nazi de Dinamarca y Noruega, en la primavera de 1940, se crearon "compañías de trabajo", donde fueron a parar aquellas personas, sobre todo comunistas, que fueron consideradas un peligro para la seguridad de Suecia. Veintitantos antiguos brigadistas, según el Comité de Ayuda a España, estuvieron en ellas. Sujetos a disciplina y régimen militar, no se les permitía llevar armas y eran destinados a trabajos de fortificación, a construcción de carreteras o a "campos de trabajo". En el verano de 1943 fueron disueltas. Sin embargo, la mayoría de los voluntarios estuvieron en unidades militares ordinarias.

\footnotetext{
101 RA, SÄPO, Vol. 493, Informe Vissa omständigheter kring den svenska Spanienvarvningen (algunas circunstancias en relación con el reclutamiento de suecos para España), del Comisario Erik Lönn, de fecha 9.V.1942.

102 FÖRSVARSSTABEN, Det spanska inbördeskriget I - II, Estocolmo: Militärlitteraturföreningen, 1938/1941. La Ministra de España en Suecia, Isabel de Palencia, calificó de "superficial” a la primera parte de este libro, cfr. AMAEC R 642, 3 e, despacho de 3.I.1939. No nos parece acertada su opinión.

${ }^{103}$ SJÖSTEDT, Jonas, Masthugget, Moskva, Madrid, Estocolmo: Carlsson, 2009, p. 91 y s.; cfr. también RA, SÄPO, vol. 493, Informe 263/42 28.V.1942; Informe de 22.V.1943 al Comandante Berendt (Estado Mayor de la Defensa); y PM secreto de Erik Lönn y Lars P Lindroth, 9.V.1942: Informe del Comisario de Gotemburgo Berneklou de 21.III.1942;

${ }^{104}$ JÄNDEL, Richard, op.cit., p. 34; cfr. también ARAB, Frontkämparnas stödfond 1236/D I:1 PM 1958.
} 
Al menos cuatro veteranos y al menos otros dos veteranos de la guerra española, (Andersson, Staf, Risto y H. Ericsson) participaron activamente en Suecia, durante la Segunda Guerra Mundial, en la organización Bernhard, la red de los servicios de inteligencia soviéticos para operaciones de sabotaje en otros países ${ }^{105}$.

Además de en el Ejército sueco, un número apreciable de antiguos brigadistas volvieron a empuñar las armas en la lucha contra el nazismo en otros ejércitos. Quizá el mayor contingente fuera el que participó en el SFK, el Cuerpo de voluntarios suecos en la guerra de invierno soviético-finlandesa, que duró 100 días entre diciembre de 1939 y marzo de 1940 y que en toda Suecia motivó oleadas de simpatía hacia su vecino nórdico.

Un par de decenas de veteranos suecos de las Brigadas Internacionales lucharon en el SFK. Hubo algunos anarcosindicalistas, como Olov Jansson, presidente de las Juventudes anarcosindicalistas suecas (Syndikalistiska Ungdomsförbundet), y Gösta Näslund, evadido en su día de las prisiones de la llamada zona nacional en España. El más conocido de los exbrigadistas que participaron en la defensa de Finlandia contra la agresión estalinista fue Conny Andersson, socialdemócrata, quien dijo haberse encontrado en el SFK con un pequeño grupo de suecos que habían luchado por la parte enemiga, es decir, la franquista, en la guerra civil ${ }^{106}$. Este dato no ha sido contrastado hasta la fecha.

Además de la participación de exbrigadistas al servicio de Finlandia y de la Unión Soviética, hubo alrededor de 15 de ellos que lucharon contra el invasor nazi en la campaña de Noruega. Uno de ellos fue el bien conocido Conny Andersson, veterano ya de dos guerras, que sería capitán de una compañía noruega ${ }^{107}$.

Una gran parte de los brigadistas suecos eran marinos de profesión. Como tales, un buen grupo de ellos se vieron involucrados en la Segunda guerra mundial. En efecto, tras la invasión nazi de Noruega y Dinamarca el 9 de abril de 1940 y el consiguiente cierre del estrecho del Skagerrak, la flota mercante sueca quedó dividida en dos mitades más o menos iguales. La parte que quedó fuera del mar Báltico participó en muchas operaciones de avituallamiento a favor de los aliados. La otra mitad de la flota contribuiría a abastecer de hierro sueco a los ejércitos del III Reich ${ }^{108}$.

\footnotetext{
${ }^{105}$ LUNDBERG, op.cit., p. 139; GYLLENHAAL \& WESTBERG, “I spansk tjänst...”, p. 162 y 336 y ss.

${ }^{106}$ GYLLENHAAL \& WESTBERG, "I spansk tjänst...”, . p. 234.

${ }^{107}$ ERICSON, op.cit., p. 110; HUGEMARK, Bo (coord.), Urladdning. 1940 - blixtkrigens år. Estocolmo: Svensk militärhistoriskt bibliotek, 2002, p. 313. GYLLENHAAL \& WESTBERG, "I spansk tjänst...", p. 180.

${ }^{108}$ LUNDBERG, op.cit., p. 138.
} 
Tras la guerra mundial, los voluntarios suecos de la guerra civil española llevaron una existencia discreta a nivel personal, aunque siguieron colectivamente honrando la memoria de sus camaradas fallecidos en los frentes de guerra españoles.

En 1967, por iniciativa del presidente de la Asociación de Camaradas voluntarios suecos en España (Svenska Spanienfrivilligas kamratförening), el partido comunista sueco propuso con éxito al Ayuntamiento de Estocolmo que se pusiera un monumento conmemorativo de los brigadistas, en el barrio de Södermalm, en el centro de la ciudad. Por medio de colectas se había reunido la cantidad necesaria, pero el Ayuntamiento decidió correr con los gastos del monumento, donándose entonces las cantidades recaudadas, por partes iguales, al PSOE y al PCE.

La escultura de Liss Eriksson denominada La Mano (el nombre se le puso en castellano) ganó el concurso y fue erigida el 11 de junio de 1977. También en Gotemburgo se erigiría más tarde otro monumento. Ante ellos, la asociación de camaradas voluntarios organizaba todos los años un acto conmemorativo, en el que tradicionalmente han participado todos los partidos y organizaciones del movimiento obrero, olvidando para la ocasión sus diferencias políticas.

Durante la guerra civil, el Comité sueco de Ayuda a España, creado ya en 1936 en apoyo del gobierno legítimo de España, con participación de todas las fuerzas políticas y sindicales afines al movimiento obrero sueco, si bien con predominio del Partido comunista, canalizó la amplia ayuda humanitaria del pueblo sueco a España, bajo la dirección de Georg Branting. La mayor parte de los fondos provenían de trabajadores, aunque tampoco faltaron donativos de ambientes burgueses.

A partir del regreso de los voluntarios, el espíritu de su lucha fue canalizado a través de nuevas organizaciones, como el ya mencionado Fondo de Apoyo a los luchadores del Frente (Frontkämparnas stödfond), o la Svenska Frontkämpeförbundet (Federación sueca de luchadores del Frente., que posteriormente se llamaría Svenska Spanienfrivilligas Kamratföreningen (Asociación de Camaradas voluntarios suecos en España).

A través de ellas, antiguos brigadistas colaboraron en acciones de protesta, mítines, manifestaciones y actos culturales, y, bajo el lema "Romped con Franco" (Bryt med Franco) propagaron el boicot comercial y turístico al régimen vigente en España y el apoyo a la resistencia española ${ }^{109}$.

\footnotetext{
${ }^{109}$ OLSSON, op.cit., 198-204.
} 
Ya desde 1939, algunos voluntarios comenzaron a publicar sus experiencias. A través de ellas es fácil seguir la trayectoria posterior de sus autores y de un cierto número de exbrigadistas ${ }^{110}$. Con ellas, y con la labor y el material de las organizaciones anteriormente citadas, el Archivo del Movimiento Obrero en Estocolmo (Arbetarrörelsens arkiv och bibliotek, ARAB) ha conseguido reunir un ingente fondo documental, aún no totalmente estudiado. Como mencionamos en la parte introductoria, la archivera Lucy Viedma ha catalogado esos fondos relativos a la guerra española.

Las experiencias de los voluntarios suecos de las Brigadas Internacionales fueron importantes para el desarrollo del movimiento obrero, como comentó uno de ellos:

la experiencia de la lucha armada en España dio nueva vida a las ideas del internacionalismo proletario de un modo anteriormente desconocido en la historia del movimiento obrero. Y desempeñaron un papel decisivo en el desarrollo de la labor de solidaridad internacional incluso hasta nuestros días ${ }^{111}$.

En noviembre de 2009 falleció el último de los voluntarios suecos conocidos, el marino Ernst Larsson, a los 89 años de edad. Su memoria, en cambio, sigue viva en el pueblo sueco, y singularmente en las organizaciones vinculadas al movimiento obrero.

No nos es posible extendernos aquí sobre el papel jugado por los voluntarios suecos. Como hemos tenido oportunidad de constatar, los fondos documentales en los archivos suecos y la bibliografía existente en este país al respecto son muy amplios. Las experiencias y memorias de los brigadistas, que han servido de base a gran cantidad de artículos y citas posteriores en libros y revistas, han dado a conocer este aspecto de la historia contemporánea de Suecia a las generaciones posteriores, en una visión no del todo exenta de un cierto romanticismo.

Es lógico que así fuera, pues fueron precisamente los exbrigadistas más significados políticamente, tanto entre la organización anarcosindicalista SAC como, sobre todo, en el Partido Comunista (SKP), los más prolíficos en publicar y divulgar sus experiencias, lo cual no puede dejarse de lado a la hora de realizar una valoración histórico-crítica de sus contenidos. Con excepción de Lundvik y especialmente de Gyllenhaal \& Westberg, que no ocultan el papel desempeñado por la Internacional Comunista - e incluso por los Servicios soviéticos de Inteligencia - al tratar de los brigadistas, la tendencia general en la

\footnotetext{
${ }^{110}$ Las más conocidas son: BRÄNNSTRÖM, op. cit.; OLSSON (ROGEBY), opera citata; MEURLING, op. cit.; SJÖSTEDT, Jonas, (coord.), Masthugget....

${ }^{111}$ OLSSON (ROGEBY), Spanska frontminnen..., epílogo.
} 
bibliografía ha sido la de situar el alistamiento de los voluntarios en el marco de un movimiento de solidaridad propio de las masas trabajadoras de Suecia y su deseo de colaborar activamente a la derrota del fascismo internacional.

Concluimos así este apartado dedicado a la intervención sueca a favor de la República en la guerra civil española. De lo aquí expuesto se desprenden, a nuestro entender, dos conclusiones interesantes: la primera es que la actitud oficial tomada por Suecia en el conflicto español, que le llevó a alinearse decididamente con la política inglesa de la no intervención y en ese marco a criminalizar el alistamiento de sus ciudadanos en las Brigadas Internacionales, coexistió con un claro compromiso moral, por parte de amplios estratos de la población sueca y no sólo de la clase trabajadora, a favor de la República española, aunque la política oficial estuvo siempre presidida por un pragmatismo práctico, que se manifestó en la ayuda al retorno de los brigadistas y en la no aplicación de las disposiciones punitivas contra los voluntarios suecos.

Otra conclusión que se refiere en particular a los brigadistas suecos de las brigadas internacionales es que la desconfianza y recelo de la Suecia oficial respecto a ellos no estuvo relacionada con su participación en las Brigadas en cuanto tal, sino en el contacto con el comunismo soviético que se derivaba de esa participación. En este sentido, la actitud de las autoridades suecas es coherente con la decidida política anticomunista vigente en Suecia en todo el período de entreguerras, tanto bajo gobiernos de centro-derecha como socialdemócratas.

\subsubsection{Los voluntarios suecos al servicio de la España de Franco}

Por contraste con la ingente cantidad de estudios existentes en la historiografía sueca acerca de los voluntarios suecos al servicio de la República, solamente tres hacen alguna referencia - y muy somera - a los voluntarios "del otro lado"112. La razón es obvia: su escaso número en proporción al anterior, como también lo es el motivo de este hecho, a saber, la decisión de las autoridades militares franquistas de no aceptar voluntarios extranjeros no encuadrados en las unidades militares aliadas como la Legión Cóndor, las unidades italianas, o la brigada irlandesa de O'Duffy. La excepción fueron las Banderas de Falange y especialmente la Legión Española, en la que el total de voluntarios extranjeros pasó de 67 antes del 18 de julio de 1936 a 1245 en el verano de $1938^{113}$.

\footnotetext{
${ }^{112}$ NILSSON, op.cit., p. 79 y 214; SCHÖN, Bosse, Hitlers svenska soldater, Estocolmo:DN, 2004, p. 101.

${ }^{113}$ AGMAV, C. 2385, L. 168, Cp.30/1;
} 
Sobre los voluntarios al servicio de Franco hay dos estudios internacionales recientes, uno de la historiadora australiana Judith Keene y otro del escritor anglo-galés Christopher Othen. Keene estima el número de estos voluntarios no incluidos en las unidades extranjeras organizadas - alemana, italianas, irlandesa y portuguesa, además de las tropas marroquíes - en torno al millar y medio de personas, mientras que Othen habla de entre 2.000 y 3.000 personas.

Las pocas referencias que hacen estos autores a voluntarios escandinavos se refieren mayormente a finlandeses (especialmente Carl von Haartman, jefe de la Centuria Catalana de la Columna Moliner falangista) o a noruegos ${ }^{114}$. Esto no es extraño, ya que el número total de suecos que luchó al servicio de Franco, según los datos disponibles, no llegó a la docena.

Fue José Luis de Mesa quien por vez primera dio a conocer los nombres de los ocho suecos que sirvieron en la Legión. Todos fueron reclutados ya comenzada la guerra, y con nombres ficticios. La lista de nombres citada por Mesa y recogida por Gyllenhaal y Westberg es la siguiente ${ }^{115}$ :

\author{
Charles Fraskfikgger (Quinta Bandera) \\ Juan Gutiérrez del Castillo (Novena Bandera) \\ Gonzali Oinelli (Once Bandera) \\ Fernando Rocha (Once Bandera) \\ Hans Scherrer (Once Bandera) \\ Anton Chevor (Diecisiete Bandera) \\ Armando Chevor (Bandera de Depósito) \\ Alphons Walberg (sin información sobre unidad)
}

Gyllenhaal supone que Hans Scherrer es en realidad su pariente el marqués sueco Hans Leuhusen, de quien le consta que sirvió en la Legión de 1936 a 1938. Apunta también la posibilidad de que Anton y Armando Chevor sean la misma persona. Respecto a Alphons Walberg, escribe Gyllenhaal que todo parece indicar que se trata del estocolmiense Frans Alfons Wahlberg que fue funcionario bancario en Perú en los años

\footnotetext{
${ }^{114} \mathrm{KEENE}$, op. cit.; OTHEN, op. cit..

${ }^{115}$ MESA, José Luis de, Los otros internacionales: voluntarios extranjeros desconocidos en el bando nacional durante la guerra civil (1936-1939), Madrid: Barbarroja, 1998, p. 185; GYLLENHAAL \& WESTBERG, “I spansk tjänst...”. p. 119.
} 
treinta y posteriormente luchó como Unterscharführer en la division Norrland de las SS alemanas durante la segunda guerra mundial ${ }^{116}$.

El dato de ocho suecos en la Legión está documentado en el Archivo General Militar de Ávila, así como sus nombres, que coinciden con los arriba señalados salvo en el caso de Anton Chevor, de la Diecisiete Bandera, que aparece como Antonio Zuber. También consta el nombre de un soldado sueco en el II Cuerpo de Ejército, llamado Alfonso Torgren Sund (¿acaso el mismo Frans Alfons Wahlberg?) ${ }^{117}$.

Aparte de estos legionarios, un conocido aviador sueco, el conde Douglas Hamilton, ofreció sus servicios, incluido su avión, a la aviación franquista. La propuesta fue aceptada, aunque parece que Hamilton no pudo hacerla efectiva debido a un accidente con su aparato.

El asunto no está del todo claro, porque por otra parte aparece su nombre en los diarios del Agregado militar sueco para España, y parece ser, además, el autor de unos detallados informes sobre los guerra española para las autoridades militares suecas que llevan por título "Observaciones de Hamilton como persona particular durante un viaje a España en 1938".

No cabe descartar que fuera uno de las fuentes básicas para la elaboración del libro sobre la guerra civil española publicado por el Estado Mayor sueco, cuya primera parte apareció en 1938. Da la impresión de que Hamilton, además de - o acaso, en lugar de voluntario franquista, era un informador de las Fuerzas Armadas suecas. De hecho, éstas habían intentado, sin éxito, enviar un observador militar a la España de Franco, el capitán Patrik Gyllenhammar ${ }^{118}$.

Aunque la documentación disponible no permita afirmarlo con certeza, es posible que hubiera algunos suecos más al servicio de Franco. Un informe de la Policía de Seguridad menciona como presunto voluntario franquista a un hijo de un conocido miembro del partido nazi sueco ${ }^{119}$. Y según el brigadista socialdemócrata sueco Conny

\footnotetext{
${ }^{116}$ GYLLENHAAL \& WESTBERG, “I spansk tjänst...”., p. 119, y GYLLENHAAL, “Skandinaviska...”. ${ }^{117}$ AGMAV, C. 2385, L. 168, Cp. 30/ 7; Cp. 30/1; Cp. 31/9; Cp 31/13; Cp. 31/15; Cp. 31/2 ; AGMAV, C. 2483, Cp. $5 / 4$.

118 AGMAV C. 2305, L. 10 cp. 15 (Hamilton) y cp. 11 (Gyllenhammar); RA, UD, Beskickningsarkivet: Madrid C 5 Vol. 1 Militärattachéns diarier (diarios del Agregado Militar), entrada de 17.VIII.1939; GYLLENHAAL \& WESTBERG, "I spansk tjänst...", pp. 119-121. Al respecto cfr. también AMAEC R 1058, 11, despacho de 23.VII.1938 de la representación franquista en Estocolmo preguntando sobre el presunto viaje a España de militares suecos pretendiendo ser delegados de la Cruz roja, pese a la denegación de la solicitud del capitán Gyllenhammar.

${ }^{119}$ RA, SÄPO, Vol. 497, rapport från kriminalkonstapel Olle Mattson (informe del comisario-detective Olle Mattson), Sundsvall, 26.IX-1942: El presunto voluntario era Göra Åkerblom, nacido en Skeppsholmen
} 
Andersson, que luchó también como voluntario en Finlandia en las filas del Cuerpo Sueco de Voluntarios allí, se había encontrado con un pequeño grupo de gente que antes había luchado en España "en el otro bando" "120. Es posible que se tratara de algunos de los legionarios citados anteriormente. Pero mientras no haya más evidencia documental, no cabe afirmar nada con certeza ${ }^{121}$.

En cualquier caso, en lo aquí expuesto queda clara la escasa - por no decir nula importancia de la aportación sueca al esfuerzo bélico de la España de Franco por lo que se refiere a la participación de voluntarios. Las causas hay que buscarlas, sin duda, en la falta de interés de las autoridades franquistas y de sus aliados por fomentar la participación de voluntarios extranjeros, con la consiguiente inexistencia de campañas de reclutamiento al estilo de las existentes para las Brigadas Internacionales. Asimismo, no debe olvidarse la marginalidad de los movimientos suecos de extrema derecha en el conjunto de la sociedad sueca de la época, y la falta de afinidad de las derechas suecas con sus homónimas españolas, como expusimos en capítulos anteriores.

\subsubsection{Material bélico sueco en la guerra civil española}

Nos enfrentamos ahora a un aspecto de la intervención sueca española que apenas ha estado presente en la historiografía, tanto sueca como española: la cuestión de la presencia de armas suecas en la guerra civil. Sorprende un tanto, ya que no faltan fondos documentales al respecto. El presente trabajo es, por tanto, pionero en este aspecto, y podría servir de inspiración a futuros estudios monográficos.

La industria armamentística sueca era ya conocida en los años treinta del siglo XX como una de las más poderosas del mundo. En particular, los cañones antiaéreos de la casa Bofors gozaban de prestigio universal. Es lógico, por tanto, que los esfuerzos de los

(Estocolmo), el 21.10.1905, baja laboral en 1936 por alcoholismo. Era hijo del difunto capitán de navío Nils Åkerblom, miembro del partido de Furugård. La policía no consiguió pruebas concluyentes al respecto.

${ }^{120}$ GYLLENHAAL \& WESTBERG, "I spansk tjänst...”, p. 234.

${ }^{121}$ Cfr. AMAEC R 602, 5, despacho de Fiscowich de 21.XII.1936: "La indudable simpatía que en ciertos sectores de este país existe hacia la causa nacional de España se ha traducido en algunos ofrecimientos para ir a combatir en las filas del ejército libertador", y sugiere aceptarlas. Cfr. también RA: Beskickningsarkivet: Madrid F1 C, Vol. 41, recorte de prensa español donde se afirma que el príncipe Eugenio de Suecia prestaba servicio como capitán de requetés de Navarra. No parece fiable esta información, no ratificada por ninguna otra fuente. Consta, en cambio, que el Príncipe contribuyó, con palabras de apoyo y acciones concretas a las actividades de propaganda de la Legación republicana en Suecia y del Comité de Ayuda a España, mediante el préstamo de cuadros de Picasso, de su propiedad, para la exposición de Arte Moderno Español organizada en Suecia en 1937 y 1938, cfr. AMAEC R 1785, 13, despacho n. 190 de 27.VII.1938 y AMAEC 642, 1, Anejo al despacho n. 209 de 7.VIII.1938. 
agentes y compradores de armas de ambos bandos procuraran adquirir material bélico en Suecia.

Las gestiones parecen haber comenzado inmediatamente, ya que hay constancia documental de que a primeros de agosto de 1936, una empresa sueca ofreció un avión en venta a los militares rebeldes. Por las mismas fechas, documentación del bando sublevado menciona envíos suecos de dinamita ${ }^{122}$.

Por parte republicana, fue precisamente el encargo dado por el gobierno al Ministro de España en Suecia, Alfonso Fiscowich, de adquirir armas el detonante del paso de éste al bando rebelde ${ }^{123}$. Acaso éste sea uno de los dos aviones suecos que, según Moradiellos, formaron parte del material bélico republicano ${ }^{124}$. Poco a poco, el Servicio de información organizado por el Embajador de España en Praga, Luis Jiménez de Asúa, cuya relación personal con Suecia ya tuvimos ocasión de mencionar, estableció conexiones en Suecia y ya desde principios de 1937 tenía listas de personas de confianza para el transporte y propaganda en Estocolmo y Malmö ${ }^{125}$.

Incluso la Ministra de España en Estocolmo, Isabel de Palencia, hizo gestiones directamente cerca de las autoridades suecas y de la fábrica Bofors para la adquisición de cañones antiaéreos. Tras obtener una respuesta negativa, trató de conseguirlos por otras vías, también sin resultado. Palencia se quejó en diciembre de 1938 a su amiga la Embajadora Soviética Alejandra Kollontai de la "traición del gobierno sueco a a la democracia y a los principios marxistas", dándole cuenta de su profundo desencanto, especialmente respecto al Ministro de Negocios Extranjeros del gobierno socialdemócrata sueco, Rickard Sandler:

En tensión estuve pendiente de los señores Wenner-gren y Wallenberg. ¿Te acuerdas de las negociaciones secretas entre estos industriales y banqueros y yo, tras las victorias de Guadalajara y del Ebro, para que nos consiguieran material bélico? (...)

\footnotetext{
${ }^{122}$ El asunto tuvo caracteres de opereta, pues la empresa sueca dirigió su oferta dirigida al "General Franco, Ministerio de la Guerra, Madrid”, razón por la que el cónsul sueco Olsén tuvo conocimiento del tema, cfr. RA, UD, 1920-års dossier, HP 36, vol. 1504, PM de Olsén de 10.VIII.1936; AMAEC R 613, 5 telegrama E.M. del Cuartel general del Generalísimo de 18.VIII.1936 y AMAEC R 602, 5 documentación sobre intento de comprar armas suecas, 20.IX.1936.

${ }^{123}$ AMAEC PG 0033, 15430, expediente personal de A. Fiscowich: El 6.VIII.1936 recibe Fiscowich desde Madrid un telegrama participándole haberse abierto a su nombre, en Estocolmo, un crédito de 92000 coronas suecas para la adquisicion de un avión y dándole instrucciones sobre esta compra. Dimitió de su cargo y el 11 de agosto se adhiere al bando sublevado.

${ }^{124}$ MORADIELLOS, El reñidero de Europa..., p. 263.

${ }^{125}$ EIROA, Matilde, "La Embajada en Praga y el servicio de información de Jiménez de Asúa", en VIÑAS, Ángel (coord.), Al servicio de la República: Diplomáticos y guerra civil, Madrid: Marcial Pons Historia, 20, pp. 207-240.
} 
Per Albin es más honrado y más decente que Sandler, pues no tuvo la valentía de dar tal golpe a un pueblo que de forma tan heroica defiende su independencia y su libertad. No tuvo agallas para mirarme a los ojos y decirme a la cara que el gobierno socialdemócrata está dispuesto a enviar a Franco cañones de la Bofors, fabricados por las manos de los trabajadores $\operatorname{suecos}(\ldots)^{126}$.

Probablemente conocía la representante de la República Española en Suecia la actitud oficial sueca de no permitir la venta de armas para España, en consonancia con los acuerdos internacionales, la actitud oficial sueca quedó clara desde un primer momento: Prohibición total de exportación a España. No se concedería licencia alguna ${ }^{127}$.

La prohibición estuvo vigente toda la guerra, a pesar de los intentos de la República y de diversas organizaciones del movimiento obrero sueco por cambiar esa decisión. En una reunión de políticos socialdemócratas nórdicos en 1938, Sandler insistió en la necesidad de no alterar los acuerdos en este sentido, pues en caso contrario, todo el mundo sabía que era precisamente a Suecia donde la República acudiría a comprar sus cañones antiaéreos $^{128}$.

La falta de facilidades con que se encontraron en Suecia los compradores de armas republicanos fue incluso destacada por los agentes de Franco:

En la actualidad se encuentran en Estocolmo varios agentes rojos que tratan de adquirir armas, con poco éxito, pues el gobierno sueco se mantiene en actitud neutral, y la gran industria de armas Bofors tiene la consigna de no procurar armamento a los comunistas españoles, de parte de las fábricas Krupp que poseen las acciones de aquella en su mayor parte. Sin embargo, los agentes referidos lograron comprar en Estocolmo 500 ametralladoras inglesas y 20.000 fusiles Mauser, y en la actualidad están tratando de revender, con pérdida, unas y otros. Se ignora en absoluto cual pueda ser la causa de que quieran vender las ametralladoras; en cuanto a los fusiles, ocurre que los fabricados en Suecia lo son para cartuchos cónicos, en lugar de cilindricos, que es lo corriente, y como por otra parte, los suecos no les ofrecen sino un muy reducido stock de municiones, resultaría que al poco tiempo no podrían utilizar aquellos. Además de los españoles aludidos, actuan para los rojos, en Estocolmo, agentes de la casa inglesa New Zealand Manufactures Ltd, un tal Roger, medio francés medio ruso, el checo

${ }^{126}$ KOLLONTAI, op.cit., p. 527 y s.

127 RA, UD, 1920-års dossiersystem, HP 36, vol. 1504, respuesta a la pregunta al respecto del Ministro Plenipotenciario belga.

${ }^{128}$ Reunión de Oslo 15-17.V.1938, en WAHLBÄCK \& BLIDBERG, (ed.) op.cit., pp. 180-182: Jacobsen dudaba del carácter democrático de la República Española. Allan Vought veía difícil conciliar los principios ideológicos del movimiento obrero con la política pacifista nórdica. Sandler adoptó la postura pragmática reseñada. 
Mirdish y otros dos que por haber mostrado demasiada curiosidad en la fábrica Bofors han sido

expulsados del territorio sueco ${ }^{129}$.

Es posible que Isabel de Palencia ignorara que la fábrica Bofors había recibido de la casa alemana Krupp la consigna de no vender armas a la República ${ }^{130}$.

Eso no implica, necesariamente, que las armas suecas no llegaran a España. Consta, por el contrario, que sí lo hicieron. Un cañon antitanque de marca Bofors fue expuesto en el otoño de 1938 en la muestra sobre el material bélico republicano organizado por las autoridades franquistas en San Sebastián ${ }^{131}$. Howson menciona 12 cañones antitanque Bofors-M 35 de 37 mm. y 16 cañones antiaéreos de fuego rápido Bofors-M 38 de 40 mm. en el Ejército republicano español, y dice al respecto:

No se sabe con certeza cuántos de estos cañones modernos suecos consiguieron adquirir los republicanos ni a través de quién; pero las pruebas apuntan a una conexión suiza, a través de Rosenfeldt, Rosenbaum y los estados bálticos. Fernando Valdés, agente de Franco en Estocolmo, dijo a su gobierno que sospechaba que George Branting, dirigente socialista sueco, estaba destinando dinero recogido para ayuda de los niños españoles a la compra de piezas de artillería. En realidad, los Bofors fueron otra de tantas compras que los republicanos hicieron en el otoño de 1936 y luego pasaron el siguiente año y medio tratando -casi en vano- de recibir las entregas. Los cañones antitanque puede que se compraran a través del SEPEWE, pues el cargamento del Jarón (apéndice II, 25 sept. 1937) incluía veintiséis cañones de 37 mm, de tipo no especificado, cuyo precio unitario era de $\$ 4.150$, que daba casi justo para un Bofors M35.

\footnotetext{
129 AGA, Asuntos Exteriores, Caja 12048, L. 12, despacho n. 90 de la Representación franquista en Estonia de 23.XII.1937; cfr. también AMAEC R 613, 1, informe de Fiscowich: "Jose Arnaldo Weissberger fue a Estocolmo con encargo oficial del gobierno rojo de Madrid de hacer envios de celulosa y pasta para papel. Igualmente hizo gestiones cerca de la firma Bofors fabricante de armamentos para la compra de tres baterias de artilleria. Parece ser que no halló facilidades en Suecia”; y AMAEC R 602, 5 despacho 48 de Fiscowich, de18.XII.1936, informando que el Ministro de Méjico en Berlin había tratado infructuosamente de adquirir material de guerra sueco para los republicanos espanoles.

${ }^{130}$ La Policía de Seguridad sueca dejó constancia de sus fundadas sospechas acerca de la existencia de un acuerdo secreto entre la empresa sueca Bofors y la alemana Krupp, cfr. RA, SÄPO, Äldre aktsystem, Vol. 95, I C 3 1-399. Bofors obtuvo del gobierno sueco licencia de exportación de sus cañones de $40 \mathrm{~mm}$. para los países siguientes: Hungría, Austria, Bélgica, Holanda, Noruega, Finlandia, Inglaterra y Polonia. El capital alemán en la industria armamentística sueca de la época es conocido, aunque la información de que la Krupp fuera accionista mayoritario de la Bofors (cfr. el recién citado despacho n. 90 de la Representación franquista en Estonia de 23.XII.1937, AGA, Asuntos Exteriores, Caja 12048, L. 12) quizá no sea exacta: CANTERA CARLOMAGNO (Ett folk av mänsklig granit..., p. 72 y s) afirma que la fábrica alemana había vendido sus acciones en 1935 a una empresa sueca. No hemos tenido oportunidad de controlar este dato.

${ }^{131}$ AGMAV C. 2532, cp. 26; RA, UD, Beskickningsarkivet: Madrid F1C:43: El 10.I.1939, Berencreutz, el agente sueco ante la España franquista, desmentía al Diario Vasco que la Bofors hubiera enviado material de guerra a España por valor de 24 millones. Según él, no era posible ya que el gobierno sueco no había dado ninguna licencia de exportación de armas para España. Cfr. también Ibidem, carta confidencial de Berencreutz al Ministerio de Negocios Extranjeros sueco, de 14.I.1939, sugiriendo se pregunte a la Bofors cómo habían llegado a España los ocho cañones capturados en Villareal.
} 
Convendría recordar, no obstante, que ninguna porción de su cargamento llegó ni siquiera a Francia hasta que no fue transportado por el vapor Diana en abril y mayo de $1938^{132}$.

La existencia de estos cañones en el frente de Aragón está atestiguada por el general republicano Manuel Tagüeña, y era asunto conocido por los servicios de Franco en Estocolmo $^{133}$.

Diplomáticos y espías franquistas alertaron repetidas veces a su gobierno de las adquisiciones de armas en el norte de Europa por parte de los republicanos. Un informe reservado del SIFNE franquista se refiere a la posible adquisición por "el Gobierno de Barcelona" de "6 grupos de 3 baterías de 4 piezas de artillería ligera y proyectiles de la casa Bofors, de Suecia”, y las representaciones diplomáticas franquistas en Estonia y Finlandia pusieron especial cuidado en denunciar el tráfico de armas llevado a cabo por contrabandistas suecos en connivencia con el gobierno de Estonia, mencionando expresamente a la Bofors ${ }^{134}$.

Al mismo tiempo, también las fuentes diplomáticas de la España republicana y la prensa favorable a ésta presentaron denuncias de grandes suministros de material bélico por parte de la casa Bofors a los militares rebeldes; unas denuncias que tienen base real, como se desprende de los fondos del archivo de la Policía de Seguridad sueca.

También la conexión báltica mencionada por Howson respecto a los cañones Bofors republicanos, queda confirmada por esos mismos fondos. La exportación "indirecta" de armas, por el procedimiento de venderlas a un país no beligerante, aunque su destino final fuera uno en guerra - en el caso que nos ocupa, a Portugal o Méjico, para su llegada posterior a España - era política comúnmente aceptada en la Suecia de la época, según se reconoce en una instrucción "estrictamente confidencial" del Ministerio de Negocios Extranjeros a Palmstierna (Embajador sueco en Londres), donde se explica la postura tradicional de exportación indirecta de armas sin límites siempre que el comprador sea un gobierno extranjero, y se recuerda lo expuesto por Suecia a la Sociedad de Naciones el 14

\footnotetext{
${ }^{132}$ HOWSON, op.cit., p. 419 y ss. A la intervención de Georg Branting en operaciones de contrabando de armas nos referiremos más adelante.

${ }^{133}$ TAGÜEÑA LACORTE, Manuel, Testimonio de dos guerras, Barcelona: Planeta, 2005, p. 205; AMAEC R 1047, 51.

${ }^{134}$ AGMAV, C. 2472, Cp.1/3, 6, 7, 10, 11-17 y Cp.18/ 6, 12 y 13; AMAEC R 1048, 34 nota confidencial fechada en París el 7.VIII.1938, informando del envío de 20 cañones de la marca Bofors que estaban en Lituania, comprados por el embajador lituano por cuenta del gobierno republicano. Según esta información, en Lituania quedaban todavía otros 10 cañones marca Bofors.
} 
julio 1934 en el caso del conflicto del Chaco y el 18 de octubre de 1935 respecto al conflicto italo-etíope.

Se reconoce que en la exportación de explosivos al gobierno portugués, este criterio no se había seguido "en parte" [porque se sabía que el destino final era España, parece dar a entender] y se informa al Embajador que el gobierno sueco había pedido a la Bofors, que se abstuviera de momento de enviar armas a Mejico y a Portugal ${ }^{135}$.

¿Qué decir de todo esto? El análisis de la documentación disponible, contrastando los datos proporcionados por los representantes de la España de Franco y de la República Española en Suecia, Finlandia y Estonia, con las detalladas informaciones, hasta ahora inéditas, contenidas en los archivos policiales suecos, muestra un escenario complicado en los detalles, pero no por ello falto de claridad.

Todo parece indicar la existencia de un entramado de contrabandistas de armas con ramificaciones en muchos países europeos que, con pocos escrúpulos, ofrecían sus actividades de intermediación a cualquiera de los bandos en litigio en España. Además, para maximizar su beneficio económico personal, en algunas ocasiones no tuvieron escrúpulo alguno en realizar un doble juego, vendiendo las armas por duplicado o prescindiendo de cumplir lo acordado, como lo muestra inequívocamente la documentación sueca referida a varios asuntos que acabaron en los tribunales ${ }^{136}$.

La documentación disponible sugiere la existencia de una veintena de barcos al servicio del gobierno de la República, controlados durante algún tiempo desde Gotemburgo. No parece haber sido infrecuente el cambio de pabellón, bien oficialmente,

\footnotetext{
${ }^{135}$ AMAEC R 577, 4, despacho n. 246 de 1.IX.1938, y diario Ny Dag, 3.IX.1936 y 20.IX.1938 denunciando entregas de armas de Bofors a Franco via Alemania y Portugal, así como el desmentido del Ministro sueco de Comercio. Al respecto cfr. también RA, UD,1920-års dossierssystem, HP 36, Vol. 1504, PM del 7.IX.1936 sobre protesta de los socialdemócratas por un envío de armas de Bofors a Alemania, oficialmente para China pero probablemente para España; RA, UD, 1920-års dossierssystem, HP 36, Vol. 1507, tidningsuppgifter rörande krigsmateriel till Spanien (noticias de prensa sobre material bélico a España), y carta confidencial de Wisén a Söderblom de 10.VI.1938 sobre rumores de grandes cantidades de cañones Bofors en la defensa antiaérea republicana; RA, SÄPO, Vol. 496, boletín de la SSK de 28.I.1939, donde algunos brigadistas internacionales suecos afirman haber incautado al enemigo 2 cañones marca Bofors en Brunete; AMAEC R 642, 2, despacho n. 57 de la Legación de España en Suecia, de 8.III.1938;. Por lo que respecta a la llegada de armas a la España de Franco a través de Portugal, que está bien documentada, cfr. AGMAV, C.2320, L.40. Cp. 37; AMAEC R 613, 5 telegrama E.M. del Cuartel General del Generalísimo de 18.VIII.1936 y especialmente RA, UD, 1920-års dossierssystem, HP 430: Bl (instrucciones dadas a Palmstierna, representante diplomático sueco en Londres).

${ }^{136} \mathrm{Cfr}$. notas posteriores respecto al asunto Allegro, al asunto Lola, y al caso Diana.
} 
bien de manera subrepticia alzando pabellones de conveniencia según lo exigieran las circunstancias, como denunció en su día una organización naviera sueca ${ }^{137}$.

A pesar de ello, no parece que el contrabando de armas adquiriera grandes proporciones en Suecia, y fueron pocos los casos donde se pudo comprobar sin género de duda. Los más destacados fueron el asunto Allegro, el asunto Lola, y el caso Diana, llamados así según los nombres de los buques suecos implicados en el contrabando.

El llamado asunto Allegro está ampliamente documentado por fuentes franquistas, republicanas y suecas. Se trataba de un envío de armamento sueco adquirido para el gobierno de la República que cayó en manos de los sublevados el 15 de febrero de 1937. Fue un caso flagrante de doble juego por parte de los implicados en la adquisición y transporte del material. Así resumió el asunto un escrito de la Secretaría militar y política de la Presidencia del Consejo de Ministros y del Ministerio de la Guerra a Largo Caballero:

He recibido del Secretario General del Ministerio de Estado una comunicación cuya copia va adjunta respecto a lo ocurrido con el vapor Allegro que, como sabes, conducía material de guerra adquirido por los elementos de la antigua comisión de París, los cuales, asimismo, fueron por lo visto los fletadores de dicho barco.

Según refiere Isabel de Palencia, el mismo agente que intervino en la carga del barco, fue el que intervino en la descarga en el puerto faccioso de El Ferrol ${ }^{138}$.

El asunto trajo consecuencias policiales y judiciales en Suecia, y está perfectamente documentado en los fondos de la Policía de Seguridad sueca. Por estimarlo representativo de la forma en que se llevaban a cabo este tipo de operaciones, exponemos aquí los detalles del caso.

La iniciativa fue tomada por el suizo Roten, el francés Rosenberg, y el español J.C. Ozores, de la comisión republicana de compra de armas con sede en París. Tomaron éstos contacto con los empresarios suecos Nils Gustav Herbert Söderberg e Ivan Scheja (de la empresa naviera Macedonia), quienes a través del coronel Per Nyström, conocido agente de compraventa de armas, acordaron con la empresa berlinesa Veltjens la compraventa de $620.000 \mathrm{~kg}$ de cartuchos de fusil alemanes.

137 AMAEC R 1048, 34, despacho de 24.II.1938; AGA 54/12048, L. 12, despacho reservado n. 44, de la Representación franquista en Estonia, de 14.VIII.1937; AGMAV, C.2481, Cp.13; AGMAV C.2603, Cp. 26 y Cp. 80; RA, Beskickningsarkivet: Madrid, F1 C, Vol. 41.

${ }^{138}$ FPI, ALA-97-34; Cfr. también AMAEC R 642, 2, despacho n. 57 de 8.III.1938 y AMAEC R 634, 9, despacho n. 74 de 17.III. y n. 83 de 3.IV.1937. 
Los compradores obtuvieron la licencia de exportación sueca declarando que el destino de las armas era Méjico, destino que luego cambiaron a Yemen. En enero de 1937 fingió Söderberg la compra a Scheja del Allegro, vapor de 2.650 toneladas, que el 27 de enero tomó su carga en Lübeck, bajo la supervisión de un representante de la Olson \& Wright de Estocolmo (representante a su vez de la Lloyds londinense). De allí viajó el Allegro a Danzig ${ }^{139}$, donde estaba previsto traspasar la carga a un barco soviético, pero no fue posible. El Allegro prosiguió su viaje, oficialmente a la ciudad yemení de Hodeida, llevando a bordo como representantes del gobierno español a Leonard Dupont como sobrecargo y a de Weer como segundo piloto.

El 15 de febrero de 1937 el Allegro fue detenido cerca de la costa española por un bou de la flota franquista y conducido a El Ferrol, donde se comprobó que la carga era 1.000 cajas de municiones y 12.437 de ladrillos. No cabe duda de que las autoridades de la España franquista habían recibido información de los alemanes, pues la empresa Veljens, según confesó el sueco Söderberg ante el tribunal sueco, creía haber vendido las armas para los Ejércitos franquistas. El capitán del buque, B.E. Andersson, por su parte, estaba al tanto y entregó de buen grado su carga a las autoridades franquistas.

Söderberg, Nyström y Scheja ganaron un millón de coronas de esta operación, en cuya transacción económica también estuvo implicado el sueco John Elis Hultkrantz (exteniente coronel del ejército estonio) y, en su fase inicial, el Ministro de México en Suecia Adalberto Tejeda ${ }^{140}$.

El nombre del Senador Georg Branting apareció más de una vez en relación con el contrabando de armas para España. Lo hizo especialmente en relación con el caso Lola, el contencioso sobre contrabando de armas suecas a la España en guerra que más repercusiones tuvo. Existe detallada documentación sobre el caso en los archivos suecos ${ }^{141}$. También en este caso no llegaron las armas a su destino, la República Española.

El Lola era un barco sueco, construido en Glasgow en 1920 y llamado originariamente Tuskar, adquirido por la República Española en 1937 para el transporte de

\footnotetext{
${ }^{139}$ Danzig era un punto neurálgico en el entramado de la exportación de armas a España, cfr. RA, UD, 1920års dossier, HP 36, vol. 1505, informe confidencial del Consulado sueco en Danzig de 12.XII.1936.

${ }_{140}$ RA, SÄPO Äldre aktsystem, Vol. 95, I C 3 1-399 PM om vissa vapenaffärer, 20.XI.1942; RA, SÄPO, Äldre aktsystem, Vol. 96, IC 3 a) Allegro; Artículo del diario Aftonbladet de 5.IV.1937 y del Folkets dagblad de 28.VI.1937. Estas informaciones están corroboradas también por la investigación que el Ministerio de Estado encargó respecto al Allegro a Isabel de Palencia, cfr. FPI-ALA-97-34 y AMAEC R 642, 1, despacho n. 57 de 8.III.1938.

${ }^{141}$ Existe un Legajo especial dedicado al asunto Lola en el Archivo del Ministerio sueco de Negocios Extranjeros (RA, UD, 1920-års dossierssystem, HP 36, Vol. 1522), del que proceden los datos que exponemos aquí sobre el tema, salvo cuando indicamos otra referencia documental.
} 
material de guerra. Oficialmente era propiedad de su capitán, el sueco Erik Eriksson, a quien al parecer se ofreció un sueldo cuatro veces superior al normal en los barcos suecos $^{142}$. En el verano de 1937, estando el buque cargando municiones - oficialmente, "latas de conserva" - en el puerto rumano de Constanza ${ }^{143}$ se descubrió accidentalmente el verdadero contenido de las cajas. Las autoridades rumanas, hábilmente presionadas por la diplomacia franquista - cuyo representante en Rumania era Prat i Soutzo ${ }^{144}$ - requisaron el barco hasta después de acabada la guerra, resultando inútil un intento de escapada y los esfuerzos de los armadores suecos por liberarlo. El gobierno sueco rehusó mediar en el asunto e incluso trató de retirarle al buque la nacionalidad sueca "por tratarse de un barco de una organización bolchevique"145.

La noticia llamó la atención del Comité de No Intervención, que pidió explicaciones al Embajador sueco en Londres, y a los representantes franquistas en Estocolmo, que el 30 de julio de 1937 protestaron ante las autoridades suecas, acusando explícitamente a Georg Branting de estar implicado. También la prensa sueca se hizo eco al respecto, en particular la de extrema derecha - que llamó a Branting "el instrumento sueco de los contrabandistas de armas" - pero incluso el principal diario del país ${ }^{146}$.

Georg Branting protestó con firmeza y denunció al diario nazi sueco (Den svenska Nationalsocialisten) ante el Pressens Opinionsnämnd (organismo de la Prensa sueca para el autocontrol de la profesión).

¿Tenían razón los acusadores? No parece que pudiera probarse la implicación del Senador en el asunto Lola, pero consta que la Policía sueca tomó las acusaciones en serio, llegando a solicitar datos bancarios de las cuentas privadas del político socialista ${ }^{147}$. Por otra parte, entre las propias filas de los simpatizantes de Branting no faltaban quienes

\footnotetext{
${ }^{142}$ PERSSON, John E., "Vapensmugglaren från Surte", en Nautisk Tidskrift 7/1999.

${ }^{143}$ Constanza era uno de los puertos principales para el abastecimiento de armas para la República, cfr. VIÑAS, Ángel, "Una carrera diplomática y un Ministerio de Estado desconocidos" en VIÑAS, Ángel, $A l$ servicio de la República: diplomáticos y guerra civil, Madrid: Marcial Pons, 2010, pp. 267-424, p. 282.

${ }^{144}$ Así consta en un escrito confidencial de la Legación de Suecia en Bucarest a su gobierno de fecha 29.VII.1937, cfr. RA, UD, 1920-års dossierssystem, HP 36, Vol. 1522. Cfr. también EIROA, Matilde, Las relaciones de Franco con la Europa Centro-Oriental, Barcelona: Ariel, 2001, pp. 22 y s.: "Prat y Soutzo logró la simpatía y el apoyo de los representantes de Argentina, Austria, Bélgica, Brasil, Bulgaria, Chile, Egipto, Hungría, Irán, Japón, Polonia, Portugal, Suecia, Yugoslavia y Finlandia, al aumentar éstos sus suspicacias sobre las intenciones democráticas del frente popular y su aliado, la Rusia de Stalin".

${ }_{145}$ RA, UD, 1920-års dossierssystem, HP 36, Vol. 1522, nota del 14.IV.1938.

${ }^{146}$ Artículos en Stockholms Tidning de 24.VII.1937, Den svenske Nationalsocialisten de 28.7.1937 y Dagens Nyheter de 23.VII.37.

${ }^{147}$ RA, SÄPO, Äldre aktsystem, Vol. 95, I C 3 1-399 escrito confidencia de la Policía al gobernador de Estocolmo, 11.V. 1937. Cfr. también al documentación de la Policía de Seguridad sobre el asunto Lola, en RA, SÄPO, Äldre aktsystem, Vol. 96, I C 3 b) Lola.
} 
daban por descontado su implicación en el contrabando de armas ${ }^{148}$, cosa lógica, pues gran parte de la opinión pública sueca, especialmente en las clases trabajadoras, consideraba injusta la decisión del gobierno sueco de negar a la República Española el derecho a comprar armas.

Con motivo del asunto Lola tuvo lugar una reunión singular en el Ministerio de Negocios Extranjeros de Estocolmo, entre el funcionario sueco Christian Günther - el futuro Ministro sueco de Negocios Extranjeros durante la Segunda Guerra Mundial- y el representante oficioso de Franco en Estocolmo, Gabriel Dafonte. El hecho es significativo, pues como es sabido el gobierno sueco no había aún establecido contactos oficiales con la España de Franco. De esa entrevista, oficialmente sobre el asunto Lola, informó Dafonte a las autoridades de Burgos lo siguiente:

Con caracter más particular, el Sr. Gunther me aseguró con reiterada insistencia que el movimiento nacional español contaba con todas sus simpatías y que dentro de la medida de lo que para él era posible estaba siempre dispuesto a hacer todo aquello que pudiera favorecerlo: "Espero que usted, Sr. Dafonte, creera en la sinceridad de mis sentimientos", dijo ${ }^{149}$.

El capitán del vapor Lola, Eric Ericsson, siguió involucrado en el contrabando de armas a favor de la República en otros barcos y en 1939 escribió sus experiencias en un libro. El Lola, por su parte, fue vendido en 1941 a la Marina alemana, y fue finalmente hundido por ésta en el puerto de Salónica en $1944^{150}$.

No fue el caso Lola, sino otra complicada operación de venta de armas a la República, la que hizo que el papel de Branting en estos asuntos quedara al descubierto. Fue una operación a través de Finlandia, orquestada por el empresario sueco Nils Löfström - figura habitual en los negocios relacionados con la contraventa de armas - y el ya citado representante republicano español Ozores.

Como de costumbre, el asunto se complicó con la presencia de otras partes interesadas en actuar como intermediarias, en concreto otro grupo que se decía representante del gobierno de la República dirigido por el alemán Goldberg, en el que

\footnotetext{
${ }^{148}$ Cfr. por ejemplo carta a Branting de Greta Engqvist de 13.XI.1937 sobre un nuevo prototipo de fusil que se había enseñado a Isabel de Palencia por si pudiera ser de interés, en ARAB, Georg Brantings arkiv, 90/11. ${ }^{149}$ AMAEC R 602, 5 despacho n. 64 de la Representación franquista en Estocolmo, de 21.VIII.1937. En fecha tan temprana como septiembre de 1936 recibió Günther información de los representantes de Franco acerca de las gestiones republicanas por comprar armas en Suecia, cfr. RA, UD, 1920-års dossierssystem, HP 36, Vol. 1504, carta de Fiscowich a Günther de 22.IX.1936.

${ }^{150}$ LUNDBERG, op.cit., p.107 y s. Cfr. también el libro del capitán, ERICSSON, Eric, Lola, Estocolmo: Wahlström \& Widstrand, 1939.
} 
estaba presente un austriaco, Ernst Deutscheländer. Fue éste último quien recibió de la Legación de la Unión Soviética en Estocolmo las 400.000 libras esterlinas para la compra de las armas, cantidad que en la Legación de la Unión Soviética había depositado el abogado de la misma, Georg Branting.

En el tema estaba también implicada la empresa Veltjens, que disponía desde hacía tiempo de un "cheque en blanco" para sus operaciones de contrabando de armas en forma de un poder general para comprar armas otorgado por el emperador de Yemen.

La Veltjens hacía doble juego: por un lado tenía un contrato con el comprador republicano Ozores, por otro tenía acordado con los representantes de la España de Franco que les informaría de todos los transportes, con el resultado conocido. La Policía sueca sospechaba incluso la complicidad de Ozores en el esquema, a cambio de dinero ${ }^{151}$. Es el único caso en que consta en los documentos policiales la intervención de Branting, sin que ello suponga necesariamente que fuera la única.

El tercer caso de contrabando de armas con ramificaciones suecas que fue internacionalmente conocido fue el del vapor Diana. Llevaba este buque, que navegaba bajo pabellón panameño, una partida de 12.500 toneladas de pólvora procedente de la fábrica sueca Åkers. Su capitán, Cyrén, era sueco, compañero del capitán del Lola, Ericsson, y conocido contrabandista. También algún otro caso, de menor renombre mediático, quedó recogido en los archivos policiales.

Se puede afirmar, por tanto, que los ciudadanos suecos involucrados en este comercio no eran muchos y la policía parecía bien informada de todo lo relacionado con las exportaciones de armas suecas ${ }^{152}$. De hecho - al menos durante la segunda guerra mundial - los nombres de cualquier persona que solicitara empleo en la Bofors y otras industrias armamentísticas suecas eran comunicados a la Policía de Seguridad ${ }^{153}$.

\footnotetext{
${ }^{151}$ RA, SÄPO Äldre aktsystem, Vol. 95, I C 3 1-399, Memorándum secreto del 21.IX.1938.

152 RA, SÄPO Äldre aktsystem, Vol. 95, I C 3 1-399 PM om vissa vapenaffärer, 20.XI.1942; RA, SÄPO, Äldre aktsystem, Vol. 96, IC 3 a) Allegro y I C 3 b) Lola: Los nombres más significativos que aparecen son: los empresarios Nils Gustav Herbert Söderberg, Ivan Scheja, Nils Fredrik Ernst Löfström y J.F. Thelander, los exmilitares Per Nyström, Werner Gyllencreutz y John Elis Hultkrantz; el banquero H. Sjöstedt, el fiscal B.E. Brimberg; un tal Kjell Malte Wallin y el empleado de radio Thor Wibom; y el Senador Georg Branting. Los agentes franquistas añaden los nombres de dos banqueros, Hilmer y Grafmann, y del empresario Eric Selander, junto con algunos representantes de las empresas de Wallenberg, cfr AGA, Asuntos Exteriores, Caja 12047, anejo al despacho n. 25 de 26.I.1939 de la representación franquista en Helsinki y AGA, Asuntos Exteriores, Caja 12048, L. 12, despacho n. 28 de 28.VI.1937 del representante franquista en Tallinn.

${ }^{153}$ RA, SÄPO, Äldre aktsystem, Vol. 54, IC 2 K. 1-500, Bofors: Como dato curioso merece destacarse la presencia entre el personal de esa empresa, durante la Segunda Guerra Mundial, de algunos brigadistas internacionales suecos.
} 
En la guerra civil española hubo una cierta presencia, por tanto, de armamento sueco, a pesar de la actitud oficial del gobierno, que siempre hizo oídos sordos al clamor de sus bases, en los partidos y organizaciones relacionadas con el movimiento obrero, que abogaban por un levantamiento de la prohibición de vender armas a la República Española ${ }^{154}$. No cabe duda de que, de haberse llevado esto a cabo, la industria armamentística sueca hubiera podido contribuir en alto grado al esfuerzo bélico de la República. Ya lo dijo un conocido brigadista sueco en su día:

La ayuda que nos envía el Comité [sueco de ayuda a España, SKfS] y particulares suecos nos dan mucho consuelo. Es prueba de que la mayor parte de las clases trabajadoras tienen sentimientos saludables de paz y libertad, y de que están dispuestos a sacrificarse por ellos. Pero... ¿ ¿cuando llegarán los cañones Bofors ${ }^{155}$

Concluimos así este breve recorrido de los aspectos principales de la intervención sueca en la guerra civil española. Hemos podido constatar que ésta fue más amplia de lo que cabría esperar de un país que contaba entonces con 6,3 millones de habitantes. La ayuda fue especialmente intensa y - dentro de lo que cabe en las latitudes nórdicas apasionada a favor de la República Española, de manera particular entre las clases trabajadoras.

La Spanienhjälpen fue el primer gran movimiento sueco de solidaridad internacional. Los voluntarios suecos de las Brigadas Internacionales, movidos en su mayoría por fuertes convicciones antifascistas, se batieron con empeño y tenacidad formidables en defensa de la República española. Tampoco cabe olvidar la amplia labor humanitaria de asilo y mediación en canjes llevada a cabo por los diplomáticos suecos y del personal a su servicio, fueran cuales fueran sus convicciones y motivos. Todo ello, junto con el hospital sueco-noruego de Alcoy, los orfelinatos de Denia, Teyá y Guetaria, y la ayuda material en forma de alimentos y víveres enviada a España desde Suecia, da fe del compromiso solidario sentido por amplios estratos de la población sueca por apoyar en la medida de sus posibilidades a la España en guerra.

\footnotetext{
${ }^{154}$ Según informes de la Legación sueca en Berna en julio de 1938, las autoridades franquistas mantenían una actitud hostil hacia Suecia "porque, habida cuenta de la amplísima actividad de espionaje que ambas partes llevan a cabo, probablemente tiene claro que las ayudas que los gubernamentales han recibido de nuestro país no han sido exclusivamente en beneficio de la población civil". El gobierno británico, a través de Halifax, mostró interés por esta información, cfr. RA, UD, 1920-års dossierssystem, HP 36, Vol. 1507.

${ }^{155}$ SJÖSTEDT, Brev till en broder..., p. 29: extracto de la carta, fechada el 25 de enero de 1938, de Bengt Segerson, comisario político de la Compañia Branting, a su hermano.
} 



\section{CONCLUSIONES}



Ha llegado el momento de analizar resultados y concretar conclusiones.

El presente trabajo de investigación pretendía cubrir una laguna historiográfica en el campo de las relaciones internacionales en el siglo XX: las relaciones que, durante la década de los años treinta, tuvieron entre sí Suecia y España, dos Estados situados en la periferia europea pero con peso específico en sus áreas geográficas respectivas, el Mediterráneo y el mundo escandinavo y báltico, respectivamente. Ambos habían sido neutrales durante la Primera Guerra Mundial y ambos lo serían también en la segunda.

El objeto de este estudio era proceder a un análisis en profundidad de las relaciones diplomáticas entre Suecia y España durante la década de los años treinta del siglo XX a partir de la amplia documentación contenida en los respectivos Ministerios de Asuntos Exteriores, y en particular mediante el estudio de los despachos enviados por los representantes diplomáticos que cada uno de los dos países había acreditado ante el otro.

En el capítulo primero expusimos las coordenadas de carácter teórico y metodológico que presidirían nuestro quehacer. Optamos allí por utilizar un método cualitativo clásico en las investigaciones históricas, basado principalmente en la llamada teoría fundamentada propuesta por Barney Glaser y Anselm Strauss a finales de la década de los sesenta del siglo XX, enriquecida con algunas perspectivas metodológicas más modernas y algunos aspectos propios de las teorías del análisis de discursos y de recientes aportaciones de la teoría de la historia - de la mano de Koselleck, Rüsen y Skinner, principalmente - que considerábamos importante tener en cuenta en el análisis de las narrativas creadas por los diplomáticos.

Siguiendo a Skinner hemos procurado tener presentes las intenciones de los autores y la retórica de la época en el análisis de los documentos diplomáticos, sin perder de vista los cambios de valoración que se perciben a veces en la visión de los diplomáticos, especialmente perceptibles cuando un mismo acontecimiento es evaluado en un despacho ad hoc y también en el informe trimestral. Vistos a la luz de las teorías de Koselleck, esos cambios de valoración manifiestan un cambio en el horizonte de expectativas de los diplomáticos motivados por la experiencia de la rápida evolución de la realidad política y social.

El método utilizado nos ha permitido realizar un análisis científico en profundidad de las fuentes documentales en relación con el objeto de nuestra investigación. La abundancia y la diversidad de temas y aspectos contenidos en las fuentes utilizadas se adecuaban bien a ese enfoque metodológico. Por otra parte, una consecuencia de nuestra opción teórico- 
metodológica ha sido que el material efectivamente estudiado ha sido mucho mayor del que suponíamos en un principio. El motivo ha sido el entrelazamiento de los distintos asuntos, con la aparición de nuevas ramificaciones y perspectivas surgidas especialmente del contraste de documentos suecos y españoles sobre un mismo hecho.

Las cuestiones que nos planteábamos al comenzar nuestra investigación estaban estructuradas en torno a cuatro grupos básicos. En primer lugar estaban las relacionadas con la visión que dio la diplomacia sueca del desarrollo político de la España republicana durante el período 1931-1936 y de los avatares de los tres años de guerra civil subsiguientes, con especial énfasis en las preocupaciones específicas y en la valoración de la política exterior republicana. Un segundo grupo eran esas mismas preguntas en relación con Suecia. El tercer grupo se refería a las relaciones de Suecia con la República Española y el cuarto, a las relaciones con la España de Franco.

Nos interesaba analizar, en definitiva, tres aspectos fundamentales. En primer lugar, cómo fue vista la España republicana y la guerra civil española por los diplomáticos suecos. En segundo lugar, de forma paralela, qué imagen dio la diplomacia española de Suecia en esa década tan importante para el establecimiento del llamado Modelo sueco. Y finalmente, cuáles y cómo fueron las relaciones entre ambos países, diferenciando, en el período 1936-1939, las dos zonas en que estuvo dividida España.

Un punto importante a tener en cuenta es el protagonismo de un grupo muy reducido de personas en el tema que nos ocupa, los diplomáticos y políticos suecos y españoles involucrados en las relaciones: Danielsson, Ytterberg, Wisén, Berencreutz, Günther, Sandler y el Rey Gustavo V por parte sueca; García Conde, López Oliván, Fiscowich, Madariaga, Palencia, Dafonte, Valdés, Pita Romero, Suanzes y pocos más, por parte española. En total, docena y media de personas. Fueron ellas, y sus informadores, los actores principales en la formación de la imagen de España en Suecia, o de la de Suecia en España.

Especialmente útiles, por esa razón, han sido en nuestra investigación los casos de "contra-tendencia", es decir, juicios o valoraciones en sentido contrario a lo que sería de esperar de las ideas y opiniones de los actores en cuestiones de fondo.

Como primera conclusión de nuestra investigación, merece destacarse la visión crítica que la diplomacia sueca dio de la España republicana. En contra de lo que hubiera podido suponerse, los diplomáticos suecos no consideraron a la República 
española como un régimen plenamente democrático. Todo lo más, la vieron como una democracia en período de gestación, siempre en peligro constante de ser sofocada antes de nacer por cualquiera de las formas de totalitarismo tan en boga en la época, ya fueran de corte fascista, comunista o de dictadura militar tradicional.

En esta línea, los diplomáticos suecos censuraron con fuerza todos los comportamientos que consideraron extremistas, independientemente de su signo político. Denunciaron lo que consideraron deficiencias democráticas de la República, especialmente la falta de espíritu parlamentario, traducida en la toma arbitraria de decisiones con poco respeto hacia las posturas minoritarias, y la actitud - en su opinión, poco enérgica - de las autoridades respecto al ambiente de desunión y tensión social presentes en el país.

Una vez empezada la guerra civil, Danielsson, Wisén, el cónsul Olsén y varios cónsules honorarios, siguiendo las huellas de sus colegas daneses y de los de muchos otros países, estimaron que había tenido lugar la sustitución del gobierno legítimo por un "régimen soviético". Wisén llegó a utilizar la expresión "una España bolchevizada" e Ytterberg, por entonces destinado en Moscú, citaba la opinión de Lenin de que en España triunfaría el comunismo debido "a su atraso material y social".

Para la diplomacia sueca, por tanto, la República, desde el 19 de julio de 1936 y especialmente con el gobierno de Largo Caballero, habría dejado en la práctica de existir para dar paso a un nuevo régimen de carácter comunista y anárquico. Y esa fue la imagen de la situación de la República que recibió el gobierno sueco precisamente en el momento en que estaba sobre el tapete la cuestión de la adhesión del país escandinavo a la política británica de no intervención en la guerra española. Por tanto, es muy probable que esta visión influyera en la decisión del gobierno sueco en la llamada “cuestión española”.

Esta misma imagen, siguió prevaleciendo, de alguna manera, durante toda la guerra, a pesar de que se moderó mucho a partir de la primavera de 1937 y especialmente tras la caída del gobierno de Largo Caballero.

Asimismo, la diplomacia sueca alertó de manera recurrente en sus despachos, desde abril de 1931, de los peligros para la República por parte de los extremismos de derecha y de izquierda: el del establecimiento de una dictadura militar de corte fascista o de un régimen comunista de tipo similar al de la Rusia soviética.

Su preocupación les llevó a criticar todo lo que pensaban que podría aumentar esos peligros, insistiendo especialmente al respecto en la política de la República en materia religiosa, la gestión - en su opinión desafortunada - de la economía española, los poderes 
"dictatoriales" otorgados al gobierno por la Ley de Defensa de la República, las huelgas revolucionarias, las luchas partidistas, la falta de solidaridad institucional o la actitud hostil hacia la República de importantes sectores del mundo empresarial y del Ejército. Azaña, Alcalá-Zamora, Gil Robles y, de modo especial, Largo Caballero y el Frente Popular fueron blanco de comentarios críticos por parte de los diplomáticos suecos en Madrid.

En relación con este punto, nuestra investigación ha puesto de manifiesto la clarividencia de análisis de la diplomacia sueca, que alertó del peligro de guerra civil desde los albores del segundo bienio republicano y de la posibilidad de una dictadura militar desde noviembre de 1934, llegando incluso a sugerir el nombre del dictador, el general Francisco Franco. Los diplomáticos suecos consideraron también peligrosa la actitud de Gil Robles y la falta de participación de los partidos republicanos y socialistas en la actividad parlamentaria durante 1935. Además, en octubre de 1936, no dudaron en resaltar la dureza y el carácter dictatorial del nuevo régimen que se estaba creando en España.

Con todo, aparte de la lógica preocupación por el asentamiento de la democracia, el gran tema que captó la atención de la diplomacia sueca fue fue la amenaza, imaginada o real, de la transformación de España en un país comunista. Este aspecto, que sería luego esencial en la narrativa franquista de los años de la República - y sería la base sobre la que la dictadura del general Franco trató de justificar su legitimidad - parece un tanto sorprendente en la pluma de los diplomáticos de una de las naciones del mundo con mayor tradición democrática.

Nuestro estudio permite concluir que, a pesar de las seguridades en contrario dadas por los líderes políticos de la España Republicana, los temores suecos de que España se deslizase poco a poco hacia la órbita soviética - tema poco menos que obsesivo para el Ministro Plenipotenciario de Suecia en Madrid entre 1931 y 1936 - nunca dejaron de estar especialmente presentes en la información transmitida a Estocolmo. En definitiva, aparece de nuevo la misma idea de la República como una democracia en gestación, pero que fácilmente podía degenerar en un régimen dictatorial.

¿Por qué esa insistencia de la diplomacia sueca en España en la amenaza del comunismo? Una primera aproximación al problema, demasiado simplista, buscaría una explicación en las ideas conservadoras de Carl Ivan Danielsson y de sus fuentes de información. Este aspecto es ciertamente importante y constituye uno de los factores determinantes en este contexto. Sin embargo, al margen de las opiniones personales de los 
actores, no cabe olvidar otros aspectos, de tipo estructural, que fueron también decisivos al respecto.

En efecto, tras la preocupación específica de la diplomacia sueca por los avances del comunismo en España se esconden también consideraciones de orden político, económico y comercial. A la rivalidad política se unía, de una parte, el recelo de Suecia ante las actitudes expansionistas de su poderoso vecino oriental, y de otra, los aspectos relacionados con la competencia comercial entre ambos países en lo referente a la exportación de algunas materias primas. En relación con España, temía Suecia que una mejora de las relaciones de la República con la Unión Soviética se tradujera en una disminución de las importaciones españolas de madera sueca, producto que podía obtenerse también del país eslavo, como expresamente mencionó Danielsson.

En definitiva, la explicación probablemente más plausible radica en las tensas relaciones de Suecia - y especialmente del grueso del movimiento obrero sueco, la socialdemocracia - con el comunismo como ideología y con la Unión Soviética en cuanto potencia que la encarnaba en ese momento. Este aspecto, ampliamente tratado en la historiografía, viene confirmado por la documentación examinada, que avala esta explicación, como se desprende de los discursos y de las acciones de los principales actores de la política exterior sueca del momento, en especial el Ministro de Negocios Extranjeros Rickard Sandler.

Pensamos que, sin olvidar el papel que al respecto tuvo también la personalidad del Ministro de Suecia en España, estos aspectos estructurales son los fundamentales para explicar el interés sueco por el comunismo en España. El proyecto comunista, con su insistencia en la lucha de clases, era un obstáculo para el proyecto de sociedad por el que había apostado el socialismo sueco. Éste, como indicó Berman, fue flexible en vez de dogmático, y su objetivo era la creación de un hogar popular - según la conocida expresión acuñada por Per Albin Hansson - en el que todas las clases sociales colaborarían y del que todas se beneficiarían. En su desarrollo práctico, fue aspecto clave, como señaló Luebbert, la alianza de la socialdemocracia con los grupos defensores de los intereses de los trabajadores agrícolas, especialmente operativa a partir del "tira y afloja" de 1933.

La imagen de conjunto dada por la diplomacia sueca sobre la República española fue, por tanto, más negativa que positiva, insistiendo más en los fracasos que en los logros de la misma - por ejemplo, en política de educación, agraria o de la organización del Estado que no supieron o no quisieron destacar. 
Suecia veía con buenos ojos el proyecto democratizador y modernizador de la República, pero al mismo tiempo la vio con desconfianza, no sólo por el propio desarrollo político y social de España durante los dos bienios republicanos y los años del conflicto bélico, sino probablemente también por la tensa situación de la política internacional del momento, en los albores de un nuevo orden internacional. Los tiempos no eran precisamente propicios para experimentos políticos de tal magnitud en una Europa occidental amenazada por una crisis económica sin precedentes y el rápido avance de las nuevas y poderosas ideologías totalitarias que pretendían erigirse en sustitutas del Estado liberal, que había quedado sepultado en los campos de batalla de la Gran Guerra.

Llama la atención el contraste entre la minuciosidad y detalle con que los diplomáticos suecos se interesaron por la política interior de la República española y el desinterés del que dieron muestras respecto a su política exterior. En los despachos diplomáticos suecos apenas aparecen referencias a las relaciones de la República con otros países. La diplomacia sueca llegó a afirmar directamente que España no estaba interesada por la política europea.

Es posible que esa visión de la República fuera influida también por la ambigüedad que caracterizó su política en la Sociedad de Naciones, puesta de manifiesto en las cuestiones del desarme en 1933 y 1934 - en la que no secundó algunas iniciativas suecas, como destacaron Egido León y Berdah - o en la crisis de Abisinia. Nuestro estudio da pie para matizar, en este sentido, la afirmación de Quintana Navarro de que la República apostó decididamente por la colaboración de las pequeñas potencias democráticas europeas, el straight eight.

El hecho de que España, en 1934-1935, deseara retomar la idea de la cooperación de las pequeñas potencias y a esos efectos llegar a un entendimiento íntimo con Suecia - con la idea de compartir el liderazgo del llamado "grupo de los neutrales" y presentar un frente común en la Sociedad de Naciones, aspecto central de las relaciones bilaterales entre ambos países - no fue suficiente para que la diplomacia sueca cambiara su opinión acerca de la política exterior española. Suecia se mostró moderadamente interesada, pero en su política de cooperación en el marco de la Sociedad de Naciones antepuso siempre sus relaciones con los demás países nórdicos a sus contactos con España.

A la luz de la documentación diplomática analizada, parece obvio que la República no comprendió del todo la profundidad de los vínculos que unían al país escandinavo con los demás de su entorno geográfico. De haberlo hecho, no hubiera llegado a proponer a 
Suecia un acuerdo que anteponía las conversaciones sueco-españolas a la discusión de los asuntos con los demás países escandinavos.

La política exterior de la República española aparecía a ojos suecos como "mucho ruido y pocas nueces", grandes palabras sobre neutralidad y pacifismo, pero falta de una política definida al respecto.

Podemos concluir que a pesar de lo mucho que tenían en común en cuanto pequeñas potencias - y de que, tras el fracaso de las conferencias de desarme, ambas siguieran el mismo modelo de paso de un pacifismo societario a un pacifismo neutralista - Suecia mostró poco interés por la política exterior de la República española, probablemente porque ésta no tenía una política definida en las grandes cuestiones de la política europea, que a la sazón constituían las preocupaciones prioritarias de Suecia en política exterior: el expansionismo alemán y soviético y la política de contención franco-británica.

Paralelamente a la visión de la República española transmitida por la diplomacia sueca nos preguntábamos también cómo vieron los diplomáticos españoles a Suecia y su desarrollo político durante el período 1931-1939. En esa década tuvo lugar el asentamiento definitivo de la socialdemocracia como fuerza rectora de los destinos del país escandinavo y ya al final de la misma se había convertido Suecia en uno de los primeros Estados de bienestar del mundo.

La diplomacia española se hizo eco de los acontecimientos principales de la actualidad sueca de la época - los llamados sucesos de Ådalen, el suicidio del magnate de la industria sueca Ivar Kreuger, el acuerdo entre el Partido socialdemocráta y la Liga Agraria, la avanzada legislación en materia social y laboral, etc. - que resultaron determinantes para el asentamiento de la socialdemocracia en el poder. De la importancia que los diplomáticos españoles dieron a estos aspectos da testimonio fehaciente el hecho de que a finales de 1938 - en momentos de extrema dificultad para la República española y cuando Suecia ya había intercambiado agentes con el gobierno del general Franco - la Legación de España en Estocolmo enviara un despacho relativamente largo informando de los Acuerdos de Saltsjöbaden.

Frente a la visión negativa de la diplomacia sueca acerca de la España de la época, cabe resaltar la clara visión positiva que la diplomacia española tuvo de Suecia. En efecto, fue constante en los despachos diplomáticos españoles sobre el desarrollo de la vida política y parlamentaria sueca la insistencia en la gran tranquilidad, civismo y espíritu de 
búsqueda de consenso que la caracterizaba De las fuentes estudiadas se desprende la admiración de los diplomáticos españoles por el tono de los debates políticos suecos, acaso por el contraste con la realidad española, que atravesaba momentos de enfrentamiento, desunión, agitación y crispación.

La diplomacia española insistió en la moderación y huida de los "extremismos" que caracterizaba a la vida política sueca de la época y a su protagonista principal, el partido socialdemócrata. Más adelante, ya empezada la guerra civil, el Ministro de España en Estocolmo - pasado a la causa franquista - se referiría a la "duplicidad" como nota característica del mismo, pero ni siquiera entonces descalificó a Per Albin Hansson, a quien consideraba como una "recia personalidad de especial capacidad y relieve".

Los acuerdos entre socialdemócratas y agrarios, el "tira y afloja" (kohandeln) de 1933, que rompió la política de "bloques" (la burguesa contra la izquierda), fue explicado por los diplomáticos españoles principalmente como resultado de un deseo de formar un frente político para prevenir el desarrollo del nazismo en Suecia. La historiografía sueca, por su parte, aunque no ajena a esta idea, tiende a explicar el "horsetrading" básicamente en términos de política económica y social, y también señala que la Liga Agraria mostró a principios de 1930 una cierta afinidad con el Nazismo alemán, tanto en sus estatutos, como en las simpatías de algunos de sus representantes. El despacho del Encargado de Negocios de España, Fernández Villaverde, parece contradecir esta conclusión. Sin embargo, los informes posteriores de Fiscowich, en agosto y septiembre de 1936, sobre la actitud del gobierno provisional dirigido por el agrario Axel Pehrsson-Bramstorp hacia la causa franquista, parecen dar una visión bien distinta y más acorde con las tendencias dominantes al respecto en la historiografía sueca.

El especial interés de la diplomacia española por la política sueca de defensa, que cambió de signo a lo largo de la década, ha quedado patente en la gran cantidad de despachos sobre el tema. Llegó este interés a extremos tales que casi merecerían la calificación de espionaje. La capacidad militar de las Fuerzas Armadas suecas, que no impresionó en absoluto a Fiscowich, fue la excepción que confirma la regla de la admiración de la diplomacia española por Suecia.

El otro gran tema objeto de preocupación especial para la diplomacia española en Suecia fue la cuestión del posible avance del nazismo en Suecia y de las relaciones del país escandinavo con la Alemania de Hitler. 
Nuestro análisis permite concluir que la República española se interesó por los progresos del nazismo en Suecia y que en los informes diplomáticos españoles quedó claramente reflejada la decidida actitud antinazi del gobierno de Suecia, del partido socialdemócrata sueco y, con pocas excepciones de escasa relevancia, de la opinión pública y del pueblo sueco.

La diplomacia española confirma básicamente confirman básicamente las conclusiones de la historiografía sueca al respecto: el nazismo, carente en Suecia de cohesión interna y de apoyo popular, no constituyó nunca un peligro serio para el país. Sin embargo, en algunas cuestiones específicas, existen algunas diferencias, como en el punto mencionado de la presencia de algunas ideas cercanas al nazismo en los estatutos de la Liga Agraria, de los que no se hizo eco la diplomacia española.

Otro aspecto discordante es la apreciación de la extensión de las ideologías de corte fascista en el ejército sueco: la Legación informó a finales de 1931 que las simpatías por ese tipo de doctrina estaban muy difundidas entre la oficialidad sueca. En general, la historiografía sueca ha hablado más de simpatías hacia Alemania que de simpatías hacia el nazismo en el seno del ejército sueco.

Podemos concluir, en suma, que la Legación de España en Suecia dio una visión muy positiva de la evolución política, económica y social de la Suecia de los años treinta, especialmente a partir de la llegada al poder del partido socialdemócrata. Esa visión, ponderada y ajustada a la realidad, concuerda en general con las líneas básicas de la historiografía sueca del período.

Respecto a la política exterior de Suecia, caracterizada por los parámetros de pacifismo y de neutralidad, la diplomacia española resaltó el cambio paradigmático a mediados de década, cuando Suecia decidió anteponer el ideal de la neutralidad pacifista a la defensa a ultranza de los principios inspiradores del Pacto de la Sociedad de Naciones.

Destacaron también los diplomáticos españoles el acercamiento de Suecia a Inglaterra durante esos años, que llevaría al gobierno sueco, a pesar de su celoso deseo de salvaguardar su neutralidad, a prestar su apoyo a la política inglesa de apaciguamiento dirigida a Hitler y posteriormente a la de no intervención en la guerra española. A la larga, según los diplomáticos españoles, la tradición parlamentaria y democrática de Suecia, que la hacía afín a Gran Bretaña, pesaría más que su afinidad cultural con Alemania, por lo cual apostaría por aquella en caso de que estallara el conflicto armado que acechaba en el horizonte internacional de la época. 
La diplomacia española caracterizó a Suecia como país que, en su política exterior, apoyaba firmemente los principios de la Sociedad de Naciones, pero también como país pragmático que no podía ocultar su pesimismo respecto al porvenir de la misma y de la paz en Europa. Además insistió en la actitud distante de Suecia frente a la Alemania nazi y a la Rusia soviética y en los intentos de estrechamiento de los tradicionales vínculos existentes con los demás países escandinavos.

La diplomacia española resaltó acertadamente que esos vínculos no tendrían consecuencias prácticas importantes, por la dificultad de presentar un frente común al no tener todos los gobiernos escandinavos el mismo signo político; y por un presunto interés sueco de no poner en entredicho su hegemonía dentro del grupo nórdico a través la firma de convenios concretos que limitaran su libertad de acción. Este argumento, que consideramos sugerente, no parece haber sido desarrollado suficientemente en la historiografía sueca.

Frente a la visión preponderante en la historiografía sueca que ve la política exterior del país en la época, como anodina y rutinaria, y atenta sólo a relacionarse bien con sus vecinos nórdicos, contrasta en cierta medida la visión de la diplomacia española, que resaltó el papel de Suecia como potencia regional, cuyo papel en el Báltico era comparable al de España en el Mediterráneo, pero sin que eso implicara necesariamente que Suecia estuviera dispuesta a erigirse en garante de la seguridad de sus vecinos a costa de la suya propia.

Podemos concluir que, respecto a la política exterior sueca de este período, la diplomacia española destacó la mesura, la actitud de mantenerse a la expectativa, el pacifismo en las intenciones y el pragmatismo a la hora de las decisiones, la inclinación hacia Inglaterra tratando de no irritar a Alemania, y el distanciamiento claro del nazismo y del comunismo como ideologías y de los países que las sustentaban en ese momento, las dictaduras alemana y soviética.

Contrasta, en definitiva, esta positiva actitud con que los diplomáticos españoles vieron la Suecia de la época con la actitud de cierta reserva hacia la República por parte de los diplomáticos suecos, aspecto que ha sido puesto de manifiesto en las fuentes examinadas.

Hemos podido constatar también la existencia de esa actitud sueca en la forma en que se articularon las relaciones bilaterales entre ambos países durante esos años. Se 
observa esto con claridad en la intención sueca de retrasar al máximo el reconocimiento de la República en abril de 1931 y la llegada a Estocolmo de un nuevo Ministro Plenipotenciario republicano en el 1936, así como en la fría actitud tomada ante los Presidentes de la República, manifestada en la ausencia de las atenciones protocolarias debidas, especialmente clara en relación con la toma de posesión de su cargo por parte de Azaña en 1936. Este aspecto es desconocido hasta ahora en la historiografía

Esa actitud de Suecia, que sin duda puede resultar un tanto sorprendente, es plenamente congruente con la constante sueca de no tomar decisiones precipitadas, y conservar hasta el último momento posible su libertad de acción en cuestiones de política internacional. Suecia adoptaría posteriormente una estrategia similar en relación con el régimen de Franco, o ante las exigencias que las partes beligerantes en la segunda guerra mundial le fueron planteando; y en tiempos recientes, hizo lo propio respecto a la entrada en la Unión Europea. En definitiva, una postura pragmática de mantenerse a la expectativa el máximo tiempo posible, para no atarse las manos en ningún sentido mientras no sea absolutamente necesario.

Nuestro estudio ha puesto de manifiesto también un aspecto particular que, sin duda, influyó un tanto en las relaciones hispano-suecas: la antipatía mutua entre Manuel Azaña y el Ministro de Suecia en Madrid, Ivan Danielsson, que llevaría incluso al Presidente de la República poco menos que a exigir la retirada de Madrid del diplomático, aspecto que quedó difuminado por el comienzo de la guerra civil. Al respecto, jugó un cierto papel las simpatías por la extrema derecha de la esposa del diplomático sueco. La teoría de unas presuntas simpatías del propio Danielsson por las ideas nazis, sin embargo, carece de base documental alguna en la que apoyarse, habiendo, en cambio, fuertes razones en contra, principalmente la inclusión del diplomático sueco en la lista de "Justos entre las Naciones" por sus acciones en defensa de los judíos húngaros en 1944.

Justo es reconocer, en relación con este aspecto, que a pesar de no ser Danielsson amigo de la República, su impresión inicial sobre Manuel Azaña fue positiva. Esa impresión fue cambiando a medida que Azaña iba adoptando decisiones políticas de gran envergadura en formas consideradas por el diplomático sueco como arbitrarias, poco democráticas e incluso - como repitió en bastantes ocasiones - dictatoriales.

También los contactos de Alfonso XIII con Suecia fueron un motivo de distanciamiento entre la República Española y el país escandinavo. El ex-Rey visitó Suecia en el verano de 1931, y allí hizo algunas declaraciones a la prensa. 
Sin embargo, esas desavenencias no tuvieron mayores consecuencias y las relaciones se normalizaron con rapidez, como manifiesta el apoyo prestado por Suecia a la reelección de España para el Consejo de la Sociedad de Naciones, que se mantuvo invariable a lo largo de todo el período que nos ocupa, incluso a pesar de ir en contra de la praxis habitual en Suecia.

Con todo, el punto culminante de las relaciones políticas entre Suecia y la República española fueron los planes de cooperación hispano-sueca a favor de la paz en el marco de la Sociedad de Naciones, que Berdah llamó el primer impulso internacional de la República. Probablemente, el aspecto más interesante que se desprende de nuestro análisis sea la cuestión de la autoría de la iniciativa de las declaraciones comunes de los países neutrales, que la historiografía sueca - como puede observarse en los estudios de Carlgren, Zetterberg, Ohlsson y Ottoson, por citar los más específicos - ha atribuido, sin más, a Rickard Sandler, el Ministro sueco de Negocios Extranjeros.

Nuestro estudio confirma el importante papel desempeñado por España, a través del memorándum de Madariaga y las iniciativas de Pita Romero y López Oliván, en la elaboración de las declaraciones comunes de los países neutrales en la Sociedad de Naciones: la "declaración de los seis" del 14 de abril de 1934 y el llamado "manifiesto de los siete" del 1 de julio de 1936. Ambos surgieron de una iniciativa española que Suecia hizo suya, desarrolló y consiguió anclar en el foro de los países neutrales, desplazando en cierta medida a España.

La conclusión que se desprende de estos aspectos es que la cooperación suecoespañola en el marco de la Sociedad de Naciones, entre 1933 y 1936, fue más intensa e importante de lo que cabría esperar a la vista de los antecedentes señalados, de la forma en que se desarrollaron las negociaciones, y de la manifiesta falta de comprensión de la idiosincrasia del otro país de que dieron muestra las respectivas autoridades en Madrid y Estocolmo. Esa cooperación quedó truncada por la guerra civil, pero tras el final de la contienda volvieron a surgir conatos de normalización y profundización del camino iniciado, concretados en los contactos diplomáticos con vistas a un llamamiento común hispano-sueco a favor de la paz, en septiembre de 1939.

Cabe afirmar, por tanto, que las relaciones bilaterales hispano-suecas se intensificaron durante los años treinta del siglo XX a través de iniciativas políticas concretas en el marco de la cooperación entre los países neutrales en la Sociedad de Naciones, aunque no estuvieran exentas de tensiones, como han puesto de manifiesto la 
actitud un tanto recelosa de la diplomacia sueca hacia la República, la divergencia de criterios entre ambos países en las crisis internacionales del Chaco y de Abisinia, y la existencia de desavenencias de cierta entidad entre ambos países en relación con la reglamentación del comercio exterior bilateral, que dio lugar a largas y difíciles negociaciones diplomáticas entre Estocolmo y Madrid.

Las relaciones bilaterales entre Suecia y España entraron en una nueva fase durante la guerra civil. El pueblo sueco, en su gran mayoría, apoyó la causa de la República en una campaña de solidaridad internacional sin precedentes en la historia de Suecia. Por otra parte, bastantes cónsules honorarios suecos y los empresarios de ese país con intereses en España se mostraron en general favorables a la causa franquista.

Nuestro estudio corrobora el cuadro general presentado por la historiografía sueca, que destaca la dicotomía entre la actitud popular y la actitud oficial del gobierno sueco respecto a la República: en privado, máximas simpatías; en público, política pragmática y de no intervención. Probablemente, el motivo sea la dependencia sueca de Gran Bretaña, que implicaba la necesidad de seguir en todo la política británica. En todo caso, nuestra investigación ha sacado también a la luz aspectos nuevos, parcial o incluso totalmente ignorados por la historiografía.

Un primer aspecto, sorprendentemente ausente por completo en la historiografía sueca sobre la guerra civil española, es la actitud del gobierno sueco durante los dos primeros meses del conflicto. En efecto, al citar a Per Albin Hansson, la historiografía sueca parece haber pasado por alto el hecho de que el político socialdemócrata no era entonces presidente del gobierno sueco. Su gabinete había dimitido en junio de 1936, y desde entonces - y hasta las elecciones del 20 de septiembre siguiente - presidía los destinos del país el llamado "gobierno de verano" presidido por el líder de la Liga Agraria Axel Pehrsson-Bramstorp. ¿Cómo reaccionó este gobierno al estallido del conflicto armado español?

Al respecto, nuestro estudio muestra que el gobierno sueco pasó de una actitud de expectativa ante la situación, en julio de 1936, a una de apoyo subrepticio a la causa franquista en el último mes de su mandato, es decir, desde mediados de agosto hasta las elecciones del 20 septiembre de 1936. Ese apoyo se manifestó en el mantenimiento de contactos diplomáticos con el representante de la España de Franco y en el intento de diferir el reestablecimiento de las relaciones diplomáticas normales con la República 
española, dilatando la concesión del placet al nuevo Ministro Plenipotenciario propuesto por el gobierno de Madrid e incluso ordenando al Encargado de Negocios en Madrid, el cónsul Axel Olsén, que abandonara España. Volveremos a insistir en este importante aspecto al recapitular las relaciones de Suecia con el régimen de Franco.

Esta situación cesó al poco tiempo de la subida al poder de la socialdemocracia, reestableciéndose las relaciones diplomáticas ordinarias con la República, aunque siguió habiendo contactos discretos y oficiosos con los representantes franquistas en Estocolmo. Erik Wisén volvió a ocuparse de la Legación de Suecia en España, primero en Valencia y posteriormente en Barcelona. Por razones prácticas, las relaciones diplomáticas ordinarias se canalizaron principalmente a través de la Legación de la República en Estocolmo.

Hemos podido constatar que Suecia, ya bajo el nuevo gobierno socialdemócrataagrario que surgió de las elecciones de septiembre de 1936, se adhirió a la política de no intervención con el apoyo de la mayoría de la clase política. Solamente se opusieron los partidos a la izquierda del socialdemócrata (socialistas, comunistas y sindicalistas), que durante toda la guerra mostraron su incondicional apoyo a la causa de la República, pero que apenas tenían peso político específico en Suecia. La opinión pública estuvo anímicamente dividida - ya que las grandes masas del partido socialdemócrata simpatizaban con la República, aunque no lo exteriorizaran - pero exteriormente firme en su apoyo a la política del gobierno, de neutralidad y no intervención.

En definitiva, se optó por la opción más pragmática, como señaló más adelante Per Albin Hansson acerca de la posibilidad de reconocer al régimen franquista: "el asunto está claro, si se dejan aparte las cuestiones sentimentales". Isabel de Palencia mencionó también repetidamente que el gobierno socialdemócrata sueco, aunque sentía simpatía por la República, no era "de ninguna manera hostil” a la España de Franco y criticó con dureza lo que consideraba traición a los ideales democráticos de los principales políticos socialdemócratas suecos.

Tras el debate parlamentario de febrero de 1937, el gobierno sueco prohibió la participación de voluntarios en la guerra civil, aunque dejó abierta la puerta para la ayuda humanitaria. Nuestro estudio coincide con lo expuesto por Lundvik y Cantera Carlomagno acerca de la actitud sueca en el Comité de No Intervención: Suecia fue fiel a la política de no intervención, pero adoptó una actitud bastante pasiva en la llamada "cuestión española" en el seno del Comité y en la Sociedad de Naciones. 
Las relaciones diplomáticas entre Suecia y la República durante los años de la guerra no fueron fáciles, a pesar de los esfuerzos de diplomacia española en Estocolmo, que logró realizar una labor considerable mediante la organización de actos culturales y visitas de algunos diputados y otras personalidades suecas a la España republicana, y la coordinación de las acciones de solidaridad organizadas por el Comité sueco de Ayuda a España, presidida por el político socialdemócrata Georg Branting. Hubo también conflictos ocasionados por la realidad bélica - el asesinato a manos de un miliciano del hijo del cónsul en Gijón, la condena a muerte de un pariente del cónsul en Alicante, la incautación de vehículos o el allanamiento de locales consulares - y alguno de carácter puramente diplomático.

Las relaciones políticas y diplomáticas, a nivel oficial, entre Suecia y la República durante la guerra civil españolas fueron, en definitiva, correctas pero discretas, como reconoció incluso la Causa general franquista. Llama la atención, asimismo, la escasez de contactos entre las organizaciones políticas y sindicales españolas - tanto socialistas como comunistas - con sus homónimas suecas, con la notoria excepción de la CNT.

A nivel no oficial, de apoyo popular y por parte de algunas organizaciones políticas a la República, fueron, por el contrario, extraordinariamente cálidas y amistosas. Es grande la desproporción entre la ayuda prestada a la República y la prestada a la España de Franco, a favor de aquella: el hospital sueco-noruego de Alcoy - "establecimiento modelo" según el general republicano Julio Bejarano -, los hogares infantiles de Denia, Teyá y Francia, y la amplia ayuda material en forma de víveres y medicamentos, son datos fehacientes al respecto, al igual que la participación de más de quinientos voluntarios suecos en los frentes de guerra españoles en el bando republicano, frente a una decena en el bando franquista.

Los protagonistas principales de esta gran manifestación de solidaridad internacional con la República española fueron los dos partidos y el sindicato situados políticamente a la izquierda de la socialdemocracia: el partido comunista, el partido socialista y, en particular, el sindicato de corte libertario y anarquista SAC, la organización europea que más próxima estuvo a la CNT española. Las organizaciones socialdemócratas, por el contrario, apenas están representadas en la lista de organizaciones del movimiento obrero sueco que protestaron abiertamente contra la política gubernamental.

Nuestra investigación ha confirmado también la ambivalente actitud de las autoridades suecas hacia la República en relación con los voluntarios suecos de las 
Brigadas Internacionales. Formalmente habían incurrido éstos en delito castigado con penas de prisión, pero las autoridades adoptaron una actitud pragmática y flexible respecto a la aplicación de la ley, llegando a prestarles ayuda material concreta para su repatriación y dejando sin efecto la ley una vez hubieron regresado a Suecia. Esto no fue óbice, sin embargo, para que fueran sometidos a cuidadosa vigilancia policial, por el temor de que el contacto de esos brigadistas suecos con el comunismo internacional, durante su estancia en España, pudieran ser perniciosos para la seguridad de Suecia.

El acceso a nuevas fuentes archivísticas nos ha permitido actualizar las listas de voluntarios suecos conocidas hasta la fecha. Asimismo, hemos podido aportar nombres y detalles específicos acerca del contrabando y de la presencia de armas suecas en España, tema en gran medida desconocido hasta ahora por la historiografía, salvo contadas excepciones, como Howson y, por parte sueca, Lundberg. Sobre este aspecto, la conclusión es que, aún siendo de dimensiones modestas, hubo una red de contrabando de armas suecas, que fue utilizada tanto por los agentes republicanos como por los franquistas, y que de manera habitual realizó un doble juego, vendiendo a ambas partes las mismas partidas de armas. De hecho, gran parte del material bélico en cuestión parece haber acabado en manos de la España de Franco.

En definitiva, las autoridades suecas trataron de hacer compatibles la necesidad pragmática de apoyar la política inglesa de no intervención con el deseo, hondamente sentido en amplios sectores de la sociedad sueca, de prestar apoyo humanitario y moral a la República y favorecer así el establecimiento en España de la democracia.

Llegamos así al último punto de este apartado final: las relaciones de Suecia con la España de Franco.

Las relaciones de Suecia con la España franquista atravesaron varios momentos principales: Un período inicial en el que Suecia se mantuvo a la expectativa, entre julio de 1936 y el final de la batalla de Madrid; un período de distanciamiento, si bien con relaciones oficiosas, hasta el verano de 1938; un tercer período de relaciones oficiales a nivel de agentes, desde el otoño de 1938 hasta el final de la guerra; y finalmente, el período de reconocimiento oficial y de reestablecimiento de las relaciones diplomáticas ordinarias, desde el 31 de marzo al 31 de diciembre de 1939.

El gobierno provisional sueco del verano de 1936, dirigido por el político de la Liga Agraria Axel Pehrsson-Bramstorp, tras una primera reacción adversa, mantuvo una actitud 
expectante pero abierta al bando sublevado, al que apoyó bajo cuerda, poniendo trabas al restablecimiento de las relaciones diplomáticas normales con la República. Esta conclusión se apoya en el testimonio explícito de Alfonso Fiscowich, el Ministro de España en Suecia desde 1934 que desde el 11 de agosto representaba a la España de Franco en vez de a la República, y constituye un aspecto desconocido hasta la fecha en la historiografía sueca.

Hombres clave en esta actitud de apoyo solapado a la España de Franco fueron el Rey Gustavo V y el Subsecretario sueco del Ministerio de Negocios Extranjeros, Christian Günther, que habría sustituido a Danielsson en Madrid si no hubiera comenzado la guerra civil y que a partir de diciembre de 1939 pasó a ocupar esa cartera ministerial en el gobierno de concentración nacional dirigido por Per Albin Hansson durante los años de la segunda guerra mundial.

Hasta ahora, ningún estudio histórico sueco había comentado las simpatías por la España de Franco de Günther y del Rey Gustavo V, que invitó a comer al representante franquista en Estocolmo el 25 de octubre de 1936, brindando por el triunfo de la causa rebelde, y posteriormente tuvo un par de intervenciones directas para conseguir el paso a la zona franquista de algunas personas, incluido un militar español de alta graduación refugiado en la Legación de Suecia en Madrid. La diplomacia sueca se ocupó, discretamente, de las gestiones necesarias al efecto.

Oficialmente, el gobierno de Pehrsson-Bramstorp se adhirió a la política británica de no intervención, facilitando así las cosas al gobierno siguiente, de Per Albin Hansson, que simplemente prosiguió la política iniciada por su antecesor.

Durante el segundo período, Suecia fue firme en su postura neutral, aunque toleró la presencia en Estocolmo de representantes oficiosos del gobierno franquista, con acceso a funcionarios del Ministerio de Negocios Extranjeros y una amplia red de contactos en el país, especialmente - pero no exclusivamente, ya que ha quedado constancia de contactos con las autoridades policiales - en círculos empresariales.

Asimismo, la España de Franco pudo contar en Suecia con el apoyo de la Asociación sueca de Comercio Exterior, que realizó una activa labor de lobby a favor de la regularización, por parte de Suecia, de las relaciones comerciales con el gobierno de Burgos, siguiendo el modelo británico. Los empresarios suecos - y en particular aquellos con intereses en España, como el cónsul sueco en San Sebastián, Andrés Åkerman entreveían el triunfo franquista en la guerra y no estaban dispuestos a que Suecia sufriera 
desventajas comerciales por no haber regularizado a tiempo sus relaciones con el nuevo Estado español.

Este apoyo, conocido en la historiografía sueca gracias a los trabajos de Lundvik y Cantera Carlomagno, fue decisivo para evitar un acercamiento del gobierno a la España republicana, a partir del verano de 1937 y para las discretas negociaciones del Ministerio de Negocios Extranjeros de Suecia con los representantes franquistas en el país para el intercambio de agentes comerciales. Sin embargo, y a pesar de las amenazas de Juan Antonio Suanzes de tomar represalias comerciales contra Suecia, ese intercambio no tuvo lugar hasta finales de 1938, cuando la situación internacional y el desarrollo de la guerra civil lo hicieron poco menos que inevitable. La misión principal de los agentes, Fernando Valdés en Estocolmo y Nils Berencreutz en Burgos, fue preparar el reconocimiento oficial, que Suecia - tras ponerse de acuerdo con los otros países escandinavos - prefería dilatar lo más posible y no haría efectivo hasta la tarde del 31 de marzo de 1939.

La conclusión fundamental de lo expuesto es que, a pesar de la retórica oficial, el gobierno sueco no adoptó una postura hostil hacia la España de Franco. Antes bien, al igual que con la República, la actitud sueca ante la España de Franco fue ambigua. Probablemente, el motivo radica simplemente en la ya conocida línea tradicional sueca en política exterior: conservar a toda costa su neutralidad, manteniéndose a la expectativa mientras sea posible, sin tomar decisiones apresuradas que pudieran comprometerla.

La actividad humanitaria sueca se extendió también a la zona franquista, tanto en forma de apoyo material - sobre todo medicinas, y un hogar de acogida a niños en Guetaria - como, especialmente, en relación con el ejercicio del derecho de asilo y la labor de mediación en el intercambio de presos, como el canje del hijo del general Goded y su familia.

La Legación de Suecia en Madrid, gestionada - en ausencia de diplomáticos suecos profesionales - por personal subalterno sueco y español, acogió a 174 refugiados políticos, entre ellos 21 militares españoles. Consiguió evacuar a todos, salvo a 13 militares, que hubieron de esperar al final de la guerra. Las cuestiones relacionadas con esta labor de asilo trajeron muchos quebraderos de cabeza para la diplomacia sueca, especialmente cuando se pudo comprobar que el cónsul provisional sueco en Madrid, Gumersindo Vallejo, estaba involucrado en las actividades de lo que ha venido en llamarse la quinta columna. 
En realidad, la mayor parte de los refugiados fueron mujeres, niños, y familiares de personas que tenían algún tipo de relación con intereses suecos en España. En todo caso, el gobierno sueco negó las acusaciones de la prensa izquierdista de que estaba protegiendo a fascistas, a pesar de ser consciente - como nuestro estudio ha podido constatar - de la veracidad de algunos datos publicados, como el de la protección ofrecida por la Legación a algunos militares de alta graduación.

En el otro lado de la balanza, sin embargo, se sitúan los conflictos que Suecia tuvo con la España de Franco durante los años de la guerra. Los más conocidos hasta ahora eran los relacionados con el apresamiento e incautación de barcos mercantes suecos por parte de la Armada franquista. En algunos casos - el Allegro es el más conocido - se produjo esa intervención como resultado del doble juego de los intermediarios de compraventa de armas en el norte de Europa, pero existieron también conflictos de mayor entidad, desconocidos en la historiografía, que nuestro estudio ha sacado a la luz, fundamentalmente el caso de los vicecónsules honorarios de Suecia en Coruña y Sanlúcar de Barrameda detenidos en la España de Franco.

El caso de este último, Antonio Maestre, conocido dirigente republicano condenado a muerte por las autoridades militares de la España franquista, motivó contactos al más alto nivel entre Suecia y la España de Franco, incluidas cartas y telegramas de Rickard Sandler a Queipo de Llano, al Cuartel general del Generalísimo y al gobierno republicano español, intentando salvarle. La última gestión, casi desesperada, del intento de canje de Maestre por la hermana de Queipo de Llano no fue, sin embargo, autorizado por el gobierno de la República española, por lo que todo acabó en un fracaso. Sí culminaron con éxito, en cambio, las gestiones suecas para obtener la liberación de los brigadistas internacionales suecos prisioneros en las cárceles y campos de concentración de la España franquista.

Finalmente, hemos analizado las relaciones entre Suecia y la España de Franco una vez terminada la guerra, durante el resto del año 1939. El resultado de nuestra investigación presenta aspectos un tanto sorprendentes, si se considera que las relaciones de Suecia con el régimen de Franco fueron ambiguas durante la guerra, y muy tensas en años posteriores, hasta culminar en la retirada del Embajador sueco en Madrid en 1975 como protesta por las últimas condenas a muerte llevadas a cabo en España.

En efecto, podemos concluir que la imagen que se desprende del análisis de las fuentes diplomáticas de ambos países es una de normalidad institucional, e incluso de continuidad respecto a las relaciones. Las fuentes muestran un estrechamiento de los 
vínculos entre ambos países, en un intento de retomar el antiguo discurso de la colaboración en política exterior entre los países neutrales, uno de los puntos claves de la política exterior de la República española.

La conclusión, por tanto, es que Suecia mantuvo una actitud discreta y de cierta distancia, pero no especialmente hostil a la España de Franco durante los años de la guerra y que trató de mantener unas relaciones diplomáticas plenamente normales en los meses que siguieron al final de la contienda.

Nos acercamos así al final de este estudio de historia comparada, centrado en las relaciones internacionales entre España y Suecia durante los años treinta del siglo XX, que fueron los de la Segunda República en España y de la formación del Modelo sueco en el país escandinavo. Confiamos en que haya aportado nuevas luces para una mejor comprensión de ese período tan importante en la historia de ambos países. Al mismo tiempo, somos conscientes de que, como es habitual, nuestra investigación ha sacado a la luz un abanico de nuevas posibilidades que quedan abiertas a la investigación futura.

Entre ellas, pensamos que las más sugerentes son las siguientes: en primer lugar, un estudio monográfico de las relaciones entre la CNT y la SAC, a partir del material conservado en el Archivo del Movimiento Obrero sueco en Estocolmo, que contiene abundante correspondencia entre los representantes de ambas organizaciones, y que, aparte de las cuestión de las relaciones entre ambas organizaciones, permitiría ver cómo presentó la CNT la guerra civil española, en sus diversas fases, a las organizaciones europeas de carácter anarcosindicalista y al movimiento obrero en general.

En este contexto, una cuestión interesante es el posible efecto de los dramáticos acontecimientos de España de julio de 1936 en la decisión del gran sindicato socialista sueco Landsorganisationen ( $L O$ ) - en su Congreso de 27 de septiembre a 4 de octubre de 1936 - de promover la línea del consenso en lugar de la del enfrentamiento con las asociaciones patronales. El resultado de esa decisión tan importante fueron los Acuerdos de Saltsjöbaden, que dieron lugar al especial modelo de sociedad sueco. Dada la situación internacional europea y mundial en la década que nos ocupa, no parece fuera de lugar partir de la hipótesis afirmativa, como hipótesis de trabajo.

Otro de los resultados de nuestra investigación que, en nuestra opinión, no está suficientemente estudiado por parte de la historiografía sueca, es el acercamiento político de Suecia a Gran Bretaña durante la década de los treinta del siglo XX. Es un dato interesante, en especial a la luz del desarrollo posterior de los acontecimientos, ya que, 
comenzada la guerra mundial, Suecia no solamente se alejaría de la posición británica, manteniendo una estricta neutralidad, sino que llegaría a tener una relación algo tensa con el gobierno de Su Graciosa Majestad, que llegó incluso a considerar la posibilidad de intervenir militarmente contra el país escandinavo para evitar el abastecimiento de mineral de hierro sueco a Alemania. Por ello, un estudio de las relaciones bilaterales suecobritánicas durante la época en cuestión, similar al que nosotros hemos abordado con España, podría resultar de sumo interés.

Un tercer campo abierto a la investigación futura es el estudio de las relaciones en el período 1900-1930 - quizá con particular énfasis en los años de la Primera Guerra Mundial o los de la Dictadura primorriverista - y especialmente, el de las relaciones de Suecia con la España de Franco entre 1939 y 1975. Como hemos podido ver, la documentación sueca para un trabajo de este tipo, especialmente los fondos del archivo del movimiento obrero, ocupa muchos metros de estantería, y apenas ha sido utilizada hasta ahora a nivel académico.

Podría ser interesante también profundizar en el aspecto de la cooperación y relaciones mutuas entre los llamados países neutrales en tres momentos principales: la Primera Guerra Mundial, el período de entreguerras, y la Segunda Guerra Mundial. De ellos, el más estudiado ha sido el tercero. También aquí, un análisis comparado de los fondos diplomáticos de los países en cuestión, especialmente los escandinavos, los del Benelux, Suiza y España podría aportar nuevos datos a la historiografía.

Estas sugerencias de futuros trabajos se refieren a aspectos sustantivos, dentro de un marco teórico-metodológico análogo al adoptado por nosotros. La lista puede hacerse mucho más larga si ponemos el punto de mira en otros marcos conceptuales. Un aspecto sugerente sería el estudio diacrónico de los despachos diplomáticos utilizados desde el punto de vista del análisis de los conceptos utilizados y de su posible cambio de significado, siguiendo especialmente las teorías y métodos de Ricoeur o de Koselleck. O bien, profundizar en algunos aspectos en los que, dado el marco de nuestro estudio, no hemos podido detenernos, como serían las cuestiones relacionadas con las variables constituidas por los conceptos de clase, generación o género.

Ponemos aquí punto final a estas líneas, recordando el paradigmático discurso del Ministro de Negocios Extranjeros del gobierno socialdemócrata de Suecia a finales de 1936: 
No es posible tomar partido por uno de los frentes en el problema español, y sostener al mismo tiempo los principios democráticos, por ser dos cosas que se contradicen. Se puede lamentar profundamente que el camino de España a un orden social moderno y democrático vaya a través de convulsiones tan sangrientas y crueles y que el desarrollo parezca por ahora tan incierto, pero no debe afirmarse que el destino de la democracia en el mundo se resuelva en las luchas callejeras de Madrid. Este depende de la manera de solucionar sus propios asuntos de los Estados democráticos y de su voluntad de defenderse de ataques tanto materiales como inmateriales. Pero a ese fin es de la mayor importancia que la democracia afirme su idiosincrasia y no se coloque en la situación de tener que elegir entre dictaduras de distintos matices.

Esas palabras de Rickard Sandler dan una clave fundamental para comprender los motivos de la ambivalente actitud mantenida por Suecia ante España, un país con el que Suecia, a pesar de todo, mantuvo durante la década de los años treinta del siglo XX unas relaciones políticas y diplomáticas más estrechas de lo que a primera vista hubiera podido suponerse. 



\section{Apéndice 1}

Despacho n. 46 de 15 de febrero de 1934, Legación de España en Estocolmo*

\author{
LEGACIÓN DE ESPAÑA \\ ESTOCOLMO \\ Europa \\ N. 46
}

Excmo. Señor:
Estocolmo, 15 de febrero de 1934

ASUNTO: Relaciones políticas con Suecia

Antes de dar por terminada mi misión en este país, creo de cierta utilidad expresar a V.E. algunas consideraciones fruto de la experiencia adquirida durante el ejercicio del cargo. He de señalar, sin embargo, que la circunstancia de haberlo ejercido sólo durante un año y de haber pasado una buena parte de él en comisiones en el extranjero, limita tal vez la extensión de mis juicios y puede, al propio tiempo, aconsejar el aceptarlos con determinadas reservas.

Separadas España y Suecia por una considerable distancia geográfica y sin problemas políticos de carácter general derivados de la postguerra, las relaciones entre ambos países, si han sido consideradas como excelentes, se debe tal vez al hecho de que no existían. La creación y funcionamiento de la Sociedad de Naciones, al establecer la colaboración internacional en multitud de cuestiones, aun en aquellas en que muchos países no tienen intereses directos, ha permitido establecer relaciones, siquiera fueran de cierto carácter efímero. En una ocasión, como recordará V.E., hubo de cruzarse este país en el camino de las aspiraciones de España, al solicitar éste un puesto permanente en el Consejo. En tiempos de la monarquía, las visitas recíprocas de ambos Soberanos establecieron también una relación, siquiera fuera de carácter efímero y de un interés puramente dinástico.

El advenimiento de la República en España, si tal vez ha podido ser visto con recelo y disgusto por la Corte, ha despertado, por el contrario, una curiosidad viva y simpática en los medios políticos, sobre todo de la izquierda y, principalmente, en el socialismo, que asume en estos momentos la gobernación del Estado.

\footnotetext{
* AMAEC R, 860, 74.
} 
Partiendo de la afirmación, basada en los hechos, de que no existen relaciones políticas entre ambos países, salvo la simpatizante hacia un régimen de ideales muy semejantes, atenuada últimamente, hay que decirlo, con la salida de los socialistas en España, cabe examinar: a) si convendría fomentar la creación de relaciones de carácter político; b) cual sería la finalidad; y c) cuales los medios y procedimientos adecuados.

a) Es indudable que en cualquier circunstancia y más en aquellas que hoy parecen predominar en el mundo, el aislamiento político de un país, aun en el caso dudoso de ser posible, puede ser extraordinariamente peligroso, ya que supone que en el momento de tener que salir de él por la fuerza de los hechos y aun en contra de la voluntad nacional, no se ofrecen más caminos ni salidas que aquellas que impone la misma o las mismas fuerzas que hacen romper el aislamiento. Partiendo de este supuesto, y aunque sea invadiendo un terreno vedado a mi competencia, lo que me permito hacer para llegar a una conclusión en cuanto a la política específica con este país, me imagino que ni los intereses ni la situación de España aconsejan trabar lazos políticos con todas las grandes Potencias ni con ninguna de ellas singularmente. Si es así, habría que orientar el fomento de las relaciones políticas con las pequeñas Potencias europeas, libres de compromisos políticos a su vez y cuyos ideales sean la paz y la cooperación internacional. Esta política, además de ser, al parecer, la conveniente para España, habría de permitirle, en su día, ser la primera de las pequeñas Potencias y preparar su eventual neutralidad ante un conflicto europeo.

Suecia figura en ese grupo y si se reconoce que el aserto que me permito hacer en las líneas que anteceden no es equivocado, se llegará a la conclusión de que el fomento de las relaciones políticas con este país es conveniente y necesario para la acción política internacional de España. Reconocidas la conveniencia y la finalidad ya indicadas, convendría examinar los medios y procedimientos adecuados para llevar a la práctica el principio, y a este respecto llego a las siguientes conclusiones:

1. La acción no debe ser ejercida aisladamente con Suecia, sino con todos los países similares (por ejemplo: Noruega, Dinamarca, Países Bajos, Suiza, eventualmente Bélgica).

2. No debe, en un principio, caracterizarse políticamente.

3. Los objetivos han de estar impregnados de "moral internacional": defensa de la Sociedad de Naciones, cooperación internacional, etc.

4. La acción política ha de ir acompañada de una acción económica y cultural.

5. España no debe tratar de asumir en modo alguno ninguna especie de hegemonía. 
En los momentos actuales puede considerarse como iniciada esta política y si las reuniones previstas en principio en Ginebra para el examen de las cuestiones que afectan al Pacto de la S. de N. llegan a celebrarse, la realidad podrá permitir apreciar mejor que las afirmaciones del que suscribe si esta política es hacedera y conveniente.

He de añadir que las circunstancias políticas por que atraviesa actualmente este país pueden ser muy favorables al desarrollo de un plan semejante. Hasta ahora, sin constituir un designio y aun guardando una escrupulosa neutralidad, ha sido Alemania el país con el que Suecia ha mantenido mayores relaciones en todos los órdenes. Ello se explica por razones geográficas. Pero imperante en Alemania un régimen tan contrario a la ideología del partido que hoy está en el Poder y que lucha para contrarrestar la propaganda "nazi", parece como si el Gobierno quisiera ir poco a poco desanudando esas relaciones y buscándolas en otros países en los que impera un régimen de Gobierno más en armonía con el que hoy rige los destinos de Suecia.

El Ministro de España

Julio López Oliván

Excmo. Señor Ministro de Estado 



\section{Apéndice 2}

\section{Despacho n. 322 de 8.VII.1933, Legación de Suecia en Madrid*}

(Traducción del original sueco)

\section{LEGACIÓN DE SUECIA}

Informe político sobre España

en el segundo trimestre de 1933

Ref. 7.4.33
Madrid, 8 de julio de 1933

N. 322

HP 1

A Su Excelencia el Señor Ministro de Negocios Extranjeros:

La situación parlamentaria al final del trimestre pasado anunciaba tiempos difíciles para el gobierno de Azaña. En los últimos tres meses el gobierno se ha visto envuelto en una continua serie de confrontaciones parlamentarias con la oposición, en las que partidos netamente republicanos como el grupo Radical, se han mostrado a veces como los enemigos más irreconciliables del presidente del gobierno español.

Como VE ha podido observar por los informes de la Legación, el gobierno de Azaña ha sido el vencedor indiscutible de esas confrontaciones y el bloque ministerial socialistarepublicano de izquierda está más firmemente asentado que nunca, contando incluso con el apoyo del pequeño grupo federalista, que anteriormente estaba en la oposición.

En las luchas políticas se involucró incluso el propio Jefe del Estado, con el fracasado intento de Alcalá-Zamora - de forma considerada en algunos ambientes anticonstitucional - de provocar un cambio de gobierno para conseguir uno con mayor base parlamentaria. Sin embargo, la crisis ministerial que surgió de ese intento se resolvió con la constitución de un tercer gobierno Azaña, cuya composición política era básicamente idéntica a la del anterior.

Para una mejor comprensión de la actual situación política española, conviene proceder a una sucinta recapitulación del desarrollo político tras la proclamación de la República el 14 de abril de 1931. El primer gobierno revolucionario estuvo compuesto por representantes de los socialdemócratas y de republicanos de todo tipo. Tras la aprobación de la nueva Constitución por la Asamblea constituyente, los grupos republicanos moderados abandonaron la coalición gubernamental a consecuencia de desavenencias respecto a la solución del problema eclesiástico. En la primavera de 1932, con motivo de la

\footnotetext{
* RA, UD, 1920-års dossierssystem, HP, vol. 421.
} 
cuestión catalana, abandonó incluso el Partido Radical el bloque ministerial, por lo que el recientemente nombrado segundo gobierno de Azaña sólo contaba con el apoyo de los grupos siguientes: socialistas, socialistas radicales, Acción Republicana (el grupo del presidente del gobierno), la izquierda catalana y el grupo gallego.

La oposición parlamentaria, compuesta actualmente por todo tipo de grupos, desde los agrarios hasta el Partido Radical, numéricamente muy superior, llegó a considerar que con la aprobación de la Constitución había terminado el cometido de las Cortes constituyentes, propugnando la celebración de nuevas elecciones para conseguir una representación parlamentaria más acorde con la proporción real de las fuerzas políticas en el país.

El gobierno, por su parte, respondió a esto diciendo que correspondía a las Cortes constituyentes la aprobación de todas las leyes que constituyeran un desarrollo necesario de la Constitución y que, en consecuencia, el gobierno permanecería en el poder mientras siguiera teniendo mayoría en la Cámara. Sin embargo, en varias ocasiones, el gobierno se ha visto amenazado de disolución.

En efecto, importantes sectores del partido socialdemócrata están en contra de que el partido siga formando parte de la coalición gubernamental e incluso los socialistas radicales se han planteado a veces negar su apoyo a la política del gobierno de Azaña, aunque a la hora de la verdad ha vencido la disciplina de voto y la mayoría parlamentaria del gobierno se ha podido mantener.

Durante los últimos meses, la oposición parlamentaria ha venido desarrollando de forma sistemática una política obstruccionista en la esperanza de forzar la caída del gobierno de Azaña. El resultado de unas elecciones municipales parciales, a finales de abril, en las que perdieron apoyo los partidos del gobierno, dio nuevas esperanzas a la oposición, que durante las semanas siguientes consiguió paralizar completamente los trabajos parlamentarios.

Sin embargo, el presidente del gobierno consiguió movilizar a todos los diputados progubernamentales y, utilizando el procedimiento "guillotina" frente a la obstrucción de la oposición, pudo aprobar la Ley de Congregaciones y otras leyes, imponiendo su voluntad a la oposición. En contra de lo que cabría esperar, el Presidente de la República, cuya disconformidad con la política eclesiástica del gobierno es bien conocida, sancionó la Ley de Congregaciones. Al mismo tiempo, al proponer Azaña la cuestión de la posible sustitución del ministro de Finanzas, que había enfermado, Alcalá-Zamora aprovechó la 
oportunidad para sondear las posibilidades de formar un nuevo gobierno con mayores apoyos parlamentarios.

Este intento del Jefe del Estado español, motivado por su deseo de cambiar el rumbo político de la nación en sentido menos radical, quizá a través de la exclusión del gobierno de los socialdemócratas, acabó en fracaso, y Azaña constituyó su tercer gabinete con el apoyo de la misma mayoría que el anterior.

Durante el debate parlamentario sobre la nueva declaración de intenciones del nuevo gobierno, concretada en la realización de la reforma agraria votada y la aplicación de las disposiciones de la Ley de Congregaciones sobre la laicización de la enseñanza, el principal líder de la oposición, Lerroux, declaró que su partido iba a dejar su política obstruccionista para pasar a ejercer una oposición normal tras un análisis en conciencia de las acciones del gobierno. Este cambio inesperado de actitud del partido Radical ha sido achacado por muchos a un posible acuerdo entre el jefe del partido y el presidente del gobierno, por el cual éste se habría comprometido a convocar elecciones municipales en toda España en el otoño próximo.

Sin embargo, a pesar de que la última crisis ministerial no ha tenido más resultado que el de afianzar la posición del gobierno de Azaña, la situación política y social del país dista mucho de ser tranquilizadora, a consecuencia del "proceso de fermentación" que se deja sentir en las diversas clases sociales de la nación. Dadas las circunstancias, es posible que el presidente del gobierno haya considerado que no debía esperar más tarde del otoño para convocar elecciones locales que den a la nación la posibilidad de pronunciarse sobre la situación política actual.

En la redistribución de carteras ministeriales que tuvo lugar con la formación del tercer gobierno de Azaña, el socialdemócrata Fernando de los Ríos ha pasado a ocupar la cartera de Negocios Extranjeros. Dado que éste es personalmente partidario del establecimiento de relaciones con la Unión Soviética, se considera probable que España proceda al reconocimiento oficial de las Repúblicas Soviéticas, y se espera que en breve comiencen las negociaciones al respecto.

Además de la competencia de la madera rusa en el mercado español, que sin duda amenaza a Suecia cuando se establezcan las relaciones oficiales con la Unión Soviética, ha aparecido otra amenaza para el comercio exterior sueco con España, ya que el gobierno español, con vistas a corregir el desnivel de la balanza de pagos, está considerando proceder a una política de cuotas o contingentes respecto a aquellos países que exportan a 
España más de lo que importan de ella. De momento, parece que esos planes siguen estando en estudio.

Ivan Danielsson 


\section{Apéndice 3}

\section{Discursos de Per Albin Hansson sobre el Hogar Popular}

\section{En el Parlamento sueco (1928):}

El fundamento del hogar es el estar y el sentirse juntos y unidos. El buen hogar no conoce privilegiados ni desfavorecidos, ni niños mimados ni hijastros. En él no mira nadie por encima del hombro a otro, en él no trata nadie de obtener ventajas para sí mismo a costa de los otros, en él no hay opresión ni despojo por parte del más fuerte respecto al más débil. En el buen hogar reina la igualdad, la preocupación de unos por otros, la colaboración, la ayuda mutua.

Aplicado esto al gran hogar popular y ciudadano, supondría la abolición de todas las barreras sociales y económicas que actualmente dividen a los ciudadanos en privilegiados y desfavorecidos, en dirigentes y dependientes, en ricos y pobres, en propietarios y empobrecidos, en saqueadores y saqueados.

La sociedad sueca no es todavía el buen hogar de los ciudadanos. Aquí rige ciertamente una igualdad formal, la igualdad de derechos políticos, pero desde el punto de vista social persiste aún la sociedad clasista y desde el punto de vista económico existe la dictadura de unos pocos. Las diferencias, en ciertos casos, claman al cielo: mientras algunos viven en palacios, otros se consideran privilegiados si se les permite quedarse a vivir en sus cabañas incluso durante el frío invierno; mientras unos viven en la abundancia, vagan otros de puerta en puerta pidiendo pan, y los pobres están angustiados ante el futuro, donde ven el espectro de la enfermedad, el desempleo y otras desgracias.

Si la sociedad sueca ha de ser el buen hogar de los ciudadanos deben desaparecer las diferencias de clase, deben desarrollarse los auxilios sociales, debe producirse una nivelación económica, debe favorecerse la participación de los empleados incluso en la administración económica, debe realizarse la democracia también en los ámbitos social y económico.

\section{En 1921:}

(...) No es nuestro propósito establecer ninguna dictadura del proletariado, no pretendemos cambiar una opresión antigua por otra nueva. Luchamos para que por el camino seguro de 
la democracia, con el mandato de la mayoría del pueblo, hacer subir a las clases sociales hasta ahora desfavorecidas a un nivel de igualdad, luchamos por la abolición de las clases, por hacer de Suecia un buen hogar para todos los suecos (...)

Estas tremendas injusticias deben desaparecer. Todos los niños suecos deben tener las mismas posibilidades iniciales, todos los hijos e hijas del país deben tener la posibilidad, no sólo de conseguirse un buen sustento, sino de participar de todo lo bueno que enriquece la vida humana. Las diferencias sociales deben desaparecer. ¡Suecia para todos los suecos! 


\section{Apéndice 4}

\section{Despacho n. 30 de 27.II.1937, Legación de Suecia en Madrid (Valencia) ${ }^{*}$}

(Traducción del original sueco)

LEGACIÓN DE SUECIA

Sobre la situación actual

en Madrid
Madrid (Valencia), el 27 de febrero de 1937

N. 30

HP 1

A Su Excelencia el Señor Ministro de Negocios Extranjeros:

Basado en los relatos recibidos de personas de confianza, que han llegado de Madrid en los últimos días, me permito enviar la siguiente información acerca de la situación en la capital.

Los bombardeos aéreos y las luchas en los distintos frentes cercanos a Madrid han convertido en ruinas las áreas periféricas de la ciudad, pero incluso las zonas centrales han sido en gran medida devastadas.

Los nacionalistas han tomado especialmente como objetivos de sus bombardeos aéreos los edificios oficiales, los cuarteles y los puntos importantes desde el punto de vista bélico. El Museo del Prado ha sufrido daños exteriores pero los objetos de arte que contiene habían sido empaquetados y puestos a recaudo en los sótanos del museo.

Madrid está bien fortificado, en particular en la zona norte y en la zona este, mientras que los demás frentes, especialmente el del oeste, son más débiles, aunque los trabajos de fortificación allí continúan con gran entusiasmo. Según me dicen mis informadores, es prácticamente imposible tomar la ciudad por las armas desde los frentes norte o este, aunque también es difícil hacerlo desde el frente oeste, donde proseguían las luchas actuales.

No se puede contar con que los defensores de Madrid entreguen voluntariamente la ciudad, sino que la forma de conquistar la ciudad será probablemente el ponerle cerco y ahogarla por hambre, cosa que llevaría al menos otro mes y medio o dos meses más.

La población de la ciudad posee una gran voluntad de defensa y se ha atrincherado poco a poco frente a las penalidades ocasionadas por la guerra. Los repetidos ataques

\footnotetext{
*RA, UD, 1920-års dossierssystem, HP, vol. 1505.
} 
aéreos lanzados por los nacionalistas, cuyo objetivo primordial es sembrar la desmoralización entre los defensores de la ciudad, han producido el efecto contrario. Por otra parte, esos ataques han prácticamente desaparecido en los últimos tiempos, probablemente porque los nacionalistas han comprendido que no conducían al efecto deseado.

Hay rumores - que la población madrileña en general considera como verdaderos de que las autoridades han minado la mayoría de los barrios de la ciudad, para hacerla volar por los aires si fuera necesario antes de rendirla.

Madrid se ha habituado a los rigores de la guerra en mucha mayor medida que otros lugares como Valencia, y hay allí un espíritu más positivo que el que reina en Valencia. Actualmente, puede considerarse que el poder en Madrid está en manos del comité de Defensa de la ciudad, bajo el General Miaja, que ha conseguido básicamente eliminar la influencia de las organizaciones obreras y de los comités políticos, con la consecuencia de que reina en Madrid mucho más orden y disciplina que en Valencia. Por otra parte, la influencia del gobierno de Valencia en el comité de defensa de Madrid es débil, algo que muchos detalles puntuales han puesto de manifiesto.

Dadas las circunstancias, las condiciones sanitarias de Madrid pueden definirse como bastante buenas. Ha habido algunos casos aislados de tifus, pero no ha habido epidemias propiamente dichas. El riesgo de que se produzcan aumenta, naturalmente, en la medida en que prosigan las actuales circunstancias, que han de minar poco a poco la resistencia de la población. La falta de alimentos se deja sentir con fuerza, pero gracias a que el clima ha sido suave, la población ha podido sobrevivir el invierno. La situación al respecto mejorará pronto, lógicamente, pues el invierno toca a su fin. Hay escasez de agua y la ciudad se sume en la oscuridad a partir de las nueve de la noche, aunque está permitido encender luces dentro de las casas, de forma moderada.

Erik Wisén 


\section{Apéndice 5}

\section{Despacho n. 2 de 28.VIII.1936 de Alfonso Fiscowich a la Junta de Defensa Nacional de Burgos *}

\section{LEGACIÓN DE ESPAÑA ESTOCOLMO}

N. 2

Excmo. Sr.:

Continúa este Gobierno manteniendo hacia nuestra causa la actitud favorable que hacía mención en el informe n. 1 de 20 de los corrientes. Lo efectúa, claro está, con aquella reserva y prudencia que las circunstancias aconsejan y lo exigen los compromisos internacionales de los que todavía no se ha separado.

Ni el transcurso de los días, ni las vicisitudes de la campaña, le han hecho cambiar de actitud. Antes al contrario, mantiene su discreto punto de vista, procurando ir relajando los lazos que le unen al Gobierno de Madrid y a través de los cuales se mantienen las relaciones diplomáticas.

Convencido el Gobierno de Suecia de la verdadera situación del que se llama Gobierno de Madrid, y conocedor de la tendencia política de los elementos que le han mediatizado, no tiene interés alguno en sostener por el momento relaciones ni representación diplomática con aquel, especialmente después de la partida de sus súbditos de las regiones ocupadas por los rojos.

Con la mayor reserva me ha indicado este Ministerio de Negocios Extranjeros que había dado orden a su Encargado de Negocios en Madrid (nombrado días antes con carácter interino) de abandonar el territorio español. Así lo ha efectuado el Sr. Olsén, quien ha llegado ayer a esta capital.

Esta orden obedece al propósito de quedar este Gobierno en fácil postura para no admitir ni reconocer a los representantes diplomáticos que Madrid intentase enviarles, en vista de no haber quedado nadie que lo represente en Suecia.

Bien oportuna ha sido la actitud tomada, pues ya se ha presentado la hipótesis que la inspiró. El Gobierno de Madrid, por telegrama del 26 del actual, dirigido directamente al

\footnotetext{
* AMAEC R 602, 5.
} 
Gobierno sueco, ha pedido el placet para nombrar Ministro en Estocolmo al Sr. López Rey, catedrático de Derecho penal, y según me dicen, actual Director general de Policía.

Por el propio Secretario general del Ministerio de Negocios Extranjeros, sé que este telegrama no recibirá contestación, y que caso de insistencia, se buscará una fórmula que, sin entrar en discusiones de principio, evite el que sea acreditado un representante del Gobierno de Madrid con el solemne y alto carácter de Ministro Plenipotenciario. Se desea y se aspira a demostrar que no habiendo representación alguna de Suecia en Madrid no es necesario ni oportuno que la tenga Madrid en Estocolmo.

Creo deber poner de relieve a V.E. a los fines que estime oportunos, el valor y trascendencia de esta actitud, que ha de sostenerse mientras perdure el actual criterio de este Gobierno respecto a la situación militar y posibilidades de nuestro valeroso ejército, a cuyo efecto mantengo con él un estrecho contacto, exteriorizado en diarias entrevistas de las que dejo gráfica constancia de nuestras posiciones y de la labor política que realizamos. Hasta ahora, he logrado los propósitos a que mis gestiones aspiran.

El Ministro de España

Alfonso Fiscowich

Excmo. Sr. Presidente de la Junta de Defensa Nacional BURGOS 


\section{Apéndice 6}

\section{Lista de refugiados en la Legación de Suecia en Madrid ${ }^{*}$}

\section{Asilados en el edificio de la Legación}

\begin{tabular}{|c|c|c|c|}
\hline Nombre & Edad & Nac & Profesión \\
\hline 1. Luisa Kebbon vda. de Scharfhausen & 66 & Sueca & Su casa \\
\hline 2. Jorge Scharfhausen Kebbon & 37 & Sueca & Comercio \\
\hline 3. Ines Muñoz de Scharfhausen & 36 & Sueca & Su casa \\
\hline 4. Jorge Scharfhausen Kebbon & 6 & Sueca & \\
\hline 5. Manuel Scharfhausen Muñoz & 5 & Sueca & \\
\hline 6. María Paz Scharfhausen Muñoz & 3 & Sueca & \\
\hline 7. Mercedes Fernández de Scharfhausen & 22 & Española & Su casa \\
\hline 8. Jorge Scharfhausen Fernández & 1 & Española & \\
\hline 9. Tomás García Consuegra & 44 & Española & Policía \\
\hline 10. Concepción Dahlander Vda. de Gimeno & 69 & Sueca & Su casa \\
\hline 11. Luisa Vidal Fernández & 45 & Española & Dama Compañía \\
\hline 12. Luis Verdugo Font & 33 & Española & Marino \\
\hline 13. Andrés Galán Armario & 35 & Española & Marino \\
\hline 14. José Garnica Pombo & 34 & Española & Marino \\
\hline 15. Luis Rodríguez Pascual & 56 & Española & Marino \\
\hline $\begin{array}{l}\text { 16. Desamparados Rodríguez de la Encina de } \\
\text { Rodríguez Pascual }\end{array}$ & 49 & Española & Su casa \\
\hline 17. Rafael Enamorado Álvarez & 51 & Española & Ingeniero \\
\hline 18. Gregorio García Chamón & 43 & Española & Médico \\
\hline 19. Manuel Flethes de Casso & 35 & Española & Marino \\
\hline 20. Juan Cisneros Carranza & 37 & Española & Militar \\
\hline 21. Maria Luisa Peña de Cisneros & 36 & Española & Su casa \\
\hline 22. Carlos Guerra Taboada & 36 & Española & Militar \\
\hline 23. Hellmut Wolff & 24 & Alemana & Comercio \\
\hline 24. Grete Landerberger de Wolff & 22 & Alemana & Su casa \\
\hline 25. Claus Wolff & $3 \mathrm{~m}$ & Alemana & \\
\hline 26. Erna Schelaschzke & 35 & Alemana & Su casa \\
\hline 27. Segismundo Laks & 39 & Polaca & Comercio \\
\hline 28. Irma Sommerfeldt de Laks & 29 & Polaca & Su casa \\
\hline 29. Tessi Sommerfeldt & 27 & Alemana & Su casa \\
\hline 30. Victor Andresco & 17 & Lituano & Estudiante \\
\hline 31. Luis Fernández Rodríguez & 30 & Española & Marino \\
\hline 32. Carmen Hermida de Taxonera & 25 & Española & Su casa \\
\hline 33. Luciano Taxonera Hermida & 8 & Española & Su casa \\
\hline 34. Luis Taxonera Hermida & $2 \mathrm{~m}$ & Española & \\
\hline 35. Rafaal Zahoner Rochet & 39 & Española & Comercio \\
\hline 36. José de la Peña & 41 & Española & Marino \\
\hline 37. Ramona Roncero de Peña & 37 & Española & Su casa \\
\hline 38. Ramón Peña Roncero & & 12 & Española \\
\hline
\end{tabular}

* AMAEC R, 673, 13. 


\begin{tabular}{|l|r|l|l|}
\hline 39. Jose Luis Peña Roncero & 10 & Española & \\
\hline 40. Luis de la Peña & 39 & Española & Arquitecto \\
\hline 41. Consuelo Navarro de Peña & 36 & Española & Su casa \\
\hline 42. Luis de 1a Peña Navarro & 11 & Española & \\
\hline 43. Juan de la Peña Navarro & 9 & Española & \\
\hline 44. Consuelo de la Peña Navarro & 8 & Española & \\
\hline 45. María de la Peña Navarro & 6 & Española & \\
\hline 46. Santiago de la Peña Navarro & 5 & Española & \\
\hline 47. Carmen de la Pana Navarro & 41 & Española & \\
\hline 48. Carlos de la Peña Navarro & 1 & Española & \\
\hline 49. Consuelo Ortoll de Navarro & 58 & Española & Su casa \\
\hline 50. Victoria Navarro de Sala & 33 & Española & Su casa \\
\hline 51. María Victoria Sala Navarro & 5 & Española & \\
\hline 52. María Teresa Sala Navarro & 3 & Española &. \\
\hline 53. María Luisa Sala Navarro & 1 & Española & \\
\hline 54. José Armijo Gallardo & 38 & Española & Militar \\
\hline 55. Teresa Navarro de Armijo & 34 & Española & Su casa \\
\hline 56. Teresa Armijo Gallardo & 2 & Española & \\
\hline 57. Eduardo Pérez Hickman & 50 & Española & Militar \\
\hline 58. Carlos O'Connor & 29 & Española & Técnico ind. \\
\hline 59. Alberto O'Connor & 34 & Española & Ingeniero \\
\hline 60. José Barrachero & 30 & Española & Comercio \\
\hline 61. Fernando Gil Stauffer & 29 & Española & Comercio \\
\hline 62. Esteban de 1a Torre & 34 & Española & Comercio \\
\hline 63. Rafael Bausa Ruiz & 46 & Española & Marino \\
\hline 64. Fermina Ruiz & 38 & Española & Sirvienta \\
\hline 65. María Umbau & 52 & Española & Sirvienta \\
\hline 66. Victoria Somoza & 25 & Española & Sirvienta \\
\hline
\end{tabular}

\section{Asilados en el anexo de la Calle Cisne 13}

\begin{tabular}{|l|l|l|l|}
\hline 1. Eugenio Mariñas Gallego & 40 & Española & Marino \\
\hline 2. Jesús Aguirre y Ortiz de Zárate & 46 & Española & Militar \\
\hline 3. Carlos de Caballos y Alviach & 28 & Española & Militar \\
\hline 4. José de Reina y Travieso & 58 & Española & Militar \\
\hline 5. Amador Villar y Marín & 34 & Española & Marino \\
\hline 6. Luis Pérez Peñamaría & 46 & Española & Militar \\
\hline 7. Fernando San Martín Domínguez & 35 & Española & Marino \\
\hline 8. Dario San Martín Domínguez & 42 & Española & Marino \\
\hline 9. Rafael García Rodríguez & 52 & Española & Marino \\
\hline 10. Jesús Aguirre Ortiz de Zárate & 19 & Española & Estudiante \\
\hline 11. Alfonso Bermúdez Rodríguez & 18 & Española & Estudiante \\
\hline 12. Ricardo Varela Fiscowich & 25 & Española & Estudiante \\
\hline 13. José María del Busto y Castañón & 25 & Española & Estudiante \\
\hline 14. Luis de León García de la Barga & 25 & Española & Estudiante \\
\hline 15. Francisco Yarava y Azuar & 16 & Española & Estudiante \\
\hline 16. Eduardo Fernández Méndez & 49 & Española & Médico \\
\hline
\end{tabular}




\begin{tabular}{|c|c|c|c|}
\hline 17. Carlos del Busto y Castañón & 24 & Española & Estudiante \\
\hline 18. Alberto Aguilar y Fernández & 20 & Española & Estudiante \\
\hline 19. Manuel Fernández Wazarambroz & 18 & Española & Estudiante \\
\hline 20. Francisco Ruiz de Arava y Osorio & 73 & Española & Propietario \\
\hline 21. Antonio Porlier y Ugarte & 34 & Española & Abogado \\
\hline 22. Luis Bailo y Manso & 36 & Española & Propietario \\
\hline 23. Eugenio Vargas Rodríguez & 43 & Española & Empleado \\
\hline 24. Julio López Sanz & 9 & Española & Estudiante \\
\hline 25. Braulio López Sanz & 32 & Española & Estudiante \\
\hline 26. José Machinena Austegui & 55 & Española & Sacerdote \\
\hline 27. Manuel Requejo Herrero & 56 & Española & Propietario \\
\hline 28. Fernando Septién Puente & 17 & Española & Estudiante \\
\hline 29. Domingo Septién y García & 45 & Española & Empleado \\
\hline 30. Manuel Cavanillas y Rodríguez & 38 & Española & Sacerdote \\
\hline 31. Álvaro Sánchez y Sánchez & 45 & Española & Guardia \\
\hline 32. Justo Requejo y Pérez & 23 & Española & Estudiante \\
\hline 33. Gonzalo de la Puerta y Mausi & 21 & Española & Estudiante \\
\hline 34. Guillermo González Arnau & 26 & Española & Abogado \\
\hline 35. José María de la Vega Samper & 36 & Española & Arquitecto \\
\hline 36. Casimiro Peñalva Estola & 58 & Española & Perito eléctrico \\
\hline 37. Ricardo Benjumea y Benito & 38 & Española & Abogado \\
\hline 38. León Ortiz Huertas & 36 & Española & Industrial \\
\hline 39. Justo Aznar Salmerón & 25 & Española & Perito químico \\
\hline 40. Ramón Enríquez de Luna & 46 & Española & Mecánico \\
\hline 41. Emilio Losada Drake & 32 & Española & Ingeniero \\
\hline 42. Ángel Lorenzo y Fernández Vega & 46 & Española & Propietario \\
\hline 43. Manuel de la Vega Samper & 33 & Española & Estudiante \\
\hline 44. Fernando Corral Álvarez & 46 & Española & Abogado \\
\hline 45. Máximo Garso Esteban & 49 & Española & Farmacéutico \\
\hline 46. Luis Alonso Calleja & 32 & Española & Ingeniero \\
\hline 47. Emilio Echevarría Tagore & 52 & Española & Empleado \\
\hline 48. Luis Giménez Ganga & 56 & Española & Abogado \\
\hline 49. Camilo García de Polavieja & 23 & Española & Estudiante \\
\hline 50. Julián Menga Peinador & 64 & Española & Comercio \\
\hline 51. Gerardo Fernández Moreno & 50 & Española & Propietario \\
\hline 52. José Luis Fernández del Amo & 22 & Española & Estudiante \\
\hline 53. Carlos de Bruhn & 60 & Sueca & Ingeniero \\
\hline 54. Miguel Henríquez de Luna & 33 & Española & Propietario \\
\hline 55. Carlos de Bruhn y Pinet & 14 & Sueca & Estudiante \\
\hline 56. Domingo Rubio Guerra & 23 & Española & Estudiante \\
\hline 57. Rafael Enamorado Sánchez & 19 & Española & Estudiante \\
\hline 58. José María Cavanillas Rodríguez & 30 & Española & Licenciado Ccas. \\
\hline 59. Concepción Navaez y Ulloa & 39 & Española & Sus labores \\
\hline 60. Amparo Fernández Garrido & 15 & Española & Sus labores \\
\hline 61. Maria Paloma Benito & 25 & Española & Sus labores \\
\hline 62. Antonia Huerta Herranz & 52 & Española & Sus labores \\
\hline 63. Isabel Giménez Flores & 32 & Española & Sus labores \\
\hline 64. Concepción Jover Laborda & 29 & Española & Sus labores \\
\hline
\end{tabular}




\begin{tabular}{|c|c|c|c|}
\hline 65. Josefa Fiscowich Gullón & 56 & Española & Sus labores \\
\hline 66. Manuela Fernández Garrido & 20 & Española & Sus labores \\
\hline 67. Rogelia Boloix Martínez & 32 & Española & Sus labores \\
\hline 68. Anita Boloix Martínez & 44 & Española & Sus labores \\
\hline 69. Brigida Martínez Boloix & 13 & Española & Sus labores \\
\hline 70. Brigida Martínez Reyes & 68 & Española & Sus labores \\
\hline 71. Isabel Flores Giménez & 28 & Española & Sus labores \\
\hline 72. Concepción Vera Huerta & 23 & Española & Sus labores \\
\hline 73. Ana Pinet de Bruhn & 44 & Sueca & Sus labores \\
\hline 74. Germán Peñalva Baillo & 27 & Española & Sus labores \\
\hline 75. Isabel Flores de Lemus & 8 & Española & Sus labores \\
\hline 76. Rosario Boceta Ruiz-Zorrilla & 40 & Española & Sus labores \\
\hline 77. José Jordán de Ubiries y Ulloa & 40 & Española & Propietario \\
\hline 78. Antonio Jordán de Ubiries & 38 & Española & Propietario \\
\hline 79. Luis Jordán de Ubiries & 33 & Española & Propietario \\
\hline 80. Pedro Jordán de Ubiries & 32 & Española & Propietario \\
\hline 81. Dolores Gómez Mediviela & 55 & Española & Sus labores \\
\hline 82. Adela Novo Villar & 52 & Española & Sus labores \\
\hline 83. Enrique García de Polavieja & 16 & Española & Estudiante \\
\hline 84. Manuel García de Polavieja & 14 & Española & Estudiante \\
\hline 85. Purificación Clotilde Álvarez & 68 & Española & Sus labores \\
\hline 86. Rafaela Corral Álvarez-Neira & 35 & Española & Sus labores \\
\hline 87. María Teresa Corral Álvarez-Neira & 28 & Española & Sus labores \\
\hline 88. María Rosario Saura del Pan & 45 & Española & Sus labores \\
\hline 89. Pedro Sama Coronas & 85 & Española & Médico \\
\hline 90. Avelina Lomas Marcos & 26 & Española & Sus labores \\
\hline 91. Eugenio Bru Rodríguez & 27 & Española & Estudiante \\
\hline 92. Fermina Garrido de Urizar & 47 & Española & Sus labores \\
\hline 93. Mercedes Menga Fiscowich & 26 & Española & Sus labores \\
\hline 94. Maria Jarava Aznar & 25 & Española & Sus labores \\
\hline 95. Concepción Watteler y Pere & 62 & Española & Sus labores \\
\hline 96. Concepción Benito Watteler & 33 & Española & Sus labores \\
\hline 97. María Luisa Marti Melquizo & 30 & Española & Sus labores \\
\hline 98. Pilar Benito Watteler & 33 & Española & Sus labores \\
\hline 99. José de Roda y López & 68 & Española & Ingeniero \\
\hline 100. Fernando de Roda Cassinello & 16 & Española & Estudiante \\
\hline 101. Cecilio de Roda Cassinello & 28 & Española & Ingeniero \\
\hline 102. José de Roda Cassinello & 31 & Española & Estudiante \\
\hline 103. Juan Ignacio de Roda Cassinello & 22 & Española & Estudiante \\
\hline 104. Francisco Maestre de Boda & 3 & Española & \\
\hline 105. Francisco Maestre y Gomez & 35 & Española & Abogado \\
\hline 106. Araceli Cassinello y Núñez & 58 & Española & Sus labores \\
\hline 107. M. Socorro de Boda y Cassinello & 20 & Española & Sus labores \\
\hline 108. Gracia de Boda y Cassinello & 29 & Española & Sus labores \\
\hline
\end{tabular}




\section{Apéndice 7}

\section{Listas de Voluntarios Suecos al servicio de la República en la Guerra civil Española*}

\section{Voluntarios que sobrevivieron a la guerra:}

\begin{tabular}{|c|c|c|c|c|}
\hline Nro & Apellido & Nombre & ar nacimiento & Fecha \\
\hline 1 & Ahlberg & Albin & Lund & 13 ago 99 \\
\hline 2 & Ahlberg & Rolf Harry & Gotemburgo & 27 abr 18 \\
\hline 3 & Ahlden & Arne Oskar & Gotemburgo & 16 may 07 \\
\hline 4 & Ahlnäs & Göte Axel & Estocolmo & 22 sep 12 \\
\hline 5 & Ahlstrand & Fritz Rickard & & 31 dic 11 \\
\hline 6 & Ahlstrand & Per Olof & Estocolmo & 29 ago 13 \\
\hline 7 & Ahlström & Karl Axel & Norrköping & 12 jun 16 \\
\hline 8 & Ahrnberg & Bertil & Sueco-americano & 11 dic 15 \\
\hline 9 & Alfredsson & Axel Georg Valentin & Gotemburgo & 8 jul 15 \\
\hline 10 & Alm & Gunnar & Ystad & 25 abr 07 \\
\hline 11 & Alm-Andersson & Erik Gustav & Porjus & 8 nov 31 \\
\hline 12 & Almkvist & Ake & Estocolmo & \\
\hline 13 & Andersson & Adolf & Gotemburgo & \\
\hline 14 & Andersson & Albert Georg & Ramsö & 26 may 11 \\
\hline 15 & Andersson & Axel Torsten & Gotemburgo & 6 nov 06 \\
\hline 16 & Andersson & Bror Axel & Estocolmo & 4 may 06 \\
\hline 17 & Andersson & Conny & Estocolmo & 27 ene 14 \\
\hline 18 & Andersson & Edgar Paul & Svart sjö & 14 ene 95 \\
\hline 19 & Andersson & Erik Fridolf & Västerås & 14 mar 16 \\
\hline 20 & Andersson & Fred & & \\
\hline 21 & Andersson & \begin{tabular}{|l|} 
Frithiof \\
\end{tabular} & Trondheim & 4 ene 93 \\
\hline 22 & Andersson & Gunnar Harry Fridolf & & 7 sep 05 \\
\hline 23 & Andersson & Gösta & Estocolmo & 11 jun 02 \\
\hline 24 & Andersson & John Helge & Karlskrona & 10 abr 10 \\
\hline 25 & Andersson & Karl Axel & Valldemarsvik & 13 dic 05 \\
\hline 26 & Andersson & Karl Eric & Estocolmo & 8 feb 01 \\
\hline 27 & Andersson & Karl Henry & Sala & 16 abr 01 \\
\hline 28 & Andersson & Kurt Arnold & Estocolmo & 29 mar 18 \\
\hline 29 & Andersson & Olle & Estocolmo & 29 mar 13 \\
\hline 30 & Andersson & Oskar V & Enånger & 1 ago 06 \\
\hline 31 & Andersson & Sven Johan & Södra Åby & \\
\hline 32 & Andersson & Tage Ernst & Estocolmo & 4 mar 02 \\
\hline
\end{tabular}

\footnotetext{
* Las listas aquí presentadas han sido elaboradas por nosotros a partir de datos de las listas publicadas por Lundvik y Lundberg, de las del Archivo de la Policia de Seguridad Sueca (RA, SÄPO), y de los fondos de los distintos archivos utilizados en este estudio (AMAEC R; RA, UD, Beskickningsarkivet: Madrid, ARAB, CDMH yAGMAV), así como las recientes aportaciones de la historiografía. Sin embargo, no pueden considerarse totalmente definitivas, debido a la fragmentación de las fuentes, a la proliferación de nombres comunes, a la utilización de nombres falsos por parte de algunos brigadistas para viajar a España (a veces con cesión de pasaportes a otras personas, especialmente a voluntarios finlandeses), etc.
} 


\begin{tabular}{|c|c|c|c|c|}
\hline 33 & Andersson & Tage Gunnar & Dalby & 18 jun 15 \\
\hline 34 & Andersson & Wilhelm & & \\
\hline 35 & Andersson & Yngve & & \\
\hline 36 & Andersson Blixtsköld & Hugo Emanuel & & 19 oct 14 \\
\hline 37 & Andreasson & John Algot Isidor & Gotemburgo & 6 sep 07 \\
\hline 38 & Antonsson & Arvid & Estocolmo & \\
\hline 39 & Augustsson & Charles Viktor & Gotemburgo & 18 feb 16 \\
\hline 40 & Axelsson & Kurt Göte & Kvickjokk & 11 jul 17 \\
\hline 41 & Backlund & Fritz & Kramfors & 29 nov 94 \\
\hline 42 & Baudin & Karl Åke & & 17 mar 03 \\
\hline 43 & Baum & Eric Karl Abert & Landskrona & 23 dic 14 \\
\hline 44 & Berg & Erik & Karlskrona & 5 jul 10 \\
\hline 45 & Berg & Oskar Alrik & Skelleftehamn & 1 ene 15 \\
\hline 46 & Berggren & Lars Birger & Gävle & \\
\hline 47 & Berggren & Stig Gustav Otto & Estocolmo & 24 jul 11 \\
\hline 48 & Berglund & Per Johan & & 5 may 16 \\
\hline 49 & Bergman & Otto Henning & Hudiksvall & 7 dic 04 \\
\hline 50 & Bergström & Bernhard & Gotemburgo & 3 dic 11 \\
\hline 51 & Bergström & Ivan & Lundby, Gbg & 28 may 09 \\
\hline 52 & Bjurén & Ernst Edvard Tage & Östersund & \\
\hline 53 & Björck & Erik Emanuel & Svedala & 3 jun 14 \\
\hline 54 & Björck & Helge & Malmö & \\
\hline 55 & Björnstad & Hjalmar & Svarteborg & 4 may 03 \\
\hline 56 & Blom & Herbert & Estocolmo & 10 jul 18 \\
\hline 57 & Blom & Herbert Johan & Gotemburgo & 16 jun 17 \\
\hline 58 & Blom & Sigvard & Landskrona & \\
\hline 59 & Blomberg & Alvar & Hamra & \\
\hline 60 & Blomberg & Olov Efraim & Gotemburgo & $7 \operatorname{sep} 98$ \\
\hline 61 & Blomgren & Gustav & Enskede & 23 jul 12 \\
\hline 62 & Bohlin & Gustav Adolf F & Gotemburgo & \\
\hline 63 & Bohman & Erik Tore & & \\
\hline 64 & Bokvist & Knut Hilding & Arvidsjaur & 20 feb 10 \\
\hline 65 & Boström & Oskar Henning & Karlskoga & 19 abr 10 \\
\hline 66 & Brobäck & H David A & Estocolmo & 24 ene 07 \\
\hline 67 & Brosell & Alf Gösta Martin & Estocolmo & 3 may 08 \\
\hline 68 & Brännare & Helge Paulus & Karungi & 28 mar 12 \\
\hline 69 & Brännström & Sven Fredrik & Ursviken & 19 abr 11 \\
\hline 70 & Bystedt & Karl Eugen & Kramfors & 28 ene 98 \\
\hline 71 & Bystedt & Karl Gunnar & Östby,Gudmundrå & \\
\hline 72 & Byström & Carl·Erik & Estocolmo & 28 nov 08 \\
\hline 73 & Byström & Edvin & Dala Asbo & 24 may 08 \\
\hline 74 & Börjesson & Erik & Halmstad & 29 may 16 \\
\hline 75 & Carlsson & Lars Göte & Gotemburgo & 27 ene 14 \\
\hline 76 & Cederlund & Gunnar Emanuel & Hällefors & 12 may 18 \\
\hline 77 & Classen & Gustav & & \\
\hline 78 & Dahlberg & Martin Emanuel & Estocolmo & 4 ene 04 \\
\hline 79 & Danielsson & Ernst Sigvard & Hudiksvall & $15 \operatorname{dic} 16$ \\
\hline 80 & Danielsson & Gunnar Rolf & Västervik & 8 ene 17 \\
\hline
\end{tabular}




\begin{tabular}{|c|c|c|c|c|}
\hline 81 & Danielsson & Henry Emil & Halmstad & 14 dic 02 \\
\hline 82 & Danielsson & Knut & Landskrona & 29 abr 00 \\
\hline 83 & Danielsson & Tage Jonas & Bollnäs & 18 abr 10 \\
\hline 84 & Davidsson & David Vilhelm & Estocolmo & \\
\hline 85 & Dyberg & Sven Bernhard & Kramfors & \\
\hline 86 & Ek & Karl Artur Emanuel & Estocolmo & 24 ene 13 \\
\hline 87 & Ekblad & Erik Roland & Borås & 27 jun 19 \\
\hline 88 & Eldh & Lennart & Gotemburgo & 31 oct 18 \\
\hline 89 & Elfstrand & Verner & & \\
\hline 90 & Engberg & Viktor & Harmånger & 22 mar 14 \\
\hline 91 & Englund & Oskar Emil Rudolf & $07-02-24$ & \\
\hline 92 & Engvall & Albin Alvar & Bollestabruk & 1 abr 14 \\
\hline 93 & Ericsson & Allan & Malmö & 21 jun 12 \\
\hline 94 & Ericsson & Kurt Emil & Norrköping & 22 may 13 \\
\hline 95 & Eriksson & Ernst & & \\
\hline 96 & Eriksson & Evert & Ekerö & 5 mar 04 \\
\hline 97 & Eriksson & Gustav Hilmer & Estocolmo & $24 \operatorname{dic} 15$ \\
\hline 98 & Eriksson & Harry Axel & Gyttorp & 1 nov 09 \\
\hline 99 & Eriksson & Harry Oskar & Gävle & 31 oct 12 \\
\hline 100 & Eriksson & John Gustaf Eskil & Årsunda & 2 ene 09 \\
\hline 101 & Eriksson & Karl Börje & Sundsvall & 13 mar 15 \\
\hline 102 & Eriksson & Karl Gunnar & Estocolmo & 17 feb 13 \\
\hline 103 & Eriksson & Per Mauritz & Kristinehamn & 21 sep 07 \\
\hline 104 & Eriksson & Sven Martin & Linköping & 30 jun 11 \\
\hline 105 & Eriksson & Ture Ragnar & Hagfors & 28 abr 15 \\
\hline 106 & Esplund & Charles Edgar & Estocolmo & 31 oct 04 \\
\hline 107 & Fagerström & Knut & Estocolmo & 7 may 10 \\
\hline 108 & Fastberg & Hjalmar Reinhold & Krokås & \\
\hline 109 & Flemström & Knut Uno & Kramfors & 20 ene 05 \\
\hline 110 & Flintberg & John Emil & Malmö & 1 mar 14 \\
\hline 111 & Formgren & Klas & & \\
\hline 112 & Forsberg & Hjalmar & Gotemburgo & 31 ene 04 \\
\hline 113 & Forslund & Eskil & Kramfors & \\
\hline 114 & Forsman & Gusten F & Sollefteå & 28 abr 06 \\
\hline 115 & Fransson & John Alrik & Estocolmo & \\
\hline 116 & Franzén & Bruno Vincent & Estocolmo & 15 sep 07 \\
\hline 117 & \begin{tabular}{|l|} 
Fredriksson \\
\end{tabular} & Hilding & Gotemburgo & 22 sep 06 \\
\hline 118 & Fridén & Gustav A & Rockesholm & 15 nov 12 \\
\hline 119 & Frånberg & Elis Matias & Sueco-americano & 8 may 04 \\
\hline 120 & Gerhardsson & Helge & Helsingborg & 11 mar 08 \\
\hline 121 & Goldbach & Willi Albert Bruno & Landskrona & 2 ene 10 \\
\hline 122 & Grahn & Göthe Eugen & Estocolmo & 13 dic 06 \\
\hline 123 & Granath & Gösta Henrik & Halmstad & 16 sep 07 \\
\hline 124 & Granberg & Stig Jean & Östersund & 13 nov 15 \\
\hline 125 & Granlund & Erik Holger & & 14 dic 22 \\
\hline 126 & Granlund & Karl Henry & Franshammar & 18 jul 18 \\
\hline 127 & Gröndahl & Ragnar & Oxie (Malmö) & \\
\hline 128 & Gunnarsson & Gustav & Gotemburgo & 8 ene 11 \\
\hline
\end{tabular}




\begin{tabular}{|c|c|c|c|c|}
\hline 129 & Gustafsson & Axel & Nora (amer) & $24 \operatorname{dic} 02$ \\
\hline 130 & Gustafsson & Erik Helmer & Hudiksvall & 11 jun 07 \\
\hline 131 & Gustafsson & Sven Fredrik & Gotemburgo & 9 oct 13 \\
\hline 132 & Göransson & Ernst Wilhelm & Hökbåda Lit & 18 nov 04 \\
\hline 133 & Hagberg & Eilert & & \\
\hline 134 & Haglund & Ivar & Gävle & 19 feb 07 \\
\hline 135 & Halldin & Erik Sterner & Örebro & 13 oct 09 \\
\hline 136 & Hallén (Hallin) & Gustav & Madesjö & 10 jun 15 \\
\hline 137 & Hallman & Gunnar Sigfrid & Hybo Hudiksvall & 7 ene 11 \\
\hline 138 & Hammarin & Karl Erik & Nybro & 21 dic 07 \\
\hline 139 & Hammarström & John Sigrid & Backaryd & 9 feb 10 \\
\hline 140 & Hansen & Axel Oskar & Gotemburgo & 25 may 07 \\
\hline 141 & Hansson & Bengt Harald & & 12 abr 01 \\
\hline 142 & Hansson & Helmer Emanuel & Lit & 14 may 08 \\
\hline 143 & Hartford & Östen Hans & & 11 abr 21 \\
\hline 144 & Hedin & Helge Guy & Vetlanda & 30 dic 06 \\
\hline 145 & Heikki & Veinö Isak & Korpilombolo & 6 oct 14 \\
\hline 146 & Helgesson & Nils & Karlskoga & $2 \operatorname{mar} 09$ \\
\hline 147 & Hellberg & Tage Randolf & Estocolmo & 30 jul 05 \\
\hline 148 & Hendersson & Georg & Oskarhamn & \\
\hline 149 & Henriksson & Einar & & 11 oct 24 \\
\hline 150 & Henriksson & Uno Allan Ture & Jokkmokk & 7 feb 09 \\
\hline 151 & Hensen & Marius & & \\
\hline 152 & Hiitala & Gunnar & Övertorneå & \\
\hline 153 & Hilding & Knut Elof & & 18 ene 16 \\
\hline 154 & Hjärpe & Carl Gösta & Rättså, Ramsberg & \\
\hline 155 & Hollertz & Einar Herman Emanuel & Örebro & 2 may 06 \\
\hline 156 & Hollstedt & Sven Oskar & Estocolmo & 2 mar 04 \\
\hline 157 & Holmgren & Edmund Napoleon & Byske & \\
\hline 158 & Holmlund & Frans Hjalmar & Malmberget & 2 jun 17 \\
\hline 159 & Håkansson & Axel Gustav & Estocolmo & 30 mar 18 \\
\hline 160 & Höglin & Hilding & Estocolmo & 22 sep 15 \\
\hline 161 & Hörnfeldt & Per Olof & Estocolmo & 19 jul 96 \\
\hline 162 & Hörnqvist & Ragnar Johan & Storuman & 1 jun 06 \\
\hline 163 & Israelsson & Gösta & & \\
\hline 164 & Jakobsson & Anton Ivar & & \\
\hline 165 & Jannesson & Osvald & Gotemburgo & 2 jun 07 \\
\hline 166 & Jansson & Bo & Estocolmo & 4 may 16 \\
\hline 167 & Jansson & Henry Andreas & Lidingö & 2 abr 13 \\
\hline 168 & Jansson & Ingvar Göran & Strömstadsbruk & 10 feb 19 \\
\hline 169 & Jansson & Johan Rune & Ludvika & 24 dic 16 \\
\hline 170 & Jansson & Karl Olov & Gotemburgo & \\
\hline 171 & Jansson & Petrus Emanuel & Karlstad & 12 ago 15 \\
\hline 172 & Johansson & Arne & Estocolmo & \\
\hline 173 & Johansson & Arvid & Gotemburgo & 15 sep 08 \\
\hline 174 & Johansson & Axel Wilhelm & Estocolmo & 25 may 13 \\
\hline 175 & Johansson & Bert Egil & & 13 sep 23 \\
\hline 176 & Johansson & Bertil Osborne & Gotemburgo & 30 nov 15 \\
\hline
\end{tabular}




\begin{tabular}{|c|c|c|c|c|}
\hline 177 & Johansson & Bo & & \\
\hline 178 & Johansson & Erik & & $4 \operatorname{sep} 01$ \\
\hline 179 & Johansson & Erik Jarl & Nybro & 20 dic 02 \\
\hline 180 & Johansson & Gunnar & Överkalix & 3 abr 06 \\
\hline 181 & Johansson & Ivar Napolion & Grebbestad & 31 ene 08 \\
\hline 182 & Johansson & Jean Thor & Nynäshamn & 17 dic 94 \\
\hline 183 & Johansson & John Helge & Gotemburgo & \\
\hline 184 & Johansson & Sigvard Sune & Estocolmo & 2 jun 94 \\
\hline 185 & Johnsson & Erik H B & Norrköping & $9 \operatorname{dic} 13$ \\
\hline 186 & Jonsson & Adolf Ferdinand & Jokkmokk & 7 oct 14 \\
\hline 187 & Jonsson & Karl A E & Mölndal & 18 ene 14 \\
\hline 188 & Jonsson & Tore Noge Napoleon & Estocolmo & 27 nov 13 \\
\hline 189 & Jonsson & Ake Gunnar & Estocolmo & 24 ene 19 \\
\hline 190 & Jönsson & Bengt Alban & Gotemburgo & 18 abr 19 \\
\hline 191 & Jönsson & Carl Olof & Estocolmo & \\
\hline 192 & Jönsson & Harald Sigvard & Timsfors & 27 abr 08 \\
\hline 193 & Jönsson & Ragnar & & \\
\hline 194 & Jönsson & Sigvard & Landskrona & 6 sep 06 \\
\hline 195 & Jönsson & Sixten Albin & Estocolmo & 19 abr 12 \\
\hline 196 & Karlsson & Artur & Gusum & \\
\hline 197 & Karlsson & August E Georg & Estocolmo & 23 sep 06 \\
\hline 198 & Karlsson & Erik Arthur & Skövde & 14 abr 10 \\
\hline 199 & Karlsson & Ernst Ingvar & Karlskoga & 8 feb 15 \\
\hline 200 & Karlsson & Fritz Ivar & Karlshamn & 2 ago 11 \\
\hline 201 & Karlsson & Gustav Harald (Gösta) & Hällefors & 19 abr 15 \\
\hline 202 & Karlsson & Georg Harry & Skövde & 1 abr 05 \\
\hline 203 & Karlsson & Harry Sigfrid & Hasslö & 15 feb 09 \\
\hline 204 & Karlsson & Hilding Ernst & Linköping & 14 may 10 \\
\hline 205 & Karlsson & Ivar Helmer Emanuel & Kalmar & 30 dic 12 \\
\hline 206 & Karlsson & Johan Artur & & 27 ene 95 \\
\hline 207 & Karlsson & Karl & Karlstad & 2 abr 09 \\
\hline 208 & Karlsson & Ture Einar & Karlskrona & 30 jun 08 \\
\hline 209 & Karlström & Karl Rune Manfred & Karlstad & 14 oct 21 \\
\hline 210 & Kieri & Johan Petter August & Kuivikankas & 26 oct 10 \\
\hline 211 & Kihlberg & Fred Erik & Karlskrona & 12 may 14 \\
\hline 212 & Kjellberg & Hilding & Lamhult & 17 sep 10 \\
\hline 213 & Kjällblad & Per Tage & Estocolmo, Orsa & 8 ago 14 \\
\hline 214 & Klarström & Kurt Allan & Karlstad & 22 oct 98 \\
\hline 215 & Krig & Richard & Vrestorp & \\
\hline 216 & Kurkio & Jöns Fredrik & Pajala & 17 sep 99 \\
\hline 217 & Käck & Gerhard & Örebro (amer) & 14 abr 95 \\
\hline 218 & Kääriä & Arthur & Kiruna & 25 abr 05 \\
\hline 219 & Larsson & Bernt & Estocolmo & 22 feb 09 \\
\hline 220 & Larsson & Bror Elis & Eskilstuna & 20 dic 09 \\
\hline 221 & Larsson & Ernst Alfred & Estocolmo & 3 mar 19 \\
\hline 222 & Larsson & Gunnar Arne & Gotemburgo & 7 mar 17 \\
\hline 223 & Larsson & Lars & Vessigebro & 3 oct 11 \\
\hline 224 & Larsson & Sven Gunnar & Estocolmo & 22 nov 14 \\
\hline
\end{tabular}




\begin{tabular}{|c|c|c|c|c|}
\hline 225 & Larsson & Ture Arvid & Borås (amer) & 17 sep 08 \\
\hline 226 & Larsson & Vilhelm Alexander & Gävle & 12 dic 07 \\
\hline 227 & Lehto (Larsson) & Yngve Sigurd & Pajala & 20 ene 12 \\
\hline 228 & Levander & Kurt Einar & Halmstad & 4 ene 15 \\
\hline 229 & Lidvall & Nils Petter & Gudmundrå & 21 ene 05 \\
\hline 230 & Liljegren & Folke Olof & Umeåstrand & 5 sep 09 \\
\hline 231 & Liljemark & Erik & Estocolmo & 11 mar 07 \\
\hline 232 & Liljengren & Folke & Sueco-americano & $1 \mathrm{feb} 08$ \\
\hline 233 & Liljeros & Axel & Gotemburgo & 29 mar 05 \\
\hline 234 & Lind & Arne Albert & Hudiskvall & 6 ene 13 \\
\hline 235 & Lind & Gösta Adolf & Estocolmo & 19 abr 15 \\
\hline 236 & Lindberg & Johan Hjalmar & & 1 abr 21 \\
\hline 237 & Lindblad & Erik & Västervik & 10 may 98 \\
\hline 238 & Lindblom & Arne Erik & & \\
\hline 239 & Lindgren & Emil Henning & Gotemburgo & 22 may 02 \\
\hline 240 & Ljungberg & Kurt Oskar & Estocolmo & 14 jun 07 \\
\hline 241 & Lott & Nils Einar & Gotemburgo & 5 ene 99 \\
\hline 242 & Ludvigsson & Tord Volmar & Gudmundrå & 9 ago 16 \\
\hline 243 & Lundberg & Sten Harry & & 7 abr 11 \\
\hline 244 & Lundgren & Karl Johan & Köping & 13 jun 13 \\
\hline 245 & Lundin & Karl Johan & Munkedal & 4 sep 08 \\
\hline 246 & Lundkvist & Karl T & Lindesberg & 10 sep 98 \\
\hline 247 & Lundmark & Knut Holger & Gotemburgo & 6 mar 08 \\
\hline 248 & Lyberg & Arne Gunnar & & 12 ene 16 \\
\hline 249 & Lyckholm & Nils Gerhard & & 15 abr 28 \\
\hline 250 & Läth & Klas Ragnar & Örebro & 21 oct 18 \\
\hline 251 & Lätt & Nils & Landskrona & 30 dic 07 \\
\hline 252 & Lönnbäck & Ake Bertil & Nyköping & 1 mar 14 \\
\hline 253 & Lövenius & Ludvig Ivan & Borås & \\
\hline 254 & Magnusson & Sven Erik & Boden & 16 abr 11 \\
\hline 255 & Malmberg & Folke & & 10 oct 30 \\
\hline 256 & Malmkvist & Hans Axel Tore & Malmö & 18 nov 14 \\
\hline 257 & Malmqvist & John A & Gräsö, Estocolmo & 16 sep 01 \\
\hline 258 & Malmsten & Stig Gösta & Örebro & 24 jul 15 \\
\hline 259 & Marjasin & Elis & Estocolmo & 10 dic 07 \\
\hline 260 & Mattsson & Karl & Sunne & 27 oct 06 \\
\hline 261 & Mattsson & Sten & Estocolmo & 30 may 09 \\
\hline 262 & Mauer & Erik & Landskrona & \\
\hline 263 & Mejer & Emil Helge & Malmö & 4 feb 11 \\
\hline 264 & Moberg & Knut Allan & Skövde & 4 may 14 \\
\hline 265 & Molin & Elof Jean & Estocolmo & 18 nov 11 \\
\hline 266 & Munther & Frans Johan & Estocolmo & 26 dic 09 \\
\hline 267 & Mård & Gustav & & 14 oct 02 \\
\hline 268 & Nilsson & Axel & Landskrona & 5 abr 03 \\
\hline 269 & Nilsson & Axel Gösta & Trelleborg & 26 jun 14 \\
\hline 270 & Nilsson & Bror Olof Georg & Jokkmokk & 20 abr 98 \\
\hline 271 & Nilsson & Egon & Trelleborg & 10 sep 15 \\
\hline 272 & Nilsson & Elof & Hunnebostrand & 8 sep 13 \\
\hline
\end{tabular}




\begin{tabular}{|c|c|c|c|c|}
\hline 273 & Nilsson & Erik Birger & Vasa & 21 oct 09 \\
\hline 274 & Nilsson & John & Borås & \\
\hline 275 & Nilsson & Karl Edvin & Malmö & 23 abr 98 \\
\hline 276 & Nilsson & Karl Erik & Karlstad & 27 jul 11 \\
\hline 277 & Nilsson & Nils Emil & Lund & 8 feb 10 \\
\hline 278 & Nilsson & Rudolf & Estocolmo & 3 sep 11 \\
\hline 279 & Nilsson & Tore & Malmö & \\
\hline 280 & Nordberg & Karl & Saleby, Gbg & 17 ago 06 \\
\hline 281 & Nordin & Erik & & \\
\hline 282 & Nordin (Dahlström) & Einar Holger & Timrå (Uppsala) & 24 abr 16 \\
\hline 283 & Nordström & Knut Hilding & Borås & 16 oct 18 \\
\hline 284 & Nordström & Stig Valter & Norrköping & 24 abr 14 \\
\hline 285 & Norén & Erik Torsten & Helsingborg & 28 sep 07 \\
\hline 286 & Norrblom & Carl & Estocolmo & \\
\hline 287 & Norrman & Harald & Estocolmo & 21 nov 06 \\
\hline 288 & Nyberg & S.B & Kramfors & \\
\hline 289 & Nyström & Karl Erik & Estocolmo & \\
\hline 290 & Nyström & Nils & Kristianstad & 22 sep 10 \\
\hline 291 & Nährström & Knut Olof & Estocolmo & 23 dic 04 \\
\hline 292 & Näslund & Gösta "Texas" & Sundsvall & \\
\hline 293 & Ohlin & Gunnar & & \\
\hline 294 & Olofsson & Ernst Vilhelm & Gotemburgo & \\
\hline 295 & Olofsson & Vilgot & Gotemburgo & 9 sep 15 \\
\hline 296 & Olovsson & Ossian William Louis & Estocolmo & 20 abr 07 \\
\hline 297 & Olsson & Arnold & Södra Ny (Säffle) & \\
\hline 298 & Olsson & Bror Martin & & 3 mar 14 \\
\hline 299 & Olsson & Erik Einar & Örebro & 6 dic 16 \\
\hline 300 & Olsson & Folke Emil & Malmö & 29 dic 04 \\
\hline 301 & Olsson & Karl Martin & Estocolmo & 10 nov 12 \\
\hline 302 & Olsson & Olof W & Dalby & 20 jul 06 \\
\hline 303 & Olsson & Åke & & \\
\hline 304 & Olsson (Rogeby) & Olle Sixten Isidor & Gotemburgo & 7 ago 10 \\
\hline 305 & Ottosson & Gustav & Kalmar & 9 abr 11 \\
\hline 306 & Persson & Sixten Robert & Matfors & 5 mar 09 \\
\hline 307 & Petersson & Enoch Hugo & Klintehamn (ame) & $29 \operatorname{dic} 97$ \\
\hline 308 & Pettersson & Axel Fredrik & Uppsala & 8 dic 18 \\
\hline 309 & Pettersson & Axel Fredrik & Östrand & 27 mar 08 \\
\hline 310 & Pettersson & Axel Herbert & Gotemburgo & 19 feb 98 \\
\hline 311 & Pettersson & Carl Otto & Karlskrona & 21 mar 00 \\
\hline 312 & Pettersson & Gustav Alfred & Klastorp & 9 abr 11 \\
\hline 313 & Pettersson & Gösta Arvid & Estocolmo & 20 ene 09 \\
\hline 314 & Pettersson & Valter Yngve Sigvard & Huskvarna & 17 ago 10 \\
\hline 315 & Pihlblad & Roland Einar & Estocolmo & 13 feb 15 \\
\hline 316 & Pikka & Ralf & & \\
\hline 317 & Quarfordt & Gustav Andreas & & 30 jun 12 \\
\hline 318 & Richter & Nils Åke & Estocolmo & 8 oct 05 \\
\hline 319 & Risto & Karl Einar & Luleå & 26 jun 11 \\
\hline 320 & Rogerstam & Georg Harry & & 25 oct 18 \\
\hline
\end{tabular}




\begin{tabular}{|c|c|c|c|c|}
\hline 321 & Rohlin & Axel Gotthard & Ahus & 5 may 00 \\
\hline 322 & Ryberg & Karl Henry & Gotemburgo & 26 sep 19 \\
\hline 323 & Ryhn & Harald Julius & & \\
\hline 324 & Rönnkvist & Runar & & \\
\hline 325 & Sachnowitz & Sune & Estocolmo & 23 feb 19 \\
\hline 326 & Sahlström & Elof Hugo Emanuel & Gotemburgo & \\
\hline 327 & Sand & Ragnar Fritiof Uno & Karlskoga & 13 ene 13 \\
\hline 328 & Sandberg & Karl Fritiof & Arvidsjaur & 14 jun 13 \\
\hline 329 & \begin{tabular}{|l|} 
Sandell \\
\end{tabular} & Nils & Gotemburgo & 16 mar 05 \\
\hline 330 & Sandkvist & Sigfrid A & Skellefteå & 15 feb 01 \\
\hline 331 & Seger & Tage Reinhold Melker & Gotemburgo & 1 jun 19 \\
\hline 332 & Segersson & Bengt & Jonsered & 6 sep 14 \\
\hline 333 & Sillén & Karl Gustav Edward & Estocolmo & 31 ene 14 \\
\hline 334 & Sjöberg & Erik & & \\
\hline 335 & Sjögren & Gustaf & & $6 \operatorname{sep} 06$ \\
\hline 336 & Sjögren & Karl Hans E & Karlskoga & 17 ene 18 \\
\hline 337 & Sjögren & Åke & Estocolmo & 20 sep 10 \\
\hline 338 & Skantze & Axel & & 2 ago 14 \\
\hline 339 & Sommelius & Bertil & Estocolmo & 3 jun 20 \\
\hline 340 & Spetz & Kurt Julius & Borås & 16 ene 19 \\
\hline 341 & Staaf & Karl Ivar & Helsingborg & 18 mar 15 \\
\hline 342 & Stenborg & Arne Gustav Lennart & Estocolmo & \\
\hline 343 & Stenman (Pettersson) & Bror Johan & Porjus & 6 sep 11 \\
\hline 344 & Strand & Rolf M & Estocolmo & 5 jun 09 \\
\hline 345 & Strandberg & Runar Albin & Porjus & 31 oct 18 \\
\hline 346 & Stridsberg & Hjalmar & Skelleftehamn & 13 dic 08 \\
\hline 347 & Strömberg & Nils H & Karlskoga & 10 feb 16 \\
\hline 348 & Strömbäck & Åke & Nyköping & \\
\hline 349 & Strömkvist & Johan Ragnar & Stensele & \\
\hline 350 & Ståhl & Harry Rudolf & & 4 nov 14 \\
\hline 351 & Ståhl & Karl Oskar & Norrköping & 13 mar 07 \\
\hline 352 & Sundkvist & Sigge & Vilhelmina & \\
\hline 353 & Svensson & Bernt Olov & Estocolmo & 8 oct 06 \\
\hline 354 & Svensson & Eric Johan & Malmö & 11 feb 00 \\
\hline 355 & Svensson & John & Borås & \\
\hline 356 & Svensson & John Gustav Adolf & Gotemburgo & 27 ene 06 \\
\hline 357 & Svensson & John Ragnar & Beateberg & 18 mar 07 \\
\hline 358 & Svensson & Karl Axel & Oskarshamn & 15 may 19 \\
\hline 359 & Svensson & Nils Gustav Andreas & & 9 jun 04 \\
\hline 360 & Svensson & Oskar & Landskrona & 4 ene 06 \\
\hline 361 & Svensson & Oskar Olof G F & Malmö & 15 ene 06 \\
\hline 362 & Svensson & Rudolf & Sueco-americano & 9 ene 06 \\
\hline 363 & Svensson & Sture & Gotemburgo & 23 oct 14 \\
\hline 364 & Svensson & Sven Gunnar & Ås & 22 oct 15 \\
\hline 365 & Svärd & Kurt Ingvar & Skenevad & 29 ene 11 \\
\hline 366 & Sällborg & Bernhard V & Estocolmo & 6 sep 13 \\
\hline 367 & Söderberg & Elof Valdemar & Örgryte & 19 sep 06 \\
\hline 368 & Söderström & Axel Bernhard & Kalmar & 6 ene 13 \\
\hline
\end{tabular}




\begin{tabular}{|c|c|c|c|c|}
\hline 369 & Sörenssen & Kurt & Holmsund & \\
\hline 370 & Tenggren & TageErik & Växjö & 19 sep 18 \\
\hline 371 & Thingvall & Axel & Boden & 30 dic 11 \\
\hline 372 & Thorell & Georg Robert & Gotemburgo & 24 may 12 \\
\hline 373 & Thörnell & Stig Lennart & Estocolmo & 13 sep 14 \\
\hline 374 & Tjärner (o Tjäder) & Julius & & \\
\hline 375 & Tjörndahl & Albert & Estocolmo & 9 jun 13 \\
\hline 376 & Tornberg & Ulrik Herman & & 1 ene 05 \\
\hline 377 & Udden & Sten Fabian & Linköping (amer) & 9 ene \\
\hline 378 & Uldén & Fredrik & & \\
\hline 379 & Utanskog & Gillis Gustav Reinhold & Gotemburgo & 19 mar 17 \\
\hline 380 & Wadström & Evert Erik & Gotemburgo & 9 ago 18 \\
\hline 381 & Wahlström & Klas Elis Ossian & & 7 may \\
\hline 382 & Valentin & Nils & & \\
\hline 383 & Valin & Fritz & Silverdalen & 25 abr 12 \\
\hline 384 & Vallin & Sven Erik & Karlstad & 19 oct 16 \\
\hline 385 & Wallström & Gottfrid & Estocolmo & 8 may 93 \\
\hline 386 & Vennerholm & $\mathrm{O} \mathrm{G} \mathrm{C}$ & Växjö & 15 may 00 \\
\hline 387 & Vernström & Sven Verner & Slite, Gotemburgo & 26 nov 08 \\
\hline 388 & Wessel & Hilding & & 1 dic 22 \\
\hline 389 & Westin & Harry Teodor & Arvidsjaur & 9 nov 05 \\
\hline 390 & Vestlund & Gustav Adolf & Estocolmo & 27 may 19 \\
\hline 391 & Westlund & Valdemar Karl & Estocolmo & 7 nov 13 \\
\hline 392 & Wettergren & Axel (Karl) & Mariestad & 9 feb 00 \\
\hline 393 & Wiberg & Nils Gustav & Växjö & 28 jul 18 \\
\hline 394 & Wiberg & Sven Bernhard & Kramfors & 15 jul 15 \\
\hline 395 & Wickman & Wilhelm Ferdinand & Västerås & 29 ago 05 \\
\hline 396 & Vig & Sven August & Boden & 11 abr 12 \\
\hline 397 & Wohlin & Herman Olov & Gävle & 11 jul 97 \\
\hline 398 & Wohlin & Sven Erik & Karlstad & 19 oct 16 \\
\hline 399 & Åberg & Hugo & Estocolmo & 3 feb 1 \\
\hline 400 & Öhr & Leonard & Estocolmo & \\
\hline
\end{tabular}

\section{Voluntarios muertos o desaparecidos en combate:}

\section{Nro Apellido}

\begin{tabular}{|c|c|}
\hline 1 & Abrahamsson \\
\hline 2 & Abrahamsson \\
\hline 3 & Alexandersson \\
\hline 4 & Andersson \\
\hline 5 & Andersson \\
\hline 6 & Andersson \\
\hline 7 & Andersson \\
\hline 8 & Andersson \\
\hline 9 & Andersson \\
\hline 10 & Aronsson \\
\hline
\end{tabular}

Nombre

Erik Alrik Holger

Karl Elof

Axel Bernhard

Birger

Fritz Alvar

Georg Lars Julius F

John

Karl Gösta

Kurt Erik Wilhelm

Rolf
Lugar nacimiento

Fecha

\begin{tabular}{|l|l|}
\hline Sollefteå & 20 may 15 \\
\hline Ursviken & 31 oct 13 \\
\hline Atvidaberg & 6 jul 08 \\
\hline Eskilstuna & 17 feb 03 \\
\hline Vitå & 16 sep 08 \\
\hline Oskarshamn & 23 abr 07 \\
\hline Gotemburgo & 18 dic 06 \\
\hline Borås & 18 oct 07 \\
\hline Gotemburgo & 15 feb 05 \\
\hline Gotemburgo & 13 sep 06 \\
\hline
\end{tabular}




\begin{tabular}{|c|c|c|c|c|}
\hline 11 & Beckman & Tage & Karlskrona & 10 abr 99 \\
\hline 12 & Berg & Rune & Örebro & 17 sep 10 \\
\hline 13 & Bergkvist & Algot Verner Eugen & Gotemburgo & 15 may 03 \\
\hline 14 & Bielke & Erik & Kungshamn & 15 abr 99 \\
\hline 15 & Bjärlingsson & Erik & Gotemburgo & 27 ago 04 \\
\hline 16 & Björck & Knut Alvar & Gotemburgo & 12 ago 04 \\
\hline 17 & Björkman & Nils Rudolf Agaton & Estocolmo & $12 \operatorname{mar} 90$ \\
\hline 18 & Blomkvist & Nils & örebro & 1 ago 15 \\
\hline 19 & Borg & Erik Henry & Norrköping & 7 oct 08 \\
\hline 20 & Brommesson & Henning & Eslöv & 16 oct 03 \\
\hline 21 & Carlsson & Oskar Herbert & Rogberga & 25 maj 07 \\
\hline 22 & Dahlström & Karl & Eslöv & 13 jul 08 \\
\hline 23 & Dahlström & Karl Birger & Värmland & 9 jul 06 \\
\hline 24 & Dahlvid & Arne & Helsingborg & \\
\hline 25 & Davidsson & Alfred (Axel) & Malmö & 1914 \\
\hline 26 & Edin & Gustaf Adolf & Bastuträsk & 1914 \\
\hline 27 & Edström & Lars August & Örnsköldsvik & 1915 \\
\hline 28 & Ekholm & Emil Fredrik & Estocolmo & 3 ene 12 \\
\hline 29 & Ekström & David Holger & & 29 jun 18 \\
\hline 30 & Ekström & Karl Åke & Gotemburgo & 29 jun 18 \\
\hline 31 & Eliasson & Elis Olov & Vilhelmina & 1915 \\
\hline 32 & Engström & Karl Edvard & Sundsvall & 5 jul 12 \\
\hline 33 & Eriksson & Axel Rune Sebastian & Sundsvall & 19 mar 12 \\
\hline 34 & Eriksson & Folke Valdemar & Karlskrona & 13 jul 03 \\
\hline 35 & Ernstedt & Karl Erik Georg & Enskede & 26 oct 12 \\
\hline 36 & Fernström & Nils Joel & Estocolmo & 1 oct 15 \\
\hline 37 & Flodin & Knut Ludvik Sanfrid & Borås & 14 apr 05 \\
\hline 38 & Frykberg & Georg Sigfrid & Sundbyberg & 7 nov 10 \\
\hline 39 & Granhult & Gustav & Karlskrona & 15 abr 01 \\
\hline 40 & Grankvist & Kurt Axel & Västerås & 14 abr 14 \\
\hline 41 & Gren & Anton Hilding & Hidingebro & 12 feb 15 \\
\hline 42 & Grönberg & Georg & Estocolmo & 27 maj 15 \\
\hline 43 & Gustavsson & Fritz Emil & Nora & 16 dic 10 \\
\hline 44 & Gustavsson & Lennart Herman & Estocolmo & 22 oct 14 \\
\hline 45 & Gustavsson & Nils Gustav Evert & Estocolmo & 28 jun 15 \\
\hline 46 & Gustavsson & \begin{tabular}{|l|} 
Sten Sigurd \\
\end{tabular} & Estocolmo & 12 sep 14 \\
\hline 47 & Hector & Tore Percival & Estocolmo & 3 ene 13 \\
\hline 48 & Henriksson & Alfred & Borås & 22 jun 09 \\
\hline 49 & Henriksson & Erik & & 19 maj 12 \\
\hline 50 & Hermansson & Gunnar Allan & Gotemburgo & 11 sep 03 \\
\hline 51 & Holmi & Torsten & Sundbyberg & 1 sep 03 \\
\hline 52 & Holmström & Axel Lennart & Estocolmo & 15 abr 16 \\
\hline 53 & Jakobsson & Einar Gustav & Grums & 31 oct 14 \\
\hline 54 & Jansson & Einar Halvard & Norrköping & 21 jun 12 \\
\hline 55 & Jansson & Erik Helmer (Elis) & Estocolmo, Falun & 31 oct 05 \\
\hline 56 & Jansson & John Adolf & & 24 abr 95 \\
\hline 57 & Johansson & Bertil & Karlskrona & 30 ago 13 \\
\hline 58 & Johansson & Bertil Julius & Gotemburgo & 25 dic 05 \\
\hline
\end{tabular}




\begin{tabular}{|c|c|c|c|c|}
\hline 59 & Johansson & Erik W & Mörrum & 12 sep 00 \\
\hline 60 & Johansson & Frans Hjalmar & Borås & 6 mar 14 \\
\hline 61 & Johansson & Gunnar & & \\
\hline 62 & Johansson & Hilding & Karlskrona & 21 ene 01 \\
\hline 63 & Johansson & Karl Edvard & Finspång & 07 jun 10 \\
\hline 64 & Johansson & Nils Evert & Örebro & 24 dic 16 \\
\hline 65 & Johansson & Oskar Erland & Ljusdal & 21 ago 11 \\
\hline 66 & Johansson & Sven Östen Eugen & Norrköping & 29 oct 07 \\
\hline 67 & Jönsson & Georg & & \\
\hline 68 & Jönsson (Johnsson) & Erik Vilhelm & & \\
\hline 69 & Karlsson & August Enar Georg & Karlskrona & \\
\hline 70 & Karlsson & Evert Johan & Skövde & 23 oct 14 \\
\hline 71 & Karlsson & Henry Einar Sigurd & Gotemburgo & 21 mar 18 \\
\hline 72 & Karlsson & Karl Evald & Gotemburgo & 3 nov 04 \\
\hline 73 & Karlsson & Karl Gunnar & Estocolmo & 8 ago 15 \\
\hline 74 & Karlsson & Kurt & Ringarum & 18 jun 15 \\
\hline 75 & Karlsson ("Glory") & Oskar Harry Vilhelm & & \\
\hline 76 & Karlsson & Oskar Herbert & & \\
\hline 77 & Kautto & Henning & Arvidsjaur & 12 okt 18 \\
\hline 78 & Kempe & Erik August & Graningebruk & 7 jun 99 \\
\hline 79 & Larsson & Herbert Vendel & Borås & 24 nov 04 \\
\hline 80 & Larsson & Karl Henry & Oskarshamn & 08 oct 10 \\
\hline 81 & Larsson & \begin{tabular}{|l|} 
Mauritz \\
\end{tabular} & Lysekil & 31 may 06 \\
\hline 82 & Larsson & Nils & Estocolmo & 15 abr 02 \\
\hline 83 & Larsson & Olof & Västerås & \\
\hline 84 & Larsson & Vilhelm & Estocolmo & \\
\hline 85 & Liljegren & Tore Alexander & Estocolmo & 11 ago 17 \\
\hline 86 & Lindberg & Per Gustav & & 28 feb 00 \\
\hline 87 & Lindgren & Ernst & & \\
\hline 88 & Ljörner & Bertil & Estocolmo & 17 sep 12 \\
\hline 89 & Lundberg & Johan Sigurd & Holmsund & 6 may 15 \\
\hline 90 & Lundin & Sven Edvard & Sundbyberg & 17 mar 13 \\
\hline 91 & Lundkvist & Vincent & Estocolmo & 1 mar 13 \\
\hline 92 & Lundström & Seth Robert & Arje & 9 oct 03 \\
\hline 93 & Lööf & Nils & Sundbyberg & 30 oct 99 \\
\hline 94 & Mattson & Ernst Albert Emanuel & Gotemburgo & 13 ago 05 \\
\hline 95 & Mattsson & Isak & & \\
\hline 96 & Meurling & Olle & Uppsala & 1909 \\
\hline 97 & Mohlin & Sven Erik & Ringstorp Motala & 23 ene 14 \\
\hline 98 & Morin & Erik Viktor & & 22 oct 02 \\
\hline 99 & Mossfeldt & Åke & Estocolmo & \\
\hline 100 & Nilsson & Eugen & & 20 feb 04 \\
\hline 101 & Nilsson & Folke Evert & Gotemburgo & 11 nov 19 \\
\hline 102 & Nilsson & Gustav & Malmö & 16 ago 00 \\
\hline 103 & Nilsson & Hilding & Lomma & 12 abr 08 \\
\hline 104 & Nilsson & Karl Ingemar & Piteå & 25 ene 05 \\
\hline 105 & Nilsson & Knut & Malmö & 13 ene 13 \\
\hline 106 & Norén & Karl Ingvar & Arvidsjaur & 19 mar 09 \\
\hline
\end{tabular}




\begin{tabular}{|c|c|c|c|c|}
\hline 107 & Nyholm & Sune Hilding & Alnö & 8 ago 15 \\
\hline 108 & Olofsson & Gottfrid Leonard & Örebro & 18 dic 01 \\
\hline 109 & Olofsson & Hans Ruben Ove & Umeå & 29 dic 14 \\
\hline 110 & Olsson & Harry Sigvard & Estocolmo & 17 ene 15 \\
\hline 111 & Olsson & Nils Evert & Skoghall (Örebro) & 6 feb 15 \\
\hline 112 & Olsson & Sven Albanus & & 1 abr 12 \\
\hline 113 & Olsson Thor & Henry Teodor Christian & Gotemburgo & 29 sep 07 \\
\hline 114 & Paavo & Oskar & Tärendö & \\
\hline 115 & Paulsson & Bror Nils Bernhard & & 3 jul 15 \\
\hline 116 & Persson & Åke Bertil & Uddevalla & 23 oct 18 \\
\hline 117 & Petterson & Henry Valdemar & Gotemburgo & 1 sep 16 \\
\hline 118 & Pettersson & Gunnar & Gotemburgo & 8 feb 12 \\
\hline 119 & Pettersson & Gunnar Evert & Gotemburgo & 14 abr 17 \\
\hline 120 & Pettersson & Tore & Eskilstuna & \\
\hline 121 & Reuterswärd & Krister & Estocolmo & 26 oct 15 \\
\hline 122 & Ringkvist & Göte Emanuel & Gotemburgo & 29 sep 13 \\
\hline 123 & Rooth (Johansson) & Harry & Lidköping & 1 ago 08 \\
\hline 124 & Samuelsson & Nils & Hovmantorp & 24 abr 11 \\
\hline 125 & Samuelsson & Tage Albin Hjalmar & Kalmar & 1892 \\
\hline 126 & Sandahl & Gunnar & Norra Råda & 25 ene 08 \\
\hline 127 & Sandelin & Gunnar Fredrik "Orre" & Gotemburgo & 4 dic 19 \\
\hline 128 & Sanell & Gunnar Alrik & Gislaved & 19 may 10 \\
\hline 129 & Seth & Klas & Motala & \\
\hline 130 & Sethson & David Oskar Gösta & Oskarshamn & 26 jun 07 \\
\hline 131 & Severin & Olov & Starrkärr & 20 ago 14 \\
\hline 132 & Sjöberg & Karl (Kurt) & Gotemburgo & \\
\hline 133 & Sjödin & Ragnar & Sundsvall & \\
\hline 134 & Skotte & Ragnar & Askersund & 1 jun 00 \\
\hline 135 & Sten & Nils Anders Tore & Gotemburgo & 10 nov 12 \\
\hline 136 & Stenholm & Gösta & Säffle & 29 jun 13 \\
\hline 137 & Söderberg & Kurt Gösta & Estocolmo & 21 nov 08 \\
\hline 138 & Söderkvist & Erik Olof Gustav & Jokkmokk & 2 dic 03 \\
\hline 139 & Söderström & Robert Gustav & Estocolmo & 2 jul 10 \\
\hline 140 & Thegelberg & HES & Estocolmo & 10 feb 08 \\
\hline 141 & Thunström & Per Harry & Estocolmo & 1 dic 03 \\
\hline 142 & Tidström & Alf Skoglar & Gävle & 20 nov 99 \\
\hline 143 & Timm & Robert & & \\
\hline 144 & Vadman & Bror Helmer & Trehörningsjö & 22 ago 90 \\
\hline 145 & Wedin & Edward & & \\
\hline 146 & Vennberg & Johan Evald & Kuivikangas & 2 oct 12 \\
\hline 147 & Wennergren & John Ivar Gustav & Gotemburgo & 23 nov 17 \\
\hline 148 & Westberg & Gustav Arne & Gotemburgo & 9 nov 18 \\
\hline 149 & Westerlund & Per Leonard & Gotemburgo & 9 ene 18 \\
\hline 150 & Westlund & Per Leonard & Estocolmo & 28 ago 11 \\
\hline 151 & Wiström & Karl Erik Olov & Hallstahammar & \\
\hline 152 & Zettermark & Thure Herman & & \\
\hline
\end{tabular}




\section{FUENTES}





\section{FUENTES NO IMPRESAS}

\section{Archivos Españoles}

Archivo de la Fundación Pablo Iglesias (FPI)

Archivo Histórico

Archivo de Luis Araquistáin

Archivo de Francisco Largo Caballero

Archivo de Luis Jiménez de Asúa

Archivo General de la Administración (AGA)

Libros-registro, Embajadas y Legaciones

Sección Asuntos Exteriores, Embajadas en Estocolmo, Helsinki y Oslo.

Archivo Histórico Nacional-Madrid (AHN)

Sección Estado, Suecia

Sección Diversos Títulos y Familias

Causa General de Madrid, Embajadas y Legaciones

Presidencia del Gobierno (Adquisiciones)

Archivo histórico del Partido Comunista de España (AHPCE)

Archivo del Ministerio de Asuntos Exteriores y Cooperación, Madrid (AMAEC)

Archivo Renovado (R), fondos relacionados con Suecia.

Sección de Personal (PG)

Centro Documental de la Memoria Histórica (CDMH)

Sección Político-Social

Colección Armero

Guías de Documentación de las Brigadas Internacionales

Bases de datos digitales sobre personas que aparecen en el Archivo Archivo General Militar de Ávila (AGMAV)

Legajos varios

\section{Archivos suecos}

Archivo Nacional de Suecia, Estocolmo (Riksarkivet, RA)

Archivo del Ministerio de Negocios Extranjeros (UD) 
Sistema de expedientes de 1920 (1920-års dossierssystem)

Archivos de las Embajadas: Madrid (Beskickningsarkivet: Madrid).

Sección de Personal (UD: $P$ )

Sección Diplomática Hispánica (Diplomatica Hispanica)

Registro de los Jefes de las representaciones diplomáticas suecas ante potencias extranjeras de 1720 a 1961 (UD:s kalender 1961, Register över Sveriges beskicningschefer hos främmande makter från 1720 till ca 1960)

Archivo del Comité de Asuntos Exteriores (Utrikesnämnden)

Archivo del Ministerio de Justicia (Justitiedepartamentet)

Archivo de la Policía de Seguridad (SÄPO)

Archivo de la Guerra (Krigsarkivet)

Archivo de C. Adlercreutz (Jefe del Servicio sueco de Inteligencia Militar)

Archivo de Ivan Holmquist

Archivo de la Asociación Sueca General de Exportadores (Svenska Allmänna Exportföreningen, SAE)

Archivo Regional de Härnösand, Colección de Magnhild Olsson (Landsarkivet $i$

Härnösand, Magnhild Olssons samling).

Archivo y Biblioteca del Movimiento Obrero, Estocolmo (Arbetarrörelsens arkiv och bibliotek, ARAB)

Colección "Guerra civil española" (Spanska Inbördeskriget)

Archivo de la Unión de Sindicatos (Landsorganisationen i Sverige,, LO)

Archivo del Partido Socialdemócrata (Socialdemokratiska Arbetarepartiet, SAP)

Archivo del Partido Comunista (Kommunistiska partiet, SKP)

Archivo del Partido Socialista (Socialistiska partiet, SP)

Archivo de la Organización Central de Trabajadores de Suecia (Sveriges arbetares centralorganisation, SAC)

Archivo del Comité Sueco de Ayuda a España (Svenska hjälpkommittén för Spanien, SHfS)

Colección Knut Olsson (Kunt Olssons samling)

Archivos de algunas de organizaciones locales del SHfS

Archivo del Fondo de Ayuda a los Combatientes suecos (Svenska frontkämparnas stödfond) 
Archivo de la Asociación de Voluntarios suecos en España (Svenska Spanienfrivilligas kamratförening)

Archivo personal de Georg Branting (Georg Brantings arkiv).

Archivos personales de Albert Jensen, Gösta Andersson, Stig Berggren, Gustav Blomberg, Per Eriksson, Gösta Hjärpe, Max Hodann, Ernst Ingvar Karlsson, Carl Mattson, Sixten Rogeby, Knut Olsson, Kajsa Rothman y Helmut Rüdiger y de Olof Palme.

Archivo municipal de Estocolmo (Estocolmos Stadsarkivet, SSA)

Registro de defunciones, población de Suecia, 1900 (Sveriges Dödbok version 5, Sveriges befolkning 1900).

Biblioteca Real, Estocolmo, (Kungliga Biblioteket, KB)

Archivo de Medios audiovisuales y digitales (SMDB)

Archivo particular de Ellen Hagen (Ellen Hagens samling)

Archivo particular de Gustaf Collinj y de Anna Lenah Elgström (Gustaf Collijns och Anna Lenah Elgström-Collijns samling).

\section{FUENTES IMPRESAS, DIARIOS Y MEMORIAS}

ADAMSSON, Einar; FALUDI, Ivan; FLYG, Nils; HOLMSTRÖM, Axel; LINDE, Ebbe; NERMAN, Ture \& ÖSTERBERG, Axel, Spanien, arbetarklassen, militarismen (España, la clase obrera, el militarismo, colección de relatos de los autores), 1938.

ALVING, Barbro \& Ruffa, Bang om Bang (Bang sobre Bang), Möklinta: Gidlunds förlag, 2009.

AZAÑA, Manuel, Diarios completos, Barcelona: Crítica, 2000.

—: Obras completas, vol. IV, Madrid: Centro de Estudios Políticos y Constitucionales, 2007.

BERNER, Rudolf, S. A. C.: el movimiento anarcosindicalista en Suecia: su obra en favor de la España antifascista, Estocolmo, 1938.

BRANTING, Georg, Kamp och humanitet: En rapport avgiven vid möte i Auditorium den 13 febr. 1939 av Georg Branting (Lucha y humanidad: Informe dado en la reunión del Auditorium el 13 de febrero de 1939 por Georg Branting), Estocolmo: Svenska hjälpkommittén för Spanien, 1939. 
BREDBERG, Ernst C., Rebellen Franco och den lagliga regeringen: den spanska tragedin $i$ röda och vita dokument (El rebelde Franco y el gobierno legítimo: la tragedia española en los documentos blancos y rojos), Estocolmo: Svea Rikets förlag, 1938.

BRÄNNSTRÖM, Sven, "En spanienfrivillig från Västerbotten berättar" (Narración de un voluntario en España de la región de Västerbotten) en Oknytt 1998 (19:1/2), Holmsund: Oknytt, 1998.

CARLSSON, Holger, Sverge, ett nytt Spanien? (Suecia, ¿una nueva España?), Estocolmo, 1938.

DIMITROV, Georgij, Tagebücher 1933-1943 (Diarios 1933.1943), Berlin: Aufbau-Verlag, 2000.

ERICSSON, Eric, Lola (El vapor Lola), Estocolmo: Wahlström \& Widstrand, 1939.

GACETA de Madrid, 28.V.1933, 1.IX.1935 y 1.VII.1936.

GOGMAN, Lars, "Tårarna kommo ofrivilligt i ögonen" (Las lágrimas asoman sin querer a los ojos), Sovjetunionen, (Unión Soviética), Guía de fondos del archivo del Movimiento obrero sueco (ARAB), Estocolmo.

GÓMEZ JORDANA, Francisco, Milicia y diplomacia. Los diarios del Conde de Jordana 1936-1944, Burgos: Dossoles, 2002.

HANSSON, Per Albin, "Den spanska tragedin" (la tragedia española), discurso publicado en Social-Demokraten, 22.VII.1936.

INTERNATIONAL COURT OF JUSTICE, "Case Concerning Military and Paramilitary Activities in and Against Nicaragua (Nicaragua V. United States of America): Oral arguments on jurisdiction and admissibility", United Nations Publications, 2000.

KOLLONTAI, Alexandra M., Aleksandra Kollontajs dagböcker 1930-1940, (los diarios de Alexandra Kollontai 1930-1940, traducción al sueco de Lars Olsson), Estocolmo: Bonnier, 2008.

LINDBAECK, Lise, Bataljon Thäelmann (El batallón Thaelmann), Estocolmo: Solidaritetens förlag 1938

-: De internationella brigaderna (Las brigadas internacionales), Estocolmo: Solidaritetens förlag, 1939.

LÖFLING, Petri, Petri Loefling Iter Hispanicum eller Resa til spanska länderna uti Europa och America, förrättad ifrån år 1751 til år 1756, med beskrifningar och rön öfver de märkvärdigaste växter (El Iter Hispanicum de Petri Löfling o el viaje a las tierras españolas de Europa y América, realizado entre el año 1751 y el año 1756, con descripciones y descubrimientos de las plantas más sorprendentes), publicado tras su muerte por Carl Linnaeus, Estocolmo, 1758. 
MEURLING, Per, Den blodiga arenan: en bok om det spanska kriget (La arena sangrienta: un libro sobre la guerra civil española), Estocolmo: Universal Press 1937.

OLSSON (ROGEBY), Sixten, Spanska frontminnen (Recuerdos del frente español), Estocolmo: Arbetarkultur, 1938.

—: De stupade för Spaniens demokrati (Murieron por la democracia española), Estocolmo: Arbetarkultur, 1977.

PALENCIA, Isabel de, Spanien mot friheten (España hacia la libertad, versión sueca del libro Smouldering freedom), Estocolmo: Medén, 1946.

PETRI, Lennart, Sverige i stora världen. Minnen och reflexioner från 40 års diplomattjänst (Suecia en la escena mundial: Recuerdos y reflexiones de 40 años de servicio diplomático), Estocolmo: Atlantis, 1996.

ROTHMAN, Kajsa, Spanska barn ritar om kriget, med inledning av Kajsa Rothman (Dibujos sobre la guerra de niños españoles, con introducción de Kajsa Rothman), Estocolmo, 1937.

SANDLER, Rickard, Svenska utrikesärenden: anföranden 1934-1935 (Negocios extranjeros suecos: discursos 1934-1935), Estocolmo: Tiden, 1936.

—: Utrikespolitiska kringblick: anföranden 1936 (Perspectivas de política exterior: discursos de 1936), Estocolmo, 1937.

—: Strömväxlingar och lärdomar: utrikespolitiska anföranden 1937-39 (Cambios de corriente y experiencias: discursos de política exterior 1937-1939), Estocolmo: Tiden, 1939.

SJÖSTEDT, Jonas, (coord.), Brev till en broder! Spanienkämpen Bengt Segersons personliga skildring från det spanska inbördeskriget (Carta a un hermano: la narración personal del voluntario en España Bengt Segerson acerca de la guerra civil española) Simrishamn: Svenska Spanienfrivilligas vänner, 2009.

-: Masthugget, Moskva, Madrid: berättelsen om Bengt och Greta (Masthugget, Moscú, Madrid: la historia de Bengt y Greta), Estocolmo: Carlsson, 2009.

SOCIEDAD DE NACIONES, Diario Oficial, 1939.

SOU 2000:20 (SOU, Statens Offentliga Utredningar, Investigaciones Públicas Estatales).

STAËL VON HOLSTEIN, Lage, Vad blir det av Spanien? En medlings möjligheter (¿Qué va a ser de España? Las posibilidades de una mediación), Estocolmo: Fritzes Bokförlag, 1938.

SVENSÉN, Bo, “The Nobel Prize in Literature: Nominations and Reports 1901-1950". Nobelprize.org. 14 Apr 2012 http://www.nobelprize.org/nobel_prizes/literature/ articles/ svensen 
SVENSK FÖRFATTNINGSSAMLING (SFS, BOE sueco), 1937.

SVENSK-SPANSKA NYHETSBULLETIN (Boletín sueco-español de noticias) n. 221 del 31.III.1939.

SVENSKA HJÄLPKOMMITTÉN FÖR SPANIEN, Spanienhjälpen: en redogörelse över Svenska Hjälpkommitténs för Spanien verksamhet under tiden 9 oktober 1936-31 augusti 1938, (La ayuda a España: Memoria de las actividades del Comité sueco de Ayuda a España en el período 9 de octubre de 1936 a 21 de agosto de 1938), Estocolmo: SHFS, 1938.

TIDENS KALENDER 1941: almanack och uppslagsbok (Almanaque y manual de consulta para 1941), Estocolmo, 1940.

VIEDMA, Lucy, “La guerra civil española 1936-1939”, presentación y guía de fondos documentales sobre el tema en el Archivo del Movimiento Obrero de Estocolmo, Estocolmo, ARAB.

WAHLBÄCK, Krister. \& BLIDBERG, Kersti (eds.), Protokoll från den nordiska arbetarrörelsens sammankomster 1932-1946 (Actas de las reuniones del movimiento obrero de 1932 a 1946).

WEDEL JARLSBERG, Fredrik, Reisen giennem livet (El viaje de la vida), Oslo 1932.

WESTMAN, Karl Gustaf, Politiska anteckningar april 1917 - augusti 1939 (Apuntes políticos de abril de 1917 a agosto de 1939), editadas por CARLGREN, Wilhelm M., Estocolmo: Kungl. Samfundets handlingar, 1987.

ZULUETA, Luis de, “La política exterior de la República”, Tierra firme, 3, 1935.

\section{PRENSA}

Arbetaren (El trabajador)

Dagens Nyheter (Noticias del día)

Folkets Dagblad (Diario del Pueblo)

Frente Popular

Frihet (Libertad)

Husmodern (El ama de casa)

Ny Dag (Nuevo día)

Nya Dagligt Allehanda (Nuevos sucesos del día)

Smedjan (Fragua)

Social-Demokraten (El socialdemócrata)

Svensk Tidskrift (Revista sueca)

Svenska Dagbladet (Diario sueco) 
* Los autores cuyo apellido contiene las letras suecas $\AA$, Ä y Ö, que no existen en español, se han colocado en la bibliografía - al igual que en el apartado anterior, fuentes - según la posición que ocupan en el alfabeto sueco, es decir, detrás de la $\mathrm{Z}$ y en el orden citado 



\section{Aspectos generales, teoría y método histórico.}

ALVESSON, Mats \& SKÖLDBERG, Kaj, Tolkning och reflektion: vetenskapsfilosofi och kvalitativ metod, $2^{\mathrm{a}}$ ed. (Interpretación y reflexión: filosofía de la ciencia y método cualitativo), Lund: Studentlitteratur, 2008.

ASKLÖF, Louise \& CARLQUIST, Erik, Humanismen som salt och styrka (Acta Bibliothecae regiae Estocolmoiensis 45) (El humanismo como sal y fuerza), Estocolmo: Atlantis, 1987.

AURELL, Jaume \& PÉREZ LÓPEZ, Pablo (Eds.), Católicos entre dos guerras. La historia religiosa de España en los Años 20 y 30, Madrid, Biblioteca Nueva, 2006.

BARRUSO BARÉS, Pedro \& MARTÍN NÁJERA, Aurelio, Diccionario Biográfico del Socialismo Español, Madrid: FPI, 2010.

BERMAN, Sheri, The primacy of politics: social democracy and the making of Europe's Twentieth Century, Cambridge University Press, 2006.

—: The Social Democratic movement: ideas \& politics in the making of interwar Europé, Cambridge, Mass: Harvard University Press, 1998.

CARLSHAMRE, Staffan, Förklara och berätta vad som hänt. Fyra uppsatser om historiens filosofi (Explicar y narrar lo que ha sucedido. Cuatro ensayos de filosofía de la historia), Gotemburgo: Universidad de Gotemburgo, 1995

ERDMANN, Jürgen, Coburg, Bayern und das Reich 1918-1923 (Coburgo, Baviera y el Reich 1918-1923), Coburgo: Druckhaus \& Rossteutscher, 1969.

GEIS, Michael, The language of Politics, Nueva York: Springer, 1987.

GLASER, Barney G. \& STRAUSS, Anselm L., The discovery of grounded theory, Chicago: Aldine, 1967.

GRÖNDAHL, Birgitta, De ideologiska motsättningarna $i$ den spanska syndikalismen 1910-1936 (Las diferencias ideológicas en el sindicalismo español de 1910 a 1936), Estocolmo: Federativs förlag, 1981.

—: Frihetlig kommunism i praktiken: experiment i självförvaltning i Spanien 1936-1939 (El comunismo libertario en la práctica: el experimento autogestionario en España de 1936 a 1939), Estocolmo: Federativs förlag, 1986.

HEXTER, Jack H., The History Primer, New York: Allen Lane, 1972.

JERNECK, Magnus, MÖRNER, Magnus, TORTELLA, Gabriel \& ÅKERMAN, Sune (coord.), Different paths to Modernity: A Nordic and Spanish perspective, Lund: Nordic Academic Press, 2005. 
JOVER ZAMORA, José María, GÓMEZ-FERRER, Guadalupe \& FUSI, Juan Pablo, España: sociedad, política y civilización (siglos XIX y XX), Madrid: Areté, 2001.

KARLSSON, Klas-Göran \& ZANDER, Ulf (coord.), Historien är $n u$, Lund: Studentlitteratur, 2004.

KOSELLECK, Reinhart, Erfarenhet, tid och historia. Om historiska tiders semantik (Experiencia, tiempo e historia. Sobre la semántica de los tiempos), Gotemburgo: Daidalos, 2004.

-: The Practice of Conceptual History. Timing History, Spacing Concepts, Stanford: Stanford University Press, 2002.

LEITZ, Christian \& DUNTHORN, David J. (Eds.), Spain in an International Context, 1936-1959, Nueva York: Berghan Books, 1999.

LUEBBERT, Gregory, Liberalism, fascism and socialdemocracy, Oxford: Oxford University Press, 1996.

MAQUEDA ABREU, Consuelo, (coord.), Poder, derecho y legislación, Madrid: Marcial Pons y Fundación Berndt Wistedt, 2001.

MAZA ZORRILlA, Elena, La España de Franco (1939-1975), San Sebastián de los Reyes (Madrid): Actas, 2002.

MEAKER, Gerald H., "A Civil War of words: The ideological impact of the First World War on Spain, 1914-1918”, en SCHMITT, Hans A. (ed.) Neutral Europe between war and revolution, Charlottesville: University of Virginia Press, 1988, pp.1-65.

OLBERG, Paul, Sovjet-Rysslands internationella fackföreningspolitik (LO Skriftserie 21) (La política sindical de la Rusia soviética), Estocolmo: LO, 1928.

PELAZ LÓPEZ, José-Vidal, El Estado de las Autonomías: Regionalismos y nacionalismos en la historia contemporánea de España, Madrid: Actas, 2002.

PAYNE, Stanley, "The concept of fascism", en LARSEN, Stein Ugelvik, HAGTVET, Bernt \& MYKLEBUST Jan Petter (coord.), Who were the Fascists? Social roots of European fascism, Oslo: Universitetsforlaget, 1980, pp. 14-25.

POTTER, Jonathan \& WETHERELL, Margaret, Discourse and Social Psychology, Londres: Sage 1987.

REES, Tim \& THORPE, Andrew, (coord.), International Communism and the Communist International, 1919-1943, Manchester: Manchester University Press, 1998.

RÜSEN, Jörn, "Historical Narration: Foundation, Types, Reason", en History \& Theory, n.4, 1987, pp. 87-97. 
—: Berättande och förnuft. Historieteoretiska texter (Narración y razón. Textos de teoría de la historia), Gotemburgo: Daidalos, 2004

SANDNER, Harald, Hitlers Herzog (El duque de Hitler), Aquisgrán: Shaker Media, 2011.

SKINNER, Quentin, "Rhetorical and Conceptual Change", Finnish Yearbook of Political Thought, no. 3, 1999, pp. 61-80.

SCHMITT, Hans A. (coord.), Neutral Europe between war and revolution, Charlottesville: University of Virginia Press, 1988.

TULLY, James (coord.), Meaning \& Context: Quentin Skinner and his Critics, Cambridge: Cambridge University Press, 1988.

VENNERSTRÖM, Ivar, Den ryska fackföreningsrörelsen (LO Skriftserie 20) (El movimiento sindical ruso), Estocolmo: LO, 1928.

WALLERSTEIN, Immanuel, World-systems analysis: an introduction, Durham, North Carolina: Duke University Press, 2004.

WIKLUND, Martin, "Meaning in History beyond instrumental Rationality: The concepts of meaning and rationality of meaning in Jörn Rüsens's theory of history", en Ideas in History, no. 2, 2008, pp. 57-86.

\section{Historia de Suecia}

ALlENDESAlAZAR, Ursula, La Reina Cristina de Suecia, Madrid: Marcial Pons Historia, 2009.

ALMAZÁN, Vicente, Santa Brígida de Suecia - peregrina, política, mística, escritora, Santiago de Compostela: Xunta de Galicia, 2000.

ALMGREN, Birgitta, Drömmen om Norden: nazistisk infiltration i Sverige 1933-1945 (El sueño del Norte: infiltración nazi en Suecia de 1933 a 1945), Estocolmo: Carlsson, 2005 .

ANDERSSON, Ingvar, Sveriges historia. 6 ed. (Historia de Suecia), Estocolmo: Natur och Kultur, 1964.

ANDERSSON, Lars M. \& TYDÉN, Mattias (coord.), Sverige och Nazityskland. Skuldfrågor och moraldebatt (Suecia y la Alemania nazi. Cuestiones acerca de la responsabilidad y debate moral), Estocolmo: Dialogos, 2007.

ANDERSSON, Lars M. \& BACHNER, Henrik, "Nationalsocialismen, en begreppsdiskussion" (Sobre el concepto de nacionalsocialismo), en ANDERSSON, Greger \& GEISLER Ursula (coord.), Fruktan, fascination och frändskap: det svenska 
musiklivet och nazismen (Temor, fascinación y parentesco: el mundo musical sueco y el nazismo), Malmö: Sekel, 2006, pp. 11-30.

ARGENZIANO, Mikael, "Klasskamp och kulturell inmunitet. Svenska socialisters reaktion inför den italienska fascismen 1919-1929" (La lucha de clases y la inmunidad cultural. La reacción de los socialistas suecos ante el fascismo italiano 1919-1929), en Scandia 4/1995, pp. 197-238.

BACHNER, Henrik, Judefrågan: Debatt om antisemitism i 1930-talets Sverige (La cuestión judía: debate sobre el antisemitismo en la Suecia de los años treinta del siglo XX), Estocolmo: Atlantis, 2009.

BAUER, Yehuda, Förintelsen i perspektiv (El holocausto en perspectiva), Estocolmo: Natur \& kultur, 2001.

BERGGREN, Lars \& GREIFF, Mats, En svensk historia från vikingatid till nutid (Una historia de Suecia desde la edad vikinga hasta la actualidad), Lund: Studentlitteratur, 2000 .

BERGGREN, Lena, "Den svenska mellankrigsfascismen - ett ointressant marginalfenomen eller ett viktigt forskningsobjekt?" (El fascismo sueco de entreguerras: ¿un fenómeno marginal sin interés o algo importante que debe ser objeto de investigación?), en Historisk tidskrift, 2002:3, 427-443.

BJÖRKEGREN, Hans, Ryska Posten. De ryska revolutionärerna i Norden 1906-1917 (El correo ruso. Los revolucionarios rusos en los países nórdicos de 1906 a 1917), Estocolmo: Bonnier, 1985.

BJÖRLIN Lars, "För svensk arbetarklass eller sovjetisk utrikespolitik? Den kommunistiska rörelsen i Sverige och förbindelserna med Moskva 1920-1970” (¿Por la clase trabajadora sueca o por la política exterior soviética? El movimiento comunista en Suecia y sus relaciones con Moscú entre 1920 y 1970) en JUNGAR, Sune \& JENSEN, Bent (coord.) Sovjetunionen och Norden (La Unión Soviética y los países nórdicos), Helsinki: FHS, 1997, pp. 201-225.

BJÖRNSSON, Anders, Skuggor av ett förflutet: Bondeförbundet och trettiotalet (Sombras de un pasado: La Liga Agraria y los años treinta), Lund: Sekel, 2009.

BLOMQVIST, Håkan, Socialdemokrat och antisemit?: den dolda historien om Arthur Engberg (¿Socialdemócrata y antisemita? La historia oculta de Arthus Engberg), Estocolmo: Carlsson, 2001.

BOËTHIUS, Maria-Pia, Heder och samvete, Sverige under andra världskriget (Honor y conciencia, Suecia durante la Segunda Guerra Mundial), Estocolmo: Ordfront, 1999.

CASPARSSON, Ragnar, Saltsjöbadsavtalet $i$ historisk belysning (Los Acuerdos de Saltsjöbaden en perspectiva histórica), Estocolmo: Tiden, 1966. 
EDGREN, Lars \& OLOFSSON, Magnus (Red.), Political outsiders in Swedish history, 1848-1932, Newcastle upon Tyne: Cambridge Scholars Publishing, 2009.

EDLUND, Sten E. (ed.), Saltsjöbadsavtalet 50 år: forskare och parter begrundar en epok 1938-1988 (50 años desde los Acuerdos de Saltsjöbaden: reflexiones de investigadores y partes contratantes sobre una época, 1938-1988) Estocolmo: Arbetslivscentrum, 1989.

ELIASSON, Ulf, I försvarets intresse: Säkerhetspolisens övervakning och registrering av ytterlighetspartier 1917-1945 (Por los intereses de la Defensa: la vigilancia y registro de datos de los partidos extremistas por parte de la Policía de Seguridad de 1917 a 1945), Lund: Nordisk akademisk press, 2006.

ENGLUND, Peter, "Om Sven, Senator och Orestes" (Sobre Sven, Senator y Orestes), prólogo al libro de AGRELL, Wilhelm, Venona: spåren från ett underrättelsekrig (Venona: huellas de una guerra de los servicios de Inteligencia), Lund: Historiska Media, 2003.

ERICSON, Lars, Svenska frivilliga. Militära uppdrag i utlandet under 1800- och 1900talen (Voluntarios suecos: encargos militares en el extranjero durante los siglos XIX y XX), Lund: Historiska Media, 1996.

ERIXON, Dick, "Socialist med konservativa metoder" (Socialista con métodos conservadores), recensión del libro de ISAKSSON, Anders, Per Albin, Estocolmo: Wahlström \& Widstrand 1985- 2000, en revista digital Smedjan (www.smedjan.com), de 24.VIII.2000.

GEER, Gerhard de, Sveriges andra stormaktstid: några ekonomiska och politiska betraktelser (La segunda edad de oro de Suecia: algunas consideraciones políticas y económicas), Estocolmo: Bonnier, 1928.

GREIFF, Mats, “Trabajo retribuido y desempleo entre las mujeres durante la crisis de los años treinta en Suecia", en Historia, Anthropologia y Fuentes Orales 1, 21, Barcelona: Universidad de Barcelona, 1999, pp.29-36.

GUILLEMOT, Agneta, "Från Sundsvall 1879 - Ådalen 1931: Om militära kommenderingar vid strejker och sociala konflikter" (De Sundvall en 1879 a Ådalen en 1931: el empleo del ejército en relación con con huelgas y conflictos sociales), en ERICSSON, Tom \& GUILLEMOT, Agneta (coord.), Individ och struktur $i$ historisk belysning, Festskrift till Sune Akerman, (Individuo y estructura en una perspectiva histórica, homenaje a Sune Åkerman), Umeå, 1997, pp. 53-90.

—:"Svår omställning till demokratiskt försvar" (El difícil cambio a una Defensa democrática), en Framsyn, 2004.

GUSTAFSSON, Bo, "Foundations of the Swedish Model" en The Nordic Journal of Political Economy (NOPEC), no 22, 1995, pp. 5-26. 
GYLLENHAAL, Lars \& WESTBERG, Lennart, "I etiopisk tjänst 1934-1936. För lejonet av Juda", (Al servicio de Etiopía de 1934 a 1936. Por el león de Judá"), en Svenskar $i$ krig 1914-1945 (Suecos en guerra de 1914 a 1945), Lund: Historiska Media, 2006, pp. 104-109.

HADENIUS, Stig, Svensk politik under 1900-talet (La política sueca en el siglo XX), Lund: Hjalmarsson \& Högberg, 2000.

HUGEMARK, Bo (coord.), Urladdning 1940 - blixtkrigens år (El descargo, en 1940: el año de la guerra relámpago), Estocolmo: Svensk militärhistoriskt bibliotek, 2002.

ISAKSSON, Anders, Per Albin, Estocolmo: Wahlström \& Wistrand, 1985-2000.

JOHANSSON, Alf W, "Den svenska socialdemokratin och fascismen på trettiotalet : några reflexioner" (La socialdemocracia sueca y el fascismo en los años treinta), en BERGQUIST, Mats, JOHANSSON Alf W. \& WAHLBÄCK, Krister (coord.), Utrikespolitik och historia (Política exterior e historia), Estocolmo: Militärhistoriska förlaget, 1987, pp. 91-101.

—: Den nazistiska utmaningen: aspekter på andra världskriget (El desafío nazi: aspectos de la segunda guerra mundial), Estocolmo: Prisma, 2006.

JOHANSSON, Roger, Kampen om historien. Ådalen 1931 - sociala konflikter, historiemedvetande och historiebruk 1931-2000 (La lucha por la historia. Ådalen 1931 - conflictos sociales, conciencia histórica y usos de la historia de 1931 a 2000), Estocolmo: Hjalmarson \& Högberg, 2001.

KOBLIK, Steven, "Sweden, 1917: Between reform and Revolution", en SCHMITT, Hans A. (coord.), Neutral Europe between war and revolution, Charlottesville: University of Virginia Press, 1988, pp. 111-132.

LANE, Jan-Erik (ed.), Understanding the Swedish Model, Londres: Frank Cass, 1991.

LEVINE, Paul A., Raoul Wallenberg i Budapest. Människan, myten och förintelsen (Raoul Wallenberg en Budapest: el hombre, el mito y el holocausto), Lund: Historiska Media, 2011.

LÖÖW, Helene, Hakkorset och Wasakärven (La esvástica y la gavilla de Wasa), Gotemburgo: Universidad de Gotemburgo, 1990.

—: Nazismen i Sverige 1924-1979: pionjärerna, partierna, propagandan (El nazismo en Suecia de 1924 a 1979: los pioneros, los partidos, la propaganda), Estocolmo: Ordfront, 2004.

LUNDH, Christer (red.), Nya perspektiv på Saltsjöbadsavtalet (Nuevas perspectivas sobre los Acuerdos de Saltsjöbaden), Estocolmo: SNS förlag, 2009.

MELIN, Jan, HEDENBORG, Susanna \& JOHANSSON, Alf W., Sveriges historia: koncentrerad uppslagsbok - fakta, årtal, tabeller, kartor (la historia de Suecia: 
manual concentrado - sucesos, fechas, tablas, mapas), Estocolmo: Rubén Prisma, 1997.

MYRDAL, Gunnar \& Alva, Kris $i$ befolkningsfrågan (Crisis en la cuestión de la población), Nora: Nya Doxa, 1934/1997.

NILSSON, Karl N. Alvar, Svensk överklassnazism 1930-1945 (El nazismo de la clase alta sueca de 1930 a 1945), Estocolmo: Carlsson, 1996.

NORBORG, Lars Arne, Sveriges historia under 1800- och 1900-talen. Svensk samhällsutveckling 1809-1993, (La historia de Suecia durante los siglos XIX y XX: el desarrollo social de Suecia de 1809 a 1993), Estocolmo: Almqvist \& Wiksell, 1993.

NORMAN, Birger, Ådalen, en berättelse (Ådalen, un relato), Estocolmo:Rabén \& Sjögren, 1974.

OHLSSON, Per T, Rickard Sandler, Estocolmo: Bonnier, 2010.

PEIX GELDART, Benito, "Isabel la luterana”, en ZALAMA, Miguel Ángel (dir.) et al., Juana I en Tordesillas: su mundo, su entorno, Valladolid, 2010, pp. 333-346.

—: "Drottning Kristinas trosförändring: den svenska reaktionen 1655-1660" (El cambio de fe de la Reina Cristina: la reacción sueca de 1655 a 1660), trabajo inédito fin de máster, Universidad de Estocolmo, 1998.

ROSAL CRESPO, Mario del, "Los límites del socialismo reformista: el caso de Suecia. Una aproximación crítica al Modelo Rehn-Meidner desde una perspectiva histórica (1932-1983)", trabajo de Investigación bajo la dirección de Xabier Arrizabalo, Madrid: UCM, 2007.

SCHÖN, Bosse, Hitlers svenska soldater (Los soldados suecos de Hitler), Estocolmo: DN, 2004.

SILANDER, Martin, "Debatten om NF och dess sanktionssystem: Vilhelm Lundstedt och hans antagonister" (El debate sobre la Sociedad de Naciones y su sistema de sanciones: Vilhelm Lundstedt y sus antagonistas), Trabajo inédito fin de máster, Halmstad: Högskolan i Halmstad, 2006.

SJÖGREN, Hans, Kreditförbindelser under mellankrigstiden. Krediter $i$ svenska affärsbanker 1924-1944 fördelade på ekonomiska sektorer och regioner (Research Report n. 21) (Las relaciones de crédito durante el período de entreguerras. Los créditos en los bancos suecos de 1924 a 1944 distribuidos por sectores económicos y regiones), Uppsala: Uppsala Papers in Economic History, 1989.

TRÖNNBERG, Stefan, Nedrustning under mellankrigstiden: Sverige och nedrustningskonferensen i Geneve 1932 (El desarme en el período de entreguerras: Suecia y la conferencia de desarme de Ginebra de 1932), Solna: Seelig, 1985. 
TYDÉN-JORDAN, Astrid, "Kungamötet på strömmen" (Encuentro de reyes en el canal), Populär Historia, 3/2000, Estocolmo: LRF Media.

WAHLBÄCK, Krister "Finland: en politisk nervknut. Aleksandra Kollontaj i Sverige 1930-1945" (Finlandia: un centro neurálgico político. Alejandra Kollontai en Suecia 1930-1945), en SÖRBYE, Yngvild (coord.) Revolusjon, kjaerlighet, diplomati Aleksandra Kollontaj og Norden, (Revolución, amor, diplomacia. Alejandra Kollontai y los países nórdicos), Oslo: Unipub 2008, pp. 177-180.

WESTRIN, Theodor (red.), Nordisk familjebok (2 ed.) (Enciclopedia Familiar nórdica), Estocolmo: Nordisk familjeboks förlag, 1919, voz "Thyrén, Johan Karl Vilhelm”.

WÄRENSTAM, Eric, Fascismen och nazismen i Sverige (El fascismo y el nazismo en Suecia), Estocolmo: Almqvist \& Wiksell, 1973.

ÅKERLUND, Andreas, "De svenska universiteten och nazismen”, (Las universidades suecas y el nazismo), en Historisk Tidskrift (Sweden) 129:1, 2009, pp. 65-72.

\section{Relaciones Suecia- España}

ALÉX, Peder \& HJELM, Jonny (coord.), Efter arbetet (Tras el trabajo), Lund: Studentlitteratur, 2001.

BALLESTER, Gemma \& BENEITO LLORIS, Ángel, L'Hospital Sueco-Noruego d'Alcoi durant la guerra civil espanyola: un exemple de solidaritat, Barcelona: L'Ullal Ediciones, 2010.

BENEITO LLORIS, Ángel, El Hospital Sueco Noruego de Alcoi durante la Guerra Civil Española., Alcoy: Alfa Ediciones Gráficas, 2004.

BENSON, Ken, MÖRNER, Magnus \& SÖHRMAN, Ingmar, Relaciones entre España y Suecia desde mediados del siglo XVII hasta comienzos del XIX: simposio en Uppsala, 20-24 septiembre 2000: actas = Spanish-Swedish relations from the mid seventeenth century to the early nineteenth century: symposium in Uppsala, 20-24 september 2000: conference papers. Sección de español, Universidad de Gotemburgo, Gotemburgo, 2002.

BERENCREUTZ, Nils (Ed.), Don Antonio Pimentels depescher från drottning Christinas hov 1652-1656 jämte svarsskrivelser och spanska statsrådsprotokoll (Los despachos de Don Antonio Pimentel desde la corte de la Reina Cristina de 1652 a 1656 y las respuestas y actas del gobierno español), Estocolmo: Norstedt, 1961.

BERGLUND, Åsa, Spanska inbördeskriget i svensk arbetarpress (La guerra civil española en la prensa obrera sueca), Estocolmo, 1974.

BJÖRK, Kaj, Spanien i svenska hjärtan (España en nuestros corazones), Estocolmo: Arbetarrörelsens arkiv och bibliotek, 2001. 
BORGENSTIERNA, Anne Christine (coord.), Santa Brígida, patrona de Europa, Fundación Berndt Wistedt, Valladolid, 2005.

BORRÁS, Isabel, Svenskarna och det spanska inbördeskriget $:$ en bibliografi $=$ Los suecos y la guerra civil española : una bibliografia, Borås, 1977.

CASTIELLA, Fernando María, Una batalla diplomática, Barcelona: Planeta, 1976.

CANTERA CARLOMAGNO, Marcos, "Bang, Dagens Nyheter och Utrikesdepartementet" (Bang, el Dagens Nyheter y el Ministerio de Negocios Extranjeros) en När Alving blev Bang (Cuando Alving se convirtió en Bang), Estocolmo, 2001, pp. 69-85.

—: Sverige och spanska inbördeskriget (Suecia y la guerra civil española), Historiska Media, Lund, 1999, p. 78-80.

—: "El comercio hispano-sueco de 1870 a 1940: Algunos rasgos generales", en RAMOS SANTANA, Alberto, (coord.) Comercio y navegación entre España y Suecia (Siglos $X-X X)$, Cádiz: Fundación Berndt Wistedt, 2000, pp. 483-492

CORREDERA NILSSON, Enrique J., Todos somos godos. Las relaciones hispano-suecas desde la década de 1640 hasta la Paz de Oliva, Madrid: Editorial complutense, 2009.

DALIN, Stefan, "En bortglömd solidaritetsrörelse: det svenska Spanien-engagemanget 1936-1939" (Un movimiento de solidaridad olvidado: el compromiso sueco a favor de España de 1936 a 1939), en ALÉX, Peder, \& HJELM, Johnny (coord.), Efter arbetet, Lund: Studentlitteratur, 2001, pp. 101-119.

—: "Värmlandspressen och Spanienfrågan", (La prensa de Värmland y la cuestión española) en GUSTAFSSON, Karl Erik \& RYDÉN, Per, Folk och press i rörelse (Pueblo y prensa en movimiento), Gotemburgo: Nordicom-Sverige, 1999, pp. 151170.

—: "Den svenska lokalpressen och spanska inbördeskriget", (La prensa local sueca y la guerra civil española), en Presshistorisk årsbok 22, 2005, pp. 87-101.

DUROUX, Rose, "La ayuda de Noruega y Suecia", en ALTED VIGIL, Alicia, GONZÁLEZ MARTELL, Roger \& MILLÁN, María José, El exilio de los niños, 2003, pp. 126-143.

EKSTRÖM, Kerstin, Överlevarna: Från spanska inbördeskriget och Francodiktaturen (Los sobrevivientes de la guerra civil española y de la dictadura de Franco), Estocolmo: Carlsson, 2010.

FREDRIKSSON, Berndt, "La historia de las relaciones bilaterales entre Suecia y España. Embajadores suecos en España", en MAQUEDA ABREU, Consuelo, (coord.), Poder, derecho y legislación, UNED, Marcial Pons y Fundación Berndt Wistedt, Madrid, 2001, pp. 47-80. 
GONZÁLEZ CAÑAL, Rafael, "El Conde de Rebolledo y la Reina Cristina de Suecia: una amistad olvidada", en Tierras de León, 26 (62), 1986, pp. 93-108.

GUSTAFSSON, Karl Erik \& RYDÉN, Per, Folk och press i rörelse (Pueblo y prensa en movimiento), Gotemburgo: Nordicom-Sverige, 1999.

GUSTAFSSON, Kerstin \& KARLSSON, Mekki, Spaniens sak var vår (La causa de España fue la nuestra), Estocolmo: Svenska fredskommittén \& Svenska Spanienfrivilligas vänner, 1992.

GYBERG, Erik, Spanien i svensk litteratur: en bibliografi = España en la bibliografía sueca: una bibliografía, Gotemburgo: Biblioteca universitaria de Gotemburgo, 1973.

GYLLENHAAL, Lars \& WESTBERG, Lennart, "I spansk tjänst 1936-1939: På titanernas första slagsfält" (al servicio de España de 1936 a 1939. En el primer campo de batalla de los titanes) en Svenskar i krig 1914-1945 (Suecos en guerra), Lund: Historiska media, 2006.

GYLLENHAAL, Lars, "Skandinaviska bataljonen Hans Beimler” (El batallón escandinavo Hans Beimler), publicación digital en http://www.smb.nu/index.php/militaraartiklar/andra-vaerldskriget/1442-skandinaviska-bataljonen-hans-beimler.

HENRIKSON, Göran, “Spaniens sak är vår: Spanienrörelsen i Örebro län 1936-1939” (La causa de España es la nuestra: el movimiento a favor de España en la región de Örebro de 1936 a 1939) en Från bergslag och bondebygd (De la montaña y el campo), Örebro: Örebro läns museum; 1979 (33), pp. 61-85.

HILLMAN, Adolfo, "Ojeada a las relaciones históricas entre España y Suecia”, en Revista crítica de historia y literatura, 1894.

JÖNSSON, Claes-Göran \& KENNERSTRÖM, Bernt, Den svenska arbetarradikalismen och spanska inbördeskriget (El radicalismo obrero sueco y la guerra civil española) Estocolmo: Arkiv 1977.

KENNERSTRÖM, Bernt, "Socialistiska partiet och spanska inbördeskriget - den problematiska principfastheten" (El partido socialista y la guerra civil española - el problema de ser fiel a los propios principios), en Arkiv 6, 1974.

LAVANDEIRA HERMOSO, Juan Carlos, "Las relaciones diplomáticas hispano-suecas: Una visión de conjunto a mediados del siglo XVIII", en BENSON, Ken, MÖRNER, Magnus \& SÖHRMAN, Ingmar, Relaciones entre España y Suecia desde mediados del siglo XVII hasta comienzos del XIX: simposio en Uppsala, 20-24 septiembre 2000: actas = Spanish-Swedish relations from the mid seventeenth century to the early nineteenth century: symposium in Uppsala, 20-24 september 2000: conference papers. Sección de español, Universidad de Gotemburgo, Gotemburgo, 2002, p. 4161.

—: "Política y comercio de mediados del siglo XVIII: Algunos informes del marqués del Puerto desde la Embajada española en Suecia”, en RAMOS SANTANA, Alberto, 
(coord.) Comercio y navegación entre España y Suecia (siglos $X-X X$ ), Cádiz: Fundación Berndt Wistedt, 2000.

LIÉBANA, Elena, "Isabel, hija de Juana I, reina de Dinamarca, Noruega y Suecia", en ZALAMA RODRÍGUEZ, Miguel Ángel (coord.), Juana I de Castilla, 1504-1555: de su reclusión de Tordesillas al olvido de la historia: I Simposio Internacional sobre la Reina Juana I de Castilla, Tordesillas (Valladolid), 23 y 24 de noviembre de 2005, Tordesillas 2006, pp. 107-124.

LUNDBERG, Lennart, Svenskarna i spanska inbördeskriget 1936-1939 (Los suecos en la guerra civil española de 1936 a 1939), Gotemburgo: Tre böcker, 2001.

LUNDVIK, Bertil, Solidaritet och partitaktik: den svenska arbetarrörelsen och spanska inbördeskriget 1936-1939, (Solidaridad y táctica de partido: el movimiento obrero sueco y la guerra civil española de 1936 a 1939), Uppsala: Studia historica Upsaliensia, 114 y Estocolmo: Almqvist \& Wiksell International (distr.), 1980.

—: "De svenska handelsintressena och utrikespolitiken under spanska inbördeskriget", (Los intereses comerciales suecos y la política exterior durante la guerra civil española) en ERIKSSON, Maj-Lis, Med eller mot strömmen? en antologi om svenska folkrörelser (¿A favor o en contra de la corriente? Una antología sobre los movimientos de masas suecos), Estocolmo: Sober, 1980, pp. 61-79.

MARTÍNEZ RUIZ, Eduardo \& PI CORRALES, Magdalena de Pazzis, "Guerra y comercio. La propuesta de un tratado comercial hispano-sueco a mediados del siglo XVIII", en RAMOS SANTANA, Alberto, (coord.) Comercio y navegación entre España y Suecia (siglos X-XX), Fundación Berndt Wistedt, Cádiz, 2000, pp. 223-250.

—: (coord.), España y Suecia en la Época del Barroco (1600-1660), Fundación Berndt Wistedt, Madrid, 1998.

-: (coord.). El mundo escandinavo, Santa Brígida y el Camino de Santiago. Encuentros Históricos Suecia-España VIII, Fundación Berndt Wistedt, Santiago de Compostela, 2002.

—: Sweden in Spain's general archives: Sources for hispano-Swedish history. Suecia en los Archivos generales españoles. Fuentes para la historia hispano-sueca, Madrid: Fundación Berndt Wistedt, 2001.

MATTSON, Carl, Spaniens sak var vår: solidaritetsrörelsen $i$ Värmland 1936-1939: kampen mot krig och fascismen (La causa de España fue la nuestra: el movimiento de solidaridad en Värmland de 1936 a 1939: la lucha contra la guerra y el fascismo), Karlstad: ABF Värmland, 1982.

MURAI, Michiko, "Los voluntarios suecos y escandinavos en la guerra civil española, una aproximación lingüística", en CELADA, Antonio R., PASTOR GARCIA, Daniel y LÓPEZ ALONSO, Rosa María (Eds.), Las Brigadas Internacionales: 70 años de memoria histórica, Salamanca: Amarú, 2007, pp. 299-305. 
MORALES ROMERO, Eduardo, Historia de los Vikingos en España, Madrid: Colección Malos Tiempos, 2006.

MÖRNER, Magnus, España y Suecia en el siglo XVII: problemas y alcandes de los enfoques comparativos. Gotemburgo: Inst. Ibero-americano, 1998.

—: Episodios de la historia de las relaciones hispano-suecas: España y Suecia a través de los tiempos, imágenes y realidades $=$ Episoder ur de svensk-spanska förbindelsernas historia: Spanien och Sverige genom tiderna, bilder och verklighet, Madrid: Fundación Berndt Wistedt, 1996.

MYKLEBUST, Jon Olav \& BENEITO LLORIS, Ángel, A hospital for Spain!: Scandinavian solidarity in a time of Civil War, 2009.

NILSSON, Göte, Svenskar i spanska inbördeskriget (Suecos en la guerra civil española), Estocolmo: Norstedt 1972.

NILSSON, Per, Spanska inbördeskriget och Sverige: Estocolmospressen och krigsslutet (La guerra civil española y Suecia: la prensa de Estocolmo y el final de la guerra), Estocolmo, 1976.

NILSSON, Torbjörn, "Ebro. Spanienfrivilligas sista strid" (El Ebro: la última batalla de los voluntarios suecos", en Guide till svensk historia i Europa (Guía de la historia de Suecia en Europa), Estocolmo: Wahlström \& Wistrand, 2002, pp. 190-199.

OLSSON, Kent, "El comercio entre España y Suecia en el siglo XX: las consecuencias del cambio industrial" en Ramos Santana, Alberto, (coord.) Comercio y navegación entre España y Suecia (Siglos X-XX), Cádiz: Fundación Berndt Wistedt, pp. 493-505.

QUATREFAGES, Rene, "Las relaciones diplomáticas hispano-suecas (s. XVI-XVII)", en MARTÍNEZ RUIZ, Eduardo y PI CORRALES, Magdalena de Pazzis (coord.), España y Suecia en la Época del Barroco (1600-1660), Madrid: Fundación Berndt Wistedt, 1998, pp. 993-1006.

PEIX GELDART, Benito, "Suecia y las elecciones españolas a Cortes de 1936", en GONZÁLEZ CALLEJA, Eduardo \& NAVARRO COMAS, Rocío (coord.), La España del Frente Popular. Política, sociedad, conflicto y cultura en la España de 1936, Granada: Comares, 2011, pp. 223-240.

—: "Efter Spanien. De svenska frivilligas hemkomst" (Después de España. La vuelta a casa de los voluntarios suecos) en Arbetarhistoria 1, Estocolmo: ARAB, 2012, pp. $10-16$.

-: "Svenska syndikalister i Francos arkiv" (Sindicalistas suecos en los archivos de Franco), ponencia en el Congreso de Historiadores del Mundo Obrero, en Landskrona, Suecia (26-27.V. 2011), de inminente publicación. 
—: "Relaciones políticas y diplomáticas entre España y Suecia de 1929 a 1939. Estado de la cuestión, introducción y fuentes para su estudio", trabajo inédito fin de máster, Valladolid, 2010.

RABO, Erik, "Spanienhjälpens fältsjukhus under spanska inbördeskriget: svensk-norsk insats för demokratin" (El hospital militar del Comité de Ayuda a España durante la guerra civil española: una aportación sueco-noruega a favor de la democracia) en Läkartidningen 2003(100):44, pp. 3522-3525.

RAMOS SANTANA, Alberto, (coord.), Comercio y navegación entre España y Suecia (siglos $X-X X$ ), Cádiz: Fundación Berndt Wistedt, 2000.

RISBERG, Åsa, "Att försöka påverka världen med ord”: Eyvind Johnson och spanska inbördeskriget (El intento de influir en el mundo a través de la palabra: Eyvind Johnson y la guerra civil española), Estocolmo: Natur och kultur, 1975.

RODÉN, Marie Louise, "La reina Cristina de Suecia, España y la política de la corte papal en el siglo XVII", en MARTÍNEZ RUIZ, Eduardo \& PI CORRALES, Magdalena de Pazzis (coord.), España y Suecia en la Época del Barroco (1600-1660), Madrid: Fundación Berndt Wistedt, 1998, pp. 793-810.

SÁNCHEZ DIANA, José María, "Relaciones de España con Suecia en el siglo XVIII", Revista Hispania LXXXVIII, 1962, pp. 590-627.

SILVÁN, Leandro, "Relaciones científicas hispano-suecas en el siglo XVIII", Boletín de la Real sociedad bascongada de amigos del país, San Sebastián, 1981, pp. 267-299.

SJÖSTEDT, Jonas, "Från Västerbotten till Spanien” (Desde Västerbotten hasta España), en Västerbotten 3, 2008, pp. 32-51.

STRINDBERG, August, "Relations de la Suède avec l'Espagne et le Portugal jusqu'à la fin du dix-septième siècle", Boletín de la Real Academia de la Historia, T.16, Madrid, 1890, pp. 321-342.

—: "Spanska och portugisiska minnen ur svenska historien", (Recuerdos españoles y portugueses de la historia sueca), Samlade skriften 27, Estocolmo, 1917, pp. 67-90.

TORTELLA, Gabriel, "Sweden and Spain - Different Paths towards Modernity?", en JERNECK, Magnus, MÖRNER, Magnus, TORTELLA, Gabriel \& ÅKERMAN, Sune, (coord.), Different paths to Modernity: A Nordic and Spanish perspective, Lund: Nordic Academic Press, 2005, pp. 18-30.

VÁSQUEZ LOPESA, Julián, Bajo el signo de la diplomacia: la reina Cristina en la literatura del Siglo de Oro: del Conde Bernardino Rebolledo a Calderón y Bancer Candamo. Gotemburgo: Instituto iberoamericano, 1998.

YRAOLA, Aitor, "La repercusión de la Guerra Civil Española en los Países Nórdicos con especial referencia a Islandia", Cuadernos de Historia Contemporánea, 16, Madrid, 1994, pp. 132-149. 
YRLID, Rolf, Till Madrid: tre svenskars närvaro under det spanska inbördeskriget (A Madrid: la presencia de tres suecos durante la guerra civil española), Lund: Atlantis, 2006.

\section{Política exterior y relaciones diplomáticas de España y Suecia}

AF MALMBORG, Niklas, Neutrality and State-Building in Sweden, New York: Palgrave, 2001

—: "Sverige i det fascistiska Italiens utrikespolitik" (Suecia y la política exterior de la Italia fascista), en Historisk Tidskrift, 1997, pp. 158-167.

ÅHLSBERG, Bengt, Studenter och storpolitik - Sverige och det internationella samarbetet 1919-1931, (Estudiantes y la gran política: Suecia y la cooperación internacional de 1919 a 1931), Lund: Lunds University Press, 1995.

ANDRÉN, Nils, Maktbalans och alliansfrihet: svensk utrikespolitik under 1900-talet (El equilibrio de poder y la libertad de alianzas: la política exterior sueca durante el siglo XX), Estocolmo: Nordstedt, 1996.

ANDRÉS SÁENZ DE SANTA MARÍA, María Paz, El arbitraje internacional en la práctica convencional española: (1794-1978), Oviedo: Universidad de Oviedo, 1982.

ARÓSTEGUI, Julio, "De lealtades, deslealtades y defecciones. La República y la memoria de la utopía", en VIÑAS, Ángel (coord.), Al servicio de la República: Diplomáticos y guerra civil, Madrid: Marcial Pons Historia, 2010, pp. 23-54.

ARTEUS, Gunnar \& LEIFLAND, Leif (coord.), Svenska diplomatprofiler under 1900talet (Perfiles diplomáticos suecos del siglo XX), Estocolmo: Probus, 2001.

AUBERT, Paul, "España, Europa y el Mediterráneo”, Bulletin d'Histoire Contemporaine de l'Espagne, n. 27, junio 1998, pp. 133-150.

AZCÁRATE, Pablo de, Mi embajada en Londres durante la Guerra civil española, Barcelona: Ariel, 1976.

BALFOUR, Sebastian \& PRESTON, Paul, (coord.), España y las grandes potencias en el siglo XX. Barcelona: Crítica, 2002.

BALLESTEROS, Ángel, Diplomacia y relaciones internacionales, 4. ${ }^{a}$ edición, Madrid, 2009.

BÉCKER, Jerónimo, Historia de las relaciones exteriores de España durante el siglo XIX. Apuntes para una historia diplomática (Volumen 3 de Historia de las Relaciones Exteriores de España durante el siglo XIX) Madrid: Estab. tip. de J. Ratés, 1924. 
BERGQUIST, Lars, "Lennart Petri”, en ARTEUS, Gunnar \& LEIFLAND, Leif (Eds.), Svenska diplomatprofiler under 1900-talet, Estocolmo: Probus, 2001, pp. 398-409.

BERGQUIST, Mats \& JOHANSSON, Alf W., Säkerhetspolitik och historia: essäer om stormaktspolitik och Norden under sjuttio år: vänbok till Krister Wahlbäck (Política de seguridad e historia: ensayos sobre la política de las grandes potencias y los países nórdicos durante setenta años: homenaje a Krister Wahlbäck), Estocolmo: Hjalmarson \& Högberg, 2007, pp. 263-284.

BERGQUIST, Mats, "Fyra paradigmskiften i svensk utrikespolitik", (Cuatro cambios paradigmáticos en la política exterior sueca), en Nordisk tidskrift för vetenskap, konst och industri (Revista nórdica de ciencia, arte e industria) 2009(85):1, pp. 47-58.

—: "Sverige och Nationernas Förbund" (Suecia y la Sociedad de Naciones), en Statsvetenskaplig Tidskrift, 1970, pp. 130-152.

BERGQUIST, Mats, JOHANSSON Alf W. \& WAHLBÄCK, Krister (coord.), Utrikespolitik och historia, Estocolmo: Militärhistoriska förlaget, 1987.

BLEDSOE, Gerie Brown, La oficina española de la Sociedad de Naciones, Revista de Política Internacional 127, 1973.

—: "The Quest for Permanencia: Spain's Role in the League Crisis of 1926", Iberian Studies, 4/1975, pp. 14-21;

—: Spain in the League of Nations, 1919-1931, Florida State University, 1972.

CALDUCH CERVERA, Rafael (coord.), La política exterior española en el siglo XX, Madrid: Ciencias Sociales, 1994.

CANTERA CARLOMAGNO, Marcos, Ett folk av mänsklig granit: Sverige $i$ den italienska utrikespolitiken 1932-1936, Lund: Historiska Media, 1995.

CARLGREN, Wilhelm, "Karl Ivan Westman", en ARTEUS, Gunnar \& LEIFLAND, Leif (coord.), Svenska diplomatprofiler under 1900-talet (Perfiles diplomáticos suecos del siglo XX), Estocolmo: Probus, 2001, pp. 132-151.

CASANOVA, Marina, "Las relaciones diplomáticas hispano-belgas durante la Guerra Civil Española: el caso del barón de Borchgrave", Espacio, Tiempo y Forma. Serie V. Historia Contemporánea, 5, (1992), pp. 293-301.

—: "Depuración de funcionarios diplomáticos durante la Guerra Civil", Espacio, Tiempo y Forma. Revista de la Facultad de Geografía e Historia, 1, UNED, 1987, pp. 361378.

—: La diplomacia española durante la guerra civil, Biblioteca Diplomática Española, Sección Estudios 13, MAE, Madrid 1996. 
DAHLBERG, Leif, Över folkets huvud: om svensk utrikespolitik (Por encima de la gente: sobre la política exterior sueca), Estocolmo: Bonnier, 1967.

DELGADO GÓMEZ-ESCALONILLA, Lorenzo, "Las relaciones culturales de España en tiempo de crisis: de la Segunda República a la Guerra Mundial", en Espacio, Tiempo y Forma, Serie V, Historia Contemporánea, t. 7, 1994, pp. 259-294.

EGIDO LEÓN, María de los Ángeles, La concepción de la política exterior española durante la segunda República, Madrid: UNED, 1987.

EIROA, Matilde, Las relaciones de Franco con la Europa Centro-Oriental, Barcelona: Ariel, 2001.

—: "La Embajada en Praga y el servicio de información de Jiménez de Asúa", en VIÑAS, Ángel, Al servicio de la República: Diplomáticos y guerra civil, Madrid: Marcial Pons Historia, 2010, pp. 207-240.

HUCKSTORF, Axel, Internationale Beziehungen 1933-1939: Schweden und das Dritte Reich (Relaciones internacionales 1933-1939: Suecia y el III Reich), Frankfurt am Main: Lang, 1997.

GARRIDO CABALLERO, María Magdalena, Las relaciones entre España y la Unión Soviética a través de las Asociaciones de Amistad en el siglo XX, Murcia, 2008.

GOÑI, Fernando, Tratado de las relaciones internacionales de España: Lecciones pronunciadas en el Ateneo de Madrid, Madrid: R. Rodríguez de Rivera, 1848.

HANSSON, Tommy, Neutralitetsmyten: en granskning av svensk utrikespolitik (El mito de la neutralidad: un estudio de la política exterior sueca), Estocolmo: Contra, 1991.

HIRSCHFELDT, Lennart (coord.), Svensk utrikespolitik under 1900-talet, (La política exterior sueca en el siglo XX), Estocolmo, 1958.

HULDT, Bo \& MISGELD, Klaus, (coord.), Socialdemokratin och svensk utrikespolitik: från Branting till Palme (La socialdemocracia y la política exterior sueca: de Branting a Palme), Estocolmo, 1990.

JANSSON, Per, Säkerhetspolitikens språk - Myt och metafor $i$ svensk säkerhetspolitisk diskurs 1919-1939 (El idioma de la política de seguridad: mito y metáfora en el discurso sueco de política de seguridad de 1919 a 1939), Lund: Studentlitteratur 1991.

JUNGAR, Sune \& JENSEN, Bent (coord.), Sovjetunionen och Norden (La Unión Soviética y los países nórdicos), Helsinki: FHS, 1997.

LARSSON, Ulf, Svensk socialdemokrati och Baltikum under mellankrigstiden (La socialdemocracia sueca y los países bálticos en el período de entreguerras), Estocolmo: Almqvist \& Wiksell, 1996. 
LEJIN̦Š, Atis, "Sveriges och Lettlands relationer 1987-1991: ockupationsfrågan” (Las relaciones entre Suecia y Letonia de 1987 a 1991: la cuestión de la ocupación"), en Kungl. Krigsvetenskapsakademiens handlingar och tidskrift. (209):4; 2005, pp. 97107.

LINDER, Jan, Mellankrigstiden: Sverige och Europa (El período de entreguerras: Suecia y Europa), Estocolmo: Infomanager, 1993.

LÖNNROTH, Erik, Den svenska utrikespolitikens historia, Del 5, 1919-1939 (La historia de la política exterior sueca, parte 5, 1919-1939), Estocolmo: Norstedt, 1959.

MARTÍN DE LA GUARDIA, Ricardo \& PÉREZ SÁNCHEZ, Guillermo Á., "La Europa del Este en la historiografía española de las relaciones internacionales", en $L a$ historia de las relaciones internacionales, Ayer n. 42, Madrid: Marcial Pons, 2001, pp. 125-148.

MARTÍNEZ RIAZA, Ascensión \& MORENO CEBRIÁN, Alfredo, "Al servicio de la República. La acción exterior de España en el Perú, 1936 - 1939” en CSIC Revista de Indias, vol. LXVII, núm. 241, 2007, pp. 713-762.

MARTINEZ RIAZA, Ascensión: "La lealtad cuestionada. Adscripción política y conflicto de autoridad en la representación española en el Perú, 1933-1939", en Hispania. Revista Española de Historia, LXVI/ 223, Madrid, 2006, pp. 671-694.

MIRALLES, Ricardo, "El duro forcejeo de la diplomacia republicana en París. Francia y las Guerra civil española", en VIÑAS, Angel, (coord.), Al servicio de la Republica, Madrid: Marcial Pons, 2010, pp. 121-154.

MONTERO CALDERA, Mercedes, "La acción diplomática de la Segunda República Española en México (1931-1939)", en Espacio, Tiempo y Forma, Serie V, Historia Contemporánea. 14, 2001, pp. 251-286.

MORADIELLOS, Enrique, "La Embajada en Gran Bretaña durante la guerra civil", en VIÑAS, Angel, (coord.), Al servicio de la Republica, Madrid: Marcial Pons, 2010, pp. 99-119.

MORAL RONCAL, Antonio Manuel, "El Madrid de 1936 a través de las memorias inéditas del marqués de Alquibla", Madrid. Revista de Arte, Geografía e Historia, 5, (2002), pp. 293-313.

-: "Asaltos y cierres de legaciones extranjeras: un grave asunto diplomático en el Madrid de la Guerra Civil (1936-1939)", Madrid. Revista de Arte, Geografía e Historia, 4, (2001), pp. 221-247.

—: Diplomacia, humanitarismo y espionaje en la Guerra Civil española, Madrid: Biblioteca Nueva, 2008.

—: El asilo diplomático en la Guerra Civil Española, Madrid, 2001. 
—:"El asilo diplomático como condicionante de las relaciones internacionales de la República durante la guerra civil", en Congreso La guerra civil Española 1936-1939, Sociedad Estatal de Conmemoraciones Culturales, 2006.

—: "El auxilio diplomático suizo (1936-1939): Humanitarismo y neutralidad benevolente en la Guerra Civil Española", en Cuadernos de Investigación Histórica, 22, (2005), pp. 349-372.

MORALES LEZCANO, Víctor, "Historia de las relaciones internacionales: España contemporánea" en Revista de Estudios Internacionales Vol. 7. Núm. 2. Abril-junio 1986, pp. 575-582.

MORENO JUSTE, Antonio, "Del problema de España a la España europeizada: excepcionalidad y normalización en la posición de España en Europa", en PEREIRA, J.C. (coord.), La política exterior de España (1800-2003), Madrid: Ariel, 2003, pp. 295-317.

-: "La historia de las relaciones internacionales en España", en Cuadernos de Historia Contemporánea. N. 18, Madrid: Universidad Complutense, 1996, pp. 215-218.

NEILA HERNÁNDEZ, José Luis, "La política exterior de la España Republicana (19311936): excepcionalismo y normalidad historiográfica”, Studia Historica, Historia Contemporánea 22, Salamanca, 2004, pp. 47-83.

—: "Regeneracionismo y política exterior en el reinado de Alfonso XIII (1902-1931)", en Cuadernos de Historia de las Relaciones Internacionales, n. 3, Madrid, 2002, pp. 5052.

-: "La historia de las relaciones internacionales: Notas para una aproximación historiográfica", en La historia de las relaciones internacionales, Ayer n. 42, Madrid: Marcial Pons, 2001, pp. 17-42.

—: "Amanecer sin mediodía en la política exterior democrática de la Segunda República: transición sin consolidación” en Aportes, 47, XVI (3/2001), pp. 4-22 y 48, XVII (1/2002), pp. 88-102.

-: "El proyecto internacional de la República. Democracia, paz y neutralidad (19311936)", en PEREIRA CASTAÑARES, Juan Carlos (coord.), La politica exterior de España: de 1800 hasta hoy, Madrid: Ariel, 2010, pp. 587-608.

—: "España y la Sociedad de Naciones: un tránsito historiográfico inacabado". Cuadernos de historia contemporánea, $N^{o}$ Extra 1, 2003, pp. 49-67.

-: "La mediterraneidad de España en las relaciones internacionales del periodo de entreguerras (1919-1939)", Cuadernos de Historia Contemporánea, 19, Madrid: Universidad Complutense, 1997, pp. 15-64.

NILSSON, Bengt, Handelspolitik under skärpt konkurrens: England och Sverige 1929-39 (Bibliotheca historica Lundensis, 58) (Política comercial bajo una fuerte 
competencia: Inglaterra y Suecia de 1929 a 1939, n. 58 de la Biblioteca historica Lundensis), Malmö: Gleerup, 1983.

NILZÉN, Göran, “Anders Nordencrantz som konsul i Portugal” (Anders Nordencrantz como cónsul en Portugal), en Personhistorisk tidskrift, 1986, pp. 38-49.

NIÑO RODRÍGUEZ, Antonio, "Política de alianzas y compromisos coloniales para la Regeneración internacional de España, 1898-1914”, en TUSELL, Javier, AVILÉS, Juan \& PARDO, Rosa (coord.), La política exterior de España en el siglo XX, Madrid: Biblioteca Nueva, 1997, pp. 31-94.

NOORD, Fredrik, Den diplomatiska stormakten (La gran potencia diplomática), Karlstad: Karlstads Universitet, 2001.

NORMAN, Torbjörn, "Det brittiska alternativet: vägvalsfrågor i svensk utrikespolitik efter första världskriget" (La alternativa británica: opciones abiertas en la política exterior sueca después de la Primera Guerra Mundial), en \& CARLQUIST, Erik, Humanismen som salt och styrka (Acta Bibliothecae regiae Estocolmoiensis 45) Estocolmo: Atlantis, 1987, pp. 432-449.

OCHOA BRUN, Miguel Ángel, Embajadas y embajadores en la Historia de España, Aguilar, Madrid, 2002.

OLAYA MORALES, Francisco, La intervención extranjera en la guerra civil. Móstoles: Madre Tierra, 1990.

OTTOSSON, Ingemar, Krig i fredens intresse eller neutralitet till varje pris? Sverige, NF och frågan om kollektiv säkerhet 1935-36, (¿La guerra al servicio de la paz o neutralidad a toda costa? Suecia, la Sociedad de Naciones y la cuestión de la seguridad colectiva), Malmö: Liber/Gleerup, 1986.

PÁEZ-CAMINO, Feliciano: "Manuel Azaña y la política exterior de la Segunda República española”, en Boletín de la institución libre de enseñanza 10, 1990, pp. 69-78.

PALOMARES LERMA, Gustavo, "La política exterior española: de la Dictadura de Primo de Rivera a la Guerra Civil" en CALDUCH CERVERA, Rafael (coord.), La política exterior española en el siglo XX, Madrid: Ciencias Sociales, 1994, pp. 46-70.

PEREIRA CASTAÑARES, Juan Carlos (coord.), La política exterior de España: de 1800 hasta hoy (2 ed.), Madrid: Ariel, 2010.

—: La política exterior de España (1800-2003), Madrid: Ariel, 2003.

PEREIRA CASTAÑARES, Juan Carlos, "De la historia diplomática a la historia de las relaciones internacionales: algo más que un cambio de término", en Historia Contemporánea, n. 7, 1992, pp. 155-182. 
-: "La historia de las relaciones internacionales en España. Respuestas, propuestas y conclusiones", en Cuadernos de Historia Contemporánea. n. 18, Madrid: Universidad Complutense, 1996, introducción.

—: Introducción al estudio de la política exterior de España (siglos XIX y XX), Madrid: Akal 1983.

-: Las relaciones bilaterales entre España y la Gran Bretaña durante el reinado de Alfonso XIII (1919-1931), Madrid: UCM, 1986.

PEREIRA CASTAÑARES, Juan Carlos \& NEILA HERNANDEZ, José Luis, "La España de Alfonso XIII en el sistema internacional de la posguerra (1919-1931)", Historia Contemporánea 34, 2007, pp. 117-154.

PEREZ GIL, Luis V., Análisis de la política exterior de los Estados. Su aplicación a las relaciones exteriores de España durante el bienio republicano-socialista (19311933), La Laguna: Universidad de la Laguna, 2001.

PÉREZ RUIZ, José Luis, La depuración de la carrera diplomática española (1931-1980), Burgos: Dossoles, 2006.

PORTERO RODRÍGUEZ, Florentino, "España, el Reino Unido y la guerra fría”, en BALFOUR, Sebastian and PRESTON, Paul (eds.), España y las grandes potencias en el siglo XX. Barcelona: Crítica, 2002, pp. 162-178.

—: "Un siglo de política exterior", en La historia de las relaciones internacionales, Ayer n. 42, Madrid: Marcial Pons, 2001, pp. 253-262.

QUINTANA NAVARRO, Francisco, España en Europa, 1931-1936. Del compromiso de paz a la huida de la guerra, Madrid: Nerea, 1993.

-: "La política exterior española en la Europa de entreguerras: cuatro momentos, dos concepciones y una constante impotencia", en TORRE GÓMEZ, Hipólito de la (coord.) Portugal, España y Europa. Cien años de desafío (1890-1990), Madrid: UNED, 1991, pp. 64-65.

—: "Salvador de Madariaga, diplomático en Ginebra (1931-1936). La película de la política exterior de la Segunda República”, Historia Contemporánea 15, 1996. pp. 107-124.

RODRIGUEZ BALLANO, Elena, "Un socialista y una atalaya del SIDE en Berna", en VIÑAS, Ángel (coord.), Al servicio de la República: diplomáticos y guerra civil, Madrid: Marcial Pons, 2010, pp. 177-206.

RADOWITZ, Sven, Schweden und das Dritte Reich 1939-1945: die deutsch-schwedischen Beziehungen im Schatten des Zweiten Weltkrieges (Suecia y el III Reich 1939-1945: las relaciones germano-suecas a la sombra de la Segunda Guerra Mundial), Hamburgo: Krämer, 2005. 
RUSSELL, Roberto \& TOKATLIAN, Juan Gabriel, "Relaciones internacionales y política interna: los neutrales en la segunda guerra mundial, un estudio de caso", en Foro internacional núm.163, 2001, pp. 63-103.

SANTORO, Carlo Maria, La politica estera di una media potenza. L'italia dall'Unità ad oggi (La política exterior de una potencia media. Italia desde la Unificación hasta hoy), Bologna: Il Mulino, 1991.

SECO SERRANO, Carlos, "Alfonso XIII y la diplomacia española de su tiempo", en Corona y diplomacia: La monarquía española en la historia de las relaciones internacionales, Madrid: Biblioteca Diplomática Española, 1988, pp. 185-211.

SILANDER, Martin, "Debatten om NF och dess sanktionssystem - Vilhelm Lundstedt och hans antagonister", (El debate sobre la Sociedad de Naciones y su sistema de sanciones: Vilhelm Lundstedt y sus adversarios), trabajo fin de máster inédito, Halmstad: Högskolan i Halmstad, 2006.

SÖRBYE, Yngvild (coord.), Revolusjon, kjaerlighet, diplomati - Aleksandra Kollontaj og Norden, (Revolución, amor y diplomacia: Alexandra Kollontai y los países nórdicos), Oslo: Unipub 2008.

STEENE, Michael, "Role model or power pawn? - The changing image of Swedish foreign policy, 1929-1987", en SUNDELIUS, Bengt (coord.), The committed neutral: Sweden's foreign policy, Boulder: Westview Press, 1989, pp. pp. 167-194.

SUEIRO, Susana, "España, potencia mediterránea 1898-1930”, en España, Europa y el Mediterráneo, Bulletin d'Histoire Contemporaine de l'Espagne, n. 27, 1998, Aix-enProvence: Université de Provence, pp. 55-110.

SUNDELIUS, Bengt (coord.), The committed neutral: Sweden's foreign policy, Boulder: Westview Press, 1989.

SYDOW, Erik von, "Diplomatiska relationer mellan Estland och Sverige under mellankrigstiden”, (Las relaciones diplomáticas entre Estonia y Suecia en el período de entreguerras), en Estländare i Sverige: historia, språk, kultur (Estonios en Suecia: historia, idioma, cultura), Uppsala: Uppsala multiethnic papers, 1988, pp. 49-53.

TABANERA, Nuria, Ilusiones y desencuentros. Acción de la diplomacia Republicana en Hispanoamérica (1931-1939), Madrid, CEDEAL, 1996.

THORSELL, Staffan, Mein lieber Reichskanzler!: Sveriges kontakter med Hitlers rikskansli, (Mi querido Canciller del Reich: Los contactos de Suecia con la cancillería de Hitler), Estocolmo: Bonnier, 2006.

TINGSTEN, Herbert, Svensk utrikesdebatt mellan världskrigen (El debate sueco de política exterior entre las guerras mundiales), Estocolmo: Aldus/Bonnier, 1944/1964.

TORRE DEL RÍO, Rosario, "Recogimiento, crisis del 98 y nueva orientación internacional", en PEREIRA CASTAÑARES, Juan Carlos, La política exterior de 
España (1800-2003): historia, condicionantes y escenarios, Madrid: Ariel, 2003, pp. 421-435.

TUSELL, Javier \& GARCIA QUEIPO DE LLANO, Genoveva, El dictador y el mediador, Madrid: CSIC, 1986.

TUSELL, Javier, AVILÉS, Juan, \& PARDO, Rosa (coord.), La política exterior de España en el siglo XX, Madrid: Biblioteca Nueva, 1997.

VARGAS CARIOLA, Juan Eduardo, COUYOUMDJIAN, Juan Ricardo \& DUHART, Carmen Gloria, España a través de los informes diplomáticos chilenos, 1929-1939, Santiago de Chile: Ministerio de Relaciones Exteriores de Chile, 1994.

VIÑAS, Ángel, "Las relaciones hispano-francesas, el gobierno Daladier y la crisis de Munich", en Españoles y franceses en la primera mitad del siglo XX, CSIC, Madrid, 1986, pp. 161-202.

—: "Una carrera diplomática y un Ministerio de Estado desconocidos" en VIÑAS, Ángel (coord.), Al servicio de la República: diplomáticos y guerra civil, Madrid: Marcial Pons, 2010, pp. 267-424.

VIÑAS, Ángel, (coord.), Al servicio de la República: Diplomáticos y guerra civil, Madrid: Marcial Pons, 2010.

VV. AA., Ángel Sanz Briz: Homenaje a la memoria del Excmo. Sr. Embajador de España, Valladolid: Instituto de Estudios Europeos (Univ. de Valladolid), 2009.

ZETTERBERG, Kent, "Carl Hamilton", en ARTEUS, Gunnar \& LEIFLAND, Leif (coord.), Svenska diplomatprofiler under 1900-talet, Estocolmo: Probus, 2001, pp. 157-164.

ÅMARK, Klas, Makt eller moral: svensk offentlig debatt om internationell politik och svensk utrikes- och försvarspolitik 1938-1939 (Poder o moral: el debate público sueco sobre la política internacional y la política exterior y de defensa sueca de 1938 a 1939), Uddevala: Allmänna förlaget, 1973.

-: Att bo granne med ondskan. Sveriges förhållande till nazismen, Nazityskland och Förintelsen (Vivir con el mal como vecino. La relación de Suecia con el nazismo, la Alemania nazi y el Holocausto), Estocolmo: Bonniers, 2011.

\section{Segunda República y Guerra civil española}

ALBA, Víctor \& SCHWARTZ, Stephen, Spanish marxism versus Soviet communism: a history of the P.O.U.M. in the Spanish Civil War, Nueva Jersey: Transaction Publishers, 2009. 
ALEXANDER, Sally, "Women's voices in the Spanish Civil War", en Becoming a woman, Londres: Irago Press, 1994, pp. 171-181.

ALTED VIGIL, Alicia, GONZÁLEZ MARTELL, Roger \& MILLÁN, María José, El exilio de los niños, Madrid: FPI, 2003.

ÁLVAREZ, Santiago, Historia política y militar de las Brigadas Internacionales, Madrid: Compañía literaria, 1996.

ARÓSTEGUI, Julio \& GODICHEAU, Francois (eds.), Guerra civil: mito y memoria, Madrid: Marcial Pons, 2006.

AVILÉS FARRÉ, Juan, La izquierda burguesa y la tragedia de la II República, Madrid: Comunidad de Madrid. 2006.

-: "El contexto europeo: intervención y no intervención", en PAYNE, Stanley \& TUSELL, Javier (eds): La guerra civil, Madrid: Temas de Hoy, 1996, pp. 267-332.

—: Pasión y farsa: franceses y británicos ante la guerra civil española, Madrid, Eudema, 1994.

BAHAMONDE MAGRO, Ángel, "El mundo republicano durante la guerra civil: opciones y proyectos contrapuestos", Cuadernos republicanos 54, 2004, pp. 117-133.

BAHAMONDE MAGRO, Ángel \& CERVERA GIL, Javier, Así terminó la guerra de España, Madrid: Marcial Pons, 2000

BEEVOR, Antony, La guerra civil española, Barcelona: Crítica, 2005.

BERDAH, Jean- François, La democracia asesinada: la República española y las grandes potencias, 1931-1939, Barcelona: Critica, 2002.

BERG, Angela, Die Internationalen Brigaden im Spanischen Bürgerkrieg 1936 - 1939, Essen: Klartext, 2005.

BOLloteN, Burnett, La Guerra Civil española: Revolución y Contrarrevolución, Madrid: Alianza Editorial, 1997.

CARASA SOTO, Pedro, MARCOS DEL OLMO, María de la Concepción, MARTÍNEZ FERNÁNDEZ Manuel, MARTÍN DE LA GUARDIA Ricardo M. \& PÉREZ SÁNCHEZ, Guillermo A., Alfonso XIII y la Segunda República 1898-1936, Madrid: Gredos, 1991.

CASANOVA, Julián (coord.), Tierra y Libertad. Cien años de anarcosindicalismo en España, Barcelona: Crítica, 2010.

CATELL, David Tredwell, Communism \& the Spanish Civil War, New York, 1965. 
CERVERA, Javier, Madrid en guerra: La ciudad clandestina, Madrid: Alianza Editorial, 2006.

CIERVA, Ricardo de la, Brigadas Internacionales 1936-1939, Madridejos, Toledo, 1997.

CORDERO OLIVERO, Inmaculada \& LEMÚS, Encarnación, "La internacionalización de la guerra civil española (1936-1939)", en PEREIRA CASTAÑARES, Juan Carlos, La política exterior de España: de 1800 hasta hoy, Madrid: Ariel, 2010, pp. 609-629.

ELORZA, Antonio \& BIZCARRONDO, Marta, Queridos camaradas: La internacional comunista y España, Barcelona: Planeta, 1999.

ERICSON WOLKE, Lars, "Frivilliga i strid" (Voluntarios en guerra), en Populär historia 2006:7/8, pp. 32-36.

ESPADAS BURGOS, Manuel, "El contexto de una conmemoración", en REQUENA GALLEGO, Manuel (coord.) La guerra civil española y las brigadas internacionales, Cuenca: Universidad de Castilla-La Mancha, 1998, pp. 15-28.

FÖRSVARSSTABEN (Estado Mayor del Ejército sueco), Det spanska inbördeskriget I - II (La guerra civil española I y II), Estocolmo: Militärlitteraturföreningens förlag, 1938 y 1942.

GONZÁLEZ CALLEJA, Eduardo \& NAVARRO COMAS, Rocío (coord.), La España del Frente Popular. Política, sociedad, conflicto y cultura en la España de 1936, Granada: Comares, 2011.

HEIBERG, Morten \& ROS AGUDO, Manuel, La trama oculta de la guerra civil. Los servicios secretos de Franco, 1936-1945, Barcelona: Crítica, 2006.

HOWSON, Gerald, Armas para España. La historia no contada de la guerra civil española, Barcelona: Península, 2000.

JACKSON, Michael W., Fallen sparrows: the international brigades in the Spanish Civil War, Philadelphia: American Philosophical Society, 1994.

JULIÁ, Santos, (coord.), República y Guerra en España (1931-1939), Madrid: Espasa, 2006.

JÄNDEL, Richard, HELGESON, Patrik \& Weijdegård, Nils, (coord.), No pasaran!: Spanska inbördeskriget och uppgörelsen med fascismen (¡No pasarán! La guerra civil española y la confrontación con el fascismo), Svenska Spanienfrivilligas vänner, 2008-

JÄNDEL, Richard, Kämpande solidaritet, (Solidaridad en lucha), Estocolmo: Arbetarnas kulturhistoriska sällskap och Arbetarrörelsens arkiv och bibliotek, 1996. 
JÖNNSON, Claes-Göran, "SKP och den svenska spanienrörelsen" (El partido comunista sueco y el movimiento a favor de España), en Arkiv, 4, Lund: Sociologiska Institutionen, 1973.

KEENE. Judith, Fighting for Franco: International volunteers in Nationalist Spain during the Spanish Civil War 1936-1939, Londres/Nueva York: Leicester University Press, 2001.

KVALØY, Arve, Norske frivillige $i$ den spanske borgekrig (Voluntarios noruegos en la guerra civil española), Oslo: Universidad de Oslo, 1996.

LUENGO TEIXIDOR, Félix, Espías en la Embajada. Los servicios de información secreta Republicanos en Francia durante la guerra civil, Bilbao: Universidad del Pais Vasco, 1999.

MARQUINA BARRIO, Antonio, "Planes internacionales de mediación durante la Guerra Civil”, en Revista de Estudios Internacionales, volumen 5, núm. 3, 1984, pp. 569591.

MESA, José Luis de, Los otros internacionales: voluntarios extranjeros desconocidos en el bando nacional durante la guerra civil (1936-1939), Madrid: Barbarroja, 1998.

MORADIELLOS, Enrique, El reñidero de Europa: las dimensiones internacionales de la Guerra Civil española, Barcelona: Península, 2001.

—: La perfidia de Albión: El gobierno británico y la Guerra Civil Española, Madrid: Siglo XXI, 1996.

-: "El mundo ante el avispero español: intervención y no-intervención extranjera en la Guerra Civil”, en JULIÁ, Santos, (coord.), República y Guerra en España (19311939), Madrid: Espasa, 2006, pp. 287-362.

MORAL RONCAL, Antonio Manuel, "The Allies and the Spanish Civil War", en BALFOUR, Sebastian \& PRESTON, Paul, (coord.), Spain and the Great Powers in the Twentieth Century, Londres: Routledge, 1999, pp. 96-126.

NORLING, Erik, “¡Viva la República! Voluntarios suecos en la Guerra Civil española”, Historia Militar, octubre 2005, pp. 127-133.

OLSSON, Folke, "Solidaritetens soldater" (Los soldados de la solidaridad), en HELGESON, Patrik; JÄNDEL, Richard \& WEIJDEGÅRD, Nils, (coord.), No pasaran!: Spanska inbördeskriget och uppgörelsen med fascismen (¡No pasarán! La guerra civil española y la confrontación con el fascismo), Linköping: Nixon, 2008, pp. 153-213.

OTHEN, Christopher, Las brigadas internacionales de Franco (General Franco's international brigades), Barcelona: Destino, 2007. 
PAYNE, Stanley \& TUSELL, Javier, La guerra civil: una nueva visión del conflicto que dividió España, Madrid: Temas de Hoy 1996.

PAYNE, Stanley, La primera democracia española: la Segunda República, 1931-1936. Barcelona: Paidos Ibérica, 1995.

PERSSON, John E., "Vapensmugglaren från Surte" (el contrabandista de Surte), en Nautisk Tidskrift 7/1999.

PETROU, Michael, Renegades: Canadians in the Spanish Civil War, Vancouver: University of British Columbia Press, 2008.

PORTERO RODRÍGUEZ, Florentino, Franco aislado. La cuestión española, 1945-50, Madrid: Aguilar, 1989.

PRESTON, Paul, We saw Spain die: foreign correspondents in the Spanish Civil War, Nueva York: Skyhorse Publishing, 2009.

—: Revolución y guerra en España, 1931-1939, Madrid: Alianza, 1986

—: La guerra civil española: reacción, revolución y venganza, Barcelona: De Bolsillo, 2011.

RADOSH, Ronald, HABECK, Mary \& SEVOSTIANOV, Grigory (Eds.), España traicionada, Barcelona: Planeta, 2002.

REES, Tim \& THORPE, Andrew (coord.), International Communism and the Communist International, 1919-1943, Manchester: Manchester University Press, 1998

RICHARDSON, Dan, Comintern Army: The International Brigades and the Spanish Civil War. Lexington: University Press of Kentucky, 1982.

ROBERTS, Geoffrey, “Soviet Foreign Policy and the Spanish Civil War 1936-1939”, en LEITZ, Christian \& DUNTHORN, David J., Spain in an International Context, 1936-1959, Nueva York: Berghan Books, 1999, pp. 81-103.

RODRÍGUEZ DE LA TORRE, Fernando, Bibliografía de las Brigadas Internacionales y de la participación de extranjeros a favor de la República (1936-1939), Albacete: Instituto Estudios Albaceteños, 2006.

RUBIO, Javier, Asilos y canjes durante la guerra civil española, Barcelona: Planeta, 1979.

RUIZ-MANJÓN, Octavio, "La vida política en el segundo bienio republicano", en JULIÁ, Santos (coord.), República y Guerra en España (1931-1939), Madrid: Espasa, 2006, pp. 83-85.

SALAS LARRAZÁBAL, Jesús, Intervención extranjera en la guerra de España, Madrid: Editora Nacional, 1974. 
SCHIEDER, Wolfgang \& DIPPER, Christoff, Der Spanische Bürgerkrieg in der internationalen Politik (1936-1939) (La guerra civil española en la política internacional), Munich: Nymphenburger Verlagshandlung, 1976.

SEIDMAN, Michael, Republic of egos: a social history of the Spanish Civil War, Madison: Univ of Wisconsin Press, 2002.

SEPÚLVEDA LOSA, Rosa María, Las brigadas internacionales. Imágenes para la historia, Albacete: Universidad de Castilla-La Mancha, 2006.

SKOUTELSKY, Rémi, Novedad en el frente: las brigadas internacionales en la guerra civil española, Madrid, 2006.

TAGÜEÑA LACORTE, Manuel, Testimonio de dos guerras, Barcelona: Planeta, 2005.

THOMAS, Hugh, La guerra civil española, Barcelona: De Bolsillo, 2003.

VIDAL, César, Las Brigadas Internacionales, Madrid: Espasa, 1998.

VIÑAS, Ángel, La soledad de la República. El abandono de las democracias y el viraje hacia la Unión Soviética, Barcelona: Crítica 2006.

-: El escudo de la República. El oro de España, la apuesta soviética y los hechos de mayo de 1937, Barcelona: Crítica, 2007.

—: El honor de la República. Entre el acoso fascista, la hostilidad británica, y la política de Stalin. Barcelona: Crítica 2009.

—: El oro de Moscú: Alfa y Omega de un mito franquista, Barcelona: Grijalbo, 1979.

WEICKERT, Eugen, Frihetens soldater (Los soldados de la libertad), Malmö: Acupress, 1974.

WEIJDEGÅRD, Nils, "Spanienhjälpen - några minnesbilder" (La Ayuda a España: algunos recuerdos) en HELGESON Patrik, JÄNDEL Richard, WEIJDEGÅRD Nils (coord.), No pasaran!: spanska inbördeskriget och uppgörelsen med fascismen (¡No pasarán! La guerra civil española y la confrontación con el fascismo), Linköping: Nixon, 2008, pp. 110-122. 



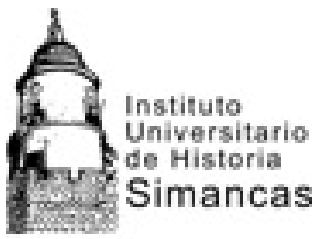

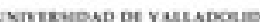

Instituto Universitario de Historia Simancas

Valladolid University

European Doctorate program "Europe \& the Atlantic world: power, culture and society" PhD-thesis with International distinction

Author: Benito Peix Geldart

Directors: Dr. José-Vidal Pelaz López \& Dr. Lars Berggren

\section{POLITICAL AND DIPLOMATIC RELATIONS BETWEEN SPAIN AND SWEDEN 1931-1939}
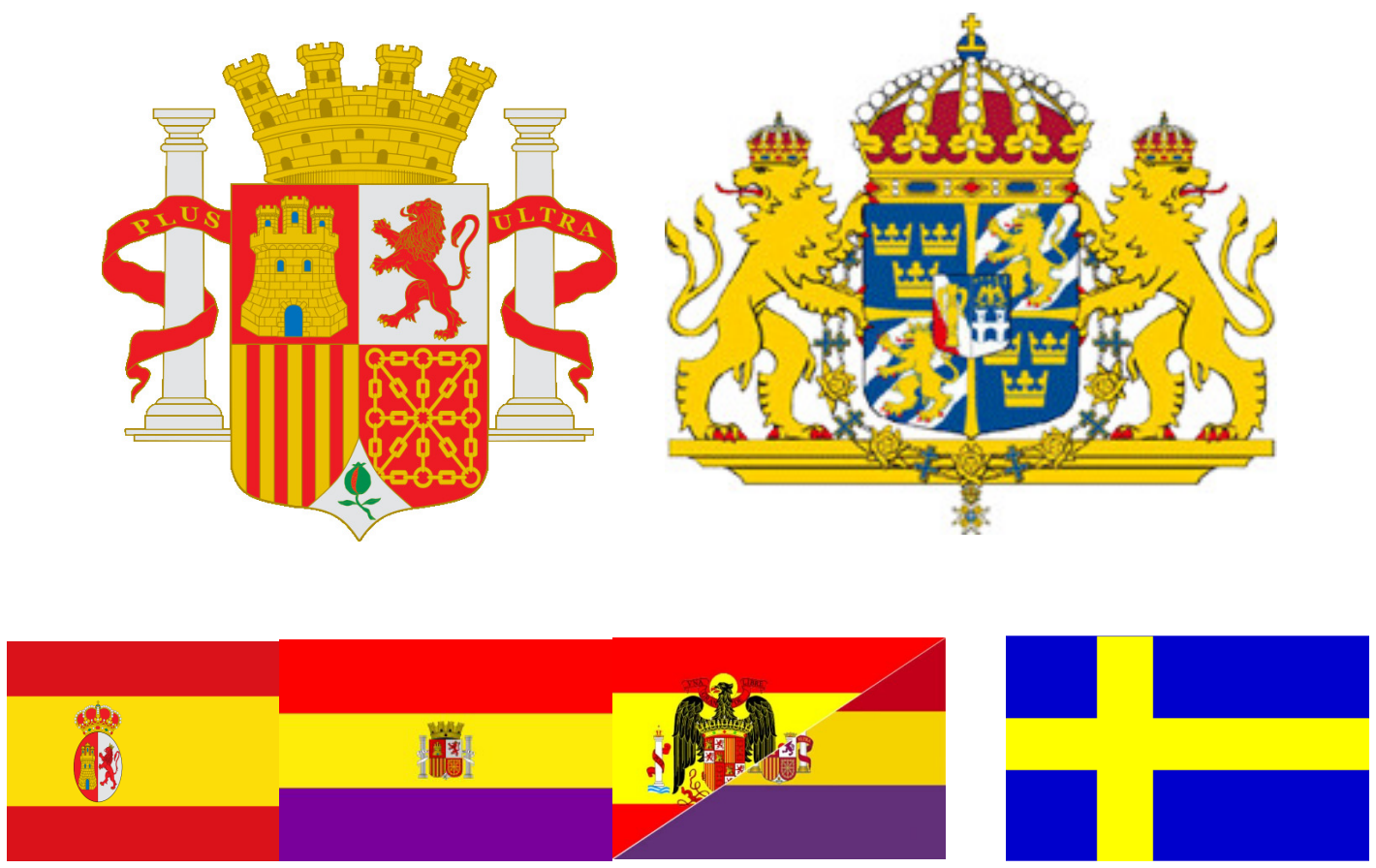

ENGLISH SUMMARY 



\section{TABLE OF CONTENTS}

TABLE OF CONTENTS

ABSTRACT 9

$\begin{array}{ll}\text { ABBREVIATIONS } & 11\end{array}$

$\begin{array}{ll}\text { INTRODUCTION } & 13\end{array}$

Chapter 1

GENERAL APPROACH AND GUIDELINES $\quad \mathbf{1 5}$

$\begin{array}{lr}\text { 1.1. General approach and purpose of this study } & 15\end{array}$

$\begin{array}{ll}\text { 1.2. Theoretical and methodological framework } & 20\end{array}$

1.2.1. Possibilities and problems of comparative history and history of international relations 20

$\begin{array}{ll}\text { 1.2.2. Methodological options } & 26\end{array}$

1.2.3. Clarifications of concepts and terminology 32

1.3. Sources for the study of the relations between Spain and Sweden from 1931 to 193934

$\begin{array}{ll}\text { 1.4. Outline of the current study } & 40\end{array}$

Chapter 2

HISTORICAL CONTEXT AND PREVIOUS RESEARCH ON THE TOPIC 43

2.1. Swedish-Spanish relations throughout history 43

2.1.1 Sweden and Spain until 1900

2.1.2 Sweden and Spain from 1900 to $1930 \quad 49$

2.2. Swedish-Spanish relations from 1931 to 1939 in Swedish historical research 58

2.3. Swedish-Spanish relations from 1931 to 1939 in Spanish historical research 63

$\begin{array}{lr}\text { 2.4. Main contributions of foreign historical research } & 68\end{array}$

\section{PART I}

REPUBLIC IN SPAIN, SOCIAL DEMOCRACY IN SWEDEN

\section{Chapter 3}

THE SPANISH REPUBLIC 1931-1936 AS SEEN BY SWEDISH DIPLOMATS 75

3.1. The Swedish Legation in Madrid. The Plenipotentiary Ministers of Sweden in Spain 75

3.2. Spanish domestic policy from 1931 to 1936 according to Swedish diplomats 80

3.2.1. The eve of the Republican era and the change of political regime 80

3.2.2. Spain's politics during the first Republican period (1931-1933) 89

3.2.3. Spain's politics during the second Republican period (1933-1936) 106 
3.3. Specific concerns of Swedish diplomacy towards Spain (1931-1936)

3.3.1. The growth of communism and Spain's relations with the USSR

\section{Chapter 4}

\section{SWEDEN BETWEEN 1931 AND 1936 AS SEEN BY SPANISH DIPLOMATS 139}

4.1. The Spanish Legation in Stockholm. The Plenipotentiary Ministers of Spain in Sweden 139

4.2. La política interior sueca de 1931 a 1936 según la diplomacia española 144

4.2.1 Swedish domestic politics until the rise to power of the Social Democratic Party 144

4.2.2. Swedish domestic politics under the rule of Per Albin Hansson (1932- 1936) 151

4.3. Specific concerns of Spanish diplomacy regarding Sweden (1931-1936) 163

4.3.1. Sweden's Defense politics 163

4.3.2. Sweden's attitude to Nazism and Hitler's Germany 169

4.4. Swedish foreign policy from 1931 to 1936 according to Spanish diplomats 180

4.4.1. Overview of Swedish foreign policy 1931-1936 180

4.4.2. Swedish cooperation with the other Nordic countries 186

4.4.3. Swedish relations to some specific countries between 1931 and $1936 \quad 190$

\section{Chapter 5}

BILATERAL RELATIONS BETWEEN SPAIN AND SWEDEN 1931-1936

5.1. Sweden and the change of political regime in Spain

5.1.1 Recognition by Sweden of the Spanish Republican government 199

5.1.2. Former King Alphonse XIII and Suecia after the introduction of the Republic 205

5.2. Spanish-Swedish cooperation within the League of Nations 211

5.2.1. Neutrality and pacifism as common key foreign policy issues in both Spain and Sweden 211

5.2.2. Spanish-Swedish joint initiatives for peace: The "group of neutrals" 214

5.3. Specific bilateral issues between Spain and Sweden 235

5.3.1. The image of Spain in Sweden and vice versa 235

5.3.2. The running of Swedish-Spanish bilateral diplomatic affairs 242

5.4. Contacts between Spanish and Swedish politicians and Union leaders 250

\section{PART II}

WAR, INTERVENTION AND NON INTERVENTION

\section{Chapter 6}


6.3. Sweden's diplomatical relations with the Spanish Republic 1936 - 1939282

6.3.1. The activities of the Swedish Legation in Madrid 283

6.3.2. The activities of the Spanish Legation in Stockholm 289

6.4. Swedish politics as seen by Spanish diplomats 301

6.4.1 Swedish domestic politics 1936 - 1939

6.4.2. Swedish foreign policy 1936 - 1939

\section{Chapter 7}

\section{SWEDEN AND FRANCO'S SPAIN 1936 - 1939}

7.1. Swedish diplomacy regarding Franco's Spain until the exchange of agents 313

7.1.1 Information on Franco's Spain provided by Swedish diplomats 314

7.1.2 Sweden's bilateral issues and conflicts with Franco's Spain 319

7.2 The exchange of agents between Sweden and Franco's Spain 326

7.2.1 The lobbying activities of Swedish industrial and business circles for Franco's Spain 327

7.2.2 The diplomatic negotiations on the exchange of agents 332

7.2.3 Sweden's agent in Burgos and the official recognition of Franco's government by Sweden 340

7.3. The activities of Franco's representatives in Sweden 346

7.4. Diplomatic relations between Sweden and Spain from April 1 to December 31, 1939

\section{Chapter 8}

SWEDEN'S INTERVENTION IN THE SPANISH CIVIL WAR

8.1. Swedish humanitarian aid to Spain during the war 371

8.1.1 Diplomatic asylum and mediation in exchange of war prisoners 371

8.1.2 The Swedish material aid to Spain during the war 379

8.2. The Swedish military aid to Spain during the war 391

8.2.1. Swedish Volunteers in the service of the Spanish Republic 391

8.2.2. Swedish volunteers serving Franco's Spain 405

8.2.3. Swedish military equipment in the Spanish Civil War 408

CONCLUSIONS $\quad 421$

APPENDICES

$\begin{array}{ll}\text { SOURCES } & 477\end{array}$

$\begin{array}{ll}\text { UNPRINTED SOURCES } & \mathbf{4 7 9}\end{array}$

1. Spanish Archives $\quad 479$

2. Swedish Archives 479

PRINTED SOURCES, DIARIES AND MEMOIRS

NEWSPAPERS AND MAGAZINES $\quad 484$ 
1. On general issues, historical theory and methods 487

2. On Swedish history 489

3. On Swedish-Spanish relations 494

4. On foreign policy and Swedish-Spanish diplomatical relations 500

5. On the Second Spanish Republic and the Spanish Civil War 508

ENGLISH SUMMARY $\quad 515$

TABLE OF CONTENTS

NOTE TO THE ENGLISH SUMMARY $\quad 520$

$\begin{array}{ll}\text { INTRODUCTION } & 521\end{array}$

SUMMARY OF PART I AND PART II (CHAPTERS 3 - 8) 573

$\begin{array}{ll}\text { CONCLUSIONS } & 591\end{array}$

\section{NOTE TO THE ENGLISH SUMMARY}

According to Valladolid University regulations concerning doctoral dissertations "with International distinction", a summary comprising at least the table of contents, the conclusions and a short review of all the chapters in between should be written in one of the languages that are commonly used in scholarly work. Apart from these parts, I have opted to provide a full translation of Chapters 1 and 2, to help international readers get a better view of the current study. However, please note that this English summary is just a summary. It is important to keep this in mind, as the conclusions are not grounded on the English summary but on the original Spanish text, where all the details and a more thorough analysis are provided. 


\title{
INTRODUCTION
}

\section{Chapter 1}

\section{GENERAL APPROACH AND GUIDELINES}

\begin{abstract}
Lack of mutual knowledge and understanding has been the main problem in Swedish-Spanish relations during the 20th Century (...). Bearing this in mind, further investigation and a better knowledge of the history of both countries is paramount for the development of deeper and ever better relations ${ }^{l}$
\end{abstract}

\subsection{General approach and purpose of this study}

The quoted words from Swedish diplomat Berndt Fredriksson have been inspirational for this study. Sweden and Spain are two European countries with many issues in common but also far from one another due to differences in mentality, temperament, and lack of mutual understanding.

A vast majority of the existing studies dealing with Swedish-Spanish relations focus on the differences and the distance between the two countries on a cultural rather than a geographical level. Both share, nonetheless, a common ground in a European context because of their geographical location, which places them on a peripherical position in the life of the Continent.

This fact is uncontroversial in Sweden, and it is assumed as plain fact by most Swedes. Even today, when more than 20 years have elapsed since the moment Sweden joined the European Union, it is quite common in Sweden to use the word "Europe" to refer to Central and Western Europe, not including Scandinavia or the Southern European - "Mediterranean" - countries.

Things are a bit different in Spain, where, for obvious historical reasons, many people including academics feel reluctant to considering their country as belonging to Europe's "periphery". Instead, there has been, and still is, a general understanding of Spain as a country that belongs to the very core of Europe.

\footnotetext{
${ }^{1}$ FREDRIKSSON, Berndt., "La historia de las relaciones bilaterales entre Suecia y España. Embajadores suecos en España”, en MAQUEDA ABREU, Consuelo, (coord.), Poder, derecho y legislación, Madrid: UNED, Marcial Pons y Fundación Berndt Wistedt, 2001, pp. 45-77, p. 75.
} 
For this reason, many Spanish scholars prefer the word "semi-peripherical", as suggested by Immanuel Wallerstein ${ }^{2}$, to refer to Spain in a European context.

This difference of approach notwithstanding, it is in our opinion perfectly legitimate, both from a geographical and a historical point of view, to use the term "peripherical" in connection with both Sweden and Spain in the last 200 years. The term is used here in the same sense Roberto Russell and Juan Gabriel Tokatlian do:

The peripherical condition includes a geographical aspect - countries located far off the centre of power in an international context - a political aspect -countries with limited possibilities to autonomous decisions in a foreign policy context - and a military aspect strategically irrelevant areas from the point of view of the most powerful actors in the international scene ${ }^{3}$.

Despite Sweden's and Spain's geographical and cultural distance from one another, both shared a common feature in the 1910's, namely their condition of neutral Powers in the Great War. Their similar status in international politics would bring the countries closer together as they shared a common interest: the need to develop a policy towards the greater powers, which would meet the political and economical needs of their countries.

The lack of a wide range of comparative history studies between Sweden and Spain for this important period, the interwar period, is quite surprising ${ }^{4}$.

Tortella analysed from a comparative point of view the modernization processes in both geographical areas, insisting on what Sweden and Spain had in common: both were the largest country (except Russia) in their near environment, the Baltic or the Mediterranean; both were important mining countries, especially in iron ore, a product they were two of the leading exporting nations in the $19^{\text {th }}$ Century. Both countries entered the $20^{\text {th }}$ Century with a diminished economical power, and there was a blatant disproportion

\footnotetext{
${ }^{2}$ WALLERSTEIN, Immanuel, World-systems analysis: an introduction, Duke University Press, 2004.

${ }^{3}$ RUSSELL, Roberto \& TOKATLIAN, Juan Gabriel, "Relaciones internacionales y política interna: los neutrales en la segunda guerra mundial, un estudio de caso", en Foro internacional, núm. 163, 2001, pp. 63103.

${ }^{4}$ There are a few exceptions to this rule SCHMITT, Hans A. (coord.), Neutral Europe between war and revolution, Charlottesville: University of Virginia Press, 1988 and JERNECK, Magnus; MÖRNER, Magnus; TORTELLA, Gabriel \& ÅKERMAN, Sune (coord.), Different paths to Modernity: A Nordic and Spanish perspective, Lund: Nordic Academic Press, 2005. This is probably the most detailed comparative history study of Sweden and Spain in our times.
} 
between the amount of their natural resources and their political and military weight in a European context ${ }^{5}$.

Furthermore, there was also a similar social and political upheaval in both Sweden and Spain in 1917, as a consequence of the impact of the Great War in the neutral countries ${ }^{6}$.

On the other hand, there are obvious contrasts and differences between both countries, such as Sweden's homogeneity vs. Spanish regional diversity, Sweden's longer democratic tradition and, unlike Spain, the primacy of the ideal of consensus.

In recent years, there has been a minor renaissance in the field of comparative history studies. It is not an easy field of study, but its importance cannot be overrated, as comparative history studies often make important contributions to historical research by presenting new perspectives that are seldom possible in ordinary studies only based on local or national sources.

A certain amount of research papers on Swedish-Spanish relations have appeared lately, as a result of a Swedish Government initiative through the Swedish Ambassador to Spain in the 1990s, Tomas Bertelman, who launched the idea of the so-called SwedishSpanish Historical Encounters ("Encuentros históricos Suecia-España") 7 .

Nevertheless, the Encounters focused on Early Modern History rather than on Contemporary History. In fact, there are very few papers on Swedish-Spanish relations in the $20^{\text {th }}$ Century, and all these deal in one way or another with the Spanish Civil War. The years of the Primo de Rivera Dictatorship and the Spanish Republican experience remain

\footnotetext{
${ }^{5}$ TORTELLA, Gabriel, "Sweden and Spain - Different Paths towards Modernity?" in JERNECK, Magnus; MÖRNER, Magnus; TORTELLA, Gabriel \& ÅKERMAN, Sune (coord.), Different paths to Modernity: A Nordic and Spanish perspective, Lund: Nordic Academic Press, 2005, pp. 18-30;

${ }^{6}$ KOBLIK, Steven, "Sweden, 1917: Between reform and Revolution", en SCHMITT, op.cit., pp. 111-132; MEAKER, Gerald H., "A civil war of words: The ideological impact of the First World War on Spain, 19141918”, en SCHMITT, Hans A. (coord.), op. cit., pp.1-65. The comparison of the social unrest in Sweden and Spain with the Russian Revolution which is suggested by these scholars seems nevertheless a little far fetched. The Swedish 1917 events (divisions within the Social Democratic party, access of this party to shared political power for the first time, the limits imponed on the Powers of the Crown, etc.) are certainly far from being revolutionary by Russians standards. The same applies to the events in Spain, (demonstrations, riots with Army officers involved, general strike, Cabinet crisis, etc), even though the level of social upheaval was greater than in Sweden.

${ }^{7}$ The meetings were organised under the auspices of the Berndt Wistedt Foundation, with the participation of several Universities and a great number of public and private organisations of both countries, including the National Governments and, in Spain, even the Regional Authorities. Coordinatoors were Swedish retired Professor Mörner from Gothemburg University and Professors Enrique Martínez Ruiz and Magdalena de Pazzis Pi Corrales, from Madrid Complutense University.. These encounters were very successful and, as a whole, have made a great contribution to the history of the Swedish-Spanish relations. Several of the papers published through these Encounters are relevant to our study and will consequently appear in these pages later on.
} 
mostly unstudied as far as Swedish-Spanish relations are concerned. There is also very little research on the Franco years, in spite of the huge amount of available sources in Swedish Archives. Future research projects on these topics, therefore, will have to start almost from scratch.

It is also somewhat strange that no mention is made of Swedish-Spanish diplomatic relations before 1979 in the official web pages of the Foreign Ministries of both countries. This confirms the fact that the topic of this study is basically unexplored in historical research thus enhancing the need for research work on the issue.

The purpose of this study is the analysis of the political and diplomatic relations between Sweden and Spain in the 1930s.

Hopefully, the study of the Swedish and Spanish diplomatic documents of the time will offer valuable contributions towards a better understanding of the historical development of both countries in the 1930s, concerning both domestic and foreign policy. It would thereby fill a gap in Swedish and Spanish historical research on that decade; a gap that is quite striking considering that Sweden was one of the leading countries, in relative terms, to provide humanitarian aid to the Spanish Republic in its most trying years.

This analysis of Swedish-Spanish diplomatic relations in these crucial years in modern history will focus on several questions about both countries that are worth a closer look:

Concerning Spain: What vision did Swedish diplomacy provide of the political development of Republican Spain during the period 1931-1936, and of the vicissitudes of the three-year-long Civil War that was its tragic climax? What aspects of Spanish political life especially interested Swedish diplomats in Spain, and why? What did Swedish diplomats think of Spanish foreign policy during those years?

One aspect to consider in each question is the consistency or otherwise of the Swedish image of Spain at the time with the data provided by Spanish historical research.

Concerning Sweden: What image did Spanish diplomats in Sweden give of the Scandinavian country's transformation, during the period in question, into one of the first welfare states in the world? What issues did Spanish diplomacy focus on, and why? How did Spanish diplomats value Sweden's foreign policy, especially within the League of Nations? Similarly to the above for Spain, one wonders if the image that Spanish diplomats gave about Sweden confirms or denies the vision of the period in Swedish historical research. 
A third group of questions deals with the bilateral relations between Sweden and the Spanish Republic: How were these bilateral relations? What kind of cooperation was developed between Sweden and Spain as members of the League of Nations, and in which fields did they primarily collaborate? What about Sweden's relations with the Spanish Republic during the Civil War? How did Sweden support the Republic at war? Were there any conflicts between Sweden and the Spanish Republic?

Finally, a fourth group of questions focuses on Sweden's relations with Franco's Spain: Were there any relations between Sweden and Franco's Spain from July $18^{\text {th }}, 1936$ to the end of the decade? What help did Franco's Spain get from Sweden during the Civil War, if any? Was there any major conflict between Sweden and Franco's Spain?

The activities and performance of the Spanish Legation and the Spanish diplomats in Sweden, and that of their Swedish counterparts in Spain, during the 1930s will be specifically dealt with, and some reference will also be made to the non-institutional contacts between politicians and Union leaders of the two countries insofar they are on record in Swedish or Spanish diplomatic documents.

To do this, the available sources in the archives of the Foreign Ministries of both countries, Swedish UD (Utrikesdepartementet) and Spanish AMAEC (Ministry of Foreign Affairs and Cooperation) will be analysed. For the study of the Swedish intervention in the Spanish Civil War, even primary sources contained in other Swedish and Spanish archives, both civil and military, will be researched.

\subsection{Theoretical and methodological framework}

Before moving forward to the analysis and discussion of the sources available on the relations between Spain and Sweden in the 1930s and presenting the state of affairs in Swedish and Spanish history research, the theoretical and methodological assumptions of this study will be outlined.

\subsubsection{Possibilities and problems of comparative history and history of international relations}

This paper has an interdisciplinary character. It could hardly be otherwise when dealing with the international relations between two European countries in the $20^{\text {th }}$ 
Century, a topic straddling Modern history, Public International Law and the History of International relations.

This kind of studies became rare in the second half of the $20^{\text {th }}$ Century. Many historians considered the study of the history of political and diplomatic relations as an outdated topic, which should have no room in the modern historical debate on the purpose and scope of History. Indeed, not infrequently, even today, diplomatic relations as a research subject were seen as an obsolete item, typical of a forlorn historiography for which the rise of nations and their political history seemed the only topic worth a historian's efforts.

Traditional historiography emphasized power relations between States, in which diplomacy was seen as the appropriate instrument in the hands of the authorities concerned to put across in the international scene their own insights and their national interests. It is also a fact that, from a methodological point of view, research has generally followed conventional methods, often of a quantitative rather than a qualitative nature, when studying the documentation generated by Embassies and Foreign ministries.

Very often, the focus has been laid on the analysis of intentions and the degree of compliance with the Foreign policy objectives of each country, neglecting all other aspects. This has led to a situation where the History of International Relations has landed in no man's land, somewhere between History and Social Sciences such as Political Science, Sociology, and Public International Law, with a predominance of methods proper to the latter. This can be observed, for instance, in the primacy of a theoretical framework placing power relations as the key perspective, or in the application of the "rational actor theory" as the only adequate and available one. This has happened in Sweden and, perhaps even to a larger extent, in Spain.

The rise of economic and social history and of new methodological prospects focusing on class, gender, generation, ethnicity or micro history, during the second half of the last Century, together with theoretical and methodological approaches based on discourse analysis and postmodernist theories put forward by authors such as Foucault or Ricoeur, has led to a sharp decline of studies on the history of international relations, both in Sweden and in Spain.

This phenomenon is especially evident in Sweden, where research on political history has been more or less wiped out from the History Departments of most Universities. There are exceptions that emphasise the rule, but it is a fact that historical 
research is predominantly centred on conceptual analyses of mentality changes and social and gender topics concerning mostly the period from the First World War to the end of the $20^{\text {th }}$ Century.

This is also reflected in the organization of the History Departments at Swedish Universities: There are practically no Chairs on Ancient, Medieval, Modern or Contemporary History. Although it is not a general rule, chairholders often bear the general title of Professor of History, with the addition, in some cases, of the clause "especially history of..." Common specialities are gender history, sports history, history of labour relations, environmental history, social history, local history, history didactics, and even, in some cases, what has been called "early history" (äldre historia), which includes all history before 1750 .

In general, one could say that while in Spain the material aspects of history, which require specialization in the area of knowledge and historical period involved, are still largely present in history research projects, formal aspects have prevailed in Sweden, with an insistence on the theoretical framework rather than in the empirical data. There is consequently less need for chronological or thematic specialization. In other words, while Spanish historians are experts in a specific historical era, their Swedish counterparts are "generalists" with a developed expertise in the application of theories and historical methods to their research subject regardless of the period of research.

Accordingly, courses on the Theory and Methodology of History have been particularly relevant in the curriculum in historical studies within Swedish universities for decades. There are, however, some signs of a change of trend nowadays, and some quite forgotten areas like medieval history are beginning to thrive.

The history of international relations has not been a booming field of study in Spain either. Except for the Revista de Estudios Internacionales (Review of International Studies of the Centro de Estudios Constitucionales), the Cuadernos de Historia Moderna y Contemporánea (Journal of Modern and Contemporary History) of Madrid Complutense University and Espacio, Tiempo y Forma (Space, Time and Form), articles on the subject have been rare before the 1990s. It is striking, moreover, that a country like Spain does not even have a collection of diplomatic documents as there are in other countries of the Western world ${ }^{8}$.

\footnotetext{
${ }^{8}$ MORALES LEZCANO, Víctor, "Historia de las relaciones internacionales: España contemporánea" en Revista de Estudios Internacionales Vol. 7. Núm. 2. Abril-junio 1986, pp. 575-582.
} 
A change took place after the creation in 1992 of the Comisión Española de la Historia de las Relaciones Internacionales (Spanish Commission for the History of International Relations), resulting in a growing interest in the subject. At the "Primeras Jornadas sobre Historia de las Relaciones Internacionales" (First Conference on the History of International Relations), in 1994, Pereira Castañares clearly stated some basic aspects to be taken into account and thoroughly discussed, such as the main subject of the history of international relations, the selection of a number of themes to develop, the international aspects and the methodological issues involved ${ }^{9}$.

Earlier this Century, Neila Hernandez provided a good overview of the development of the history of international relations in different countries (Spain, France, UK, Germany, Italy, etc.). After some theoretical considerations concerning the role of history within the "International Social Sciences", this scholar presented the main theoretical contributions in this field, illustrating well the transition from traditional 'diplomatic history', of strong historicist flavour, to the modern 'history of international relations', as well as the attempts to overcome the State paradigm which, nevertheless, has remained dominant ${ }^{10}$.

There are obviously different approaches to our field of study, as the participation in the 1994 Conference of several experts from outside Spain clearly manifested. This was pointed out by Moreno Juste:

The close collaboration between researchers with different national, educational and ideological backgrounds appears to be particularly suitable for the study of the history of international relations, which necessarily involves personal and ideological aspects, where different methodological approaches and interpretations of recent events, and even different conceptions of history itself, coexist side by side (...)

The debate on the situation of the History of international relations in each country seems nevertheless to share a common ground, namely the connection of methodological problems to epistemological gaps ${ }^{11}$.

\footnotetext{
9 PEREIRA CASTAÑARES, Juan Carlos, "La historia de las relaciones internacionales en España. Respuestas, propuestas y conclusiones", in Cuadernos de Historia Contemporánea. n. 18, Madrid: Servicio de Publicaciones de la Universidad Complutense, 1996.

10 NEILA HERNÁNDEZ, José Luis, "La historia de las relaciones internacionales: Notas para una aproximación historiográfica", in La historia de las relaciones internacionales, Ayer n. 42, Madrid: Marcial Pons, 2001.

${ }^{11}$ MORENO JUSTE, Antonio, "La historia de las relaciones internacionales en España”, en Cuadernos de Historia Contemporánea. N. 18, Servicio de Publicaciones de la Universidad Complutense, Madrid, 1996, p. 217. All papers included herein are relevant for a detailed study of this question in the 1990s.
} 
Even in the $21^{\text {st }}$ Century, bilateral relations between States have continued to overweigh general issues on foreign policy, as can be seen in the studies by Marina Casanova, Mercedes Montero ${ }^{12}$, Ascensión Martínez and Alfredo Moreno ${ }^{13}$.

However, it is clear that, since 2000, studies on the history of international relations have entered a period of great splendor and of far greater diversification. Proof of this is the recent second edition of the book coordinated by Pereira Castañares entitled "Spain's foreign policy: from 1800 to today", covering a wide range of topics and approaches and including a long list of valid contributions from a large number of scholars, such as Calduch Cervera, Cordero Olivero, García Pérez, Huguet Santos, Lemus, Neila Hernandez, Montero Juste or Torre del Rio, among others.

This work also presents the detailed state of affairs in Spanish historiography (in Chapter 2, Pereira Castañares's own), and an overview of the development of Spain's foreign policy, especially focused in recent years: the geostrategic position of Spain, the importance of the external sector for the Spanish economy, the organization of its Foreign Service, the activity of the Autonomous Regions, the role of diplomacy, the military and the media, the impact of migration, the cultural factor and development cooperation. Furthermore, the basic coordinates of Spain's foreign policy in its different aspects are presented: Europe, Latin America, the Mediterranean world, Asia and Africa. Finally, several chapters give an overview of Spain's foreign relations throughout history ${ }^{14}$.

There are also some Swedish studies on bilateral relations with other countries, especially those closer to Sweden for different reasons (England, Russia, Turkey, etc.).

Remarkably, a different theoretical and methodological approach of the issue in both countries seems to prevail: while Spanish historians generally focus on an actor perspective, Swedish studies tended to insist on structural issues; while, in Spain, what might be called a "vertical down perspective" has prevailed, focusing on the role and actions of the individual diplomatic representatives in compliance with instructions from their government, as well as on the defence of national interests in an international context, in Sweden the predominant perspective is "horizontal", i.e. the study of different social groups with had an influence on international politics, as well as, in some instances, the so-

\footnotetext{
${ }^{12}$ MONTERO CALDERA, Mercedes, "La acción diplomática de la Segunda República Española en México (1931-1939)", in Espacio, Tiempo y Forma, Serie V, Historia Contemporánea. 14, 2001, pp. 251-286.

${ }^{13}$ MARTÍNEZ RIAZA, Ascensión \& MORENO CEBRIÁN, Alfredo, "Al servicio de la República. La acción exterior de España en el Perú, 1936 - 1939” en CSIC Revista de Indias, vol. LXVII, núm. 241, 2007.

${ }^{14}$ PEREIRA CASTAÑARES, Juan Carlos (coord.), La politica exterior de España: de 1800 hasta hoy, Madrid: Ariel, 2010.
} 
called "history from below" perspective, as shown in historical studies based on the memoirs and books written by Swedish veterans of the Spanish Civil War.

Approaches within the framework of the history of mentalities are also common in Sweden, while there are fewer of this kind in Spain. María de los Ángeles Egido León's study on the Spanish Republic's foreign policy is perhaps the most notorious Spanish example ${ }^{15}$.

Modern Swedish studies ${ }^{16}$ on the history of International relations follow the main lines of Swedish historical research as a whole. They are often heavily influenced by postkuhnian epistemological theories and a relativistic conception of reality, embodied in what Alvesson and Sköldberg called the "trilateral concept of truth" (det trilaterala sanningsbegreppet), i.e. truth as a correspondence to facts, truth as a practical usage and truth as significance or meaning. In these hermeneutics, most Swedish studies focus on this third aspect which, as Heidegger and Ricoeur pointed out, does not entail any correspondence of the concepts to the reality or things or a coherent use of them, but only a meaning, the discovery, at a personal and subjective level, of a deeper meaning ${ }^{17}$.

These epistemological options have resulted, in practice, in the almost complete predominance of a highly theoretical historiography, where the aim is a better understanding of the structures underlying the historical development of a particular historical period. The emphasis is on theoretical and conceptual discussions with previous research contributions, rather than on the empirical analysis of a wide range of available sources. The impact of schools of knowledge such as the Frankfurt School with its "critical theory" has been important.

We have deemed this introduction appropriate because it is essential to be aware of the differences in approach proper to the research traditions of each country involved, when dealing with comparative history studies, both for a correct understanding and interpretation of the available bibliography and to be able to provide valid contributions.

${ }^{15}$ EGIDO LEÓN, María de los Ángeles, La concepción de la política exterior española durante la II República. Madrid: UNED, 1987.

${ }^{16}$ The titles of Swedish books and articles quoted and referred to in this study will appear in the original Swedish except for the name of the place of edition and the Spanish abbreviation "pp" for "pages" instead of the Swedish "ss". On the bibliography list at the end, a Spanish translation of the Swedish titles is provided.

17 ALVESSON, Mats, \& SKÖLDBERG, Kaj, Tolkning och reflektion: vetenskapsfilosofi och kvalitativ metod, 2 ed., Lund: Studentlitteratur, 2008, p. 47 s. 


\subsubsection{Methodological options}

In the present study, being as it is a doctoral thesis within a Spanish university, although in collaboration with Lund University in Sweden (where the author had a long stay), the focus will be placed on the common Spanish approach, consisting in a thorough empirical analysis of the so-called evidencia primaria relevante de época (the relevant primary evidence of the historical period i.e. the many primary sources available), and their interpretation in the light of the latest contributions of other researchers. However, as the author has received his basic historical training in Sweden, some viewpoints or aspects more akin to Swedish than to Spanish historical research traditions are likely to appear in the analysis, in a more or less conscious manner.

It is obvious that there can be different methodological approaches to a study of the diplomatic relations between Sweden and Spain, but mainly a qualitative method in line with modern historical hermeneutics, focusing on the concept of "abduction" as a further development of the traditional inductive methods proper to Glaser and Strauss' grounded theory $^{18}$ - probably the most widely used internationally - will be used. Abduction integrates some aspects proper to deductive methods of the Popperian, Marxist and some Postmodernist traditions, whereby the interaction of empirical data with interpretative theories demand new empirical data, which lead in their turn to new adjustments in the interpretation model. This will hopefully prove to be a valid instrument for the study of bilateral diplomatic relations in a historical perspective.

Moreover, because of the specific character of the primary sources involved in this study, especially the diplomatic dispatches of Swedish and Spanish diplomats in the 1930s, the need arises to keep in mind some aspects of discourse analytical approaches which are common in postmodern and poststructuralist historical studies for the interpretation and analysis. This means, specifically, the study of historical narratives from the conceptual point of view of narrative theory.

Leaving deeper epistemological discussions aside, these approaches deserve nevertheless a few considerations: According to Carlshamre, the concept of historical narrative can heuristically be defined as distinct from the concepts of chronicle, description and annals. The essential feature of the narrative as a concept is its timing, when referring to events that occurred in a particular order and for a certain period of time. Description

\footnotetext{
${ }^{18}$ GLASER, Barney G. \& STRAUSS, Anselm L., The discovery of grounded theory, Chicago: Aldine, 1967.
} 
has, on the contrary, a timeless character, in which no reference is made to change, repetition, duration, etc. Historical narrative is also different from the Annals, which just retell the events without interrelation with each other, as historical narrative does, taking into account causality and the teleological aspects, i.e., the intentions that motivate the actors and the aim sought by them ${ }^{19}$.

Taken as a whole, the diplomatic dispatches on the political, economic and social development of a country, produced and sent during a certain period of time, constitute a specific historical narrative, as Carlshamre defines the concept: Social and political events are seen through the filter of the information sources available to the reporting diplomat, and are interpreted according to the informant's subjective mental categories, but are nevertheless a written account of the events of a country, a narrative with a strong teleological meaning. The aim of the dispatches is, indeed, to provide the own Government with all necessary data to enable it to make informed decisions on Foreign policy.

In this sense, the diplomatic narrative, regardless of its specific content, is an important source of decisions. It has a direct impact, as it were, on the subsequent historical development, inasmuch as it decisively influences the actions of other actors in a historical process. Therefore, the study of diplomatic dispatches is important for a better understanding of the Foreign policy decisions made in a specific historical period.

The correct understanding of the historical context in which they arose is a key issue to be considered, and the historian's attention is thereby drawn to the individual informants, the specific diplomats involved. They are, like everyone else, influenced by the historical events that have formed their lives, by their origin, family and the cultural traditions of the society and social environment they belong to. At the very moment they wrote down their views and interpretation of the political life in the country they lived in, the meeting took place between the historical events and the informant as a person, with his or her 'horizon of expectations' and his or her 'space of experience, ${ }^{20}$.

Traditional historiography on Diplomatic Relations insisted on the personality and character of Ministers and Ambassadors as a decisive aspect in bilateral international relations. This is consistent with the traditional approach in which individual personality

${ }^{19}$ CARLSHAMRE, Staffan, Förklara och berätta vad som hänt. Fyra uppsatser om historiens filosofi, Gotemburgo: Universidad de Gotemburgo, 1995, pp. 71-84.

${ }^{20}$ Cfr. WIKLUND, Martin, "Meaning in History beyond instrumental Rationality: The concepts of meaning and rationality of meaning in Jörn Rüsens's theory of history" in Ideas in History, no. 2, 2008, pp.74-77; KOSELLECK, Reinhart, Erfarenhet, tid och historia. Om historiska tiders semantik, Göteborg: Daidalos, 2004, passim; RÜSEN, Jörn, "Historical Narration: Foundation, Types, Reason", Histor.y \& Theory, no.4, 1987. 
prevailed over structural aspects, but it's not unproblematic. Obviously, the personal characteristics of Ministers and Consuls, their training and contacts, their particular vision of the international political situation at any given moment and their knowledge of the country to which they are accredited, have an influence, and sometimes a great influence, on bilateral relations and on the information they send to their home Government.

Granted this, the structural aspects of all international bilateral relations should also be taken into account: "no man is an island", as the saying goes, let alone a career diplomat, imbued by training, by occupation and by tradition of behavioural patterns and an esprit de corps dating back many centuries.

Furthermore, in the diplomatic world, this structural aspect is not limited to the Ministry itself and its own staff, but extends to the entire Diplomatic Corps accredited in any capital city. This institution has a position of its own as the representing body for the foreign diplomats in a country, headed by a Dean and endowed by international usage of powers of coordination within the diplomatic community. As a consequence, the influence of foreign diplomats on one another is a specific reality, and the use of common information sources in the recipient country as well as a certain amount of cooperation in reporting to the respective governments are not uncommon practices. This ever present aspect was particularly relevant during the Spanish Civil War.

The renowned German philosopher of history Jörn Rüsen stated that historical events have a pre-narrative character, and become narratives when the person involved (the historian or, in our case, the informing diplomat) gives his own interpretation of them. According to Rüsen, the great historical narratives play a guiding role, legitimating the historical identity of peoples. A historical narrative is true if it is respectful of the events narrated and of the interpretative standards established by the consensus of historians. The narrative must be credible and consistent, both empirically and normatively ${ }^{21}$.

Furthermore, it is worth keeping in mind that rhetorical aspects are especially important in foreign relations. Per Jansson, in a study of the Swedish political discourse on security in interwar Europe, argues that language is not only a transmitter of meaning, but contributes also to its creation. Thus, from a constructivist approach, the role of metaphors goes beyond mere rhetoric. By analysing the language used by Swedish politicians in the League of Nations, Jansson could pin an extended use of "mythic narratives", i.e. the use of words and phrases that appeal to the deepest feelings and beliefs of the audience they

\footnotetext{
${ }^{21}$ RÜSEN, Jörn, Berättande och förnuft. Historieteoretiska texter, Göteborg: Daidalos, 2004, pp. 55-73.
} 
are aimed at. He concluded that political discourse is often dependent on a very simple explanatory scheme, based on the beliefs of a society ${ }^{22}$.

In this, Jansson followed Geis ${ }^{23}$ and in fact also Potter and Wetherell ${ }^{24}$, who claimed that texts not only describe but make social realities, and therefore have political implications. While not sharing Geis' extreme views - he is a keen supporter of an unlimited constructivism, according to which language is an even more objective reality than reality itself - there is no doubt that the role of political language as a means of creating new social realities is an important factor in order to understand history properly. This can be clearly seen, not only in the overused examples of Hitler's or Goering's speeches, but also in the ones by Azaña and Prieto during the Spanish election campaign of 1936, or in Per Albin Hansson's speeches on "the People's Home" (folkhemmet) and Swedish Foreign Minister Rickard Sandler's public declarations in $1936^{25}$.

Another interesting feature of diplomatic dispatches as a historical source is the combination they offer of the synchronic with the diachronic aspect, provided they are not studied individually, but as a group of related sources over a given period of time. Sometimes this is possible even concerning a single event and very short time spans. Often, the same event is narrated twice, first when it happened, and then in the quarterly or semi-annual report.

The combination of the synchronic with the diachronic dimensions can show shifts in values and even conceptual changes in the way terms are used. In fact, the importance of diachronic studies, which often reveal a tension between the changes of meaning of words and historical changes, which do not always go together, is one of the main topics in the works of German historian Reinhart Koselleck, for whom "time" is almost a historical actor in its own right. On the contrary, British author Quentin Skinner believes synchronic studies are to be preferred, as the words used by a writer should be understood in their own rhetorical context, i.e. their specific meaning depends on the moment in which they were used, and on the writer's intentions ${ }^{26}$.

\footnotetext{
${ }^{22}$ JANSSON, Per, Säkerhetspolitikens språk - Myt och metafor i svensk säkerhetspolitisk diskurs 1919-1939, Lund: Studentlitteratur 1991.

${ }^{23}$ GEIS, Michael, The language of Politics, New York: Springer, 1987.

${ }^{24}$ POTTER, Jonathan \& WETHERELL, Margaret, Discourse and Social Psychology, London: Sage 1987.

${ }^{25}$ SANDLER, Rickard, Utrikespolitiska kringblick: anföranden 1936, Stockholm, 1937.

${ }^{26}$ KOSELLECK, Reinhart, The Practice of Conceptual History. Timing History, Spacing Concepts, Stanford: Stanford University Press, 2002, p. 36 y s.; SKINNER, Quentin, "Rhetoric and Conceptual Change", Finnish Yearbook of Political Thought, no. 3, 1999, pp. 73 y ss.
} 
All these theoretical aspects will be taken into account in this study. However, in line with the adopted theoretical and methodological choice, i.e. an "abductive" qualitative method based on Glaser and Strauss' "grounded theory”, focus will be laid on Skinner's ideas on conceptual interpretation. This author rejects discourse analytical methods, arguing that it is not possible to make history of the concepts as such, but only of the rhetorical use of them in different situations. Instead, the writers' intentions, what they meant to say, should be the interpretation $\mathrm{key}^{27}$.

Finally, we wish to emphasize the value of diplomatic dispatches as a historical source, but without forgetting their limitations. These are indeed highly interesting sources, not just as primary narrative sources, but also because dispatches place on record expectations, rumours, plans, thoughts, and the day by day development of political life. Through them it is made clear how foreign diplomats and their information sources (i.e. the people they relied upon) as well as the general public, viewed different events at the very moment these were taking place. In this sense, diplomatic reports are like the pages of a newspaper with highly qualified sources at its disposal, including the highest political circles in the host country and Intelligence officers from friendly countries.

In a sense, what constitutes their strength as sources is also their limitation: for better or worse, historical events are seen through the eyes of one informant, maybe two at most, on the occasions when junior diplomats, in the absence of the Head of mission, write the reports. As informants, they enjoy a privileged position, from the point of view of their temporal and spatial proximity to events and to the centres of political power, but they are also likely to give a biased interpretation of them, because of their training, their own cultural or political interests, or the sources available to them. This possible bias is mitigated, however, by the fact of their being outsiders to the country they report on.

It is clear, however, that a diplomatic dispatch, especially if it deals with political issues, is dependent on the information gathered by the Ambassador or Consul, usually from nationals of the country of residence close to them. Undoubtedly, these people, and their view of the political and economic situation of their country, will greatly influence the final outcome of the reports. This should be kept in mind when evaluating the information they contain.

\footnotetext{
${ }^{27}$ TULLY, James (coord.), Meaning \& Context: Quentin Skinner and his Critics, Cambridge: Cambridge University Press, 1988, p. 283.
} 
At the same time, it is important not to lose sight of the historical context in which the reports were written and also of what American historian Hexter called the macrorethoric in vogue in a society, i.e., the kind of rhetorical arguments accepted in a particular social context, in this case the Spanish and Swedish diplomatic circles of the $1930 s^{28}$.

In the present study, the diplomatic sources available are presented systematically, drawing heavily on the use of direct quotes. The most extensive are presented in separate paragraphs, while the shorter ones will be included in the main text, in quotation marks. The Spanish version of quoted Swedish documents is given in our own translation. Sometimes the Swedish term will also be given in brackets.

This methodological choice is motivated by a desire for greater transparency and credibility as far as the analysis is concerned. This is a conscious strategy, in line with the theoretical contributions of Quentin Skinner stated above, since the expressions and words used by the authors (in our case, the diplomats) are essential for a better understanding of the message they wanted to put across.

\subsubsection{Clarifications of concepts and terminology}

Before closing this section, some clarifications need to be done about the use of concepts and terminology in this study.

In these pages, the word "Ambassador" is not used to refer to the Heads of the diplomatic missions of Sweden in Madrid and of Spain in Stockholm, even though that is the usual term today. Instead, the technical terms used at the time (Plenipotentiary Ministers or, in short, Ministers of Sweden/Spain in Madrid/Stockholm) have been preferred.

Until the early 1950s, there were two types of diplomatic representations, Embassies (led by an Ambassador) and Legations (led by a Minister). Basically, the difference between an Embassy and a Legation was its rank. There were fewer Embassies than Legations. Each country maintained an Embassy only in those countries that were especially important to its Foreign policy, maintaining Legation level relationships with the rest. In the 1930s, there were no Embassies at all in Stockholm, but just Legations. Madrid

\footnotetext{
${ }^{28}$ HEXTER, Jack H., The History Primer, New York: Allen Lane, 1972, p. 299 y ss.
} 
hosted a few Embassies - UK, France, USA, Germany, Argentina, Mexico.... - and many Legations.

Even though the use of the term "Minister" in this context may be misleading - and that's why some historians today use the term "ambassador" instead -, it seems preferable to maintain the correct historical term, to avoid anachronisms.

As a rule, the terms in use at the time have been preferred in this study, as can be seen, e.g., in the way the Swedish and Spanish Foreign Ministries and its holders are designated: Ministry of State in Republican Spain, and Ministry of Foreign Affairs (Ministerio de Negocios Extranjeros) in Sweden, as Spanish diplomats then referred to the Swedish Utrikesdepartementet. Occasionally, an exception has been made, as in the use of the term "Foreign ministry" (Ministerio de Asuntos Exteriores) to designate the body responsible for those duties in Franco's Spain, although during the war it had the status of Secretariat and sometimes changed names.

Also the Spanish term Presidente del gobierno ("Prime Minister") is used to refer to the Swedish Head of Government, rather than using the literal translation of the Swedish title, "Minister of State" (Statsminister). The reason is obvious: to avoid confusion, as that term was used at the time in Spain to refer to the Spanish Foreign Ministry. Spanish diplomats did not have in the 1930s a standard Spanish term for the Swedish Statsminister. $\mathrm{He}$ is sometimes called "President of the Council of Ministers", sometimes "Head of government", "Prime Minister" or simply by his own Christian name.

In this study, the expression "Franco's Spain" is used to designate the so-called "National Spain", or Spanish State, though technically this term is not entirely correct. The reason for this choice of terminology is that 'Franco's Spain' (Francospanien) was the name most commonly used by Swedish diplomacy to refer to the territories controlled by the rebels, even though sometimes other expressions such as "Nationalist Spain", "Salamanca government" or "Burgos government" also appear in Swedish reports. The latter was the most common in the first two months of the war, but after that the name "Franco's Spain" became the usual one in Sweden.

\subsection{Sources for the study of the relations between Spain and Sweden from 1931 to 1939}

An overview of the documents in Swedish and Spanish Archives that are most relevant for this study on the political and diplomatic relations between those countries 
from 1931 to 1939 is presented herein. Given the abundance of primary documentary sources, there is no need to resort to other materials.

The main Archives containing the most relevant collections of documents are undoubtedly those of the respective Ministries of Foreign Affairs: the Archives of the Ministry of Foreign Affairs and Cooperation in Madrid (AMAEC) and the Archives of the Swedish Foreign Ministry available at the Riksarkivet, the National Archives of Sweden $(R A, U D)$ in Stockholm.

Other Spanish Archives of interest are the Centro Documental de la Memoria Histórica de Salamanca (Documentation Centre of Historical Memory of Salamanca, $\mathrm{CDMH}$, formerly called the Spanish Civil War Archives), the Archivo General de la Administración General (Archives of the Spanish Administration, AGA), the Archives of the Fundación Pablo Iglesias (FPI) in Alcala de Henares, the Archivo Histórico Nacional (National Historical Archives, AHN) in Madrid and the Archivo General Militar in Ávila (General Military Archives in Avila, AGMAV).

In Sweden, relevant documents are also to be found at the Arbetarrörelsens arkiv och bibliotek (Swedish Labour Movement's Archives and Library, ARAB) in Stockholm, at the Kungliga Biblioteket, Sveriges Media och Databas arkiv (Royal Library, Swedish Media Database Archives, KB, SMDA), at the Säkerhetspolisens arkiv (Swedish Security Police Archives within the National Archives, RA, SÄPO), the Krigsarkivet (War Archives, RA, KA) and some local archives.

It is surprising that no National History Archives documents referring to the 1930s are listed in Ruiz Martinez and Pi Corrales' guide over available sources for the study of Swedish-Spanish relations, probably because this guide does not descend to details but includes primarily complete documentary sets $^{29}$. There are nonetheless a few useful documents there, mainly about Republican politicians with Swedish connections and a few more issues, but generally of little interest ${ }^{30}$.

The documentation at the General Archives of the Administration contains more relevant sources for this study, but the main collections concerning Sweden refer to earlier

\footnotetext{
${ }^{29}$ MARTÍNEZ RUIZ, Eduardo \& PI CORRALES, Magdalena de Pazzis, Sweden in Spain's general archives. Sources for hispano-swedish history. Suecia en los Archivos generales españolas. Fuentes para la historia hispano-sueca, Madrid: Fundación Berndt Wistedt, 2001.

${ }^{30}$ AHN, Diversos Títulos Familias, 3251, N. 229; 3254, N. 7 y Causa General de Madrid, Embajadas y Legaciones, L. 1563, paquete 10, doc. 4; There are also some documents in other parts of the Causa General, which has recently been transferred to the CDMH in Salamanca.
} 
periods. Unfortunately, the correspondence of the Spanish Embassy with the Swedish Foreign Ministry during the first half of the $20^{\text {th }}$ Century is not complete ${ }^{31}$.

The most interesting AGA documentation for the purposes of this study is to be found in the Registry books of the correspondence between the Ministry of State and Spanish Embassies or Legations abroad. Thanks to these books, the issues on which there has been correspondence can be known. This is important to fill the gaps in the Archives of the Foreign Ministry that, unfortunately, are quite large: for instance, all the reports of the Spanish Legation in Stockholm for the year 1931 are missing ${ }^{32}$.

Fortunately, information can be checked against the one contained in the National Archives of Sweden (Riksarkivet). This documentation is generally complete and well organised, and therefore very useful to fill the gaps in the Spanish documents, together with the reports from other Spanish Embassies abroad, such as the 1937 and 1938 dispatches of the Spanish diplomats in London, Paris, Oslo and especially Helsinki, where Spanish Minister in Sweden, Isabel de Palencia, also was accredited ${ }^{33}$.

The Archives of the Spanish Foreign Ministry, in the so-called Renewed Section (AMAEC R), contain the main group of documents on Swedish-Spanish relations during the 1930s. Unfortunately, these are scattered around in many different files, sometimes not properly classified, and therefore difficult to study.

A relatively small number of files contain complete documentation, from a chronological point of view. A good example is file AMAEC R 341, which includes most of the dispatches of the Spanish Legation in Stockholm to the Ministry of State during the years 1932 to 1934. The reports deal with many different topics, even though most of them are on political issues such as the results of local or general elections, government change, the state of public opinion or copies of the daily sessions of the Swedish Parliament. Many provide information on the most significant events of national life, such as the suicide of Ivar Kreuger and its political implications, new guidelines on labour legislation, or the policies to prevent the spreading of Fascism and Nazism. Especially important are the

\footnotetext{
${ }^{31}$ AGA, Asuntos Exteriores, Caja 14068, carpeta 25; Cajas 14076 al 14078.

${ }^{32}$ AGA, Asuntos Exteriores, L. AE 6402, pp. 178-183 y AE 6403, pp. 126-128(año 1931); L. AE 6422, pp. 168-176 (año 1932); L. AE 6443 pp. sueltas, pp. 29-30 y pp. 118-125 (año 1933). L. AE 6464, pp. 143-152 (año 1934); L AE 6489, PP. 169-182 (AÑO 1935); L AE 6533 pp.189-199 (año 1936-37); L. AE 6544 (año 1937); L AE 3194 (año 1938); L AE 5991 pp. 160-240 (año 1939); AGA, Secretaría General del Movimiento, caja 27.

${ }^{33}$ Cfr. AGA, Asuntos Exteriores, cajas nn. 5297, 5289, 5302, 5310 y 12093.
} 
semi-annual reports sent by the Ministers of Spain in Sweden, with a summary of the most relevant events of the half-year.

On the other hand, it is not altogether uncommon to find documents that have been done away or trampled with, or even left unregistered. This is important as far as the reliability of the sources is concerned ${ }^{34}$.

The reports of 1934 are more widespread, and those of 1931 seem to be lost. The documents of the Civil War years, with the logical gaps, are scattered in many different files. These include information sent to the Franco authorities by their representatives in Stockholm ${ }^{35}$.

The Fundación Pablo Iglesias in Alcala de Henares houses the personal Archives of several leading Spanish socialist politicians and Union leaders, some of whom had Swedish connections, such as Margarita Nelken, who visited the country in 1935 and held a series of political meetings there. There is also some documentation about Isabel Oyarzábal de Palencia ${ }^{36}$.

The Documentation Center of Historical Memory (CDMH) of Salamanca, housing millions of files, has unfortunately very little material concerning Sweden. Still, there are some letters addressed to members of the SAC, the Swedish organization akin to the Spanish CNT-FAI, sending lists of subscribers to magazines such as Frente Libertario or informing about CNT National Committee instructions to its members on foreign policy issues during the Civil War. There is also a report of the CNT delegate who attended the Congress of the SAC held in Stockholm on September 11, $1938^{37}$.

The basic problem for researches of this archive is the dispersion of the documentation, and also the fact that many files still haven't been properly labelled and classified. There are, for instance, many files concerning the International Brigades but these are not classified according to their country of origin. In this study, however, a

\footnotetext{
${ }^{34}$ Cfr. AMAEC R 341, where one document has been teared up in such a way that the intention to get it removed from the file is quite obvious; AMAEC R 850, 18, despacho de 29 de enero de 1935, answering Foreign Ministry Order 129/1934, with a marginal note in pencil writing: "Keep but don't file as told". It deals about Sweden's possible attitude in the event of a major international war.

${ }^{35}$ Cfr. AMAEC R 860, 74, AMAEC R 698, 10; AMAEC R 1785, AMAEC R 642, AMAEC R 1058, AMAEC R 4016, AMAEC R 1069, AMAEC R 1051, AMAEC R 1048 y AMAEC R 4002. La lista de legajos utilizables de este archivo es muy amplia.

${ }^{36}$ FPI-AH-73-38; FPI-ALA-98-27 y 28; FPI-AFLC-195-17; FPI-ALJA-450-1. El Archivo histórico del Partido Comunista de España, por su parte, no contiene nada de interés relativo a Suecia.

${ }^{37}$ CDMH, PS-Madrid, 1008/18; PS-Madrid 468/2; CDMH, PS-Barcelona, 523/10-17; CDMH, PS-Madrid, $663 / 44$
} 
thorough search of the International Brigades files will be attempted, looking for Swedish names that may be on record, and then compare these data with existing Swedish lists and the contributions of Swedish historiography.

The same happens with the Spanish military archives in Avila, where the files concerning Sweden are scattered, and are difficult to locate. However, there are some references and files about Swedes who fought in the Spanish Legion as well as information on foreign prisoners in concentration camps, and a few documents of the Intelligence services of the Condor Legion and of the Spanish Army (SIFNE) on arms smuggling. This kind of files may provide information hitherto unknown in Sweden ${ }^{38}$.

As for Swedish archives, the main one for the purposes of this study is the Swedish National Archives (Riksarkivet) in Stockholm, which all general Swedish State Archives are currently a part of. Documentation concerning Spain for the period 1920-1945 is on record at the Foreign Ministry archives, (Utrikesdepartementet, UD), in the section called "File System of 1920" (1920 dossierssystem-års system). There are four files with the dispatches written by Swedish diplomats in Spain during the period November 1929 to July 1936. The files seem to be detailed and complete, as usual in Swedish State documents, among other things due to the so-called "publicity principle" included in Swedish laws imposing many restrictions on State officials' attempts to keep documents confidential $^{39}$.

Documents relating to the three years of Civil War are kept in a special collection called "Spanish Civil War", in 23 separate files. Apart from the diplomatic reports on the progress of the war, the rest is sorted out according to thematic instead of chronological criteria: "Swedish humanitarian aid to Spain", "The Lola conflict" or "establishment of relations with the Franco government", to name a few files ${ }^{40}$.

Other files contain documents on topics such as Swedish diplomatic activity within the London Non-Intervention Committee, the records of the meetings of Swedish Foreign Minister with foreign diplomats in Stockholm, the discussions within the Parliamentary Committee on Foreign Affairs or the Swedish Export Trade Spanish connections. The

\footnotetext{
${ }^{38}$ AGMAV, Cajas 2472, 2481, 1092.

${ }^{39}$ RA, UD, 1920-års dossierssystem, H. Vol. 420-423.

${ }^{40}$ RA, UD, 1920-års dossierssystem, Vol. 1504-1528.
} 
personal records of Swedish diplomats in Spain, especially Ivan Danielsson, are also a major source ${ }^{41}$.

Furthermore, the archives of the Swedish Legation in Madrid from 1880 to 1995 have been preserved. These include a total of 460 files occupying 35 meters of shelving, mainly relating to the period 1920-1995. Most refer to procedural issues, primarily in commercial and consular matters. Not all documents are available to researchers, as some are still confidential in accordance with the Official Secrets Act. The most relevant files for this study are the diaries of the Swedish Military Attaché for the 1936-1942 period, the registration books on incoming and outgoing correspondence, and the correspondence on some specific issues between Swedish diplomats accredited in Madrid and some officials within the Swedish Foreign Ministry ${ }^{42}$.

The Swedish Labour Movement Archives and Library (ARAB) in Stockholm collect the Archives of Swedish political parties and Trade Unions of a "non-bourgeois" type, to use common terminology in Sweden. There is a large amount of files on the Spanish Civil War. Apart from institutional archives, even the private archives of many Swedish volunteers of the International Brigades are included here. These sources are interesting as they are primary witness accounts, but are obviously biased, which should be taken into account in connection with their reliability as sources. In short, there is certainly no lack of available sources ${ }^{43}$.

Finally, the Swedish Media and Database Archives at the National Library in Stockholm also have some relevant files, such as a 1937 BBC interview to two Swedish

\footnotetext{
${ }^{41}$ RA, UD, HP 430:B; RA, Utrikesnämnden, Vol. 3, 4 y 5; RA, UD: P1: 167.

${ }^{42}$ RA, UD, Beskickningsarkivet: Madrid, Vol. C3 (1929 - 1933) C4 (1934 - 1939), C5 (enero - abril 1939), C6 (mayo - diciembre 1939); C2 (1934 - 1939), C3 1939 (hasta abril 1939) y C4 1939 (desde mayo 1939); Vol. E1 31 (1925-1937), E1 32 (1937-38) y E1 33(1938-39); F 1 C Vol. 44-49.

${ }^{43}$ Many personal archives within ARAB contain references to Spain, mainly Gösta Andersson's, Stig Berggren's, Gustav Blomberg's, Georg Branting's, Per Eriksson's, Gösta Hjärpe's, Max Hodann's, Ernst Ingvar Karlsson's, Carl Mattson's, Sixten Olsson Rogeby's, Knut Olsson's Kajsa Rothman's and Helmut Rüdiger's archive. There are also institucional archives of organisations with Spanish connections in the 1930s, such as the International Rescue Committee, Svenska frontkämparnas stödfond (Aid fond for Swedish combatants), Svenska hjälpkommittén för Spanien (Swedish Spanish Aid Committee), Spanienkommittén för Stockholm (Stockholm Spanish Aid Committee), Nyköpings lokala Spanienkommitté (Nyköping Spanish Aid Committee), Sveriges arbetares centralorganisation (SAC, Swedish Workers Central Organisation), Södra förstädernas Spanienkommitté (South Stockholm Spanish Aid Committee), and especially the Svenska Spanienfrivilligas kamratförening (Association of Swedish volunteers in Spain). Furthermore, the archives of the main political parties linked to the Labour Movement incluye refences to Spain: Swedish Communist party (SKP, 4 files), Swedish Socialist party (SP, 6 files), Swedish Trade Unions (LO, 8 files), Swedish Social Democratic Party (SAP, 13 files): cfr. ARAB, VP Kommunistiska partiet, Serie ÖS, vol. 4-7; ARAB, Socialistiska partiet, Serie E1, vol. 3, 7, 10, 14, 18 y 23; ARAB, LO, arkiv nr. 2964, E09A, vol. 016 a 022; F08E, vol. 09; ARAB, SAP, Serie F02, D y serie E5.
} 
war reporters in Spain, several documentaries about the Civil War and Swedish initiatives in connection with it (Homes for Orphans and the Swedish-Norwegian Hospital at Alcoy), and a documentary on the visit of former King Alfonso XIII to Sweden in August $1931^{44}$.

\subsection{Outline of the current study}

Having discussed the general approach, the theoretical and methodological framework and the primary sources for the current study, the time has come to present its general outline.

The temporal scope of this research work are the years 1931-1939, a crucial period in the history of the two countries considered here, Sweden and Spain. In Spain, those years correspond to the birth, development, and end of the Second Republic. The start of the Civil War in July 1936 provides a dividing line of the period. In Sweden, the 1930s have traditionally been divided into two main periods, the "age of parliamentary minorities" (until the general elections in September 1932), and the "Per Albin Hansson's era". He was Swedish Prime Minister for the rest of the decade, except during the summer months of 1936.

The current study will follow the traditional division in Spanish historiography on the Second Republic: the period of peace (1931-1936), as Part I and the Civil War years (1936-1939) as Part II, preceded by an introduction.

The introduction consists of two chapters, shorter than the rest. On Chapter 1 the general approach is discussed in four different sections. First, the purposes and key issues of the study have been outlined. The second section presented the theoretical and methodological framework, discussing a) the possibilities and problems of comparative history and history of international relations, b) the theoretical and methodological choices of this study, and c) some clarifications of concepts and terminology. The two final sections give an overview of the primary sources available in both Swedish and Spanish archives, and the general outline of the thesis.

Chapter 2 focuses on the historical setting of the political and diplomatic relations between Sweden and Spain and also the present state of Swedish and Spanish research work on the specific topic, namely Swedish-Spanish political and diplomatic relations in the 1930s.

${ }^{44}$ KB, SMDB, SR-Minnen 2009-09-25; Skånefilmer, n. 55-94/2000-94 rollo 03. 
Following the introduction, Part I, entitled "Republic in Spain, Social Democracy in Sweden", will deal with Swedish-Spanish relations between 1931 and 1936. After that, Part II, "War, Intervention and non Intervention" will follow suit, analysing the relations between Sweden and both parts of Spain during the Civil War years.

Each part will be divided into three chapters: chapters 3, 4 and 5 in Part 1 and chapters 6, 7 and 8 in Part 2.

Chapter 3 presents the image of the Spanish Republic from 1931 to 1936 that Swedish diplomats transmitted to the Swedish government. Chapter 4 focuses on the vision of Sweden given by Spanish diplomats in Stockholm and finally, Chapter 5 will deal with the bilateral diplomatic relations between Spain and Sweden in those years.

Part 2 will analyse Sweden's relations with the Spanish Republic during the Civil War years (chapter 6) and then its relations with Franco's Spain (chapter 7). The last chapter deals with Swedish intervention in the Spanish Civil War (chapter 8).

After that, a final discussion and conclusions will follow.

I do not want to put an end to these introduction without the expression of my deep appreciation to all those who have made this work possible. Any doctoral dissertation is a difficult, yet exciting process involving many people, in different ways, all of them important. I am especially grateful to the Head and the staff of the Instituto de Historia Simancas at Valladolid University, who accepted my research project within its prestigious PhD-program "Europe and the Atlantic world: power, culture and society". My thanks go also to my thesis supervisors, Dr. Jose Lopez-Vidal Pelaz and Dr. Lars Berggren and to the Department of History at Lund University in Sweden, where I was able to spend a oneyear-long research stay.

Many thanks also to the helpful and highly professional staff of the different Spanish and Swedish Archives where I conducted my research, in particular the Foreign Ministry in Madrid, the General Administration Archives in Alcala de Henares, the Documentation Centre of Historical Memory in Salamanca and the Ávila Military Archives; and also, in Sweden, the Riksarkivet, the Arbetarrörelsens Arkiv and the Swedish Royal Library. And finally, thank you, dear colleagues and all my friends, for your patience and support along this journey. 


\title{
Chapter 2
}

\section{HISTORICAL CONTEXT AND PREVIOUS RESEARCH ON THE TOPIC}

\author{
In the $20^{\text {th }}$ Century, Spain opted for \\ isolation and neutrality and then became a \\ victim to the Non intervention policy of the \\ Western Democracies. As a result, Spain \\ lost the European pace ${ }^{1}$
}

\subsection{Swedish-Spanish relations throughout history}

\subsubsection{Sweden and Spain before 1900}

Until very recently, Swedish-Spanish relations throughout history have seldom interested historians. In Sweden, Magnus Mörner ${ }^{2}$ and the Ibero-American Institute at Gothenburg University were pioneers in this field of research. After that, the "SwedishSpanish historical encounters", a project launched in the 1990s, provided important contributions. In Spain, with only a few exceptions ${ }^{3}$, there has been practically no research on relations with Sweden until the $21^{\text {st }}$ Century.

The following is an overview, mostly based on Swedish historiography, of SwedishSpanish relations through history until the beginning of the $20^{\text {th }}$ Century.

The word "Gothicism" has been used for five centuries, starting with the first kings of the Vasa dynasty. Originally, the term referred to the line of thought that considered Sweden, and especially Sweden's Götaland region, as the homeland of the Goths. According to some theories, its western part (Västergötland) would have been the stronghold of the Visigoths, although this is not a historically proven fact. Later the term was applied to the pan-Scandinavian nationalistic and cultural movement, which emerged

\footnotetext{
1 AUBERT, Paul, “avant-propos”, en "España, Europa y el Mediterráneo", Bulletin d'Histoire Contemporaine de l'Espagne, n. 27, junio 1998, p. 15: “L'Espagne, en choisissant, au cours du XXe siècle, l'isolement et la neutralité, avant d'être victime de la non-intervention des démocraties occidentales, s'est détachée du rythme européen"

${ }^{2}$ MÖRNER, Magnus, España y Suecia en el siglo XVII: problemas y alcandes de los enfoques comparativos. Gotemburgo: Instituto Ibero-americano, 1998; BENSON, Ken, MÖRNER, Magnus \& SÖHRMAN, Ingmar, Relaciones entre España y Suecia desde mediados del siglo XVII hasta comienzos del XIX, Gotemburgo: Sección de español, Universidad de Gotemburgo, 2002; GYBERG, Erik, Spanien i svensk litteratur: en bibliogralfi = España en la bibliografía sueca: una bibliografía . Gotemburgo: Biblioteca universitaria de Gotemburgo, 1973.

${ }^{3}$ HILLMAN, Adolfo, “Ojeada a las relaciones históricas entre España y Suecia”, Revista crítica de historia y literatura, 1894.
} 
in the $19^{\text {th }}$ Century. In this context, interest in Spain as a "Gothic" country was aroused, as shown, for instance, in some works on Sweden's relations with Spain and Portugal, by Sweden's most famous writer, August Strindberg ${ }^{4}$.

The Viking raids in the Iberian Peninsula during the ninth, tenth and eleventh centuries are well known ${ }^{5}$. Swedish Vikings had their trade and shipping routes to the east, while the Vikings who had contact with Spain came from the south and west of the Scandinavian Peninsula, i.e. Denmark, Scania, Halland and Norway.

In the Middle Ages, contacts were established mainly through pilgrimages to Santiago de Compostela, especially that of St. Bridget of Sweden and her entourage. St. Bridget had some Spanish collaborators, especially former Bishop of Jaén Alonso Pecha, who was her confessor in the last years of her life and the custodian and editor of her famous Revelations ${ }^{6}$.

In the early modern period, contacts between Sweden and Spain were sporadic, as the access to the Swedish throne in 1520 of Elizabeth, the sister of Emperor Charles V and the consort of Kalmar Union King Christian II $^{7}$, or the diplomatic mission of Francisco de Eraso in Sweden in 1579. The latter was a result of the first diplomatic contacts which had taken place in Rome between Spanish Ambassador Juan de Zuñiga and Swedish Ambassador Pontus de la Gardie in the time of King Philip II. Sweden had offered the Spanish King the support of the Swedish fleet and army, to help resolve his problems in Flanders. In return, Sweden wished a commercial basis (a harbour or a piece of land) in Western Frisia. The King of Spain sent Captain Francisco de Eraso to discuss the offer, but no alliance was ever made although a preliminary agreement had been reached ${ }^{8}$.

During the first half of the $17^{\text {th }}$ Century, relations between the two countries could hardly be more strained. Sweden's entry into the Thirty Years' War made the country a

\footnotetext{
${ }^{4}$ STRINDBERG, August, "Relations de la Suède avec l'Espagne et le Portugal jusqu'à la fin du dix-septième siècle", Boletín de la Real Academia de la Historia, T.16, Madrid, 1890, pp. 321-342; "Spanska och portugisiska minnen ur svenska historien", Samlade skriften 27, Stockholm, 1917, pp. 67-90.

${ }_{5}^{5}$ For a reference work in Spanish, see MORALES ROMERO, Eduardo, Historia de los Vikingos en España, Madrid: Colección Malos Tiempos, 2006.

${ }^{6}$ About St. Briget and Spain cfr. ALMAZÁN, Vicente, Santa Brígida de Suecia - peregrina, política, mística, escritora, Santiago de Compostela: Xunta de Galicia, 2000; MARTíNEZ RUIZ, Enrique y PI CORRALES, Magdalena de Pazzis (coord.), El mundo escandinavo, Santa Brígida y el Camino de Santiago. (Encuentros Históricos Suecia-España VIII), Santiago de Compostela: Fundación Berndt Wistedt, 2002; BORGENSTIERNA, Anne Christine (coord.), Santa Brígida, patrona de Europa, Fundación Berndt Wistedt, Valladolid, 2005.

${ }^{7}$ Sobre Isabel de Suecia cfr. PEIX GELDART, Benito, "Isabel la luterana", en ZALAMA, Miguel Ángel (dir.) et al., Juana I en Tordesillas: su mundo, su entorno, Valladolid, 2010, pp. 333-346.

${ }^{8}$ QUATREFAGES, René, "Las relaciones diplomáticas hispano-suecas (s. XVI-XVII)", en MARTÍNEZ RUIZ, Eduardo y PI CORRALES, Magdalena de Pazzis (coord.), España y Suecia en la Época del Barroco (1600-1660), Fundación Berndt Wistedt, Madrid, 1998, p. 995.
} 
direct enemy of the Habsburg Monarchy. The armies of Gustavus Adolphus - known in Spain as "the monster of Stockholm" - and Spanish troops clashed on the battlefield. Sweden and Spain were found, as Mörner said, at opposite poles. Only the signing of the Treaty of Westphalia, which put an end to the Thirty Years War, brought together the chief diplomats of both countries, Schering Rosenhane and Saavedra Fajardo. Diplomatic activity between Spain and Sweden was intense in the 1640s and resulted in several encounters 9 .

After the accession to the Swedish throne of Queen Christina, Spain had some ambassadors in Stockholm, Bernardino de Rebolledo and Antonio Pimentel de Prado. Pimentel's dispatches are a primary source for the knowledge of that period in Swedish history. He had a great influence on Christina and was her confident even after her abdication as Queen ${ }^{10}$.

Meanwhile, Matthias Palbitzki, the first Swedish Ambassador in Madrid, managed to achieve commercial benefits through a free trade agreement with Spain on some products, especially salt and copper, and also won the release of prisoners of the battle of Nordlingen $^{11}$.

There is a major study on the relations between the two countries in the late Baroque, dealing with national policies, Spain and Sweden as military powers, baroque culture in Sweden and Spain, Spanish-Swedish relations as reflected in art, and a final comparative analysis by Magnus Mörner ${ }^{12}$.

\footnotetext{
${ }^{9}$ MÖRNER, Magnus, Episodios de la historia de las relaciones hispano-suecas: España y Suecia a través de los tiempos, imágenes y realidades, Madrid: Fundación Berndt Wistedt, 1996, pp. 8 y ss; CORREDERA NILSSON, Enrique, Todos somos godos. Las relaciones hispano-suecas desde la década de 1640 hasta la Paz de Oliva, Madrid: Editorial complutense, 2009, especialmente pp. 109-130

${ }^{10}$ There is some research on Queen Christina and her connections with Spain: RODÉN, Marie Louise, "La reina Cristina de Suecia, España y la política de la corte papal en el siglo XVII", en MARTÍNEZ RUIZ, Eduardo \& PI CORRALES, Magdalena de Pazzis (coord.), España y Suecia en la Época del Barroco (16001660), Madrid: Fundación Berndt Wistedt, 1998; OCHOA BRUN, Miguel Ángel, Embajadas y embajadores en la Historia de España, Madrid: Aguilar, 2002, pp. 305-309; GONZÁLEZ CAÑAL, Rafael, "El Conde de Rebolledo y la Reina Cristina de Suecia: una amistad olvidada". Tierras de León, núm. 26, 1986, pp. 93-108; ALlENDESAlAZAR, Ursula, La Reina Cristina de Suecia, Madrid: Marcial Pons Historia, 2009; VÁSQUEZ LOPESA, Julián, Bajo el signo de la diplomacia: la reina Cristina en la literatura del Siglo de Oro: del Conde Bernardino Rebolledo a Calderón y Bancer Candamo, Gotemburgo: Instituto iberoamericano, 1998; Spanish Ambassador Pimentel de Prado's dispatches have been published in Swedish by BERENCREUTZ, Nils (ed.), Don Antonio Pimentels depescher från drottning Christinas hov 1652-1656 jämte svarsskrivelser och spanska statsrådsprotokoll, Stockholm, 1961. Cfr. also our own study on the Swedish reaction to Christina's change of religion: PEIX GELDART, Benito "Drottning Kristinas trosförändring: den svenska reaktionen 1655-1660”, Master thesis at Stockholm University, 1998.

${ }^{11}$ MÖRNER, Magnus, Episodios de la historia de las relaciones hispano-suecas..., p. 10; FREDRIKSSON., op. cit., pp. 47.

${ }^{12}$ MARTÍNEZ RUIZ, E. y DE PAZZIS PI CORRALES, M. (coord.), España y Suecia en la Época del Barroco..., índice, pp. 5-9.
} 
In 1667 Sweden sent an ambassador to Madrid, Carl Tungel. The following year, after the Peace of Aachen in which Spain agreed to pay subsidies to some nations including Sweden, Count Fernan Nunez was sent as an ambassador to Sweden to further discuss subsidies and trade. His task was not easy. According to him, the Swedes "as a rule, neither admit nor exclude anything". Sweden was in a difficult position, being a signatory part of the Triple Alliance of 1668 with England and the Netherlands, but also having close ties to France, whose side it eventually took ${ }^{13}$.

The $18^{\text {th }}$ Century brought radical changes to both countries: in Spain, the Bourbon era with its centralization of the state, in Sweden, the "era of freedom", in which Parliament took over all political power. As a result of the $17^{\text {th }}$ and early $18^{\text {th }}$ Century wars, both countries had lost prominence on the international stage, becoming second-rate powers. This was reflected in the rank of the diplomatic representatives that were exchanged, which clearly reveal the lack of importance that both countries attached then to their mutual relations.

Cooperation between the two countries improved in the middle of the Century because of the Barbary pirates in the Mediterranean, who forced the Swedish Navy to send ships against them. In general, Swedish-Spanish relations were good. Spain wanted Sweden to support France in international conflicts, a policy in line with Swedish interests as well. In 1749 the Marquis of Grimaldi, later the Secretary of State under Charles III, arrived to Sweden and advised against the signature of the Swedish-Spanish commercial and military treaty which had been negotiated since the time of the Marquis of Puerto. Later, The Marquis of Puertefuerte also served as Spanish ambassador to Sweden, to try to prevent Sweden from supporting Maria Teresa of Austria as a candidate to the imperial throne ${ }^{14}$.

In those years, Swedish merchants had settled in Cadiz, thus encouraging the sending of Swedish ambassadors to Madrid to protect their interests. Sweden's first permanent

\footnotetext{
${ }^{13}$ RA, Hispanica, Vol. 2, Tungel's dispatches; QUATREFAGES, op. cit., p. 1001-1005.

${ }^{14}$ SÁNCHEZ DIANA, José María, "Relaciones de España con Suecia en el siglo XVIII", Revista Hispania LXXXVIII, 1962, pp. 590-627; LAVANDEIRA HERMOSO, Juan Carlos, "Las relaciones diplomáticas hispano-suecas: Una visión de conjunto a mediados del siglo XVIII" en BENSON, MÖRNER \& SÖHRMAN, op. cit.; Cfr. FREDRIKSSON, op.cit., p. 51, on Swedish Ambassador's Ernst August Vellingk attempts to get a Spanish loan for Charles XII's Wars. On the performance of Marquis del Puerto, Bourbon Spain's first Ambassador to Sweden, cfr. MARTÍNEZ RUIZ, Enrique y PI CORRALES, Magdalena de Pazzis, "Guerra y comercio. La propuesta de un tratado comercial hispano-sueco a mediados del siglo XVIII" and LAVANDEIRA HERMOSO, Juan Carlos, "Política y comercio de mediados del siglo XVIII: Algunos informes del marqués del Puerto desde la Embajada española en Suecia”, en RAMOS SANTANA, Alberto, (coord.) Comercio y navegación entre España y Suecia (siglos $X$-XX), Cádiz: Fundación Berndt Wistedt, 2000.
} 
ambassador in the Spanish capital, Axel Peter Fleming, was appointed in 1741. His dispatches show that Swedish-Spanish relations were at the time mostly commercial. Not surprisingly, the famous Swedish East India Company used the port of Cadiz as the basis of all transactions with China, especially in the period $1732-1806^{15}$.

As of 1761, the Spanish Ambassadors' main task was “to be a reminder of Spain's existence" and to gather information on political, economic and commercial affairs. The same can be said of the Swedish ambassadors in Madrid. Trade and cultural contacts between the two countries increased, and the relations were peaceful and normal ${ }^{16}$.

There are no major studies on Swedish-Spanish relations during the $19^{\text {th }}$ Century ${ }^{17}$. One mention to Sweden appeared in a lecture by Facundo Goñi:

As for Sweden, its relations with Spain have remained friendly ever since the peace Treaty concluded in Stockholm on March $19^{\text {th }}, 1813$. This treaty gave rise to the European war against Napoleon, in which Sweden, as it is well known, moved away from the party of the conqueror, joining Russia against him. In that Treaty, Sweden explicitly recognized the Cadiz Parliament and the constitution it promulgated, following the example of other powers in that dangerous conflict. Later on, on April 26, 1841, an agreement was reached allowing Swedish and Spanish subjects to purchase goods in each other's countries, without having to pay the jus detractas or any other tax, in the same terms of Spain's agreements with other nations, as I said before. Spain has currently a Chargé d'Affaires in Stockholm and the Swedish court has sent a diplomatic agent of equal rank to Madrid. ${ }^{18}$.

Between 1813 and 1815 Jacob Gustaf De la Gardie served as Swedish Ambassador in Madrid. 1812 and 1813 were important years for Spanish-Swedish relations. As a consequence of a conflict during the Napoleonic wars, Spanish relations with Sweden were bad and the Swedish Ambassador in Madrid, Adlerberg, had been withdrawn in 1806. In

\footnotetext{
${ }^{15}$ FREDRIKSSON, op. cit., p. 53.

${ }^{16}$ SILVÁN, Leamdro, "Relaciones científicas hispano-suecas en el siglo XVIII", Boletín de la Real sociedad bascongada de amigos del país, San Sebastián, 1981; LÖFLING, Petri, Petri Loefling Iter Hispanicum eller Resa til spanska länderna uti Europa och America, förrättad ifrån år 1751 til år 1756, med beskrifningar och rön öfver de märkvärdigaste växter publicado tras su muerte por Carl Linnaeus, Stockholm, 1758; NILZÉN, Göran, “Anders Nordencrantz som konsul i Portugal”. Personhistorisk tidskrift 1986, pp. 42-56; LAVANDEIRA HERMOSO, Juan Carlos, op. cit., 2002, p. 54-61; MÖRNER, Magnus, "España y Suecia desde finales del siglo XVII hasta comienzos del XIX: algunas notas introductorias", in BENSON, MÖRNER \& SÖHRMAN, Ingmar, op. cit., p. 15-26.

${ }^{17}$ See BÉCKER, Jerónimo, "Historia de las relaciones exteriores de España durante el siglo XIX (apuntes para una historia diplomática)" Volumen 3 de Historia de las Relaciones Exteriores de España durante el siglo XIX, Madrid: Estab. tip. de J. Ratés, 1924.

${ }^{18}$ GOÑI, Facundo, Tratado de las relaciones internacionales de España: Lecciones pronunciadas en el Ateneo de Madrid, Madrid: R. Rodríguez de Rivera, 1848, p. 194.
} 
1810, Sweden appointed former French Marshall Jean-Baptiste Bernadotte, turned Napoleon's enemy, heir to the Swedish throne. Sweden joined the anti-Napoleonic league, thus becoming Spain's ally. The result was the Treaty of Peace and Friendship between Sweden and Spain in 1813. In 1815, Gustaf Daniel Lorich was appointed Charge d'affaires in Madrid, a position he occupied for 37 years. In the 1830s, Lorich took the Elisabethan side in the Spanish sucession conflict ${ }^{19}$.

Later on, many Norwegians would serve as Swedish ambassadors in Madrid Norway been at the time, 1815-1905, in a personal union with Sweden. During those years, the preponderance of Norwegian diplomats in the joint Monarchy's Foreign Service was remarkable. The memoirs of one of them, Wedel Jarlsberg, describe very well the life of diplomats at that time ${ }^{20}$.

\subsubsection{Sweden and Spain from 1900 to 1930}

Surprisingly, Berndt Fredriksson's work on Swedish Ambassadors and Ministers in Spain, does not mention any of them between 1914 and 1940. This silence is difficult to understand, and it is one of the reasons why a detailed study of Spanish-Swedish relations in the interwar period is sorely needed. Quite simply, there appears to be none. There is a significant historiographical gap herein.

Spain has been said to have withdrawn into itself as of the first decades of the $19^{\text {th }}$ Century, avoiding engagement in foreign policy issues. This is thought to be a consequence of the war crisis, the political instability, the critical economic situation and the loss of the American colonies. After 1833, the ideas of Europeanism, the need for a balance of power and an international order, as well as neutrality, became the aims of Spanish foreign policy, in order to ensure peace and preserve the country's remaining colonies.

Modern Spanish historiography on international relations - Jover Zamora, Martinez Carreras, Pereira Castañares, Seco Serrano, Tusell Gomez, Neila Hernandez, etc. - has questioned the alleged tibetization of Spain and its isolation from the international arena in the $19^{\text {th }}$ and the first third of the $20^{\text {th }}$ Century. Some foreign scholars, such as Sebastian

\footnotetext{
${ }^{19}$ FREDRIKSSON, op. cit., p. 63; see also RA, Hispanica, Gustaf Daniel Lorichs depescher. Lorich's dispatches give a thorough análisis of Spanish politics during the period and haven't been properly researched.

${ }^{20}$ WEDEL JARLSBERG, Fredrik, Reisen giennem livet, Oslo 1932.
} 
Balfour and Paul Preston, said the crisis and Civil Wars in Spain are specific forms of global crises at a European level ${ }^{21}$, and Spanish scholar Torre del Río pointed out that

Between 1875 and 1914, Spanish foreign policy depended on the three major processes that were transforming the European international system at the time: the Bismarckian system, the colonial redistribution of the 1890s and the formation of the FrancoBritish entente and the bipolar system preceding the First World War ${ }^{22}$.

Moreover, as a consequence of the bipolar international system and the increase of capitalism in the interwar period, Spain started to catch up with the leading European countries, and this helped to give some "autonomy" to Spanish foreign policy. Spain's king, Alphonse XIII, took a leading role in foreign policy. The King envisioned neutrality, provided Spain's and the remaining Spanish colonies' territorial integrity was respected. However, many people thought that Spain lacked a clear vision in foreign policy, and was more interested in its own domestic problems ${ }^{23}$.

Moreno Juste mentioned the concept and the desire of "Europeanization" as one of the main criteria of Spanish foreign policy throughout the $19^{\text {th }}$ and $20^{\text {th }}$ Centuries $^{24}$. If so, one would expect Swedish-Spanish relations, as two of Europe's "great peripherals" and as leading neutral countries in the World Wars, to have been intense. At first sight, however, judging by the low amount of references to Sweden in Spanish historiography on international relations during this period, this seems not to have been $\mathrm{so}^{25}$.

General Primo de Rivera's dictatorship brought great changes, in an attempt to strengthen and reorganise the Spanish administration, although this was not made in a

\footnotetext{
21 BALFOUR, Sebastian \& PRESTON, Paul (coord.), España y las grandes potencias en el siglo XX. Barcelona: Crítica, 2002.

${ }^{22}$ TORRE DEL RÍO, Rosario de la, "Recogimiento, crisis del 98 y nueva orientación internacional", in PEREIRA CASTAÑARES, Juan Carlos, La política exterior de España (1800-2003): historia, condicionantes y escenarios, Madrid: Ariel, 2003.

${ }^{23}$ This is pointed out, among others, by JOVER ZAMORA, José María, GÓMEZ-FERRER, Guadalupe \& FUSI, Juan Pablo, España: sociedad, política y civilización (siglos XIX y XX), Madrid: Areté, 2001.

${ }^{24}$ MORENO JUSTE, Antonio, "Del problema de España a la España europeizada: excepcionalidad y normalización en la posición de España en Europa", in PEREIRA CASTAÑARES, Juan Carlos (coord.), La política exterior de España...., pp. 295-317.

${ }^{25}$ No mention of Sweden appears in SECO SERRANO, Carlos, "Alfonso XIII y la diplomacia española de su tiempo", in Corona y diplomacia: La monarquía española en la historia de las relaciones internacionales, Madrid: Biblioteca Diplomática Española, 1988, pp. 185-211. And the only mention of Sweden in Pereira Castañares's bibliography list (PEREIRA CASTAÑARES, Juan Carlos (coord.), La política exterior de España..., pp. 575-607) is a minor overview by MÖRNER, Magnus, Episodios de la historia de las relaciones hispano-suecas: España y Suecia a través de los tiempos, imágenes y realidades = Episoder ur de svensk-spanska förbindelsernas historia: Spanien och Sverige genom tiderna, bilder och verklighet, Madrid: Fundación Berndt Wistedt, 1996.
} 
consistent manner. "Cultural" diplomacy was enhanced and the Ministry of State was replaced by the Military Board. When the so-called Civil Directory was established in 1925, the Minister of State was reinstated, with Jose Yanguas Messia as Foreign Minister. After his resignation, Primo personally took over, until its suppression in 1928. The Ministry was not restored until February 21, $1930^{26}$.

In the 1920s, Sweden vetoed Spanish endeavours to get a permanent place at the Council of the League of Nations. The result was Spain's temporary abandonment of the League. This Spanish "diplomatic offensive" in the League of Nations must be seen, in our view, in the context of the Spanish dictator's policy of establishing closer relations with Italy, at a time when the control of the western Mediterranean had become an international issue due to the aggressive attitude of Abd-el-Krim in Morocco. Once again, there is very little historical research on this conflict ${ }^{27}$.

The same can be said concerning the Swedish-Spanish trade agreement of 1928 or the exchange of Royal visits between the monarchs of both countries ${ }^{28}$. Even Alphonse XIII's stay in Sweden in the summer of 1931, as Gustav V's guest once the Republic had been established in Spain, is practically unknown in Swedish and Spanish historiography ${ }^{29}$.

The Spanish Foreign Service underwent a reorganisation in 1928, and would soon be sorely tested, partly due to the arrival of the Republic in 1931 but mainly as a result of the military rebellion of July 1936, which split it in two uneven halves ${ }^{30}$.

The arrival of the Republic was a clear break from Spain political traditions, but its effects on political and diplomatic relations could not be immediately seen. However, the idea of a "discreet" instead of a "secret" diplomacy and the will for a change based on a "psychology of dialogue" were soon proposed by Luis de Zulueta, the Spanish Republic's Minister of State from December 1931 to June $1933^{31}$.

\footnotetext{
${ }^{26}$ NEILA HERNÁNDEZ, José Luis, "Regeneracionismo y política exterior en el reinado de Alfonso XIII (1902-1931)", en Cuadernos de Historia de las Relaciones Internacionales, n. 3, Madrid, 2002, pp. 50-52.

${ }^{27}$ There is a Spanish doctoral thesis on this Swedish-Spanish conflict: CASTIELLA, Fernando María, Una batalla diplomática, Barcelona: Planeta, 1976; cfr. also BLEDSOE, Gerie Brown, "The Quest for Permanencia: Spain's Role in the League Crisis of 1926", Iberian Studies, 4/1975, pp. 14-21; BLEDSOE, Gerie Brown, "La oficina española de la Sociedad de Naciones", Revista de Política Internacional 127/1973, p. 123.; ANDERSSON, Ingvar, Sveriges historia. Stockholm: Natur och Kultur, 5 ed., 1962, p. 442.

${ }^{28}$ Cfr. AMAEC, R, 1164, 2 about the Swedish-Spanish Trade Agreement of 1928; AMAEC, R, 4017, 19 on Swedish-Spanish conciliation of april 26,1928; AMAEC, R 1075, 22 on arbitration regarding Sweden.

${ }^{29}$ Cfr. Registry books for 1931, Embassies and Legations, in AGA, L. AE 6402, pp. 178-183, input of August 19, 1931.

${ }^{30}$ CASANOVA, Marina, La diplomacia española durante la guerra civil, Biblioteca Diplomática Española, Sección Estudios 13, MAE, Madrid 1996.

${ }^{31}$ ZULUETA, Luis de, "La política exterior de la República", Tierra firme, 3, 1935, p. 14.
} 
The Second Republic took on the challenge of giving prominence to Spain abroad in a spirit of reform. Its basic principles, as Neila Hernandez pointed out ${ }^{32}$, were the ideals of peace and neutrality as a reformulation of Spain's foreign policy. There is consensus among researchers that this policy was neither an original approach nor a very specific one. The Republic never had an official neutrality doctrine of its $\mathrm{own}^{33}$.

Egido Leon described the Republic's foreign policy as a policy of "positive neutrality". This expression is, in our view, equally applicable to the foreign policy of both Spain and Sweden in the interwar years ${ }^{34}$.

The historical development and the role of Spain in the interwar period are well known for Spanish readers, in its three fundamental periods, Dictatorship, Republic and Civil War, and consequently there is no need for an overview in these pages. On the contrary, an overview of Swedish history and its specific role in the international scene, particularly in Europe, from 1900 to 1930, would probably be welcome here.

The years between 1905 and 1920 witnessed the definitive establishment of democracy and parliamentarism in Sweden. After the separation of Norway in 1905, the attention of the Swedish Liberal government could focus on domestic issues, particularly the question of the organization and financing of the Swedish military defense, and the question of political representation, which would lead to universal male suffrage in 1909. Women could vote for the first time in 1921.

The early years of the $20^{\text {th }}$ century were also a period of major reforms: the creation of the Supreme Administrative Court, the modernization of the tax system and corporate law, and the extension of civil marriage. Social conflict was felt especially in the general strike of 1909. In the 1911 election, with the defeat of the Conservatives, the Liberal victory and the breakthrough of the Social Democratic Party showed clearly that Sweden was turning from a liberal system to a democratic one.

One significant point in this development was the issue of defense. Parliament was divided and the dissatisfaction of large sectors of Swedish society with the delays in rearmament, culminated in the massive demonstration of February $6^{\text {th }}, 1914$, where 30,000 farmers marched on Stockholm in support for a policy of immediate increase of the

\footnotetext{
${ }^{32}$ NEILA HERNÁNDEZ, José Luis, "El proyecto internacional de la Segunda República: Democracia, paz y neutralidad" en PEREIRA CASTAÑARES, Juan Carlos (coord.), La política exterior de España..., pp.453474; p. 458.

${ }^{33}$ QUINTANA NAVARRO, Francisco, España en Europa, 1931-1936. Del compromiso de paz a la huida de la guerra, Madrid: Nerea, 1993.

${ }^{34}$ EGIDO LEÓN, op.cit., pp. 82-90 y pp. 254-256
} 
military defense budget. The demonstration caused a severe political crisis and marked the swan song of the liberal system and the position of the monarch as arbiter of politics. It was a breakthrough towards the definitive establishment of a fully democratic system.

During the First World War, in which Sweden remained neutral, the country's traditional links with Germany were subjected to a difficult test. The war led to a government crisis and to the formation of a strictly technical Cabinet, led by Hjalmar Hammarsköljd as Prime Minister, a government that would stay in office for most of the conflict. There were many problems, beginning with the lack of food, which led to social unrest (with demonstrations to protest against the rationing system), the expropriation of peasant land and clashes between demonstrators and the Police.

The 1917 parliamentary elections were won by the Social Democrats and the Liberals, who formed a coalition government. Both had the common goal of a full democratisation of the electoral system, taking away the existing legal restrictions, especially numerous concerning municipal elections. The inauguration of the new government, with Eden as Prime Minister and Hjalmar Branting as Minister of Finance, on October $19^{\text {th }}, 1917$, is traditionally considered in Swedish historiography as the moment of the final settlement of democracy and parliamentarism. The new government's legislative efforts culminated in the adoption in May 1919 of the new constitutional laws proclaiming universal suffrage and of labor legislation, introducing the eight-hour working day.

In 1920 Sweden joined the League of Nations, and for the first time a social democrat, Hjalmar Branting, was Prime Minister. The period from 1920 to 1932 is known as the "era of parliamentary minorities" (minoritetsparlamentarismens tid), characterized by a succession of nine weak governments without a parliamentary majority, with frequent crises of government: in twelve years there were eleven Prime Ministers. By mid-decade, the cultural climate of the country was one of intense pacifism, and the organization of the defense became a priority. Legislation on education and on labor relations was also given an important place in Swedish domestic politics.

The diplomatic crisis with Spain in the League of Nations took place under the Liberal government of Carl Gustaf Ekman (1926-1928): Sweden opposed Spanish, Brazilian and Polish requests of a permanent position in the Council of the League, 
supported the entry of Germany and finally gave up its own seat on the Council in Poland's favor to enable a compromise in line with the spirit of Locarno ${ }^{35}$.

A well-known study on Swedish foreign policy claims that it has had four paradigm shifts: in 1434, 1630, 1812 and 1991. Since 1812 - the last time the country was directly involved in a war - until 1991, Swedish foreign policy pivoted on two basic coordinates: neutrality and mediation in international conflicts ${ }^{36}$.

Was the 1926 Swedish veto on the Spanish aspirations to obtain a permanent seat on the Council of the League of Nations in line with this policy? In Sweden, the answer is yes: Sweden's intention was to mediate in favor of Germany, which had been unfairly treated by the Treaty of Versailles.

In recent decades the debate has gone strong in Sweden over its neutrality policy. A book by a Swedish journalist in the early 1990s broke several decades of silence about a policy that, in the opinion of many, was actually undercover collaborating with the Nazi regime. The traditional image of Sweden having acted under permanent coertion as a result of the threat of invasion by the Third Reich has also been questioned by recent German historiography ${ }^{37}$.

Since then, many studies have followed suit, with meaningful titles: "The balance of power and permanence outside alliances: Swedish foreign policy in the $20^{\text {th }}$ Century" by Nils Andrén ${ }^{38}$; "On behalf of the Swedish working class or Soviet politics?: the communist movement in Sweden and its relations with Moscow 1920-1970" by Lars Björlin";9; "The British alternative: a possible way forward in Swedish foreign policy after the First World

\footnotetext{
${ }^{35}$ NORBORG, Lars-Arne, Sveriges historia under 1800- och 1900-talen. Svensk samhällsutveckling 18091992. Stockholm: Almqvist \& Wiksell, 1993, pp. 183-187; MELIN, Jan, JOHANSSON, Alf W.\& HEDENBORG, Susanna, Sveriges historia: koncentrerad uppslagsbok - fakta, årtal, tabeller, kartor. Stockholm: Rubén Prisma, 1997, pp. 210-214; ANDERSSON, Ingvar, op. cit., p. 442.

${ }^{36}$ BERGQUIST, Mats, "Fyra paradigmskiften i svensk utrikespolitik", Nordisk tidskrift för vetenskap, konst och industri 2009(85):1, pp. 47-58; About this subject, see also TINGSTEN, Herbert, Svensk utrikesdebatt mellan världskrigen, Stockholm: Aldus/Bonnier, 1944/1964; HIRSCHFELDT, Lennart (coord.), Svensk utrikespolitik under 1900-talet, Stockholm, 1958; ÅMARK, Klas, Makt eller moral: svensk offentlig debatt om internationell politik och svensk utrikes- och försvarspolitik 1938-1939. Stockholm, 1973; STEENE, Mikael, "Role model or power pawn?: the changing image of Swedish foreign policy, 1929-1987", en SUNDELIUS, Bengt (coord.), The committed neutral : Sweden's foreign policy, Boulder: Westview Press, 1989

${ }^{37}$ RADOWITZ, Sven, Schweden und das Dritte Reich 1939-1945: die deutsch-schwedischen Beziehungen im Schatten des Zweiten Weltkrieges, Hamburgo: Krämer, 2005.

38 ANDRÉN, Nils, Maktbalans och alliansfrihet: svensk utrikespolitik under 1900-talet, Stockholm: Nordstedt, 1996.

${ }^{39}$ BJÖRLIN Lars, "För svensk arbetarklass eller sovjetisk utrikespolitik?: den kommunistiska rörelsen i Sverige och förbindelserna med Moskva 1920-1970", in JUNGAR, Sune \& JENSEN, Bent (red.) Sovjetunionen och Norden, Helsinki : FHS, 1997.
} 
War" by Torbjörn Norman ${ }^{40}$; the harsh criticism of Swedish socialism entitled "The myth of neutrality: critical analysis of Swedish foreign policy" by Tommy Hansson ${ }^{41}$; Leif Dahlberg's "Above the will of the people: on Swedish foreign policy"42; and Ingemar Ottosson's "War in the name of peace or neutrality at all costs? Sweden, the League of Nations and the issue of collective security in 1935-36",43. The list is not exhaustive.

Swedish neutrality in the First World War was also discussed at the time, although Hammarskjöld always wanted it to be strict neutrality in accordance with the rules of international law. Spain did likewise. However, neutrality, in practice, favored Germany. There are many examples for this: Sweden interceded with the British, the Italian and the Romanian asking them not to enter the war against Germany. Sweden also refused to participate in the trade embargo to Germany, but this led to cuts in the Entente exports to Sweden and the result was shortage of food. When Hammarskjöld's government fell in 1917, the Allies supported the Liberals and Social Democrats by making public the socalled "Luxburg affair". Luxburg was a German diplomat in Buenos Aires, who had delivered information on Entente ship movements to Berlin through the Swedish Ministry of Foreign Affairs. The Eden-Branting new government immediately went into negotiations with the Entente powers and managed to sign a trade agreement that put an end to the shortage of basic commodities in Sweden ${ }^{44}$.

Swedish foreign neutrality policy was once again put to the test by the Finnish Civil War in 1918. With a divided public opinion, the right favoring the "white" army of Marshal Mannerheim and the left supporting the "red" army ${ }^{45}$, the Swedish government remained neutral. This did not please the victorious Finns, and the relationship with Sweden cooled further when some Swedish warships were sent to the Alland archipelago, placed under Finnish sovereignty but predominantly Swedish-speaking (even today, there are 300,000 people in Finland whose mother tongue is Swedish, which is also an official language in the country, and the only official one in the Aland archipelago). A local

\footnotetext{
40 NORMAN, Torbjörn, "Det brittiska alternativet: vägvalsfrågor i svensk utrikespolitik efter första världskriget”, en ASKLÖF, Louise \& CARLQUIST, Erik, Humanismen som salt och styrka, (Acta Bibliothecae regiae Stockholmiensis), : Kungl. Bibloteket, 1987, pp. 432-449

${ }^{41}$ HANSSON, Tommy, Neutralitetsmyten : en granskning av svensk utrikespolitik, Stockholm: Contra, 1991

${ }^{42}$ DAHLBERG, Leif, Över folkets huvud : om svensk utrikespolitik, Stockholm: Bonnier, 1967

${ }^{43}$ OTTOSSON, Ingemar, Krig i fredens intresse eller neutralitet till varje pris? Sverige, NF och frågan om kollektiv säkerhet 1935-36, Malmö: Liber/Gleerup, 1986.

${ }^{44}$ NORBORG, Lars-Arne, op. cit., 1993, p. 259.

45 The terms "white" or "bourgeois block" and "red block" are common in Swedish politics and have no pejorative overtones. The terms "white" and "red" are used here in the Swedish sense.
} 
referendum in 1919 returned a $96 \%$ vote for the return to Sweden. However, the League of Nations decided it should continue to belong to Finland, although with a special status.

The end of the First World War marked a big change for Sweden on the international stage: its two powerful neighbours, Germany and Russia, were now very weak, and the newly founded League of Nations gave wings to a pacifist optimism that was particularly strong among the liberals and social democrats.

The first question Sweden was confronted with was whether the country should join the League of Nations or not. From the Swedish point of view, the League had many defects: neutral countries had had nothing to say in its foundation, the vanquished nations even less, and both the USSR and the United States had opted out. In Sweden, the question was whether the entry into the League of Nations was or was not a departure from the neutrality policy ${ }^{46}$. Eventually the government decided to join the League, to give it a vote of confidence in its attempts to ensure world peace, with only the Conservative Party voting against, as a protest for the treatment Germany had received. There is a recent study on Sweden and the system of sanctions of the League of Nations, with many bibliographical references ${ }^{47}$.

Swedish policy in the League of Nations was the defence of the interests of the small countries against the great powers, trying to make the League more universal by opening it to the losers in the Great War, and promoting international disarmament agreements ${ }^{48}$. This line was not only consistent with the humanitarian and internationalist ideals of the time, but it was probably the one that best promoted Sweden's national interests: security and peace in its close environment, enabling a reduction in defense expenses and the investment in social reforms ${ }^{49}$.

It is also worth mentioning that Sweden's policy of support to Germany within the League of Nations was not just official government policy but enjoyed wide public support, for example, in academic and student circles $^{50}$.

\footnotetext{
${ }^{46}$ See, e.g. ANDERSSON, op. cit., p. 449.

${ }^{47}$ SILANDER, Martin, Debatten om NF och dess sanktionssystem: Vilhelm Lundstedt och hans antagonister. Master thesis, Halmstad: Högskolan i Halmstad, 2006.

${ }^{48}$ A specific study on Sweden's role in the Conference of Disarmament of 1932 in TRÖNNBERG, Stefan, Nedrustning under mellankrigstiden: Sverige och nedrustningskonferensen i Geneve 1932, Solna: Seelig, 1985.

${ }^{49}$ NORBORG, Lars-Arne, op. cit., p. 263.

50 ÅHLSBERG, Bengt, Studenter och storpolitik - Sverige och det internationella samarbetet 1919-1931. Lund: Lunds University Press, 1995; cfr. also JANSSON, op. cit., 1991 and LINDER, Jan, Mellankrigstiden: Sverige och Europa, Stockholm: Infomanager, 1993.
} 
Spain is not mentioned in any general works on Swedish foreign policy. It is a consequence of Spain's secondary role in Swedish foreign policy priorities. On the other hand, there are several studies on Sweden's intervention in the Spanish Civil War.

Financial issues are a separate chapter, but are undoubtedly important for a right understanding of Swedish policies in the interwar years. Credit and trade agreements were a major issue in Swedish-Spanish relations ${ }^{51}$.

Swedish neutrality policy during World War II and the Cold War, and the leading role taken by the country within the United Nations since 1950 - to the point of considering itself as a diplomatic power of first order $^{52}$ - was a result of a policy pursued consistently since 1812, and especially in the period 1919-1939.

\subsection{Swedish-Spanish relations from 1931 to 1939 in Swedish historical research}

Some references to historical research that are directly or indirectly relevant to this study have already been made. The time has come for a more structured presentation and discussion of the existing Swedish and Spanish historiography, on its specific topic, the political and diplomatic relations between Sweden and Spain in the 1930s, as well as some works from researchers from third countries.

General works on the internal politics of each country, on the Spanish Republic and the Spanish Civil War as such, or on Swedish-Spanish relation before 1931 will not be discussed here.

Swedish research on Swedish-Spanish relations in the 1930s is not abundant, and the few available contributions, with some exceptions ${ }^{53}$, focus on a specific aspect of those relations (the commercial, cultural or humanitarian aspect).

Above all, it should be emphasized that there is no Swedish case study on the political and diplomatic relations between Sweden and Spain in the period 1931-1939. In contrast, there are several on Sweden's intervention in the Spanish Civil War, especially on the Swedish volunteers who fought in the International Brigades and about the humanitarian work of the Swedish Committee for Aid to Spain.

\footnotetext{
51 On Swedish credit agreements at the time cfr. SJÖGREN, Hans, Kreditförbindelser under mellankrigstiden: krediter i svenska affärsbanker fördelade på ekonomiska sektorer och regioner, Uppsala 1989.

${ }^{52}$ NOORD, Fredrik, Den diplomatiska stormakten, Karlstad: Karlstads Universitet, 2001.

${ }^{53}$ JERNECK, Magnus, MÖRNER, Magnus, TORTELLA, Gabriel \& ÅKERMAN, Sune (coord.), op. cit., 2005.
} 
The main Swedish researcher in this field is undoubtedly Marcos Cantera Carlomagno $^{54}$. His most important work as far as this study is concerned is the one entitled "Sweden and the Spanish Civil War". It analyzes the role of Sweden from different points of view, although the main focus is on the issue of trade relations, with the resulting relationships between employers and business organizations in each country.

Cantera Carlomagno has performed a comparative analysis and contrasted available sources from both countries. His theoretical and methodological approach is more akin to the dominant in Spain, closer to the empirical material. In his works, he presents a very expressive and versatile picture of Swedish relations with Spain during the Civil War, analysing different aspects: solidarity, the policy dilemma, the trade problem, the diplomatic problem caused by the partition of Spain into two sovereign areas in practice, and the vicissitudes of the decisions taken by the Swedish government in the Spanish question. He used sources from the Swedish Foreign Ministry (Utrikesdepartementet), the Parliamentary Committee for Foreign Affairs (Utrikesnämnden), the Archives of the Swedish Exporters Association (SAE) and some major Swedish newspapers, as well as the memoirs of two preeminent figures in Sweden at the time, Tage Erlander and Herbert Tingsten. In this book, he used Spanish sources in a much lesser degree (only seven documents from the Spanish Foreign Ministry Archives). This is one of the shortcomings of this study.

Furthermore, Cantera Carlomagno's doctoral dissertation about Sweden according to the reports of Italian diplomats in the 1930s, which brought to light hitherto unknown data and paved the way for future research, is similar in structure and content to this research study, and it obviously contains interesting items ${ }^{55}$.

Nevertheless, this study was heavily criticised in Swedish academic circles, mainly for some deficiencies in the use of Italian diplomatic sources, not always contrasted with other available sources, and the extrapolation of conclusions, which sometimes seem to lack sound empirical ground ${ }^{56}$.

\footnotetext{
${ }^{54}$ His main contributions are: CANTERA CARLOMAGNO, Marcos, "El reconocimiento del gobierno nacionalista por parte de Suecia: una primera prueba de fuerza", in TUSELL, Javier, AVILÉS, Juan \& PARDO, Rosa (coord.), op. cit., Madrid 1997; Sverige och spanska inbördeskriget, Lund: Historiska media, 1999; and "Bang, Dagens Nyheter och Utrikesdepartementet", en När Alving blev Bang, Lund: Historiska Media, 2001, pp. 69-85

55 CANTERA CARLOMAGNO, Marcos, Ett folk av mänsklig granit: Sverige $i$ den italienska utrikespolitiken 1932-1936, Lund: Historiska Media, 1995.

${ }^{56}$ There is a very critical recension of Canteras book by AF MALMBORG, Niklas, "Sverige i det fascistiska Italiens utrikespolitik" (Sweden and Fascist Italy's foreign policy), in Historisk Tidskrift, 1997, pp. 158-167.
} 
Much more important for our study is Bertil Lundvik's doctoral thesis ${ }^{57}$. In it he analyses the actions of the five main actors within the Swedish labor movement (the three parties: Social Democratic, Socialist and Communist, and the two dominant unions: LO and SAC), in relation to the Spanish Civil War.

Lundvik's main conclusions were:

a) The Social Democratic party and the LO Union opted for a policy of complete neutrality, although their sympathies were on the side of the Republic;

b) The Socialists and the syndicalists (SAC) strove to create an opinion that would make the Government change course, while supporting the Republic as much as they could; and the Communist Party managed to organize the shipment of more than 500 volunteers to fight in the International Brigades.

Several works deal with the role the Swedish Labour Movement played in the Spanish Civil War. Jändel focused on the political aspects of solidarity, whereas Jönsson and Kennerström analysed thoroughly the Swedish workers' radicalism in connection with the war, showing the position of different groups and the discussions thereon within the Labour movement, and especially within the syndicalist unions ${ }^{58}$.

A recent book entitled "They will not pass! The Spanish Civil War and the confrontation with Fascism" provides a good overview of the different aspects of Swedish intervention in the Spanish Civil War".

There are also several interesting printed sources, such as a book by anarchist activist Berner and the speeches of social democrat politician Georg Branting. Also the contributions by Kennerström, Gustavsson \& Karlsson, Dalin, Henrikson, and Mattson \& Gröndahl deserve a special mention. All these researchers have personal and ideological

Af Malmborg claims Cantera does not question the opinion expressed by Italian diplomats that Fascism and the Swedish social-democratic ideology shared a common ground.

${ }^{57}$ LUNDVIK, Bertil, Solidaritet och partitaktik: den svenska arbetarrörelsen och spanska inbördeskriget 1936-1939, Uppsala/Stockholm: Almqvist \& Wiksell international (distr.), 1980. Another work by the same author is: "De svenska handelsintressena och utrikespolitiken under spanska inbördeskriget", en ERIKSSON, Maj-Lis (coord.), Med eller mot strömmen? en antologi om svenska folkrörelser, Stockholm: Sober, 1980, pp. 61-79;

58 JÄNDEL, Richard, Kämpande solidaritet, Stockholm: AKS/ARAB, 1996; JÖNSSON, Claes-Göran \& KENNERSTRÖM, Bendt, Den svenska arbetarradikalismen och spanska inbördeskriget, Stockholm: Arkiv 1977.

59 HELGESSON, Patrik, JÄNDEL, Richard, \& WEIJDEG̊̊RD, Nils (coord.), No pasaran!: Spanska inbördeskriget och uppgörelsen med fascismen, Svenska Spanienfrivilligas vänner, 2008. 
links to the Swedish labour movement, and this is reflected in their works, all useful contributions to our subject ${ }^{60}$.

Other Swedish researches such as Berglund, Nilsson and Dalin have analysed the Spanish Civil War as seen by the Swedish press ${ }^{61}$. There are also some interesting case studies on the Swedish-Norwegian hospital established in Alcoy ${ }^{62}$.

The largest group of Swedish research works on the Spanish war focuses on the Swedish members of the International Brigades. Most complete are Lundvik's doctoral dissertation and Lundberg's and Gyllenhaal \& Westberg's recent contributions. Lennart Lundberg's book is of particular interest for this study, because it also analyses - albeit very briefly - the role of the Swedish Legation in Madrid and of the Swedish military officers in charge of monitoring the fulfilment of the non intervention agreement. Gyllenhaal and Westberg's is the most comprehensive and detailed report on the activities of Swedish volunteers in the Spanish war. It contains photographs and is well grounded in the available sources, even though it is almost completely centred on military aspects ${ }^{63}$.

Also the studies by G. Nilsson and Ericson Wolke provide useful insights. One of their main sources was the analysis of the Spanish Civil War produced in two volumes by

\footnotetext{
${ }^{60}$ KENNERSTRÖM, Berndt, "Socialistiska partiet och spanska inbördeskriget: den problematiska principfastheten", en Arkiv 6, 1974; GUSTAFSSON, Kerstin \& KARLSSON, Mekki, Spaniens sak var vår, Stockholm: Svenska fredskommittén \& Svenska Spanienfrivilligas vänner, 1992; DALIN, Stefan, "En bortglömd solidaritetsrörelse: det svenska Spanien-engagemanget 1936-1939”, en ALÉX, Peder, \& HJELM, Johnny (coord.), Efter arbetet, Lund: Studentlitteratur, 2001; HENRIKSON, Göran, "Spaniens sak är vår: Spanienrörelsen i Örebro län 1936-1939”, en Från bergslag och bondebygd, Örebro: Örebro läns museum; 1979 (33), pp. 61-85; MATTSON, Carl, Spaniens sak var vår: solidaritetsrörelsen i Värmland 1936-1939: kampen mot krig och fascismen, Karlstad: ABF Värmland, 1982; GRÖNDAHL, Birgitta, De ideologiska motsättningarna i den spanska syndikalismen 1910-1936, Stockholm: Federativs förlag, 1981, y de la misma autora Frihetlig kommunism i praktiken: experiment i självförvaltning i Spanien 1936-1939, Stockholm: Federativs förlag, 1986; BERNER, Rudolf, S. A. C.: el movimiento anarcosindicalista en Suecia: su obra en favor de la España antifascista, Barcelona: Tierra y Libertad, 1938; BRANTING, Georg, Kamp och humanitet: En rapport avgiven vid möte i Auditorium den 13 febr. 1939 av Georg Branting; Stockholm: Svenska hjälpkommittén för Spanien, 1939.

${ }^{61}$ BERGLUND, Åsa, Spanska inbördeskriget $i$ svensk arbetarpress, Uppsala: Uppsala Universitet, 1974; NILSSON, Per, Spanska inbördeskriget och Sverige: stockholmspressen och krigsslutet, Stockholm: Historiska Institutionen, 1976; DALIN, Stefan, "Den svenska lokalpressen och spanska inbördeskriget", en Presshistorisk årsbok, 22, 2005, y del mismo autor "Värmlandspressen och Spanienfrågan" en GUSTAFSSON, Karl Erik \& RYDÉN, Per (coord.), Folk och press i rörelse, Gotemburgo: NordicomSverige, 1999, pp. 151-170.

${ }_{62}$ RABO, Erik, "Spanienhjälpens fältsjukhus under spanska inbördeskriget: svensk-norsk insats för demokratin" en Läkartidningen 2003(100):44, pp. 3522-3525); MYKLEBUST, Jon Olav \& Beneito Lloris, Ángel, "A hospital for Spain!: Scandinavian solidarity in a time of civil war, Alcoy: ZOE Imatge-Arts, 2009.

${ }^{63}$ LUNDBERG, Lennart, Svenskarna i spanska inbördeskriget 1936-1939, Gotemburgo: Tre böcker, 2001; GYLLENHAAL, Lars \& WESTBERG, Lennart, "I spansk tjänst 1936-1939: På titanernas första slagsfält", en Svenskar i krig 1914-1945, Lund: Historiska media, 2006, pp. 111-164.
} 
the Swedish Army General Staff, dated 1938 and 1942, which the Minister of the Spanish Republic in Stockholm dismissed as "superficial", a view we do not share ${ }^{64}$.

A special group within this line of research consists of the memoirs and letters of International Brigades veterans or their relatives (Brännström, Olsson Rogeby, Meurling, etc.) and the studies based on them, such as Risberg's, Yrlid's, Sjöstedt's and Björk's. There were also war time propaganda books or leaflets, as the ones written by Norwegian journalist Lise Lindbaeck ${ }^{65}$. The list could be made far longer.

As can be observed, there are some studies indirectly touching on some aspects of Swedish-Spanish political relations, but none on diplomatic relations as such.

Moreover, Swedish historiography on the Spanish Civil War as such (not in terms of its connections with Sweden) is almost nonexistent, apart from the aforementioned book by the Army Staff, a collection of Spanish children drawings about the war published by Kajsa Rothman in 1937 and a collection of speeches and statements of prominent Swedish supporters of the Spanish Republic entitled "Spain, the working class and militarism"66.

All other texts written in Swedish on the war in general are translations of foreign works or abstracts on the subject in textbooks for schools. In this context, therefore, it is worth mentioning that one original Swedish book has just been published: "Survivors of the Spanish Civil War and Franco's dictatorship”, by Kerstin Ekström ${ }^{67}$.

If there are few Swedish studies on the Spanish Civil War, the situation is even worse in connection with the Second Spanish Republic between 1931 and 1936. There is,

\footnotetext{
${ }^{64}$ NILSSON, Göte, Svenskar i spanska inbördeskriget, Stockholm: Norstedt, 1972; ERICSON WOLKE, Lars, "Frivilliga i strid", Populär historia 2006:7/8, pp. 32-36; FÖRSVARSSTABEN, Det spanska inbördeskriget I (1938) y Det spanska inbördeskriget II (1942), Stockholm: Militärlitteraturföreningens förlag, 1938 y 1942; The Spanish diplomat's comments are in AMAEC, R 642, 3.

${ }^{65}$ BRÄNNSTRÖM, Sven, "En spanienfrivillig från Västerbotten berättar", en Oknytt 1998 (19:1/2)., Holmsund: Oknytt, p. 44.; RISBERG, Åsa, Att försöka påverka världen med ord: Eyvind Johnson och spanska inbördeskriget, Stockholm: Natur och kultur, 1975, pp. 76-83; OLSSON (ROGEBY), Sixten, Spanska frontminnen, Stockholm: Arbetarkultur, 1938 and De stupade för Spaniens demokrati, Stockholm: Arbetarkultur, 1977); YRLID, Rolf Till Madrid: tre svenskars närvaro under det spanska inbördeskriget, Lund: Atlantis, 2006; SJÖSTEDT, Jonas, Brev till en broder. Spanienkämpen Bengt Segersons personliga skildring från det spanska inbördeskriget, Simrimshamn: Svenska Frivilligas vänner, 2009, "Från Västerbotten till Spanien”. Västerbotten 2008:3, pp. 32-51, and Masthugget, Moskva, Madrid: berättelsen om Bengt och Greta, Stockholm: Carlsson, 2009; MEURLING, Per, Den blodiga arenan: en bok om det spanska kriget, Stockholm: Universal Press 1937; LINDBAECK, Lise, Bataljon Thäelmann, 1938 у De internationella brigaden, Stockholm: Solidaritetens förlag, 1939; BJÖRK, Kaj, Spanien i svenska hjärtan, Stockholm: Arbetarrörelsens arkiv och bibliotek, 2001.

${ }^{66}$ ADAMSSON, Einar; FALUDI, Ivan; FLYG, Nils; HOLMSTRÖM, Axel; LINDE, Ebbe; NERMAN, Ture \& ÖSTERBERG, Axel, Spanien, arbetarklassen, militarismen, 1938.

${ }^{67}$ EKSTRÖM, Kerstin, Överlevarna: Från spanska inbördeskriget och Francodiktaturen, Stockholm: Carlsson, 2010.
} 
as far as we know, quite simply not a single book or article to be found on the subject in Swedish. Even studies on Sweden's diplomatic relations with other countries are rare, although there are some on relations with England, France, Prussia, Russia, the United States, Turkey, Greece, Latvia, Estonia, Poland, Korea and Japan ${ }^{68}$.

The shortage of specific modern works on Swedish relations with other powers may be surprising. One possible explanation is the focus of Sweden's foreign policy on multilateral relations, first within the League of Nations and later in the United Nations, rather than on bilateral contacts. Another one is Swedish historians' lack of interest in political history as such during the last sixty years.

\subsection{Swedish-Spanish relations from 1931 to 1939 in Spanish historical research}

Spanish historical research on the Second Republic and the Civil War is so large that any attempt to summarize it here would be out of place. Instead, only the most relevant contributions to the topic of this study will be named.

The research works on the Second Republic's foreign policy by Egido León, Pereira Castañares - one of the principal researchers on modern Spain's foreign policy - and Neila Hernández enjoy a key position among the relevant Spanish publications for this study ${ }^{69}$.

In chapter two of his famous work on international relations, entitled "International Studies in Spain's foreign policy: A state of the matter", Pereira Castañares provides a good overview on the basic principles of Spanish foreign policy. One of his subtitles is very suggestive: "Republic and war: from intellectual debate to ideological analysis"

\footnotetext{
${ }^{68}$ Two classical works are the doctoral dissertations of GRIMBERG, Carl, De diplomatiska förbindelserna mellan Sverige och Preussen 1804 - 1808, Gotemburgo: Universidad, 1903 and BEHRE, Göran, Underrättelseväsen och diplomati: de diplomatiska förbindelserna mellan Sverige och Storbritannien 17431745, Gothenburg: Gothenburg University, 1965; See also LEJIN̦Š, Atis, "Sveriges och Lettlands relationer 1987-1991: ockupationsfrågan", in Kungl. Krigsvetenskapsakademiens handlingar och tidskrift (209):4; 2005, pp. 97-107; SYDOW, Erik von, "Diplomatiska relationer mellan Estland och Sverige under mellankrigstiden” in Estländare i Sverige : historia, språk, kultur, Uppsala: Uppsala multiethnic papers, 1988, pp. 49-53.

${ }^{69}$ See NEILA HERNÁNDEZ, José Luis, "El proyecto internacional de la República. Democracia, paz y neutralidad (1931-1936)", in PEREIRA CASTAÑARES, Juan Carlos (coord.), La política exterior de España...; y también "La política exterior de la España Republicana (1931-1936): excepcionalismo y normalidad historiográfica", Studia Historica, Historia Contemporánea, 22, Salamanca, 2004.

${ }^{70}$ PEREIRA CASTAÑARES, Juan Carlos, La política exterior de España...; See also his work Introducción al estudio de la política exterior de España (siglos XIX y XX), Akal, Madrid, 1983.
} 
Generally speaking, all basic historiography on international relations is important to understand the context of the diplomatic relations between Sweden and Spain in the $1930 s^{71}$.

In this respect, recent works by Ángel Viñas are also a point of reference. Viñas is a connoisseur of the subject and a very thorough researcher of primary sources and documents. He has also a long international research experience outside Spain, something important for studies on international relations.

In "The loneliness of the Republic: The abandonment of democracy and the turn to the Soviet Union", Viñas discusses the change of direction and the strategy of Republican Spain's diplomacy to to win over the support of the Western democracies ${ }^{72}$.

Also his work entitled "The Shield of the Republic: The gold of Spain, the Soviet bet and the events of May 1937', is relevant concerning the funding of the Republican war effort, as there were also connections in the Nordic and Baltic countries ${ }^{73}$. Finally, "The honor of the Republic: harassed by fascism, British hostility, and Stalin's policies" is a major work because of the great amount of information and the interesting discussions with previous research it contains, as well as its appendix, but there is no mention of Sweden in it. It will be interesting to see whether Viñas' conclusions on Negrin's role and on the British attitude in relation to Spain are echoed in the Swedish diplomatic documentation $^{74}$.

Even more important for the purpose of this study is probably the recent book on Republican diplomats coordinated by Viñas, where the activities of the Spanish Republic's Embassies and Legations in London, Paris, Washington, Bern, Prague and Mexico are discussed in detail, preceded by a common introduction by Julio Aróstegui on the Republic's war time diplomacy ${ }^{75}$.

\footnotetext{
${ }^{71}$ Some interesting contributions are: MORALES LEZCANO, op.cit., pp. 575-582; y MORENO JUSTE, Antonio, "La historia de las relaciones internacionales..."; BALLESTEROS, Ángel, Diplomacia y relaciones internacionales, $4^{\mathrm{a}}$ edición, Madrid, 2009.

${ }^{72}$ VIÑAS, Ángel, La soledad de la República. El abandono de las democracias y el viraje hacia la Unión Soviética, Barcelona: Crítica 2006, pp. 256-265.

${ }_{73}$ VIÑAS, Ángel, El escudo de la República. El oro de España, la apuesta soviética y los hechos de mayo de 1937, Barcelona: Crítica, 2007.

${ }^{74}$ VIÑ̃S, Ángel, El honor de la República. Entre el acoso fascista, la hostilidad británica, y la política de Stalin. Barcelona: Crítica 2009.

${ }^{75}$ VIÑAS, Ángel, (coord.), Al servicio de la República: Diplomáticos y guerra civil, Madrid: Marcial Pons Historia, 2010.
} 
The well known works by Elorza and Bizcarrondo about the 3rd International, Quintana Navarro about Spain in Europe between 1931 and 1936, and Cervera on war time Madrid (where Sweden is expressly mentioned) also deserve a special mention here ${ }^{76}$.

Two other scholars, Moradiellos and Moral Roncal, are particularly relevant to this study, having written several works on Spanish foreign policy and diplomacy in the 1930s. Moradiellos describes well the international situation with regard to Spain in those years as well as the new strategy of the Comintern, the prevailing hostility, etc. His research on British attitudes, a topic he is an expert on, are of particular interest for our study, because of Sweden's close relationship with England during the years when British appeasement policy was at its peak. Moradiellos numerous references to diplomatic sources, both Spanish and British, are particularly useful ${ }^{77}$.

Moral Roncal is so far the only Spanish scholar who has studied the role played by Sweden's Legation in Madrid during the Civil War years. It is part of a serious and thorough case study on the humanitarian activities of foreign Embassies and Legations in the Spanish capital, based on many primary sources, which is a starting point for any further study on the issue. Unfortunately, it gives little attention to Sweden, being perhaps unaware of the leading role the Scandinavian country played during the war, considering the importance of its humanitarian aid to the Republic and the large number of Swedish volunteers who fought for it. This is possibly surprising for Swedish historians, although it is understandable that Sweden's intervention on the Spanish Civil War is little known outside the country's borders ${ }^{78}$.

Most of Moral Roncal's works focus on issues relating to diplomatic asylum during the Civil War, and are therefore relevant to the present study ${ }^{79}$.

\footnotetext{
${ }^{76}$ ELORZA, Antonio \& BIZACARRONDO, Marta, Queridos camaradas: La internacional comunista y España, Barcelona: Planeta, 1999; QUINTANA NAVARRO, España y Europa...; CERVERA, Javier, Madrid en guerra: La ciudad clandestina, Madrid: Alianza Editorial, 2006, p. 379.

${ }^{77}$ MORADIELLOS, Enrique, El reñidero de Europa: las dimensiones internacionales de la Guerra Civil española, Barcelona: Península, 2001 and also his work "El mundo ante el avispero español: intervención y no-intervención extranjera en la Guerra Civil", in JULIÁ, Santos (coord.), República y Guerra en España (1931-1939), Madrid: Espasa, 2006, pp. 287-362.

${ }^{78}$ MORAL RONCAL, Antonio Manuel, Diplomacia humanitarismo y espionaje en la Guerra Civil española, Madrid: Biblioteca Nueva, 2008, pp. 494-496.

${ }^{79}$ MORAL RONCAL, Antonio Manuel, El asilo diplomático en la Guerra Civil Española, Madrid, 2001; "Asaltos y cierres de legaciones extranjeras: un grave asunto diplomático en el Madrid de la Guerra Civil (1936-1939)", Revista de Arte, Geografia e Historia, 4, (2001), Madrid, pp. 221-247; "The Allies and the Spanish Civil War", in BALFOUR, Sebastian. \& PRESTON, Paul, (coord.), Spain and the Great Powers in the Twentieth Century, Londres: Routledge, 1999, pp. 96-126; "El auxilio diplomático suizo (1936-1939): Humanitarismo y neutralidad benevolente en la Guerra Civil Española", in Cuadernos de Investigación
} 
Casanova has also done a lot of research on Spain's diplomatic relations during the Second Republic and the Civil War years. Also Perez Ruiz has an interesting contribution on the topic ${ }^{80}$.

In the field of bilateral diplomatic relations, works concerning Latin American countries are common in Spanish historiography. However, connections with Sweden are, in this respect, virtually nonexistent ${ }^{81}$. In recent years, the amount of studies about Eastern Europe has also increased in Spanish historiography on the History of International relations ${ }^{82}$.

Azcárate's classical book about his years at the head of the Spanish Republic's London Embassy mentions some issues affecting Sweden, as both countries had near ties with each other in the 1930s. The same happens with the works by Luengo Teixidor concerning espionage in France and Marquina Barrio on mediation plans to put an end to the $\operatorname{war}^{83}$.

Finally, there is a book on the impact of the Spanish Civil War in the Nordic countries, especially focusing on Iceland, which reflects well popular Scandinavian ideas about the Spanish War. However, this work does not use primary sources from the other Scandinavian countries, and it gives a rather naïve vision of the topic ${ }^{84}$.

The fact that no research works on the foreign policy of Franco's Spain have been mentioned may perhaps be somewhat surprising. The reason is most of the research work

Histórica, 22, (2005), pp. 349-372; "El Madrid de 1936 a través de las memorias inéditas del marqués de Alquibla", Revista de Arte, Geografía e Historia, 5, Madrid, 2002, pp. 293-313.

80 CASANOVA, Marina, La diplomacia española..., "Las relaciones diplomáticas hispano-belgas..." and "Depuración de funcionarios diplomáticos durante la Guerra Civil", Espacio, Tiempo y Forma. Revista de la Facultad de Geografía e Historia, 1, UNED, 1987; PÉREZ RUIZ, José Luis, La depuración de la carrera diplomática española (1931-1980), Burgos: Dossoles, 2006.

${ }^{81}$ To mention but a few: TABANERA, Nuria, Ilusiones y desencuentros. Acción de la diplomacia Republicana en Hispanoamérica (1931-1939), Madrid: Cedeal, 1996; MARTÍNEZ RIAZA \& MORENO CEBRIÁN, “Al servicio de la República...; MARTÍNEZ RIAZA, Ascensión, "La lealtad cuestionada. Adscripción política y conflicto de autoridad en la representación española en el Perú, 1933-1939", Hispania. Revista Española de Historia, LXVI/ 223, Madrid, 2006, pp. 671-694; VARGAS CARIOLA, Juan Eduardo, COUYOUMDJIAN, Juan Ricardo \& DUHART, Carmen Gloria, España a través de los informes diplomáticos chilenos, 1929-1939, Santiago de Chile: Ministerio de Relaciones Exteriores de Chile, 1994.

${ }^{82}$ Cfr. MARTÍN DE LA GUARDIA, Ricardo \& PÉREZ SÁNCHEZ, Guillermo A., in La historia de las relaciones internacionales, Ayer n. 42, Madrid: Marcial Pons, 2001, pp. 125-148.

83 AZCÁRATE, Pablo de, Mi embajada en Londres durante la Guerra civil española, Barcelona: Ariel, 1976; LUENGO TEIXIDOR, Félix, Espías en la Embajada. Los servicios de información secreta Republicanos en Francia durante la guerra civil, Bilbao: Universidad del Pais Vasco, 1999; MARQUINA BARRIO, Antonio, "Planes internacionales de mediación durante la Guerra Civil", en Revista de Estudios Internacionales, tomo 5, núm. 3, 1984.

${ }^{84}$ YRAOLA, Aitor, "La repercusión de la Guerra Civil Española en los Países Nórdicos", Cuadernos de Historia Contemporánea, 16, 1994. 
on the topic refers to later periods. The contributions in this regard concerning the Civil War years deal mainly with Spanish relations with four countries, namely Germany, Italy, England and France. Allusions to "the early Franco years" in research works on Franco's foreign policy usually refer to the years following Franco's victory in the Civil War.

Although research work on the Franco regime has increased a lot at all levels in recent years - sometimes with a focus on new perspectives such as "cultural history" there are still very few references to Francoist Spain's diplomacy during the war years. This stresses the need for studies on the diplomatic reports sent by Franco's representatives abroad to the Burgos Government ${ }^{85}$.

There is also extensive Spanish historical research on the International Brigades, not all of it of a high scientific standard. Some books mentioning the Scandinavian volunteers provide quite different facts and figures from the ones available in Scandinavian primary sources ${ }^{86}$.

The first approach in Spanish historiography to the Swedish volunteers was a book by Borrás from 1977. However, and despite its brevity, the most informative work in Spanish on the subject is an article by Norling - a Swedish lawyer resident in Spain - in 2005 , which correctly presents the contributions of the Swedish research on the subject ${ }^{87}$.

Some other works focus on specific aspects of Swedish humanitarian aid during the Civil War, as those of Beneito's and Duroux ${ }^{, 88}$.

Finally, general Spanish studies on the International Brigades may prove useful for this study ${ }^{89}$.

\footnotetext{
${ }^{85}$ The Earl of Torata's dispatches from Stockholm provide interesting insights, see AGA, AE 6544, libro de Entradas de Embajadas/Legaciones, 1937; AE 5991 Libro de Entradas de Embajadas y Legaciones de 1939 (pp. 160-240);

${ }^{86}$ A typical example of this is VIDAL, César, Las Brigadas Internacionales, Madrid: Espasa, 1998.

${ }^{87}$ BORRÁS, Isabel, Svenskarna och det spanska inbördeskriget: en bibliografi $=$ Los suecos y la guerra civil española: una bibliografia, 1977; NORLING, Erik, "iViva la República! Voluntarios suecos en la Guerra Civil española", Historia Militar, octubre 2005, pp. 127-133.

${ }^{88}$ BALLESTER, Gemma \& BENEITO, Ángel, L'Hospital "Sueco-Noruego" d'Alcoi durant la guerra civil espanyola: un exemple de solidaritat, Barcelona: L'Ullal Ediciones, 2010; DUROUX, Rose, "La ayuda de Noruega y Suecia”, en ALTED VIGIL, Alicia, GONZÁLEZ MARTELL, Roger \& MILLÁN, María José, El exilio de los niños, 2003, Madrid: FPI, pp. 126-143.

${ }^{89}$ RODRÍGUEZ DE LA TORRE, Fernando, Bibliografía de las Brigadas Internacionales y de la participación de extranjeros a favor de la República, (1936-1939), Albacete: Instituto Estudios Albaceteños, 2006; ÁLVAREZ, Santiago, Historia política y militar de las Brigadas Internacionales, Madrid: Compañía literaria, 1996; CIERVA, Ricardo de la, Brigadas Internacionales 1936-1939, Madridejos, Toledo, 1997; OLAYA MORALES, Francisco, La intervención extranjera en la guerra civil. Móstoles: Ediciones Madre Tierra, 1990;
} 
Research on the Spanish Civil War is so large, that it has fallen out of this presentation, which has focused instead on the specific purpose of our study. Nevertheless, knowledge of the main contributions of modern Spanish research on foreign relations during the 1930s and on the Civil War is essential for all studies on the subject.

\subsection{Main contributions of foreign historical research}

Finally, a presentation of the main contributions of foreign research (i.e. outside Sweden or Spain) on Swedish-Spanish relations during the 1930s will put an end to this chapter.

There are several very important general works by foreign scholars on this period of Swedish and Spanish history. For better or worse, they approach the historical evolution of both countries from an external point of view. For worse, inasmuch as there is a higher risk of wrong interpretations due to the lack of understanding of local circumstances; for better, because they provide an external, and therefore a more unbiased, perspective, to the issues involved. However, an external point of view does not necessarily mean a more objective one, as any historian is always dependent on his own subjective views, his own "historical reality". On the other hand, it is usually a different view from the one held by local historians, and this is always enriching and might provide new and interesting insights.

One of the most important contributions of modern foreign research is the book by Radosh, Haveck and Sevastianov entitled "Spain betrayed", since it presented new primary sources of capital weight. The results of their research have been thoroughly discussed in scholarly debate, among others by Ángel Viñas in his recent trilogy on the Spanish Republic at war ${ }^{90}$.

Another work of special relevance to our study, because it deals in some detail with a fundamental issue in it, namely the Swedish-Spanish diplomatic negotiations on a common policy within League of Nations in the mid-1930s, is Berdah's study on the Spanish Republic's relations with the great powers of the day. This book is a good complement to

\footnotetext{
${ }^{90}$ RADOSH, Ronald, HABECK, Mary \& SEVOSTIANOV, Grigory (Eds.), España traicionada, Barcelona: Planeta, 2002.
} 
Balfour and Preston's research on the issue ${ }^{91}$. Berdah's contributions will be thoroughly analysed in this study, and contrasted with Spanish and Swedish primary sources.

Furthermore, all major foreign contributions to historical research on the Spanish Civil War - by Thomas, Payne, Preston, Bolloten, Beevor, to name a few of the best known ones - are a must to the purposes of this study ${ }^{92}$.

On the role played by communism and other ideologies in the Spanish Civil War, besides Catell's classical and controversial work, there are interesting contributions by Rees and Thorpe, Roberts and Schieder et al. ${ }^{93}$

One basic work among the specific studies on the International Brigades is Skoutelsky's, probably the most complete recent work on the subject, which clarifies many debated issues, such as the Comintern's intervention in the organization of the Brigades. According to Skoutelsky, more than $80 \%$ of the volunteers had a working class background. On these questions, there are also other general works that may be of interest ${ }^{94}$.

Keene, Othen and Howson have done extensive research on the international volunteers fighting for Franco's Spain and on shipments of foreign military equipment to the contendants in the Civil War. Howson's very detailed study on the contestants' efforts and achievements concerning the purchase and acquisition of weapons abroad includes

\footnotetext{
${ }^{91}$ BERDAH, Jean-François, La democracia asesinada: la República española y las grandes potencias, 1931 1939, Barcelona: Crítica, 2002; BALFOUR \& PRESTON, op. cit.

${ }^{92}$ These works are mentioned here in their Spanish version: THOMAS, Hugh, La guerra civil española, Barcelona: De Bolsillo, 2003; PRESTON, Paul, Revolución y guerra en España, 1931-1939, Madrid: Alianza, 1986; La guerra civil española: reacción, revolución y venganza, Barcelona: De Bolsillo, 2011; PAYNE, Stanley, La primera democracia española: la Segunda República, 1931-1936. Barcelona: Paidos Ibérica, 1995; PAYNE, Stanley \& TUSELL, Javier, La guerra civil: una nueva visión del conflicto que dividió España, Madrid: Temas de Hoy, 1996; BOLLOTEN, Burnett, La Guerra Civil española: Revolución y Contrarrevolución, Madrid: Alianza Editorial, 1997; BEEVOR, Antony, La guerra civil española, Barcelona: Crítica, 2005.

${ }^{93}$ CATELL, David Tredwell, Communism \& the Spanish Civil War, New York, 1965; REES, Tim \& THORPE, Andrew (coord.), International Communism and the Communist International, 1919-1943, Manchester: Manchester University Press, 1998; ROBERTS, Geoffrey, "Soviet Foreign Policy and the Spanish Civil War, 1936-1939", en LEITZ, Christian. \& DUNTHORN, David J., Spain in an International Context, 1936-1959, Nueva York: Berghan Books, 1999, pp. 81-103; SCHIEDER, Wolfgang \& DIPPER, Christoff, Der Spanische Bürgerkrieg in der internationalen Politik (1936-1939). Munich: Nymphenburger Verlagshandlung, 1976.

${ }^{94}$ SKOUTELSKY, Rémi, Novedad en el frente: las brigadas internacionales en la guerra civil española, Madrid, 2006; BERG, Angela, Die Internationalen Brigaden im Spanischen Bürgerkrieg 1936 - 1939, Essen: Klartext, 2005; JACKSON, Michael, Fallen sparrows: the international brigades in the Spanish civil war, Philadelphia: American Philosophical Society, 1994; RICHARDSON, Dan, Comintern Army: The International Brigades and the Spanish civil war, Lexington: University Press of Kentucky, 1982.
} 
some mentions, albeit marginal, to the presence of Swedish-made weapons in the Spanish Republican army ${ }^{95}$.

As a consequence of the methods used in this study, it is likely that insights given by the diplomatic dispatches require a reconsidering of the theoretical and historiographical framework. Specifically, the issues and aspects of Swedish and Spanish politics highlighted by the diplomats, will necessarily lead to an extension of the research overview presented here to other contributions proper to the issues concerned. These will be presented in due course.

The main results of Spanish and foreign historical research on Swedish-Spanish political and diplomatic relations in the 1930s can be summarised as follows:

1. There is no evidence of close Swedish-Spanish political relations in the 1930s.

2. During the Spanish Civil War, Sweden made no secret of its sympathies for the Republican side, but was officially neutral.

3. Although Sweden hosted some refugees in the building of its legation in Madrid, the country provided substantial assistance to the Republic at war, specifically in medical aid (Swedish-Norwegian Hospital at Alcoy), help to children (orphanages), financial aid (food and money sent by the Swedish Committee for Aid to Spain) and military aid (Swedish volunteers in the International Brigades).

4. Sweden was a democratic country with no connections to the Franco regime during the Civil War. In fact, it was one of the last European countries to grant it official recognition.

Swedish historical research, while broadly in line with Spanish and foreign results, especially the more specific studies conducted by Lundvik and Cantera Carlomagno, shows a more nuanced picture of Sweden's relations with the Spanish Republic. These appeared to have been a bit more problematic. Sweden's agrarian-socialdemocratic government deliberately adopted an ambiguous non intervention policy since the beginning of the war, which had the tacit support of the general public, but not of the majority of the

\footnotetext{
${ }^{95}$ KEENE, Judith, Fighting for Franco: International volunteers in Nationalist Spain during the Spanish civil war 1936-1939, Londres/Nueva York: Leicester University Press, 2001; OTHEN, Christopher, Las brigadas internacionales de Franco, Barcelona: Destino, 2007. This work was later published in English (Franco's International Brigades:Foreign Volunteers and Fascist Dictators in the Spanish Civil War, Londres: Reportage Press, 2008), and in 2012 in a revised version entitled Franco's International Brigades: Adventurers, Fascists, and Christian Crusaders in the Spanish Civil War, Londres: C Hurst \& Co Publishers Ltd, 2012.
} 
supporters and members of left wing parties. According to their analysis, the relations between Sweden and Spain were closer and more intense than it is commonly thought, and this is applicable as well to Swedish relations with Franco's Spain, especially promoted by Swedish industrial circles.

We hope that this study, which extensively uses the primary documentation available both in Sweden and in Spain, will make a valid contribution to the study of international relations between the two countries, contradicting, confirming or qualifying the current state of the question.

We put hereby an end to this presentation of relevant research contributions to the topic. Obviously, this selection is open for discussion. In any case, the amount of research on Swedish-Spanish political and diplomatic relations is certainly not large, and therefore there is a gap worth filling by a detailed study. 



\section{SUMMARY OF PART I AND PART II (CHAPTERS 3 - 8) PART I: REPUBLIC IN SPAIN, SOCIAL DEMOCRACY IN SWEDEN}

Part I focuses on the period 1931-1936. Chapter 3 deals with the image given by Swedish diplomats of the Spanish Republic. Chapter 4 presents the Spanish diplomats views on Sweden during the 1930s. Finally, chapter 5 focuses the bilateral relations between Sweden and Spain during that period.

Chapter 3 begins with an overview of the Swedish Legation in Madrid throughout the period, presenting the diplomats in charge and especially Carl Ivan Danielsson, Minister of Sweden in Madrid and one of the main characters in this study. He led the Legation between 1921 and 1937, except the first two years of Primo de Riveras' dictatorship (1923-1925).

The vision of Swedish diplomacy on Republican Spain before the war was based primarily on the dispatches of two Swedish diplomats: Carl Ivan Danielsson and Einar Ytterberg. Although not a member of the Swedish nobility, in an era when half of his colleagues in the Swedish diplomatic service met that condition, Danielsson had an upper class background. He did not hide his conservative political views and was unsympathetic for the Spanish Republic. Azaña, who disliked the Swedish diplomat and even more his wife, made representations to the Swedish government to get his dismissal. It did not become effective due to the outbreak of the Civil War.

Danielsson's main informants, according to his own reports to Stockholm, were Sweden's General Consul in Spain, Luis de la Peña (a Spanish businessman with contacts in liberal and conservative political circles, such as Alejandro Lerroux), the German Ambassador and sometimes the Apostolic Nuncio. Einar Ytterberg, who would be sent to the Swedish Legation in Moscow after his time in Madrid, appears as politically less conservative than his superior, and was undoubtedly a deep and shrewd observer. Generally speaking, the personal bias of each of the diplomats left its mark on the vision they gave of Republican Spain. On the other hand, they sought to give a nuanced vision of events, conscious of their responsibility towards the Swedish Government.

All Swedish diplomats in Spain were very critical of all extremistic actions, whatever their political sign. Danielsson did not hesitate to use the word "fanatics" to refer both to right-wing groups and to left-wingers who burned churches and monasteries or threatened 
the established legal order by undemocratic means. They were equally critical of the Republican government itself whenever it acted in ways they deemed unbecoming a democratic state.

Chapter 3 shows the Swedish diplomats' vision of Spain's domestic politics from 1931 to 1936, in three stages: a) the eve of the Republican era up to the establishment of the Republic in April 1931 b) the first Republican period (April 1931 to November 1933) and c) the second Republican period (November 1933 - februari 1936). Each section follows primarily a thematic display, and a chronological one within each topic. These were not preselected, but - in accordance with the methodological options - were determined by the primary documentary sources. In other words, the highlighted issues are those the diplomats themselves emphasized in a special way in their reporting.

The last period of the monarchy was followed with great interest by Swedish diplomats. Not just during General Berenguer's time, in 1930, but even after Admiral Aznar took over the government at the beginning of 1931, they did not believe a Republic in Spain was forthcoming. Danielsson was quite confident the country would soon return to a normal constitutional path, and believed in Berenguer's good intentions, albeit he understood the General was not up to what his mission required. However, by the middle of 1930, coinciding with the tightening of censorship and a return to more dictatorial ways, the tone of his dispatches began to change.

The road to the Republic was described vividly by the Swedish Legation, stressing the existing political disunity and the danger of interference by the Spanish Army. The military revolt at Jaca, described as an "organized plot to introduce a Republic in Spain", and the progress of republicanism, were seen as serious episodes of an imminent popular revolution, something Swedish diplomats viewed as an imposition by intellectual groups and foreign (mainly Soviet) pressure. Danielsson thought - wrongly - they would not succeed because the majority of the Spanish people were against it.

The advent of the Republic in April 1931 was, therefore, a quite unexpected event for Sweden's Minister in Madrid. Nevertheless, the fact that the Republic had been established without bloodshed and without the intervention of the army had a positive impact on Danielsson, who even had words of cautious optimism about the new political leaders, particularly Azaña and Martinez Barrio.

During the first Republican period, the main themes in Swedish diplomatic reports were: a) the legislation on religion and the difficult Church-State relations b) the 
Constituent Parliament and the settlement of the Republican regime in Spain, c) the attempted military coup in 1932 and the revolutionary strikes d) The major reforms: the Catalan question and land reform, and e) the financial and political developments in 1933.

In particular, the religious policy of the new regime was considered by Swedish diplomacy as a huge mistake that could have dire consequences for Spain. Danielsson called it an example of Azaña's political myopia for ignoring the sociological reality of the country, mainly Catholic. This critical view appeared also in connection with many other aspects of the political development of the Republic during the first biennium. The "Defence of the Republic Act", giving the Spanish Prime Minister "dictatorial powers" was viewed with particular apprehension by the Swedish diplomats in Spain, who considered the way decisions were made by the Republican government as often arbitrary and undemocratic.

The negative view of the Spanish Republic transmitted by the Swedish Legation softened as of 1932, when the danger of a military dictatorship became more apparent with the attempted coup of General Sanjurjo. Army reform was one of the few measures taken by the Republic to be praised in the Swedish reports. The danger to the Republic posed by fascism - as the foundation of the Falange in 1933 would show - and by the revolutionary strikes encouraged by leftist organizations - sometimes described in diplomatic dispatches as terrorist acts - had, according to the Swedish Legation, tangible negative consequences for the economy and social peace. The Swedish Legation feared that the discrediting of republican institutions would pave the way to a military dictatorship.

These fears were duly transmitted by the Legation to the Swedish Government, especially during the second republican period, where two topics were prevalent in Swedish reports: a) Spanish political instability and the dangers to the breakthrough of democracy, and b) the October Revolution of 1934 and its aftermath.

The defeat of the republican and socialist parties in the 1933 elections, according to Swedish diplomats, was a result of the reaction of the electorate, especially the women who could vote for the first time - against an unfortunate religious policy, a misguided management of the Spanish economy and harsh partisan struggles that prevented any consensus decision-making at the parliamentary level. All this evidenced the great difficulties involved in the establishment in Spain of a democratic parliamentary system. In this context it is worth mentioning the criticism of the President of the Republic, Alcalá- 
Zamora, by Danielsson, who repeatedly accused him of violating his constitutional duties to his own advantage.

The lack of institutional solidarity, political instability and the risks that it entailed for democracy was the general tone of the image of the Spanish Republic in the Swedish diplomatic dispatches during the second Republican period. The October Revolution of 1934 and its aftermath were interpreted - apart from a prejudiced mention of cruelty as an alleged distinctive Spanish feature - particularly in the context of the lack of social peace, caused by the political instability and aggravated by the consequences of the social reforms, that hade a strong impact on the traditional economic system of Spain. Swedish diplomats insisted on the dangers this entailed to the Republic, by inclining the minds of the more radical elements of Spanish society towards violent solutions. In November 1933 and once again after the October 1934 revolution, the Legation warned also of the danger posed by fascist views within the Spanish Army (mentioning explicitly General Francisco Franco as a possible dictator-to-be). How right they were!

However, the main problem was - according to the Swedish view - the fact that the Republic did not enjoy the support of the Spanish business circles, and also what they believed was the country's tradition of abuse of power on the part of the government of the day and the lack of a dialogue with the political opposition. Major reforms such as the Catalan Statute or land reform were thus deemed to failure.

A third section in chapter 3 is devoted to the specific concerns of Swedish diplomacy in Spain. The main ones were two: a) the progress of communism and the relations with the USSR, and b) the social and political situation of Spain in the spring of 1936 and the threat of Civil War.

The social and political situation deteriorated a lot in the months prior to the Civil War. After the fall of Portela Valladares and Chapaprieta, and even more with the seizure of power by the Popular Front - that Danielsson thought was as revolutionary, radical and undemocratic as one of its main leaders, Largo Caballero - Swedish diplomatic fears for the future of Spain reached a peak, second only to the terror deeds that followed the military uprising. No doubt influenced by this view of the Spanish reality, the leader of the Swedish Social Democrats, Per Albin Hansson, highlighted the dangers that a similar policy could entail for Sweden in his famous speech of July 1936: "Let them who, in our country, advocate the creation of a Popular Front take due notice". 
References to the progress of communism in Spain were present in Swedish diplomatic dispatches already in 1930, when Danielsson wrote about an alleged Soviet support in relation to the Jaca uprising of captains Fermín Galán Rodríguez and Ángel García Hernández. Soviet communism was, in Danielsson's view, a threat to the Republic despite assurances to the contrary given him by leading Spanish politicians (Lerroux, Alcalá-Zamora, Besteiro, Azaña) and Foreign Ministers (Zulueta, Sanchez Albornoz and Pita Romero). The Swedish government had also received information in the same vein from its London Minister, who had discussed the matter with Ramsay MacDonald.

The issue was often present in Swedish reports. Danielsson compared the situation in Spain with Russia under Kerensky, a common comparison in Spanish conservative circles at the time. According to him, both a senior civil servant at the Spanish Foreign Ministry and also future Minister Casares Quiroga thought the progress of communism in Spain and all revolutionary strikes to be due to Bolshevik support.

However, Danielsson's main informant was Sweden's General Consul, Luis de la Peña, to whom the more "sensational" pieces of information in Swedish reports should be attributed. Danielsson himself was careful to mention Peña as his informant when transmitting such kind of information.

Swedish Madrid Legation fears of the "communist threat" escalated after the 1934 October Revolution, decreased clearly in 1935 (when the danger of a fascist or a military dictatorship had grown) and increased again in the spring of 1936, together with concerns about the imminent danger of a Civil War. By then, Swedish diplomats (Danielsson, Wisén, Consul Olsén and several honorary consuls), following in the footsteps of their colleagues from Denmark and many other countries, were blunt in their description of the situation in Republican Spain as an alleged ongoing "Bolshevization project for Spain" and even as “a Bolshevized Spain”. Ytterberg, then stationed in Moscow, quoted Lenin's words about communism becoming a reality first in Russia and Spain due to the "material and social backwardness" of these countries.

Later, as of the spring of 1937, Swedish diplomatic reports from both Spain and Russia would give a more balanced view, mentioning the cautious attitude adopted by the Soviet rulers concerning Spain: The USSR was unwilling to jeopardise its relations with the London Non Intervention Committee powers, and did not want to confront Germany directly. Viewed as a whole, however, the question of the spread of communism in Spain - 
inseparable from the concern for the development of democracy in Spain - was the great concern of Swedish diplomats in Madrid.

Chapter 3 concludes with the presentation of the vision given by Swedish diplomacy on the Spanish Republic's foreign policy between 1931 and 1936. Swedish diplomats seem not to have been especially interested in Spanish foreign policy, except concerning the relations of the Republic with the Soviet Union, and some minor specific issues that could perhaps affect Sweden such as the Spanish Morocco policy, the issue of disarmament and the Spanish position in the Chaco and Abyssinia conflicts.

These issues had a common background, the maintenance of peace in the Mediterranean, a hot issue in Italian relations with England and France, and in which Spain could perhaps have some influence by taking France's side against Italy. It could hardly be the other way round, because of the Spanish Republic's hostile attitude towards fascism.

For Swedish diplomats, the role of Spain in the Mediterranean was only a secondary one. More striking still is the fact that hardly any comments appear in Swedish diplomatic reports on Spain as a major neutral country during World War I and a member of the League of Nations. Instead, there were specific statements about Spain not being interested in European politics.

Chapter $\mathbf{4}$ is structured in a similar way to the previous chapter but analyses instead the image of Sweden given by Spanish diplomats. It starts with an overview of the Spanish diplomats in Stockholm. While one two people were heads of the Swedish Legation in Madrid during the 1930s, there were as many as five Spanish Ministers in Stockholm, apart from the so-called agents that Sweden exchanged with the Franco government as of December 1938.

The second section of chapter 4 is devoted to Swedish domestic politics as reflected in the Spanish diplomatic dispatches, and contains two subsections: a) Period before the accession to power of social democracy in September 1932, and b) Per Albin Hansson's first government 1932-1936. Unlike chapter three, the structure is here chronological instead of thematic. The reason is none other than the multiplicity of issues the Legation took up and the lack of focus on any of them.

The two main events of the early 1930s in Sweden, the Ådalen events and the suicide of Swedish industry tycoon Ivar Kreuger, were obviously addressed by Spanish diplomats. However, the specific terms on which they reported about the Adalen events are unknown, as the dispatches for 1931 are missing. Judging from the general tone of later reports, it is 
possible that a social uproar that caused five deaths was considered by the Spanish diplomacy as a small matter, especially when compared with what was customary in Spain at that time. However, it does not seem to have been so, since the number of dispatches on the issue, as is clear from the record books of Spanish Foreign Ministry, was considerable. This suggests that Spanish diplomacy in Stockholm was aware of the importance of the Ådalen events for Sweden.

Kreuger's suicide, which led to the resignation of Sweden's liberal Prime Minister and to a social democratic victory in the elections of September 1932 - an event that affected Spain due to alleged contacts between the Swedish business group and the Alphonsine Royal Court in the previous decade - was followed in detail by the Swedish Legation in Spain.

A constant in the Spanish diplomatic dispatches on the development of the Swedish political and parliamentary life is the insistence on the great calm, civility and consensusseeking spirit that characterized it. This impressed Spanish diplomats a lot, maybe because of the contrast with Spanish political life. All Spanish Ministers in Stockholm during the 1930s praised Swedish political procedures and results. At the request of the Ministry of State, a detailed report was sent in 1933 about the Swedish system of government and political parties, in which the Conservatives were described as supporters of a moderate progress policy, the Agrarian League (Bondeförbundet), as "more leftist" that the Conservative Party, the Liberal parties as "leftist bourgeois parties" and the Social Democratic Party as a progressive, distinctly liberal party, a convinced defender of democracy and parliamentary methods, and far away from extremism.

The agreements between the Agrarian League and the Social democrats, known in Sweden as the 1933 horse-trading (kohandeln), were seen in a somewhat special way by Spanish diplomats, who not only saw it as a political agreement on economical and financial issues but also as a consequence of a distinct Nazi-refraining policy. In this sense, it seems to contradict modern Swedish views on some alleged sympathies for Nazism within the Agrarian League at the time.

Spanish diplomacy was also impressed at the development of economic and social life in Sweden during this period, and praised the economic and social legislation measures adopted by Sweden, especially in the field of labour law and other social measures such as unemployment and sickness insurance, state subsidies for housing, rental law, refugee assistance laws, motherhood and childhood, etc. 
The third section in chapter 4 deals with the specific concerns of Spanish diplomacy in Sweden: a) Swedish defense policy, b) the attitude of Sweden to Nazism and Hitler's Germany.

The question of the defense was one of the major issues on the agenda of the League of Nations in the first half of the 1930s. One result was the international disarmament conference of 1932-1933, which ended in failure. Spain and Sweden maintained in it discordant positions.

Increased political instability in its immediate neighborhood caused a defense policy dilemma for Sweden. This led the country's social democratic government, a few months after the rise of Hitler in Germany, to radically change its position on defense issues. Swedish Foreign Minister, Rickard Sandler, said in the League of Nations that in the current international situation Sweden could not lower the level of its defense forces.

In May the Spanish Legations in Sweden and in other former neutral countries received orders from the new Spanish Foreign Minister, Pita Romero, on the need to coordinate the national positions of the neutrals on defense issues. Thereafter, the Spanish Legation of Spain would regularly keep Madrid informed of Swedish defense policy, to a point almost akin to espionage, as shown in a report on the Swedish military maneuvers in Scania in November 1935. For a change, Sweden's military capacity failed to impress the Spanish diplomats.

Spanish diplomats in Stockholm followed closely Sweden's attitude to Nazism and Hitler's Germany. The triumph of the Nazi ideology in Sweden's neighbour country was a nuisance. While both Swedish politicians and the general public were unanimous in their rejection of Nazism, the country had traditional political, cultural and commercial ties with Germany, apart from the security risk that confronting the German dictator entailed.

After an overview of modern Swedish research on Sweden's controversial relations with Nazi Germany, the views of Spanish diplomats are presented: they echoed German government protests against political statements made by Swedes or by the Swedish media, and insisted on the lack of effective influence of the Fascist and Nazi organisations in Sweden. Fiscowich openly stated his view that Nazi ideas could only be successful in Sweden if they were accepted by the right wing of the Conservative party, an interesting statement coming from the pen of a diplomat of entrenched conservative convictions. The opposition to Nazism in the country was so strong - according to the Spanish Legation that even the Stockholm local authorities had refused to decorate the city for the wedding 
of Prince Gustav Adolf and the German princess Sybilla, parents of the present King of Sweden, because Hitler and the father of the bride were friends.

Finally, the chapter presents the Spanish view of Swedish foreign policy from 1931 to 1936, in several subsections: an overview; Swedish cooperation with the other Nordic countries and Sweden's relations with England, Italy - especially the Swedish-Italian crisis in connection with Abyssinia - and the Soviet Union, which were far from friendly.

Sweden' foreign policy underwent a paradigm shift in 1935, coinciding with the Abyssinian crisis. Thereafter the pacifist ideal of neutrality would take precedence over the stubborn defense of the League of Nations' principles. This point was duly recorded by Spanish diplomats, who followed the development of Swedish foreign policy through Rickard Sandler's speeches and through personal meetings with him and other ministry officials.

Spain's Legation in Stockholm reported on the Swedish disappointment at the failure of the London World Economic Conference of 1933 and on the visits to Sweden of HRH the Prince of Wales in October 1932 and of the Lord Privy Seal, Anthony Eden, in the autumn of 1934. These visits tightened the commercial and political ties between the two countries. Sweden's rapprochement to Britain was due, according to Spanish diplomats, to Hitler's rise to power in Germany, the global economic crisis, the linking of the Swedish currency to the pound sterling and Britain's attempts to win Scandinavia over to its policies. Should there be an armed conflict between Britain and Germany, therefore, Sweden would probably side in with Britain, said the reports.

The Legation of Spain reported on the Swedish Foreign Minister's important speech of October $29^{\text {th }}$, 1933 on the Swedish position on international trade and foreign policy, where Sandler proclaimed Swedish neutrality and defended its right to maintain good business relations with all countries, regardless of the political regime they had. This pragmatic attitude in economic and trade issues was well in line - according to Spanish diplomats - with the number one priority presiding Sweden's foreign policy at the time, namely, the will to keep Sweden free from the scourge of war, at all costs.

Spanish diplomats saw Sweden as a strong supporter of the principles of the League of Nations, but also as a pragmatic country that did not trust either Nazi Germany or Soviet Russia. The Spanish Minister in Stockholm described Sandler as "an ardent anti-Bolshevik shocked by Stalin's terror" and a "fervent anti-Nazi, always opposed to any concession to Nazi Germany". They also mentioned Sweden's will to strengthen its relations with the 
other Scandinavian countries, in a special wave of "Scandinavism" motivated by the German threat, but did not think it would result in any far-reaching political and military alliances. They were right, as the Soviet attack on Finland on November $30^{\text {th }}, 1939$ would make painfully evident.

Chapter 5 deals specifically with the bilateral political and diplomatic relations between Spain and Sweden. It begins with a presentation of Sweden's attitude to the change of political regime in Spain, with a subsection on Alfonso XIII's trip to Sweden in the summer of 1931, invited by Swedish Royals, during which the former King gave an interview to a Swedish journalist.

The diplomatic sources - including encrypted telegrams between the Spanish Foreign Ministry and Spain's Legation in Stockholm on April 1931 - reveal a hitherto unknown aspect, namely Sweden's reservations concerning the Spanish Republic, shown in a willingness to differ recognition of the Provisional Government of the Republic as much as possible (it took intense diplomatic pressure to obtain it soon enough to avoid speculations on the matter), and in the failure to congratulate Alcalá-Zamora on his inauguration as President. On Azaña turning president, in 1936, no high ranking Swedish diplomats were present, although this was rather a diplomatic retaliation for Azaña's hostile attitude towards Swedish Minister Ivan Danielsson. However, these disagreements did not have major consequences.

Next section focuses on collaboration between Spain and Sweden in the League of Nations, the main field for the political and diplomatic relations between the two countries during this period. Following an overview of neutrality and pacifism as common key foreign policy features of both Spain and Sweden, the specific - and important - joint Spanish-Swedish initiatives to promote peace within the so-called "group of neutrals" are presented.

Already in 1932, there had been Spanish attempts to be fully included in the socalled "Oslo group" consisting of Sweden, Norway, Denmark, Belgium, Holland and Luxembourg. However, Spanish projects to share the leadership of this group with Sweden gained new strength with the arrival of Leandro Pita Romero to the Ministry of State. After several meetings between the Spanish Minister in Stockholm, López Oliván, and high ranking Swedish officials such as Rickard Sandler and Östen Undén (which are explained in detail in this chapter), Spain failed to overcome the Swedish reluctance to formalize 
alliances or written agreements of cooperation, let alone come to terms with Spain without previously discussing the issues with the other Scandinavian powers.

Although no agreement was reached in writing, a joint statement of the neutrals was presented at Geneva by the Swedish Foreign Minister, in April 1934. On that occasion, Fiscowich lamented that Sandler had presented the initiative as if it had been his own. Later, in the summer of 1936, there was another joint declaration, the "memorandum of the Seven", also a result of a far-reaching cooperation between Sweden, Spain, the other Scandinavian countries and Holland.

The third section focuses on specific bilateral interests between Spain and Sweden, such as Spanish diplomacy's successful rallying to get Sweden's support for Spain's reelection to the Council of the League of Nations, questions concerning the image of the Spanish Republic conveyed by the Swedish press, some cultural initiatives, and the diplomatic contacts in connection to the signing of a new Spanish-Swedish trade agreement.

The Republic's decision to renegotiate all its trade agreements with other countries resulted in long and difficult diplomatic negotiations between Stockholm and Madrid, where both parties had to compromise on their initial positions. Eventually, the agreement that was reached was never truly effective because of the Spanish Civil War.

Finally, there is a section on contacts between Spanish and Swedish politicians and union leaders during this period that are mentioned in diplomatic documentation. Margarita Nelken's Scandinavian journey deserved special attention in Spanish Legation reports, as it placed the Spanish socialist party in a rather awkward position due to Nelken's defence of Stalin's policies, which irritated Scandinavian social democrats, especially in Denmark.

\section{PART II: WAR, INTERVENTION AND NON INTERVENTION}

The second part focuses on Sweden's relations with each of the two zones in which Spain was divided during the Civil War years. These relations could have been presented following a purely chronological scheme, which would have had the advantage of showing the evolution of Swedish relations to Republican and Francoist Spain as events unfolded. However, the option has been made to have two separate chapters, for a better understanding of what kind of relationship Sweden had towards the Spanish Republic, on one side, and to Franco's Spain, on the other. 
Chapter 6 is dedicated to Sweden's relations with the Spanish Republic during the war years. Firstly, the image of the Civil War in Swedish diplomatic reports is given.

Despite the unstable situation caused by the division of the country in two halves, the evolution of the war and of domestic Spanish politics was closely followed by Swedish diplomats, especially with regard to Republican Spain. In the Franco zone, until the exchange of official agents in late 1938, monitoring could be done only through the Consuls, most of them conservative Spanish businessmen who rather approved of the military coup. As their colleagues from other countries, especially Denmark, did, the Swedish diplomats that remained in Republican Spain after July 1936 reported that the legitimate government had been replaced, in practice, by a "communist regime with committees of various kinds".

They denounced in unequivocal terms the terror that dominated the streets of Spanish cities and villages, on both sides of the country, during the first months of the war. All in all, Swedish diplomats in Spain, Italy, Germany and the Soviet Union gave a thorough view of the development of the war and the involvement of those countries in it. All the main issues of the war - Nazi and Fascist help to Franco, the participation of the International Brigades, the Guernica and Barcelona bombings, the Deutscheland incident, and the ins and outs of the complex politican situation in the Republican zone of Spain were duly echoed in Swedish diplomatic dispatches.

A second section of chapter 6 presents Sweden's official policy of non-intervention in the Spanish conflict, as agreed with other European powers. It was a pragmatic attitude, following in the footsteps of Britain that coexisted with a huge solidarity wave on the part of most Swedish people, especially in the working class movement.

Sweden's adherence to the non-intervention policy was supported by the majority of Swedish political parties, namely the Social Democratic Party and the so-called "bourgeois parties" (Conservatives, Liberals, Agrarians, etc...) and was ratified without a parliamentary debate, on September $28^{\text {th }}, 1936$. The parties to the left of the Social Democrats (socialists, communists and trade unionists) were against it and did not cease in their opposition to it during the three years the war lasted.

Pursuant to the agreement of the Non-Intervention Committee of London, in February 1937 the Swedish government presented to the Riksdag a law "on measures to prevent the participation of volunteers in the Spanish Civil War", which criminalized any attempt of recruitment of volunteers and the delivery of weapons to Spain. The law was 
passed on March $5^{\text {th }}, 1937$ and was in force until February $28^{\text {th }}, 1939$. At least 351 Swedish workers organisations (communists, socialists and anarcho-syndicalists) protested vehemently against these measures, but to no avail.

The third section examines the diplomatic relations between Sweden and the Republic, focusing specifically on the diplomatic conflicts that arose as a result of Sweden granting asylum to a certain amount of Spanish refugees, including 21 military officers, and also on the activity of the Spanish Legation in Sweden, which is described in detail.

Diplomatic relations between Sweden and the Spanish Republic during the war years were not easy. Isabel de Palencia, the Spanish Minister in Sweden, had first to dislodge her predecessor, who had joined the rebel cause, from the Legation premises. Despite logistical difficulties and staff shortages, the Republican Legation in Sweden developed during those years a significant propaganda work. Some of its accomplishments were the organization of a "Spanish Week" in several Swedish cities, the development of friendly contacts with Swedish polititians, and the coordination of actions of solidarity organized by the Swedish Committee for Help to Spain, chaired by social democratic politician Georg Branting. Isabel de Palencia also held several interviews with Rickard Sandler, on cordial terms, but in which the Swedish government was careful not to compromise its neutrality in the Civil War.

The final section of this chapter, presents Swedish domestic politics and foreign policy during this period, as recorded by Spanish diplomatic reports.

There aren't any Spanish diplomatic dispatches on Swedish politics between July 1936 and March 1937, as the Spanish Minister in Stockholm had not remained loyal to the Republic, and the only issue he focused on thereafter was Sweden's position in the Spanish conflict. Once the Spanish Republican Legation could be operative again, in March 1937, reports on Sweden's politics were reassumed.

It is striking that the Spanish Republic's Legation in Stockholm continued devoting effort and attention, during the years of the Civil War, to the monitoring of the current political and economic issues in Sweden. Moreover, the reports were sound and deep, as shown in Legation Secretary Aurelio Romeo's detailed report on the financial situation of Sweden in June 1937 or in the analysis of the political situation sent by Isabel de Palencia in March and July 1938. All reports were imbued with deep respect and admiration for the achievements of Sweden, a country that according to the Minister of Spain in Stockholm had reached "the most advanced standard of living of our time" thanks to the long period 
of peace it had experienced, the fair distribution of wealth and land, its sparse population, its wise organization of economic affairs and, above all, its long democratic tradition.

Specifically, Swedish social legislation attracted the attention of the Spanish diplomats in Stockholm, as shown by the fact that in December 1938 - at a time of extreme difficulty for the Spanish Republic, when Sweden had already exchanged official diplomatic agents with the government of General Franco - the Republican Spanish Legation sent a relatively long dispatch reporting on the Saltsjöbaden Agreement, a milestone in the process of creation of the Swedish Model.

Chapter 7 presents Sweden's relations with Franco's Spain since the beginning of the Civil War to the end of 1939. At first, Swedish contacts with Francoist Spain were conducted in a discreet manner, until the exchange of "agents" in late 1938. A key issue is the attitude adopted towards the Spanish military rebellion by the Swedish provisory government - the so-called summer government of 1936 - and of the social democratic government that took power after the parliamentary election of September $20^{\text {th }}, 1936$. The dispatches on this important subject by Francoist representative in Stockholm Alfonso Fiscowich, hereto unknown in Swedish historical research, are presented. They show the existence of close contacts between Fiscowich and high ranking Swedish diplomats, politicians and even the King himself.

The Swedish government firmly refused, however, to give any official character to these contacts with the Franco regime, resisting the pressure exerted in the opposite direction by the Exporters Association, until the international situation and the development of the Civil War made it unavoidable.

Furthermore, the information sent by Swedish diplomats concerning Franco's Spain, together with the bilateral issues and diplomatic conflicts between the Stockholm and Burgos governments are described in detail in the first section of this chapter. These conflicts were mainly due to the detention of Swedish merchant ships by Franco's navy and the imprisonment - and condemnation to death in one case - of Swedish honorary consuls in the territory controlled by the rebels.

The second section analyses the negotiations leading to the exchange of diplomatic agents and the subsequent official recognition of Franco regime's by Sweden. Special attention is given to the lobbying of Swedish business groups on their own government in favour of Franco's Spain. During the negotiations, the Francoist Minister of Industry and Trade, Juan Antonio Suanzes, even threatened Sweden with trade retaliation if it did not 
regularise relations. The section ends with a reference to the work of the Swedish agent in Burgos and the official recognition of the Franco government by Sweden.

The third section is devoted to the diplomatic and propaganda activity of the representatives of Franco's Spain in Sweden, which was quite successful. Apart from the efforts to try to prevent or delay the normal functioning of diplomatic relations between Sweden and the Spanish Republic, Fiscowich continued working for the interests of Franco's Spain from his informal position in Sweden, among other things by warning the Swedish authorities about Republican attempts to purchase arms in Sweden. He even managed to get the Swedish police put Spanish Republican Ambassador in Moscow, Marcelino Pascua, under surveillance when he passed through Sweden on his way home. As could be expected, most of the activity of the representatives of Franco's Spain in Sweden focused on issues connected in one way or another with the Civil War.

The fourth (and last) section of chapter 7 analyzes the state of relations between Sweden and Franco's Spain in the final period of the decade, once the Spanish dictator had won the war, from April $1^{\text {st }}, 1939$ to December $31^{\text {st }}$ of that year. The picture that emerges from the analysis of the diplomatic reports of the time is one of institutional normality, and even of continuity of relations. The sources show attempts at retaking the old discourse of foreign political collaboration between neutral countries, which had been one of the key foreign policy aims of the Spanish Republic before the war.

Spanish diplomacy tried to get Swedish support for Franco's call to peace in Europe. The Legation of Spain in Stockholm transmitted to the Swedish Ministry for Foreign Affairs the contents of Circular n. 23 of its Spanish counterpart, containing Franco's appeal for peace and for the need to prevent the spread of the conflict, arguing the experience of the Spanish war and highlighting the "very deep and insuperable disturbance in the economy of the world" that the internationalization of the war would entail. The Swedish government answered that it highly appreciated the Spanish initiative and was willing to support it, as it was a cause of joy "seeing Spain among the countries wishing to contribute to the end of the current catastrophe". The initiative was, thus, welcomed by the Swedish government as a declaration of pacifism on the part of the new Spanish regime, and diplomatic negotiations on the issue followed suit. Eventually, further developments made unviable a common Spanish-Swedish call for peace in Europe, but the fact that there were bilateral diplomatic efforts in this regard, is not without significance. 
Finally, chapter 8 focuses on the most studied aspect of Swedish-Spanish relations in the 1930s, namely Sweden's intervention in the Spanish Civil War.

That intervention included humanitarian aspects, and also military ones, and was a clear political positioning of the Swedish people on the so-called "Spanish question". Despite the country's official policy of neutrality and non intervention, Swedish diplomacy involved in these issues to an extent unmatched in the diplomatic history of the country. It is therefore fully justified to devote an entire chapter to this subject.

This chapter has two main parts, one on Swedish humanitarian aid and one on military aid.

The first one studies Swedish humanitarian aid in its double aspect of a) actions on behalf of specific individuals or groups and b) material aid to the victims of the war, mainly women and children (mainly food and medicines supplies, the Swedish-Norwegian military hospital in Alcoy and the children homes for war orphans).

Swedish humanitarian aid during the Spanish Civil War, especially - but not exclusively - in favour of Republican Spain, was very considerable, and consisted in two main lines of action: first, in the diplomatic asylum and mediation in the exchange of prisoners, and the other in financial aid and aid to wounded soldiers, women and children. The first aspect meant in practice some intervention in favour of Franco's Spain, through the protection of 174 people threatened or persecuted in Republican Spain (especially in Madrid). Most of them were relatives of people with connections with the Swedish Legation, such as Swedish honorary consuls and viceconsuls or Spanish employees in branch offices in Spain of Swedish companies. But 21 of them were high ranking military officers who were sympathetic to the Francoist cause.

The second aspect, the financial aid, the Swedish-Norwegian hospital and the orphanages, helped predominantly people in Republican Spain, even though some of it also went to the Francoist zone, e.g. the children home in Guetaria.

The reasons that led Sweden to intervene, in one way or another, were mostly humanitarian, but obviously there were also political considerations, especially concerning the support to the war effort of the Spanish Republic.

The second part of chapter 8 focuses the Swedish military aid to Spain. This was not provided in an official capacity, but was exclusively the work of volunteers, about 10 individuals on the Franco side and around 550 in the International Brigades and other Republican units. 
In addition to an overview of the Swedish brigadists' contribution to the war effort, their reception in Sweden on their return and their activities after the war (such as the participation of some of them in the Second World War) are highlighted.

Also the attitude adopted by the Swedish authorities is analysed. On the one hand, the authorities restrained from the application of the law banning the participation of Swedish nationals in the war, but the Swedish veterans from the Spanish war were nevertheless subjected to a close control by the Swedish police authorities, due to their contacts with international Communism.

Finally, the last section focuses on a hereto practically unresearched field within Spanish-Swedish relations during the Civil War, namely the topic of Swedish military supplies to the belligerents.

This section presents in some detail, on the evidence of both Spanish and Swedish sources from military and security police archives, the activities in Sweden of some underground networks engaged in the purchase and smuggling of weapons to Spain, often to both sides at the same time. Some shipments even led to legal proceedings in Swedish Courts, such as the so-called Allegro and Lola affairs, named after the two cargo ships involved. The Allegro affair was a Swedish arms shipment to the government of the Republic which fell to the rebels on February $15^{\text {th }}$, 1937. It was a clear case of doubledealing on the part of those involved in the purchase and transport of the material. It had been sold to Republican agents but all the details of the intended journey were then given to the other purchasers, Franco's Navy. The Lola was a Swedish merchant ship detained by the Romanian authorities in the port of Constanza, because of its cargo of weapons and ammunition destined to Spain.

The available sources suggest the existence of a dozen ships in the service of the Republican government, controlled for some time from Gothenburg. Reflagging of ships and even surreptitiously raising flags of convenience as required by circumstances do not seem to have been uncommon.

Although the amount of Swedish weapons in Spain was not large, there is no doubt some Bofors guns and explosives and ammunition from other Swedish companies made its way to Spain during the war. 



\section{CONCLUSIONS}

The present study aimed to fill a gap in the historiography of international relations in the $20^{\text {th }}$ Century concerning Sweden and Spain. Both countries are located in Europe's periphery but both are powerful actors in their close environment, Spain in the Mediterranean and Sweden in the Baltic and Scandinavian world. Both countries had also been neutral during the First World War and would also choose neutrality in the new world conflict that started in 1939.

Specifically, the purpose of this study was the analysis of the political and diplomatic relations between Sweden and Spain during the 1930s, based on a large number of primary sources, focusing on the study of the diplomatic dispatches on record in the Foreign Ministry Archives of both countries.

In the first chapter the theoretical and methodological framework was presented. This study would follow a traditional qualitative method in line with the "grounded theory" proposed by Barney Glaser and Anselm Strauss in the late 1960s, although enriched with recent methodological perspectives, including some aspects from discourse analysis and the theorethical contributions made by Koselleck, Rüsen and Skinner, which were deemed especially relevant for an analysis of the narratives created by the diplomats involved.

Following Skinner, the intentions of the authors and the rhetoric of the time has been taken into account in the analysis of diplomatic documents. At the same time, attention has been given to the changes of view that sometimes can be perceived in diplomatic reports, especially noticeable when an event is evaluated in an ad hoc release and in the quarterly report. Seen in the light of Koselleck's theories, these differences manifest a change in the horizon of expectations of the diplomats motivated by their experience of the hastily changing political and social reality.

This approach has been instrumental to perform a thorough historical analysis of the relevant primary documentary sources. The abundance and diversity of these sources was decisive for the theoretical and methodological option. The result was that a much larger amount of primary evidence than originally intended had to be analysed. This is a consequence of the intertwining of the different issues, due to the new aspects and prospects arising from the comparative study of Swedish and Spanish reports about the same event.

In the introductory chapter, four main sets of questions were proposed. First in turn were questions concerning the vision given by Swedish diplomats of Republican Spain's 
political development during the period 1931-1936 and of the vicissitudes of the three years of Civil War that followed, with special emphasis on the specific diplomatic concerns and on the assessment of Spanish foreign policy. The second group of questions was identical, but concerning Sweden in the eyes of Spanish diplomats. The third group of questions dealt with Sweden's relations with the Spanish Republic and the fourth, its relations with Franco's Spain.

Actually, the four sets of questions could be summarised in three main issues: First, how did Swedish diplomats see Republican Spain and the Spanish Civil War? Secondly, how did Spanish diplomats see Sweden in the 1930s, a crucial period for the establishment of the Swedish model? And finally, what kind of relationship was developed between the two countries, distinguishing, for the period 1936-1939, the two areas in which Spain was divided?

The role of a very small group of people in this regard is worth pointing out. For practical purposes, the diplomats and politicians involved in Swedish and Spanish relations were but a few: Danielsson, Ytterberg, Wisén, Berencreutz, Günther, Sandler and King Gustav V on behalf of Sweden; García Conde, López Oliván, Fiscowich, Madariaga, Palencia, Dafonte, Valdés, Pita Romero, Suanzes and a few others, on the Spanish side. In total, there were less than 20 people involved. They, and their informers, were the key players in shaping Spain's image in Sweden, and Sweden's in Spain.

The available sources have shown occasionally particular instances of "antibiased" comments, i.e. statements or judgements contrary to the aforementioned stakeholders' convictions or cemented opinions on important issues. Needless to say, this has proved especially useful for the analysis contained in this study.

Swedish diplomats' critical views on Republican Spain should be highlighted as a first conclusion of this research study. Contrary to what might have been expected, Swedish diplomats did not consider the Spanish Republic as a truly democratic country. At most, they saw it as an embryo of a democratic State, always in danger of being suffocated before birth by any of the forms of totalitarianism in vogue at the time: Fascism, Communism or traditional military dictatorship.

In this connection, Swedish diplomats strongly censored all kinds of behaviour that they considered extremist, regardless of its political sign. They denounced what they saw as the Republic's democratic shortcomings, particularly the lack of parliamentary spirit, 
shown in arbitrary decision-making with little respect for minority views, and the attitude of Spanish authorities - in their view, not firm enough - at the lack of unity and social unrest in the country.

Once the Civil War had started Danielsson, Wisén, Olsén and several Swedish honorary consuls, in the footsteps of their Danish colleagues and of the diplomats of several other countries, estimated that the legitimate Spanish government had been replaced by a "Soviet regime". Wisén even used the term "a bolshevized Spain" and Ytterberg, then stationed in Moscow, quoted Lenin mentioning that communism would first triumph in both Russia and Spain because of "the material and social backwardness" of those countries.

For Swedish diplomacy, therefore, after July $19^{\text {th }}, 1936$ - and especially once the Largo Caballero government had taken over - the Spanish Republic had ceased to exist in practice to make way for a new regime of a communist and anarchic character. And that was the image of the Spanish Republic the Swedish government received at the very time the discussion whether Sweden would join the British policy of non-intervention in the Spanish war was at its peak. It is therefore very likely that these reports had an influence on the Swedish government's decision in the "Spanish question".

This same image continued to prevail, somehow, throughout the war, although it became less negative as of the spring of 1937, especially after the fall of the Largo Caballero government.

Swedish diplomatic dispatches warned repeatedly, since April 1931, of the dangers to the Republic caused by right and left wing extremists, threatening with the establishment of either a Fascist military dictatorship or a Communist regime similar to Soviet Russia's.

Their concern led them to criticize everything they thought could increase these risks, namely the Spanish Republic politics in religious matters, the mismanagement of the Spanish economy, the "dictatorial" powers granted to the government by the Defence of the Republic Act, the revolutionary strikes and partisan struggles, the lack of institutional solidarity and the hostile attitude toward the Republic adopted by important sectors of the Spanish financial and military circles. Swedish diplomats in Madrid had critical views on Azaña, Alcalá-Zamora, Gil Robles and even more so on Largo Caballero and the Popular Front.

In this connection, the current study has revealed the clairvoyance of analysis shown by Swedish diplomats, who warned of the danger of Civil War already at the beginning of 
the second Republican period and mentioned the possibility of a military dictatorship, suggesting even the dictator's name - General Francisco Franco - as early as November 1934. Swedish diplomats also considered dangerous both Gil Robles' attitude and the Republican and Socialist parties' lack of involvement in parliamentary activity during 1935. Moreover, in October 1936, they did not hesitate to denounce the hard and rough character of the new dictatorial regime that was being established in Spain.

However, apart from the logical concerns about the actual breakthrough of democracy, the big issue that caught the attention of Swedish diplomacy was the threat, whether real or imagined, of Spain's transformation into a communist country. This presumed danger - which afterwards would become a main thread in the Francoist narrative of the Republican years and would be the ground upon which General Franco's dictatorship would try to justify its legitimacy - seems somewhat surprising to find in the reports of diplomats belonging to one of the countries with a longer democratic tradition.

The current study suggests that, despite assurances to the contrary given by the political leaders of Republican Spain, Swedish fears that Spain was slipping gradually into the Soviet orbit - almost an obsessive subject for Sweden's Minister Plenipotentiary in Madrid between 1931 and 1936 - was always present in the reports sent to Stockholm. Indeed, it is but another expression of the view of the Spanish Republic as a democracy in the making that could easily degenerate into a dictatorship.

Why this insistence by Swedish diplomats in Spain on the threat of communism? A first and simplistic approach to the problem would seek an explanation in the politically conservative ideas of Carl Ivan Danielsson's and of his informants. This aspect is no doubt important and is certain to have played a role herein. However, apart from the personal opinions of the players, there are other aspects of a structural nature that also should be taken into account.

Indeed, there were political, economic and commercial considerations behind the specific concerns of Swedish diplomacy with the progress of communism in Spain. In addition to political rivalry, Sweden feared the expansionist attitudes of its powerful eastern neighbour, the Soviet Union. There existed also a commercial competition between the two countries regarding the export of some commodities. Concerning Spain - as specifically stated by Danielsson - Sweden feared that improved Spanish relations with the Soviet Republic would result in lower imports of Swedish wood, a product that could also be obtained from the Slavic country. 
In short, a feasible explanation could be sought in the tense relations of Sweden, and especially of the bulk of the Swedish Labour Movement i.e. the Social Democratic organisations, with communism as an ideology and with the Soviet Union as the embodied communist power at the time. This aspect has been extensively dealt with in historical research, ant it is confirmed by the sources examined in this study, especially the speeches and actions of the main actors of Swedish foreign policy at the time, such as Foreign Minister Rickard Sandler.

The role and personality of Sweden's Minister in Spain notwithstanding, these structural aspects help to explain the Swedish interest for communism in Spain. The communist project, with its emphasis on class struggle, was an obstacle to the social project Swedish socialism had in mind. Indeed, Swedish socialism, as Berman said, was flexible rather than dogmatic, and its goal was the creation of a "home of the people" according to the famous expression coined by Per Albin Hansson - in which all classes would collaborate and benefit from. A key feature in its practical development, as Luebbert pointed out, was the alliance of the social democrats with the groups defending the interests of agricultural workers, especially at the so-called "horsetrading" (kohandeln) of 1933.

The image of the Spanish Republic given by Swedish diplomacy was, therefore, more negative than positive, with greater emphasis on its failures than on its achievements such as the education, agricultural or State organization policies, which they were unable or unwilling to highlight.

Sweden was sympathetic to the Spanish Republic's democratization and modernization project, but also saw the regime with suspicion, not only because of the political and social development of Spain during the two Republican periods and the years of the war, but probably also due to the tense situation in the international politics of the time, at the dawn of a new international order. It was certainly not the best moment for major political experiments, as Europe was threatened by an unprecedented economic crisis and faced the fast advance of the powerful new totalitarian ideologies seeking to establish themselves as surrogates of the liberal State, which had been buried in the battlefields of the Great War.

There is a striking contrast between the thoroughness and detail of Swedish diplomatic reports on the domestic politics of the Spanish Republic and the disinterest they showed on its foreign policy. Swedish diplomats mentioned the Spanish Republic's 
relations with other countries only occasionally, an even stated directly that Spain was not interested in European politics.

It is possible that this vision of the Republic was also influenced by the ambiguity that characterized the latter's policy in the League of Nations, clearly shown in the disarmament issue in 1933 and 1934 - when Spain did not support Swedish initiatives, as Egido Leon and Berdah pointed out - or in the Abyssinian crisis. In this respect, Navarro Quintana's claims that the Spanish Republic resolutely opted for the collaboration of the small European democratic powers (the straight eight) should therefore not be taken at face value.

In 1934-1935, Spain wanted to take up again the idea of cooperation of the small powers and tried to reach an intimate understanding with Sweden aimed at sharing the leadership of the "group of neutrals" and presenting a common front in the League of Nations. This was undoubtedly the central issue of Swedish-Spanish bilateral relations in the 1930s. However, it was not enough to make Swedish diplomacy change its views on Spanish foreign policy. Sweden was only moderately interested, and in its foreign policy within the League of Nations it always gave preference to its relations with the other Nordic countries rather than fostering contacts with Spain.

In the light of the diplomatic documents analysed here, it seems obvious that the Spanish Republic did not quite understand the depth of the links connecting Sweden to its Scandinavian neighbours. If it had, the Republic would never had suggested a deal requiring Sweden to discuss foreign policy issues with Spain prior to any talks with the other Scandinavian countries.

The foreign policy of the Spanish Republic appeared to the Swedish diplomats as "much ado about nothing", i.e. great words about neutrality and pacifism, but no defined policy thereto.

Despite the many things they had in common as small powers and the fact that, after the failure of the disarmament conferences, both countries would follow the same pattern of change from a corporate pacifism to a neutralist pacifism, Sweden showed little interest in the foreign policy of the Spanish Republic, probably because the latter did not have a clear policy on the major issues of European politics, which at the time were the main concerns of Swedish foreign policy, namely German and Soviet expansionism and the Franco-British policy of appeasement. 
The second set of questions focused on how Spanish diplomats saw Sweden and its political development during the period 1931-1939. Those years witnessed the final settlement of Social Democracy as the leading political force in the Scandinavian country, which by the end of the decade had become one of the first welfare States in the world.

Spanish diplomacy reported on the main events of Swedish political development in the early 1930s, such as the so-called Adalen events, the suicide of Swedish magnate Ivar Kreuger, the agreement between the Social Democratic Party and the Agrarian League, the concrete achievements in social and labour legislation, etc. All of them were crucial to the rise to power of Social Democracy. The importance that Spanish diplomats gave these aspects is clearly shown by the fact that even in late 1938 - at a time of extreme difficulty for the Spanish Republic, when Sweden had already exchanged diplomatic agents with the government of General Franco - the Legation of Republican Spain in Stockholm found the time to send a relatively long dispatch reporting on the Saltsjöbaden Agreement.

In contrast with the negative view of Swedish diplomacy about Spain at the time, the clearly positive image of Sweden Spanish diplomats conveyed is worth highlighting. Indeed, insistence on the serenity, civility and consensus-seeking spirit that characterized the development of political and parliamentary life in Sweden was a constant feature in Spanish diplomatic dispatches. The analysed sources show the Spanish diplomats' admiration at the tone of Swedish political debates, perhaps because of the contrast with Spanish reality at a time of confrontation, discord, agitation and tension.

Spanish diplomats emphasized the moderation and avoidance of any "extremism" that characterized Swedish political life at the time and its main protagonist, the Social Democratic Party. Later, once the Civil War had started, the Minister of Spain in Stockholm, who had turned over to the Francoist side, would refer to a pretended "traditional duplicity" of the Social Democratic party, but even then he did not disqualify Per Albin Hansson, whom he regarded as a "strong personality and an utmost capable person".

The agreement between the social democrats and the agrarians, the "horsetrading" of 1933, which broke the policy of "blocks" (the bourgeois against the left), was explained by Spanish diplomats mainly as a result of a desire to form a political front to prevent the development of Nazism in Sweden. Swedish historiography, meanwhile, although not alien to this idea, tends to explain the "horsetrading" basically in terms of economic and social policy, and also points out that the Agrarian League showed in the early 1930s some 
affinity with Nazi views, both in its charter, and in the sympathies of some of its representatives.

The report sent by Fernández Villaverde as charge d'affaires of Spain in Stockholm seems to contradict this conclusion. However, subsequent reports by Fiscowich in August and September 1936 on the attitude of the provisional government led by the Agrarian politician Axel Pehrsson-Bramstorp towards Franco give a different view, much more in line with the dominant trends in Swedish historiography on the topic.

Spanish diplomacy's special interest in Swedish defense policy, which was reversed over the decade, is quite evident in the light of the large number of diplomatic reports on the subject. Sometimes that interest went so far that it almost came close to military espionage. The military capability of the Swedish Armed Forces, which did not impress Fiscowich at all, was the exception that proves the rule of Spanish diplomacy's admiration for Sweden.

The other major topic of special concern for Spanish diplomacy in Sweden was the question of the possible progress of Nazism in Sweden and the country's relations with Hitler's Germany.

This study shows that the Spanish Republic was interested in the progress of Nazism in Sweden and that Spanish diplomatic reports clearly reflected the determined anti-Nazi attitude of the Swedish government, of the Swedish Social Democratic Party and, with a few exceptions of little relevance, of Swedish public opinion and people in general.

Spanish diplomatic sources mostly confirm the results of Swedish historical research on the subject, whereby Nazism, lacking internal cohesion and popular support in Sweden, was never a serious threat to the country. However, in some specific issues, there are some differences, as for instance concerning Nazi influences in some expressions in the Agrarian League's Charter, which Spanish diplomacy failed to comment upon. Another minor difference lies in the assessment of the extent of fascist ideologies in the Swedish army: the Legation reported in late 1931 that Fascist sympathies were widespread among Swedish officers. Swedish historians generally write about pro-German rather than pro-Nazi sympathies within the Swedish army.

The conclusion, in short, is that the Swedish Legation in Spain gave a very positive view of the political, economic and social development of Sweden in the 1930s, especially after the rise to power of the Social Democratic Party. It gave a balanced and adequate vision, broadly in line with the basic lines of Swedish historiography on the period. 
Regarding Sweden's foreign policy, characterised by the parameters of pacifism and neutrality, Spanish diplomacy highlighted the paradigm shift in mid-decade, when Sweden decided to give priority to the pacifist ideal of neutrality rather than to the stubborn defense of the principles underlying the Covenant of the League of Nations.

Spanish diplomats also pointed out Sweden's rapprochement to England during those years, which would lead to the Swedish government, despite its zealous desire to safeguard its neutrality, lending its support to the British policy of appeasement towards Hitler and later to supporting non-intervention in the Spanish war. The Spanish diplomats thought that Sweden's parliamentary and democratic tradition, which drew it closer to Britain, would outweigh the country's cultural affinity with Germany, and Sweden would support Britain in the event of a war.

Spanish diplomacy characterized Sweden as a country that strongly supported the principles of the League of Nations in its foreign policy, but also as a pragmatic country that could not hide its pessimism about the future of that organisation and of peace in Europe. It also stressed Sweden's aloofness against both Nazi Germany and Soviet Russia and its desire to nurture the traditional links it had with the other Scandinavian countries.

Spanish diplomacy rightly stressed that those links would not have important practical implications, as presenting a common front would be difficult due to the different political majorities in their governments and an alleged Swedish interest not to challenge its hegemony within the Nordic group through the signing of specific agreements that would limit its freedom of action. This argument about Swedish hegemony claims is suggestive and does not seem to have been further developed in Swedish historiography.

Against the prevailing view in Swedish historiography that Swedish foreign policy at the time was dull and routinely driven, with the sole aim not to dissagree with its Nordic neighbours, contrasts somewhat the vision given by Spanish diplomacy, which highlighted Sweden's role as a regional power, with a role in the Baltic comparable to that of Spain in the Mediterranean. However, this did not necessarily mean that Sweden was ready to establish itself as the warrant of the security of its neighbours at the expense of its own.

It can be concluded that concerning Swedish foreign policy in the 1930s, Spanish diplomats stressed its cautious attitude of restraint and expectation, the proclamation of pacifism coupled with pragmatism in decision-making, a rapprochement to England without irritating Germany and a clear rejection of Nazism and communism as ideologies and of the countries supporting them at that time, the German and Soviet dictatorships. 
Generally speaking, the positive attitude Spanish diplomats showed towards Sweden contrasts with the negative one of Swedish diplomats towards the Spanish Republic, an aspect which the analysis of the diplomatic sources has made clear enough.

A somewhat reluctant attitude on the part of Sweden can also be seen in the way bilateral relations between the two countries were articulated during the period 1931 to 1936. Sweden's intention to delay full recognition of the Spanish Republic in April 1931 and the arrival in Stockholm of a new Republican Minister Plenipotentiary in 1936 were clear examples of this, as well as the cold attitude towards the Presidents of the Spanish Republic manifested in the absence of proper ceremonial attentions, especially when Azaña was made President in 1936. This aspect was unknown so far in historiography.

That attitude on Sweden's part, which may be a bit surprising, was fully consistent with the country's tradition not to make hasty decisions in order to keep as long as possible its freedom of action in international policy issues. Sweden subsequently adopted a similar strategy in relation to the Franco regime's call for a jointly Spanish-Swedish declaration addressed to the belligerents in World War II. In recent times, Sweden acted likewise when entry into the European Union was at stake. In short, Sweden adopted a pragmatic approach, avoiding taking sides as long as possible, so as not to tie its hands in any way before it was absolutely necessary.

Our study has also highlighted a particular aspect that had a negative influence on Spanish-Swedish relations, namely the mutual antipathy between Manuel Azaña and Ivan Danielsson, Sweden's Minister in Madrid. The President of the Spanish Republic went as far as inoficially asking the Swedish government to call Danielsson back, something which was about to take place when the Civil War started. The Swedish diplomat's wife's extreme right-wing sympathies played an important role in this conflict. Alleged sympathies for Nazi ideas on the part of Danielsson himself, however, are ungrounded. On the contrary, the evidence against it is quite strong, as shown by the inclusion of the Swedish diplomat in the list of "Righteous among the Nations" for his actions in defense of Hungarian Jews in 1944.

To Danielsson's credit, the fact should be mentioned that, while not being a friend of the Spanish Republic, he nevertheless showed an open and positive initial attitude towards Manuel Azaña. That impression started changing as Azaña began to make major political 
decisions in ways the Swedish diplomat considered as arbitrary, undemocratic and even as he repeated on many occasions - dictatorial.

Also the contacts of former King Alphonse XIII with Sweden were a cause of estrangement between the Spanish Republic and the Scandinavian country. The ex-King visited Sweden in the summer of 1931, making some statements on Spanish politics to the local press.

However, these disagreements had no major consequences and relations became soon normal, as is shown by Sweden's support for Spain's reelection to the Council of the League of Nations, which remained unchanged over the entire period in question even though it was contrary to Sweden's usual practices.

However, the main issue concerning the political relations between Sweden and the Spanish Republic were the plans for Swedish-Spanish cooperation in the League of Nations to promote peace, an initiative Berdah called the Republic's first international impulse. Probably the most interesting aspect that emerges from the analysis of the relevant primary sources is who took the initiative towards the joint declarations of the neutral countries. Swedish historians such as Carlgren, Zetterberg, Ohlsson and Ottoson have all attributed it to Rickard Sandler, the Swedish Foreign Minister.

Contrary to that view, our study confirms Berdah's views on the important role played by Spain, through the memorandum of Madariaga and the initiatives of López Oliván and Pita Romero, in the development of the joint declarations of neutral countries in the League of Nations, the "statement of the Six" of April 14 $4^{\text {th }}, 1934$ and the so-called "manifesto of the Seven" of July $1^{\text {st }}, 1936$. Both seem to have been a Spanish initiative that Sweden made its own, developed and managed to anchor in the forum of neutral countries, displacing Spain in some way.

The conclusion drawn from these considerations is that Swedish-Spanish cooperation in the League of Nations between 1933 and 1936 was more intense and important than might be expected from the previously existing relations, the form in which bilateral negotiations were carried out, and the apparent lack of mutual understanding shown by the authorities in Madrid and Stockholm. That growing cooperation was cut short by the Civil War, but after it was over attempts at its normalisation and deepening were reassumed, as shown by the bilateral diplomatic contacts in September, 1939 to reach an agreement on a common Spanish-Swedish call for peace in the Second World War. 
It can be argued, therefore, that Swedish-Spanish bilateral relations intensified during the 1930s through specific political initiatives in the framework of cooperation between the neutral countries in the League of Nations. These plans were not exempt from tensions, as shown by the somewhat suspicious attitude of leading Swedish civil servants and politicians towards the Spanish Republic, the divergence of views between the two countries in the international crises of Chaco and Abyssinia, and the existence of major disagreements between the two countries in connection to the regulation of bilateral trade, an issue that led to long and difficult diplomatic negotiations between Stockholm and Madrid.

Bilateral relations between Sweden and Spain entered a new phase during the Civil War. The vast majority of the Swedish people supported the cause of the Republic in an international solidarity campaign without precedent in the history of Sweden. On the other hand, many Swedish honorary consuls and businessmen with interests in Spain favoured Franco's cause.

Our study confirms the general picture presented by Swedish historiography, which emphasizes the dichotomy between popular attitudes and the Swedish government's official attitude towards the Republic: privately, a maximum of sympathy; publicly, a pragmatic policy of non-intervention. A possible explanation is Sweden's subordination to Britain, involving the need to support British politics. However, the current research has also brought to light new aspects, until now partially or even totally ignored by historians.

A first aspect, which surprisingly is completely unexplored in Swedish research on the Spanish Civil War, is the attitude taken by the Swedish government during the first two months of the conflict. Indeed, Swedish historians have quoted Per Albin Hansson's words on the war, but they seem to have overlooked the fact that the Social Democratic politician was not the Swedish Prime Minister at that time. His cabinet had resigned in June 1936, and since then - and until the elections of September $20^{\text {th }}$ later that year - the country was led by the so-called "summer government", headed by the leader of the Agrarian League Axel Pehrsson-Bramstorp. How did this government see the outbreak of the Spanish armed conflict?

In this regard, our study shows that the Swedish government went from an attitude of expectation, in July 1936, to surreptitiously supporting Franco's cause in the last month of its term of office, i.e. from mid-August until the elections of September $20^{\text {th }}$, 1936. This 
support was manifested in the maintenance of diplomatic contacts with the representative of Franco's Spain and the attempt to defer the re-establishment of such relations with the Spanish Republic, delaying the granting of the placet to the new Minister Plenipotentiary proposed by the Madrid government and even ordering the charge d'affaires in Madrid, Consul Axel Olsén, to leave Spain. More comments on this important aspect will be given later in connection with Sweden's relations with the Franco regime.

This situation ceased shortly after the retaking of power by the Social Democratic party, when ordinary diplomatic relations with the Spanish Republic were reestablished, although discreet and informal contacts with Franco's representatives in Stockholm went on. Erik Wisén turned back to the Swedish Legation in Spain, first located in Valencia and later in Barcelona. For practical reasons, regular diplomatic relations were mainly channeled through the Spanish Republic Legation in Stockholm.

After the September 1936 election, the Swedish government adhered to the policy of non-intervention with the support of most of the country's political class. Only the organisations to the political left of the Social Democratic party (socialists, communists and trade unionists) were opposed to it and showed their unconditional support to the cause of the Republic throughout the war, but they had little political weight in Sweden. Public opinion was emotionally divided - because the masses of the Social Democratic Party sympathized with the Republic, but could not show it properly - but outwardly firm in its support for the government's policy of neutrality and non-intervention.

Eventually, Sweden chose the most pragmatic way out, as Per Albin Hansson would later say about the possibility of recognizing the Franco regime: "the matter is perfectly clear, if you leave emotions aside". Isabel de Palencia repeatedly expressed the opinion that the Swedish Social Democratic government, although it was sympathetic towards the Republic, was "in no way hostile" to Franco's Spain. She criticized harshly what she saw as a betrayal of the democratic ideals by the leading politicians of the Swedish Social Democratic Party.

After the parliamentary debate of February 1937, the Swedish government banned the participation of volunteers in the Spanish Civil War, but left the door open for humanitarian aid. Our research confirms Lundvik's and Cantera Carlomagno's analysis on the Swedish position in the Non-Intervention Committee: Sweden was faithful to the policy of non-intervention, but adopted a rather passive attitude in the "Spanish question" within the Committee and the League of Nations. 
Diplomatic relations between Sweden and the Spanish Republic during the war years were not easy, despite the efforts of Spanish diplomats in Stockholm, who endeavoured to rally support for the Republican cause by organizing cultural events and visits from Swedish MPs and other VIPs to Republican Spain, and by coordinating the solidarity actions organized by the Swedish Committee for Aid to Spain, headed by Social Democratic politician Georg Branting. There were also conflicts caused by the war itself, e.g. the murder by a militia man of a son of the Swedish Consul in Gijón, the death sentence inflicted on a relative of the Swedish Consul in Alicante, the seizure of Swedish diplomatic vehicles or the raids on Consular premises, and some others of a purely diplomatic nature.

The official political and diplomatic relations between Sweden and the Republic during the Spanish Civil War were correct but discrete, as even Francoist documentation acknowledged. The limited amount of contacts between Spanish political and Trade Union organizations with their counterparts in Sweden, with the notable exception of the CNT, is also quite striking.

At the unofficial level, popular support for the Republic, especially within some political organizations, was, on the contrary, extremely warm and friendly. The assistance provided to the Spanish Republic was much larger than the one given to Franco's Spain. The Swedish-Norwegian hospital at Alcoy - called a "model facility" by Republican General Julio Bejarano - the children's homes in Denia, Teya and France, and extensive material aid in the form of food and medicines are a very clear proof of this, as well as the participation of more than five hundred Swedish volunteers in the Spanish war fronts on the Republican side, as opposed to just a few men on Franco's side.

The main protagonists of this great manifestation of international solidarity with the Spanish Republic were the two parties and the Trade Union politically situated to the left of Social Democracy, i.e. the Communist Party, the Socialist Party and, especially, the libertarian and anarchist Trade Union SAC, which was the closest European organization to the Spanish CNT. Social Democratic organizations, on the other hand, are hardly represented in the list of Swedish Labour Movement organizations that openly protested against the Swedish government's policy.

Our research has also confirmed the ambivalent attitude of the Swedish authorities to the Spanish Republic as far as the participation of Swedish volunteers in the International Brigades is concerned. Formally the volunteers had committed a crime punishable with 
imprisonment, but the authorities adopted a pragmatic and flexible approach to law enforcement, assisting them in their repatriation and restraining from the application of the law once they had returned to Sweden. This did not mean, however, that they would not be subjected to police control, which they did, for fear that their contacts with international communism in Spain could be dangerous for Sweden's national security.

Access to new primary sources has allowed us to update the lists of Swedish volunteers available until now. We have also been able to provide names and specific details about the smuggling and the presence of Swedish arms in Spain, a largely unknown topic in historiography so far, with the notable exceptions of Howson's and, in Sweden, Lundberg's contributions. On this point, the conclusion is that, although modest in size, there was a smuggling network of Swedish weapons and ammunition, which was used by both Republican and Francoist agents. The local connections routinely played a double game, selling the same items of weapons to both parts. In fact, many of these weapons seem to have ended in the hands of Franco's Army.

In short, the Swedish authorities tried to reconcile the pragmatic need to support the British policy of non-intervention with a desire to provide a moral and humanitarian support to the Spanish Republic, in line with the feelings of many sectors of Swedish society, thus promoting the breakthrough of a democratic system in Spain.

The time has come to tackle the last question: Sweden's relations with Franco's Spain.

Sweden's relations with Franco Spain went through several stages: an initial period, in which Sweden remained expectant, between July 1936 and the end of the Battle of Madrid; a period of estrangement, albeit with informal relations, until the summer of 1938; a third period of official relations at a "diplomatic agent" level, from autumn 1938 until the end of the war; and finally, the period of official recognition and re-establishment of regular diplomatic relations, from March $31^{\text {st }}$ to December $31^{\text {st }}, 1939$.

The provisional Swedish government of the summer of 1936, led by Agrarian League politician Axel Pehrsson-Bramstorp, after an initial adverse reaction, maintained an officially uncommitted, yet open attitude towards the Spanish rebels, giving them a covertly support by severely hampering the restoration of normal diplomatic relations with the Republic. This conclusion is supported by the explicit testimony of Alfonso Fiscowich, 
Minister of Spain in Sweden since 1934 and representing Franco's Spain as of August $11^{\text {th }}$, 1936. It is a hitherto unknown aspect in Swedish historiography.

Key players in this supportive attitude to Franco's Spain were King Gustav V and Foreign Ministry Undersecretary Christian Günther, who would have replaced Danielsson in Madrid, had the Civil War not started. In December 1939, Günther was appointed Swedish Foreign Minister in the special war cabinet led by Per Albin Hansson during the years of World War II.

Until now, no Swedish study has dwelt on Günther's and King Gustav V's sympathies for Franco's Spain. The Swedish monarch invited Franco's representative to a Palace dinner in Stockholm on October $25^{\text {th }}, 1936$, during which he gave a toast for the victory of the rebel cause. Later on, the King intervened directly to achieve the liberation and transfer to the Francoist zone of some people, including a high-ranking Spanish military refugee in the Swedish Legation in Madrid. Swedish diplomacy took discreetly all the necessary steps to fulfil the King's wishes.

Officially, the Pehrsson-Bramstorp government joined the British policy of nonintervention, facilitating things for the next government, Per Albin Hansson's, who simply continued the policy initiated by its predecessor.

During the second period, Sweden was adamant in its neutrality, though it tolerated the presence in Stockholm of unofficial representatives of Franco's government, allowing them access to the Foreign Ministry and letting them establish a wide network of contacts in the country, especially in business circles, but not exclusively, as it has been shown concerning contacts with law enforcement authorities, such as the Swedish police.

Franco's Spain had the support of the Swedish Foreign Trade Association, which had an active role in lobbying for the regularization of Sweden's trade relations with the Burgos government, following the British pattern. Some Swedish businessmen particularly those with interests in Spain, such as Swedish consul in San Sebastián Andrés Åkerman - foresaw Franco's victory in the war and were unwilling to suffer commercial disadvantages due to Sweden failing to regularise its trade relations with the new Spanish State.

This support, known in Swedish historiography through Lundvik's and Cantera Carlomagno's research work, was instrumental to prevent a possible rapprochement of the Swedish government to Republican Spain after the summer of 1937 and also to promote the discrete negotiations on exchange of diplomatic agents conducted by the Swedish 
Foreign Ministry with Franco's representatives. However, despite Francoist Trade Minister Juan Antonio Suanzes' threats of commercial retaliation against Sweden if it failed to comply, this exchange did not take place until late 1938, when the international situation and the development of the Civil War made this step unavoidable. The primary mission of the diplomatic agents, Fernando Valdés in Stockholm and Nils Berencreutz in Burgos, was preparing official recognition, which Sweden - after discussion with the other Scandinavian countries - would rather delay as much as possible. In fact, Swedish official recognition was not given until the afternoon of March $31^{\text {st }}, 1939$.

The main conclusion to be drawn of this is that, despite official rhetoric, the Swedish government did not adopt a decidedly hostile stance towards Franco's Spain. Rather, as with the Spanish Republic, the Swedish attitude to Franco's Spain was ambiguous. The reason seems to be the well-known traditional Swedish foreign policy line to preserve its neutrality at all costs, staying on the lookout for as long as possible, without making hasty decisions that could compromise the country in one way or another.

Swedish humanitarian activity was extended to the Francoist zone, both in the form of material support - medicines and a home for war orphans at Guetaria - and by the exercise of the right of asylum as well as mediation in the exchange of war prisoners, such as the exchange of rebel General Goded's son and family.

The Swedish Legation in Madrid, which in the absence of professional diplomats was managed by Swedish and Spanish junior staff, welcomed 174 political refugees, including 21 Spanish military officers. It managed to evacuate all but 13 officers, who had to wait in the premises until the end of the war. Refugee issues were a constant source of difficulties for Swedish diplomacy, especially when it was found out that the temporary Swedish consul in Madrid, Gumersindo Vallejo, was involved in the activities of what has been called the Fifth Column.

Actually, most of the refugees were women, children, and families of people who were somehow connected with Swedish interests in Spain. In any case, the Swedish government denied allegations from the press that it was protecting fascists, despite being aware - as this study has shown - of the veracity of some allegations, such as the protection offered by the Legation to senior Spanish military officers.

At the other end of the scale lie the conflicts that Sweden had with Franco's Spain during the war years. The best known so far were related to the detention and seizure of Swedish merchant ships by Franco's Navy. In some cases, such as the well known Allegro 
affair, that intervention occurred as a result of the duplicity of arms dealers, but there were also major conflicts, basically unknown in the existing historiography, that the current study has brought to light, such as the arrest of Swedish honorary viceconsuls at Coruña and Sanlúcar de Barrameda in Franco's Spain.

The latter, Antonio Maestre, was a well known Republican leader sentenced to death by the rebel military authorities. The affair led to contacts at the highest possible level between Sweden and Franco's Spain, including letters and telegrams from Rickard Sandler to General Queipo de Llano, to the Generalissimo's Headquarters and to the Spanish Republican government, in an attempt to save the viceconsul's life. A last, almost desperate attempt to swap Maestre by Queipo de Llano's sister who was a hostage in Republican Spain was not approved by the government of the Spanish Republic, so it all ended in failure. Swedish efforts to obtain the release of the Swedish International Brigades prisoners in prisons and concentration camps of Franco's Spain, were, on the other hand, successfully completed.

Finally, relations between Sweden and Franco's Spain after the war and for the rest of 1939 were analysed. The analysis presents some somewhat surprising aspects, considering that Sweden's relations with the Franco regime were ambiguous during the war but very strained in later years, culminating in the withdrawal of the Swedish Ambassador in Madrid in 1975 as a protest against the last death sentences carried out in Spain.

Indeed, the picture that emerges from the analysis of the diplomatic sources of both countries is one of institutional normality, and even of continuity of relations. The sources show a closer link between the two countries, when attempts were made to retake the old discourse on foreign political collaboration between neutral countries, which had been one of the key foreign policy aims for the Spanish Republic.

The conclusion, therefore, is that Sweden maintained a low profile and distanced, but not altogether unfriendly stance to Franco's Spain during the war years and that it tried to maintain fully normal diplomatic relations in the months that followed the end of the war.

This comparative history study, focusing on the international relations between Spain and Sweden during the 1930s, which were those of the Second Republic in Spain and of the formation of the Swedish model in the Scandinavian country, is coming to an end. Hopefully, it has provided new insights for a better understanding of this important period 
in the history of both countries. At the same time, we are aware that, as usual, our research has brought to light a range of new possibilities that are open to future research.

Among them, the following deserve a special mention: first, the possibility of a case study of the relations between the CNT and the SAC, based on the primary sources preserved in the archives of the Swedish Labour Movement in Stockholm, including the correspondence between representatives of both organizations. Such a study would not only highlight the the relationship between the two organizations but also would be the key to the CNT vision of the Spanish war, in its various phases, as it was transmitted at the time to European anarcho-syndicalist organizations and to the Labour movement in general.

Another interesting research field in this context would be to study whether and how the Spain's dramatic events in 1936 had an influence on the decision made by the Swedish socialist union Landsorganisationen (LO), during its Congress (September $27^{\text {th }}$ to October $\left.4^{\text {th }}, 1936\right)$, to promote a line of consensus rather than one of confrontation with the employers' associations. One of the main results of that important decision was the Saltsjöbaden Agreement, a milestone of the Swedish model. Given the international and European situation at the time, it could be assumed that the Spanish events did have an influence thereon.

Sweden's political rapprochement to Britain during the 1930s is another result of the current research study which so far has not been thoroughly researched in Sweden. These close ties between Britain and Sweden in the 1930s are worth taking a closer look at, especially in the light of the development of events once the Second World War started, when Sweden not only turned its back on the British position, maintaining a strict neutrality, but would have a somewhat tense relationship with the government of Her Britannic Majesty, to the point that Britain even considered the possibility of a military intervention against the Scandinavian country to prevent exports of Swedish iron ore to Germany. Therefore, a study of the Swedish-British bilateral relations during the time in question, similar to this study about Spain, could be interesting.

A third open field for future research is the study of Swedish-Spanish relations in the period 1900-1930 - perhaps with particular emphasis on the years of the First World War and the Primo de Rivera Dictatorship - and also the study of Sweden's relations with Franco's Spain between 1939 and 1975. Swedish primary sources for a research work of 
this kind, especially at the Swedish Labour Movements Archives, amount to hundreds of files, which have so far not been fully explored for academic research purposes.

It might also be interesting to look into the subject of cooperation and mutual relations between the so-called neutral countries, in three main stages: the First World War, the interwar period, and finally - even though there is more research available during World War II. A comparative analysis of diplomatic documentation of the concerned countries, especially the Scandinavian and Benelux countries, together with Switzerland and Spain, could provide new interesting contributions.

These suggestions for future research work concern studies with the same theoretical and methodological aproach that has been adopted in the current study. The list could be much longer by using other theoretical and methodological approaches. One possible line of research would be a diachronic study of diplomatic dispatches from the point of view of the analysis of the concepts used and their semantic evolution, in line with Ricoeur's and Koselleck's theoretical contributions. One could also delve into some aspects that have not been on the foreground in our study, such as the analysis of the diplomatic sources from a class, generation or gender perspective.

To sum up, the paradigmatic speech of the Swedish Social Democratic Foreign Minister in late 1936 is worth quoting again:

You can not take the side of anyone of the fronts in the Spanish problem, and at the same time hold on to democratic principles, as that would mean an inner contradiction. One may regret deeply that Spain's way to a modern and democratic social order should go through convulsions as bloody and cruel as these, and that development seems so uncertain right now, but one must say that the fate of democracy in the world is not resolved by street fighting in Madrid. It depends instead on the way how democratic states solve their own affairs and on their willingness to defend themselves against both tangible and intangible attacks. But to that end, it is of utmost importance that democracy assert its idiosyncrasy and not be put in a position of having to choose between dictatorships of different shades.

Rickard Sandler's words provide a fundamental key to understanding the reasons for the ambivalent Swedish attitude towards Spain, a country with which Sweden, nevertheless, maintained during the 1930s much closer political and diplomatic relations than might have been expected. 